Budapesti Corvinus Egyetem

TÁJÉPÍTÉSZETI És TÁJÖKOLÓGIAI

DOKTORI ISKOLA

Eplényi Anna

\title{
KALOTASZEG TÁJKARAKTER-ELEMZÉSE
}

- Doktori értekezés -

Témavezető: Prof. Dr. Fatsar Kristóf

Társ-témavezető: Dr. Báthoryné Nagy Ildikó Réka

Budapest, 2012 
A doktori iskola megnevezése:

tudományága:

vezetője:

\author{
Budapesti Corvinus Egyetem \\ Tájépítészeti és Tájökológiai Doktori Iskola
}

\section{Agrármúszaki}

Csemez Attila, DSc

egyetemi tanár

BUDAPESTI CORVINUS EGYETEM, Tájépítészeti Kar,

Tájtervezési és Területfejlesztési Tanszék

\author{
Fatsar Krisóf, PhD \\ tanszékvezető egyetemi tanár \\ BUDAPESTI CORVINUS EGYETEM, Tájépítészeti Kar, \\ Kertmúvészeti Tanszék
}

A jelölt a Budapesti Corvinus Egyetem Doktori Szabályzatában elöírt valamennyi feltételnek eleget tett, az értekezés műhelyvitájában elhangzott észrevételeket és javaslatokat az értekezés átdolgozásakor figyelembe vette, azért az értekezés nyilvános vitára bocsátható.

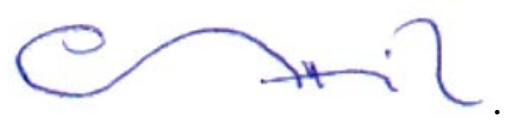

Az iskolavezető jóváhagyása Csemez Attila

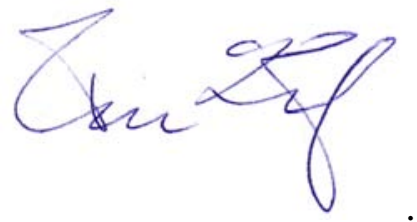

A témavezető jóváhagyása Fatsar Kristóf 
A Budapesti Corvinus Egyetem Élettudományi Területi Doktori Tanácsának 2012. november 27.-i határozatában a nyilvános vita lefolytatására az alábbi bíráló Bizottságot jelölt ki:

\section{BÍRÁLÓ BIZOTTSÁG}

Elnöke:

Csemez Attila, DSc

Tagjai:

Füleky György, DSc

Fekete Albert, $\mathrm{PhD}$

Molnár Zsolt, $\mathrm{PhD}$

Herczeg Ágnes, CSc

Dömötör Tamás, $\mathrm{PhD}$

Opponensek

Illyés Zsuzsanna, CSc

Karancsi Zoltán, $\mathrm{PhD}$

Titkár

G. Tar Imola, PhD 


\section{TARTALOM}

I. BEVEZETÉS

$\begin{array}{ll}\text { I.1. Témaválasztás } & 7\end{array}$

I.2. A tudományos kutatás célkitüzése 8

I.3. A vizsgált terület lehatárolása $\quad 9$

I.4. Szakirodalmi áttekintés 11

$\begin{array}{ll}\text { I.4.1. Kalotaszegi szakirodalom } & 11\end{array}$

$\begin{array}{ll}\text { I.4.2. Egyéb kalotaszegi források } & 15\end{array}$

I.4.3. A tájkarakter-elemzés szakirodalmi áttekintése 16

I.4.3.1. Teleki és körének tájindividuum-fogalma

I.4.3.2. A tájtörténeti-megközelítésü tájkarakter-elemzés

I.4.3.3. A tájtervezői-megközelítésủ tájkarakter-elemzés

I.4.3.4. A tájkarakter-elemzés tájesztétikai megközelítései

I.4.3.5. A történeti tájkarakterrel, tájkarakter-elemzéssel rokon hazai kutatások

I.5. A kutatás felépítése, módszere, kapcsolódó fogalmak 25

I.6. Kalotaszeg regionális kapcsolatainak és téri tagozódásának történeti áttekintése 30

I.6.1. A római kor úthálózata, védmü-rendszerei (III-V. sz)

I.6.2. Középkori, kora újkori térháló: uradalmi, vásározási kapcsolatok (X-XVI. sz.)

I.6.3. Postautak, fogadók; térháló a vasútépítést megelőzően (XVIII - XIX. sz)

I.6.4. A vasútépítés és az iparosítás hatása a térségben (XIX-XX. sz.)

I.6.5. Jelenkor: a motorizáció, szuburbanizáció és az autópálya tájalakítása (XXI. sz.)

\section{FELSZÍNMORFOLÓGIAI ÉS TÉRÉLMÉNY-ALAPÚ TÁJKARAKTER-ELEMZÉS}

II.1. A kalotaszegi térélmények és terepalakulatok leíró vizsgálata

II.1.a. Geológiai-, geomorfológia és a felszínmozgalmasság szerepe a tájképben $\quad 37$

II.1.b. Vízgyűjtők, völgytagoltság tájképi jellemzői

II. 2. A felszínmorfológiai tér-típusok megállapítása és leírása 50

II. 3. A térélményen alapuló tájkarakter-zónák lehatárolása és tájesztétikai megközelítése $\quad 52$

II.3.1 . A tájkarakter-zónák lehatárolási kérdései Kalotaszegen és környékén 52

II.3.2. A tájkarakter-zónák tájesztétikai leírásának saját szempontjai 54

II.3.3. Grafikai szemléltetés, terepmodell-látványrajzok 56

II.4. Kalotaszeg és környékének 13 tájkarakter-zónája és azok jellemzése 57

II.4.1. Bánffyhunyadi-medence - Bhm

II.4.2. Felszegi havasalja $-\mathrm{Fh}$

II.4.3. Felszegi felföld - Ff

II.4.4. Kapusi völgy $-\mathrm{K}$

II.4.5. Havasi falvak $-\mathrm{H}$

II.4.6. Havasi völgyek - Hv

II.4.7. Tordaszentlászlói vidék - To

II.4.8. Alszegi szőlősfalvak - Asz

II.4.9. Váralmási völgyek - Vv

II.4.10. Alszegi barnakőszénvidék - Ab

II.4.11. Nádas-menti völgy $-\mathrm{Nmv}$

II.4.12. Bács-Berendi terület $-\mathrm{Bb}$ 


\section{TÁJKARAKTER-JEGYEK ÉS TÁJKARAKTER-} MINTÁZATOK ELEMZÉSE

III.1. A fejezet módszertani bemutatása

$\begin{array}{ll}\text { III. 1.1. A tájkarakter-jegyek meghatározása } & 74\end{array}$

III. 1.2. Az egyes tájkarakter-jegyek vizsgálati módszere $\quad 75$

III. 1.3. A statisztikai elemzések és a térképes ábrázolás nehézségei 76

III. 1.4. A tájkarakter-jegyek jelentőségére rávilágító tájértékelési módszer leírása 77

III.2. Természetes erdők tájértékelése, és a telepített erdők tájmintázatai és típusai

III.2.1. Az erdőborítottság statisztikai különbségei megyei viszonylatban

III.2.2. A Kalotaszeget határoló „erdőszegély” éles és töredékes jellege

III.2.3. Az erdő mintázatának tájtörténeti jellemzői és eloszlása a zónákban

III.2.4. A mesterséges fenyőtelepítések megjelenési formái

III.2.5. Az erdők tájkarakterben betöltött jelentősége, morfológiai sémarajzok

III.3. Szántók tájértékelése és az agroteraszok tájmintázatai és típusai

III.3.1. Az felszín teraszolásának eredete, története a szakirodalomban

III.3.2. Az agroteraszok, szántási lépcsők, barázdák eredete Kalotaszegen

III.3.3. A kalotaszegi szántási teraszok terepkövetése és szegélyhatásai

III.3.4. A kalotaszegi szántási teraszok morfológiai csoportosítsa

III.3.5. Az agroteraszok kalotaszegi eloszlása, szegélyhelyzetei , morfológiai sémarajzok

III.3.6. A szántóföldek statisztikai tájértékelése, azok téri eloszlása zónánként

III.3.7. Az agroteraszok tájkarakter-elemzésben betöltött szerepének összefoglalása

III.4. Legeltetés, bivalytartás tájértékelése és a fás legelők tájmintázatai

III.4.1. Bivalytartás tájtörténeti vonatkozása, tájértékelése és térbeli eloszlása

III.4.2. A kosarazó juhászat táji vonatkozásai, tájértékelése és térbeli eloszlása

III.4.3. A fás legelők tájtörténete és annak változás-dinamikái

III.4.4. A fás legelők téri megoszlása, mintázata a tájkarakter-zónákban

III.5. Kertek és gyümölcsösök tájértékelése és az ültetvények tájmintázatai

III.5.1. Hagyományos gyümölcsösök megjelenései a falu-, és tájszerkezetben

III.5.2. Ültetvények, új gyümölcsfa-telepítések a faluhatárban

III.5.3. A statisztikai tájértékelése és téri eloszlása a zónákban

III.6. A szőlooterületek tájtörténete, tájmintázata és tájértékelése

III.6.1. A szőlőterületek tájtörténete, mintázata

III.6.2. A statisztikai tájértékelés és téri eloszlása a tájkarakter-zónákban

III.7. A nádasok tájtörténeti szerepe és mai előfordulása a tájkarakterben

III.8. A településszerkezet és a falukép tájkaraktert befolyásoló szerepe

III.8.1. A település-típusok bemutatása, jellemzése és azok mintázati jellemzői

III.8.2. A népi ornamentika jellege és kisugárzása a környékre

III.9. A templomtornyok és látványkapcsolataik tájkarakterre ható szerepe

III.10. A bányászati tájsebek, eróziós jelenségek tájkaraktert befolyásoló szerepe III.10.1. Bányák és bányászati tájsebek, kőfejtők téri tagozódása III.10.2. Talajok, eróziós jelenségek táji mintázata, téri eloszlása III.10.3. Az iparosodás és a szuburbanizáció hatása a tájkarakterre 


\section{A TÁJKARAKTER-ELEMZÉSEK EREDMÉNYEI,}

ÖSSZEVETÉSEK, KÖVETKEZTETÉSEK

IV. 1. A felszínmorfológiai- és térélmény-alapú tájkarakter-elemzés eredményei és összefüggései a térségi tagozódással, zónákkal

IV.2. A tájkarakter-jegyek jelentőségére rávilágító tájértékelési módszer hiányosságai

IV.3. A tájkarakter-jegyek jelentőségére rávilágító tájértékelési módszer összefoglalása, tájkarakter-zónákra vetített konklúziói a „kalotaszegiesség” tükrében

IV.4. A tájkarakter-elemzés két megközelítésnek összehasonlítása: előnyei, hátrányai

IV.5. A tájkaraktert meghatározó tájkarakter-jegyek prioritási sorrendje Kalotaszegen

IV.6. A tájkarakter-jegyek és tájkarakter-mintázatok konklúziói és az agroteraszok kiemelt jelentősége Kalotaszegen

IV.7. Kalotaszeg egységességének ill. tagoltságának megállapítása jellemző tér-élményei, tájkarakter-jegyei, tájkarakter -mintázatainak összevetésével

IV.8. A tájkarakter-zónák tagozódásának összevetése a társadalmi, néprajzi tájegységekkel, népmüvészeti jellemzőivel

V. ÖSSZEFOGLALÁS

IRODALOM

ÁBRAJEGYZÉK

DVD-MELLÉKLET AZ EREDETI ARCHÍV TÉRKÉPEKKEL (KÜLÖN CSATOLVA) 

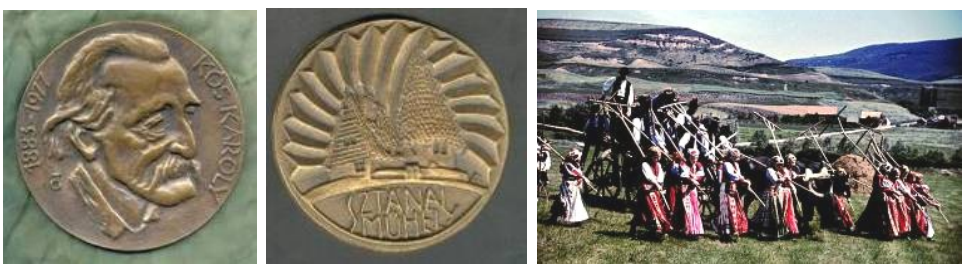

... KALOTASZEG...

„Talán még Erdélynek sincs még egy olyan vidéke, ahol a táj és a benne lakó nép művészete, hegy, völgy, növényzet és az általuk meghatározott építkezés oly tökéletes összhangot alkotna, annyira hasonló, egymásra utaló, egymás nélkül elképzelhetetlen lenne, mint éppen a Kalotaszegen." Balogh Ilona, 1935.

\section{... TÁJKARAKTER-ELEMZÉSE...}

„Minden táj akkor születik meg, amikor a benne együtt létezö földrajzi tények egymással való kapcsolatai úgy alakulnak, hogy egyéniesítő erővel választják el a szomszédos területektől. ... A táj fogalmának lényeges jegye az is, hogy az ember felismerje a földfelszín azon darabjának egyéniségét. A táj tehát kétszer születik. Elöször a Teremtő kezéből, mint természeti táj, másodszor az ember értelméből, amikor külön egyéniségének lakossága által való felismerése folytán külön nevet kap." Fodor Ferenc, 1938. 


\section{BEVEZETÉS}

\section{I.1. Témaválasztás}

Kalotaszeg az Erdélyi-medence néprajzi tájegysége, a magyar kulturális örökség egyik emblematikus vidéke, amely a XIX. sz.-i nemzeti identitás-, és hagyományos motívumkincs-keresés felfedezése során került a néprajz és képzőmüvészet célkeresztjébe. A kimagaslóan igényes tárgyi-, és szellemi kultúrájáról ismert tájegység tudományos kutatása közel 130 éves múltra tekint vissza, így mára az egyik legjobban dokumentált erdélyi tájegységünk. A népzenei, néptánc-kutatások mellett, alapos nyelvészeti, szociológiai, etnikai, földrajzi, agrártörténeti, botanikai, helytörténeti és művészettörténeti kutatások is rendelkezésünkre állnak. Ez a tény éppen annyira segíti e kutatás sikerét, mint amennyire megnehezíti azt: hiszen a tájépítészet szintetizáló szemlélete mindezeket alapul kell vegye, miközben ebből a szerteágazó ismeretanyagból a tájra-, tájképre-, tájkarakterre releváns új eredményeket, téziseket kell megfogalmazzon.

Kós Károly által tervezett, és róla elnevezett Ének-zenetagozatos Általános Iskolában kezdtem tanulmányaimat, ahol az épített környezet nagy hatással volt esztétikai értékrendemre. ${ }^{1}$ Iskolai rendezvényeken rendszeresen elökerült a kalotaszegi polihisztor élettörténete, munkássága és otthona, a sztánai Varjúvár. A későbbiekben ebből a lelkesedésből vettem részt a Hagyományőrző Sztánai Farsangi Mulatságokon, majd 2002-ben csatlakoztam a tájépítészekből szerveződött „Sztánai Mühely” által képviselt táji-értékmentő ideológiához és felmérő táborokhoz. Nyári kalákák során kezdtem terepszemle-szerüen bejárni Kalotaszeg falvait. 2004-ben a Kertész Táncegylet néptánc-oktatójaként Magyarvalkón, majd később Inaktelkén segítettük hagyományőrző programok létrejöttét.

Tájépítészmérnöki és rajztanári végzettségem, környzetpszichológia, tájesztétikai és tájtervezői ismereteim, grafikai készségeim, autodidakta módon elsajátított népmüvészeti és néptáncos jártasságom, és mindezen túl 10 éves helyismeretem ad lehetőséget e tájépítészeti, helytörténeti és néprajzi szintetizáló munka megírására [1.§. melléklet]. A BCE Tájépítészeti és Tájökológiai Doktori Iskola keretében -témaváltás után-, 2009 óta foglalkozom részletesen e kutatási területtel. A Kertművészeti Tsz. anyagi támogatásával, pályázatok, csereprogramok keretében nyertem lehetőséget arra, hogy hallgatókat és vendégoktatókat vigyek a mintaterületre helyszínelések és tájesztétikai, tájtörténeti felvételezések céljából. Az évek alatt nemcsak a „Kalotaszegként” számon tartott 40-45, zömében magyar települést jártam be, hanem sok román faluban és a peremvidéken is jártam, éppen azért, hogy tágabb kontextusban vizsgálhassam kutatási témám. Több, visszatérő táji mozzanat irányította a figyelmemet a táj karakterességére, azok téri határvonalaira és tagozódására. A helyszínelések és adatgyüjtések alkalmával az etnikai, és néprajzi ismereteimet háttérbe szorítva

\footnotetext{
${ }^{1}$ Kós Károly Ének-zenetagozatos Általános Iskolától ballagáskor kapott Érdemérmem (1995) és a Sztánai Mühely számára tervezett bronzplakettem (2003) - egy életre jelképes útravalómmá váltak.
} 
próbáltam valóban „csak” a tájra, tájképre, táji karakterekre és tájhasználati jellemzőkre fókuszálni. Eredeti célom a történeti földrajz, történeti ökológia, gazdaságtörténet, régészet, helytörténet és helynévkutatás eredményeinek komplex, szintetizáló jellegű tájtörténeti összefoglaló megírása volt. Mivel ez monografikusnak-bizonyult, módszertani szempontból tovább szükítettem a témakört a tájban fellelhető egyediségek kérdéskörére. A kutatás során nehézséget okozott a rendelkezésre álló adatbázisok kora, jellege, mintavétele, valamint a jelenkori román adatbázisok korlátozott hozzáférhetősége és a nyelvi korlátok.

\section{I.2. A tudományos kutatás célkitüzése}

Kutatásom célja, hogy a táj karakteressége szempontjából vizsgáljam meg a létező néprajzi tájegységet, Kalotaszeget és annak tágabb környezetét. A kutatás alapkérdései, hogy „Tájépitészeti szempontból vajon igazolható-e a néprajzi-etnográfiai Kalotaszeg, mint Táj?” ill. „,Milyen viszonyban van a néprajzi tájegység a tájépitészeti módszerekkel elemzett tájegységgel, és annak bemutatott tájkaraktereivel?” Nyomatékosítandó, hogy a köztudatban létezö ,,egységes Kalotaszeg”-amely az öt körülvevő román vidékkel szemben általánosan igen karakteres és hagyományos magyar népmüvészeti értékekkel bíró egység-, valójában 4-5 kisebb, egymástól társadalmi kapcsolataiban, és kulturális kohézióját tekintve szeparált „,szeg”-re oszlik: 1. Felszeg, 2. Alszeg, 3. Nádas-mente, 4-5. Kapusi-völgy és Gyalu- Tordaszentlászlói átmenet (egyes források utóbbiakat összevonják) [1. ábra].
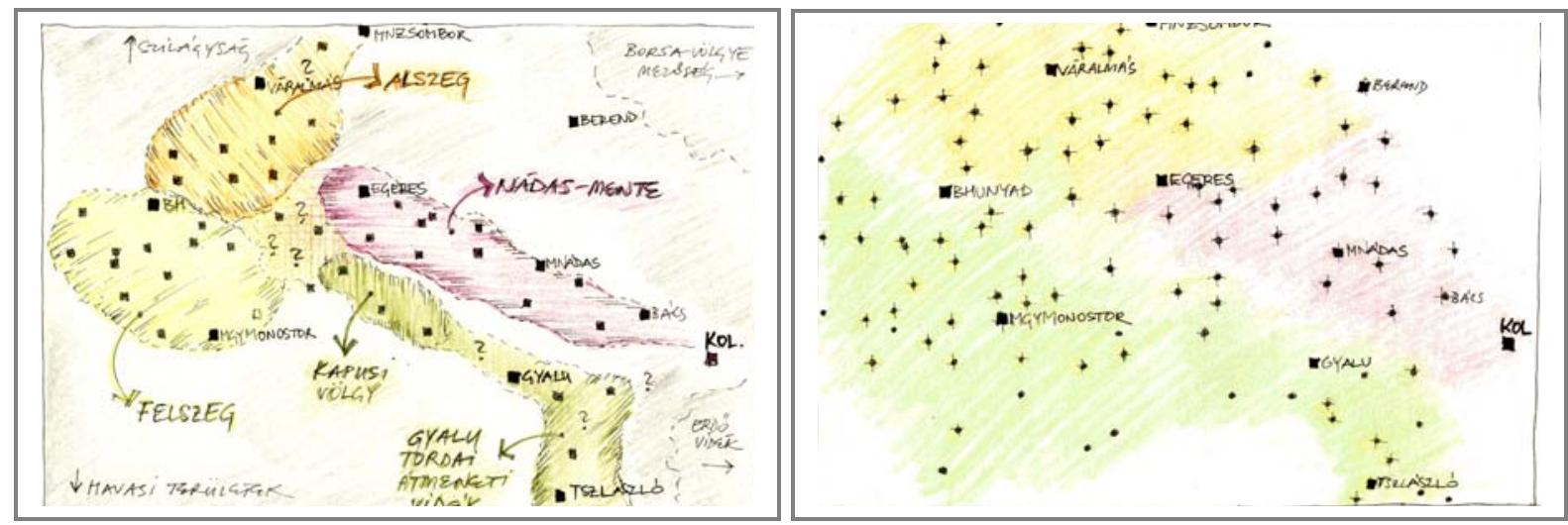

1. ábra: Kalotaszeg fekvése és a néprajzi szempontból közismert tájegységei azokkal a magyar falvakkal, ahol mélyebb néprajzi, etnográfiai kutatások készültek (kb. 45 falu)

2. ábra: Az általam vizsgált falvak (kb. 120 falu) és kereszttel az általam helyszínelt falvak

Ez a belső megosztottság tovább tagolta és finomította kutatási célomat. Így merül fel még alapkérdésként, hogy „Milyen geomorfológia térélmények; milyen tájkarakter-tájmintázatok; milyen (föként XIX-XX.sz.-i) történeti és aktuális tájkaraktert-befolyásoló folyamatok teszik tipikussá és megkülönböztethetövé Kalotaszeg vidékét? Ezek milyen tájkarakter-zónákra bontják a tágabb térséget, és hogyan lehet ezen területeket tájesztétikai-tájképi szempontból jellemezni?” Ez a kérdés 
tulajdonképpen a „Kalotaszegi Táj” tájépítészeti szempontú definiálásához, mint egységet képező Táj létezésének bizonyításához vagy elvetéséhez vezethet, ill. annak feltárásához, hogy Kalotaszeg és tágabb térségének meghatározásra kerülő tájkarakter-zónáinak hasonlóságai és különbségei milyen viszonyban (illeszkedésben, átfedésben vagy éppen ellentmondásban) állnak néprajzi tagoltságával. A vizsgálathoz a tájkarakter-elemzést két-irányból közelítem meg (térélményen, ill. tájmintázati jegyeken alapuló módszerrel), melyek eredményeit végül összevetem.

\section{I.3. A vizsgált terület lehatárolása}

Kalotaszeg határvidéke három másik néprajzi tájegységgel alkot laza kapcsolatot: É-, ÉNy-felé Szilágysággal, DK-felé a Torda-Aranyos vidékével, K-, ÉK-felé áttételesen a Szamos-menti hátsággal, a Borsa Völgyével, és a Mezőség Ny-i szélével. Határait K és D-felé a több száz éve románok által lakott hegyvidékek adják (Vlegyésza, Béles, Gyalui-hegység; ma Apuseni-Mt.). 1920-ig szinte teljes területe Kolozs Vármegyéhez tartozott, ma 3/4-e Kolozs és 1/4-e Szilágy megye közigazgatási területére esik. Kalotaszeg „magja” közel 40 magyar és 20 román települést számlál, hagyományos tájegységközpontja az egykori mezőváros, Bánffyhunyad, de Gyalu, Egeres és Kolozsvár is nagy vonzerővel bírnak. Tágabb értelemben vett K-Ny-i kiterjedése Sebesvártól-Kolozsvárig 60km; ÉD-i kiterjedése Középlaktól-Kiskalotáig 50km, K-en csak 30km, azaz összesen közel 2500km².

A táj szimbolikus tartalommal is bíró, belső magaslati pontja a 737m magas Riszeg-tető, amely a legfontosabb vízválasztó és egyben a négy kisebb tájegység, az egykori járások csatlakozópontja: Felszeg, Bánffyhunyadtól D-re eső, magasan fekvő terület a Kalota- és Kőrös vízgyüjtőjén erős havasalji kapcsolattal; Alszeg, Hunyadtól É-ra, mélyebb, védett fekvésben az Almás-patak oldalvölgyeiben; Nádas-mente, a Riszeg-tetőtől ÉK-re, a Nádas-patak K-Ny-i hosszanti völgyében Kolozsvár felé; Kapus-Gyalu vidéke, a vízválasztótól DK-re, a Gyalui-hegyvidék É-i peremén Kolozsvár felé. Ehhez a négy térséghez a déli, Tordaszentlászló környéki Fenes- és Hesdát-patak-menti területeket is sokan hozzákapcsolják. Ezen tájegységek pontos lehatárolása, peremvidékének megállapítása folytonos kutatások témái voltak.

A helyszínelés során „kalotaszegiként nyilvántartott”2 40-45 települést vizsgáltam meg alaposan, 101 faluban tudtam végezni terepbejárást [2. ábra] [1. tábla], de az adatsorokból végzett statisztikai elemzésben 116, egymással határos (Kolozs, Szilágy és Torda-Aranyos megyei) település övezetére bővítettem a vizsgált területet. A falvak körül minden olyan további települést bevettem a vizsgálatba, amelynek valaha felmerült kalotaszegies-, vagy akár szegély-volta, hogy az átmeneti jelenségeket finomabban lehessen meghatározni. Az összefoglaló táblázat első része az eddigi kutatások/kutatók lehatárolásait, besorolási-egységeit tartalmazza.

${ }^{2}$ A különböző néprajzi, földrajzi besorolások más-más számokat említenek (lásd az Összefoglaló Táblázatot). 
Ebben tüntettem fel az általam vizsgált 116 települést és a saját munkám eredményeként majd meghatározásra kerülő „,kalotaszegies tájkarakterü falvaimat”. A kalotaszegiesség megállapításához két megközelítést vetettem fel. Az első szerint [3. ábra]: ha Kalotaszeget „egészként, egy tájegységként” tekintem, akkor annak szegélyhelyzeteit, határsávját kell, keressem. Ez esetben a területet mag-szerüen, gyürüsen körbevéve: „,Kalotaszegies- Átmeneti- Nem kalotaszegi” zónákra kéne osztani. A tájkarakter szempontjából ez azt feltételezi, hogy a zöld, belső zóna koherens és egyöntetü; és az átmeneti zóna is egységesen különbözik a belső ill. külső területektől. Bár sok földrajzi, néprajzi lehatárolás éppen egy ilyen ,éles határvonalat” keres, én csak részben alkalmaztam ezt a megközelítést, mert nem tükrözte volna a finomabb, belső eltéréseket. ${ }^{3}$ A második megközelítés [4. ábra] a vizsgált 116 falu vidékét 13 kisebb tájkarakter-zónára osztja a térélményeik alapján (II. fejezet), aminek jellemző azután tájkarakter-jegyeit és mintázatait a III. fejezet jellemzi részletesen. Ez a zónás lehatárolás lehetőséget ad a belső koherenciák és diverzitások feltárására, a tájkarakter-zónák jellemzőinek mélyebb, részletesebb kifejtésére.
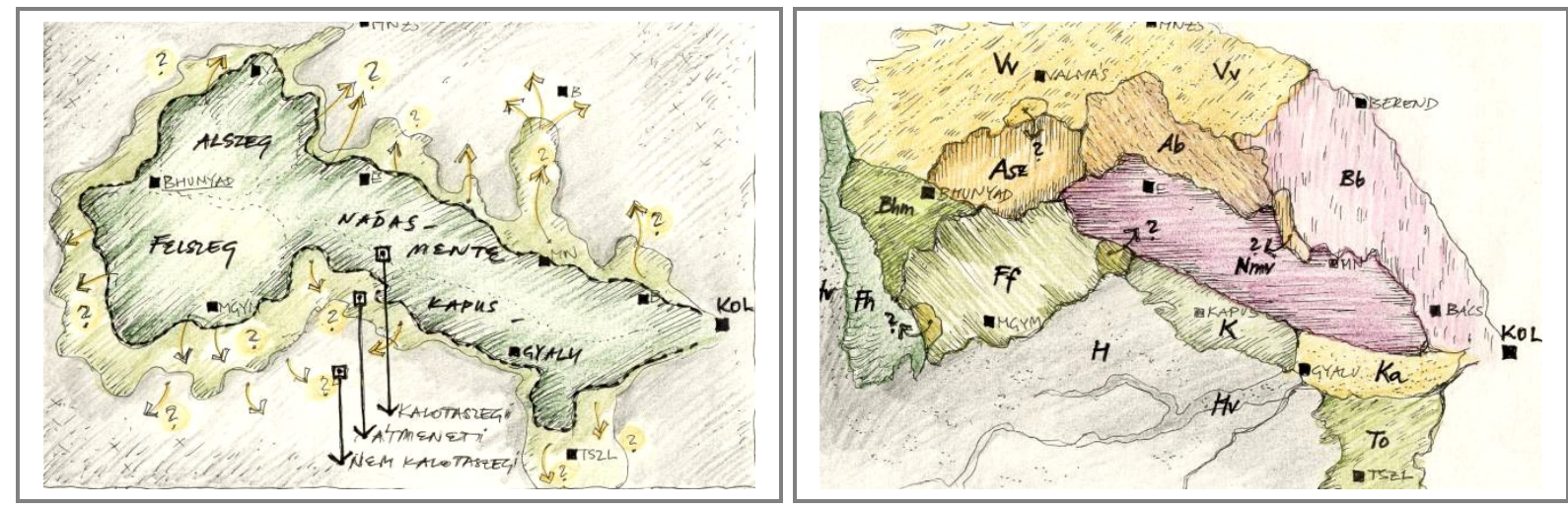

3. ábra: A gyürüs lehatárolás sémája: „Kalotaszegies- Átmeneti- Nem kalotaszegi” övezetek 4. ábra: A zónás-lehatárolás sémája; egymással érintkező, nem átfedő egységek belső karakterjegyeit vizsgálja

${ }^{3}$ Bizonyos tájkarakter-mintázatokban mégis kimutatható lesz egyfajta egységes kalotaszegi-kohézió (lásd a III. fejezetet). 


\section{I.4. Szakirodalmi áttekintés}

A szakirodalmi áttekintés három alfejeztre bomlik: Először (I.4.1.) a kalotaszegi szakirodalmi összefoglalókat, (szekunder-) forrásokat mutatom be tematikus bontásban. Másodszor (I.4.2.) az általam feltárt, eddig fel nem dolgozott térképes, statisztikai és fényképes (primer-) forrásokat, azok lelöhelyét veszem sorra. Harmadszor (I.4.3.) pedig a tájkarakter-elemzés és tájesztétikai leírás módszereit, eddigi nemzetközi és hazai eredményeit tekintem át.

\section{I.4.1. Kalotaszegi szakirodalom}

Általános összefoglalók: A XVIII. sz. második feléből származnak azok a közép-európai útleírások, amelyek az első áttekintések a térségről. Tucatnyit tanulmányozva megállapítható, hogy Kalotaszeg területe ekkor nem tartozott az utazók kiemelt érdeklődési körébe: sem politikai, sem „turisztikai”, sem gazdasági súlypontot nem jelentett. A Pestről induló útvonalak Szatmárnémeti vagy Arad-Temesvár felöl közelítették meg a dél-erdélyi szász vidéket és a Székelyföldet. Az utazók Kolozsvárig eljutnak ugyan, de a Hunyadi-medence leírásával csak későbbi földtani kutatók foglalkoznak részletesen. A szisztematikus országleírások már tartalmazzák a településneveket, etnikaivallási hovatartozást, a nagybirtokosok, nemesi családok nevét és kiemelkedő ásványi kincseit.

Legkorábbi helytörténeti összefoglaló Téglási Ercsei József, tordai erdőmérnöktől jelent meg 1842-ben „Kalataszeg rövid leírása” címmel, aki földrajzi, helytörténeti és néprajzi ismereteit határbejárásokkal szerezte. Néhány állítása szakmai vitát eredményezett személye és Merei Graza György, hunyadi adóíró között. ${ }^{4}$ Ezen cikkek értékes tájrajzi jelzőket, általános táji hangulatképeket festenek Felszegről és Alszegről. (Akkor csak e két vidéket sorolták ide.) Alapos és szisztematikus kutatást végzett még, a fiatalon elhunyt földrajz- és néprajztudós Jankó János a „Kalotaszeg magyar népe” c. könyvében. ${ }^{5}$ A 200 oldalas, szakmailag jól felépített, képeket nem közlő munka releváns ismereteket nyújt tájtörténeti - tájmorfológiai szempontból: A „Topographiai elnevezések” c. fejezet tartalmazza a dűlőnevek tipologizálását, formai elemzését és a mezőgazdasági táj változásából levonható következtetéseket (pl. a szőlő-felhagyását klimatikus okai). Malonyai Dezső 1907-ben megjelent emblematikus „A magyarság néprajza - Kalotaszeg” c. első kötete ${ }^{6}$ a vidék tárgyi néprajzával, díszítőmüvészetével foglalkozik. Szertelen ornamentika-gyüjteményét sokat kritizálta a néprajzi szakma, mégis a tájegység hírnevét e könyvnek köszönheti. A szövegtörzset tagoló ceruzarajzok, akvarellek jó dokumentumai a századforduló tájának, noha pontos helyszínüket általában nem ismerjük. A XX. sz.-ban azután bőségesen jelentek meg a különböző résztémaköröket feldolgozó publikációk, melyeket a néprajzi diszciplína fogott egybe. 1989-ben jelent meg Várady - Borbély két

\footnotetext{
${ }^{4}$ Téglás Ercsei Jószef: Kalataszeg vázolata és Merei Graza György: Kalotaszeg. Kijavítás és pótlék e’ vidék vázolatához. A cikkeket újraközli Hála, 2007. pp. 15-60.

${ }^{5}$ Jankó, 1982.

${ }^{6}$ Malonyai, 1907.
} 
kötetes népszerüsítő összefoglalója, majd Kútvölgyi Mihály fényképalbuma, ${ }^{7}$ amelyek tájképeik miatt bizonyultak hasznos forrásnak. A Erdélyi Kárpát Egyesület kiadványa ${ }^{8}$ és az Erfatur Kalotaszeg térképe helyismeretre alapozott természeti kincsekre és gyakorlati kulturális, turisztikai értékekre felhívó összefoglalók. Végül, bár társadalomtudományi, etnikai, néprajzi és müvészettörténeti alapokra épít, mégis aktuálisan a legfontosabb szintetizáló, általános összefoglaló: Balogh Balázs és Fülemile Ágnes: „Társadalom, tájszerkezet, identitás Kalotaszegen” című munkája ${ }^{9}$. A kalotaszegi kistájak határát és térszerveződését a magyar etnikum társadalmi kapcsolatrendszerei-, házassági kapcsolatai- és presztízs-viszonyai alapján vizsgálja, így a román, mára románosodó határvidék kisebb szerepet kap. Külön fejezet foglalkozik a terület középkori birtokviszonyaival és művészettörténeti emlékeivel és a XX. sz-i magyar-román etnikai feszültségekkel. A címben szereplő „tájszerkezet” a táj-építészettudományban használt fogalomtól eltérően, inkább társadalmi térháló jelentéstartalommal bír.

Földrajz - geológia: Német geológusoktól származnak az első földtani helyleírások, ${ }^{10}$ amelyek az ásványok feltérképezésre irányultak. Fichtel és Lebrecht részletesen taglalja a kolozsvári kerület helyszíneit kiemelve Bács, Gyalu, Kiskapus, Magyargyerőmonostor, Zentelke és Magyarvalkó kőzeteinek leírását. A XIX. sz második felében, párhuzamosan az erdélyi-magyar geológia fejlődésével Hauer minden körzetet részletesen bemutat. Erdély harmadkori üledékeivel és a 75000-es geológia térképek leírásával Koch Antal, az anyagnyerőhelyek, bányák országos összeírásával Schafarzik Ferenc foglalkozott. ${ }^{11}$ Kalotaszeg ,laikusok számára is közérthetö” geológia összefoglalóit ${ }^{12}$ Miháltz István, majd Tulogdy János közölte a század közepén, Pávay Elek és Szádecky Kardos Gyula földtani kutatásaira alapozva. Szakmai cikkek sora található a Magyar Orvosok és Természetvizsgálók Vándorgyüléseinek jegyzőkönyveiben, Orvos-, és Természettudományi Értesítőben, a Földtani Közlönyben és a Múzeumi Füzetek címü folyóiratok számaiban is. Az Erdélyi Kárpát Egyesület, természetjáró és helytörténeti önszervezőző társadalmi csoport „Erdély” címü lapjában szintén sok, igényes grafikával illusztrált ismeretterjesztő cikk jelent meg. Hála József néprajzkutató és geológus a Vistán mutatja be a Nádas-menti népi kőfejtés és kőfaragóipar interdiszciplináris kapcsolatát. ${ }^{13}$

Történelem - régészet - helytörténet: A terület római kori emlékeivel, észak-nyugat Dácia történelmével a XIX. sz. végén Ferenczi István, Torma Károly, Buday Árpád, majd román régészek és Wanner tájrégészeti disszertációja is foglalkozik. Kolozs megye történeti földrajzának általános árpádkori összefoglalása Györffy Györgytől, XV. sz-i összefoglalása Csánki Dezsőtől származik. Mindkét

\footnotetext{
${ }^{7}$ Várady - Borbély, 1989. és Kútvölgyi, 2005.

${ }^{8}$ Ajtai - Fogarasi - Váradi, é.n.

${ }^{9}$ Balogh - Fülemile, 2004.

${ }^{10}$ Fichtel, 1780., Lebrecht, 1804.; Marienburg, 1813.; Benigni, 1827.; Hauer - Stache, 1863.

${ }^{11}$ Koch, 1874, 1884, 1894, 1900.; Koch - Hofmann, 1889., Schafarzik, 1904.

${ }^{12}$ Miháltz, 1926a, 1926b., Tulogdy, 1930, 1943, 1944.; Pávay, 1871.; Szádeczky, 1897a, 1897b, 1900.

${ }^{13}$ Hála, 1995.
} 
munka „Kolozs megyei” fejezete a levéltári összeírásokra, tizedjegyzékekre alapozva sorolja fel a települések, lakosok rendszerét. ${ }^{14}$ A megye kialakulásával, birtokrendszerével foglalkozik a történész Balázs Éva akinek szemléltetési módszerét átemelve Fülemile Ágnes ${ }^{15}$ is térképvázlatokon vizualizálva foglalja össze a középkori Kalotaszeg térstruktúráját. A levéltári iratokból Szabó T. Attila ${ }^{16}$ gyüjtette össze a XVII-XX. sz.-i tájtörténeti adatokat tartalmazó helyneveket, alapvetően nyelvészeti céllal. Az utóbbi években néhány településről részletes helytörténeti kutatás készült. ${ }^{17}$

Mezőgazdaság - botanika: A tájhasználat és a mezőgazdaság alapvető forrásai a helynevek, dűlőnevek, mezőgazdasági statisztikák, térképek és helyszíni bejárások. A már említett Kalotaszeg helynevei című gyüjtés a helytörténet és az egyedi tájértékek tükrében kitünő forrás. ${ }^{18}$ A történeti területhasználat összeírásában átfogó munka a 1820-as Czikáry-féle Úrbéri Összeírás (Conscriptio Czirákyana, MOL F52), amelyet átiratban Takács közöl. ${ }^{19}$ Mindkettő a falu határának jellegét, legfontosabb elemeit írja le a földminőségre, malmokra, vásárhelyekre és a földesúri szolgáltatásokra vonatkozólag előre megadott kérdéssorra válaszolva. Szintén átfogó, országos jellegü a „Pesty Frigyesféle Helységnévtári” gyüjtés $1864-b o ̋ l,{ }^{20}$ amely során helyi tanítók és egyházi személyek küldték el levélben különböző alapossággal megírt helytörténeti határleírásaikat. A tájtörténet további forrása az „Erdélyi Gazdasági Egylet Évlapja” című periodika (1854-1867) és az „Erdélyi Gazda, Köz- és Mezőgazdasági hetilap" (1869-1945), amely azonban csak néhány cikkében foglalkozik kalotaszegi gazdakörökkel, rendezvényekkel. A visszacsatolás utáni időszak alapos helyismereti összefoglalója Solty: „Kalotaszeg mezőgazdasága”21 sajnálatosan hivatkozásokat nem tartalmaz. A cikk több, az Erdélyi Magyar Gazdasági Egyesület (továbbiakban EMGE) Kolozs megyei kirendeltsége által szervezett kultúrmérnöki munkára hivatkozik. Mivel az EMGE-iratok évek óta rendezésre várnak a megyei levéltárban, azok nem kutathatók. A kutatás alapjaiban támaszkodik a néprajzkutató, ifj. Kós Károly 1944-es „Népi földművelés Kalotaszegen” c. disszertációjára, amely a mezőgazdasági művelés, állattartás, a gazdálkodás teljes munkaszervezését és annak tárgyi néprajzi vonatkozását mutatja be. Növényföldrajzi témában alapkutatás Szabó Attila és Péntek János: „Ember és növényvilág Kalotaszeg növényzete és népi növényismerete" c. könyve. ${ }^{22}$ Az 198a-as évekből való munka tartalmazza a jellegzetes növénytársulások típusait és leírását; az egyes gyógynövények etnobotanikai

\footnotetext{
${ }^{14}$ Györffy, 1963-87.; Csánki, 1912, 1913.

${ }^{15}$ Balázs É., 1939. és Balogh - Fülemile, 2004.

${ }^{16}$ Szabó T. A., 1934, 1940, 1942.

${ }^{17}$ Ketesd és Körösfö: Sebestyén, 1996, 2007; K.szentkirály: Balogh-Fülemile, 2001.; Szucság: Antalné Szép I. 2007.

${ }^{18}$ A települések különböző korú, szükebb-bővebb levéltári adatai nehezen összevethetőek. A 30 000 helynévhez csak területhasználat tartozik, így helyszíni „térképiesítése” embert próbáló feladat. Az 1941-es térképvázlatok csak pontszerủen ábrázolják a dülőket, így nehéz következtetni azok téri kiterjedésére, melyre Szabó T. is rávilágít: ,„a térképvázlatok készítésekor csak a népiség-, település- és helynévtörténet érdekeit tarthattuk szem előtt és a földrajzi kutatás alapos térképezési készültséget kívánó feladatainak megoldására nem vállalkozhattunk.” in: Szabó T. A. 1944., p. XVIII.

${ }^{19}$ Takács, 2006.

${ }^{20}$ Magyar Nemzeti Múzeum, kézirattár, Fol. Hung. 1114.sz. XXII.; teljes terjedelemben közli Szabó T. A. 1942.

${ }^{21}$ Solty, 1944.

${ }^{22}$ Péntek J-Szabó A., 1985.
} 
szerepét és a házikertek dísznövényeit. Az utóbb említett két alapkutatás egyike sem fektet azonban hangsúlyt a mélyebb térképészeti elemzésekre, tájváltozási tendenciákra, a „modern” táji beavatkozásokra (udvar-kertek, mesterségesen telepített gyümölcsösök, erózió-védő fenyvesek, bányászati tevékenység) ill. ennek vizuális, tájesztétikai megközelítésekre.

Müemlékek - népi építészet: A középkori fatornyos-templomépítészet virágzása után, Kós Károly sztánai letelepedésével maga is új építészeti jelentőséget adott Kalotaszegnek. Mủemlékeivel ${ }^{23}$ elsőként Kőváry László történész fogalakozott, majd átfogóan, müvészettörténeti mélységben levéltári kutatásokra támaszkodva Kelemen Lajos, később Kabai Béla, Bíró József. B. Nagy Margit a kastélyok és udvarházak terén végzett mélyebb kutatásokat Erdély-szerte, de Kalotaszegről csak kevés emlékét érinti, mert a századforduló „másod-, és harmadrangú” kúria-épületeire, kisebb udvarházaira, nyaralóira, kevesebb figyelmet fordított (Gorbó, Zsobok, Kiskapus, Magyarókereke, Nádasszentmihály, Magyarsárd). Szinte Gábor és Balogh Ilona levéltári adatokkal és helyszíneléssel tanulmányozta a magyar és román népi fatemplomokat. ${ }^{24} \mathrm{~A}$ vidék népi építészetével ${ }^{25}$ már a XIX. sz. végén a földrajz-néprajzkutató, Bátky Zsigmond foglakozott, aki terepszemléi során egyben Felszeg és Alszeg első fotódokumentációját készítette el. Tudományos mélységü, levéltári forrásokon alapul Miklósi-Sikes Csaba: „A kalotaszegi falvak népi építészetéről” c. tanulmánya és adattára. Furu Árpád építész „Kalotaszeg népi építészete” c. új könyve igényes képanyagával és a falvak település-, és telekszerkezetének leírásával mutat be új ismereteket a témában.

Néprajz - folklór - népmüvészet: A lehatárolásához felhasználom az eddigi néprajzi kutatások téri kiterjedésre vonatkozó eredményeit. E témakörök tekintetében áttekintést ad a „Kalotaszeg bibliográfiája.” ${ }^{26}$ Pávai István „Erdély a magyar néprajz-, népzene- és a néptánckutatás tájszemléletében" c. összefoglalója ${ }^{27}$ a tájegység téri helyzetével, kistájaival foglalkozik, amelyet a táji jellemzőkkel lehet párhuzamba állítani. Mivel kutatásomnak nem célja a néprajzi szakterületek áttekintése, csak az e téren publikálók témakörét mutatom be a teljesség igénye nélkül: Kalotaszeg viseletek: Faragó J., Nagy J., Vámszer G., ifj. Kós K., Palotay G., Gönyey S., Fülöp H., Tötszegi T.; Népszokások, népdalok: Almási I., Démény P., Orosz K., Vasas S., Salamon I., Fejős Z.; Néptánc: Martin Gy., Pesovár E., Karácsony Z.; Népzene: Pávai I.; Nyelvészet- nyelvjárás: Szabó T. A., Árvay J., Péntek J., Gálffy M., Gergely P., Lakó E.

\footnotetext{
${ }^{23}$ Kőváry, 1892; Kelemen 1943, 1944, 1975; Kabai B., 1973., Bíró, 1943,

${ }^{24}$ Szinte, 1913; Balogh I., 1935; Herepei - Szabó T. A. 1939., Miklósi-Sikes, 1999.

${ }^{25}$ Bátky, 1907., Miklósi-Sikes, 1999;; Furu, 2007.

${ }^{26}$ Ercsei, 2001.

${ }^{27}$ Pávai, 2006.
} 


\section{I.4.2. Egyéb kalotaszegi források}

Statisztikák: Az 1897-es Országos Mezőgazdasági Statisztika egy a müvelési-ágakra, és részletesen a gyümölcs-, és állat-állományara vonatkozó településsoros összeírás. ${ }^{28}$ 1910-ben már árnyaltabban, 8 minőségi kategóriába sorolva földrészletekkel, adókategóriákkal vették számba a települések müvelési ágait. E két adatsor képezi statisztikai elemzéseim alapját. A századfordulós három Gazdacímtár ${ }^{29}$ a 100 kataszteri holdnál nagyobb földbirtokosok jegyzékét, birtok-összetételét, bérlőit mutatja, melyből a kalotaszegi falvak nagy-, és közepes birtok-struktúrájára következtethetünk.

Térképes források: A katonai felmérések térképei adják helyszíni kutatásom alapját, melyeket mélyrehatóan tanulmányoztam (noha teljes terjedelemben nincsenek befüzve). A harmadik, néhány évenként reambulált, 1:75 000-res szelvények általában naprakész infrastrukturális változásait is szemügyre vettem. Észak-Erdély visszacsatolásakor készült egy javított 1:50 000-es, színes térképsorozat, de ez sajnos nem tartalmazza Kalotaszeg, Romániánál maradt déli részét. 1941-ból hiányosan rendelkezésre áll egy magas repülésü katonai légifelvétel-sorozat, mely inkább Alszeg és Felszeget örökítette meg. ${ }^{30} 1970$ körül a román közigazgatás légifelvételek alapján készítette el 1:5000-es topográfiai (csak szintvonalas) és területhasználati (csak müvelési ágakat elkülönítő) szelvényeit, amelyek a Kolozs és Szilágy megyei földhivataloknál érhetőek el. A raszteres szelvények jó forrásai a tájhasználatnak, az agroteraszok szerkezetének, azonban költséges beszerzésük és a Kalotaszeget lefedő közel 500db 6km2-es szelvény feldolgozhatatlan adatmennyiség. Tájkarakter-elemzési munkához azonban jó léptékü az Erfatur 1:70000-es Kalotaszeg turistatérképe és a Googleearth adatbázisa. A tájtörténeti vizsgálatban az OSZK Térképtárának XVII-XVIII. sz.-i anyagait és a MOL Kéziratos térképeit használtam fel, valamint a XIX. sz. vármegyetérképeit és az OMM áttekintő posta-, és távolságmutató térképeit. A speciális vasúti szaktérképek (MÁV-Tervtár) és a XIX. sz. második feléből származó hiányos helyszíni kataszteri térképek is tartalmaztak értékes tájtörténeti részleteket.

Fényképes források: Sajnálatos módon a korai időszak főként müemlékeket, nagyvárosokat; a néprajzi kutatások épületeket, tárgyakat, viseleteket, szokásokat örökítettek meg, és a nyílt tájkép, a mủvelés látványa nem volt elsődleges téma. A Néprajzi Múzeum fotótárának 3000 fényképét és diasorozatát átnézve csak 70 db. tartalmazott táji háttér-részleteket (Bátky Zs., Györffy Gy., Erdődi M., Tagán S., Szabó K., Szőllősy K., Gergely P., Erdélyi Z., Hofer T., Földes L., Vámszer G.). Korai képeivel ( 1870) Veress Ferenc kolozsvári és D. Galloway angol fotóművész, majd Balogh Ernő, kolozsvári geológus emelkedik ki (ezek a Képkönyvtár honlapon érhetők el). A Kriza János Néprajzi Társaság honlapján, zömében a XX.sz. második feléből való képei digitálisan érhetőek el.

\footnotetext{
${ }^{28}$ Mezőgazdaság Stat., 1897, Kataszteri, 1914a és 1914b

${ }^{29}$ Baross, 1893.; Gazdacímtár, 1897.; Gazdacímtár, 1900. - eltérő felvételi szempontjai miatt nehezen összevethetőek.

${ }^{30}$ Hadtörténeti térképtár: (5270, 5271), légifotók: 661588- 66177, 1941. V. 24.
} 


\section{I.4.3. A tájkarakter-elemzés szakirodalmi áttekintése}

\section{I.4.3.1. Teleki és körének tájindividuum-fogalma}

A hazai földrajzi tájszemléletben először Teleki Pálnál jelent meg a tájkarakter-elemzés kérdése: „A tájak tipikus karaktere körül jegesedik ki a földrajzi leírás egész feladata ... a táj individualitásának kidomborítása, mint tájaknak egymás közötti összehasonlítása, a tipikus különbségek, de a tipikus hasonlóságok keresése is." "31 A XX. sz. első felének (Humbold, Hettner, Schlüter, Hellpach), holisztikus emberföldrajzi megközelítésében Teleki és köre hangsúlyozta, hogy minél több jelenséget és faktort hozzá kell kapcsolni a „Táj Életéhez”. Dékány összefoglalójában ${ }^{32}$ a földrajzi szemlélet céljaként a „szigulárisat” keresi, a Földön egyedülálló „földrajzi individuumot”, amely a tájat a „helyi különbségek komplexumaként” definiálja. Bár Teleki elveti az osztályozó feladatot (helyette a tájalkotó elemek szimbiózisát nézi), mégis kiemeli, hogy „minél kisebb egy terület, annál erősebb az individualitása; minél nagyobb, annál kevesebb”. Tanítványa, Fodor Ferenc is ezt a „,tájéletrajzi” megközelítést támogatja, amelyben a „karakteresség” fontosságát húzza alá: „Minden táj akkor születik meg, amikor a benne együtt létező földrajzi tények egymással való kapcsolatai úgy alakulnak, hogy egyéniesítő erővel választják el a szomszédos területektől. (...) A táj fogalmának lényeges jegye az is, hogy az ember felismerje a földfelszín azon darabjának egyéniségét. A táj tehát kétszer születik. Először a Teremtő kezéből, mint természeti táj, másodszor az ember értelméböl, amikor külön egyéniségének lakossága által való felismerése folytán külön nevet kap." 33

Ez a háború előtti korszak egyértelmüen komplex tájszemléletet tükrözött, ugyanakkor a „karaktert” csak sejteti. Nem állít fel kategóriákat, mintázattípusokat, szempontokat, és nem is kívánt minden vidéket osztályozni, hanem -a néprajzi szemlélettel párhuzamosan-, csak egyes vidékek átlagostól jobban eltérő karakterességét emelte ki. Ez a megközelítés kutatásomban is további kérdéseket vetett fel: Minden terület lefedhető egy tájkarakterrel, vagy léteznek jellegtelen tájakkal szemben erős individuumú vidékek? Mi az a természetes egység/méret, ahol a tájkaraktert relevánsan megállapítva összetartozó, egyéni, koherens zóna alakítható ki?

A háború után e holisztikus szemléleten úrrá lett a tudományosabb, rendszerelvü, analitikus leírás, és a „tájéletrajzi”- megközelítés ismételten, csak külföldi hatásra, az elmúlt húsz évben lett ismét népszerü: Nemzeti Parkok - Történeti tájak - Európai Kultúrtájak - Világörökségi Tájak Tájegyezmények - Tájidentitási antropológiai megközelitések hatására került újra elötérbe. Ma, a korábban már külföldön kidolgozott módszereket ültetjük át a hazai gyakorlatba. E kutatás néprajzi vetülete, a népmüvészeti és a táji szempontok összekapcsolása sajátos igényeket támaszt a módszerrel

\footnotetext{
${ }^{31}$ Teleki, 1917. p. 192.

${ }^{32}$ Dékány, 1918. pp. 9-13.

${ }^{33}$ Fodor, 1938. pp. 142-143.
} 
szemben, ezért a külföldi tájkarakter-elemzési módszerekből csak részleteket, elemeket tudtam adaptálni kutatási céljaimhoz.

Tájépítészeti- tájtervezői szakterületünkön a ma legáltalánosabb definíció Swanwicktól származik: „A tájkarakter, egy adott tájrészlet mintázata, jellege, amely különböző összetevők egyedien jellegzetes kombinációjából jön létre, azaz más tájrészletektől jól elkülöníthető egyedi megjelenése van." Ezt okozhatja hagyományos növénytakarója, geomorfológiai alakzatai, történeti mủvelési módja, birtokviszonyai, speciális nyersanyagai vagy gazdasági hasznosítása. „A tájkarakterelemzés, olyan strukturált megközelítés, amely az egyes tájak, tájrészletek egyediségét és annak értékeit határozza meg." ${ }^{34}$ Kutatásomban én is ezt a megközelítés és értelmezést alkalmazom. Az angol szakirodalomban két irányzat dominál: az egyik a tájak régészeti jelentősége, történetisége alapján (örökségvédelmi - múltorientált), a másik a tájtervezői, tájrendezői (beavatkozási - jövőorientált) célok alapján alakítja ki fogalmait, módszereit.

\section{I.4.3.2. A tájtörténeti-megközelítésű tájkarakter-elemzés}

(HLC = Historic Landscape Characterisation) [2.§. melléklet]

Egy 1994-es irányelv ${ }^{35}$ kimondja: minden táj, ha különböző mértékben is, de régészeti és történelmi képződmény, és értéke éppen a komplexitásában, regionális diverzitásában és megkülönböztetett helyi jellegében van. Az Egyesült Királyság területén egy régészek-köré szerveződő csoport (Rippon - Fairclough köre) a tájak történeti dimenzióit, történeti fejlödésének korszakait helyezi előtérbe alapvetően régészeti leletekre, feltárásokra alapozva. A ma funkcionáló táj történeti elemeire mutat rá, amelyek átalakulva ma is használatban vannak (pl.: vadaskertek-, telekhatárok, régi utak), vagy eredeti szerepüket elvesztve reliktumként maradtak meg a táj felszínén. Ez az irányzat az idősíkok komplexitásának jelentőségét hangsúlyozza, és célja, hogy minden tájrészletről kimondja kialakulásának időpontját, használati formáját. Éppen ezért kritikus a tájak „,csupán” természeti értékeivagy vizuális szépsége alapján történő értékelésével szemben. ${ }^{36} \mathrm{E}$ karakter-elemzés a helytörténetből, tájrégészetből és történeti földrajzból fejlődött ki, de ez nem csupán egy technika, hanem inkább megközelítési mód, amely a tájkarakter korszakonkénti téri variációit írja le és annak régészeti-történeti dokumentumait integrálja. A módszer a nyilvánosan is elérhető régészeti topográfiákra és az évenként újra felvett, 25 000-es történeti kataszteri (OS) térképekre támaszkodik. A karakterezés alapját a pontokból, elemekből, parcellákból építkező történeti tájmintázatainak (historic landscape pattern)

\footnotetext{
${ }^{34}$ Eredeti szöveg: Landscape character, which is the pattern that arises from particular combinations of the different components, can provide a sense of place to our surroundings. Landscape Character Assessment is a characterisation process, involving identifying, mapping, classifying and describing landscape character, and a process of making judgements based on landscape character to inform a range of different decisions. in: Swanwick, 2002. p.3.

${ }^{35}$ Eredeti szöveg: The whole of the landscape, to varying degrees (...) is an archaeological and historic artefact (...) much of its value lies in its complexity, regional diversity and local distinctiveness - Irányelv: PPG 15, Planning in the Historic Environment, in: Swanwick, 2002. p. 4.

${ }^{36}$ Fairclough - Rippon, 2002., és Rippon, 2004.
} 
egymásra vetítése adja. Mivel az angol táj valóban rendelkezik ezekkel az erős vizuálisan jól nyomon követhető határoló-vonalakkal, szövetekkel, ${ }^{37}$ így az elemzések általában látványosan szemléltethető grafikai mintázatot, rajzolatot adnak. A módszer hiányossága, hogy a térképezés sematikus-logikai rendszere elnyomja a tájak látványának, sziluett-vonalainak szerepét.

Adaptálás. Jelen kutatásban ennek a módszernek csak részei adaptálhatók. Mivel Kalotaszeg nem rendelkezik különböző történeti korokból fennmaradt jelentős és mintázatként (landscape pattern) definiálható útvonal-, telek- vagy határstruktúrával, így a Rippon-féle teljes módszertan nem átemelhető a jelen kutatásba, csak az erősebb alaktani jellemzőkkel bíró kalotaszegi művelési módok, visszatérő táji ritmusok kihangsúlyozhatók. (Ezek a III. fejezetben részletesen kifejtésre kerülnek.) Romániából sajnos nem állnak rendelkezésre olyan széleskörü régészeti adatbázisok és topográfiák, amelyekre egy történeti tájkarakter-elemzést alapozni lehetne. Így csak a tájrégészeti-jellegü terepszemléim során elsajátított, a tájtörténeti emlékek, a tájértékek, a reliktum-tájak felismerésére vonatkozó készséget tudtam alkalmazni.

\section{I.4.3.3. A tájtervezői-megközelítésű tájkarakter-elemzés}

\section{(LCA=Landscape Character Assesment) [3.\$. melléklet]}

A másik irányzat tájtervezői, területfejlesztői, tájvédelmi irányból közelít a tájak mai képéhez. E tájkarakter-elemzés célja nem az, hogy ellenálljon a tájat befolyásoló változásoknak, hanem inkább eszköz a döntéshozók számára abban, hogy milyen jellegü a táj mai arca, hogyan alakult ki az az állapot, és feltételezhetően hogyan fog változni a jövőben. ${ }^{38}$ A módszer megalapozója C. Swanwick, a Sheffieldi Egyetem tájépítész-oktatója. A módszer több léptékben is alkalmazható: nemzeti, regionális szinten ( 1:250 000: nagytájak, régiók), megyei, kistérségi szinten ( 1:50/25 000: finomabb tájformák, borítottság, mintázat) és helyi, lokális szinten ( 1:10 000: uradalmak, birtoktestek, falvak). Minden elemzés alapját a tájkarakter-típusok (Landscape Character TYPE) és tájkarakter-területek (Landscape Character $A R E A)^{39}$ elkülönítése és besorolási rendszere adja az adott tájrészleten. Többnyire „fentrőllefelé” (,,top-down approach” = a nagyobb területi egységböl a kisebb területi egység felé haladva) osztja be a tájat típusokba, azok területére, majd azok típusaiba és azok területeire. Az elméletben egyszerünek tünő kategorizálás a vizsgálati területen elvégezve rávilágított a módszer hiányosságaira (lásd a II.3.1. fejezetet).

\footnotetext{
${ }^{37}$ Bronzkori-, kelta-, római-, kora és későközépkori telek és útvonal rendszerek adják; majd a XVIII.sz.-i zárt legelők (enclosure) grafikus mintázata (méret, arány, határvonalak, mozaikosság) településrendszerek adják.

${ }^{38}$ LCA (Landscape Character Assesment) is not a tool designed to resist changes ... Rather it is an aid to decisionmaking - a tool to help understand what the landscape is like today, how it came to be like that, and how it may change in the future. Its role is to help ensure that change and development doesn't undermine whatever is characteristic or valued about any particular landscape, and that ways of improving the character of a place can be considered. in: Swanwick, 2002. p.6.

39 Egy adott tájkarakter típushoz a táj jellegét tekintve egynemünek tekinthető részletei tartoznak: területi szempontból tehát számos előfordulása lehet. A tájkarakter terület ezzel szemben egy adott tájkarakter típus meghatározott földrajzi egységhez kötődő, egyedi előfordulása, amely ezáltal önálló földrajzi megnevezéssel is azonosítható. in: Kabai, 2010. p. 100. (Swanwick alapján)
} 
A módszer első része egy értékítéletektől mentes tájkarakter-elemzési/jellemzési folyamat (1.Landscape Characterisation). Ez komplex, objektív módon nézi a térséget szakirodalmi, térképes és történeti kutatás nyomán (DESK study); az alapkutatások (talajtan, geológia, erdőborítottság, stb.) térképeit használja fel, de azokból csupán „szemügyre-vételezéssel” kezdi kialakítani a hasonló térségeket, amelyeket később a helyszínen tesztel. Ezután vizuális, észlelési tapasztalatokra, érzékszervi- hangulati benyomásokra épülő szubjektív terepbejárást tesz. Az itt kiválasztott helyszínekre és onnan feltáruló látványpontokra alapozza a tájleírást (FIELD survey). Tájépítészként hangsúlyt fektet a fényképezést felülíró grafikai reprezentációra; és a helyszíni tájélményekre alapozott tájesztétikai kritériumokra, ${ }^{40}$ amelyben nagy szerepet kap a felvételező személy szubjektív értékítélete (szisztematizálva v. teljesen szabadon rögzítve). Tájleíró témakörei rövid szempontokat tartalmaznak 8 témában: (1) egyensúly és arány; (2) lépték; (3) zártság; (4) textúra; (5) színhatások; (6) diverzitás; (7) egységesség és (8) formavilág. Felvételezési adatlapján a megjelölt témák skáláinak előre determinált (4-5 fokozatú jelzős) kifejezései közül lehet csak választani. Kiemeli, hogy bővített melléknévlista tartozzon a látványrajzok elemzéséhez, hogy a leírás hangsúlyozza a speciális táji jegyeket, valamint, hogy a személyes-leírások kiemelt módon befolyásoló tényezők lehetnek (e.g. a tervezők döntési folyamataiban). Véleményem szerint Swanwick kategóriái nagyon általánosak; regionális viszonylatban megfelelő ugyan, de melléknév-állománya pl. egy konkrét dombvidéki szőlőműveléssel foglalkozó tájrészlet belső individualitásának leírásához már nem elég érzékletes.

A módszer második része a beavatkozást elökészitő értékelési/javaslati folyamat (2-Making judgements). A táj jellemzőit-, állapotát-, változását-, valamint a változással szembeni érzékenységéttájépítészeti irányelvek segítségével fordítja le a gyakorlati cselekvés nyelvére. Tájkarakter-elemzési konklúziói útmutatóként szolgálnak, hogy az adott tájrészletben hogyan végezhető el bizonyos típusú beruházás vagy tájhasználat-váltás a kedvezőtlen hatások minimalizálása mellett, az előnyök kiaknázásával. Másrészt rámutat azokra a tájalakítási, tájhasznosítási lehetőségekre, amelyekkel az adott táj karaktere megőrizhető, gazdagítható vagy helyreállítható. ${ }^{41}$ A hazai gyakorlatban KonkolyGyúró Éva kutatásai állnak közel e módszerhez (lásd a I..4.3.5. fejezetet).

Adaptálás: E dolgozat nem kíván fejlesztési/rendezési javaslatokat adni, így a Swanwick-féle módszer csupán első része hasznosul. Mivel a jelent kutatási módszer inkább „belülről-kifelé” keresi a hasonlóságokat, és nem célja Kalotaszeg kárpát-medencei viszonylatban való besorolása és hasonló tájkarakter-területek és típusok felállítása. Így szükebben értelmezhető Kalotaszeg vidékének „típus >

\footnotetext{
${ }^{40}$ „Visual Assessment Criteria és Perception: Other aspects of landscape perception may be more subjective and responses to them might be more personal and coloured by the experience of the individual. Such factors include a sense of wildness, sense of security, the quality of light and perceptions of beauty or scenic attractiveness. There are also some factors that can be perceived or experienced by senses other than sight, such as noisiness or tranquillity and exposure to the elements. Judgements about all these, and other relevant perceptions, need to be incorporated into surveys in a transparent way, acknowledging the extent of subjectivity that is involved. Both checklists and written descriptions can be used to record responses in the field.”, in: Swanwick, 2002. p.34.

${ }^{41}$ Kabai, 2010. p.101.
} 
terület $>$ típus $>$ terület" lépcsős besorolása is. A tájkarakter-elemzéshez azonban átemelésre került a zónák lehatárolásának, megnevezésének, leírásának, grafikai ábrázolásának módszere.

\section{I.4.3.4. A tájkarakter-elemzés tájesztétikai megközelítései [4.§. melléklet]}

A térbeliségre és látványokra alapozott tájesztétikai leírás alapvetően a szemlélő egyéni benyomásait, percepcióit, tájérzékelését és tájészlelési megfigyeléseit veszi alapul a leírásában, amely majd a dolgozat II. fejezetében jelenik meg, és amelynek fontosságát már Swanwick is kiemeli. A tájak esztétikai leírásával több, mint 100 éve foglalkoznak esztéták, filozófusok, környezet-pszichológusok, ${ }^{42}$ de a hazai tájépítészeti diszciplínában eddig kevés szó esett ilyen jellemzésröl. ${ }^{43}$ A Magyarvalkón végzett Tájesztétikai és Tájköltészeti Mühely során ${ }^{44}$ különböző érzékszervi-, észlelési-, fenomenológiai gyakorlatokkal írtunk le több tájrészletet, amely a látványból fakadó alaktani jellemzőkre és az azokból származó spontán asszociációkra, testi/lelki hatásokra, hangulatokra, érzelmekre helyezte a hangsúlyt. A fent már említett Swanwick-féle, 8-témás leírás mellett, az alábbiakban további módszereket mutatok be:

$\underline{\text { Az asszociatív tájészlelés }}{ }^{45}$ lényege, hogy egy adott látványra való 10-15 perces elcsendesedés, ráhangolódás után spontán szavakat, asszociációkat, benyomásokat rögzítenek a résztvevők. Ebben a tájjal való aktív kommunikációban a külső/belső tájrészletek összeolvadnak és a létrejövő táji benyomások adják az elemzés alapját. Kontemplatív módon, a táj egységes, ránk gyakorolt hatását hagyjuk érvényesülni, amely alapvetően tudat alatti emlékeket, gondolatokat, asszociációkat hoz felszínre és nem objektív szakmai elemezésből fakad. A szubjektív résztvevői vélemények összevetése során a leggyakoribb fogalmak kiemelésével a tájjellemzés objektívabbá tehető. Az elemzés jelentősége, hogy éppen olyan minőségek, fogalmak társulhatnak a látványhoz, amelyek „,szigorú szakmai" szempontból nem feltétlenül jutottak volna az elemző eszébe.

$\underline{\text { A Riccabona-Frohmann-féle elemezés }}^{46}$ is kiemeli a tájak esztétikai értékelése során a szubjektumban rejlő „,belső tájak” befolyásoló és visszatükröző szerepét, amelyben a formáknak, színeknek, érzékszervei hatásoknak, közérzetnek, szépségnek és vitalitásnak is nagy szerepe van. Az elemzés hat minőségi kritériumot vizsgál: A látvány (1) egyediségét, specialitását, megismételhetetlenségét, azaz az élettér identitásának potenciáját. (2) Diverzitását, sokféleségét, azaz a tájalkotó elemek gazdagságát és komplexitását, amelynek van egy kellemes, optimális szintje a

\footnotetext{
${ }^{42}$ Részletesen nem idézett, de tájesztétikával foglalkozó kutatók: G. Simmel, W. Hellpach, D. Cosgrove, J. Bouaroussa, J. Appleton, F. Schafranski, Y. Tuan, G. Böhme, Y. Saito, S. Daniels, R.S. Ulrich, J.F. Wohlwill.

${ }^{43}$ Jómagam 2005 óta foglalkozom a környezetpszichológiával, amelynek táji kérdéseit 4 éve oktatom is a BME Környezeti Kommunikáció MA képzésben, így e megközelítés beemelését fontosnak tartottam.

${ }^{44}$ A mühelyt a bécsi Universität für Bodenkultur, Tájépítészeti Karának professzora, Erwin Frohmann és jómagam vezettük 30 magyar, osztrák és lengyel hallgató részvételével 2009-ben. In: Eplényi-Frohmann, 2011. pp. 62-66.

${ }^{45}$ Frohmann, 2009. pp.3-4. A módszert 2004-óta több tájesztétikai és környezetpszichológia műhely során jómagam is alkalmaztam, és szakmai lebonyolítással nagyon hasznos eredményeket hoz.

46 „Daß das, was draußen in der Landschaft oder in meiner Umgebung wahrgenommen, geschieht oder gestaltet wird, in enger Resonanz mit meiner/unserer inneren Landschaft steht“ (Riccabona, S.) in: Frohmann, 2009. pp.6-7.
} 
kaotikusság elérése előtt. (3) Harmóniatartalmát, amely minimum két elem, elem-együttes, ill. a részek és az egész között létrejövő egyensúlyi állapot, az összehangoltság mértéke. (4) Természetességét, ami nemcsak a természet(közel)i elemek arányában érhető tetten, hanem a szukcessziós folyamatokban, az organikus és spontán formák könnyedségében. (5) Szimbólumtartalmát, amelyben a táj mélyebb jelentéstartalmakat, belső képeket is hordoz. (6) Téri kiterjedését, amely térrendszerek és térrészek élményein, látvány ható-távolságán, dinamikáján alapul.

$\underline{\text { Wöbse tájesztétikai elemző módszere }}^{47}$ a tájrészletek beágyazottságát, a nagyobb tájképhez való viszonyát és annak karakterét írja le funkcionális-jelzős szerkezetekkel: központi kérdése, hogy milyen alakzatok, alapelemek és növényzet-típusok alkotják a látványt, azok milyen szín- és formahatásokkal, téri viszonyokkal írhatóak le és milyen táji archetípusokat keltenek a nézőben.

A Kaplan házaspár látvány-értékelő és téri-preferenciákat vizsgáló kutatásai ${ }^{48}$ négy, azóta dogmává vált fogalmat vezettek be a '90-es években: Környezetünket, az abból „,kinyert” információk alapján értjük meg (information prosessing theory), és azok által tájékozódunk benne biztonsággal (understandig). Ezt a (1) koherencia (coherence), a dolgok közötti szervezett összefüggés és az (2) olvashatóság/kiismerhetőség (legibility) segíti. A másik emberi ösztön, a felfedezés-vágy vagy kíváncsiság az új dolgok után (exploration), amelyet pedig a látványok (3) komplexitása (complexity), az elemek összetettségének gazdagsága, kontraszthatásai és a (4) misztikusság (mystery), figyelem-, izgalom-felkeltés segíti. Környezeti döntéseinket, választásainkat e szempontok tudat alatti mérlegelésével hozzuk meg.

Ode (et al.) szintetizáló cikkében a tájak vizuális karakterjegyeinek indikátorait ${ }^{49}$ keresi $^{2}$ környezetpszichológiai, humángeográfiai és tájesztétikai háttérkutatásokra és teóriákra alapozva. Ezek alapján kilenc témát állít fel. (1) komplexitás, amely a táji attribútumok eloszlását, téri szerveződését (szegélyhatását, heterogenitását és aggregációját), és az azok közötti méret-alak-, és kontrasztvariációkat vizsgálja; (2) koherencia, ami a víz jelenlétét és a vegetáció mintázatát, ismétlődését nézi; (3) zavartság, bolygató elemek, látványok; (4) ápoltság, a gondozottság esztétikája a különböző fenntartási módokkal az emberi kéz nyomaival; (5) képiesség ereje, amely a látvány különleges, ikonszerü, egyedi elemeit és fókuszpontjait tartja lényegesnek ahhoz, hogy a kép bevésődjön a szemlélöbe; (6) látványok léptéke, a nyitott és zárt/eltakart körzetek arányával, jellegével; (7) természetesség mértéke, amely a természetes vegetáció és annak szukcesszióját, a mintázati fraktálosságot és a víz jelenlétét vizsgálja; (8) történetiség jele, amely a kulturális elemek sürüsége és dominanciája mellett a tájhasználat történeti mintázataiban is felismerhető; (9) efemeritás, a tájban megjelenő időérzet, az időjárás és az évszakok, vízfelületek pillanatnyiságának tükre. Az egyes témakörökhöz 4 forrás-típust rendel (tájképek; ortofotók; térinformatikai felszínborítottsági adatok;

\footnotetext{
${ }^{47}$ Wöbse, 2002. pp. 241-275.

${ }^{48}$ Kaplan \& Kaplan,

${ }^{49}$ Ode et al., 2008. pp. 89-117.
} 
terepszemlék), majd számszerüsíthető indikátorokat definiál azok alapján (pl. felszínborítottsági típusok száma/ látvány; tájalkotó elemek száma/ látvány, heterogenitási ill. szegélysürüségi indexek, kulturális elemek sürüsége/ területegység). Véleményem szerint a módszer környezetpszichológiai háttere alapos, de az indikátorok a valóságban nem minden esetben számszerüsíthetőek, így elegendőnek tünik, ha a témaköröket csak szövegesen írjuk le.

Adaptálás: A fenti módszerek gyakorlati alkalmazásainak ${ }^{50}$ köszönhetően arra a következtetésre jutottam, hogy segítségükkel érzékletes, finom és szakmailag is alapos kvalitatív eredményt kapható, amely sokszor egybecsengve a kvantitatív értékelésekkel. Mivel a fenti kategóriák között van fogalmi átfedés, azért azokat összevonva, csoportosítva állítottam össze az ezen kutatás során használt tájesztétikai megközelítés hét szempontját (lásd a II.3.2. fejezet).

\section{I.4.3.5. A történeti tájkarakterrel, tájkarakter-elemzéssel rokon hazai kutatások}

Multidiszciplináris tájtörténeti célú kutatások közel 20 éve folynak hazánkban, amelyet a kétévente megrendezésre kerülö „A táj változása a Kárpát-medencében - Tájtörténeti Konferenciák” tanulmánykötetei gyüjtenek egybe Füleky György szervezésében. A több száz szerző általában kisebb esettanulmányt, mintaterülteken végzett felmérést közöl - mégis állandó impulzust adva a tájtörténeti szakmának. Megállapítható, hogy a térképészeti és régészeti szakma ásatásai, terepbejárásai és alapos helyszíni kutatásai adják a legjelentősebb szakmai hátteret, ugyanakkor egyre több további (botanikai, talajtani, néprajzi) műhely kollégája is csatlakozik e tájtörténeti érdeklődéshez.

A hagyományos „kultúrtájakra”, paraszti tájhasználatra, határ-menti tájakra vonatkozólag (föként Gyimesi-völgy terén) Ilyés Zoltán közöl részletes kutatásokat. Illyés Zsuzsa az egyedi tájértékek kataszterezésével és történeti térképek vizsgálatával foglalkozik. Klímatörténettel és az angol tájrégészeti módszerek átemelésével foglalkozik Kiss Andrea a SZTE-n. Egyre több tájtörténeti kutatás történik a műemlékvédelem szakterületéröl (Fatsar Kristóf, Belényesi Károly, Fekete J. Csaba, Firnigl Anett, Kékedi Andrea) és a történész mühelyekböl (Laszlovszky József, Szabó Péter). Fekete Albert erdélyi tájtörténeti kérdésekkel és történeti kastélykertekkel foglalkozik. Makkai Gergely az erdélyi Mezőség történeti középkori tógazdálkodását vizsgálta nagyon tág, általános alapinformációkból építkezve, inkább tájökológiai megközelítéssel, kevés vizuális forrással.

A számos szakembertől származó, helyhez-kötött alapos esettanulmányok ellenére máig hiányzik egy, a tájtörténészek számára készült átfogó-, metodikai összefoglaló. Jelen munka célja azonban nemcsak tájtörténeti jellegü, hanem tájképi, tájesztétikai is egyben. A hazai szakirodalom vizsgálata során megállapítható, hogy a tájkarakter-elemzés csak csekély mértékben terjedt el,

\footnotetext{
${ }^{50}$ A módszereket a Budai Arborétum Környezetpszichológia vizsgálata során, a BME-Környezeti kommunikációs képzése keretében; A BCE - Környezetpszichológia alkalmazása a tájépítészetben címü szabadon választott tantárgy keretében, valamint a Magyarvalkói terepszemle és Tájköltészet - Tájéletrajzi mühelyhét során alkalmaztam. Bővebben lásd: Eplényi - Frohmann, 2007., Eplényi - Frohmann, 2011., Eplényi, 2012a.
} 
ugyanakkor ezen kutatás megközelítése és szemlélete már több, a hazai tájakkal- foglalkozó műhely munkájában megjelent.

A tájértékelés témakörében Csemez Attila ${ }^{51}$ kutatásai már az 1980-as években részletesen foglalkoztak azokkal a paraméterekkel, amelyekkel tájlátványok minőségileg leírhatóak: felszínmozgalmasság, tagoltság, relief-különbségek, szegélyhatások, stb. A témakörökhöz számszerüsíthető faktorokat rendelve ezek célja a tájak adottságainak objektivizálása volt. Így, az összehasonlíthatóság megteremtésével lehetővé vált egyfajta -általában védelmi-, fejlesztési-, turisztikai célú - tájértékelés. Jelen kutatásban az egyes témaköröket, mint leíró faktorokat ugyan felhasználom, számszerüsítésüket azonban csak az agroteraszok szegélyhatásánál teszem meg.

Karancsi Zoltán tájföldrajzi-, tájképi-, tájesztétikai szemléletü kutatásai kvalitatív megközelítésűek. Nem célja az összehasonlítás, sokkal inkább a tájak percepcióira alapozott képiesség, képszerüség és annak kultúrtörténeti, identitásképző vonatkozása a fontos. ${ }^{52} \mathrm{Ez}$ az irány párhuzamos azokkal az egyre erősödő nemzetközi tendenciákkal, amelyekben a történeti földrajz, az esztétika és a tájkötődés területeit ötvözi. Drexler Dóra „Táj és tájértelmezés” c. összefoglaló kötete ebből a szempontból hiánypótló fordítás és rendszerezés a hazai tájszemlélet kultúrtörténeti vonatkozásainak beépítésével is. A BCE Tájvédelmi és Tájrehabilitációs Tanszék kollégái foglalkoznak karakterezési kérdésekkel. A települési tájkarakter-elemzés ${ }^{53}$ a település domborzati viszonyokkal való összefüggéseit vizsgálta, megállapítva, hogy bár vízrajzilag csak néhány-, felszínformák tekintetében nagyon sok (20 karakteresen eltérő) altípusba sorolhatóak a településhelyek, amelyek egyúttal a tájkarakter fontos jellemzői. A mezőgazdasági tájkarakter vizsgálata ${ }^{54}$ a telek és táblastruktúrák szerkezeti-, és a termesztett kultúrák funkcionális szempontjai tekintetében mutatnak lényeges jellegzetességeket a tájkaraktert illetően. Kabai Róbert foglalkozik továbbá a skót és angol tájkarakterelemzési szakirodalom hazai meghonosításával. ${ }^{55}$

A jelen kutatáshoz a soproni mühelyt vezető Konkoly-Gyúró Éva Fertő-Hansági tájkarakterelemzési munkája áll a legközelebb [5.§. melléklet]. Az ő megfogalmazásában a táj és a tájkarakter nem csupán a fizikai valóság, hanem annak szubjektív interpretálása is egyben: „,a tájkarakter a különböző alkotóelemek kombinációjából létrejövő együttes mintázat, amely a hely egyedi szellemét megjeleníti. ... A tájkarakter elemzés a jelleg, az egyediség és az értékek azonosításnak strukturált megközelítését adja, s mint ilyen, a tájvizsgálat alkalmas módszere." ${ }^{56}$ Ö is Swanwick szemléletéből

\footnotetext{
${ }^{51}$ Csemez, 1996. pp. 234-244.

${ }^{52}$ Karancsi, 2002.

${ }^{53}$ Csima - Módosné, 2010. pp. 201-210.

${ }^{54}$ Dublinszki-Boda, 2010. pp. 211-219.

${ }^{55}$ Kabai R. 2010. pp. 97-109.

${ }^{56}$ A táj az ember és a hely közötti kapcsolat kifejezője, mindennapi életünk kerete, környezete. ... Környezetünk különböző természeti és kulturális, társadalmi-gazdasági elemeinek kölcsönhatásából alakul ki a táj. Az emberi érzékelés és felfogás révén válik el a földből a táj. Ez nem pusztán egy látvány érzékelését jelenti, hanem azt a teljes szellemi befogadási folyamatot, amely révén érzékszerveinkkel felfogjuk, megismerjük környezetünket, létközegünket és mindazon benyomásokat, emlékeket és asszociációkat, amelyek felidéződnek tudatunkban. in: Konkoly-Gyúró et al, 2010. p. 9.
} 
indul ki. Elemzése ,három tájjellemző hierarchikus rendszerén alapul: (1) a domborzat (geomorfológia és hidrológia); (2) az emberi hatás mértéke (tájhasználat heterogenitása a természeti tájtól az urbánusig) és (3) a felszínborítási dominancia (alapvető látványtípusok)." Mindhárom attribútumot digitális térképeken minőségi fokozatokra osztja (max. $10 \mathrm{db}$ kategóriába); majd ezeket térinformatikailag összevetve 63 típust (,tájmozaikot”) állapít meg (a kb. $2600 \mathrm{~km}^{2}$-es területen). Ezt a 63 mozaikot „helyszíni és szakértöi megítélés alapján," ${ }^{\text {,7 }}$ egyszerüsítve 13 tájkarakter-típusba sorolja be. Megállapítható tehát, hogy a helyszínelés eredménye itt nem egy konkrét, földrajzi terület lesz (vagy tájkarakter-zóna, ahogy saját munkámban), hanem tájkarakter-típusok tipológiai leírása. Ezek a létrejött típusok legszorosabb illeszkedést a (3. számú) felszínborítási dominancia térképével mutatnak, ami alátámasztja a vizualitás jelentőségét a végső típus-megállapításban. A típusok bemutatása fénykép/rajz/látvány-orientált, habár számos esetben elsiklik a részletes alaktani-esztétikai elemzés felett és helyette a (pontszerü-) turisztikai látnivalókat emeli be, amely a típusosságtól a területiség-felé tereli az elemzést. Összességében a munka jó előfutára a tájak komplex tájjellemzőinek leírásában és megítélésében.

${ }^{57}$ Konkoly-Gyúró tanulmánya nem tér ki részletesen arra, hogy mit ért e kifejezésen. 


\section{I.5. A kutatás felépítése, módszere, kapcsolódó fogalmak}

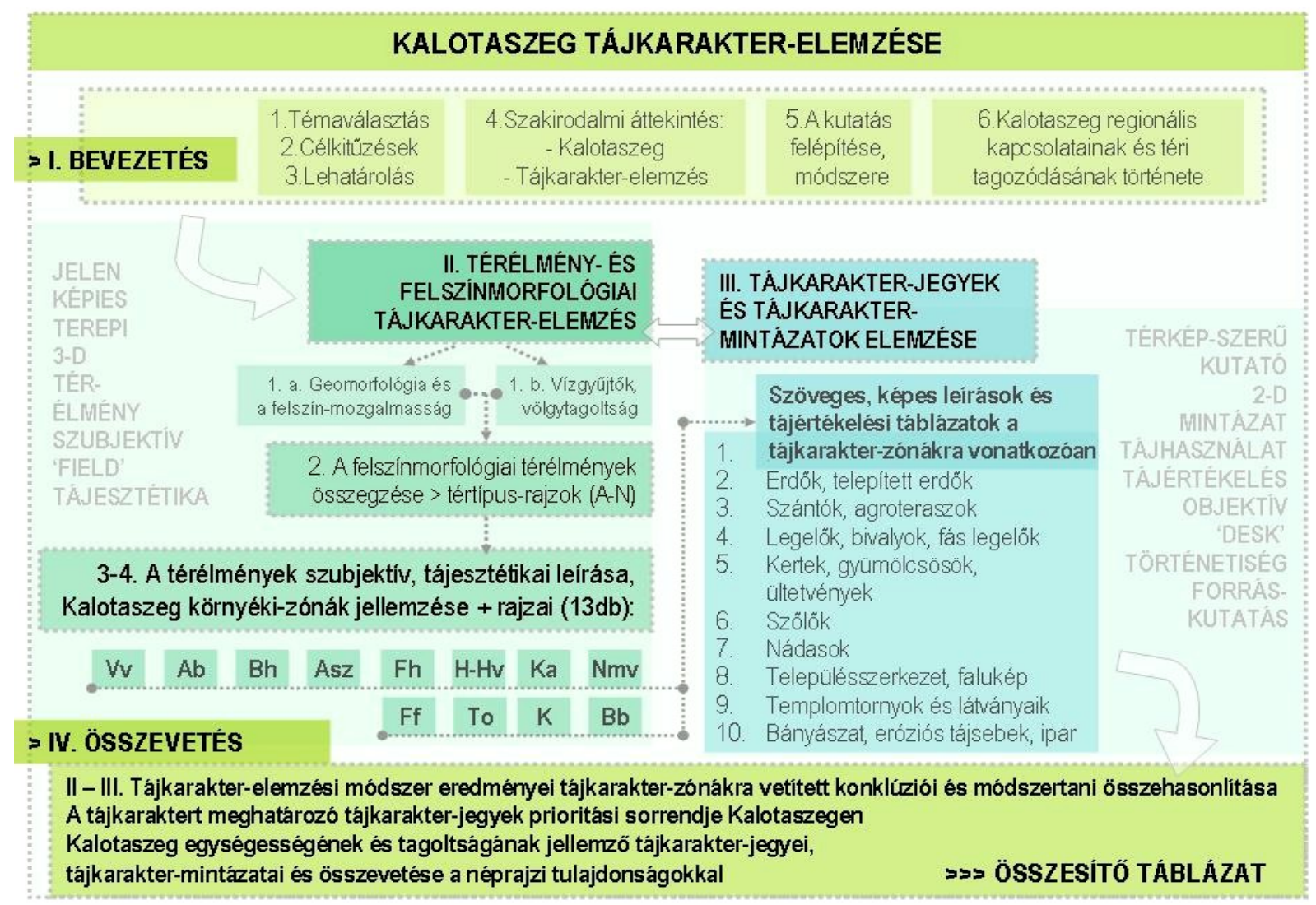

5. ábra: A kutatás módszertani folyamatábrája és tagolása

A bevezetőben definiált alapvető kutatási kérdések, hogy „Tájépítészeti szempontból igazolható-e a néprajzi-etnográfiai Kalotaszeg, mint „Táj”? Illetve, hogy milyen viszonyban van a néprajzi tájegység a tájépítészeti módszerekkel elemzett tájegységgel, annak bemutatott tájkaraktereivel?" A kérdések megválaszolásához két irányból kaptam inspirációt: egyrészt a kirándulások, terepszemlék, tájészlelési gyakorlatok élményéből (amelyek a II. fejezet hátterét adják); másrészt az archív források, régi fényképek, térképek, adatközlők, helytörténeti érdekességek tapasztalatiból (melyek pedig a III. fejezet szemléletét adják).

A II. fejezet a 8 éves helyszínelés térélményeit, és a látványok tájesztétikai leírásait rendszerezi. Alapvetően a felszínmorfológiai-térélmény köré szerveződik a fejezet. A téri viszonyokat a (II.1.a) geológia (és geomorfológia) és (II.1.b) vízrajzi szakirodalmi kutatásokból és a helyszíni térélményekböl állítottam össze. Az elemzés végig azok alaktani megjelenésére, a vidékek karakterességére, egyedi jellegzetességeire fókuszál. E kettőből alakítom ki egyszerü felszínmorfológia tér-típus-rajzaimat, amelyek a vidék legjellemzőbb térélményeit summázzák. Lényegében ezekre és a Swanwick-féle terület/típus egységeire támaszkodva soroltam be a vizsgált 120 falu vidékét 13 tájkarakter-területbe (zónába). A tájesztétikai szakirodalom alapján állítottam össze saját tájleíróesztétikai szempontjaimat ( 7 szempont); amelyeket modellrajzokkal illusztráltam, így mutatva be minden zóna aktuális arculati jellemzőit, „látható” és ,átélhető” tájkarakter-jegyeit. 
A III. fejezet kiindulásként tekint a már meghatározott zónákra. A terepszemléimen megfigyelt táji sejtéseimet alapul véve vizsgáltam 9 további tájkarakter-jegyet, amelyek visszatérő mintázattal, jellegzetes és ismétlődő alaktani ritmussal rendelkeznek: erdőeloszlás, szántók aránya, agroteraszok alaktana, legelők- bivalyok aránya, fás legelők mintázata, kertek aránya és ültetvények térhálói, szölöterületek történeti aránya és jellegzetes mintái, településszerkezeti típusok, templomtornyok táji dimenziói, és végül a bányászat-, köfejtés-, eróziós jelenségek téri eloszlása. Ezekhez szakirodalomi háttértanulmányokat, történeti térképeket és archív forrásokat kerestem, hogy a történeti dimenziót is integrálni tudjam a munkába. Alapos (azaz településsoros) mezőgazdasági statisztikák a XIX. sz. fordulójáról álltak rendelkezésre. Ezek lehetőséget adtak egy egyszerü területhasználati tájértékelésre és téri eloszlásának ábrázolására 6 szempont alapján. Összességében a III. fejezet egyfajta történeti tájkarakter-elemzésnek tekinthető: múlt-orientált, forrásközpontú, síkszerü és mintázati-szemléletet tükröz.

A szintetizáló IV. fejezet összeveti a két tájkarakter-elemzési megközelítést és összegzi azok eredményeit, módszertani hibáit, konklúzióit. Ezt összefoglaló ábrákon, táblázatokban ill. szöveges formában teszi meg: - összehasonlítja a II.- és III. fejezet vizsgálati módszereit és konklúziót a mintázatokat, tájkarakter-jegyeket és zónákat illetően; - vizsgálja a tájkarakter-zónák közötti hasonlóságokat, különbségeket, azok belső kohézióját, erősségének, jellegzetességének mértékében; keresi a jellemzően Kalotaszeget definiáló tájkarakter-jegyek prioritási sorrendjét, a kalotaszegi egységességet és széttagoltságot igazoló tájkarakter-elemzési megállapításokat.

\section{Rajzok, ábrák, táblák, mellékletek hivatkozási rendszere:}

A dolgozat kiemelten fontos részét képezi a vizsgált táj vizuális megjelenítése, amely úgy célszerü, hogy folyamatosan a szöveg mellett halad. Az évek alatt felgyült közel ezer archív és helyszínelt képnek csak egy nagyon csekély kivonata tudott bekerülni a dokumentumba.

A szövegtörzs tartalmaz szövegközi tájkarakter-zónákat bemutató MODELLRAJZOKAT és ÁBRÁKAT [1. ábra] (föként folyamatábrák, térképvázlatok, valamint összerendezett szöveges táblázatok). Szintén a szöveget kísérik a színes TÁBLÁK [1. tábla], amelyek egy-egy témakörhöz kapcsolódó összerendezett képes oldalak az oldal alján azok leírásával, megnevezésével. A MELLÉKLET [1.§. melléklet] tájtörténeti, tájkarakter-elemzési szempontból fontos, de a szöveg gördülékeny olvasását megnehezítő részleteket, elsődleges forrásokat tartalmazza, amelyhez adott esetben, a témához kapcsolódó archív és jelenkori képek is csatlakoznak. A külön nem jelzett fényképeket, képeket, rajzokat mind a szerző készítette. 


\section{Kapcsolódó fogalmak}

- Kalotaszeg: az a 40-45 faluból álló néprajzi tájegység, amelyet az eddigi szakirodalom zömében Felszeg, Alszeg, Nádas-mente és Kapus-vidék egységeként definiált.

- Kalotaszeg tágabb környezete: az általam vizsgálatba vont Kalotaszegnél lényegesen nagyobb terület, amely 116 települést vizsgál.

- Tájkarakter: A tájkarakter, egy adott tájrészlet mintázata, jellege, komplex-térélménye, amely különböző összetevők egyedien jellegzetes kombinációjából jön létre, azaz más tájrészletektől jól elkülöníthető egyedi megjelenése (individualitása) van (Swanwick). A tájkarakter a különböző alkotóelemek kombinációjából létrejövő együttes mintázat, amely a hely egyedi szellemét megjeleníti (Konkoly-Gyúró).
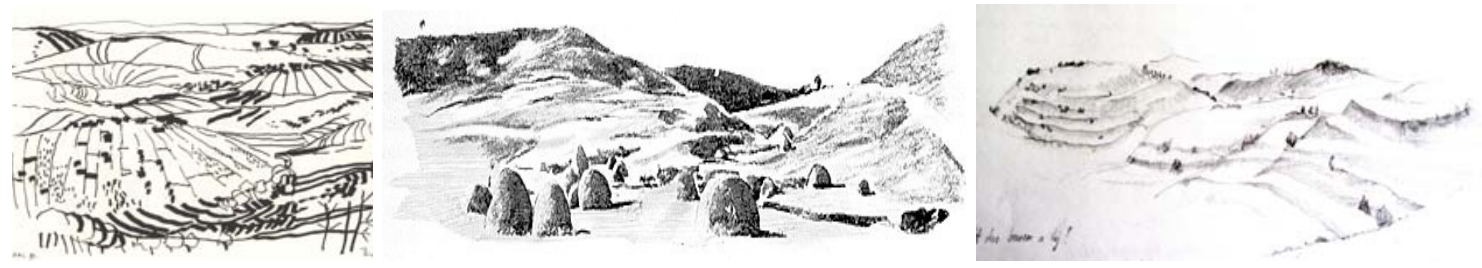

- Tájkarakter-elemzés: A tájkarakter elemzés a jelleg, az egyediség és az értékek azonosításnak strukturált megközelítését adja (Konkoly-Gyúró); ez egyben olyan megközelítés, amely az egyes tájak, tájrészletek egyediségét (tájkarakterét) és annak értékeit (paramétereit, jellemzőit) határozza meg valamilyen céllal (Swanwick). Ez lehet az adott táj régészeti/történeti-védelmi megközelítésü, de lehet fejlesztés/beavatkozás-orientált is. Jelen esetben a tájak karakterességét, azok néprajzi térszerkezetének tükrében vizsgálom.

- Tájesztétikai szempontú leírás: A tájak esztétikai jellegét, alaktani-, formai jegyeit személyes oldalról megközelítő leírás, amely szubjektív észleléseket, meglátásokat, akár szabad asszociációkat is tartalmaz (lásd részletesen az I.4.3.4. fejezetet).

- Tértípusok (tértípus-rajzok): A geológiai-, domborzati jellemzők és a völgystruktúrák formai összegzéséből kialakult táji léptékü térformák alaktani-típusai. A tájrészletek geomorfológiai dinamikáját (nyilakkal és szövegesen) leíró és (séma-) rajzban megjelenítő helyi típusok meghatározása. A terek itt nagy léptékü, tágabb térrendszereket jelentenek (saját fogalom).
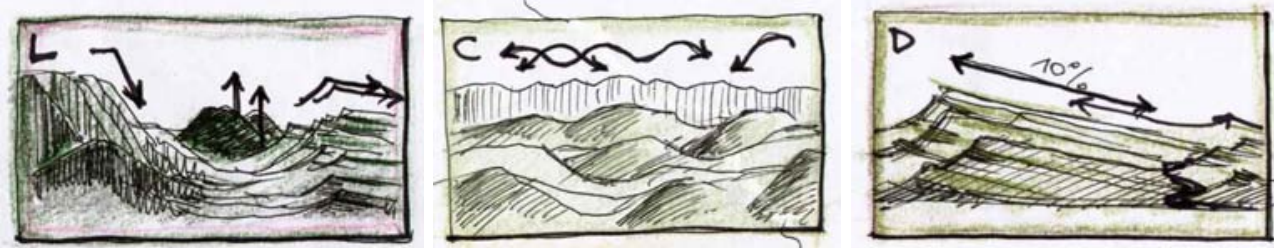
- Térélmény-elemzés: A tájkarakter-elemzés azon része, amely zömében a domborzati hatások okozta élményeket vizsgálja különösen tekintettel a felszíni formák geomorfológiai jegyeire és a völgyek ki-, átlátási viszonyaira; általában a terepi helyszínelés során. Ez a szempont nem veszi figyelembe a felszínborítást, a művelési módokat, a szimbólumokat, ellenben nagy hangsúlyt fektet a szubjektív benyomásokra, a terepen átélt térérzetekre (Riccabona, Ode et al).

- Modellrajzok: Az egyes tájkarakter-zónákat felülről, egy magaslati pontból bemutató háromdimenziós rajz, amely az adott zóna felszínmorfológiáját, látványkapcsolatait, tájkarakter-jegyeit, fókuszpontjait és egyéb, történeti tájkarakter szempontjából fontos részleteket tartalmazza. Swanwick ezeket fénykép alapján készíti, én egy elképzelt magaslati pontból, így nem annyira a valós látványt reprezentálja, hanem tájkarakter-zóna átfogó képét rekonstuálja.
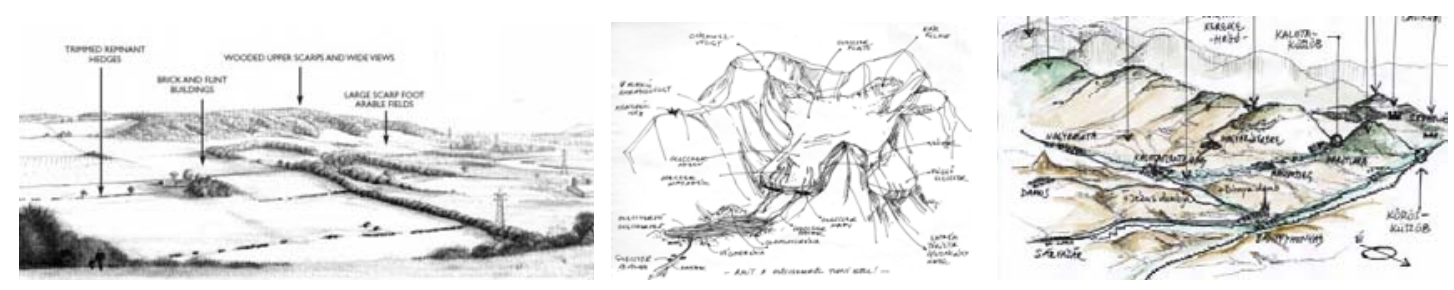

- Tájkarakter típus: a táj jellegét tekintve egynemünek tekinthető részletek, azaz hasonló jellegü táji egység, amely a különböző léptékekben más és más mélységü hasonlóságokat mutat (pl. lehet hegyvidék - dombvidék, vagy völgyek mélyebb ártere - völgyek öntéspadja) [9. ábra] [3.§. melléklet]

- Tájkarakter terület: egy adott tájkarakter típus meghatározott földrajzi egységhez kötődő, egyedi előfordulása, amely ezáltal önálló földrajzi megnevezéssel is azonosítható; a tájkarakter-elemzés léptékének függvényében különböző mélységü lehet (pl. Erdélyi Szigethegység, vagy Nádas-menti völgy, vagy Inaktelki Hasznosi-völgy) [9. ábra] [3.§. melléklet]

- Tájkarakter zóna (röviden: zóna): általam bevezetett fogalom, amelyet Swanwick hierarchikus besorolása nyomán vezettem le. Ezek alapvetően tájkarakter-területnek felel meg, azaz konkrét helyszíni megnevezéssel bírnak, azonban ebben az elemzésben nem cél sem ezek további típus-, sem területi bontása. A zóna alapvetően (domborzati) térélmények alapján kerül kijelölésre, homogén-hasonló megjelenésű tájrészletek tartoznak ide, amelyek körbezárt, folytonos határvonallal rendelkeznek, egymással összeérnek, és nem fedik egymást. Ez az általában 7-15 falu területét lefedő vidék kijelölésében utalhat/összefüggésben áll a vidék néprajzi tagozódásával, így alkalmas a kitüzött kutatási cél vizsgálatára. [9. ábra]

- Tájkarakter-jegy: A tájkarakter-elemzés egy kiemelten jelentős eleme, amely az adott tájban nagyobb hangsúllyal látható, azaz azt a tájkaraktert lényegesen befolyásoló, módosító karakteres elem. Ezek téri, formai, alaktani, vagy statisztikai- megjelenései külön-külön részletes elemzés tárgyát kell képezzék, mivel azok segíthetik egy-egy tájkarakter-zóna lehatárolását. Ezek azonban 
nem csupán mintázatok lehetnek, hanem más erős vizualitással rendelkező elemek is. Pl.: mezaplatók előfordulása, templomtornyok látványdominanciája, fás legelők, erdőszegélyek, szőlőterületek, bivalytartás (Landscape characteristics- Swanwick)

- Tájkarakter-mintázat: Olyan egyedi alakzatokkal, alaprajzi mintázattal (grafikával, rajzolattal) rendelkező természeti adottság vagy tájhasználati forma, ami egyfajta „szövetet” ad a terepfelszínen. Ez sokszor csak légifotó alapján térképezhető, mert kis léptékét a tréképek nem jelölik. A minta eloszlása, kiterjedése is jelezheti a zónák határát. Pl.: mezőgazdasági parcellák alakjai, kőfalakkal elválasztott legelők, raszteres ültetvények, agroteraszok rendszere (Landscape pattern - Rippon).
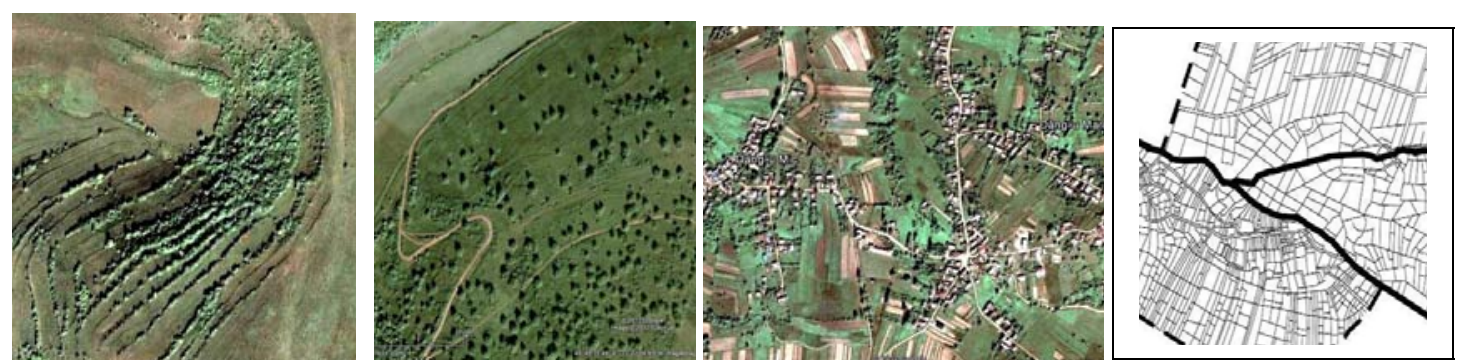

- Sémarajz: egyes tájkarakter-mintázatok domborzattal, felszínmorfológiával összefüggő téri kitettségének kis rajza, amely kiemeli és hangsúlyozza annak tipikus megjelenését. Látványrajz nélkül ez a karakter-jegyet nem lehet szemléletesen ábrázolni.
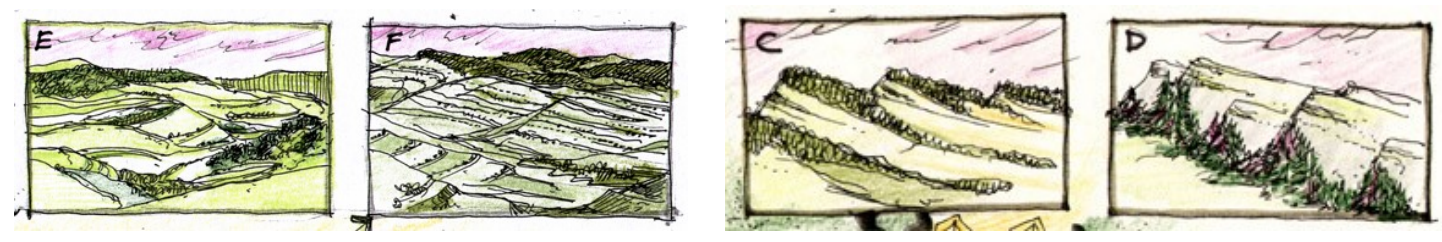

- Tájkarakter-mintázatok jelentőségétre rávilágító tájértékelés: A vizsgált területre jellemző tájkarakter-jegyeket tükröző településsoros tájhasználati (mezőgazdasági) adatsorokból súlyozással létrehozott érték, amelyet a települések közigazgatási alapterületére visszavetítve látható vált azok téri eloszlása, jelentősége. Végső célja egy „kalotaszegiességet-tükröző” tájértékelési pontszám létrehozása volt (részletesen lásd a III.1.4. fejezetben) (saját módszer). 


\section{I.6. Kalotaszeg regionális kapcsolatainak}

\section{és téri tagozódásának történeti áttekintése}

Kalotaszeg és tágabb környezetének alapvető helytörténetéhez és térszerkezeti kapcsolatainak megismeréséhez fontos a regionális kapcsolatrendszerek, út-, és infrastrukturális viszonyok bemutatása. A kutatás tájtörténeti jellegéböl adódóan nemcsak a jelenlegi állapotokat, hanem azok tájtörténeti fejlődését is áttekintem. ${ }^{58} \mathrm{~A}$ vizsgálatban történeti térképeket, régészeti topográfiákat, helytörténeti adatokat vetettem össze, hogy egyes korszakok tagozódásai, téri súlypontjai láthatóvá váljanak. Ebben egyrészt sok „pontszerü” objektum (vár, kastély, templom, kolostor, fogadó) kerül bemutatásra, amely a későbbi tájkarakter-elemzésben nem bír szereppel, de az azok között létrejövő kapcsolatrendszer (út, vasút, postaút) a tájkarakter-zónák (és határvonalaik) megállapításában többször szerepet kap. A felszínmorfológiai-, tájszerkezeti-, tájkarakter-váltások és a pontszerü tájértékek, történelmi szereppel bíró reliktum tájelemek közötti kapcsolattal, melyet „tájkapuként” neveztem korábbi vizsgálataim foglalkoznak. ${ }^{59}$

\section{I.6.1. A római kor úthálózata, védmü-rendszerei (III-V. sz)}

Dacia tartománya a III. sz. elején terjeszkedett Kolozsvártól Ny-felé, így útvonal vezetett innen Ny-ra a Nádas-, majd Almás-völgyében a Meszes-kapuig (Porolissum), ahonnan az alacsonyabban fekvő és jól megközelíthető Meszes őrtorony-rendszere indult, ${ }^{60}$ amely később évszázadokig Erdély és a Királyi Magyarország határát is jelölte [2. tábla - A]. A Vlegyászán nem találtak őrtoronynyomokat, így minden bizonnyal az egyik legépebb táborhely, a Sebesvári (Resculum) ${ }^{61}$ és az azóta eltünt Kissebesi castrum ${ }^{62}$ megközelítése a Szilágyság felől történhetett. ${ }^{63}$. Felszeg térsége kevésbé lehetett lakott, és kevesebb tájalakításon ment át. Szórványos töredékek ugyan vannak, de Wanner bizonyítja ${ }^{64}$ hogy a melegebb, védettebb völgyekben meghúzódó villák/farmok a 400m-es szintvonal alatt jellemzőek. A Napoca-Porolissum útvonal nagy jelentőségű volt: a Bácstoroki-bánya mellett, Méra-Nádas-Magyarsárdon át vezetett, ahol örtornyok felügyelték. A sárdi római út szintén egyenletesen emelkedő, mai napig kövezett, jól járható a vízválasztóig, onnan Oláhköblös-VásártelkeZutor irányban egy szintén tágas völgyön át éri el az Almás-mentét, amelynek további állomásai

\footnotetext{
${ }^{58}$ Eplényi, 2011a. pp. 59-74., Eplényi, 2012b.- in press.

${ }^{59}$ Eplényi 2008, pp. 34-43.

${ }^{60}$ Buday, 1912. pp.99-106. és König, 2001. 1416. számú rajz.

${ }^{61}$ A táborhely a Sebes-, és Körös-patak összefolyása közötti, attól csak 15m-rel magasabban fekvő padon található sáncolt téglány formájával ( 205x120m), 4 kapujával, meröleges útjaival, központi épületeivel kiemelt tájtörténeti emlék-együttes. Alacsony fekvése ellenére kilátási viszonyai megdöbbentően jók a Riszeg-tető, a Sebes-patak és a Körös-völgyei irányába.

${ }^{62}$ Torma feltételezett castruma Jósika Sámuel (Kissebesi Gránitkőbánya Rt. tulajdonosának) háza mellett lehetett az állomásnál induló ’Valea Varadestilor'-ban. in: Torma, 1880. pp. 41-53.

${ }^{63}$ Egy Váralmáson talált km-kő szerint onnan 24,5 km távolságra volt a Castrum, amely a Füldek-Hodos jól járható, tágas völgyének útvonalával egybeesik, in: Ferenczi, 1992. pp.52-55.; Ferenci szerint Körösfö- Ordományos határrészében talált pénzek római postaállomásra utalnak (de az E60-as út római eredete nem igazolt). in: Sebestyén, 2007. p.9.

${ }^{64}$ Wanner, 2010. pp. 280-286.
} 
(Optatiana, Largiana, Certia) fóútvonalként szolgáltak egykor és ma is a Szilágyság felé. A Nádasmente és a Kis-Szamos szélvédett, meleg oldalvölgyei körül több örtorony és villa ${ }^{65}$ alapját megtalálták, ami arra utal, hogy ez a terület kőbányáival, gazdasági egységeivel igen sűrün lakott volt és Napoca vonzáskörzetéhez tartozott. Ehhez a térséghez kapcsolódott még a gyalui platón lévő sáncolt táborhely (a mai vártól Ny-ra), amely a kolozsvári agglomeráció Ny-i lezárása és a sebesvári völgyszoros határkomplexumához hasonlóan a ,havas” felé kulcs-pozíciót jelzett.

\section{I.6.2. Középkori, kora újkori térháló: uradalmi, vásározási kapcsolatok (X-XVI. sz.)}

A szláv időszakból megmaradt néhány földvárat az első oklevelek már nem említik, noha azok fontos megfigyelőpontok voltak: ilyen a magyarbikali elliptikusan körbesáncolt 'Farkasvár', a dűlőnevekből ismert hunyadi 'Várhegy-földvár'; a XV. sz.-ban elpusztult szászfenesi „Leányvár” és a Bedecsi Vár, amely a Lonka-patak szük völgyének bejáratában álló sziklafalas, romos maradvány. Várhegyként említik még a Monostori mezaplatót is, amelynek kiszögellő elliptikus hegyformáját emberi kéz hatásának vélhették, ugyanakkor a vár léte igencsak kétséges. Tovább élnek a korban a római őrtornyok pontjai is Vár/Örhegy néven, ami azt követően négy nagy várral egészül ki (Sebesvár, Almási vár, Gyalu és Léta vára).

Az Árpád-korban a terület két megyére oszlott a Körösfői - Kapus/Szamosi Hágó vízválasztó dombvonulata mentén (Ny-ról Bihar, K-ről Kolozs) ${ }^{66}$; Kis-, és Nagy-'KAPUS’ környékén volt a gyepü határsáv 'kapuja' ${ }^{67}$ [2. tábla - B] A térség K-Ny-i kettős osztást tovább erősítette a sebesvár Felszeget, és váralmási váruradalom Alszeget irányító szerepe és a K-i medencék kolozsmonostori apátsághoz és a gyalui várbirtokhoz tartozó irányítása. Tordaszentlászló környéke a létai Géczy várhoz tarozott. ${ }^{68} \mathrm{~A}$ tatárjárás az első településrendszerben jelentős pusztítást végzett, ${ }^{69}$ de a XIII-XV. Sz. a művészettörténeti emlékek, a kőfaragás színvonala és jelentősége alapján virágkorszaknak ${ }^{70}$ számít $^{2}$ Kalotaszeg történetében: ennek egyik központja kolozsvári kisugárzással Nádas-mente volt kis, apszisos-egyterü kőtemplomaival (Sárd, Vista, Daróc); másik központja MagyargyerőmonostorMagyarvalkó magas kerített erdőtemplomainak és kolostorainak környéke. Míg az első egykori római alapokra helyezett, jobb infrastruktúrájú tájat és nagyvárosi kapcsolatokat „örökölt”; addig az utóbbi havasalji zóna a felgyorsuló erdőkiélést, a vízi-ipart, a kőfejtést és a mezőgazdaság lehetőségeit kellett összehangolja - így nagyobb tájváltozáson esett át, mert az új templomkörzetek építése és kolostorok

\footnotetext{
${ }_{65}^{6}$ Örtorony állt a magyargorbói Kereszt-hegyen, a szucsági Csiga-dombon (Macedonica nevü?), és Szentpál felett is. Villák jegyzéke: http://arheologie.ulbsibiu.ro/publicatii/bibliotheca/popa/repertoriu\%20a.htm- 2012.10.30.

${ }^{66}$ Györffy, 1987.

${ }^{67}$ Balázs É., 1939. p.13.

${ }^{68}$ Balogh-Fülemile, 2004. 12-13-as térképek.

${ }^{69}$ A Szabó T. A. felsorolásán túl a lakosok is több ,új pusztásodott” helyszínt is említettek nekem: pl. a Zsobok-Sztána közötti útkanyarulattól nem messze; Jákótelkétől K-re a Mészmárt alatt, Mákói Medvehegy felé futó oldalvölgye mentén.

${ }^{70}$ Balogh-Fülemile, 2004. p.194.
} 
fenntartása komoly nyersanyagigényeket támasztott: pl. a Lonka-patak stabil, havasi vízhozama energiát biztosított a (kőfaragó, köszörü, fürész, őrlő, ványoló-) malmokhoz.

Az 1600-as évek elején Basta csapatai feldúlják Hunyad környékét, az Almás- és Nádas-mentét is, és további kisebb falvak is elpusztultak. ${ }^{71}$ Ez szintén településszerkezeti átrendeződést hoz a térség életében: a megritkult, de stabilizálódott falvakat jobbágyait nemesi családok birtokolják. ${ }^{72}$ Az ezekhez tartozó kúriák, udvarházak, majorok, gazdasági egységek alig maradtak fent, így ma a vidék kastélykúriaépítészete nem olyan sürüségü és jelentőségü, mint a Székelyföldön vagy a Maros-mentén. A XV. sz. végére a legtöbb felszegi, ma színtiszta román település kezd elrománosodni; hajózható víziutak és minőségi országutak hiányában Kalotaszeg erdélyi relációban jelentőségét veszti. Eközben a nemesi erdőtagok kiélését a román hegylábi falvak végzik a földesuraik számára; akik falukörnyékek speciális, egyedi természet adta táji, gazdasági potenciáljait jól ismerték és azt messzemenőkig kihasználták adóikkal, járandóságaikkal. ${ }^{73}$

Az 1820-as Cziráky-féle összeírás közli ${ }^{74}$ a falvak vásárolási célpontjait, így azok térhálós rögzítésével láthatóvá válnak a XVIII.sz.-ban kialakult távolabbi tájszerkezeti kapcsolatok [2. tábla C], [6.§. melléklet]. A térség belső fókuszpontjai közül Hunyad bírt a legnagyobb jelentőséggel nemcsak Alszeg és Felszeg irányából, hanem Nádas-mente felől is; ehhez hasonló „emporialis” vonzerejü a kolozsvári, k.-monostori vásár is és a kolozsaknai sókamra, amelyet szinte mindegyik településről egy nap alatt meg lehetett közelíteni. A térhálót vizsgálva erős korreláció mutatkozik Kalotaszeg szegélye, és azon falvak között, akik Hunyadra járnak vásárra. ${ }^{75}$ Belső vásáros-helyek voltak még szinte az összes falu számára: Monostor, Gyalu, Almás és Zsombor (Egerest egyik forrás sem említi). Kalotaszeg belső megosztottsága itt is jól kirajzolódik. A felszegi havasalji falvak rendszeresen jártak Nagyváradra, (Feketetó, Élesd), Abrudbányára és Topánfalvára marhavásárra, amelyek a hegyen át légvonalban is $60 \mathrm{~km}$-re estek (!): menet fa és zsindelyszállítással, jövet gabonával kerestek pénzt; ugyanakkor Kolozsvárra már nem járta. Az Almás-menti térség 'sokadalmas' helyei a Szilágyság felé eső Drág, Vajdaháza, Zsombor, Zilah, Kraszna és Zsibó volt. A Nádas-mente ÉK-i falvai azonban dominánsan említik a Vajdaháza, Drág mellett a Szamos-völgye és a Mezőség vásáros helyeit: Borsát, Zsukot, Bonchidát, Szamosújvárt, Dést, Egerbegyet, de természetesen elsőként Kolozsvárt és Gyalut. Összefoglalva, a vásározás jól tükrözi a térségi kapcsolatokat mind befelé (Hunyad), mind a jelentős peremfalvak felé (Gyalu, Zsombor), és az olyan külső célpontok felé is, amelyeket már egy másik regionális tájegységhez való tartozásra utalnak.

\footnotetext{
${ }^{71}$ Pusztásodott falvak: Himtelke, Vársza, Nyírszeg, Remete, Csinkó, Ordományos, Eperjes, Hontelke, Gorbófo, Vataháza, Saság, Soma, Szentiván. In: Szabó T. A. 1942., p.XIX. és Balogh-Fülemile, 2004. 11. térkép

${ }^{72}$ Bánffy, Gyerőffi, Radó, Kemény, Kabos, Valkai, Kendeffy, Sombori, Tholdalagi, Csáky, stb.

${ }^{73}$ Pl.: Ilyen táji adottságokhoz köthető adók voltak: mogyorófa-karó , hal , rák . in. Szabó T. A. 1940. p.21.

${ }^{74}$ Átiratban közli a teljes szöveget Takács, 2006.

75 pl. Kajántó, Fejérd, Apahida, Magyarfenes települései már nem említik Hunyadot, mint vásározóhelyet.
} 


\section{I.6.3. Postautak, fogadók; térháló a vasútépítést megelőzően (XVIII - XIX. sz)}

A XVIII-XIX.sz.-i regionális útvonalak jelentőségének megállapításában már gazdagabb térképes források állnak rendelkezésre. Bár tudjuk, hogy létezett egy „romantikus látképü”76 út a mai E60-as út helyén, ennek jelentősége vitatott, hiszen az árnyas, hágós szerpentin télen hóban és jégben nehezen volt járható, és a Sebes-Körös hirtelen árvizei a csucsai szakaszt is könnyen járhatatlanná tehették. A kiegyenlített klímájú szilágysági kapcsolat megbízhatóbb utat jelölt ki Zilah (Debrecen) és Kolozsvár között: Hídalmás-Dál/Topahágó-Berend-Kóród-Papfalva vonalon. Ezzel párhuzamosan, Kajántó-Bodonkút felé is indult egy út Kolozsvárról, ami nagyjából Berendnél kapcsolódott az előbbivel. ${ }^{77}$ Ez a lapályos vidék fontos országutak találkozási pontjában feküdt, így környékén sok megálló, fogadó, tanya és majorság fejlődött jelentőssé, ezért mindenképpen a 'tágabb Kalotaszeg' egyik határ-pontjaként kell tekintsük. A szilágysági út mellett, még egy kisebb jelentőségü, eldugott belső postaút ${ }^{78}$ is kialakult a Csucsa-Almásnyíres-Bábony-Várlamás-Kispetri-Bogártelke-Türe-MéraBács vonalon Kolozsvárig. Az út a Nádas-patak árvizes-lapályos területét elkerülve, annak É-i oldalán húzódott (a Bogártelke feletti 'Postarét' is ennek emlékét őrzi) [2. tábla - D].

\section{I.6.4. A vasútépítés és az iparosítás hatása a térségben (XIX-XX. sz.)}

A vasútépítés gyökeres változást hozott a térségben. Elhomályosította az azelötti szilágysági kapcsolatrendszert és helyette egy frissebb, élőbb Nagyváradon át Budapesttel és Kolozsvárral való összeköttetést eredményezett. Ez a beavatkozás megerösítette a csucsa-sebesvári völgy infrastruk-túrafolyosó szerepét. Remeténél komoly vasúti/katonai kitérő és fogadó/kocsma komplexum alakult ki a Bánffy-vadászházzal. Hunyad vásáros szerepe ugyan megmaradt, de a vasútvonal a zsobok-sztánai térszintemelkedést legyőzve merőben új kapcsolatot nyitott Alszeg és Nádas-mente között. A sztánai alagút és állomás, vasúti kitérőjével, állandó megállópontjával fontos infrastrukturális, majd turisztikai ponttá fejlődik. Legjelentősebb volt a vasút hatása a Nádas-völgyében, ahol a falvakat gyorsabb megközelítéssel, gazdaságilag is szorosan Kolozsvár felé fordította. A munkálatokhoz tartozó patakszabályozás a völgyi szekérutat is stabilizálta az árvizek ellen. Ekkor tünik el a Dál-Berend-Kóród postaút és helyét a Topaszentkirályi-hágó és a Nádas-menti vasút felé lerövidítő sárdi út veszi át. Az 1911-es keskeny-nyomtávú kisvasút Kelecel-környékének fakitermelését Hunyadhoz kapcsolta, és a sebesvári megállóból a Vlegyésza-ormaira induló turistajelzések is ezt a hegyalji hangulatot erősítették. Az új vasúti közlekedés ellenére a falvak közötti kapcsolatteremetés legrövidebb módja még mindig a szekérrel való közlekedés, ezért a faluhatárokat keresztbe-kasul szabták a dűlőutak [7.§. melléklet]. A javuló infrastrukturális körülmények miatt az külföldi utazók és néprajzkutatók is egyre nagyobb figyelmet fordítottak Kalotaszegre, amely a századfordulón már az „ősi magyar népművészeti

\footnotetext{
${ }^{76}$ Schmidl, 1835. p.283.

${ }^{77}$ Schema, 1761.

${ }^{78} \mathrm{Schmidl}$, 1835. p.284., A postautat a Lipszky-féle postatérkép is jelöli, de az első katonai felmérés nem tünteti fel.
} 
formakincset” és „hagyományos népi kultúrát” kutatók számára „zarándokhellyé” vált. Ennek az „imázsnak” a széleskörű elterjesztését segítette Gyarmati Zsigáné háziipari termékeket népszerüsítő missziója, és a pesti világkiállítás Kalotaszegi háza. Mindezen népszerüsítés az addig szeparáltabb tájegységek ,egységesebb” Kalotaszeg-képét vezették be a közéletbe, noha az akkor még szegregált társadalmi szerkezetet, rokoni kapcsolatokat és eltérő motívumkincseket tartalmazott [2. tábla - E].

\section{I.6.5. Jelenkor: a motorizáció, szuburbanizáció és az autópálya tájalakítása (XXI.sz.)}

A XX. sz. alapvető változását a motorizáció elterjedésével járó úthierarchia kialakulása hozza, amely a helyi lakosság számára csak az elmúlt húsz évben vett át dominánsabb szerepet. ${ }^{79} 1970$ körül erdészeti célú új út épült ki Magyargorbó és Nagykapus között, ahol azelőtt nem volt kapcsolat, így a Nádas-mentéről is könnyebbé vált megközelíteni Kapus- és Tordaszentlászló környékét. Új térszerkezeti dimenziót fog eredményezni a bővülő autópálya is Gyalu-Vista-Topaszentkirály között. A megépült gyalui-csomópont egyértelmüsítette Gyalu és Kolozsvár agglomerációs összeolvadását. Míg az új útjavítások (Bábony, Farnas, Forgácskút) segítenek a kis falvak felzárkózásában és némiképp csökkentik az elvándorlási kedvet. Eközben az E60-as nemzetközi múút személy-, és kamionforgalma drasztikusan növekszik, ami döbbenetes tájképi változásokat eredményez az utak melletti szolgáltatószektorban, raktározásban, szuburbanizációban. A terepviszonyok miatt az út bővítésére nincs lehetőség, így még évtizedekig rombolja az út-menti falvak környezeti állapotát (Kissebes, Hunyad, Sárvásár, Körösfö, Gyalu), ezért e vidék számára égető lenne a tehermentesítés felgyorsítása az egykori történelmi, szilágysági útvonalakkal [2. tábla - F].

Összességében megállapítható, hogy a regionális kapcsolatok ütőerei a táj története során többször is áthelyeződtek; ugyanakkor a folyóvölgyek útvonalai szerepüket sok esetben megtartották. A tájtörténeti vizsgálat rávilágít arra, hogy Kalotaszeg természeti tagoltsága többször is visszaköszön regionális-térszerkezeti kapcsolataiban, gazdaságtörténeti tagolódásában. A tájkarakter-zónák hasonlóságának és különbségének elemzése során még visszatérek ezekre a térségi összefüggésére. A tájegységek-, tájtípusok-, tájkarater-zónák- szerkezeti határvonalain megjelenhetnek olyan reliktum tájelemek, amelyek kulturális jelentéstartalommal teltek meg egyedi tájértékké válva vagy csak egy adott korszakban, vagy egyre komplexebbé nőve századokon át. Ezek az őrtornyok, táborhelyek, várak, vasútállomások nemcsak önmagukban kultúrtörténeti-, régészeti-, müemléki-emlékek, hanem összefüggésben állhatnak tájkarakter-váltásokkal, eltérő adottságú- kilátású tájakkal, amelyek között stratégia szereppel bírnak.

\footnotetext{
${ }^{79}$ Az autós közlekedéssel egyes jól járható utak falvakat összekötő szerepe megnőtt (pl.: Zsobok és Hunyad között); míg más, egykor hagyományosan közeli falvak kapcsolata autós út hiányában megszakadt (pl.: Sztána $\diamond$ Kispetri, Inaktelke $\diamond$ Gyerővásárhely). Bár motorizáció növekszik, a középkorúak regionális kapcsolattartásában még a vasút dominál.
} 


\section{FELSZÍNMORFOLÓGIAI- ÉS TÉRÉLMÉNY-ALAPÚ TÁJKARAKTER-ELEMZÉS}

\section{II.1. A kalotaszegi térélmények és terepalakulatok leíró vizsgálata}

A disszertáció II. fejezete a tájban észlelhető és megélhető domborzati hatások keltette térélmények alapján vizsgálja Kalotaszeget és annak tágabb környékét [6. ábra]. A vidék domborzati arculatának leírásával és grafikai ábrázolásával ragadja meg a tájban tükröződő karakterjegyeket. Ehhez elengedhetetlenül szükséges a geológiai adottságok áttekintése, a felszínmorfológiai jellemzők háttérismerete, amelyhez szorosan hozzá kell tartozzon egy jelen-orientált terepbejárás és annak összes szubjektív élménye. Ez egyrészt a tömegek, térformák három dimenziós kiterjedésének vizsgálatából kell álljon, és az adott helyszínen átélt élmények tájesztétikai leírásából. Ez az erősen vizuális megközelítés rajzi illusztrációkat és kvalitatív bemutatást kíván, amely a tájépítészet komplex egyesítő szemléletét hangsúlyozza ki. Az elemzés végig az egyes tájrészletek hasonló térformáit, ismétlődő alaktani jegyeit, és visszatérő látványrelációt keresi.

\begin{tabular}{|c|} 
II. FEJEZET $<>$ III. FEJEZET \\
JELEN ORIENETÁLT $<>$ TÖRTÉNETISÉG-ORIENTÁLT \\
HÁROMDIMENZIÓS TÉRÉLMÉNY $<>$ TÉRKÉPES (pont-vonal-haló-folt) MINTÁZATOK \\
TÉRBELISÉG, TÖMEG $<>$ SÍKSZERÜSÉG, ELOSZLÁS \\
TEREPSZEMLE ALAPJÁN (field study) $<>$ FORRÁSKUTATÁS (desk-study) \\
SZUBJEKTÍV, NEM SZÁMSZERŰSÍTHETŐ ÉSZLELÉS $<>$ OBJEKTÍV ADATSOROK, TÁJÉRTÉKELÉS \\
TÁJESZTÉTIKAI MEGKÖZELÍTÉS $<>$ TÁJTÖRTÉNETI MEGKÖZELÍTÉS
\end{tabular}

6. ábra: A II. és III. fejezet megközelítésének összehasonlítása

A térélmény-alapú tájkarakter-elemzés témakörének kialakításához a történeti táj-leírásokban, geológiai szakirodalmakban megjelent kalotaszegeiességre utaló jellemzésekből indultam ki, mint pl.: meghatározó Kalotaszegen a Vlegyésza és Meszes magas-hegységek látványa; a tenger-szerűen hullámzó terepfelszín, a keskeny, szük oldalvölgyek nagy völgytagoltsága, az üledékes hegyformációk változatos felszínmorfológiája, a szöktetők mészkőpadjai.

Ebből következően a fejezet [7. ábra] célja megvizsgálni az anyag (II.1.a. = felszín, tömeg, hegyvonalatok és dombok) és az azok között keletkező ür (II.1.b. = légüresség, völgyrendszerek) viszonyát és egymásba fonódó szoros kapcsolatát, illetve ezek formai-alaktani jellemzőit az egyes tájrészletek tekintetében. E két ellentétes, de egymással szorosan összefüggő témakörből következik a szintetizáló fejezet (II.2.), amely a legfontosabb felszínmorfológiai tértípusokat (A-N) mutatja be kis sémarajzokkal, rövid jellemzéssel. 
A fejezet harmadik részében (II.3.) Swanwick terület//típus besorolásának átültetését teszem a vizsgált területre levezetve. Ebben a felülről lefelé haladó rendszerezésben kijelölöm a tájkarakter-zóna fogalmát és elemzési szintjét, amely a további tájkarekter-vizsgálathoz megfelelő léptéket ad.

A geológiai alaptérképek, tértípusok, helyszínelés és regionális térhalókapcsolatrendszer alapján a vizsgált 116 település vidékét 13 tájkarakter-zónákba sorolom be. Ezeket a bevezetőben bemutatott tájesztétikai-leírásokra alapozott, általam kialakított tájesztétikai leírási-szempontok szerint jellemzem (7db). A kvalitatív leírásokhoz háromdimenziós, terepasztal-szerü modellrajzok csatlakoznak, hogy a zóna karakteressége hitelesen, valóban téri dimenziójába legyen bemutatva.

II.

FELSZINMORFOLÓGIAI ÉS TÉRÉLMÉNY-ALAPÚ TÁJKARAKTER-ELEMZÉS

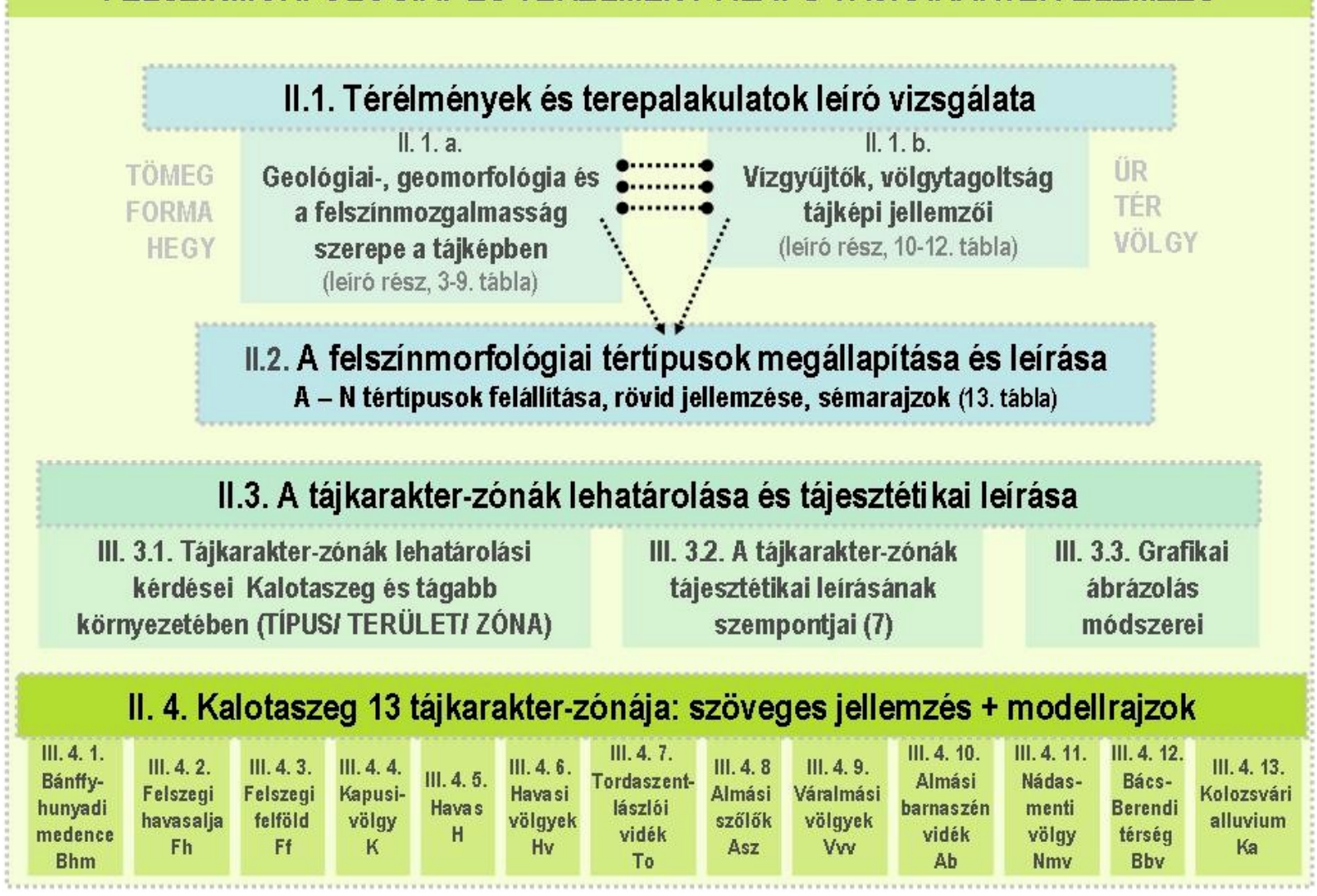

7. ábra: A térélmény és felszínmorfológiai tájkarakter elemzés folyamatábrája 


\section{II.1.a. Geológia-, geomorfológia}

\section{és a felszínmozgalmasság szerepe a tájképben}

$\mathrm{Az}$ alábbi fejezet a tájszerkezetet alapvetően meghatározó geológiai, geomorfológiai adottságokat mutatja be földtörténeti sorrendben, amely nélkülözhetetlen a látványkapcsolatok, a téri tagozódás vizsgálatához és egyben rávilágít arra, hogy milyen nagymértékben determinálják a domborzat alaktani jellemzői a tájkaraktert az erdők által alig borított felszínen. A kalotaszegi táj képét alapvetően az öreg, gránitmagú Gyalu Havasok, az eruptív Vlegyásza- és kapcsolódó hegyvonulata, a Meszes, a belső dombságok eocén-, oligocén-kori üledékes rétegeinek gazdag formakincse és végül az újkori vulkánosság és jelenkori alluviális folyamatok határozzák meg. Az eredeti geológia térképeket a DVD-mellékleten találhatók, azok általam egyszerüsített verziója a táblán. [3. tábla].

\section{A Gyalui Havasok geomorfológiája és tájképben betöltött szerepe [4. tábla]}

A Kalotaszeg DK-i részén kb. 1200m-ig kiemelkedő különféle kristályos őskőzetekből álló, igen széles, lapos hegyhát K-Ny-i irányban húzódik a Meleg-Szamos völgyétől a Vlegyásza tömegéig, sok mély, keskeny, meredek lejtőjü völggyel szabdalva. ${ }^{80}$ Mivel az újkorban megemelkedett a teljes rög, a csapadék dús területbe a Lonka-, az Egerbegyi-, a Roska-patak és a Hideg-, Meleg-Szamos völgyei ekkor vájták bele mélyen magukat, így mint jellegzetes megifjodott tönkhegység áll ma elöttünk. ${ }^{81}$ A hosszú idő alatt lepusztult röghegység teteje hatalmas tökéletlen síkfelületet mutat, amelynek platóján fekszenek a tipikus széttelepült legeltető, fakitermelő román hegyi telepek. A Gyalui-Havasok fennsíkja csak „tompán” járul hozzá Kalotaszeg geomorfológiai sziluettjéhez; nem kelti a „a monumentális, sziluett-formáló” hegyvonulat-hatását, mint a Vlegyásza. Erdőfalva, Bedecs és Pányik határában nem „ránehezedő völgyfal”-képét, hanem tölcsérszerü kis völgyeket elnyelő hátteret ad: pl. Bedecs K-i határában a falut szinte „beszívja” a Lonka-patak tölcsére, erős geomorfológiai hatást keltve. Itt találhatóak egy korai vár maradványai is [8.§. melléklet]. A bevágódott keskeny és szük völgy folytatása is árnyas, hideg, szurdok-hatású (Pányiki-szoros), és a túlsó, kiskapusi 'kijáratnál' is egyértelmű geomorfológia kaput hozva létre: itt a sötét csillámpalás meredek sziklafalak néznek szembe a lankás mészkő-kopárokkal. Ezt a környéket jellemzi a vörhenyes színű finomleveles agyagcsillámpala, amelyre a Nagykapusi Vasgyár települt a ’70-es években. A Hideg-Szamos és a Jára-Aranyos-völgye felé felbukkanó egyre gyakoribb arany-előfordulás, ${ }^{82}$ már egy másik geológiai tájegységet jelez, amely Kalotaszeget sehol nem jellemzi.

\footnotetext{
${ }^{80}$ Ajtai - Fogarasi - Váradi, é.n., p. 7.

${ }^{81}$ Tulogdy, 1944. p. 113.

${ }^{82}$ Kürthy - Koch, 1876. pp. 165-175.
} 
Az ösmasszívum K-n Gyaluig tart, ahol a Meleg-, és Hideg-Szamos torkolata okoz tájszerkezeti váltást a hegyvonulat és a Kolozsvári sík medence tájkaraktere között. A tordaszentlászlói völgy oldal-völgyeiben meghúzódó falvak (Isztolna, Kisfenes, Hasadát) hegyfelőli oldalán fontos és sokkal erősebb sziluett-jellegü térfalat képez e hegység. DK-felé nemcsak a Tordai-hasadék látványa tünik fel a távolban, hanem a vidékre jellemző függőleges mészkőfalak vad karaktere is. A magyarlétai Géczy vár merész sziklafalú környéke más -Kalotaszegtől határozottan különböző-, geomorfológiát mutat, így a Vár fontos határpont a Tordát -környékező táj felé.

Miháltz $^{83}$ megállapítja, hogy a hegyvidék körösfő-pányiki, magasabban fekvő vízválasztó terülte nem csupán a két ellenkező irányú folyórendszer (Kőrös és Kapus) hátráló forrásvidéke között fennmaradt eróziós „sziget”, hanem megemelkedése a Gyalui Havasok szerves tartozékaként tektonikai mozgással jött létre. A pleisztocénban általánosan tapasztalható medencesüllyedések alkalmával a szomszédos medencékhez képest a Gyalui Havasokkal együtt magasabbra emelödött és akkor kaphatta mai boltozatos tektonikáját. Az É-i gránitnyúlvány alulról támasztva feltűnően befolyásolta az arra addigra már lerakódott eocén üledékes rétegek fekvését és dőlését a Kalotaszegi vízválasztó körül. A rétegek: ettől K-re ÉK-nek dőlnek, É-ra lévők É felé, Ny-ra fekvők pedig kissé ÉNy-ra dőlnek, ezek látványa a tájkarakter jellemzők között domináns különbségeket eredményez.

Összefoglalva a Gyalu Havasok egy magashegységi lepusztult rögfennsík, mélyen tagolt szük völgyekkel. Sziluett-formái és átfolyó mély völgyeinek helyzete félhold alakban tájszerke-zetileg magához kapcsolja Magyargyerőmonostor, Erdőfalva, Bedecs, Pányik, Gyerővásárhely, Kiskapus, Nagykapus és Egerbegy falvait. A hegység lassan emelkedő és egyre szükülő Meleg- és Hideg-Szamos völgyei geomorfológiailag Gyalu, Kolozsvár felé orientálnak, és Kalotaszegre alig vannak hatással. A Fenesi-völgy Ny-i oldalán azonban fontos, markáns látványhatároló a vonulat. Az itt megjelenő függőleges sziklafalak már egy másik tájegység képére jellemzők.

${ }^{83}$ Miháltz, 1926. p. 153. 

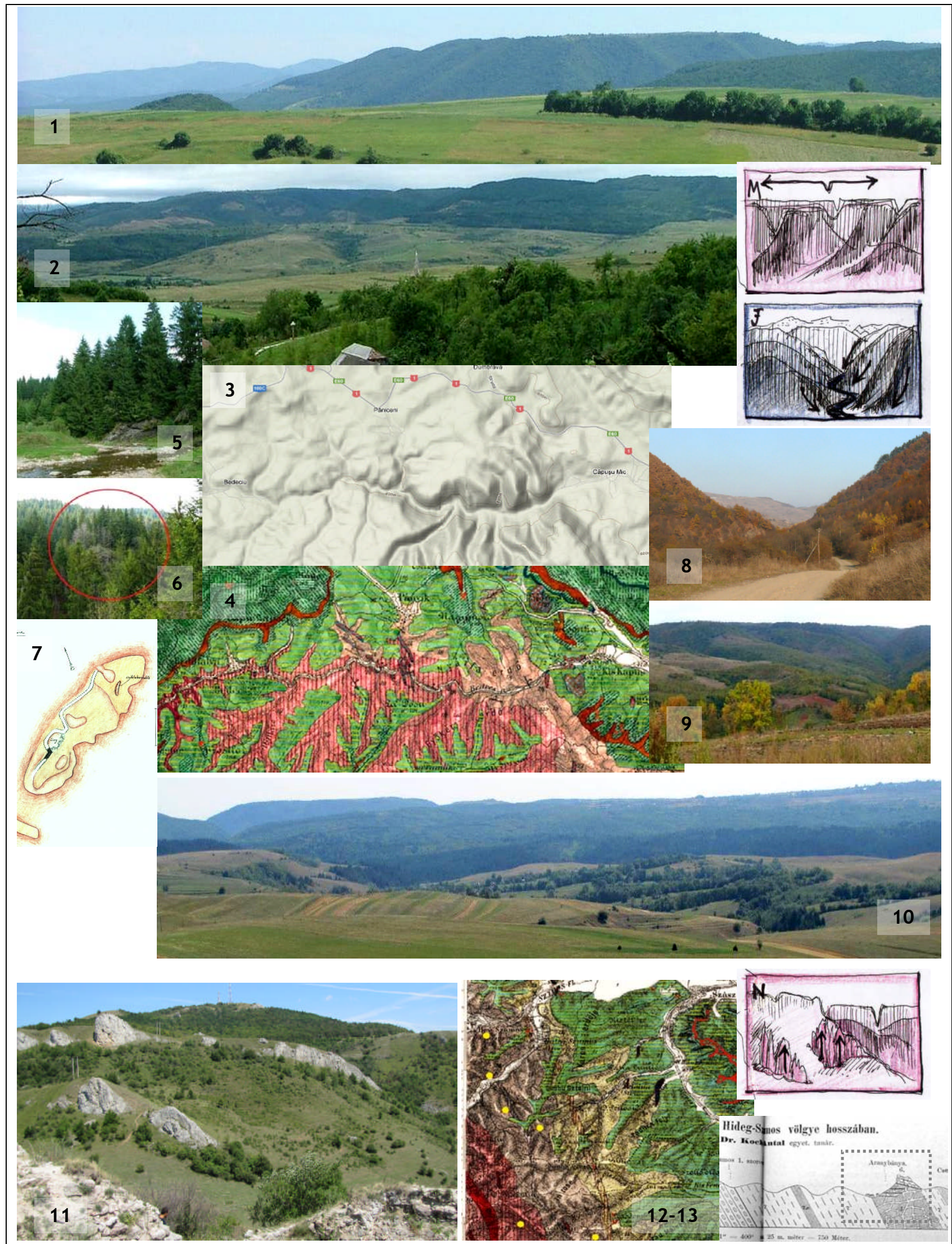

4. TÁBLA: A GYALUI HAVASOK ÉS A TORDASZENTLÁSZLÓI TERÜLET GEOMORFOLÓGIÁJA

1. Gyalui Havasok lepusztult, fennsík-jellegü, platószerü tönkje a Gyerövásárhely felöl, balra a Köves-hegy teteje. 2. A tönk Gesztrágy faluból a templommal. 3-4. A Lonka-patak völgyének felszínmorfológiája és geológiája (Koch-OSZK, TM 7628 -azután végig), amelyen látható a patak erős bevágódása és egyre magasodó völgyfalai. 5-7. A Lonka-patak Bedecsi „bejárata”, ahol dominál a csillámpala látványa és ebben a völgyszorosban áll a Bedecsi középkori vár (König, 2001.) 8-9. A Kapus-patak völgytorkolata Kiskapusnál a völgy felöl: háttérben a Medve-, Köves hegy; az itteni Nagykapus-Egerbegyi jellegzetesen vasoxid tartalmú talaj. 10. A Bedecsi völgyszáj Körösföi vízválasztóról. 11. A Magyarlétai Géczy várnál feltűnő függőleges sziklafalak. 11-12. A Tordaszentlászló vidék geológiája, aranybányák tárnái a Hideg-Szamos völgyében (Kürthy-Koch, 1876, p. 173) 


\section{A Vlegyásza hegység geomorfológiája és tájképben betöltött szerepe [5. tábla]}

Kalotaszeg Ny-i oldalán, a Kréta időszakban É-D irányú, felületig ható mély törés keletkezett a szilárd kérgen. A kifolyó láva változó vastagságban takarta be az ősi kristályos palákat. A környéket uraló hatalmas vulkanikus masszívum felszíne nem több meredek falú kis kúp, hanem egy, hosszan elnyúló, enyhén hullámzó, 1600-1800 m-es fennsík. Ez a dácit tömb átnyúlik az E60-as út É-i oldalára is Hodos felé, így a már 200 éve müködő kőfejtők ma mindkét irányban megfigyelhetőek (Kissebes, Marótlaka, Hodos). Ebbe a megszilárdult lávatömbbe vágódott be a negyedkorszakban az É-D irányú Sebes-patak, ${ }^{84}$ amely elkülönítette és kiemelte az É-D irányú Köhegy-Tomoldok-tető elö-vonulatát ${ }^{85}$ a nagy eruptív tömbtől és így az a Vlegyásza előhegységévé vált. Az előhegység közeli képének sziluettje jellegzetes tájélményt ad a Bánffyhunyadi-medencében. A Vlegyásza völgyei a gyaluihoz hasonló szerkezetűek: V-alakúak, keskenyek, mélyek, árnyasak, kanyargósak és vízben bővelkedők. ${ }^{86}$

A hegyvonulaton három különleges pontot tudunk megjelölni, amelyeknek jellegzetes geomorfológia helyzetük van és mintegy kaput nyitnak Kalotaszeg felé. A legészakibb Marótlakánál, a Kalota-patak áttörésének szük küszöbje, amely a lefolyási viszonyokat is lényegesen befolyásolja. A második, ettől D-re a Székelyjó-Magyarókereke közötti dombtetői hágón lévő nyereg. A harmadik pedig Méregjó település sajátos összetett téri helyzete: a falut a kalotaszegi-medencétöl egy kisebb tető (D1. Tiglau) választja el, így a falu képe már nem része a medence látványának, ugyanakkor táji alakzatokban még rokon jegyeket mutat Kalotaszeggel. A település éppen a Kalota/Méregjó vízválasztó oldalában ül meg, völgykatlana Ny-ra, a Méregjó felé, egy tölcsérszerü völgybe „szívja be” a kalotaszegi tájszövetet, ez tulajdonképpen a valós geomorfológia határ.

Összefoglalva a Vlegyásza vonulata sokkal erőteljesebb, mint a Gyalui Havasoké; vulkáni jellege dominánsabban hat az egész Hunyadi-medence tájképére. Látványa Felszegen és Alszegen, a vízválasztó, meghatározó, ettől K-re, a Nádas-mentén már csak a magasabban fekvő pontokról látszik. Ez egy fontos vizuális különbség a két vidék tájkarakterében, amely a térélmény szempontjából megkérdőjelezi Kalotaszeg egységességét. Az elöhegysége tompítja a 'masszívum' látványát, ugyanakkor e leválasztott, hirtelen emelkedő vonulat közelebb is hozza a hegység érzetét, így egymás mögött egy „kétrétegü” sziluett jön létre a Kalotaszegi-medence felöl, amelyek különbözően reagálnak az időjárási jelenségekre. A Vlegyésza a Felszegi táj irodalmában, néprajzában és mindennapjaiban is kitüntetett szereppel bír [10-11.§. melléklet].

\footnotetext{
${ }^{84}$ Felső folyásait Székelyjó, Henc- majd Méregjó-pataknak nevezik, a ,jó” a régi magyar nyelvben vizet jelentett.

85 Így nevezi Tulogdy ezt az előhegységet, amelyet más, korábbi források Kalota-hegységnek mondtak. Az előhegység magaslatai É-ról: Vf. Runcului, Ogasul Botului, Fata Lupului, Vf Bogdanului = Tömöldök csúcs, Vf. Chicera, Dl Gomulbat, Dl Tiglau, Ruginoasa és végül a déli szegletpontban a Magura Calatele.

${ }^{86}$ Koch-Hofmann, 1889. p. 5.
} 


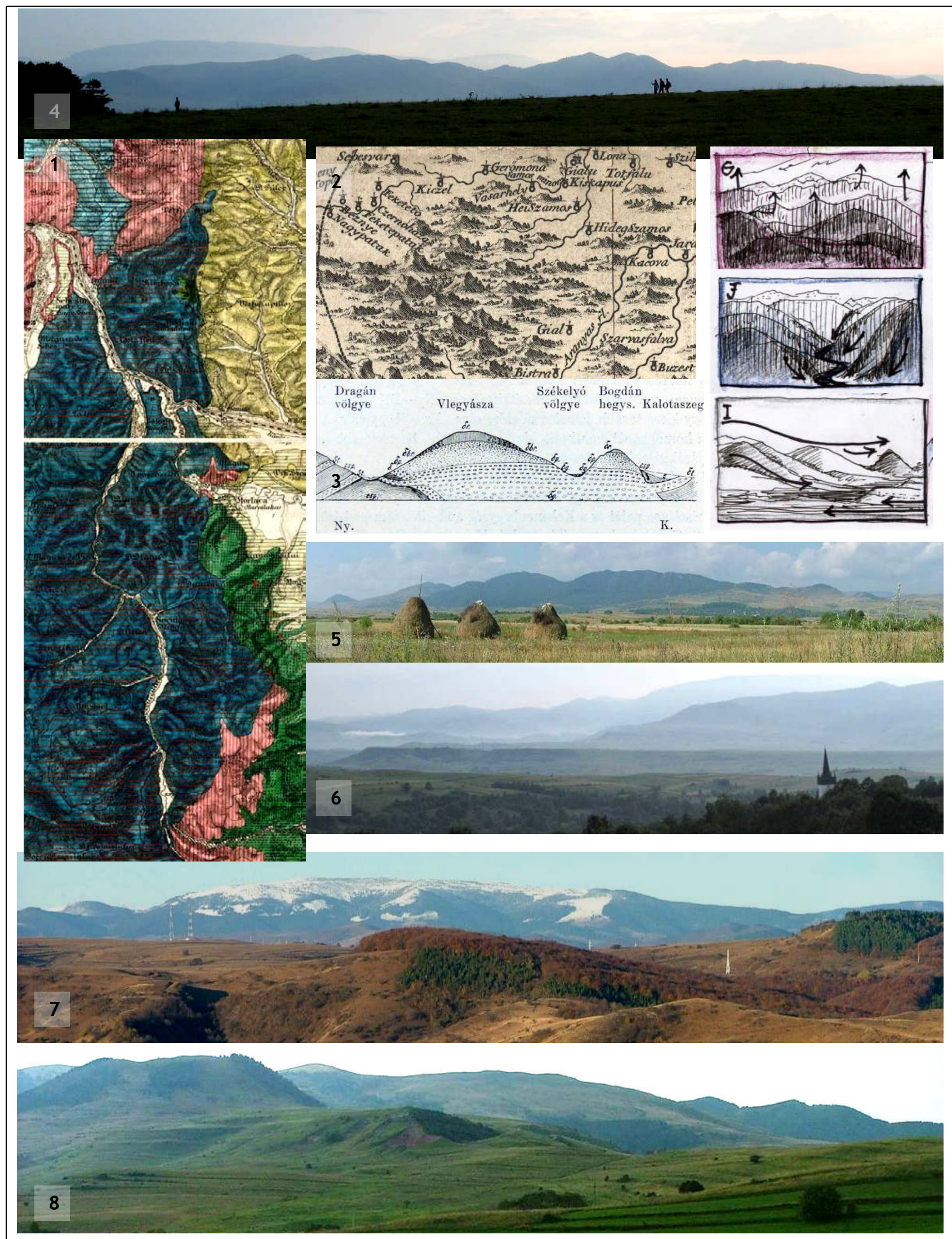

5. TÁBLA: A VLEGYÁSZA GEOMORFOLÓGIÁJA, TÁJKÉPI SZEREPE

1. A Vlegyásza geológia térképe Koch Bánffyhunyadi szelvényén. 2. A Gyalu -Vlegyászai hegyvonulatot ábrázoló 1708-as térkép (HTT, B IX a 491) 3. Egy K-NY-i geológia metszet (Koch, 1900, p. 278.) 4. A világos hátterü Vlegyásza, az előtérben a Tomoldok-Bogdán-előhegység sötétebb képe (Magyarvalkó, E. Frohmann) 5-6. Az előhegység képe a Bánffyhunyadi-medence és Magyarvalkói Tunya felöl: jól kivehető a síkság és a hirtelen emelkedő hegyvonulat éles váltása és a hatalmas „bölény”-hegyvonulat (Jékely). 7. A már októberben havas csúcsok, amelyek a Nádas-mentének csak kiszögellő magaslatairól látszódnak (Inaktelke - Gyerőffy-szögtető) 8. A Felszegi havasalja tája, Méregjó környéke, ahol a vulkáni hegyvonulatok és a mészkö-platók találkoznak 


\section{A Meszes-hegység geomorfológiája és tájképben betöltött szerepe [6.a. tábla]}

A Meszes-hegység az Erdélyi Szigethegység É-i tagja. 60 km hosszú, átlagosan csak 3-5km széles, a környező dombságból bércként kiemelkedő, 500-700 m magas gerince geomorfológiailag egységes: haránt irányú törésekkel tagolt, É-felé fokozatosan lejt. Szemben a Vlegyásza „síkságból” kiemelkedő képével, a Meszes hegyoldalai az alszegi, erősen tagolt dombvidékből alig emelkednek ki, így sziluettje csak a magaslati pontokról érvényesül (Ketesdi-, Bikali-, Zsoboki-tető, Sztánai állomás, Egeres-Nagypetri tető). Kelet felé lefutó völgyei ismétlődő alakzatúak: egymással párhuzamos, ÉNyDK-i irányú, 10-15 km-es hosszú, egyenes, széles völgyfenekü, egyenletesen emelkedő folyóvölgyek (Füldi-, Bábonyi-, Czoldi, Nyercei-völgy). Az Erdélyi-medence ÉK-i dombságában kiemelkedő őrhegyeit a rómaiak fontos határvédelmi céllal használták. ${ }^{87} \mathrm{Az}$ alszegi táj képe, karaktere rokonságot mutat már a Szilágyság felé tartó Almás-Egregy-völgyekkel. Ezen a területen egy geomorfológiai fordulópont kapott tájtörténeti jelentőséget: az Almásnyíres feletti D. Fondacului hegy melletti hágótető, ahol a régi Postaút vonala vezetett, erdőőrházzal, vadászházzal, fogadóval Csucsa felé.

Összefoglalva a Meszes a Vlegyeszánál szelídebb, a dombságból alig kiemelkedő, ezáltal alacsonyabb, kevésbé uralkodó hegyvonulatként jelenik meg. Látványa meghatározó a magasabb Felszegi vízválasztóról, valamint az Alszegi-medence perem-magaslatai felől; párhuzamos, hosszú völgyei nyitott, tágas karakterüek. A Meszesnek nincsenek magashegységi szórt telepei, sem különleges turisztikai jelentőségü pontjai.

${ }^{87}$ Ferenczi 1992., p. 54. 

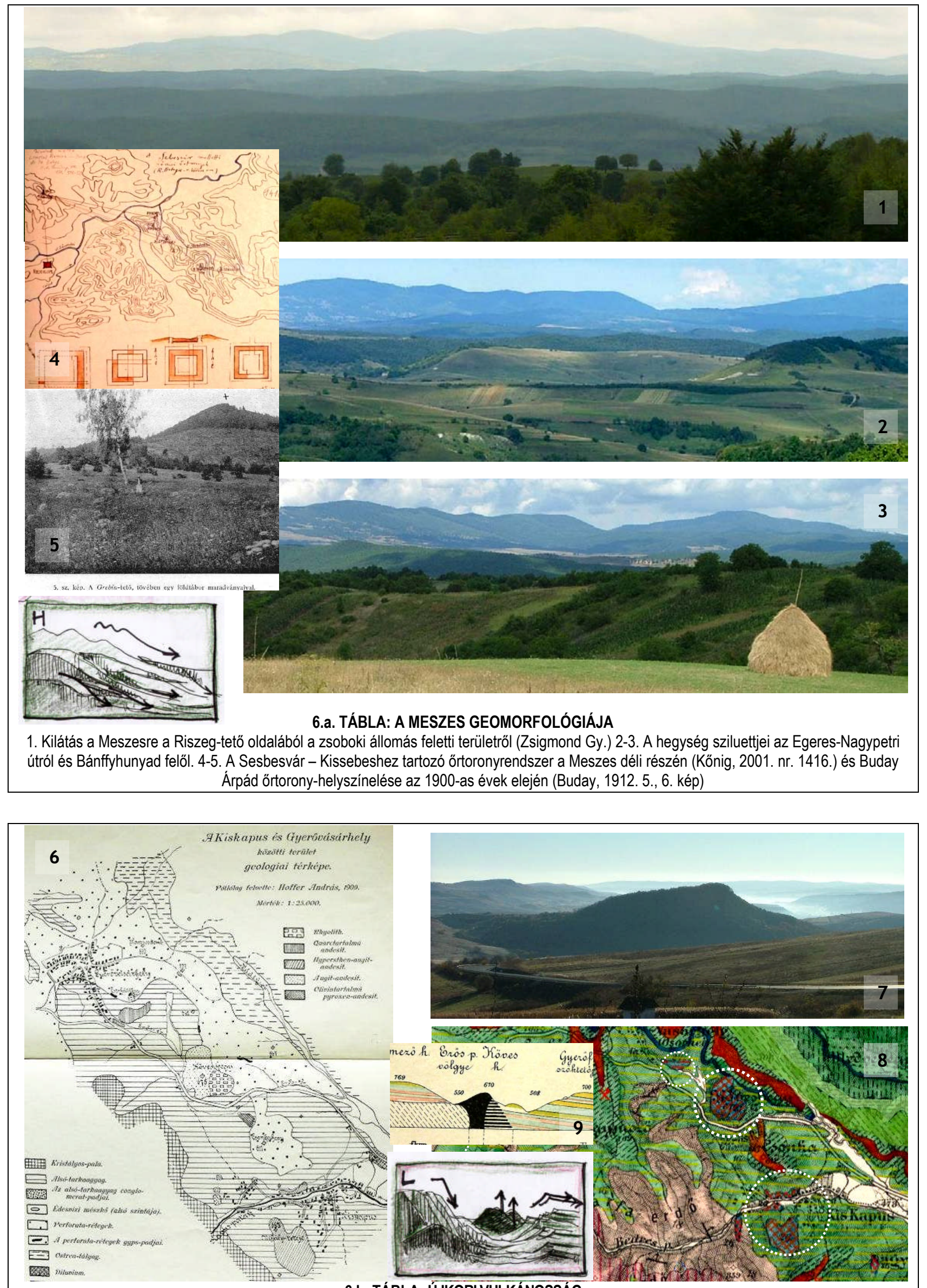

6.b. TÁBLA: ÚJKORI VULKÁNOSSÁG

6. A Gyalu-hegység újkori megemelkedése közben töréspont alakult ki és ott vulkáni riolit, andezit került a felszínre kialakítva a Köves-hegy messziröl feltűnő kúpját, amelyet erős-hágó kísér (Hoffer, 1909.) 7. A Köves-hegy látványos kúpja. 8-9. A vulkánosság a GyerővásárhelyKiskapus közötti Köves-hegy környezetében (kék-vörös straff) és Koch-metszetén (Koch, 1894, II. melléklet) 
A Kalotaszeget szegélyező hegyvonulatok mellett a táj belső térélményeit a harmadkori, eocén üledékek rétegrendjének jellege és formakincse adja. A Koch által Kolozsvári-szegélyhegységnek nevezett, lényegében Kolozs megye Ny-i részét borító dombvidék középmagas (400-800m) vonulatának tájképi jelentőségét alábecsüli az, aki csak a térkép szintvonalait vizsgálja, mivel a hullámzó dombvidék egyedi geomorfológia tulajdonságai nagyban hozzájárulnak a különböző karakterü tájlátványokhoz.

E dombvidék kialakulása földtanilag alapvetően három részre osztható. A kb. 60 millió évvel ezelőtti trópusi klíma lehordta a hordalékot a hegyvonulatokról, majd azok a sivatagi éghajlat alatt vöröses rétegekké álltak össze (1-alsó tarkaagyag). Ezután a terület megsüllyedt és tenger öntötte el (2alsó durvamész), majd kiemelkedve ismét szárazra került, később pedig újra megsüllyedt (3-felső durvamész). A bonyolult rétegrend időbeli és területi kifejtése szükséges a geomorfológia alakzatok létrejöttének és az ehhez kapcsolható kőfejtési hagyományok megértéséhez.

1- Alsó tarkaagyag rétegek:

A Gyalui Havasoktól É és Ny-felé haladva a kristályos hegység mély völgyekkel szabdalt, de a völgyek között egyenletesen és simán domborodó hegyhátainak formái lassú fokozattal mennek át a medence üledéksorozatának legrégibb tagjának, az alsó tarkaagyag területének hegyformáiba. Míg a kristályos hegységben a völgyek meredekek és mélyek, itt a csökkenő magasság és a kőzet kisebb ellenálló képessége miatt a völgyoldalak szelídebbek. Az alsó tarkaagyag kb. 100m vastag agyagos réteg, kövületmentes, amelyben 1-2m-es kavics-konglomerát betelepülések is láthatóak. A padoknak kis távolságon belül való kiékelődése miatt mégis homogén anyagból álló eróziós hegyek hatását keltik, az ettől É-ra elhelyezkedő perforata formációkhoz képest. ${ }^{88}$ Ez az alsó tarkaagyag vékony lepelként borítja Kelecel, Kalotaújfalu, Bedecs, Pányik és Kapus, Gyalu környékét (Kapulat-vonulat déli lábát); az elmosatásnak inkább ellenállt, mint az agyag, de ezen havasok lakói ritkás szénán kívül mást nemigen termelnek. ${ }^{89}$ Erre a nummulites perforatáról elnevezett rétegek sorozata következik. Ez mindenütt meredek, éles peremként húzódik végig a völgyek oldalán, sőt helyenként lapos hegytetőket is alkot (Kelecel, Magyarvalkó, Erdőfalva, Jegenye, Gyerővásárhely, Nagykapus). ${ }^{90}$ Magyargyerőmonostor, Kelecel, Incsel vidéken a gipsz helyett dús mészkőszerü konglomerát pad található, amelyből a vidék lakói malomköveket készítenek.

Feltünő és egyedülálló Jegenye geológiai helyzete: amelyet kétszer öntött el a tengervíz, így gyürüsen kettős tarka agyagra települt perforata és gipsz üledékrétege veszi körül. ${ }^{91}$ A jó minőségü

\footnotetext{
${ }^{88}$ Miháltz, 1926. pp. 146-147.

${ }^{89}$ Koch - Hofmann, 1889, p. 15.

${ }^{90}$ Miháltz, 1926. p.147.

${ }^{91}$ Szádeczky, 1900. p.43.
} 
gipsz miatt, közel 200 éve folyamatosan nyílnak meg és kerülnek felhagyásra a bányák: egykor csak mikrodomborzati változásokat okozva, a mai kitermelés ütemében már dinamikus tájképi átalakulásokat eredményeznek. ${ }^{92}$

\section{2- Alsó durvamészkő rétegek:}

Az alsó tarkaagyagra települtek a sokkal jellegzetesebb tájképi karakterjegyeket adó alsó durvamész rétegek: ezeknek alsó része nagyon laza agyagos márga, 40-50m vastagságban, tetején 8$10 \mathrm{~m}$ vastag kemény, erős mészkőlezárással. Felszeg Ny-i területén és a Nádas-mentén ebből állnak azok a hegytetők, amelyek feltünően laposak, egyenesek vagy gyengén (2-4\%) É-nak dőlnek. Ezek a tipikus mezák (=tanúhegy jellegü sziklaplatós táblahegy): peremük mindenütt meredek, sok helyen majdnem függőleges, a mészkőpad-alatti puha tályog pedig mindig homorú lejtővel jelenik meg alatta, mindenütt apróbb-nagyobb suvadásokkal tarkázva. ${ }^{93}$ Eltérő alakjuk ellenére hasonló keletkezésű a 3 kúp alakú hegy is (damosi Tordalma, magyarvalkói Kis- és Nagy Malató), amelyek kisméretủ csúcsát szintén ez a kemény, ellenálló mészkőkupak képezi. Különleges hegyalakzati viszonyairól a mezaplatók már messziröl felismerhetőek és követhetőek [12.§. melléklet]. Szokatlan formaviláguk és geológiai jelentőségük már a XVIII. sz.-ban felhívta magára német geológusok figyelmét, akik Magyarvalkó környékét különlegesen szép vidékként írják le. E réteg jellemzően horizontális-platós kiemelkedései Felszegen és a vízválasztó környékén sokszor előfordulnak, ${ }^{94}$ ezáltal alapvetően meghatározva e vidék tájkarakterét.

A durvamész-padoknak a felszínen levő terjedelmes táblái kitünően gyüjtik a vizet, amely rétegforrások alakjában mélyebb helyeken ismét a felszínre tör. A Kőrös és Nádas bő forrásai is ennek köszönhetik létüket. A Körös forrásainál különösen is látható, hogy a víz a durvamészbe messze benyúló csatornákat mosott ki, aminek következtében a hegyhátakon tölcsér alakú mélyedések keletkeztek. ${ }^{95}$ A durvamész-perem egészen Kolozsvárig a Nádék-, majd Kapus-patak É-i oldalán látható kiszögellések alsóbb részében folytatódik, végig ÉK-i irányba dőlve. Gyalunál a várostól É-ra lévő lejtőket alkotják, ahol szerkezetük jól szemügyre vehető, de Szászfenesnél a Szamos felszíne alá merülnek és végleg eltünnek A Kapulat és a Nemesek Erdeje gerincén túl a Nádas-völgyében Magyargorbó, Vista, Magyarnádas környékén látványosan, újra nagy területen felszínre bukkan.

\footnotetext{
92 Jegenye Székelyföldről idetelepített lakossága, Kalotaszegtől eltérően katolikus felekezeti hovatartozása, társadalmi és házassági kapcsolatokban is endogám izoláltsága érdekes metaforikus párhuzamba állítható „körbezárt” földtani adottságával. ${ }^{93}$ Miháltz, 1926. p.148.

${ }^{94}$ Mezaplatók: Méregjó-Incsel (D1. Ciulii), Kiskalota (D1. Cetati), Magyarvalkó (Sulyom, Tunya, Déde-hegy, Tértető), M.Gy.Monstor (Várhegy), Erdőfalva (D1. Ardeovei), Deréte (Dl. Hangaului, Nyíres), Bedecs felett (Hágó és Hágó tető) és az K.Nádas-Jegenye közötti fennsík. Az egykori bányászat nyithatta meg az Oláhbikalt különleges sziklafalként körbevevő katlant (Dl. Bicii, Farkasliget), amely dominál a tájban.

${ }^{95}$ Koch-Hofmann, 1889. p.18., Ennek az érdekes geológia jelenségnek tájtörténeti folyománya több, visszatérő helyi népmonda, miszerint korpát szórtak a dombtetői „feneketlen tóba”, és azt a völgyben lévő forrás v. tó dobott felszínre; ill. nagy esők idején szinte felszökött a víz az alacsonyabb forrásnál. E kis vízgyüjtő dolinákat bivalyfürdető tavaknak is használták (pl. az inaktelki Lügeten).
} 
3- Felső tarkaagyag és durvamészkő rétegek:

A fent említett rétegek minden irányban (Ny, É, K) dőlve tủnnek el a rájuk következő felső tarkaagyag rétegek alá. Ez a zömmel vöröses árnyalatú, kövületet nem tartalmazó réteg, a Nádasvölgyének déli oldalán figyelhető meg pl. Andrásházánál. Ezen jelenik meg az édesvízi mészkőből és felső durvamészből álló ismét ellenálló rétegsor, amely az alszegi és nádas-menti (szög)tetőket adja. Az eddig tárgyalt rétegek közül e felső durvamész található a legnagyobb területen, de mivel ez az agyaggal váltakozó mészkőrétegekből áll, és nem is olyan vastag, mint az alsó durvamészpad (2), ezért nem mutat olyan merész, meredek, éles mezaperemeket. Csak É-on, ahol az Almás mellékvizei vágódtak bele mélyebben e rétegekbe, ott találunk néhány meredekebb formát. ${ }^{96} \mathrm{Az}$ alacsonyabb térszínek miatt ezek a kiszögellések nem észlelhetők távolról, de mégis jelentősek a szük alszegi völgyekből feltáruló térélményekben. ${ }^{97}$

Az eocén üledékek által meghatározott terület (sötétzöld szín) 8-10km-es félhold alakban öleli körbe a Gyalui Havasok felszín alatti É-i nyúlványát. Zömében Felszeg DK-i dombvidékét, Alszeg magasabban fekvő falvait, a vízválasztó kiemelkedését adja és K-felé a Kapus és Nádas-patak közötti látványos vízválasztó bércvonulatot képezi. E területre jellemzőek a magas reliefenergiájú, mozgalmas, meredek és aránylag magasan kiálló, mezaplatós karakterü, konkáv-oldalú és kúpos eróziós hegyek, a világos színü kiékelődések és a köves-kopáros partfalak. A régi dülőnevek a kőfejtés kitüntetett történeti szerepét támasztják alá ezen az eocén rétegen, és a térképekről tudjuk, hogy a XIX. sz. kőbányái is mind ezen a területen voltak; ami magával hozta a mészkő településképben való hagyományos megjelenését is. Ebből jól látható, hogy a geológiai adottság markáns, hosszantartó hatással van a környék életmódjára. Ez az eocén rétegsor minden tájegység területén megjelenik, így egész Kalotaszeget jellemzi, egységesíti. Eltérő mikrodomborzati alakzatai azonban Felszeg, Alszeg és Nádas-mentének is más-más arculatot adnak. Felszegen az alsó tarkaagyag és a vízszintes mezaplatós durvamész dominál, míg Alszegen és Nádas-mentén a ferde felső agyag és durvamész rétegek. Ez utóbbi kettőnél a földtani szerkezet nagyon erös korrelációt mutat a tájkarakter-zóna határával, és a kőfejtésre is alapozott magyar falvak kiterjedésével.

\footnotetext{
${ }^{96}$ Miháltz, 1926. p. 148.

${ }^{97}$ „Nyárszó mellett a Mészmárt hegyen 6m-es telepeit kis kőbányában fejtik. A mészkő vastagsága változó, legnagyobb kifejlődésük Alszeg környékén 6-12 m vastagságban fordul elő. (Zsobok peremein, a Kispetrire futó Sztánai-patak mellett, a Farnasi-patak mellett, Tóttelke peremein és Nagypetri felé) Zsobokon a Gál domb DNy-i meredek oldalán fejtik a tarka-eres-foltos változatát, dísztárgyakat esztergálnak belöle amely „Zsoboki alabástrom” néven vált ismertté. A Nádas-folyó jobb-lejtőire emelkedik, mindenütt messze elhúzódó, széles hátú hegylaposakat alkotva (Gyeröfi-szöktető - Medve-hegy - Köves-hegy vonalában).” In: Koch-Hofmann, 1889, p. 19-20.
} 


\section{Harmadkori oligocén és neogén üledékek geomorfológiája, tájképi szerepe [9.a/b. tábla]}

A harmadkori oligocén üledékek összefüggő nagy területet borítanak Alszegen. ${ }^{98}$ A puha, homokos, agyagos Aquitaniai rétegek nem rendelkeznek sajátos ismétlődő hegyformákkal, sem erős, fejtésre alkalmas kőzetekkel, azáltal tájkarakter-képző ereje messze elmarad az eocén rétegektől. Általánosan jellemző rájuk a barnakőszén előfordulás, a gyakori felszíni kibukkanás. ${ }^{99}$ A barnaszenet Egeres (Körtvélyes-oldal), Argyas, Forgácskút vidékén 1870-óta fejtették kezdetleges bányákban , amelyekre komoly ipari beruházások, telepek, falurészek épültek. A legfiatalabb, neogén üledékek csak Kolozsvár környékén és attól K-re jellemzőek a Bácsi, Kóródi rétegekben, ezek adják a Mezőséget, a Szamos-menti hátságot és az Erdővidéket meghatározó porhanyós, eróziós sebekre a kalotaszeginél sokkal érzékenyebb alapkőzetet is. A neogén üledéksor már Kalotaszeg egyik területét sem jellemzi, megjelenése egyértelmüen más tájegységekhez köthető.

\section{Újkori vulkánosság nyomai: a Köves-hegy szerepe a tájképben [6.b. tábla]}

Az üledékes rétegekkel együtt, a Gyalui Havasok É-i törésvonalán, fiatal vulkáni tevékenység során került a felszínre a gyerővásárhely-kiskapusi erupció, amelyek ha alárendelt tömegben is, de sajátos, jellegzetes alakban jelennek meg. A kúp K-i tömzsét riolit, Ny-i kúpját „fekete bazaltra” hasonlító augit-andezit adja, ezeket a kőzeteket két kisebb bányában fejtették. ${ }^{100}$ A geomorfológiai emelkedő (5km alatt 250m-t emelkedik a felszín) a fóúton erős kaptatót okoz; ennek a középkor óta tájtörténeti nyomai is vannak fogadók formájában. A Köves-hegy kettős kúpjának képe messze feltünik a Kapus völgyének Ny-i végpontjában és „impozáns hátteréül szolgál e kis területnek.” ${ }^{101} \mathrm{Ez}$ az alaktanilag is kontrasztos formáció kiemelkedik, elkülönül a mészkőüledékek vidékéből.

\section{Jelenkori üledékek: diluvium, alluvium [9.c. tábla]}

A földtörténet legfiatalabb diluvium és alluvium üledékei borítják a dombok legfelső rétegeit és a széles völgyeket. A diluviumok Hunyad és Egeres környékén vastagabb homokos kavicsos agyagból álló rétegek, amelyekben már mamutcsontok is találhatóak. Tájképi jelentőségük abban áll, hogy e két tágas medencében lapos, tompa domb-formájú átmenetet teremtenek a völgyek síksága és a magasabb dombvidék képe között. Kőzettörmelékekből és iszapból álló jelenkori üledékek borítják a széles völgyeket: a Kalota-mentét Nagykalotától egészen a Marótlaki-szorosig; a Nádas-patak völgyét; valamint az Almás-patak mellékvölgyeit. Ez utóbbiak széles, karakteresen lapos síkokat képeznek már azok felső folyásán is a Meszesről érkező nagyobb vízhozam miatt is.

\footnotetext{
${ }^{98}$ Dank-Sólyomtelke-Türe-Bács területén, majd K-re Zutor, Topa-hágón át Berend, Méra, Papfalva, Bács területéig

99 Koch-Hofmann, 1889., pp.21-22. Fogácskút környékén három vékony barnakőszéntelep található, de azok legvastagabbika sem éri el az 1m-t. további keskeny barnakőszéntelepek találhatóak a Zsombori rétegekben Pusztaszentmihály és Zutor között és Oláhköblösnél, amelyeket felületes müveléssel fel is tártak, de csekély vastagsága miatt a müveléssel hamar fölhagytak, Koch-Hofmann, 1889, p. 22.

${ }^{100}$ Koch-Hofmann, 1889., pp.26-29.

${ }^{101}$ Hoffer, 1909 , p. 5
} 


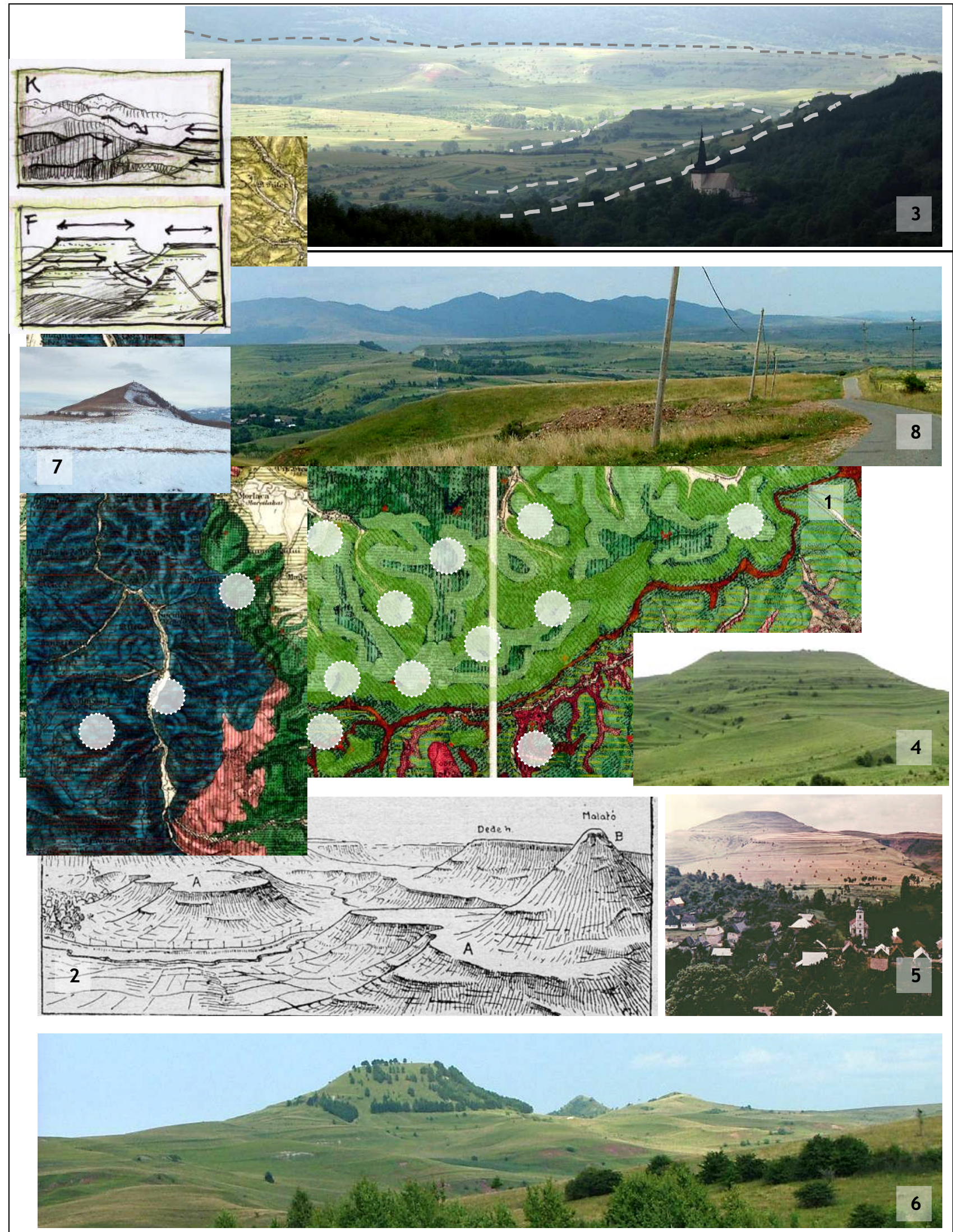

7. TÁBLA: EOCÉN ÜLEDÉKEK - A FELSZEGI ALSÓ DURVAMÉSZRÉTEGEK GEOMORFOLÓGIÁJA

1. A felszegi tájkaraktert leginkább meghatározó alsó durvamész rétegek kiterjedése, amelyek a konkáv mezaplatókat adják: Méregjó (DI. Ciulii), Kiskalota (DI. Cetati), M.Valkó (Sulyom, Tunya, Déde-hegy, Tér-tetö), M.Gy.Monostor (Várhegy), Erdőfalva (DI. Ardeovei), Deréte (DI. Hangaului, Nyíres), Bedecs felett (Hágó és Hágó tető). 2. Miháltz (1926, p. 145) rajza a kalotaszegi vízválasztó vidék jellegzetes tájképéről ( $A=$ mélyebben fekvő perforata rétegsor felső mészkőpadja, $\mathrm{B}=$ az alsó durvamészkőpaddal borított mezatetők. 3. Magyarvalkó fekvése a konkáv alsó durvamész-platók között. 4-5. A vízszintes mezák két példája: Déde-hegy és a Sulyom. 6. Panorámakép a Kalotaújfalui határból 7. A jellegzetesen kúpos-hegytípus: a Valkói „akasztófahegy”, azaz a Malató. 8. A Bogdán-előhegység képe Kalotaújfalu felöl, ahol már az eocén mészkő vízszintes, platós formációi rátelepülnek az alsó tarkaagyagra. 

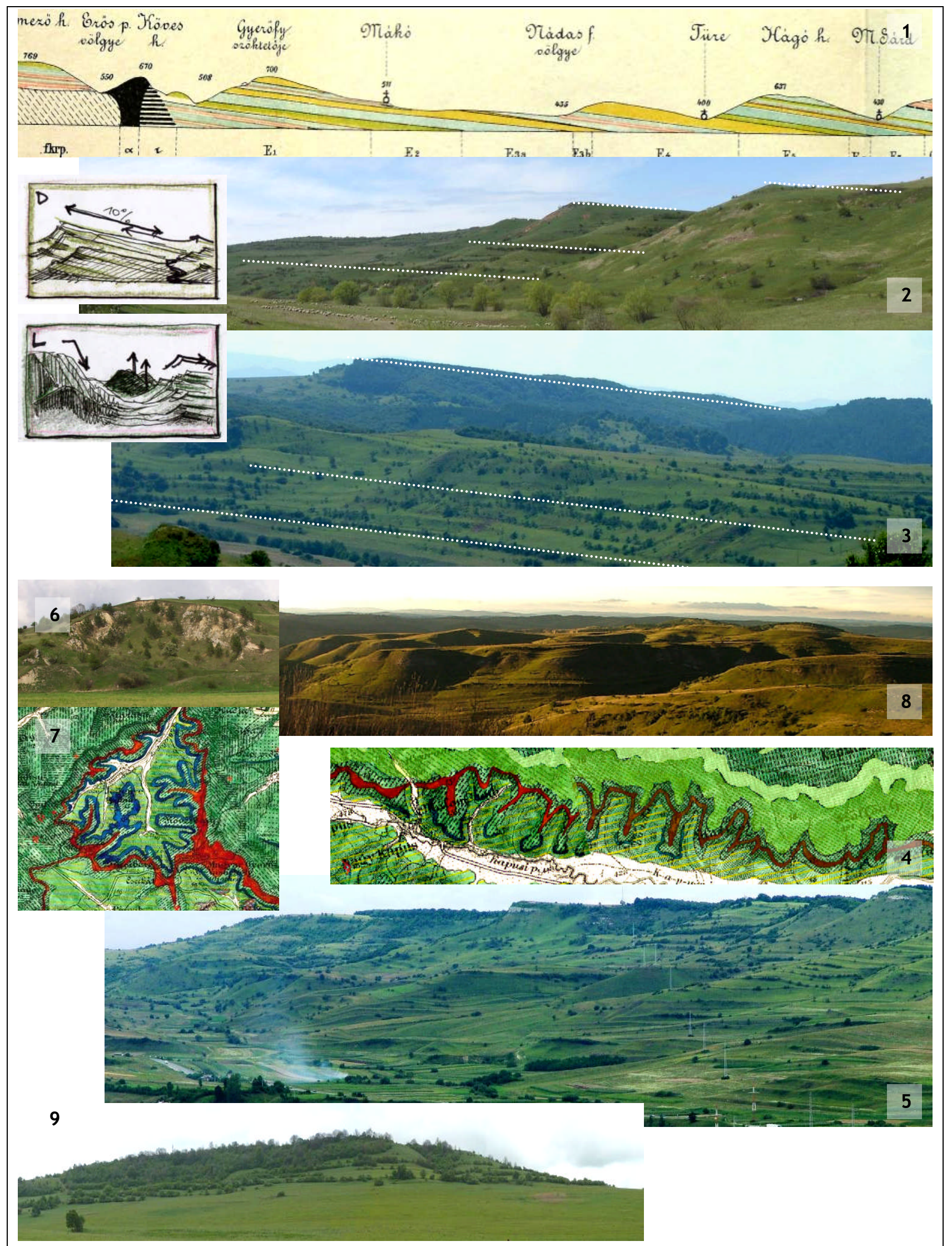

8. TÁBLA: EOCÉN ÜLEDÉKEK - A NÁDAS-MENTI FELSŐ DURVAMÉSZRÉTEGEK GEOMORFOLÓGIÁJA

1. A Koch-féle metszet jól szemlélteti az alsó- és felső eocén rétegek ferde réteges szerkezetét, amelyek a felszinen is dominálnak: Nádasmentén tipikus $10^{\circ}$ dölésben (Koch, 1894, II. melléklet) 2-3. A rétegek vetödése (D-É) a Magyargorbó - Nagykapusi útról: La Bagara oldal és a jegenyei határban. 4.-5. Gyerővásárhely - Kiskapus - Gyalu vonal dére néző domboldalain jól megfigyelhetöek a teraszszintek: középen az alsó

durvamész szint (amely Felszegen még tetöképző, itt már alábukott), és az arra települt felső tarkaagyag és durvamész-szintek, legfelül a fehéren kivillanó édesvízi peremmel: Gyeröffy-szt., Medve-hegy, Straja, Köves-hegy; ezek geológia térképe látványosan mutatja az „ajy"-okat. 6.7. A Jegenyei kettős perforata réteggel körbevett völgy és egy mára fásodott régi köfejtỏje. 8. Nagy felszínmozgalmasság, erős tagoltság Jegenye környékén. 9. A középső területének legmagasabb pontja (Riszeg-tető: 748m), egyben vízválasztója is ehhez a réteghez tartozik. 


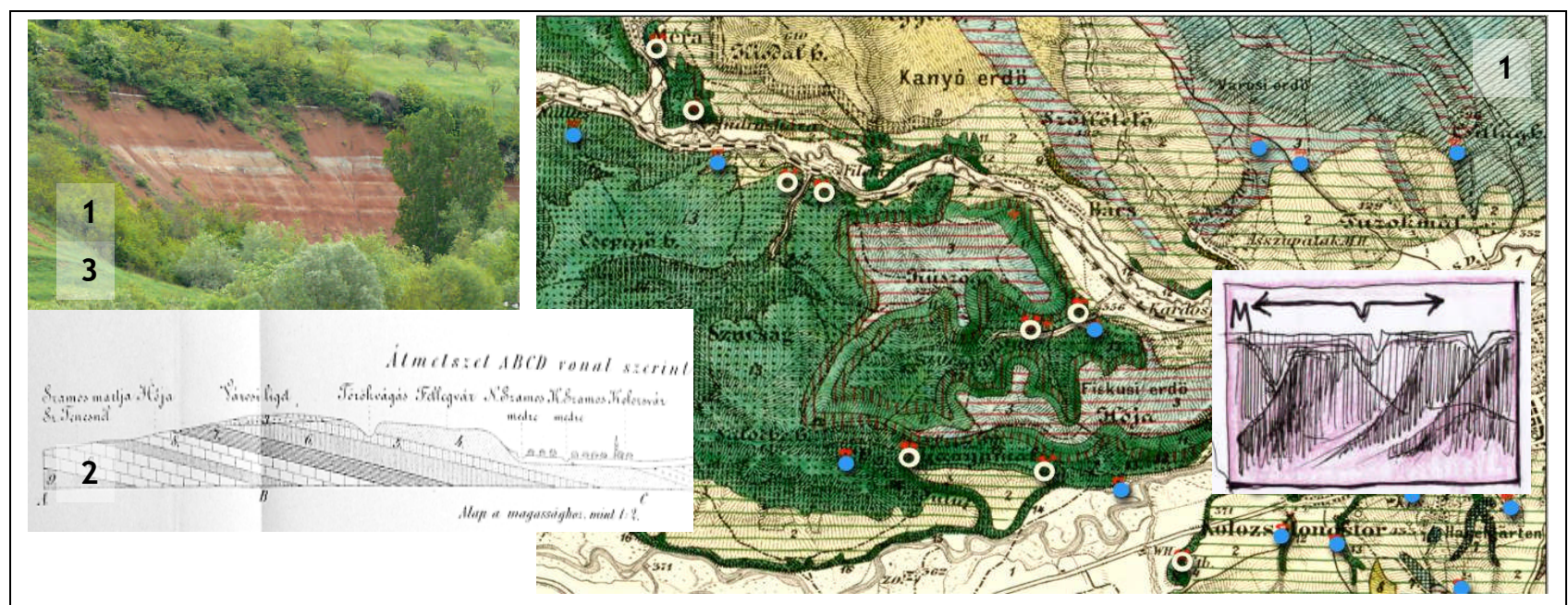

9.a TÁBLA: EOCÉN - RÉTEGEK ELTŰNÉSE KOLOZSVÁR KÖRNÉKÉN, NEOGÉN RÉTEGEK GEOMORFOLÓGIÁJA

1-2. Az eocén kori üledékek Kolozsvártól Ny-ra, a Bácsi-torok - Hója tetőn végleg az oligocén és neogén rétegek alá buknak le - azaz Mezőség irányában már nem jelennek meg: ezek kitünő vízgyüjtők, amelyek a környék jó forrásait (kék) adják és jó kőfejtőkkel is bír (fehér kör); ezt mutatja a metszet is (Koch, 1874., 1. mell.) 3. A réteg egyik utolsó kibukkanása Andrásházánál.

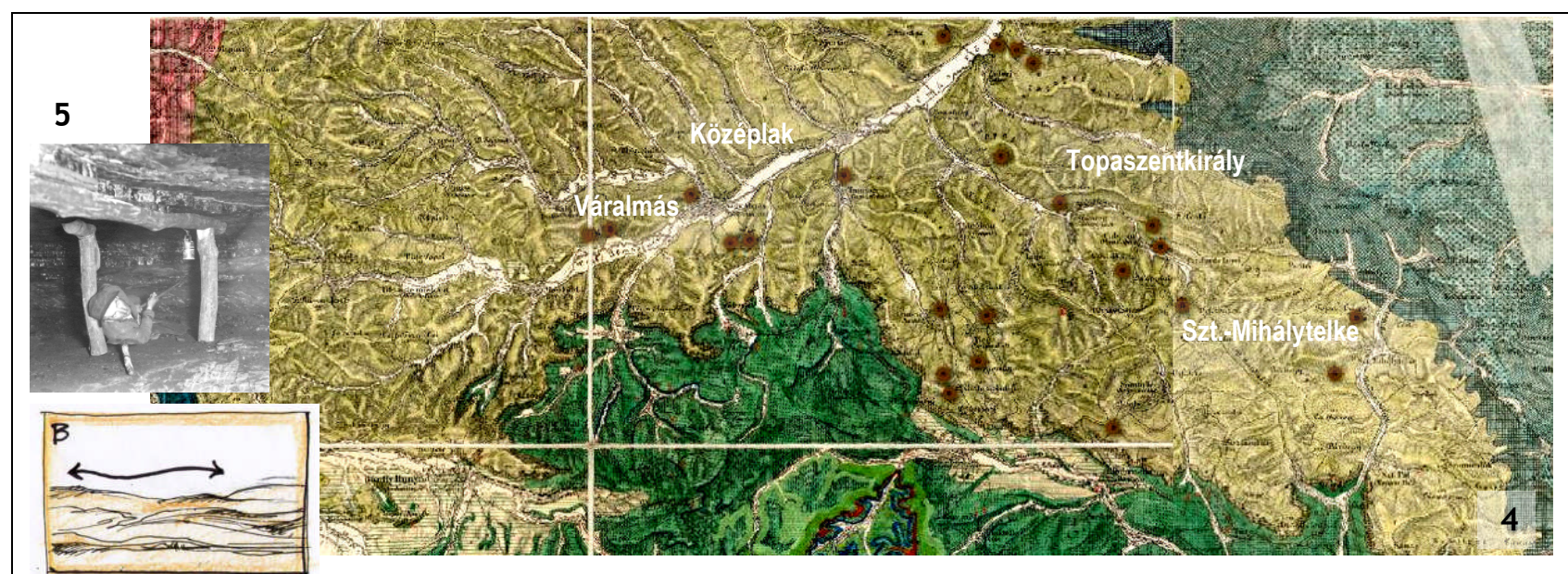

9.b. TÁBLA: HARMADKORI OLICOCÉN RÉTEGEK GEOMORFOLÓGIÁJA

4. Oligocén réteg (sárga árnyalat) borítja a Meszes keleti lábát és a teljes Almás-menti oldal-völgyeket egészen Topaszentirály Szentmihálytelkén át Kolozsvárig. Ez a réteg barnakőszén-kibukkanásokban bővelkedik (barna pont), amelynek központja a Dank-ForgácskútArgyas térsége. K-en, Berendnél a Borsa-völgyét és a Mezőséget is borító puhább, neogén üledékek tünnek fel (kék), ezek egyetlen kalotaszegi településre sem jellemzőek. 5. Barnakőszénréteg kifejtése (Balogh Ernő, 1935., Képkönyvtár 19108_22205)

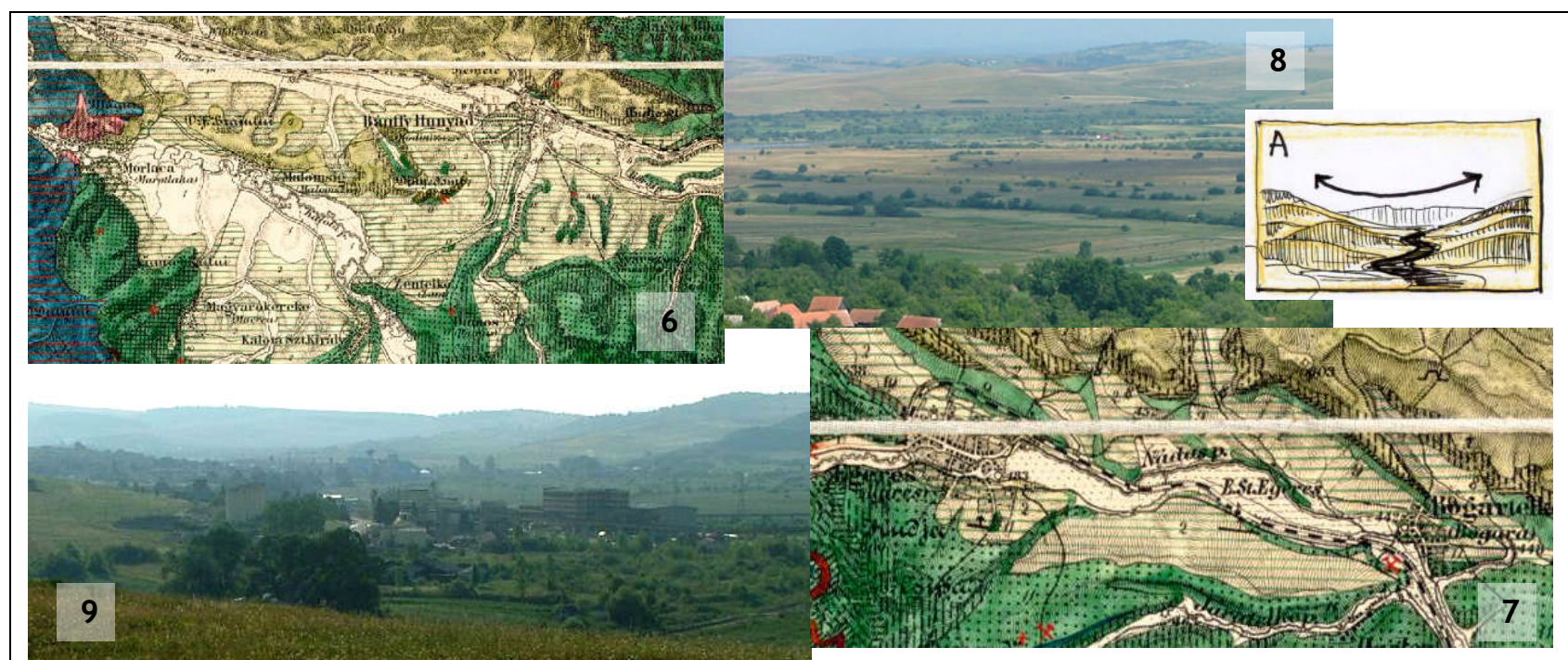

9.c. TABBLA: ÚJKORI ÜLEDÉKEK: DILUVIUM, ALLUIVIUM

6-7. Jelenkori diluviális (fehér-zöld csíkos) hordalékok és alluviális medencék (fehér tüpöttyös) a Hunyadi és az Egeresi-medencében. 8-9. A medencék széles, nyitott tág völgyeket képeznek, amelyek karakteresen eltérnek 


\section{II.1.b. Vízgyüjtők, völgytagoltság tájképi jellemzői}

Míg az előző fejezet a kiemelkedések, az agyag tájkarakterjegyeit elemezte, ez a fejezet a táj tagoltságának mély-formációira, szabad tereire és az ürök jellemzőit veszi számba. Kalotaszeg vízrajzát, vízgyüjtőit és völgystruktúráit alapvetően a geológia adottságai határozzák meg, mégis célszerủ a hidrogeográfiát elválasztva tárgyalni, mert az nagy hatással van a mikrodomborzati, talajtani jellemzőkre és a vízzel kapcsolatba hozható ipari tájhasználatra is. A terület legfontosabb vízgyüjtői Ny-felé a Kalota és a Körös; É-felé az Almás, K-felé a Nádas-, Kapus-patak, délen a Fenes-, Hesdátpatakok amelyek mind a Kis-Szamosba ömlenek. E vízgyüjtők organikus egységekre osztják a tájat, amely a közigazgatási járásokat is meghatározta a vármegye-rendszer idején.

\section{A vízgyüjtők szerkezeti tagolódása, lefolyási viszonyai [10-12. tábla]}

A kalotaszegi nagy vízválasztó, a Pányik-Kőrösfői tető K-i oldalán ered a Nádik-ér, a Kapus, és a Nádas-patak, amely Kis-Szamosként Kolozsváron és Désen át, ÉNy-nak visszakanyarodva, hosszú 200km-es, de csekély esésü út megtétele után érkezik Zsibó mellé (Turbuca, 189m), ahol egyesül az Almás vizével. Az Almás vize ugyanennek a vízválasztónak É-i oldaláról ered és ugyanazt az esést mindössze egy rövid, $65 \mathrm{~km}$-es út alatt éri el, így a patakmeder a nagy meredeksége miatt a Bánffyhunyadtól É-ra fekvő Almás forrásvidékén hirtelen, mélyebbre vágódott hátra. Ezért Alszeg nemcsak alacsonyabb fekvésü, hanem mivel puhább kőzeten fekszik, erősen tagolt terület is, sok mély, nagy esésű völggyel és éppen a gyors hátrálás miatt erősebb kimosódások, eróziók jellemzik. Ez egy hirtelen mélyülő felső-szakaszú erodált vízgyüjtőterület. A Firza- és Dorogna-patak mellékága tekintélyes hátráló eróziójával a 'közeljövőben' lefejezéssel fenyegeti a Köröst, hogy 'azután rövidesen’ egész Felszeg vízrendszerét magához ragadja. A bevágódás üteme egy emberöltő alatt is szembetünő. ${ }^{102}$ Az eróziót különösen gyorsította a Hunyadtól Ny-ra fekvő Remete-vidék talajmegkötő erdeinek kiirtása 1930 körül. ${ }^{103}$

A mélyre vágódott Alszeggel szemben a Bánffyhunyadi-medence rosszul víztelenített magas medence. Ez a terület már az eocén korban mélyedés volt, amit a vastagodó üledékrétegek is alátámasztanak. Az Ős-Kalota/Ös-Körös ekkor még K-felé folyt, amit a Kolozsvár környékén talált, Vlegyászából származó eruptív görgetegek is bizonyítanak. A Ny-felé tartó Sebes-patak forrásvidéke ekkor még Kissebes környékén volt. A vízgyüjtők megváltozásának oka a Gyalui Havasok É-i területének kiemelkedése volt, amely lapos boltozattal létrehozta a kalotaszegi fövízválasztót, majd ezután a Kalota és Körös vize Ny-felé folyt, a Szamos rovására. ${ }^{104}$ További bizonyíték a Kalota-Körös obszekvens völgyi ${ }^{105}$ helyzetére, hogy miután a Körös és a Kalota elhagyja saját meredekebb vízgyüjtő katlanát, mindketten esésüket vesztik, és széles allúviumokat raknak le. A Kalota szeszélyes

${ }^{102}$ Helyszíni vizsgálataim is alátámasztották a gyors bevágódást: a sztánai Berek-patak völgyén álló egykori malomárok vízkivételi pontján közel 50 év alatt -amióta a malmot felhagyták-, $2 \mathrm{~m}$ mélyen vágódott be a patak.

${ }^{103}$ Miháltz, 1926. pp.150-153.

${ }^{104}$ Cholnoky, 1918. p.257. 
kanyargásokkal halad a medencén végig, s kanyarulatai annál szélesebbek, minél jobban közeledik a Vlegyásza-lába felé. Ez a marótlaki Kalota-küszöb ${ }^{106}$ és a Remeténél lévő Körős-küszöb is egyfajta „duzzasztógát” szerepét veszi át és ezért is zsombékosodott el mindkét patak ártere az e feletti szakaszokon. A dácit hegységbe való bevágódásuk kezdetétől ( $\mathrm{kb}$. Sebesvár) ismét meredekebbé válik esésük Nagyvárad felé haladva.

\section{A fö vízfolyások felszínmorfológiai és tájtörténeti leírása:}

A Kalota-patak a Kelecel feletti Calatele-Padure erdőben, több mély völgy összefolyásából keletkezik: gyors lefolyású, hideg vizü patak, amely a terület névadója is egyben. ${ }^{107}$ Ettől Ny-ra egy dombpár (D1. Ciulii-D1. Tiglau) elválasztja a Méregjó vizeitől, amely mély eséssel tart a Székelyjó (=Henc patak, = Sebes-patak) felé egy erős bevágódású „V” alakú völgyben. Állandó bő vízhozammal 'lármásan csavarogva, és igen jó lisztelő malmait gazdagon locsolva vág Sebesvárának, amelyen alól a Körösbe szakad. ${ }^{\prime 108}$ A Kalota-patak Kelecel és Nagykalota közötti stabil és erős esése kedvezett a vízimalmok elhelyezésének. Már a Kolozsvári Konvent több malmot említ e völgyben. ${ }^{109}$ Az első katonai felmérés óta jelölt 15-20 malom láncolata komoly vízszabályozási szervezettséget tükrözött és egyben meghatározta a Kalota felső folyásának gazdasági jellegét is [13.§. melléklet]. Ezek lisztelő, ványoló $^{110}$ és fürészmalmok voltak, amelyek a havas nyersanyagit dolgozták fel. A havasalji kalotaszegiek számára ezek a folyóvizek elsősorban energiaforrást, de emellett szállítási lehetőséget is jelentettek Várad felé. A malmokat nemcsak a terep esése, de a kiegyenlített hegyi esők és talajvizek is megbízhatóan táplálták, így „minden időben eleget őrölhettek”. Tájtörténetileg és tájszerkezetileg egyértelmüen kirajzolódik a vízszabályozással összefüggő havasalji életforma amely SebesvárMéregjó-Nagykalota-Kelecel környékét jellemezte egészen a XVI. sz.-tól. Noha malmok minden bő víz mellett akadnak, Kalotaszeg más tájait nem jellemzik ilyen sürüségben. A 2001-es, majd 2009-es kalotai árvíz komoly károkat okozott, így 2011-ben vízrendezési munkálatok indultak meg: betonterméskő falakkal szabályozták a partokat Kelecelen, Nagykalotán és Kalotaszentkirályon (itt még vész-víztározó is lesz). Ugyanakkor a marótlaki Kalota-küszöb környezetében nem történtek munkálatok, így a hirtelen elvezetett csapadékvíz ott továbbra is torlódást fog okozni. A Kalota alsó folyását nyugodt, zsombékos, lapályos környezet jellemzi, füzesekkel, nedves láprétekkel övezve. A

\footnotetext{
${ }^{105}$ A korábbi lefolyás irányával ellentétes irányú keresztvölgy. Úgy keletkezik, hogy a hegységvonulat csapadékos oldalán a völgyfők erőteljesebben hátravágódnak és elhódítják a szárazabb lejtőoldal felső völgyszakaszait.

106 Szabó A., 1985. p.27.

${ }^{107}$ Neve szláv eredetre vall (calata), amelynek jelentése hideg, hasító víz.

${ }^{108}$ Merei Gracza György, 1842., in: Hála, 2006. p.30.

${ }^{109}$ Kelecel (1477), Székelyjó (1486), Méregjó (1499) Oláhkalota (1526) és Vársza (1552).

${ }^{110}$ A havasokon a vidék kedvelt haszonállatának, a juhnak gyapjúból condraposztót készítettek. A gyapjúszövet tömörítést a ványolómalmok (kallómalmok) végezték. - Sebestyén, 2011. p. 165.
} 
völgy látványa szélesen elterülő: a Dinnye-domb és a Tomoldok elöhegység magaslatai közötti legnagyobb szélessége $8 \mathrm{~km}$, ezáltal Kalotaszeg egyik legtágasabb térélménye, amelynek extrovertáltsága vizuálisan Marótlaka-Magyarókereke-Nagykalotáig ér.

Kalotaszeg másik vízgyüjtője, a Kőrös. A patakot jelentéktelen vízhozama ellenére erős helyi identitással ruházta fel a néphagyomány. A mára elszomorító állapotban lévő Körös"FŐ”-i befoglalás a Hágó oldalának legmagasabb forrása, de vízhozamáért többedmagával, az egész Kőrösfő feletti katlan és a bővizü Csinkó (=Újhatár)-patak oldalvölgyeinek forrásai is felelnek. ${ }^{111}$ Az 1941-es felmérés közel 20 forrást jelöl e $25 \mathrm{~km}^{2}$-es gyüjtőben, amely Sárvásárnál már olyan stabil vízhozamot adott, hogy azon malmot állítottak. Ezekből kiemelten fontos a Csinkói-völgy közel 5km-es hossza, amelyen 4 (!) malom kapott helyet. ${ }^{12}$ Ezután a Körös felveszi a Nyárszai-, Damosi-patakokat, végül a Hodos-felől jövő rövid vízfolyást, így ezt a hegyoldali települést optikailag is Felszeghez kapcsolja. A tágas völgy két magaslata közötti fesztávolság 2km, amely É-i oldalán meredekebb, D-i laposabb formájú.

Az Almás vizének szerkezete sokkal összetettebb, mint a fent említett patakoké. Az alacsonyabb fekvés és gyorsabb bevágódó hátrálás oka és egyben előremozdítója az alapkőzet csekély ellenálló-képessége. A vízhozamról a Meszes erdőtlen keleti lejtőinek (40km2) vizét begyüjtő Füldpatak gondoskodik, és ő veszi fel a Firza, Doroga-mellék-ágakat is, amelyek a Köröst szegélyező dombok alámosásáért felelnek. A patak stabil hozamán és jó esésén „Három-Füldön” a Czirákyösszeírás már 13 malmot említ. Az Almás-patak és a Bábony-patak szerkezében hasonlít a Füldpatakhoz: mind tökéletesen egyenletes esésűek és alsó részükön széles (600-800m), lapos, alluviális völgyfeneket képeznek, amely Kalotaszeg más területeire egyáltalán nem jellemző. A látvány horizontális, széles nádasokkal, és lapályokkal borított, kiegyenlített és egyáltalán nem mozgalmas felszín, mivel a patak irányváltoztatások nélkül, egyenesen halad. ${ }^{113}$ Ettől É-ra több hasonló párhuzamos hosszú bal-parti völgy következik. ${ }^{114}$ Az Almás jobb-parti mellékfolyói Bikal, Sztána, Tóttelke eocén rétegei közül erednek, és mindenhol bő vizü források táplálják. Ezzel szemben az ettől É-ra eredő danki, argyasi, köblösi, almásdáli völgyek a sokkal forrásszegényesebb oligocén rétegekből lényegesen kevesebb vizet nyernek, így ott malmot alig találunk. A zsobok-farnasi völgyben 7, a sztána-kispetriben 7, a tóttelke-tamási 5 malom müködött. Ezek a völgyek szükek, tagoltak,

\footnotetext{
${ }^{111}$ Tévesen állapítja meg Merei, hogy a Kőrös Bedecs határa felé lejtene, ugyanakkor helyesen észleli, hogy bővebb vizet hoz a Csinkó-Derite-Oláhbikali ág vízgyüjtője, mint maga a körösfői forrás, így valóban e területet is forrásvidéknek tekinthető. A nagy katlan esőzések idején a szük medrében „mint békétlen vérek az apai ház szűk falai között oly sokad magával, gyakran felduzzadva, és drága réteinken temérdek kárt okozva, bünös emberként, kígyózva csavarog a marótlaki csúp alá.” in: Hála, 2007. p.30.

${ }^{112}$ Egykori települése (1276: Terra Chynko in: Szabó T., 1941. p. 33.) valószínüleg a tatárjáráskor pusztult el, de jó hidrológia adottságai miatt funkcionálisan malomvölgyként újult meg (a lisztelö-malmoknak romjai mai is látszanak).

${ }^{113}$ Ebben egyedül Bábony helyzete kivételes, mert kissé összeszükül a völgy és erős kanyart vesz a patak, ezáltal változatosabbá (azaz „,kalotaszegiesebbé”) téve a látványt. Érdemes összevetni ezt azzal a ténnyel, hogy a környéken Bábony az egyetlen még magyarnak megmaradt kis település.

${ }^{114}$ Czold-p., Gúnya-p., Mesterága-p., Béna-völgy, Nyerce-p., Bercse-p.
} 
vonalvezetésükben is változatosak, ezért teljesen eltérnek a bal-parti mellékvölgyektől. A terület tájkarakter jellemzőit összefoglalva az Almás-menti Alszeg két völgytípusba sorolható: bal-parton nyitott, tág alluviális völgyek a két magaslat között már 4km-es távolsággal, míg jobb-parton nagy reliefenergiájú, mozgalmas dombok közötti meredek, kanyargós, éles bevágódott völgy-alakzatok sorakoznak. Alsófüld-Váralmástól Középlakon át a főfolyás mentén, a terület egyértelmüen az első csoportba sorolható, így ez éles tájkarakter-váltást jelent.

A K-i tájegységnek nevet adó Nádas-patak a Kőrösfői-hágó, Ravasz-hegy É-i oldalából, sok forrásból ered. Kalotanádas ${ }^{115}$ meredek, szük, mély völgyi helyzete is tükrözi ezt a völgyföi bevágódást. A kis vízhozamú NyÉNy-KDK irányú fövölgy egyenletes esése alkalmassá tette a vasútvonal elhelyezésére is. Bács és Szucság között, a Füleki-malomnál a felső durvamészkőben szükebb völgyszoros alakult ki, ami fontos tájszerkezeti fordulópont. A vízgyüjtő mentén kétféle jellegü tájat (tájkaraktert) különböztethetünk meg a térélmények alapján: (1) A kanyargósan fonódó fövölgyböl (50-100m-es völgyfenékkel és max. 1km-es légvonalbeli távolsággal a dombtetők között), amelynek É-i oldala erodált, köves, meredek; D-i oldala ellenkezőleg, lankásan ereszkedő. (2) Valamint ehhez két oldalt lazán kapcsolódó, zártabb oldal-völgyek sorából. A jobb oldali (déli) mellékvölgyekben, a völgytengelytől és egymástól nagyjából egyenlő távolságra jellegzetes kis eróziós völgyfö-katlanok sorakoznak több település fészkeként; míg a bal-oldali, meredekebb, kisebb völgykatlanokban kevesebb falu alakult ki. ${ }^{116}$ A Nádas-folyásán 15 nagyobb, stabil jövedelmű malom volt, ${ }^{117}$ és még Forgácskút-, Nádasszentmihály-, Pusztatopáról is 'lejártak a Nádasra őrölni'. A Kolozsvár felé egyre rövidebb és vízszegényebb völgyfőkkatlanokban a malmok száma is csökkenő tendenciát mutat. ${ }^{118}$ A víz természetes medrét először a vasútépítés szabályozta $(\sim 1870)$, amikor az időszakos vízfolyásokat csatornákba terelték, valamint Méra és Bács között több folyókanyarulatot átvágtak. ${ }^{119}$ Majd az 1896-os gorbói földcsuszamlás ${ }^{120}$ után a Nádas-túlsó partjára vezették át a vasútvonalat két nagy híddal, ami szintén módosította a patak-, és a malomárkok szerkezetét. A visszacsatolás után a Kolozsvári M. Kir. Kultúrmérnöki Hivatal 'a víz romboló munkájának megszüntetésére' vízrendezési terveket és munkálatokat indított meg, de megvalósulásuk bizonytalan a

\footnotetext{
${ }^{115}$ Kalotanádas nevén kívül a Nádas-mentén semmilyen formában nem fordul elő a „kalota” hely-, vagy víznév, ami Felszegtől való erős különállósát is tükrözi. Nevében rejlő Kalota újabb keletü (1913), és inkább a vízválasztó területre és mai körösföi járáshoz való tartozására utal; a helyiek a Nádas vagy Oláhnádas elnevezést használják.

${ }^{116}$ Kalotanádas, Jegenye, Inaktelke, Mákófalva, Vista és Szucság, ill. Türe és Méra, in: Szabó A., 1985., p.29.

${ }_{117}$ Az 1950-es évekig fennálló Nádasi malmok ( ) felfelé a folyásán: Szucsági , Andrásházi , Kis-Mérai , Magyarnádasi Vistához közel, két Vistában, az Árváthídi Vista és Gorbó határán, Gorbói a vasútállomásnál, Kis- és Nagy Türei Gorbó felett, Mákói a vasútállomásnál, Bogártelkén és Egeres faluban két-két $\sim$. Néhányat a falutól távoli tanyaként ma is laknak (Jegenye-Egeres közötti és Vistai ). Ezeken kívül az első. katonai felmérés és a Cziráky-összeírás még további malmokat is említ, de azok állapota nagyon megsérült, ma már alig fellelhető.

${ }^{118}$ A legfelső, kalotanádasi völgyben 2 malom, a jegenyeiben 2, az inaktelki Hasznos-patak bö forrása miatt a völgyben 4, végül a Mákói völgy Nádasi torkolatánál 1 malom müködött.

${ }^{119}$ A vasúti pályatest és a Nádas vízrendezési, kultúrmérnöki munkái jól tanulmányozhatóak az igényes korabeli helyszínrajzokon. (A nagyvárad-kolozsvári Vonal helyszínrajza, MÁV Tervtár, I. II. 3. fond)

${ }^{120}$ Szabó A., 1985. p.29.
} 
levéltári anyagok kutathatóságának hiányában. Összességében a Nádas koherens, összetartozó völgyegység, amelynek „gerince” a sok helyen nádasokkal szegélyezett vizes folyóvölgy, amelyet a régi szekérutak elkerültek, de a vasút stabilizációjával, majd az autóút kiépülésével fontos tájszerkezeti ütőérré vált. Vizuális egysége nemcsak a tájkarakterbe nyilvánul meg, hanem a vidék néprajzi, társadalmi egységességében is.

A Lonka-, majd Kapus-patak egyrészt a Magyarvalkó feletti Malató-kúp K-i felén, másrészt a Felsőgyerőmonostor feletti Várhegytől ered és 25 km-es hosszában Felszeg K-i vizeit összegyüjtve, Bedecs után belevágódik a Gyalui Havasok É-i nyúlványaiba és a „Pányiki-szoros” nevű szakasza után Kiskapusnál ér ki a hegyből, ahol már tetemes vízzé dagad és nem ritkán árvízzel fenyegeti a falut. ${ }^{121} \mathrm{~A}$ Lonka-patak folyásán még 1940 körül is 15 (zömében fürész-) malom müködött. Kiskapus dülőnevei között is sok víznevet találunk, ${ }^{122}$ és a 4 malom összehangolt árok-gátrendszere ma is átjárja a falut. ${ }^{123}$ Vízrajzilag tehát a település környezete a felszegi, havasi patakok alaktani jegyeivel mutat rokonságot: mély bevágódású, gyors, bő vízhozamú, nagyesésű patak, amely árnyas, hűs hegyalji hangulatot ad a tájnak. Bár Egerbegy és vizei a Meleg-Szamos felé tartanak, mégis völgykarakterében hasonló képet mutat Kiskapussal. Nagykapustól-Kolozsvárig jellemzőek az ,áj”-nevü térszíni formák. ${ }^{124}$ Ezek a mészkő-pad teraszpárkányába bevágódott ÉK-DNy-i, egymással párhuzamos, ritmikusan ismétlődő rövid, de meredek, kis időszakos vízfolyások, melyek látványos és megkülönböztető karaktert adnak a völgy dél-felé néző oldalának.

A Pádis-fennsík lefolyástalan vidékén dolinákban eltünő csapadék a fennsík K-i oldalán a Meleg-Szamos kis oldalágaiban bukkan fel. A közel 100km-es patak Gyalu felett egyesül a HidegSzamossal, majd felveszi a Kapus- és Fenes-patakot és Kis-Szamos néven érkezik Kolozsvárra. A századfordulón a fakitermelő, fafeldolgozó fürészüzemek ipari jellege dominált a Felszeggel kapcsolatban álló Josikafalván (Béles) és Gyalui völgyszakaszban is, majd az 1970-es években négy völgyzárógátas tározó és erőmü ${ }^{125}$ jelentősen megváltoztatva a völgy már akkor sem természetes képét. A folyóvölgy nem tartozik szervesen Kalotaszeg térélményéhez, de annak gazdasági hátteret ad.

\footnotetext{
121 „Kapus-pataka a határ erdei közt „Lonka” néven jőve le Monostorról, ez még több károkat szokott okozni áradásaival a lakosoknak, szárazság idején ki is szokott veszni, de a homok alól néhol ilyenkor is felbukkan.”... ill. „a két Kapus határát folya át, áradásai teméntelen károkat okoznak” in: Szabó T. A., 1942., p. 165 és p. 173.

${ }_{122}^{122}$ „Medve-patak $(\sim)$, Bödök $\sim$, Kapus $\sim$, Rétifolyam, Esztára $\sim$ Kis $\sim$, Cserajji $\sim$, Malom a, Tóji $\sim$, Sátor $\sim$, Simon a, Határ , Szappam a, Lonka, Bodos , Hótkapus a, Szelepes a, Bánya a - Szabó T. A., 1942, pp. 173-179.

${ }^{123}$ Fersőmalom $(\sim)$, Fogadós $\sim$, Ferkő és az Úr . A földkisajátításig a falu legnagyobb birtokosáé, Bíró Györgyé volt, akiről a falu legnagyobb belsőségét a Palotát nevezték el, amelyen a malom is áll. In: Szabó T. A.,1942. p.179.

124 Áj völgyet jelent és a finnugor eredetű aj áj köznevünkkel függ össze, amelynek jelentése: 'rovátka, bevágás, vájása, völgyelése vagy általában szája, nyílása valaminek'. in: Árvay, 1943. p. 15. Nagykapustól a Hója-tetőig közel 25 áj látható: Mátésáj, Kenderáj, Kiskenderáj, Harcsáj, Murkosáj, Szőlőáj - de az első katonai felmérésen olvasható még: Benedekáj, Hidosáj, Vistaáj is.

${ }^{125}$ Gyalui tó, Meleg-Szamosi tó, Tarnicai tó, Bélesi tó.
} 


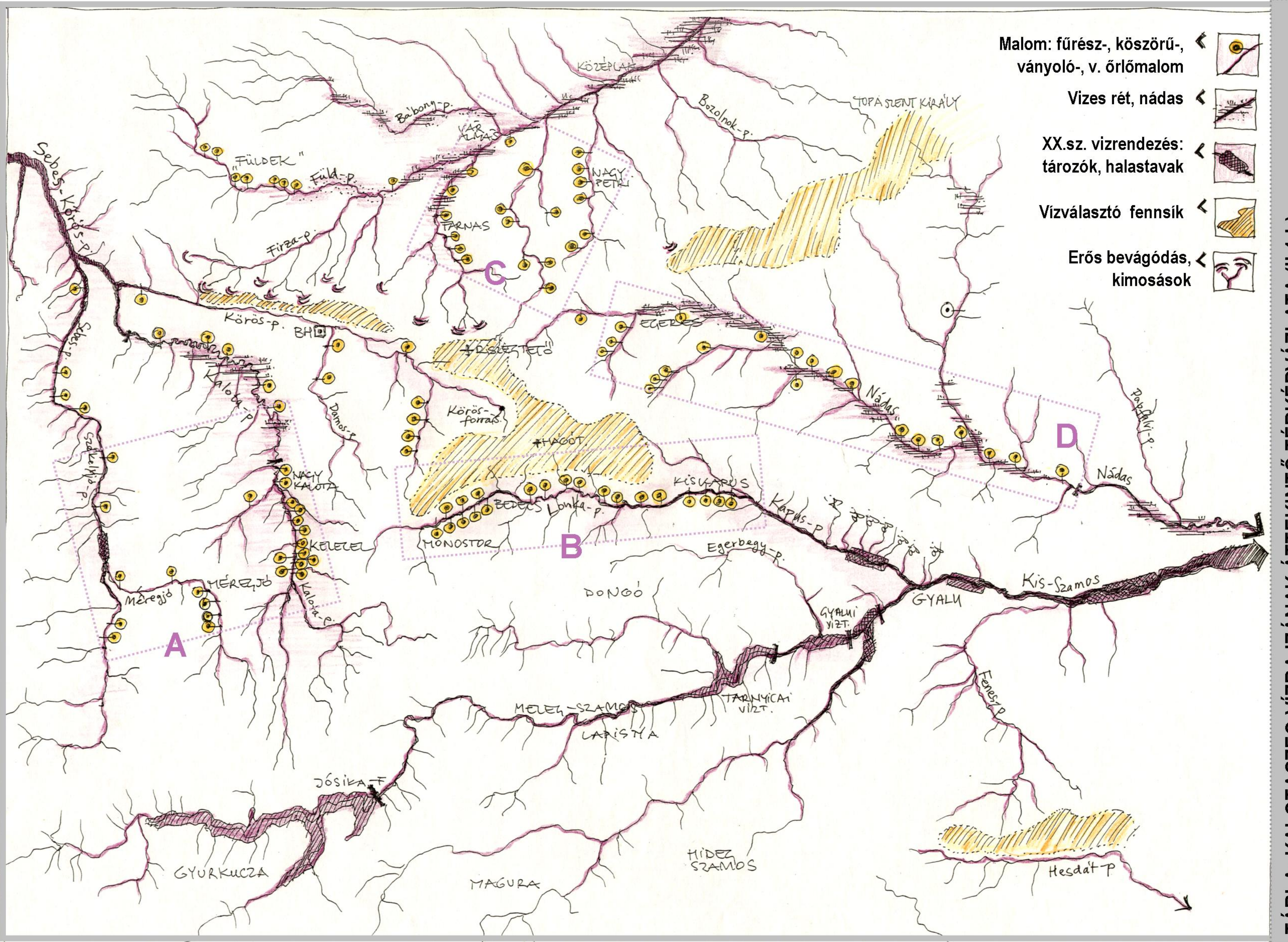

Kalotaszeg vízrendszere és a kapcsolódó vízi infrastruktúra, amely az alábbi területeken koncentrálódik: A - Kalota és Sebes-patak felső folyásán lévő intenziv ványoló-, fürészmalmok $>$ fontos viziút Nagyvárad felé 1900-ig, B - Lonka/Kapus-patak sürü fürész-, köszörū-malmai Magyargyerömonostor - Bedecs - Kiskapus között, C - Alszeg nagyesésũ oldalvölgyeiben sürũ gabonamalmok, melyek gazdasági potenciált jelentettek, D - Nádas-mente állandó, stabil vízhozamú malomrendszere, amely egészen 1950-ig jelentös gazdasági szereppel bírt. 

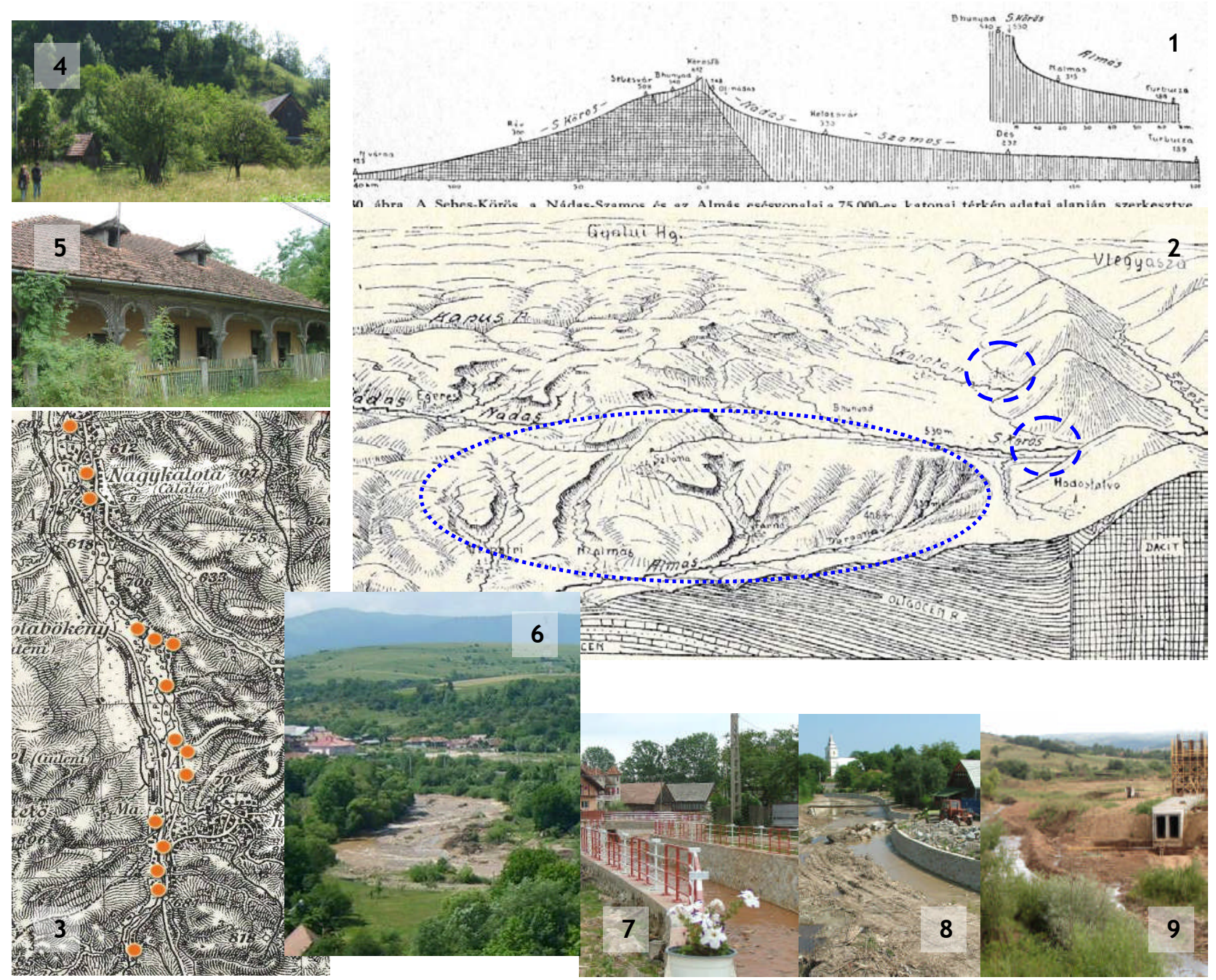

Gqfilui Hg

$\frac{-1}{100} 2$
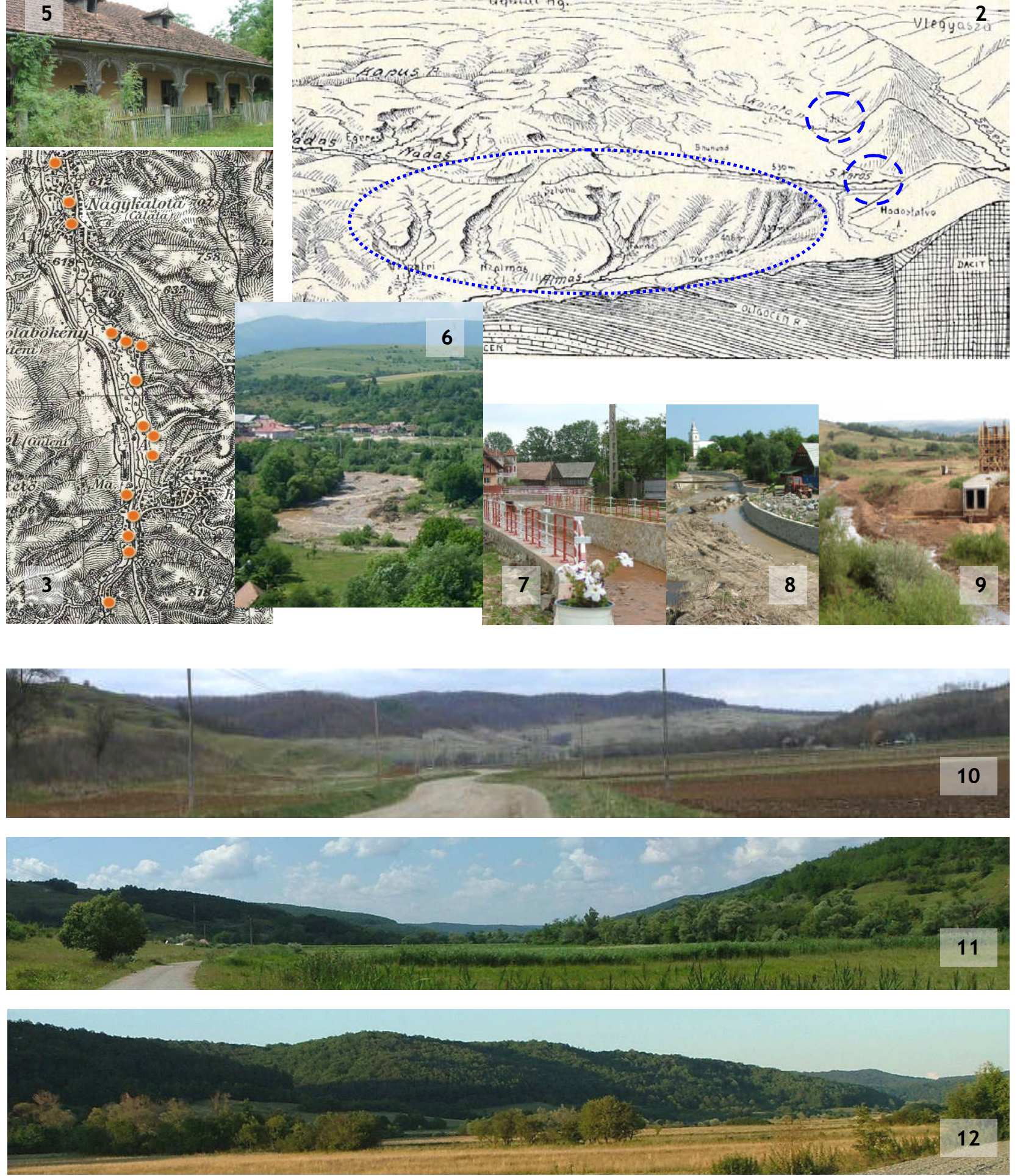

11. TÁBLA: VÍZFOLYÁSOK ÉS VÖLGYTAGOLTSÁG MORFOLÓGIÁJA - I.

1. Völgyek lefolyását elemző metszet: Ny-ra a Körös görbéje (jól látszik esésének megnövekedése Sebesvár után); KIÉ-ra a Szamos (lapos) és kimosódásokat okozó Almás (meredeken hátravágódó) lejtési íve Turbuczáig (Miháltz, 1926a, p. 147). 2. Kalotaszeg és határoló területeinek tömbszelvénye: az elötérben látszik az Almás meredek, erodált oldalvölgy-rendszere, jobbra pedig a Körös-áttörés Remeténél és a Kalotaáttörés Marótlakánál (u.o.) 3-5. A Kalota felső folyása Kelecen - Nagykalota között a malmokkal ( 15) és két megmaradt épülettel: Keleczel és Valkói malom. 6-9. A Kalota áradása 2009-ben Magyarvalkónál és az azóta történt folyószabályozások: Méregjó, Nagykalota, Kalotaszentkirály. 10-12: Az Almás három oldalvölgyének hasonló, lapos tág szerkezete: Füldi-völgy, Lapupataki-völgy, Bábonyi-völgy. 

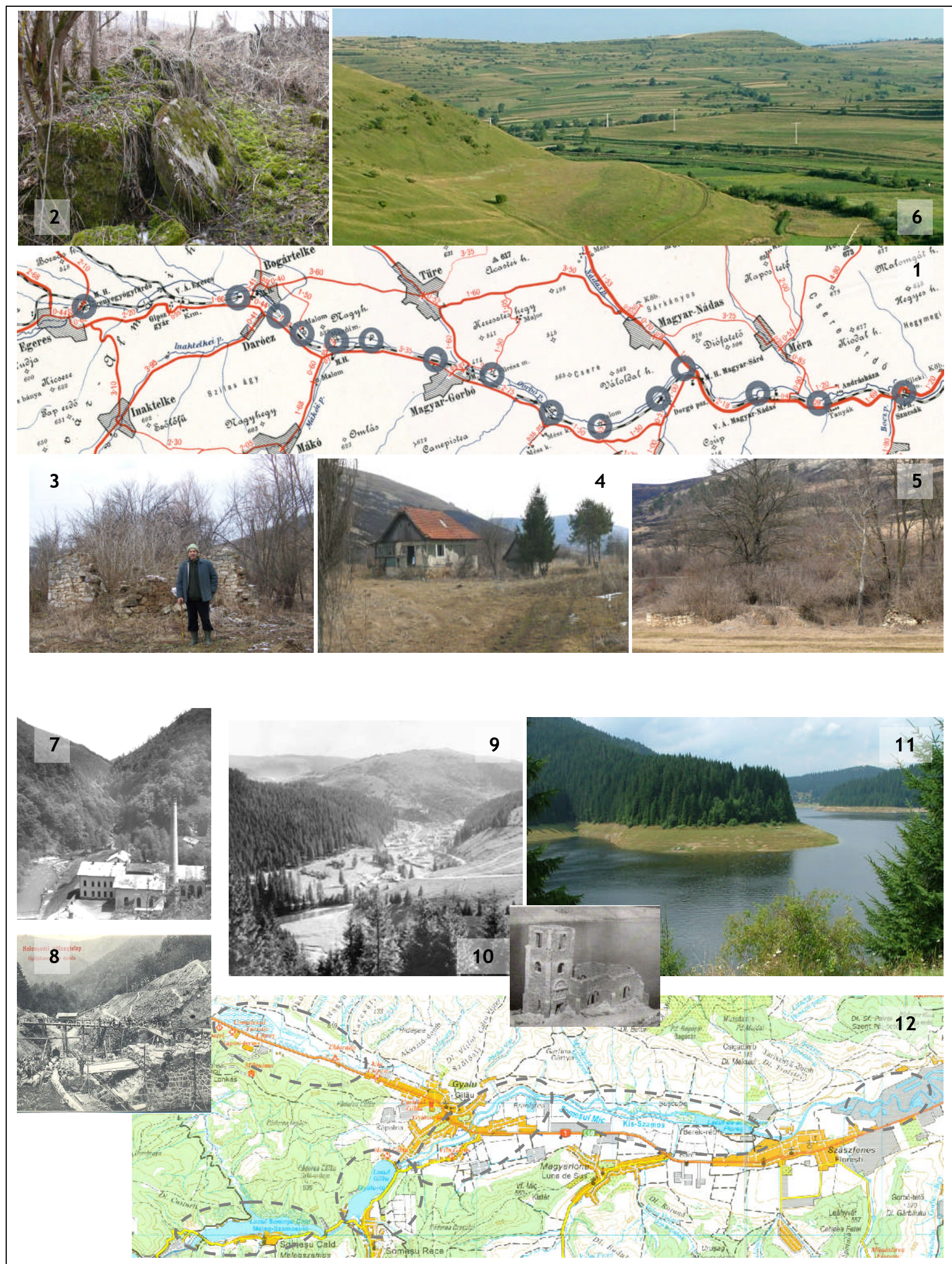

12. TÁBLA: VÍZFOLYÁSOK ÉS VÖLGYTAGOLTSÁG MORFOLÓGIÁJA - II.

1. A Nádas-patak vizes völgyében 15 nagyobb malom üzemelt Egeres és Szucság között (zömük 1950-ig), amely összehangolt vízszabályozást kívánt miközben gazdasági potenciált is adott a völgynek (OSZK, TA_7395). 2-5. A Türei Kis , a Sztánai-, a Mákófalvi-, és a Nagy Türei malom megmaradt elemei, romjai 6. A Nádas-völgyének látképe jobb oldalon egy régi malomárokkal. 7-9. A Hideg-Szamos XIX. sz.-i ipari létesítményei: gőzfürész-üzemek, villanytelep (Gyalu), fatelepek (Jósikafalva) - ezek megváltoztatták a völgy képét, miközben gazdasági hátteret adtak Kalotaszegnek. 10-11. A Jósikafalvát és a Vasvári emlék kápolnát elárasztó Bélesi-víztározó 12. Komplex vízszabályozás a Szamoson a XX. sz. második felében: völgyzáró gátak, folyószabályozás, halastavak. 


\section{2. A felszínmorfológiai tértípusok megállapítása és leírása}

Helyszíni terepbejárásaim során tett megfigyeléseimet a geológiai-földtani szakirodalommal összevetve megállapítottam, hogy Kalotaszegen és környékén a tájkarakter szempontjából több domborzat-alaktani típust lehet elkülöníteni, amelyek eltérö térélménnyel rendelkeznek. Bár önmagában, a geológiai térképekkel nem lehet térélményt rekonstruálni (ezért nem fekszenek majd össze egymással pontosan a geológia-térkép és a tértípus-térkép határoló vonalai), mégis megértve a földtani folyamatokat és azok következményeit, kirajzolódik az a geológiai adottságokra épülő gazdag felszínmorfológiai struktúra, amely egy mélyebb tájkarakter-jellemzés és tájesztétikai leírás alapját adja meg. Ezek meghatározásában az alábbi kérdéseimre figyeltem:

Mennyire meghatározó a tájképben az egyes magas-hegységek látványa? Ezek közeliek, vagy távoliak-, tompa-fennsík jellegüek vagy erőteljesen felfelé törekvők? A hegyvonulat mellett érvényesül-e dombvidéki hullámzó forma? Milyen a dombság térbeli helyzete: nyitott v. tágas, zárt v. szurdok jellegü? Vannak-e platók, vízszintes fennsíkok vagy egy-irányba dűlő vetődések, ritmikusan ismétlődő, visszatérő alakzatok? Vannak-e sziklás, meredek, függőleges falak? Milyen mozgásdinamikával lehet kifejezni a felszíni alakzatokat? Jellemzik-e egyedi színek e képződményeket? Milyen a völgyek térüressége, kapcsolatrendszere? Hol, milyen arányban jellemzőek a folyómenti síkságok a tájban? Mekkora szerepe van a nyitott vízfelületeknek?

A fenti kérdések alapján jól elkülöníthetőek voltak erös domborzati karakterekkel rendelkező térélmények, míg más vidékek jellegtelenebbeknek mutatkoztak. Annak érdekében, hogy az egész általam vizsgált területet lefedjem a térélmények, térformák alapján TÉRTÍPUSOKAT különböztettem meg. A TÉRTÍPUS geológiai-, domborzati jellemzők és a völgystruktúrák formai összegzéséből kialakult táji léptékü térformák alaktan-típusa. A tájrészletek felszínmorfológiai dinamikáját (nyilakkal és szövegesen) leírva és sémarajzban megjelenítve alkalmasnak találtam a helyi tájkarakter-típusok meghatározására. Ez egy alapvetően helyszínelésből, terepbejárásból eredő megállapítás, amely csak a „csupasz domborzat” okozta alaktani jegyekre utal. A típusokat sémarajzokkal szemléltettem és rövidtömör összefoglalóval láttam el [8. ábra], [13. tábla]. 
A: Almás- és oldalvölgyei (Füld, Bábony, Lapupatak, stb.): oligocén kori puha mészkö és újkori diluvium; nyitott, szétterülő tág, alluviális völgy, ártér, alacsony felszínmozgalmasság, lankás domboldalak, nagy átlátások, Meszes alig érvényesül.

B: Bács-berendi átmeneti terület: oligocén kori puha mészkő, barnakőszén-kibúvások, nagyon lankás, határozott ismétlődő hegyforma nélküli dombok.

C: Alszegi felső-durvamész formáció: változatos formájú, meredek falú, mély bevágódású völgyek, sok eróziós völgykatlan, a Meszes képe e magasabb felszínről jobban érvényesül.

D: Nádas-mente: felső durvamész-rétegek, aszimmetrikusan, kb 10\%-osan ÉK-felé megdőlve, mészszirtjei kiszögelléseket adnak egyrészt a Kapusi vízválasztón, másrészt a Nádas É-i oldalán, a Nádastól D-re a rétegek megdőlt oldalára látunk rá, nagy lapos platókat képezve.

E: Tordaszentlászlói környék: alsó tarkaagyag, homokkő és agyagpala; a Gyalui-Havasok impozáns sziluettet ad, erőteljesen a dombvidék felé magasodik, ugyanakkor a K-i oldalon megjelennek a Kapusi-völgyhöz hasonló kiszögellö mészpadok, de nem alkotnak erős, ritmikus vizuális hatást.

F: Felszegi mezaplatós vidék: alsó durvamész-rétegek, amelyek visszatérően ismétlődő, konkáv oldalú mezaplatókat képeznek, tetejükön erős, fehér mészkőszirtekkel, jó ellenálló-képessége miatt nem alakultak ki hosszú völgyek, hanem tagolt, elágazó rendszerü mozgalmas völgyfalakat képez, igen változatos térélményekkel.

G: Vlegyésza: eruptív kőzetü, a vulkanikusság felfelé törekvő dinamikáját megőrző magashegységi vonulat, monumentális erejü, de Tomoldok elöhegység és az időjárási körülmények miatt sokszor takarásban marad.

H: A Vlegyásza és a Meszes K-re lefutó hegylábi területe: dacit, andezit, és mészhegység hasonló szerkezetü magaslatról, végül alluviális völgybe érkező szerkezetüek, lágyan dinamikus, hullámzó alakzatúak.

I: Bánffyhunyadi-medence: újkori diluvium és alluviális terület, sík, tág, teknőszerüen nyitott belső árterekkel, felszínmozgalmasság szinte elhanyagolható, de térélményében a Tomoldok előhegység lefutó oldala és a távoli Vlegyásza is igen meghatározó.

J: Havasi mélyen bevágódott völgyek: a kemény csillámpalákba és a vulkanikus kőzetbe, Vkeresztmetszettel, mélyen bevágódott szük völgyek, árnyas hatással, de bőséges, állandó vízhozammal.

K: A Felszegi havasalja: a Gyalui gránittömbre ráfutó alsó tarkaagyag-padok, amelyek eróziós hegyek hatását adják, erős alaktani jellegzetességek nélkül, ugyanakkor már rákúsznak az első alsó mészpadok vízszintes platói is.

L: $\quad$ Kapusi völgy: a Gyalui Havasok meredek É-i oldala és a Nádas-menti szöktetők közötti árnyasabb, szükebb völgy, amelynek völgyföjében a Köves-hegy képez különleges lezáró formát újkori, pontszerủ vulkáni kettős kúpjával.

M: Gyalui Havasok: ősi csillámpala, gránit-tönk, amelynek pányiki vízválasztója utólagosan megemelkedett terület, majd a lepusztult egyenetlen fennsíkba patakjai mélyen vájták bele magukat, oldalai meredeken tagolatlanul futnak le a Kapus-Szamos felé.

N: Magyarléta környéke: a Gyalui havasok erőteljes látványa mellett megjelennek a függőleges andezit-falak és a Tordai környéket jellemző mészkőhasadékok, az alsó és felső mészkőpadoknak nincs alaktani ritmusa, visszatérö eleme.

8. ábra: A felszínmorfológiai tértípusokat jellemző táblázat 


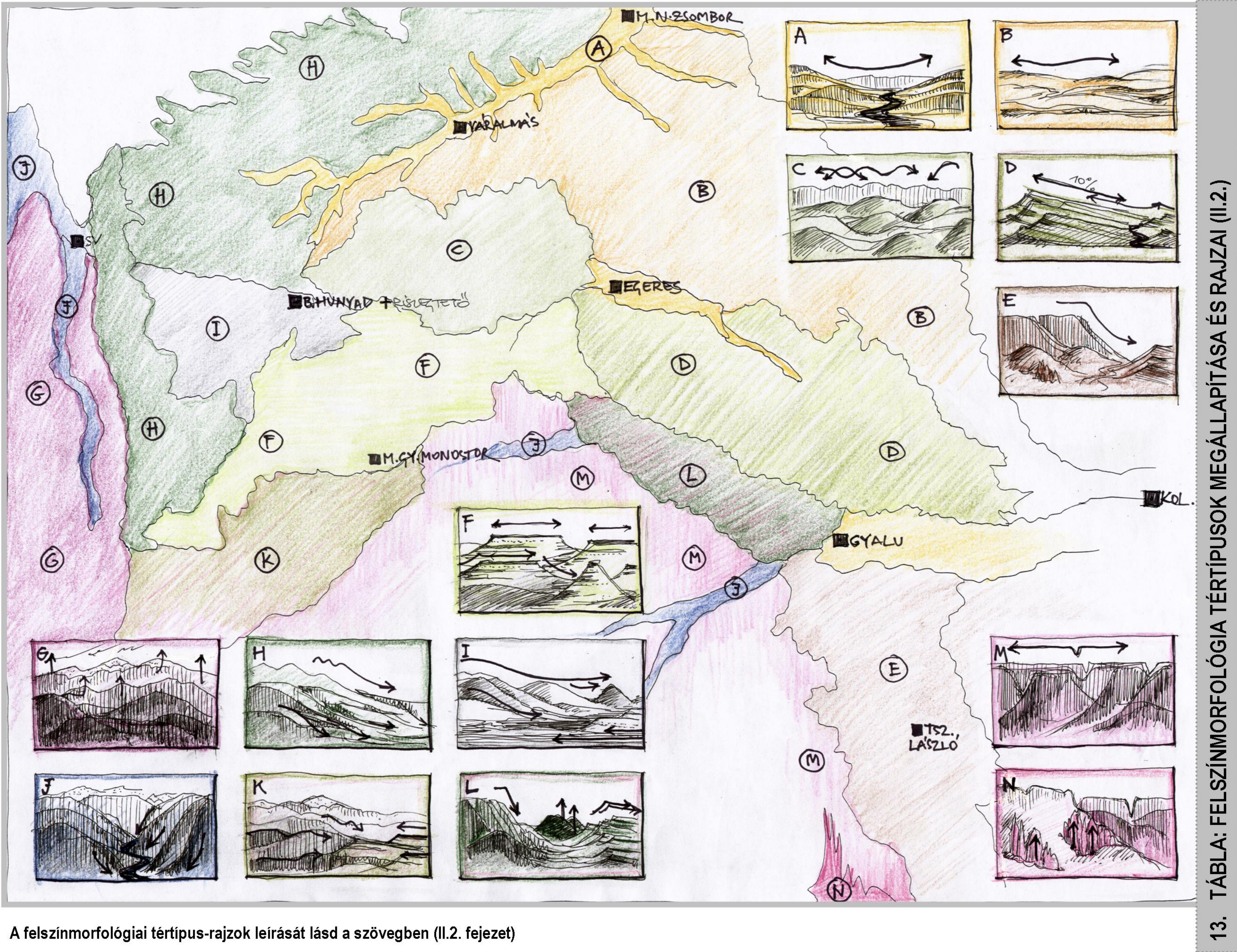




\section{3. A tájkarakter-zónák lehatárolása és azok}

\section{tájesztétikai szempontú leírása}

\section{3. 1. A tájkarakter-zónák lehatárolási kérdései Kalotaszegen és környékén}

A tájkarakter-elemzés egyik kulcskérdése olyan egységek lehatárolása, amelyek rendelkeznek közös tájkarakter-jellemzőkkel, egyediek és a környező tájrészletektől is jól elkülönülnek. A Swanwick-által kidolgozott hierarchikus metodika nagy tájegységekből szükít a kisebb területi egységek felé. Ezt a „zoomoló” módszert az általam vizsgált területen is levezettem [9. ábra].

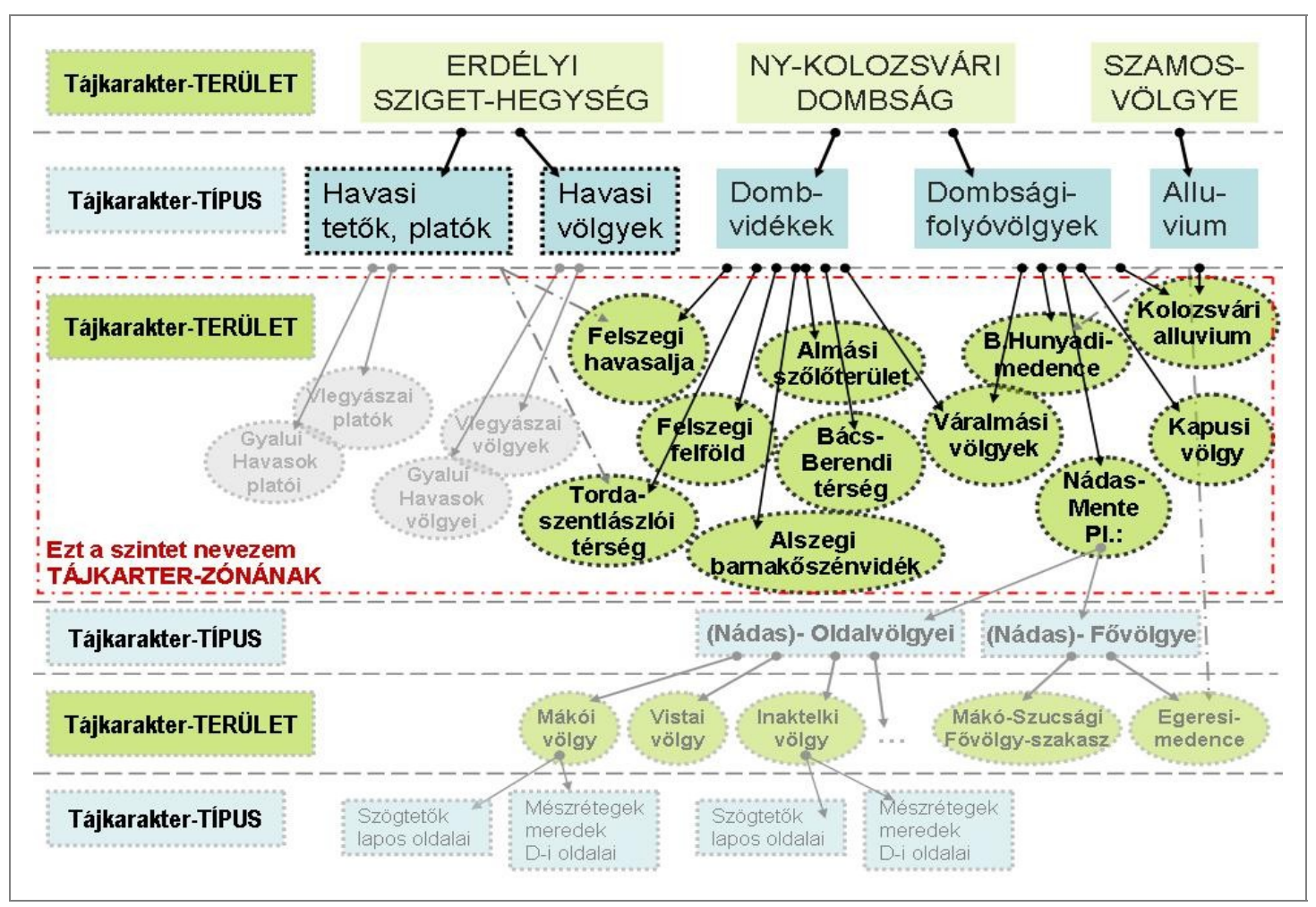

9. ábra: A tájkarakter-típusok, tájkarakter-területek és tájkarakter-zónák hierarchikus kapcsolata a Swanwick-féle módszer alkalmazása a vizsgált területre

A vizsgált vidék az Erdélyi Sziget-hegység, a Kolozsvártól Ny-ra elterülő vízválasztó dombság és a Szamos-völgyének tájkarakter-területébe tartozik. Ezek domborzati szempontból még -túl általános-, tájkarakter-típusokba bonthatóak (pl.: hegyvidéki plató, dombvidék, völgy).

Ezek újabb, tájkarakter-területi alegységei -amit én tájkarakter-zónáknak neveztem el-, már ideális léptéket adnak a tájkarakter elemzéshez. Ezek olyan körbezárt, egymással érintkező, koherens jellemzőkkel bíró tájkarakter-területek, amelyek összefüggést mutatnak néprajzi tájegységekkel, így a kitüzött kutatási célnak léptékében megfelelnek. Bár ezek al-típusokba és azok al-területeire lehetnének tagolhatók, jelen kutatásban további bontásuk nem indokolt. E lépték tájkarakter-elemzésre ideális voltát bizonyítja, hogy ha ezeket tovább osztjuk (pl.: inaktelki- és mákói- 'Nádas-menti oldalvölgyek'), akkor olyan kis terület-egységeket kapunk, amelyek egymással szinte teljesen hasonló, ismétlődő típus- 
jegyekkel bírnak (pl.: mindkettőnek egyforma „,szögtetős lapos oldala” és „,meredek D-i oldal” típusból áll). Ez a jelenség újra csak az egy-tájkarakter-zónába való összetartozásukat nyomatékosítja.

A besorolás rávilágított arra is, hogy az általános típus-kategóriák meghatározása alatti szinteken, olyan átmeneti zónák jöhetnek létre, amelyek mindkét tájkarakter-típus jellemzőit magukon viselhetik (ezeket szaggatott nyilak jelzik; pl.: a Felszegi havasalja egyszerre a hegyvidék-típus alsó pereme, és a dombság-típus felső szegélye). Az is kiderült, hogy egy zóna önmaga is alkothat egy típust és egyben egy területet adott vizsgálati kontextusba (pl.: Szamos-mente-területe csak alluviumtípusba esik, ami csak a Kolozsvár- alluvium zónáját foglalja magába; de erre látunk példát Swanwick 6.2-es, ill. 6.3-es ábráin is - 3.§. melléklet). Ez mutatja, hogy nem feltétlenül szükséges egy zóna további bontása, ha az önmagában is koherens egész. A típus // terület kevésbé konzekvens alkalmazására mutat rá Swanwick, amikor kistérségi vizsgálati szinten a területhasználati foltok kiterjedése alapján további tájkarakter-típusra való bontást végez (pl.: erdö, ligetes erdö, legelö, stb.), majd pontosan ugyanezeket a foltokat, mint újabb területeket is elnevezi (pl.: Inaktelki erdö, Mákói ligetes erdó). Ebből látható a típusok és területek közötti átfedések rendezetlensége.

A kutatás célkitüzése ebben a munkában konkrét, helynévvel definiálásra kerülő területegységek lehatárolását, megnevezését és karakterleírását igényelte és nem típus-besorolást. Swanwick kiemeli, hogy az háttérként szolgáló alaptérképek fedvényeinek szemrevételezéssel történő összevetítése alapján már lehatárolhatóak hasonló karakterü területek. ${ }^{126}$ Kalotaszeg és tágabb környékén a tájkarakter-ZÓNÁK megállapításához a következő alapadatokat használtam fel:

- geológia alaptérkép határvonalait, tagolásait (3. tábla)

- a felszínmorfológia vizsgálatból következő tértípusokat (13. tábla: A-N)

- a regionális térháló-kapcsolat történeti összefüggéseit (2.tábla)

- és a terepbejárás során észlelt tájképi, térélmény-jellemzőket.

Mindebből 13 TÁJKARAKTER-ZÓNA alakult ki, amelyek körbezárt alakzatokat alkotnak; egymással összeérnek és nem fedik egymást. Ezek közül tizenegy, konkrét földrajzi nevet tartalmazó tájkarakter-területi egység, és kettő típus-egység: a hegyvidéki területek „havasi-tetöit” és havasivölgyeit" mint tájkarakter-típusokat ismertetem, azaz nem bontom őket további területi egységekre (Vlegyészai- és Gyalui-), mert azok Kalotaszegtől minden szempontból élesen eltérnek és e vizsgálat szempontjából nincs lényeges különbség közöttük.

\footnotetext{
126 The different map overlays are combined to begin identifying areas of common character to be tested and validated in the field. These overlays should suggest clear correlations between different factors and allow areas of potentially similar character. This work may be done manually and judged by eye. = A közös karakterjegyek meghatározásához használt különböző alapadatokat tartalmazó fedvényeket a terepen kell tesztelni és érvényesíteni. Ezek a fedvények már bizonyos korrelációkra kell utaljanak a különböző adottságok terén, és kijelölhetnek potenciálisan hasonló tájkaraktereket. Ezt az összevetést kézzel és szemrevételezéssel is meg lehet tenni (példa a 3.§. melléklet 6.3. ábrája). in: Swanwick, 2002. p. 26.
} 


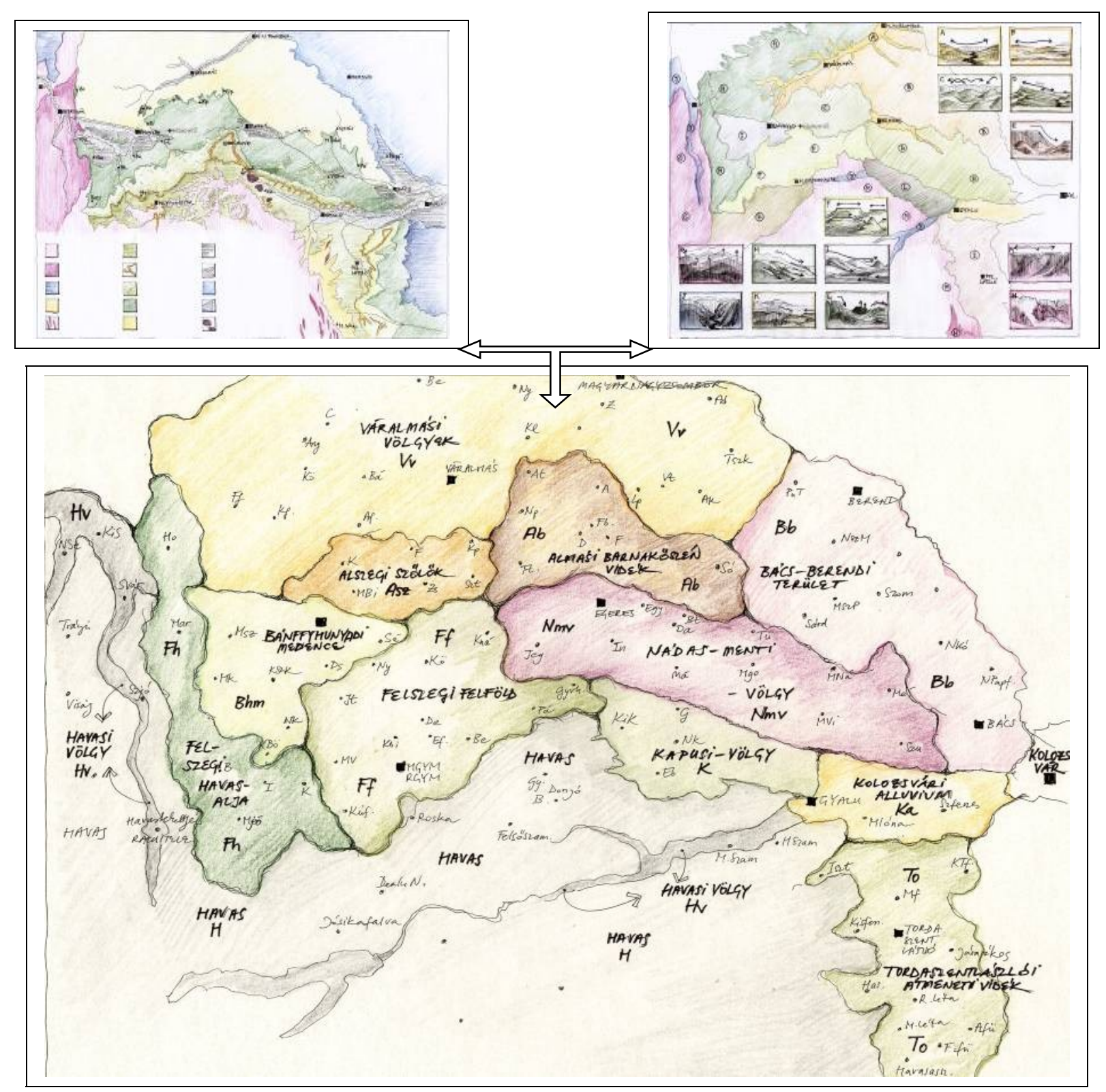

10. ábra: A tájkarakter-zónák lehatárolása a geológiai alaptérkép, a tértípusok, a regionális térháló-kapcsolatok és a helyszíni élmények alapján

A Kolozsvártól Ny-ra fekvő dombvidék zónái: Asz = Alszegi barnakőszénvidék, Asz = Alszegi szőlősfalvak, Bb $=$ BácsBerendi térség, Bhm = Bánffyhunyadi-medence, $\mathrm{Ff}=$ Felszegi felföld, Fh = Felszegi havasalja,

$\mathrm{K}=$ Kapusi-völgy, Nmv = Nádas-menti völgyi, To = Tordaszentlászlói átmeneti vidék, Vv = Váralmási völgyek; az Erdélyi Szigethegység zónái: H = Havasi falvak, Hv = Havasi völgyek (Típusok!) és a Szamos-mentének zónája: $\mathrm{Ka}=$ Kolozsvári alluviális síkság

\section{3. 2. A tájkarakter-zónák tájesztétikai leírásának szempontjai}

$\mathrm{Az}$ alább bemutatott hét elemzési szempontot a nemzetközi tájesztétikai módszerek összevetésével, azok átfedéseinek kiszürésével és a rokon témák összefüzésével állapítottam meg [11. ábra]. Ezt már több hallgatói felmérés, tájleírás során is alkalmaztam és alább, a kalotaszegi tájkarakterzónák leírásba is beépítem. Az egyes szempontok eredeti forrásait, alapgondolatait lásd az I.4.3.4. fejezetben, és a 3-4. §. mellékletben. 
- Felszínalaktan, felszínmozgalmasság, formai változatosság

Milyenek a tájformák? Milyen alakok, formák jellemzi? A formák mennyire változatosak? Milyen a formák dinamikája? Milyen a mozgásérzék: álló/ mozgalmas/ dinamikus? Hogyan viszonyul ez az egyensúlyérzethez: kiegyenlített, aszimmetrikus, harmonikus, feszült, izgalmas? (Swanwick: textúra, forma, Wöbse-féle leirás)

- Térrészek aránya, változatosságuk mértéke

Mennyire tagolt a táj? Milyen a térrészek aránya egymáshoz képest? Táj nyitottságának/zártságának mértéke? Hol jelentkezik a szük/zárt térélmény, hol jelentkezik a tágasság; egymásból nyíló terek vagy elhatárolt térrészek? Milyen a látványmélységek mértéke, változatossága? Milyen látványt eltakaró elemek vannak? (Riccabona: térbeliség, harmónia; Swanwick: egyensúly, arány, lépték; Ode: látvány-lépték)

- Természetesség jellege, mértéke

Mennyire tünik természetesnek a látvány (az adott környezetben, az elvárható archetípushoz képest)? Mi okozza ezt: a vegetáció vagy a tájmintázat jellegének természetessége (minták alakja, formája, szegélyek, fragmentáltsága, fraktálossága vagy szukcesszió)? Mennyire spontán, könnyed, tájba-simuló az elem? (Riccabona - Ode: Természetesség)

- Gondozottság, ápoltság, illetve a zavartság mértéke

Mennyire erős az ápoltság, gondozottság és a fenntartás mértéke? Miben nyilvánul ez meg? Mi az, ami nem tünik természetesnek? Mekkora a mesterséges beavatkozások mértéke? Van-e zavartság, konfliktus, kaotikusság? Hol és mennyiben? (Ode: ápoltság, zavartság, bolygatottság, Riccabona: harmónia)

\section{- Komplexitás - sokrétüség}

Mekkora a tájelemek gazdagsága, sokszínüsége, változatossága (sokféle, egyféle, hasonló)? Milyen a jellemző felszínborítások sokszínüsége (alak, szín, textúra)? Milyen a tájalkotó elemek téri elrendezése: homogén, heterogén? Milyenek a méretkülönbségek, kontraszthatások? (Riccabona: diverzitás, Swanwick: mintázat, textúra, szín, diverzitás; Kaplan-Ode komplexitás)

- Koherencia - összetartozás, összeillés

Illeszkedik-e a kép az adott környezetben elvárt természetességhez? Mennyire egységes a látvány - mennyire összetartozóak a tájalkotó elemek? Mennyire olvasható, érthető a tájszerkezet? Van-e ismétlődés, ritmus-érzet? Mennyire erős az elemek közötti összecsengés - harmónia? (Riccabona: harmóniatartalom, Swanwick: egységesség, biztonság, kellemesség; Ode: koherencia; Kaplan: olvashatóság és koherencia)

- Képiesség mértéke: szimbólumtartalom, történetiség

Mennyire erős a tájszerkezet által megjelenített tájkép, annak képiessége? Mennyire megkülönböztethetőek a táji jegyek és ez hogyan befolyásolja annak emlékezetességét? Mennyre 
„nyomja bele” az emlékezetbe magát a látkép? Mi okozza ezt az erős vizuális hatást? Ezt mennyiben kulturális tényezők vagy fókuszpontok okozzák? (asszociativ térészlelés; Riccabona: szimbólumtartalom; Ode: képiesség, történetiség)

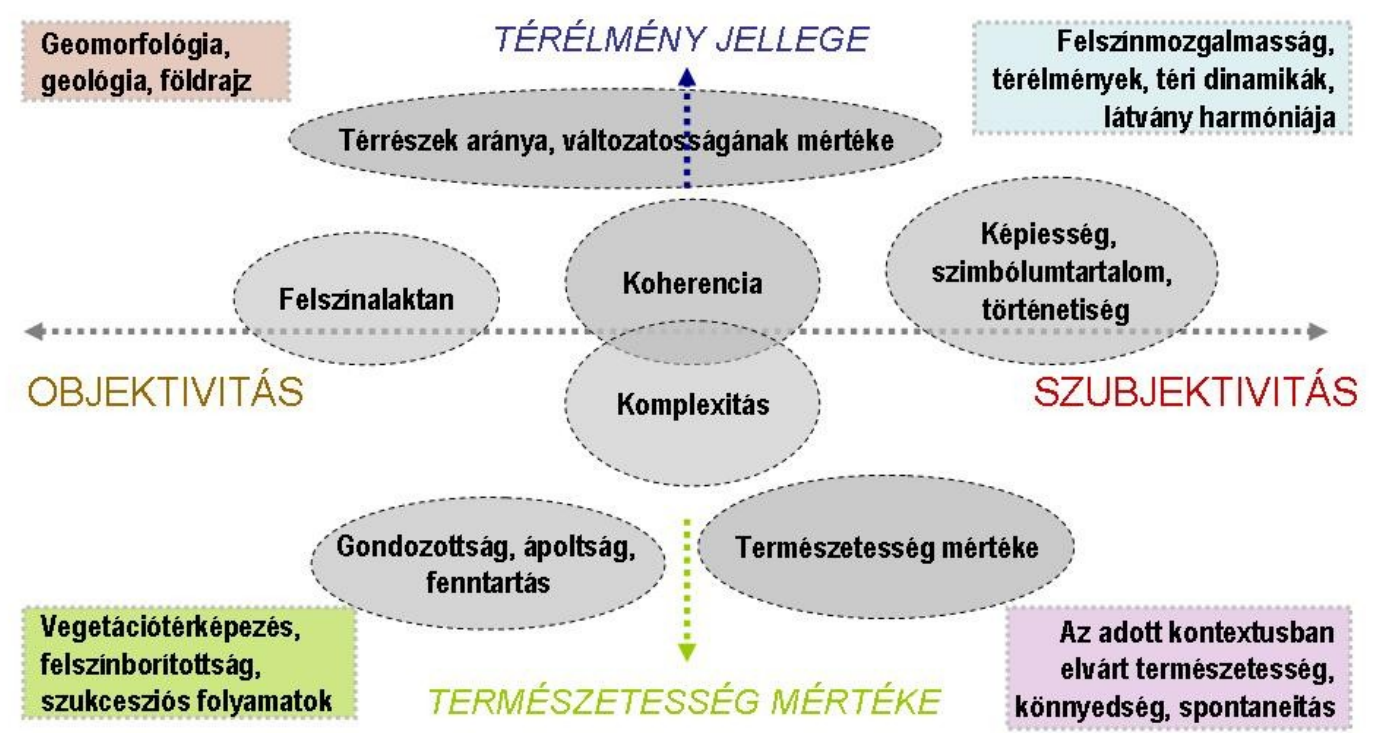

11. ábra: A tájesztétikai értékelés szempontjainak bemutatása az objektivitás - szubjektivitás skálája mentén, hozzákapcsolva a térélmény és a természetesség szerepét (saját ábra)

\section{3. 3. Grafikai szemléltetés: terepmodell-látványrajzok [14.§. melléklet].}

A tájkarakter-elemzés korai korszakában csak felszínborítottsági térképek és fényképek mutatták be az egyes tájkarakter-típusokat. Swanwick módszerébe beemelte a szabadkézi grafika jelentőségét, amelyek fényképek átrajzolásával mutatják be a tájkarakterek felépítését, kilátási viszonyait, jellemző tájképi elemeit, fókuszpontjait. Saját módszerem erre alapozva egy háromdimenziós MODELLRAJZ (terepasztalrajz), amely egy elképzelt magaslati pontról ábrázolja a tájkarakter-zóna egészét, kissé „nyomatékosítva” a legfontosabb táji elemeket, karakterjegyeket, mintázati ritmusokat, fókuszpontokat. A módszer egyrészt a 2,5 dimenziós térképek hagyományát követi, amelyek a XV.sz.-ban jelentek meg a kartográfia-történetben és a pontos helyrajz mellett, a hegyvidékek alakzatait is ábrázolták, másrészt a terepmodell-rajzok technikáját építi be, amely a XIXXX.sz.-i földrajzi szemléltetésének jó grafikai ábratípusai voltak (Koch, Cholnoky). ${ }^{127}$ Bár a mai, szintvonalakból felépített térinformatikai módszerek a terepalakulatokat tekintve pontosabbak, éppen a vizuális hatások és látványjellegzetességek tekintetében nehezebben tudnak kiemelni, mérlegelni, így a komplex tájépítészeti megközelítés miatt a helyszíni látványokból levezetett grafikus megjelenítésben továbbra is a szabadkézi szemléltetést tartom megfelelőbbnek.

${ }^{127}$ Eplényi - Oláh, 2011. pp. 168-173. 


\section{II.4. Kalotaszeg és környékének 13 tájkarakter-zónája és azok jellemzése}

\section{II.4.1. Bánffyhunyadi-medence - Bhm (felszínmorf.-típus: I)}

Típus: rosszul viztelenitett magasan fekvö lankás medence, dominánsan szántóföldi müveléssel, erdötlen

Települések-területek: Bánffyhunyad déli határa, Kalotaszentkirály, Zentelke, Malomszeg, Magyarókereke keleti határa, Nagykalota, Kalotabökény, Sárvásár, Damos, Marótlaka nyugati határa.

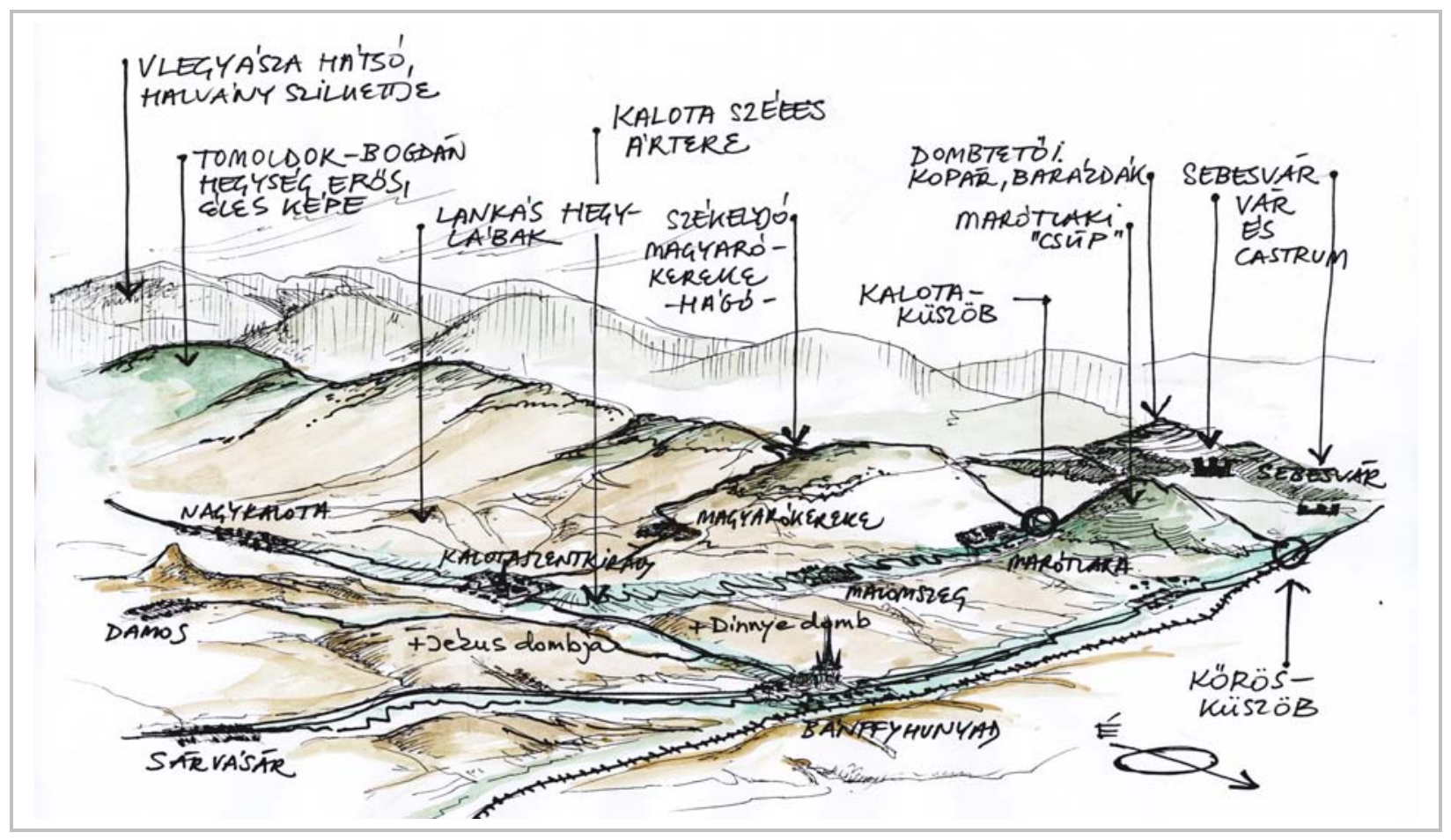

12. ábra: A Bánffyhunyadi-medence tájkarakter-zóna modellrajza ÉK-felől

A Bánffyhunyadi-medence magasan fekvő (500-600m), nyitott, lankás, alacsony belső reliefkülönbségeket mutató diluvium és alluviális medence, szélesen tág átlátásokkal, ezért területén uralkodik az általában ködös-párás, világoskék Vlegyásza, és a sötétebb, élesebb, kontrasztosabb Tomoldok-Bogdán előhegység képe. Sem a Meszes, sem a Gyalui Havasok nem jelentkeznek még a látványban. A terület legkiemelkedőbb pontja a Hunyadi Dinnyedomb és a Jézus-dombja, amely a mezővárost elválasztja a Kalota-patak széles elvizenyősödött, nádasokkal szegélyezett völgyének látványától. Mezaplatós-agroteraszos formációk nem jellemzik, csak körbeveszik e zónát. A lapos, tompa, alig változatos, szinte unalmasan-jellegtelen, síkszerü alakzatok a magashegységek tömbjeivel kiegyenlítve statikus, harmonikus képet adnak. E tájkarakter-zóna kevéssé tagolt, egymással összeköttetésben lévő, tág térrészekből áll, amelyben távoli kilátások és magával ragadó nagy látványmélységek fedezhetőek fel. Szétáradó levegősségével összekapcsolja a falvakat, amelyben Bánffyhunyad domináns központtá válik. Nyitottságát a min. 400 évvel ezelött kiirtott erdők hiánya is fokozza, amely által a magashegységek sziluettformái és a templom-építmények fókuszai még inkább meghatározóvá válnak. Látványtakaró elemként a falvak, az egykori malmok, néhány tanya, temető, vasútállomás körül kialakult kisebb fásított 'kert' szolgál csak. A medence két vízfolyásának (Körös, 
Kalota) „kifolyásának pontja” Ny-on, a jellegzetesen kúpos Marótlaki 'csúp' két oldalán van, amely erős geomorfológiai kapu-helyzetet teremt. Ma jellegzetesen extenzívebbé váló agrártáj: szántók, rétek, legelők dominálnak, amelyek nem a szintvonalakat követik, hanem négyzetes, téglány kiosztást mutatnak. Ez és kopársága ezért kevésbé mutat természetességet, ellenben a gondozottság és irányított művelés hatása érződik. Legelőin hiányoznak az erdőfoltok, fásított szegélyek, facsoportok. Kisebb konfliktust okoznak a Hunyad-környéki raktár-épületek, Tsz.-központok és más ipari beavatkozások. A zóna kevésbé sokszínű, a felszínborítottság sem változatos, kevés a kontraszthatás. Az egységes összetartozás a nyitott medence-helyzet miatt erős, és éppen ezért könnyen olvasható, átlátható, így lényeges eltér Felszeg más zónáitól. Települései zömében gyümölcsössel kerített több utcás, zárt falvak, amelyek templomtornyai messzire ellátszódnak. A képiesség Hunyadon és Kalotaszentkirályon erősödik fel, ahol a fiatornyos templomok a Vlegyásza tönkjével bevésik magukat az emlékezetbe. A századfordulós képeslapok, útleírások is ezt az ikonná váló látványt ragadták meg Kalotaszeg szimbólumaként.

II.4.2. Felszegi havasalja - Fh (felszínmorf.-típus: H)

Típus: K-i kitettségü, nyitott hegylábi dombvidék jellemzöen teraszolt müveléssel, legeltetéssel

Települések-területek: Kiskalota(Kelecel), Bocs, Incsel, Méregjó, Hodos, Marótlaka

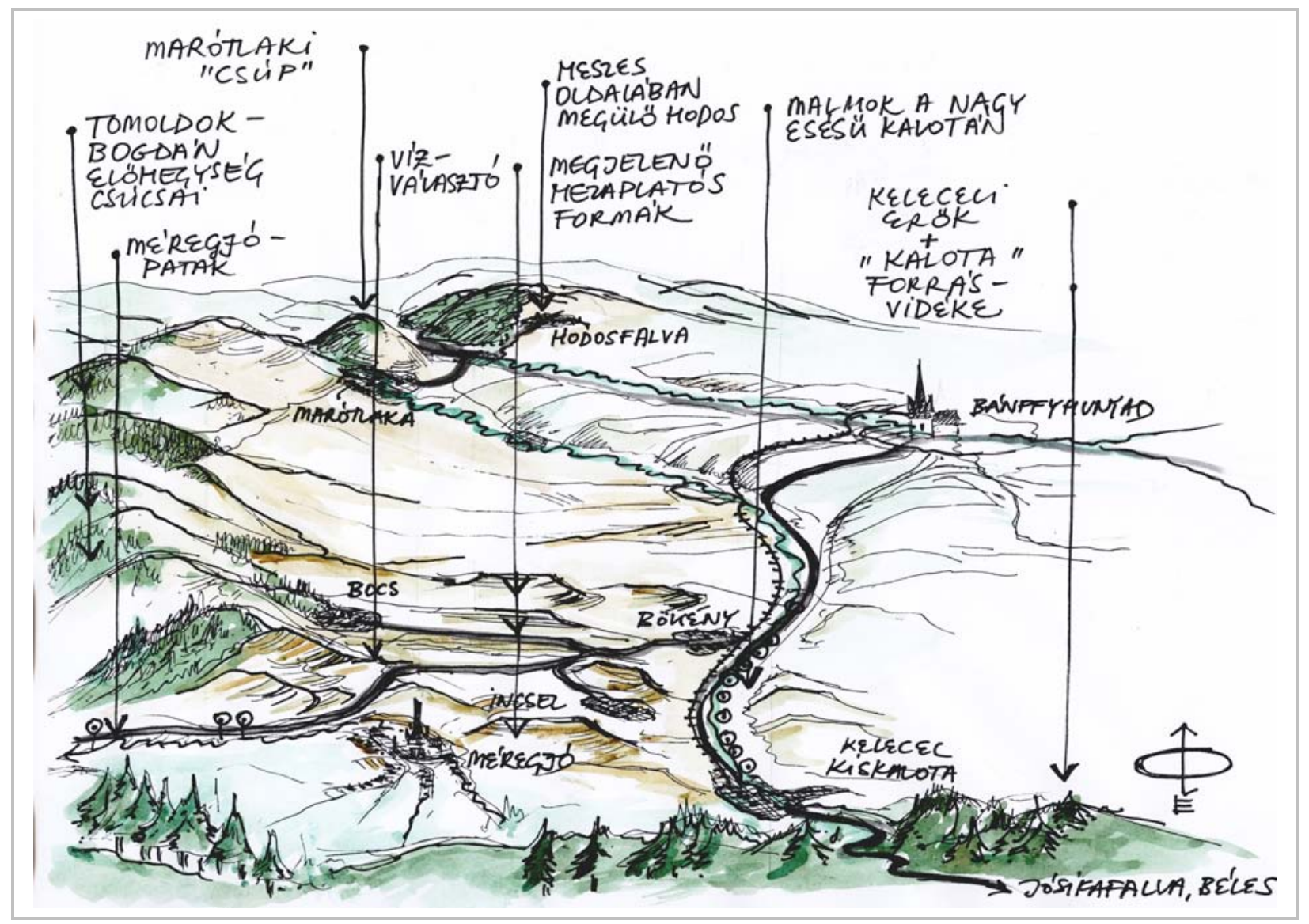

13. ábra: A Felszegi havasalja tájkarakter-zóna modellrajza D-felől 
A „Felszegi havasalja” zóna a Tomoldok-Bogdán hegység eruptív lefutásának és az alsó tarkaanyag alapkőzet K-i felkapaszkodásának átmeneti vidéke. A települések tipikusan domboldaliülésűek, így „belelátnak” a medencébe, ami nagy távlatot nyit számukra. A tájformák aszimmetrikusak, csak lefutó dinamikájúak, lendületes és izgalmas mozgást okozva. A szük völgybe felhúzódott falvak a medence felől nézve eldugottak, ugyanakkor onnan távoli rálátás van a medencére. A legeltetés tipikus, de sem a bivalyok tartása, sem gyümölcsösök nem jellemzik olyan arányban, mint pl. a felszegi felföld zónáját; szőlőterületi sosem voltak, így összességében mezőgazdasági tulajdonságait tekintve teljesen eltér a Hunyadi-medencétől és a Váralmási völgyektől, és tájértékelése sem fogja mutatni a kalotaszegiesség jeleit. Az erdősültség változékony-ligetes, és inkább a hegyvidék magasabb oldalait jellemzi. Kelecel, Bocs és a Hodos felett nagyobb záródó erdőtagok is vannak, ezáltal természetesség-érzete nagyobb, mint a medencéé. D-i részén megjelennek a mezaplatós formációk, és mivel a talaj igen rossz minőségü (erózióveszélyes), így többszáz éve is szükség volt az oldalak teraszolására, amely viszont a Felszegi felföld agroteraszolt zónájával teszi hasonlatossá. Mivel ez ebben a környezetben 'elvárható' tájmúvelés-mód, így segíti a tájba-simulást és fokozza a természetességet. A vidék művelése ma is intenzív, így az ápoltság-érzet is erősebb, amelyhez ipari beruházások nem tartoznak.

A falvak számára a XVII-XVIII.sz.-ban a Méregjó- és a Kalota-patak fontos vízi-infrastruktúrát jelentett ványoló és fürészmalmaival, a fatutajozás lehetőségével, amit azután a kisvasút is megerősített, így kerülve erősebb szimbiózisba a medence fátlan, szántóföldi tájával. Ennek tájtörténeti nyomai ma már csak Kelecel századfordulós épületeiben érhetők tetten, amelyek a fafeldolgozás mély hagyományait is a kalotaszegi népi ornamentika kisugárzását tükrözik. Méregjón kb. 100 (!) épen maradt cifraház látható a század második feléből. Geológiai-, alaktani jegyeit, fényviszonyait és tájhasználati tulajdonságait tekintve sokkal komplexebb, mint a medence; településstruktúrája egyrészt nyitott, széttelepült (Méregjó, Hodos, Marótlaka), másrészt szük völgyekbe felhúzódó (Bocs, Incsel). Koherenciája önmagában alacsony, mivel legyezőszerü peremként helyezkedik el a havas és a sík térrész között, és éppen a belátás térélménye - térbeli viszonyai alapján lesz indokolt a medencéhez és a felföldhöz való kapcsolása. A középkori méregjói kerített templom a zóna legjelentősebb szakrális emléke, amely közeli rokonságot mutat a Valkóival és a felszegiekkel. A vidék eldugottságát támasztja alá, hogy hiányzik a képi ábrázolása. Régtől elrománosodott falvakban kevés (inkább csak társadalomnéprajzi) gyüjtés történt, ezért több lehatárolás nem tekinti Kalotaszegnek. Csak Kós Károly és Gyarmathy Zsigáné által a századfordulón felerősített „Havaslaji életmód”- novellái, történetei emelték be e vidéket újra Kalotaszeg „háttér-tájaként” (Téglási Ercsei még kalotaszegként említeni, de utána már egyre kevésbé tekintettéka néprajzi zóna részeként). 
II.4.3. Felszegi felföld - Ff (felszínmorf.-típus: F)

Típus: K-i kitettségü, hegylábi dombvidék jellemzően teraszolt müveléssel, legeltetéssel

Települések-területek: Kalotanádas, Bedecs, Derite, Erdöfalva, Jákótelke, Kalotabikal, Körösfö, Magyar+Felsőgyerőmonostor, Magyarvalkó, Nyárszó, Kalotaújfalu, Pányik, Gyerövásárhely

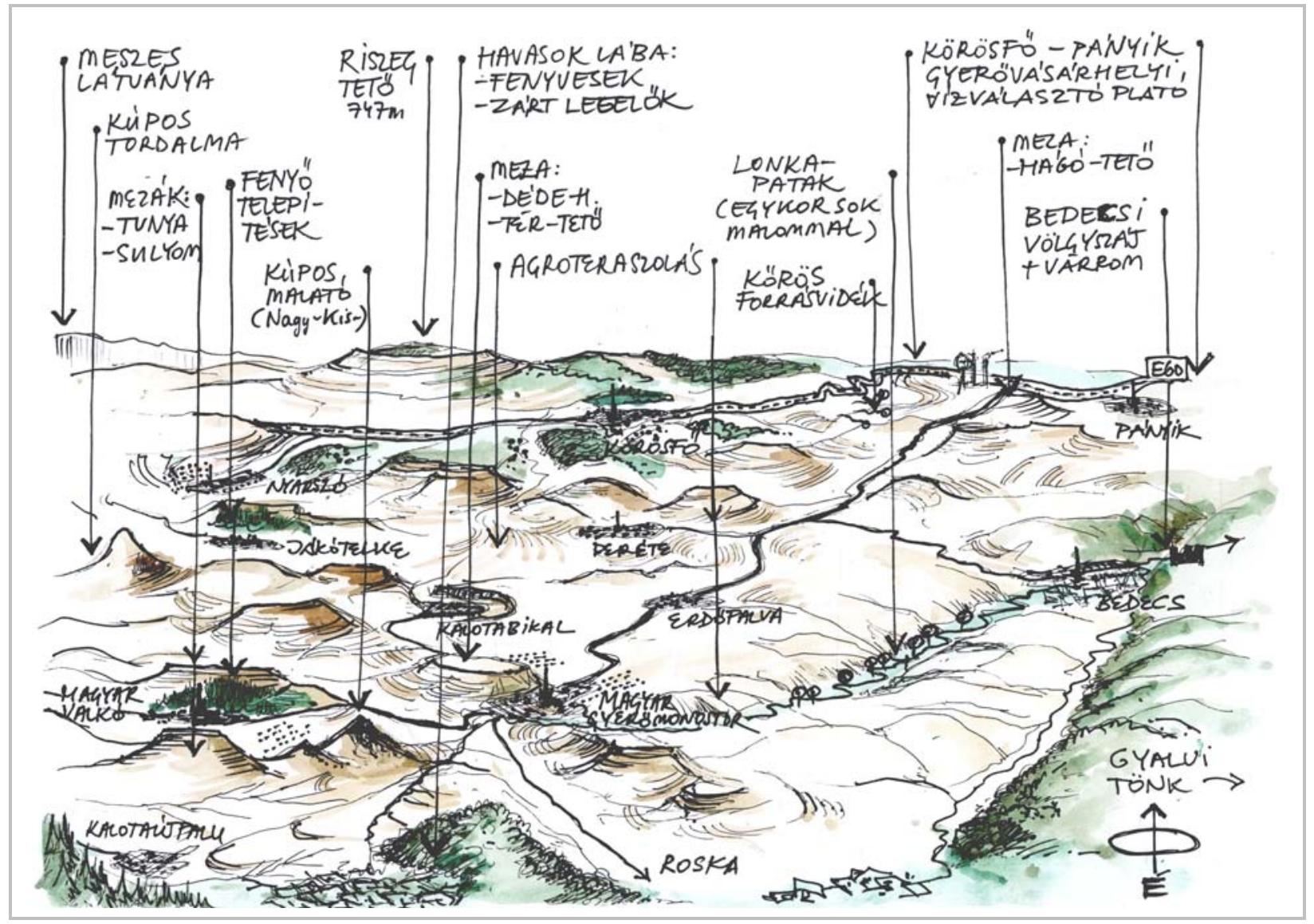

14. ábra: A Felszegi felföld tájkarakter-zóna modellrajza D-felől

Magasan fekvő (600-900m), és nagy belső reliefkülönbségeket mutató, tagolt, igen mozgalmas felszínű dombvidék, váltakozó (széles és szük) átlátásokkal. Alapvetően az alsó durvamész-rétegekből álló lepusztult vízszintes mezaplatós formációk jellemzik, konkáv domboldalakkal (pl.: Déde-h, Sulyom, Hágó-t.) és kúpos kisebb kiemelkedésekkel (Kis-, és Nagy-Malató, Tordaalma). Ezek a nagyon erős és emlékezetes morfológiai ismétlődések visszatérő domináns ritmust adnak a látványnak! A tengeri hullámokat megidéző lankás - lejtős - meredek oldalfalú ívek erős dinamikát adnak a tájnak. A „hullámok között” a kis, tagolt, zárt völgyek öblei állandó kiegyenlítését biztosítanak - így válik a vidék izgalmassá és egyben harmonikussá. A zóna legjelentősebb tájkarakter-eleme a terepre simuló szintvonalakat követő agroteraszok, amelyek minden falu határában egyöntetüen megjelennek erős vizuális hatásokat okozva. Területén a Vlegyásza látványa már kevésbé (inkább Ny-on) uralkodik, és erőteljesen megjelenik a Gyalui lepusztult rögfennsík és az távolabbi Meszes képe is. Síkszerü vagy medencei térélmény sehol nem jellemző. Sok magaslati kitekintője változó látványmélységeket ad a vidéknek, folyamatosan egymásból nyíló térrészekre bontva azt. Legmagasabb pontja a körösfögyerővásárhelyi vízválasztó-(plató), amelyet magassága ellenére nem „hegyként”, hanem csak 
felföldként él meg az utazó; és a Riszeg-hegy, amely Alszeg felé, és a Monostori Várhegy, ami a Havas felé mutatja a határt (mindkettő az utolsó mezaplatós alakú hegyforma). Legmélyebb pontja Bedecs faluja, ahol a terepszövet a Lonka/Kapus-patak tölcsérébe szükül össze (a Bedecsi vár ezt jelző stratégiai őrszemével).

E zónában is majdnem teljes egészében hiányzik az erdő (csak a Körös Hágó-körül nagyobb jelentőségü, ahol ma is több hagyásfás legelő mutatja az egykori erdők helyét). A szántóföldi művelés, bivalytartás helyett a legeltetés jellemző inkább, de a táji határokhoz alig igazodó mezőgazdasági statisztika itt a területei besorolások miatt nem reprezentatív! A zóna gyümölcsösöket tekintve igen változatos képet ad, ami a havasalji dombvidék mikroklímára való érzékenységét támasztja alá (Pá., Kúf., Kö. nagyon alacsony a kertek jelentősége - de MGYM, Mv. és KN., De., Ef. fagy-, és szélvédett helyzete alkalmas volt gyümölcsökre, később ültetvényekre is). E falvakban ma nincs már szőlő, de a történeti helynevek tanúsága szerint a XVIII.sz.-ig a magyar falvakban lehettek kisebb szőlőterületek. A falvak a zárt utcaképü, introvertált típusba tartoznak, de a kistáj szélén húzódó falvakban már megjelenik a széttelepült beépítés felé való átmenet. A térség tájképében uralkodnak a szakrális szimbólumok: a középkori magas templomtornyok (Mv., MGYM, Kö., Be.). Ezek változó távolságról, nagy téri kiterjedéssel jól láthatóak; de a román fatornyok (Kbi, Kná, Pá) is elegáns képet adnak saját kis völgyeiknek. Összességében egy markáns karakterü táji zóna, erős belső kohézióval, szerves ismétlődésekkel. Térélményei a Hunyadi-medencétől nagyon eltérnek, de felszíni alaktana miatt a Felszegi havasaljától is; viszonylag szorosabb hasonlóságot a nála sokkal zártabb Kapusi-völggyel mutat.

II.4.4. Kapusi völgy - K (felszínmorf.-típus: L)

Típus: K-Ny-i tájolású, havasalji, árnyas szük völgy

Települések-területek: Kiskapus, Nagykapus, Geszterágy, Egerbegy + Bánffydongó

A Kapusi-szük völgyben kijelölt zónát a Gyalui Havasok rámagasodó, árnyékos erdős dombsora határolja D-ről. A völgynek zártságot egyrészt a Ny-i oldalon álló Köves-hegy negyedkori vulkáni kúpja és hágója, másrészt a Gyalunál lévő szükület ad. A Nádas-menti vízválasztó teraszolt kiszögellései a felszegi felföld fehéren megcsillanó bányáira és a vízszintes mezaplatók formájára hasonlítanak. Lényeges különbség azonban ezen szirtek enyhe, ÉK-re való dőlése (10 fok). A Kolozsvár-felé való lefutó dinamikát a meredek Gyalui oldalak és a ferde mezaplatók kiszögellési kísérik, amelyek egymástól eltérnek, de mivel mindkettő visszatérően ismétlődik, ez koherenciát ad a zónának. 


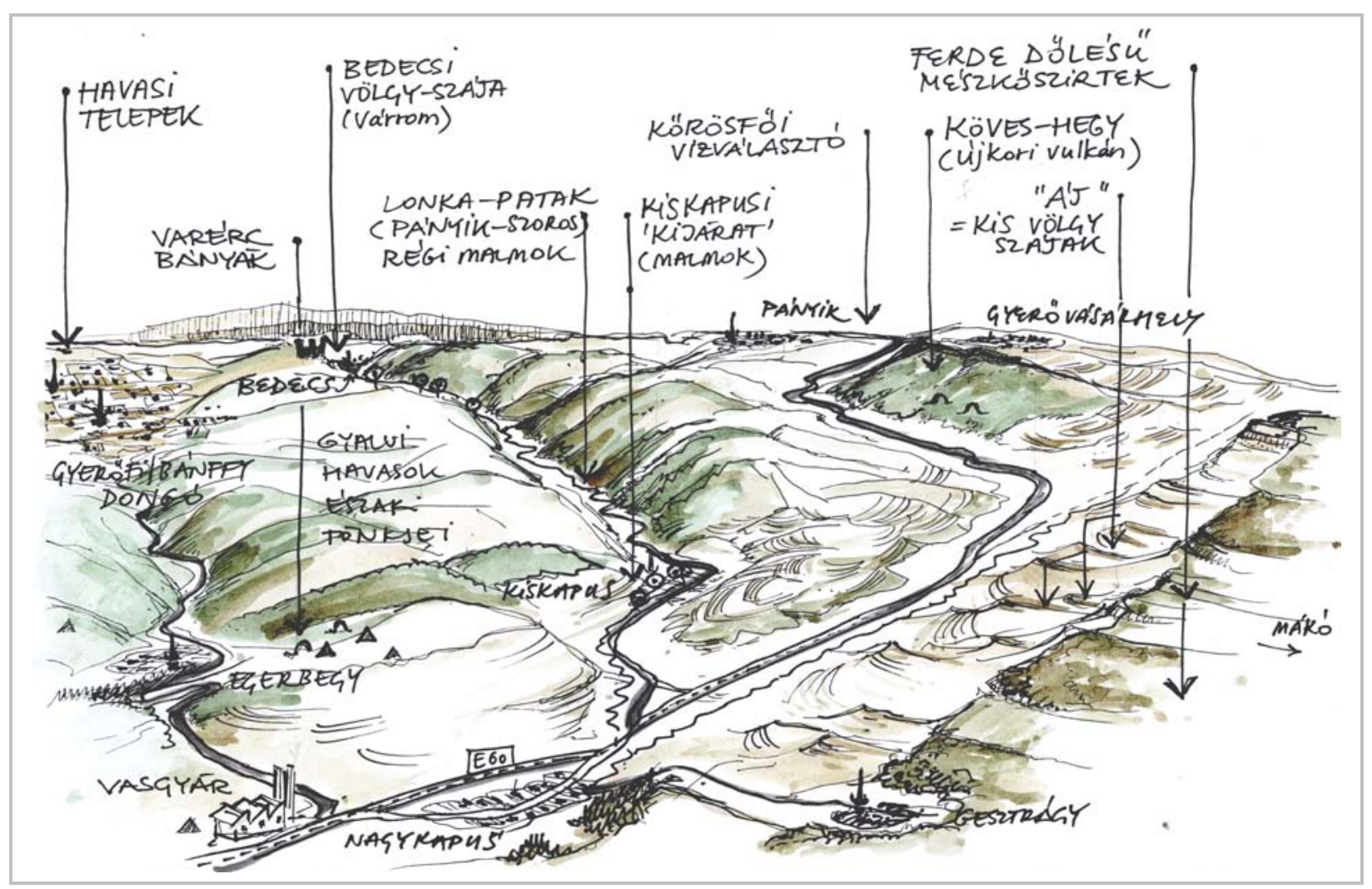

15. ábra: A Kapusi-völgy tájkarakter-zóna modellrajza ÉK-felől

A völgy alapvetően egy szükebb, hosszanti teret alkot, amiből Egerbegy különül el. Az É-i ferde oldalban megjelennek az 'áj'-ak (száj-szerü mikro-völgyek), amelyek az oldal térélményeinek tagoltságát és komplexitását növelik. Gesztrágy falu is egy nagyobb, szélesebb 'áj'-szerü völgyfőben ül meg jó átlátással a Gyalui Havasokra.

A zóna természetesség-érzete magas, mivel a tájmintázatok könnyeden hozzásimulnak a terepadottságokhoz. Egerbegy és Bedecs falu körül a tájmintázatban 50-50\%-ban jelenik meg a barázdált szántóföldek jellegzetes kalotaszegies képe, és a havasi fásszegéllyel keretezett falukörnyéki legelők mozaikos mintázata, így településszerkezete mellett, a tájképek is reprezentatív példái a tájszerkezet-váltásnak, ami majd Kalotaszeg határát kijelöli. Az állandó-hozamú, hegyvidéki Lonkavizére települt malmok szerepe kiemelt fontosságú volt, így a völgy két ellentétes vége (Bedecs + Kiskapus) erős gazdasági kapcsolatban álltak. Ez összhangban van a Magyargyerőmonostori irányítású Kemény-Kabos-Gyerőffi családok történelmi birtokviszonyaival, akik ezt a Gyalui Havasok félkörívesen lefutó területét és a vízválasztót birtokolták. A kis zóna erdőborítottsága magas, de ebben a faluhatárok torzított területének is szerep van. A XX. sz.-i vasgyár és a bányászati tevékenység nem dominál a táj képében. A kis zóna társadalmi kapcsolatai a Nádas-mentével és Gyalu irányába orientálnak, de agroteraszolt, mozgalmas, tagolt tájképe inkább a felszegi zónákhoz köthető, ami utal átmeneti helyzetére. 
II.4.5. Havasi falvak - H (felszínmorf.-típus: $G, M, K$ )

Típus: havasi, hegyvidéki, magasan fekvő, legeltetö, erdőgazdálkodó telepek

Települések-területek: Jósikafalva, Szamosfö, Tarányos, Havasnagyfalu, Havasrogoz, Viság, Gyeröffidongó,

Felsöszamos

\section{II.4.6. Havasi völgyek - Hv (felszínmorf.-típus: J)}

Típus: havasi, hegyvidéki, mély bevágódású, árnyas szük, legeltető, erdögazdálkodó falvak

Települések-területek: Melegszamos, Havasrekettye, Hidegszamos, Kissebes, Székelyjó, Nagysebes, Sebesvár

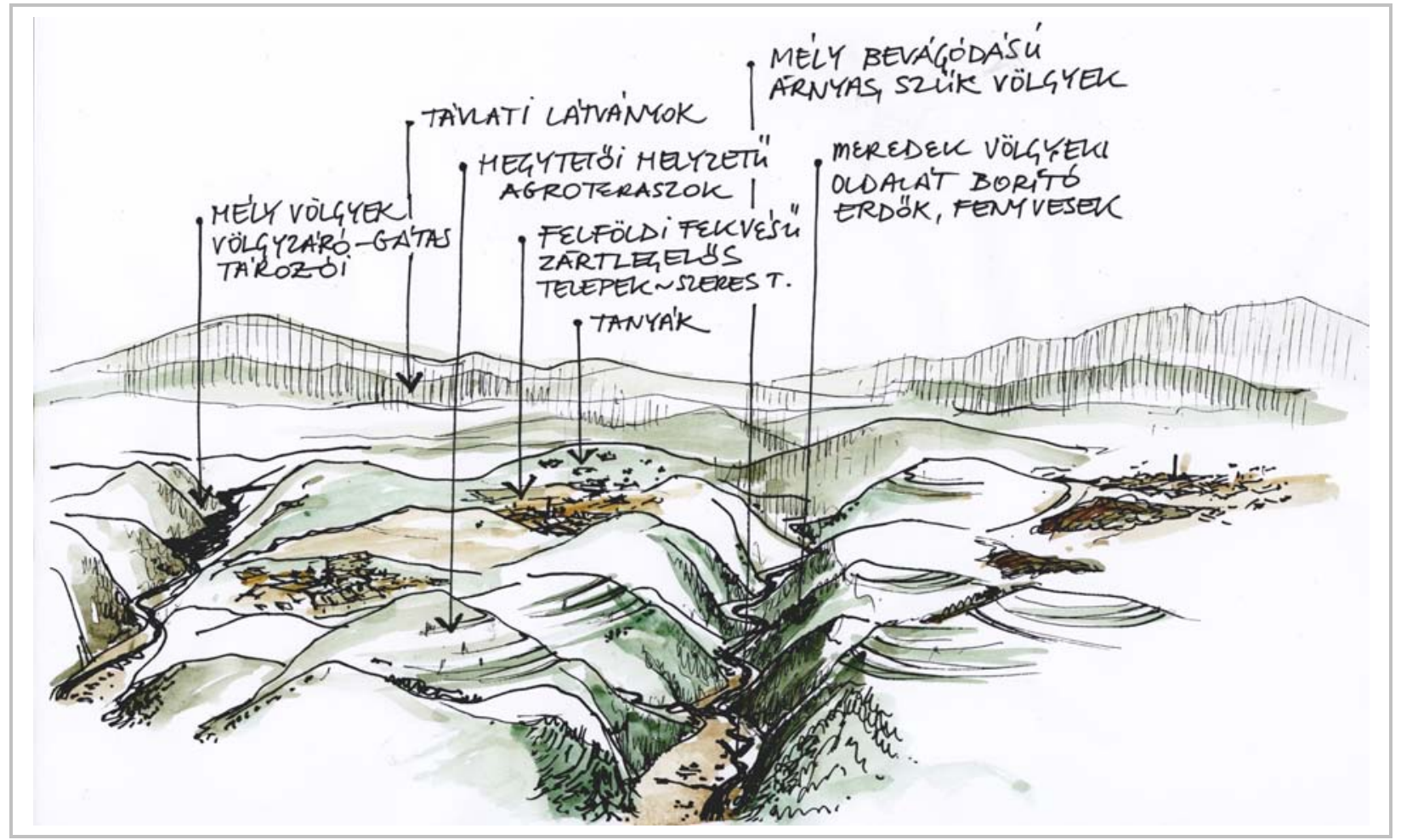

16. ábra: A Havas és havasi völgyek-tájkarakter-típusának általános modellrajza

A két tájkarakter-zóna elkülönítése az alapvető domborzati és látványbeli különbségekböl származik, ugyanakkor tájhasználatát tekintve egymással összekapcsolódó, rokon jegyeket mutatnak, ezért együtt mutatom be öket. A Havasi területek a Vlegyásza és a Gyalui-Havasok magasan fekvő (800-1200m) platóit foglalják el. A felszínformák tompák, plató-szerủek, de a magaslati helyzetből fakadó távoli átlátások nagyon extrovertálttá teszi a térélményt, amelyhez az időjárás okozta légköri viszonyok (szél, páratartalom, hideg) mindig hozzátartoznak. Magaslati kitettsége belátást enged a kalotaszegi falvakba, ugyanakkor nyilvánvalóvá teszi az eltérő gazdálkodási formákat. A zárt fenyőtársulások erdőirtása mellett havasi legeltetés a jellemző gazdasági tevékenység. Településszerkezete széttelepült, halmazos: a fadeszkákkal, cserjesávval, fásszegéllyel bekerített négyzetes legelőtagok között kisebb hegyi tanyák csoportjai tünnek fel. Ez a komplex, változatos, fragmentált tájmintázat nagyon karakteres és minden szempontból eltér más vizsgált zónákétól. Kis elemei (mozaikjai) természetesnek tűnnek, szükebb-tágabb látványmélységeket nyitnak, és 
geometrikus mintázatuk ellenére jól a terepbe simulnak. Az egymásba torkolló dombok és a telep-szerű szétterülés miatt azonban a felföldi vidék nehezen átlátható, koherenciája kisebb.

A havasi völgyek a kemény kőzetbe mélyen bevágódott szük katlanokban vannak. Alapvető élményei: az árnyas, hűvös, introvertált terek rövid kilátásokkal, amelyeket a patakok kanyargó vonalai kisebb térrészekre bontanak. Az erdők inkább a másra nem hasznosítható, meredek oldalakat borítják, és az erdőtlen kisebb platókon, tetőkön jelennek meg az agroteraszolt szántók, kaszálók - éppen ellentétesen, mint a kalotaszegies dombvidéken. A településkép összeszükül, de itt is egymástól távolabb helyezkednek el az épületek és kisebb csürök, így nem hoznak létre olyan erős utcaképet, mint a kalotaszegi falvakban. A kaszálók szénáit a kis csürök miatt a kertek szabad ege alatt tárolják, így itt a falukép fontos részei a szénaboglyák is. Mindkét zónát igen magas erdőarány és nagy legeltetési tájértékelés jellemzi. De a később vizsgálatra kerülő témakörök egyikében sem mutat hasonlóságot a kalotaszegi falvakkal (szántóföld, bivalytartás, gyümölcsös, szőlö). Egyedül a sebeskörös-menti Sebesvár és Kissebes mutat a Felszegi havasaljával tájhasználati rokonságot. Összességében e két havasi vidék egymással szimbiózisban áll - de felszínmorfológiai és tájhasználati viszonyaiban nagyon eltér az összes többi vizsgált zónától, ami mutatja, hogy a magassági domborzati viszonyok megváltozása minden téren megváltoztatja a tájkaraktert is.

\section{II.4.7. Tordaszentlászlói vidék - To (felszínmorf.-típus: E)}

Tipus: hegylábi-dombvidéki tagolt zóna, jellemzően mezőgazdasági műveléssel

Települések-területek: Isztolna, Kisfenes, Hasadat, Havasasszonyfalva, Tordaszentlászló, Magyarfenes, Magyarléta, Oláhléta, Alsófüle, Felsőfüle, Járarákos, Alsójára, Kolozstótfalu,

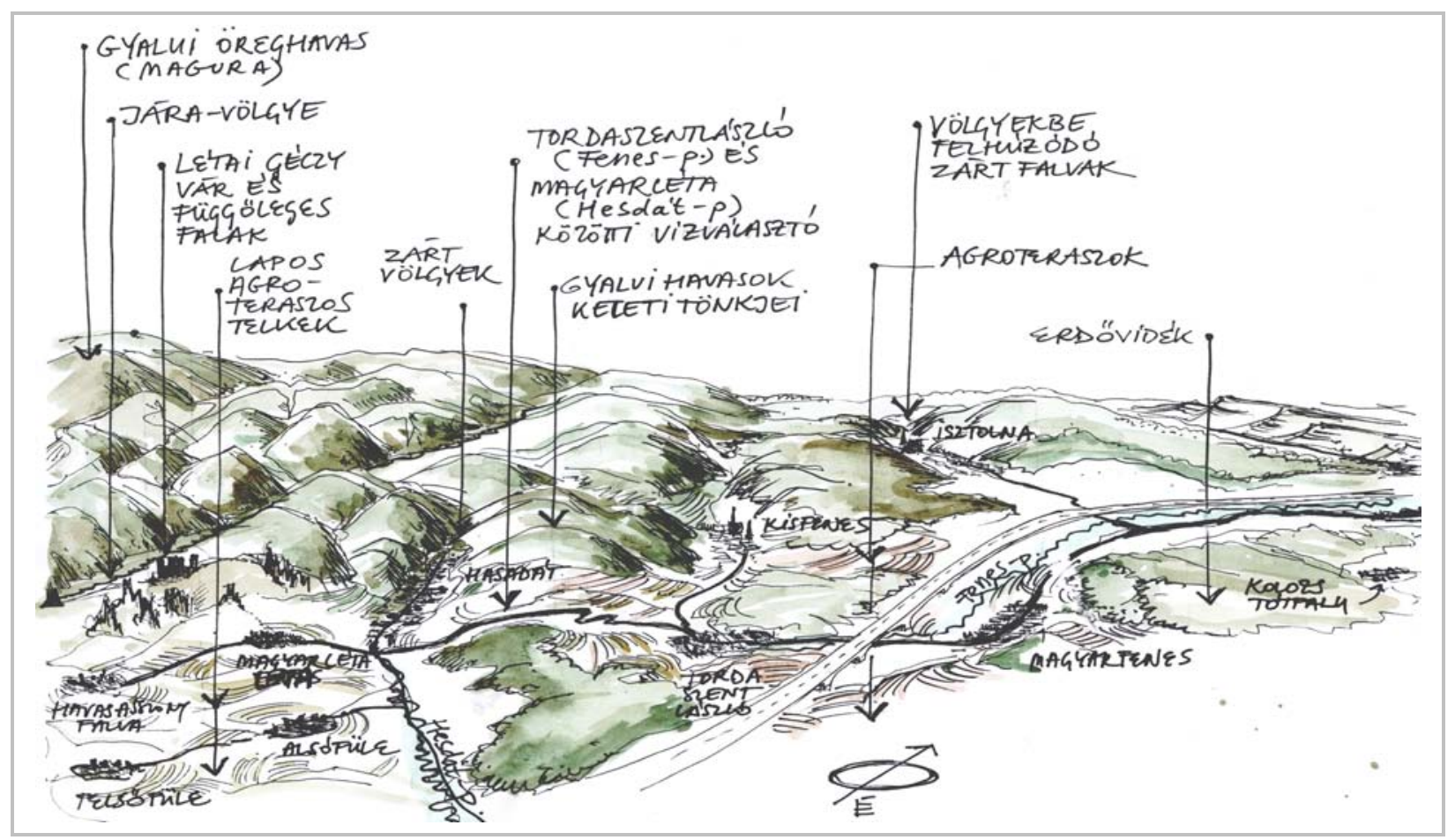

17. ábra: A Tordaszentlászlói-vidék tájkarakter-zóna modellrajza DK-felől 
A terület a Gyalui Havasok lepusztult tönkjének K-i oldalán és az Erdővidék szelídebb dombsága között helyezkedik el, a Fenes- és Hesdát patak völgyében. A különleges geológiai és geomorfológia alakzatok változatosságának hiánya nem tud a területen koherenciát létrehozni. Megjelennek az aranybányák és a Tordai-hasadékhoz hasonló merész függőleges sziklaszirtek, amelyek Kalotaszeg semelyik más vidékére nem jellemzőek, ugyanakkor az eocén-mészkőformációk a geológia térkép ellenére a látványban kevésbé jelentkeznek. A térség román, falvai (Kisfenes, Isztolna, Hasadát) nem hasonlítanak a Kőhegy-Tomoldok előhegység hasonló tájolású hegylábi falvaihoz, mert míg azok nyitottan kitekintenek a medencébe, ezek mély szűk, zárt völgyekbe húzódva találhatóak. Hiányzik a hegység lefutását kiteljesítő medence, így a völgy nem hoz létre erős térélményt. Tovább tagolja a térrészeket a T.Szentlászló és Magyarfenes közötti vízválasztó, ami megtöri az átlátásokat. Az erdősültség igen magas a Havas felé (különösen a Létai vár körül), de DK-re (Jára felé) az erdőtlen szántóföldi tájon újra megjelennek az agroterasz-szerü telekformák, de mivel sokkal laposabban hullámzó felszínen, így a teraszok közötti lépcsők magassága is alacsonyabb. Ez a terepplasztika itt egy új (Magyarléta - Alsófüle -Felsőfüle), önmagában zárt tájmintázatot hoz létre. Tájkarakterileg ez a vidék ugyanolyan kulturális „,köztes-zónát” mutat, mint népművészetét, néphagyományait és társadalmi kapcsolatait tekintve. E zónának nincsenek erős szakrális fókuszpontjai a kis völgyi fatornyokon kívül. E területen jelentős müemléki kastély-együttesek és gazdag történeti kertek voltak (Gyalun és Szentlászlón megmaradtak-, Szászfenesen és Magyarfenesen elpusztultak), amelyek Kalotaszeg más vidékén nem jellemzőek. A magyarlétai Géczy vár e kiterjesztett, átmeneti zónának a legvégső déli szegélyen helyezkedik el. E vidék az autópálya-építéssel és az agglomerációs helyzetével a Kolozsvári Alluvium zónájához és Kolozsvárhoz kapcsolható.

\section{II.4.8. Alszegi szőlősfalvak - Asz (felszínmorf.-típus: C)}

Típus: védett fekvésủ, tagolt dombvidéki zóna, jellemzően gyümölcs-, és szőlőtermeléssel Települések-területek: Ketesd, Magyarbikal, Sztána, Zsobok, Kispetri, Farnas

E vidék tájkarakter elkülönítését a tájképben domináló hagyományos és újonnan telepített gyümölcsös-területek, ültetvények és szőlöskertek nagy aránya indokolja, amiért már Téglási Ercsei is 'Bakhusz és Pomona kedvenczének' nevezte. A bánffyhunyadi és körösfői vízválasztó vonulat É-i felén, az Almás-patak gyors ütemü hátravágódásából keletkezett mély, meredek-falú völgyek nagy tagoltságot és felszínmozgalmasságot eredményeznek; amely váltakozó látványmélységeket és dinamikus térélmény-váltásokat hoz létre. Magasabban fekszik, mint a Váralmási -völgyek, így a távlati kilátásokban a Meszes sziluettje fontos szerepet tölt be; és nincsenek széles völgyfenekei sem, ami szintén a Váralmási-völgyektől való elhatárolását indokolja. Ennek a zónának is jellegzetessége a felső eocén alapkőzet és annak erős alaktani sajátosságai. 


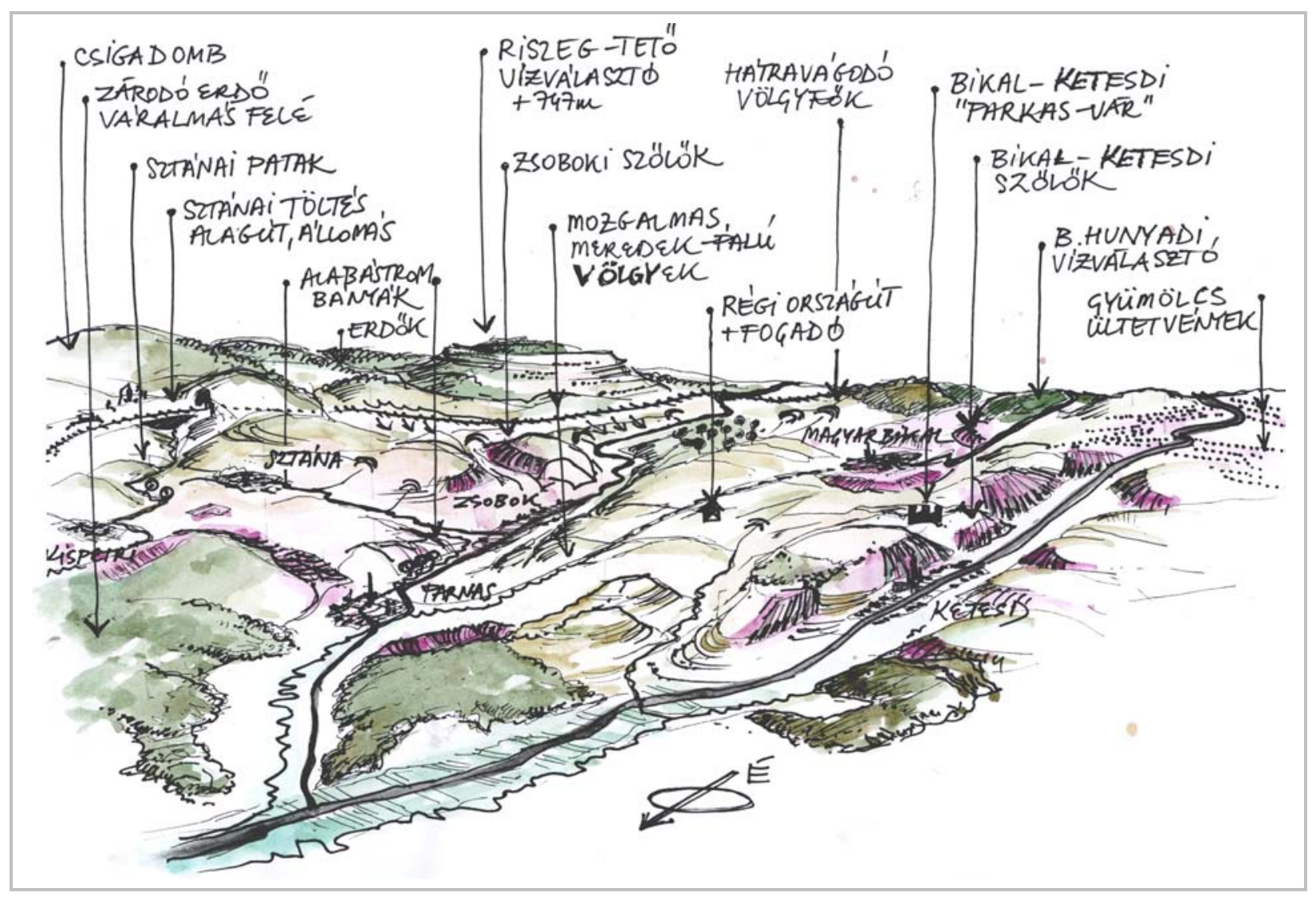

18. ábra: Az Alszegi szőlővidék tájkarakter-zóna modellrajza É-felől

A vidék komplexitását a tájhasználat és a mintázatok változatossága adja, ugyanakkor térbeli koherenciája helyett inkább a müvelési ágak tájértékeléseinek egyöntetüsége kapcsolja őket egymással össze. A határhasználatban az erdők közepesen alacsonyak, de megjelenésük a felszegi területkehez képest jelentősebb. Érdekes, hogy a szőlőmüvelés és kertek kis területi százaléka ellenére (2-4\%), mind gazdaságilag mind tájképi mintázatokban sokkal jelentősebb hányadát teszi ki a tájképnek! Az ezekhez kapcsolódó hagyományos múvelési módok, népszokások erősen beépültek a falvak identitásába, így a tágabb környék bor-, pálinkaellátó szerepével erős táji kohéziót (koherens zónát) hozott létre. Ezt a családnevek rokonsága, és az egymással szoros házassági kapcsolatrendszer is alátámasztja. Szőlősei miatt Bánffyhunyad É-határát is ide tartozónak tekinthetjük. A szük, zárt, eldugott völgyekben kalotaszegies oromfalas utcaképü, zárt szerkezetü falvakat találunk (ártéri fekvése miatt csak Farnas kivétel). A felső durvamész-rétegek alabástrom, gipszszirtjei többfelé kibukkannak, a kőfejtésbányászat egykor hagyományos, mára jelentőségét vesztett tevékenység, de a faluképekben megőrizte szerepét. XX.sz.-i ipari beavatkozások nem jellemzik, csak a teraszolt ültetvények geometrikussága hozott új tájmintázatot Ketesd környékén. A zóna egyedi képiességét itt a szőlőművelés mintázata adja, amely ilyen arányban semelyik más zónát nem jellemzi. Az agroteraszok a vidéket csak elszórtabban jellemzik, mert a meredek oldalon nem mindenhol volt megoldható a teraszolás. 
II.4.9. Váralmási völgyek - Vv (felszínmorf.-típus: $\mathrm{A}, \mathrm{B}, \mathrm{H}$ )

Típus: alacsony hegylábi lankás dombvidéki zóna, hosszanti tág folyóvölgyekkel

Települések-területek: Váralmás, Középfüld, Felsöfüld, Bábony, Almásnyíres, Czold, Bercse, Nyerce, Lapupatak, Vásártelke, Oláhköblös, Középlak, Zutor, Magyarnagyzsombor, Almásdál, Hídalmás, Topaszentkirály

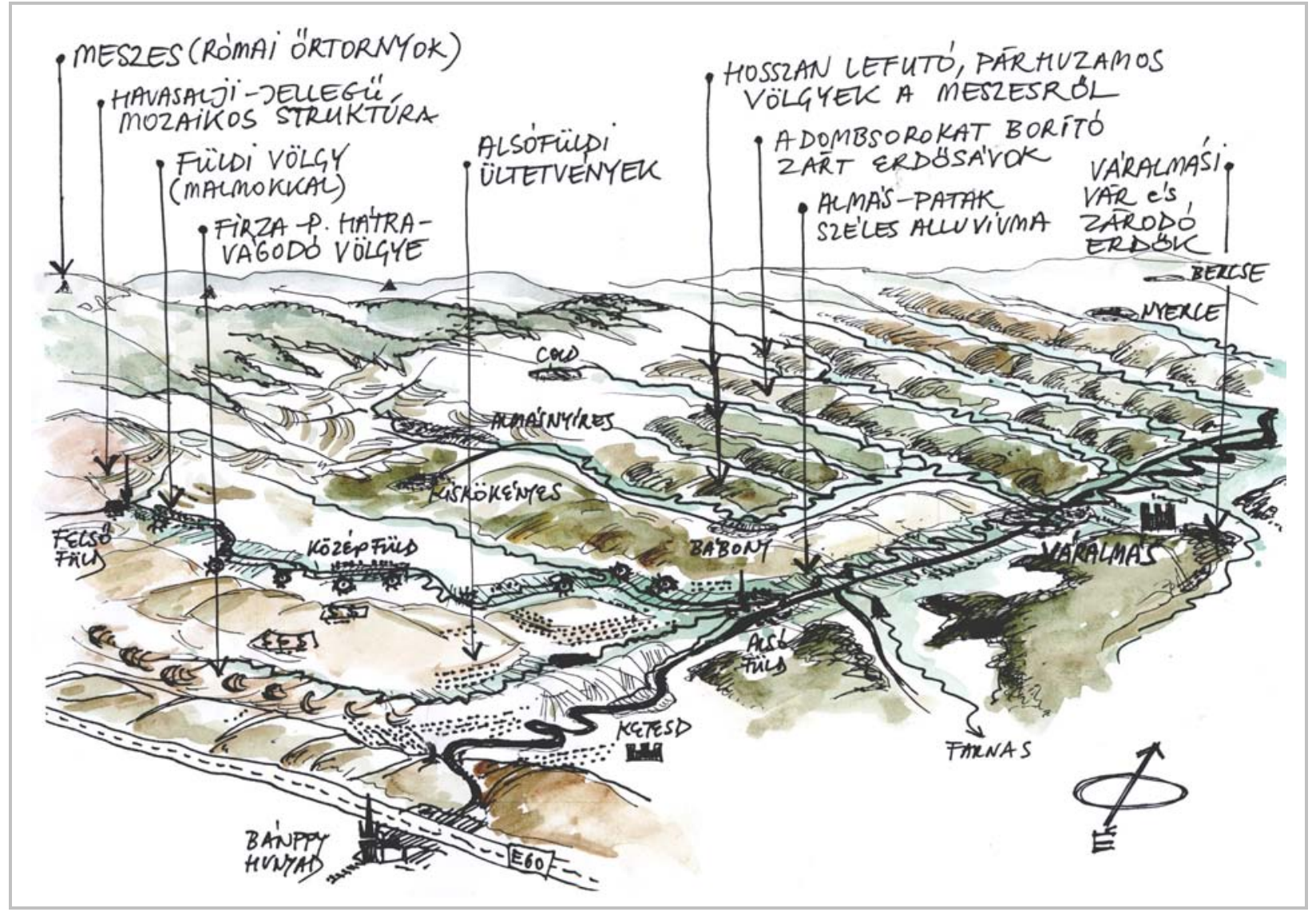

19. ábra: A Váralmási-völgyek tájkarakter-zóna modellrajza D-felöl

E zóna területét Ny-ról, a Meszes oldaláról-, és K-ről, a Kolozsvári-vízválasztó dombvonulatról hosszan lefutó, párhuzamos oldalvölgyek adják, amelyek széles, tág, elvizenyősödött mederfenekeket képeznek. Alapkőzete egyöntetüen harmadkori oligocén mészkő, amely nem rendelkezik sem kemény kőzetekkel (így itt kőbányák sincsenek), sem feltünő felszínformákkal. A tompa térformák a tágas völgyekkel együtt nem adnak olyan erős mozgalmasságot, hanem szelídebb, statikusabb, kiegyenlítettebb térélményeket. Tájhasználata kevésbé változatos (alacsony komplexitású), de a párhuzamos völgyek visszatérő ismétlődése koherens összetartozást eredményez. A párhuzamos hegyhátakat zárt erdősávok borítják, amit a Ny-i falvak magas erdőborítottsága is alátámaszt. E zóna alapterülete a legnagyobb, ezért jelentős belső eltéréseket mutat: a 'kert és ültetvények' tájértékelésében majdnem egységes jelentős, de szántó, legelő, bivaly, szőlő tájértékelése váltakozó. Az agroteraszok dominánsan csak az almásnyíresi völgyben jelennek meg, és csak távolabb (Drág környékén). Felsőfüldön a tájszerkezet a havasalji zárt legelőtípus mozaikosságához áll közel. A nagy területi zónában finomabb bontások a koherens széles patakvölgyek mentén tehetőek: Alsó+Közép+Felsőfüld, Bábony+Nyíres+Kökényes, Vásártelke+Lapupatak+Oláhköblös. A kalotaszegies népi 
épületornamentika elvétve meg-megjelenik, de a falvak már széttelepült, halmazos szerkezetet mutatnak. A völgyek között csak az Almás-patak fóága képez szerkezeti kapcsolatot, amely erősen Hídalmás, Szilágság-felé orientál. A 'három-füldi' malomrendszer és a fatemplomok szakrális fókuszpontja egykor jobban Felszeghez kapcsolták e völgyet. Mára ezek az elnéptelenedő, szegény román falvak tájai elhanyagoltak, szimbólumtartalmukat veszítették. Határát az alszegi szőlős-zóna felé a ketesdi szőlősdombok, a Bikali Farkasvár (egykor jelentős őrszem-földvár) és a Kispetri-Farnaskörnyéki záródó, nagy erdőfoltok jelzik.

\section{II.4.10. Alszegi barnakőszénvidék - Ab (felszínmorf.-típus: B)}

Típus: alacsony, lankás, tagolt, erdös dombvidéki zóna, jellemzöen ipari tájhasználattal

Települések-területek: Almástamási, Dank, Tóttelke, Nagypetri, Forgácskút, Argyas, Sólyomtelke és az azóta létrejött Ferencbánya-telep (Ticu-Colonie)

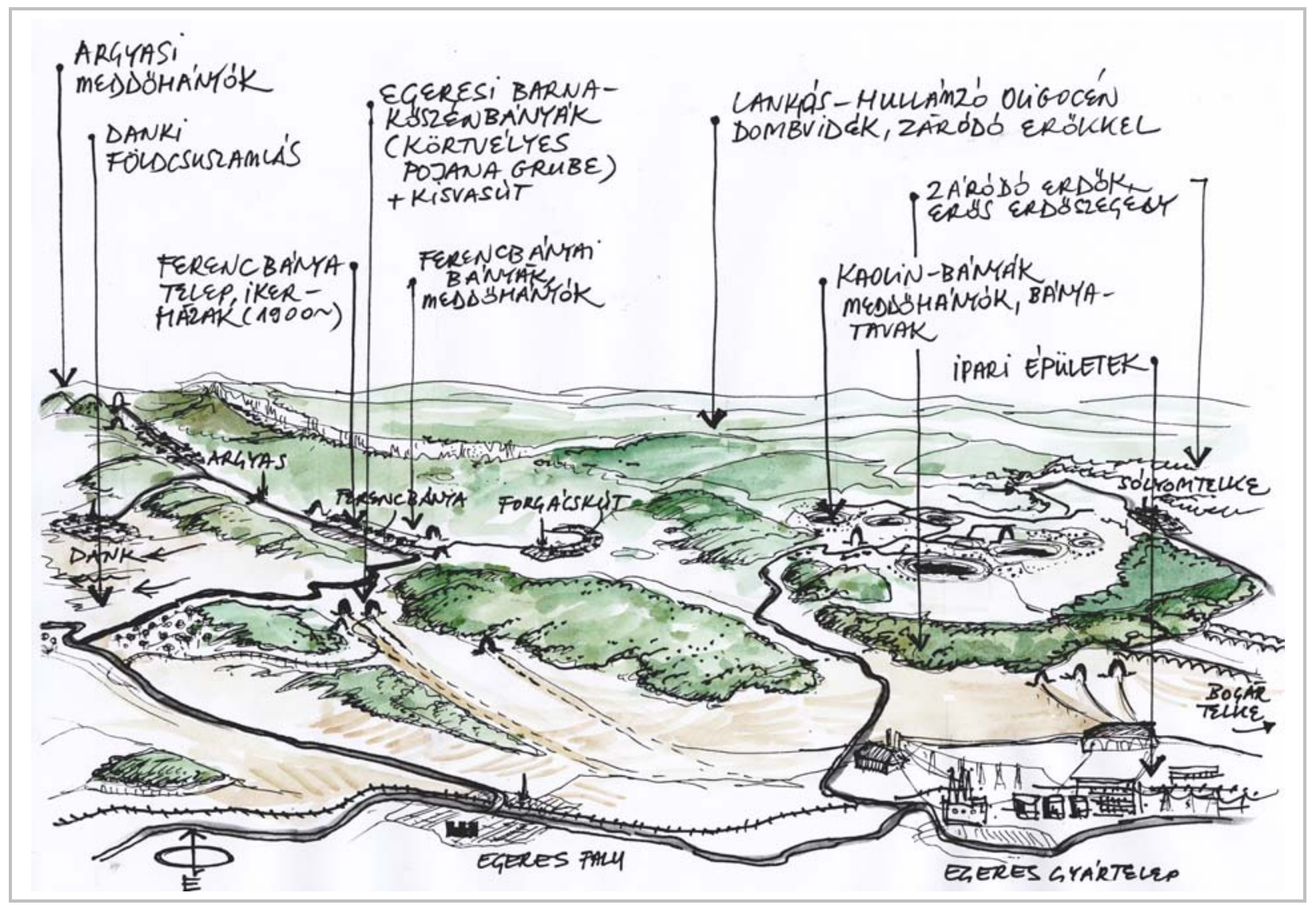

20. ábra: Az Almási barnakőszén-vidék tájkarakter-zóna modellrajza D-felől

E zóna a Kolozsvári Ny-i vízválasztó hegyvonulat megemelt részén fekszik, amelyet magaslati-helyzete miatt nem jellemezhetnek hosszú völgyek, így inkább kisebb, mélyebb, tagolt völgyekre bomlik, ahol a felszínmozgalmasság magasabb, mint a Váralmási-völgyekben. A vidék alapkőzete részben a felső durvamészkő határvonala és a harmadkori oligocén mészkő. Alaktanilag nem jellemzőek a különleges mész-szirtek, mezaplatók, ugyanakkor közös jegyük, hogy pár méter magas barnakőszén betelepülések találhatóak bennük. Ennek kifejtése a XIX. sz. végén kezdődött meg 
és tárnáival, meddőhányóival, csillerendszerével közel 80 éven át erősen hatott a tájképre, de az elmúlt 40 év felhagyása és vissza-erdősülése miatt ipari karaktere mára csökkent. A bányászfalvak (Argyas-, Forgácskút, Ferencbánya - barnakőszén, Sólyomtelke határában kaolin) infrastrukturális szempontból (út, vasút, közmü, munkahely) Egeres-Bogártelke-felé, és nem Középlak felé orientálnak. Itt a tájkép meghatározó eleme a zárt erőstársulás, amely egyöntetü borítást ad a felszínnek, kis komplexitást eredményezve. Tóttelke, Nagypetri, Almástamási és Dank tájképe sokkal változatosabb, nyitottabb, tagoltabb, komplexebb, azaz ez a terület (kisebb ipari beruházásai, meddőhányói, bányái ellenére) inkább hasonlatos az Alszegi szőlővidékkel. A román lakosú bányász-falvak társadalmi kapcsolatai egymással erősek, de nem keverednek a Nádas-mentével, ugyanakkor átvették e vidék magas színvonalú népi építészetét, amellyel a faluképek „kalotaszegiesedtek”. Határát a Nádas-mente felé az Egeres-Bogártelke-Türe É-i oldalában húzódó zárt erdőszegély adja, ugyanakkor tájtörténetét tekintve a Jegenyei - Egeresi ipari tájjal is hasonlóságot mutat.

\section{II.4.11. Nádas-menti völgy - Nmv (felszínmorf.-típus: D, A)}

Típus: fö és oldalvölgyekböl álló tagolt dombvidéki zóna

Települések-területek: Jegenye, Egeres, Inaktelke, Nádasdarócz, Bogártelke, Türe, Mákó, Magyargorbó, Magyarvista, Magyarnádas, Szucság, Méra

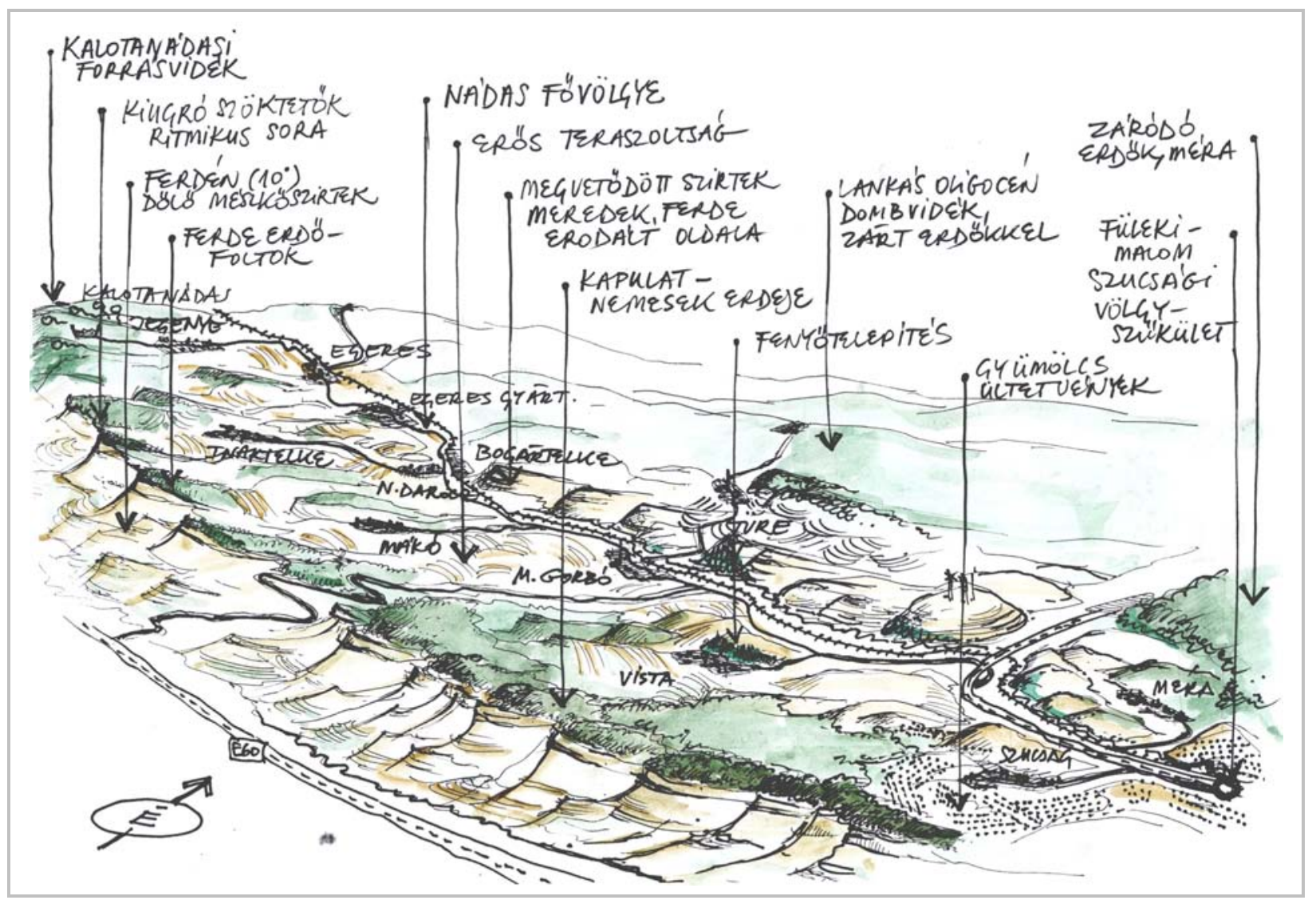

21. ábra: A Nádas-menti-vidék tájkarakter-zóna modellrajza DK-felől 
A Nádas-menti völgy a kalotanádas-jegenyei bővizü forrásoktól veszi kezdetét és K-felé bevágódik az eocén felső durvamészkő-rétegekbe. Az üledékes kőzet itt is a felszegi, alszegi rétegrendet követi, de a Köves-hegy környéki vulkáni tevékenységgel egy időben történő vízválasztókörüli kiemelkedés idején ÉK-i irányban megvetődött, ezért a vízszintes mészszirtek kb. 10 fokos dőlést mutatnak az egész tájkarakter-zónában. Ez az ismétlődő domborzati mozzanat aszimmetrikus, feszült térélményeket hoz létre, amelyek rendre ismétlődnek a zónán belül, ezáltal füzve szorosra a térélmény-kapcsolatokat közöttük. Ehhez az alaktani sajátossághoz tipikus erdőkiterjedés társul a lankás platókon, és mesterséges fenyőtelepítés a meredek oldalakon. Az egész területre magasabb erdőborítottság jellemző (mint Felszegen), de csak kisebb erdőtagokban. Az erdő a századforduló iparosodásával jelentősen csökkent, de kiterjedt fás legelők, cserék képében mégis a tájkép feltünő és jellemző mintázatává váltak egészen le a mérai erdőkig. Ez a tájkarakter-elem nem jellemzi egyik zónát sem ilyen intenzitással.

A Nádas-fővölgyhöz két-oldali, K-felé egyre rövidülő oldalvölgyek kapcsolódnak, így a táj ismétlődően tagolodó koherens képet ad: egy összefüggő hullámzó fővölgyi térélmény, amelynek ki-ki nyíló oldalágai hasonlóak. A XIX. sz. végén kialakult verőér-szerü vasút és közút is ebbe a korábban már összeköttetésben álló malomvölgy-rendszerbe települt, így még jobban összefüzte ezeket a falvakat, erősebb egységet hozva létre közöttük. A vidék falvainak adminisztratív területi-lehatárolása jól illeszkedik az organikus táji határokhoz (vízválasztók, tájszerkezeti-váltások), ezért a tájhasználatot tükröző mezőgazdasági adataik értékelése reprezentatív eredményeket fog hozni. Az egész vidékre jellemző a látványos, erős teraszoltság, a barázdák domboldalakat borító kiterjedése, ami a tájkép domináns erejét adja.

A falvak településszerkezete és népi építészete egységes. A vidék társadalmi kapcsolatai, népmüvészeti-, népviseleti és népzenei- besorolása is mind-mind hasonlóan egységes. Mindez azt igazolja, hogy ha egy vidék szorosan illeszkedik a táji határokhoz, a vízválasztók szegélyéhez, a kapcsolódó völgyek térélményeihez, akkor a falvak hasonlóan fognak alkalmazkodni, a tájat hasonlóan fogják művelni és ez a nagyfokú koherenciát, határozott tájkaraktert fog eredményezni. Ebben a zónában a XX. sz.-i változásokat is figyelembe véve két al-karakter jelölhető meg: az egyik a Jegenye-, Egeres-gyártelep-, Bogártelke környéki indusztriális táj, nagy bányagödrökkel és ipari épületekkel; másik az andrásháza-szucsági nagy kiterjedésü gyümölcsültetvények vidéke. Mindét esetben olyan nagy tájváltozás történt, amely felülírta az addigi látványkapcsolatokat, sziluetteket, müvelési formákat, és új vizuális térélményekkel, új mintázatokkal, új tájkaraktert hozott létre. 
II.4.12. Bács-Berendi terület - Bb (felszínmorf.-típus: B)

Típus: lankás dombvidék, jellegtelen alakzatokkal, jellemzően mezögazdasági müveléssel

Települések-területek: Magyarsárd, Magyarszentpál, Nádasszentmihály, Szomordok, Nádasberend, Pusztatopa, Nádaskóród, Papfalva, Bács + mára 2 újabb településsel bövült: Csonkatelep, Máriatelep

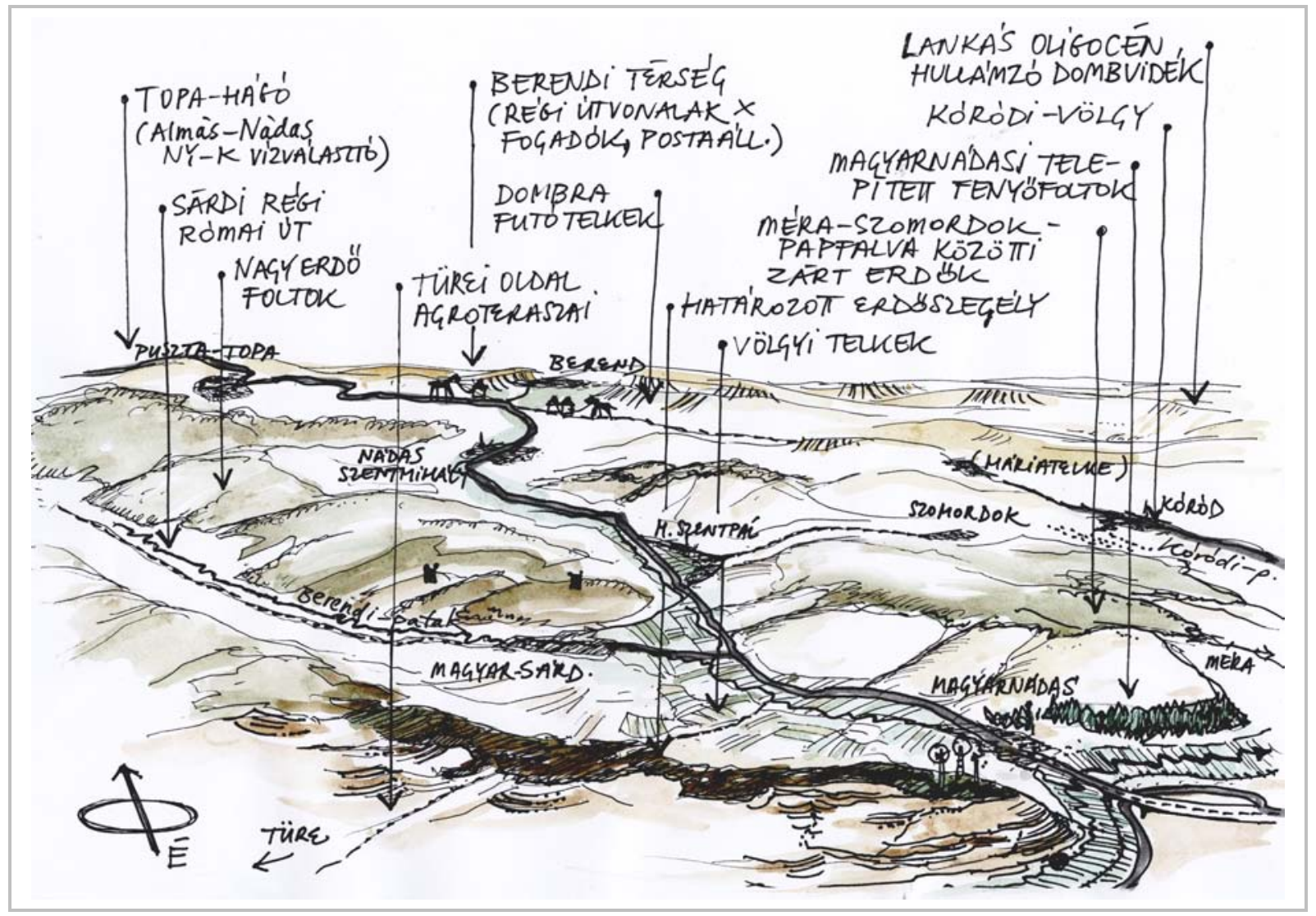

22. ábra: A Bács-Berendi-vidék tájkarakter-zóna modellrajza DNy-felől

A terület két kisebb vízfolyás (Kóródi-, és Berendi-patak) völgy közötti lankás dombság, nagyobb részben oligocén-neocén mészkő alapkőzeten. Domborzati morfológiáját tekintve Sárdig találunk a Nádas-mentihez hasonló, de egyre csökkenő 'szöktetö'- szirtperemeket, de ezek Nádasszentmihály-Berend környékén már ellaposodva eltünnek. Felszínmozgalmassága alacsony, lágyan szétterülő, ami nagyobb távlatokat-összelátásokat enged. Agroteraszok is csak a déli részeken fordulnak elő, ugyanis É-felé csökken a relief és egyre inkább megjelennek a lejtőkre merőleges, felfutó parcella-osztások. Szántóföldi müvelése és a bivalytartása sem olyan jelentős, mint a Nádasmentén. Az erdősültség lényegesen magasabb fokú, mint a Nádas-mentén, aminek oka a nagytömbben található kisnemesi, egyházi erdőtagok érintetlensége (Méra, Szomordok, Sárd környékén).

A Nádas-mente felé a Magyarnádas és Türe közötti erdőzáródás és a szucsági malomnál található völgyszükület szab határt a zónának. Gyümölcsösei inkább Bács-Kóród környékén jelentősek, ahova szintén ültetvények kerültek a '70-es években. Településszerkezetei általában zárt faluképek, kalotaszegies népi épületek kevésbé jellemezik, de román fatemplomai fontos táji fókuszpontok. A történeti regionális útviszonyokat vizsgálva a berendi térség volt e két völgyet 
összekapcsoló fogadóvidék - megállóhely. A vidék hagyományos román kapcsolatrendszere és identitása miatt a magyar Nádas-menti 'cifra-vidéktől' mindig is elkülönült, amit eltérő tájkaraktere is alátámaszt.

II.4.13. Kolozsvári alluvium - Ka (felszínmorf.-típus: A)

Típus: Szamos-menti alluviális, tág völgy-szuburbanizált ipari táj

Települések-területek: Gyalu, Szászfenes, Magyarlóna

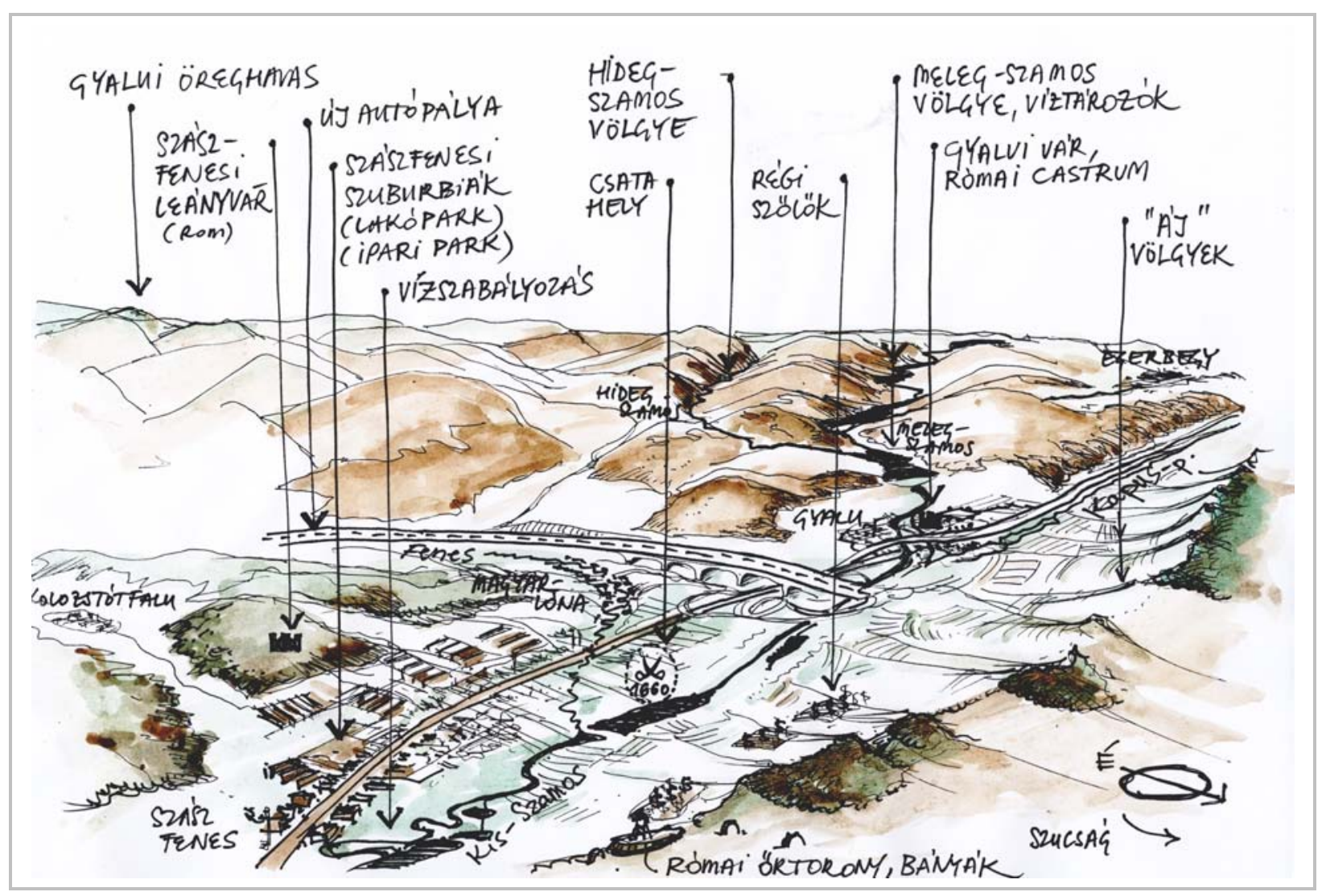

23. ábra: A Kolozsvári alluvium tájkarakter-zóna modellrajza ÉK-felől

A Kapus-patak folytatása, a Hideg és Meleg-Szamos összefolyásából származó Kis-Szamos és a Fenes-patakok meanderező völgye képezi az alluvium alapját. É-ról a Kapulat (Nádas-menti vízválasztó) tagolt mészkőpereme szegélyezi (kis ,áj”- nevü völgyszájakkal), DNY-ról a Gyalui Havasok lefutó hegylábai, DK-ről pedig az Erdővidék kezdődő alacsony dombjai adnak téri lehatárolását a zónának. Ez a téri csomópont három lefutó dinamika között jön létre, összekapcsolva azokat a völgyi térsík erejével, így morfológiailag kiegyenlített helyzetet hoz létre. De mivel a három egység különböző, így a völgy koherenciája sem túl magas: változatos erdőborítottság, erdőfoltok, sokféle müvelési mintázat, eltérő domborzati alaktan és beépítések jellemzik így komplexitása mármár a kaotikusság felé tereli. Az ártéri telkek vízvonalra merőleges telekosztásai, a négyzetes parcellák és a Kapulat oldalra felkúszó íves agroteraszok mintázati ritmusa is kaotikusan hat egy térben. 
A völgy stratégiai szerepére utal római-kori Gyalui Castrum, majd a Rákóczi vár, a Szászfenesi Leányvár, a Szucság feletti római őrtorony pozíciója, a 1660-as Rákóczi-féle ütközet helyszíne és a történeti fogadók sora is (Zöldsapka , Vörössapka , Rongyos ). A kolozsvári bér-szőlőtáblák és várost kiszolgáló Hója-tetői kőbányák már korán jelezték a nagyvárosi agglomerációs helyzetet. A XX sz.-ban a vízszabályozás (halastavak, tározók), majd ipari zónák, lakóparkok és az elkerülő autópálya indukálta újabb kamiontelepek a legdrasztikusabban alakították át a mezőgazdasági tájat. Így ma egy elővárosi, széttelepült, hagyományos tájhasználatát vesztett ipari táj. A mai szabályozatlan, 'ad-hoc' építkezések spontán megoldásainak következetlen és rendezetlen hatása a természetesség-, és a gondozottság-érzését is drasztikusan csökkentik. Az egykori „,képiességet” okozó táji szimbólumokat (Fenesi-csatahelyszín és Rákóczi vár képe) mára az ipari táj teljesen felülírta és eltörölte. A három település statisztikai tájértékelése a zóna kis alapterülete miatt diverz képet ad; és különböző alapterületük miatt sem jól összevethetőek. E zóna ma nem tekinthető kalotaszegiesnek, és ezzel összecseng a társadalmi különállósága is. 


\section{TÁJKARAKTER-JEGYEK ÉS TÁJKARAKTER- MINTÁZATOK ELEMZÉSE}

\section{III.1. A fejezet módszertani bemutatása}

A disszertáció II. fejezetében a tájban észlelhető térélmények, térformák alapján határoltam le az egységes tájkarakterü területeket, 13 zónát különítve el. A III. fejezet célja ezzel szemben, a már definiált zónák vizsgálata a rendelkezésünkre álló tájhasználati-, tájtörténeti-, statisztikai adatsorok-, források (térképek, archív felvételek, dülőnevek) segítségével [24. ábra]. A szembeállítás egyik célja elemezni, hogy az eltérő adatok és vizsgálati módszer mennyiben hoz hasonló, ill. különböző eredményeket; másik célja megvizsgálni, hogy a már kijelölt -térélményen alapuló-, zónák tájkarakterének XIX. sz.-végi tájhasználati adatai mennyire tükröznek belső egységességet: Valóban hasonlóak-e az összesorolt falvak alapadatai és tájkarakter-értékelési adatai? Tájkarakter-mintázati jegyei milyen tájtörténeti jelentöséget és téri-, időbeli eloszlásokat mutatnak?

II. FEJEZET $<>$ III. FEJEZET
JELEN ORIENETÁLT $<>$ TÖRTÉNETISÉG-ORIENTÁLT
HÁROMDIMENZIÓS TÉRÉLMÉNY $<>$ TÉRKÉPES (pont-vonal-haló-folt) MINTÁZATOK
TÉRBELISÉG, TÖMEG $<>$ SÍKSZERÚSÉG, ELOSZLÁS
TEREPSZEMLE ALAPJÁN (field study) $<>$ FORRÁSKUTATÁS (desk-study)
SZUBJEKTÍV, NEM SZÁMSZERÜSÍTHETÖ ÉSZLELÉS $<>$ OBJEKTÍV ADATSOROK, TÁJÉRTÉKELÉS
TÁJESZTÉTIKAI MEGKÖZELÍTÉS $<>$ TÁJTÖRTÉNETI MEGKÖZELÍTÉS

24. ábra: A II. és III. fejezet megközelítésének összehasonlítása

\section{III.1.1. A tájkarakter-jegyek meghatározása}

A tájkarakter-elemzési irodalomban, egy tetszőleges lépékü terület felvételezési adatlapján az összes lehetséges tájtípust létrehozó adottásgok, tájalkotó elemek sora megjelenik. Mivel e dolgozatnak nem célja kelet-európai, romániai, sőt még erdélyi táji-besorolási relációk megállapítása sem, így a tájkarakter-elemzés szempontjait és témaköreit is csak az itt előforduló jellemzőkre szükítettem (pl.: kimaradt a tengerpartok látványa, a tórendszerek és vízfelületek elemzése, magashegységi hegymorfológia vagy éppen a síkvidéki tájképet meghatározó tanyás facsoportok témaköre is).

A kalotaszegi tájkép és tájhasználat vizsgálata során az eddigi leírásokat, néprajzi-, kultúrtörténeti szakirodalmakban megjelent „sejtéseket” és helyszíni vizsgálataim során tett felismeréseimet használtam fel. A III. fejezet témaköreit is a jellemző helyi sajátosságok felismerése alapozta meg, amely e táj legfontosabb TÁJKARAKTER-JEGYEIT adják. Ezek vizsgálatához (1) tájtörténeti ismerteket, (2) a rendelkezésre álló mezőgazdasági statisztikák adatsoraiból kinyert tájértékelést és (3) tájkarakter-mintázatokat használtam fel. Ezeket a tájkarakter-jegyekre alapozott fejezeteket alább mutatom be [25. ábra]. 
A kalotaszegi tájkarakterre jellemző megállapítások:

\begin{tabular}{|c|c|c|c|}
\hline Fej. & $\begin{array}{l}\text { A táj karakterességének egyik } \\
\text { meghatározott jegye (helyszíni } \\
\text { hipotézis). }\end{array}$ & Ezek nyomán létrejött témakör fejezetcíme & $\underline{\text { Táblák }}$ \\
\hline III.2. & $\begin{array}{l}\text {... az erdök alacsony százaléka (de } \\
\text { nem a teljes hiánya), }\end{array}$ & $\begin{array}{l}\text { > Természetes erdők tájértékelése és a } \\
\text { telepített erdők tájmintázatai és típusai }\end{array}$ & $15-17$ \\
\hline III.3. & $\begin{array}{l}\text {... az agroteraszok visszatérö ritmusa, } \\
\text { és a kis, szintvonalas szalagparcellák } \\
\text { sora, }\end{array}$ & $\begin{array}{l}\text { > Szántók tájértékelése és agroteraszok } \\
\text { tájmintázatai és típusai }\end{array}$ & $18-23$ \\
\hline III.4. & $\begin{array}{l}\text {... a hagyásfás legelök kiterjedt volta, } \\
\text { és különösen a bivaly tartásának } \\
\text { szokása, }\end{array}$ & $\begin{array}{l}\text { > Legeltetés, bivalytartás tájértékelése és a fás } \\
\text { legelők tájmintázatai }\end{array}$ & $24-26$ \\
\hline III.5. & $\begin{array}{l}\text {... a kertek és gyümölcsösök nagy } \\
\text { aránya és táji sürüsége, }\end{array}$ & $\begin{array}{l}\text { > Kertek és gyümölcsösök tájértékelése és az } \\
\text { ültetvények tájmintázatai }\end{array}$ & $27-28$ \\
\hline III.6. & $\begin{array}{l}\text {... a történeti és jelenlegi alszegi } \\
\text { szölömüvelés, }\end{array}$ & $\begin{array}{l}\text { > A szőlöterületek történeti és jelenkori } \\
\text { tájértékelése és azok tájmintázatai }\end{array}$ & $29-30$ \\
\hline III.7. & $\begin{array}{l}\text {... a vizfelületek és vizes élöhelyek } \\
\text { hiánya, a nádas alacsony szerepe, }\end{array}$ & $\begin{array}{l}\text { > A nádasok történeti és jelenkori } \\
\text { előfordulása }\end{array}$ & 31 \\
\hline III.8. & $\begin{array}{l}\text {... a zárt, völgyi településstruktúra és } \\
\text { az épületornamentikák szerepe a } \\
\text { faluképben, }\end{array}$ & $\begin{array}{l}\text { > A településszerkezet és a falukép } \\
\text { tájkaraktert befolyásoló szerepe }\end{array}$ & 32 \\
\hline III.9. & $\begin{array}{l}\text {... a templomtornyok feltünö és } \\
\text { szimbólumteremtö látványa a tájban, }\end{array}$ & $\begin{array}{l}\text { > A templomtornyok és azok látvány- } \\
\text { kapcsolatainak tájkaraktert befolyásoló } \\
\text { szerepe }\end{array}$ & 33 \\
\hline III.10 & $\begin{array}{l}\text {... a köbányák gyakori elöfordulása és } \\
\text { az eróziós tájsebek visszatérö } \\
\text { látványa. }\end{array}$ & $\begin{array}{l}\text { > A bányászati tájsebek, eróziós jelenségek } \\
\text { tájkaraktert befolyásoló szerepe }\end{array}$ & $34-36$ \\
\hline
\end{tabular}

25. ábra: A tájkarakter-jegyek megállapítása során létrejött fejezetcímek

\section{III.1.2. Az egyes tájkarater-jegyek vizsgálati módszere}

A tájkarakter-jegyek vizsgálata az alábbi primer források és szakirodalmi kutatás alapján készült: történeti térképek ${ }^{128}$ igen alapos összevetése; tervek, légifotók elemzése; a tájháttér-részleteket tartalmazó régi fényképek kigyüjtése; történeti szakkönyvek feldolgozása és a helyszíni fényképek készítésével. A fejezetek közötti táblák e hatalmas képanyagnak csak csekély töredékét tartalmazzák. Egyes témakörökhöz jelentős forrásértékü, eddig nem publikált leírásokat találtam. Ezek hozzájárulhatnak Kalotaszeg helytörténetéhez, ugyanakkor e tájkarakter-elemzés gördülékenységét megnehezítik, így ezeket odavágó képeikkel együtt a mellékletben helyeztem el.

Az 1-6. fejezetekhez településsoros mezőgazdasági statisztikák álltak rendelkezésre a XIXXX.sz. fordulójáról, amelyeket a térképes ábrázolással összekötve egy a „tájkarakter-jegyek jelentöségére rávilágitó”- tájértékelési módszert dolgoztam ki, melyet alább részletesen bemutatok.

Kitüntetett figyelmet fordítottam továbbá a mintázat-szerü tájkarakter-jegyekre is (ültetvények, agroteraszok, fás legelők), különösen azok formai, alaktani eloszlására, ritmikus megjelenésükben rejlő vizuális és perceptuális hatásaikra.

\footnotetext{
${ }^{128}$ Első és második katonai felmérés és a harmadik felmérés 25000-es, és többszörösen reambulált 75000-es szelvényei
} 


\section{III.1.3. A statisztikai elemzések és a térképes ábrázolás nehézségei}

Településsoros területhasználati statisztikai $\operatorname{adatok}^{129}$ a századforduló kivételével más időszakból nem állnak rendelkezésemre, ${ }^{130}$ ezért ezt az állapotot tekintettem referenciának az elemzéshez. Ez párhuzamba állítható a korabeli adókataszteri térképekkel ${ }^{131}$ [26. ábra] és a második katonai térképezéssel is, így ehhez az állapothoz azt megelőző és azt követő változásokat is jól lehet viszonyítani. Az 1914-es kataszteri adójövedelmek megállapítását szolgáló adatsor földminőségi osztályait tekintve részletesebb (mint a 1897-es), ugyanakkor a gazdaságok leírását nem tartalmazza olyan mélyen. 1920 után a román közigazgatás nem készített településsoros felmérést, így a visszacsatoláskor újra a '14-es állapotokat tekintették relevánsnak. A háború utáni időszakból csak megyei adatsorok érhetőek el hazánkban, de azok a térség változásaihoz túl általánosak. Az ez idő alatt történt tájváltozások az 1941-es, és mai légifotókkal egybevetve ennek ellenére kiolvashatók.

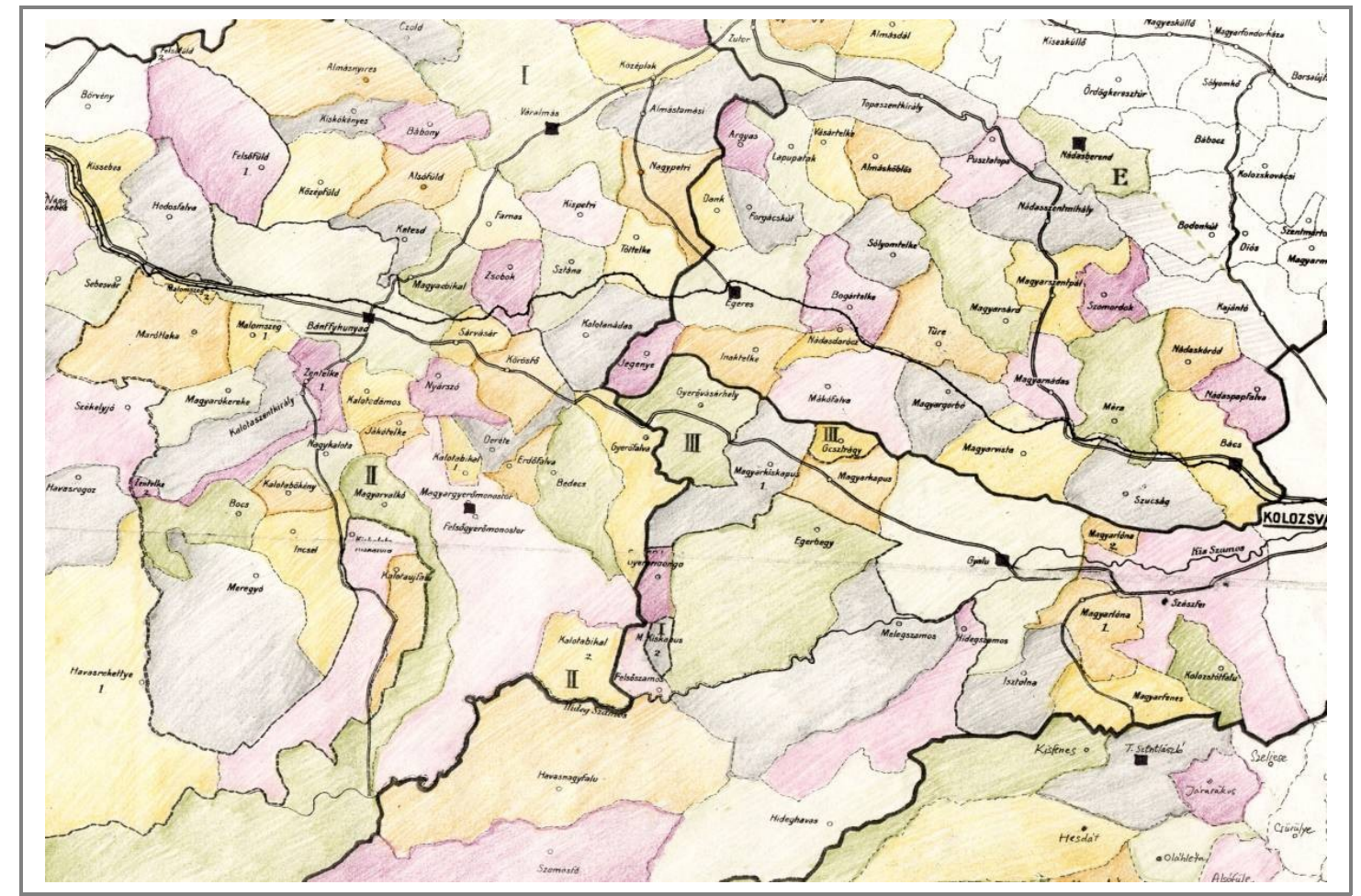

26. ábra: A vizsgált 116 település közigazgatási, adókataszteri határa (1914) OSZK, TM 3103

Elsőként a II. és III. fejezet tájkarakter-zóna lehatárolása közötti eltérésekre kell rávilágítani: amikor a II. fejezetben kialakított tájkarakter-zónák falvainak hivatalos települési kiterjedését jelöltem, több ponton láthatóvá vált, hogy azok kataszteri területe és határai nem illeszkednek a korábban kijelölt térélmény-alapú határokkal [27. ábra]. Különösen a havasalji területeket és pl.: Váralmást, Hunyadot, Kiskapust, Gyalut, Szászfenest, Egerbegyet jellemzik nagy területi-torzulások, amelyek előre vetítik ezen falvak statisztikai értékelésének bizonytalanságait.

\footnotetext{
${ }^{129}$ Mezőgazdaság Stat., 1897. pp. 646-659., Kataszteri 1914a és 1914b., Gazdacímtár 1897 és 1911.

${ }^{130}$ Kutatásokat végeztem a KSH, MM adattárában, de a XX.sz.-ból csak megyei adatsorok állnak rendelkezésre. Sem a Román Statisztikai Hivatal, sem a Kolozsvári Szakkönyvtárak nem választoltak megkeresésemre.

${ }^{131}$ OSZK TK1894_4 és TM3104
} 


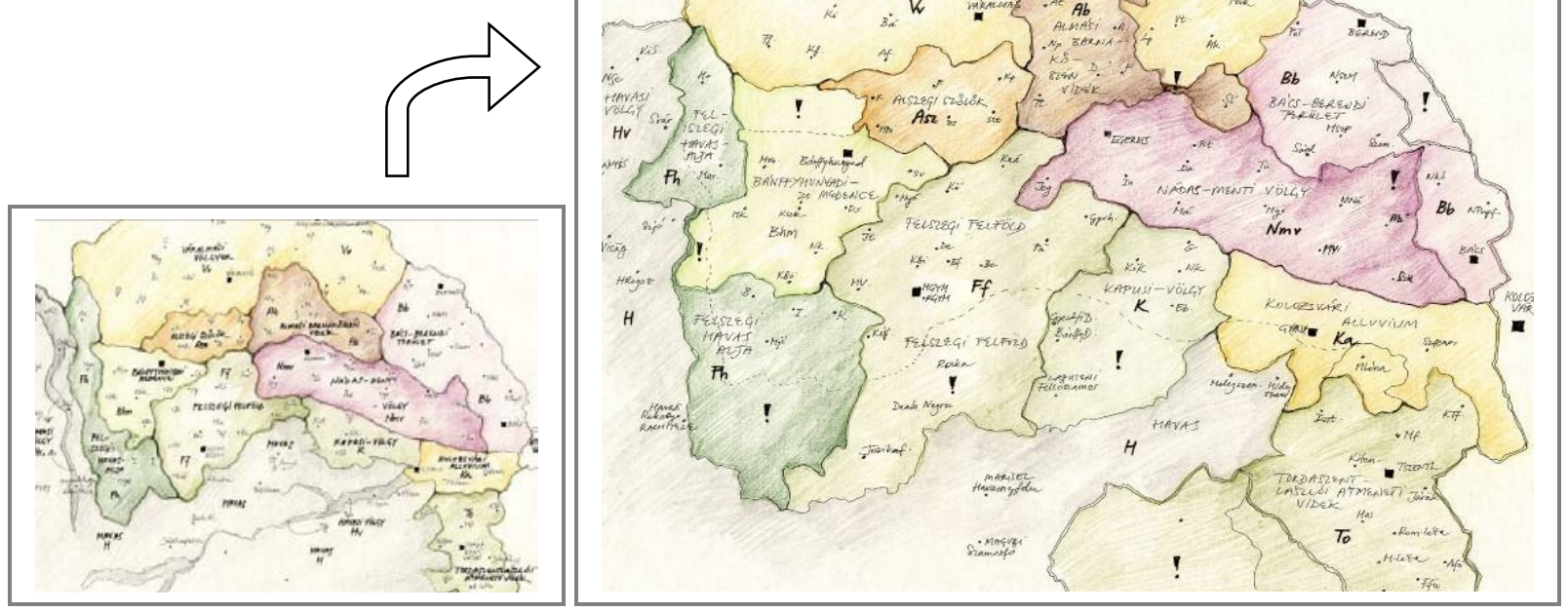

27. ábra: A tájkarakter-zónák térélmény-alapú és kataszteri besorolása közötti különbségek

Jól kivehető, hogy nem mindenhol esnek egybe határok, ! jelöli ebböl a szempontból különösen érintett részeket: a Felszegi felföldet, a Tordai térséget és a Havasalját

Az erdőségek, legelők statisztikai és térképes elemzését nehezíti, hogy az erdőtagok sokszor a településtöl messzebb (akár a Havasokban, külön tagban) helyezkedtek el, így a falu közigazgatásilag nyilvántartott erdeje a falu környékének képére nincs hatással. ${ }^{132}$ A hiba ebben a vizsgálati léptékében nem kiküszöbölhető, és csak települési határ- és birtoktérképekkel lehetne pontosabban áttekinteni.

További nehézséget okoz a havasi szórt telepeken történt közigazgatási határmódosítás (18971914), amely során bár a „telep-központok” megmaradtak, az attól távolabbi területeket mégis átnevezték és átméretezték. Mivel e telepek határhasználatának jellege egymáshoz nagyon hasonló, és éles eltérést mutat az alacsonyabban fekvő falvakkal szemben, így az átméretezett települések százalékos arányai is relevánsnak mondhatók. Nehezebben hidalható át azonban a Tordaszentlászló vidékének átszervezése Kolozs és Torda-Aranyos megyék között, ahol a határmódosításokkal egészen más \%-os arányok jöttek létre, így ez a súlyozásokban, tájértékelésben is súlyos hibákat okoz.

\section{III.1.4. A tájkarakter-jegyek jelentőségére rávilágító tájértékelési módszer leírása}

A statisztikai elemzésekhez két alapvető adatsort $(1897,1914)$ digitalizáltam [28. ábra] és általam készítetett excel táblák segítségével bizonyos adatokat újraszámoltattam a programmal, valamint az értékeléshez szükséges új adatsorokat is létrehoztam. A nyers adatokat nem lehetett a tájkaraktert meghatározó egyedüli indikátorként tekinteni, sem azokból tájértékelési következtetéseket levonni. Az adatok elemzése során kiderült, hogy egy-egy müvelési ág jelentőségét nem lehet csupán annak mérete vagy százalékos eloszlása alapján meghatározni, hanem több adatból összesítve -

132 Magyarvalkón 1897-ban a falu területe 27219(!)kh, (ebböl erdő: 19603=72\%), 1914-ben már csak 5962kh. (ebből erdő 1418=25\%). A falu közvetlen határában a pár holdnyi valódi erdő elhanyagolható, a havasival szemben. 
összedolgozva kell annak szerepét megállapítani, hogy árnyaltabb képet kapjunk a művelési ág valós jelentőségéről. ${ }^{133}$ Ebből kifolyólag az alábbi módszert találtam célravezetőnek:

\begin{tabular}{|c|c|c|c|c|}
\hline \multirow{2}{*}{$\begin{array}{c}\mathbf{E} \mathbf{V} \\
1860 \\
\end{array}$} & \multicolumn{2}{|l|}{ Statisztikai nyers adatsorok } & \multicolumn{2}{|c|}{$\begin{array}{l}\text { Számolt adatok } \\
\text { (megfelelóen kialakított, számoló excel munkafüzetekkel) }\end{array}$} \\
\hline & szőlő müvelési adatok & & - & \\
\hline & & & - & \\
\hline \multirow[t]{5}{*}{1897} & gazdaságok száma falvanként & $\mathrm{db}$ & egy gazdaságra eső átlag terület & $\begin{array}{c}\text { kat. } \\
\text { hold } / \mathrm{db}\end{array}$ \\
\hline & $\begin{array}{l}\text { összes tulajdon falvanként } \\
\text { (nem haszonélvezet és haszonbér) }\end{array}$ & $\begin{array}{l}\text { kat. } \\
\text { hold }\end{array}$ & haszonélvezet és haszonbér terület & kat. hold \\
\hline & $\begin{array}{l}\text { müvelési ágak területe falvanként/ } 9 \text { adat } \\
\text { erdö, szántó, legelö, rét, nádas, kert, szölö } \\
\text { (használt és parlag), }\end{array}$ & $\begin{array}{l}\text { kat. } \\
\text { hold }\end{array}$ & $\begin{array}{l}\text { falu teljes határterülete } \\
\text { a müvelési ágak területének \%-os megoszlása }\end{array}$ & $\begin{array}{c}\text { kat. hold } \\
\%\end{array}$ \\
\hline & $\begin{array}{l}\text { gyümölcsfák száma (falvanként, fajtánként) } \\
\text { alma, körte, cseresznye, meggy, öszibarack, } \\
\text { szilva, dió, mandula, gesztenye, eper }\end{array}$ & $\mathrm{db}$ & $\begin{array}{l}\text { gyümölcsfák összes száma } \\
\text { összes gyümölcsfasürüség a kertre vetítve } \\
\text { összes gyümölcsfasürüség az egész határra vetítve }\end{array}$ & $\begin{array}{c}\mathrm{db} \\
\mathrm{db} / \text { hold } \\
\mathrm{db} / \text { hold }\end{array}$ \\
\hline & $\begin{array}{l}\text { állatállomány (falvanként, fajtánként) } \\
\text { Bivalyfogat, bivaly, tehén, kecske, juh, }\end{array}$ & $\mathrm{db}$ & $\begin{array}{l}\text { összes állatállomány } \\
\text { bivaly százalékos aránya }\end{array}$ & $\begin{array}{l}\mathrm{db} \\
\%\end{array}$ \\
\hline \multirow[t]{5}{*}{1914} & $\begin{array}{l}\text { Kataszteri tisztajövedelmi fokozatok } \\
\text { becslőjárásonként, 8-8 minőségi fokozat } \\
\text { müvelési áganként } \\
\text { erdö, szántó, legelö, rét, nádas, kert, szőlö }\end{array}$ & $\begin{array}{l}\text { fillér/ } \\
\text { kat. } \\
\text { hold }\end{array}$ & $\begin{array}{l}\text { egész határterület tisztajövedelme falvanként a } \\
\text { múvelési ágak tisztajövedelme falvanként } \\
\text { a tisztajövedelem \%-os megoszlása az egyes } \\
\text { múvelési ágak között } \\
\text { az egyes múvelési ágak átlag (súlyozott) kataszteri } \\
\text { jövedelme falvanként }\end{array}$ & $\begin{array}{c}\text { korona } \\
\text { korona } \\
\% \\
\text { fillér/kat. } \\
\text { hold }\end{array}$ \\
\hline & $\begin{array}{l}\text { művelési ágak területe falvanként, 8-8 minőségi } \\
\text { fokozat szerint ( } 58 \text { adat/falu) } \\
\text { erdö, szántó, legelö, rét, nádas, kert, szőlö }\end{array}$ & $\begin{array}{l}\text { kat. } \\
\text { hold }\end{array}$ & $\begin{array}{l}\text { a falu összes művelési és határ területe } \\
\text { egy-egy müvelési ág összterülete } \\
\text { a müvelési terület \%-os megoszlása az egyes } \\
\text { művelési ágak között }\end{array}$ & $\begin{array}{l}\text { kat. hold } \\
\text { kat. hold } \\
\quad \%\end{array}$ \\
\hline & terméketlen terület falvanként & $\begin{array}{l}\text { kat. } \\
\text { hold }\end{array}$ & & \\
\hline & földrészek száma falvanként & $\mathrm{db}$ & egy földrészre eső határterület & $\begin{array}{c}\text { kat. } \\
\text { hold } / \mathrm{db}\end{array}$ \\
\hline & birtokívek száma falvanként & $\mathrm{db}$ & egy birtokívre eső határterület & $\begin{array}{c}\text { kat. } \\
\text { hold } / \mathrm{db}\end{array}$ \\
\hline
\end{tabular}

28. ábra: A tájértékeléshez használt nyers statisztikai adatok és az azokból számolt adatok

1. Első lépésben olyan különböző időpontokban felvett, hasonló- vagy, egymással összefüggő adatsorokat kerestem vagy hoztam létre, amelyek az adott mezőgazdasági tevékenységet és annak táji jelentőségét jól reprezentálják. Az erdőknél pl. hat, a gyümölcsösnél nyolc egymással összefüggő és egymást kiegészítő adatsort találtam (ezeket faktorokat nevezem).

2. Második lépésben egy faktor adatsorát emelkedő/csökkenő sorba rendeztem. Megfigyeltem a kapott oszlopdiagramok jellegét (lineáris/ exponenciális/ hiperbolikus). Ezek eloszlásának jellegétől függően az adatsor inflexiós pontjai/ megugrásai értékei/ vagy egyenletes eloszlása mentén 1-2-3-4-es ,jelentőség-értéket” adtam (4-es a legjelentősebb). Ezt mindegyik tájkarakter-jegy, mindegyik faktoránál elvégeztem [29. ábra].

\footnotetext{
${ }^{133} \mathrm{Pl}$. a legeltetéshez nemcsak a legelők, de a rétek (=kaszálók) aránya is fontos, hiszen a téli takarmányozásban a behordott szénának nagy szerepe van; a bivalyok tartása pedig nem elsősorban tejéért történt, hanem igavonó képessége miatt, így az nem a legelőkkel, hanem a szántókkal mutat korrelációt; a kert müvelés ág nem fedi pontosan a gyümölcsöst, így ahhoz a gyümölcsfák számát is be kellett vonni.
} 


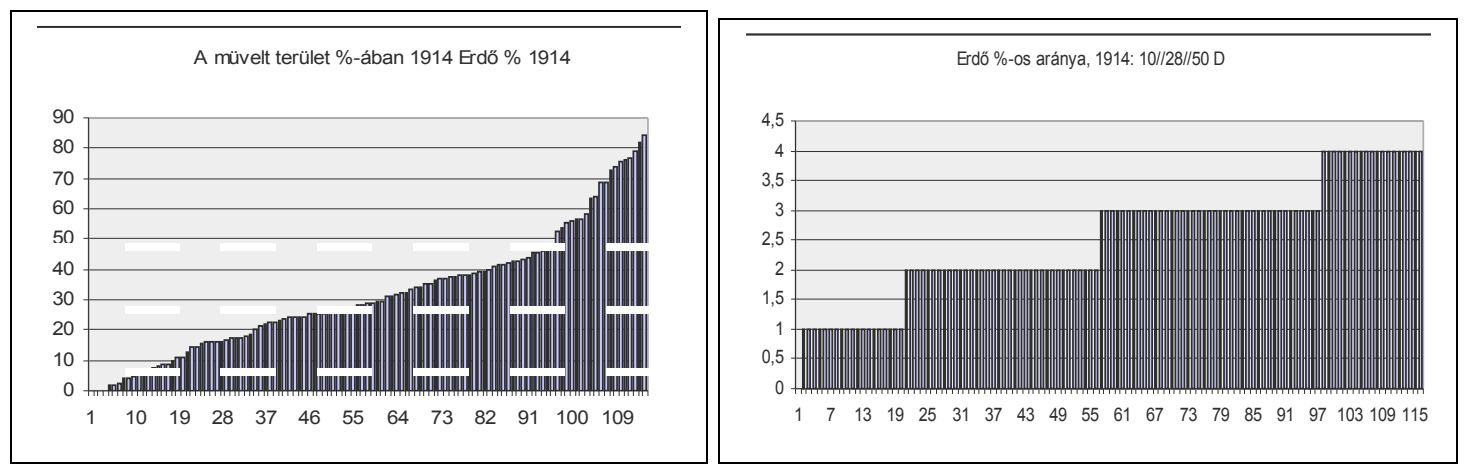

29. ábra: A tájkarakter-értékelés 2. lépése: A falvakat az erdő 1914-es, területi százalékos aránya szerint sorba állítottam, majd a 10\% // 28\% // 50\% -nál osztottam 4 csoportba, és azoknak adtam 1,2,3,4-es értéket adtam.

3. Harmadik lépésben a különböző faktorok adatsoraiból nyert (pl.: méret, területi \%, jövedelem \%) ,jelentőség-értékeket” összeadva egy „„összesített tájértékelési pontszám” keletkezett az adott tájkarakter-jegyet illetően. Ez az érték már az adott jegy jelentőségét árnyaltabban, és differenciáltabban tükrözte (pl: erdök esetében 6 faktorból: $4+3+3+3+4+4=21 / \max .24$ ).

4. Negyedik lépésben a tájkarakter-jegy összesített értéke szerint sorba állítva ismét négy kategóriába soroltam a falvakat, és a tájértékelés eredménye szerint színeztem egy egyszerüsített kataszteri térképszelvényen [30. ábra]. A 4 kategóriát színfokozatokkal jelöltem, ahol a legsötétebb árnyalat mutatta a legjelentősebb értékeket. A gyümölcsösök és szőlök esetében további minőségi jellemzőkkel (régi dűlőnevekkel, mintázati dominanciával) lehetett árnyalni a kategóriákat, így ott alkategóriák is létrejöttek: 4.a.-b.)
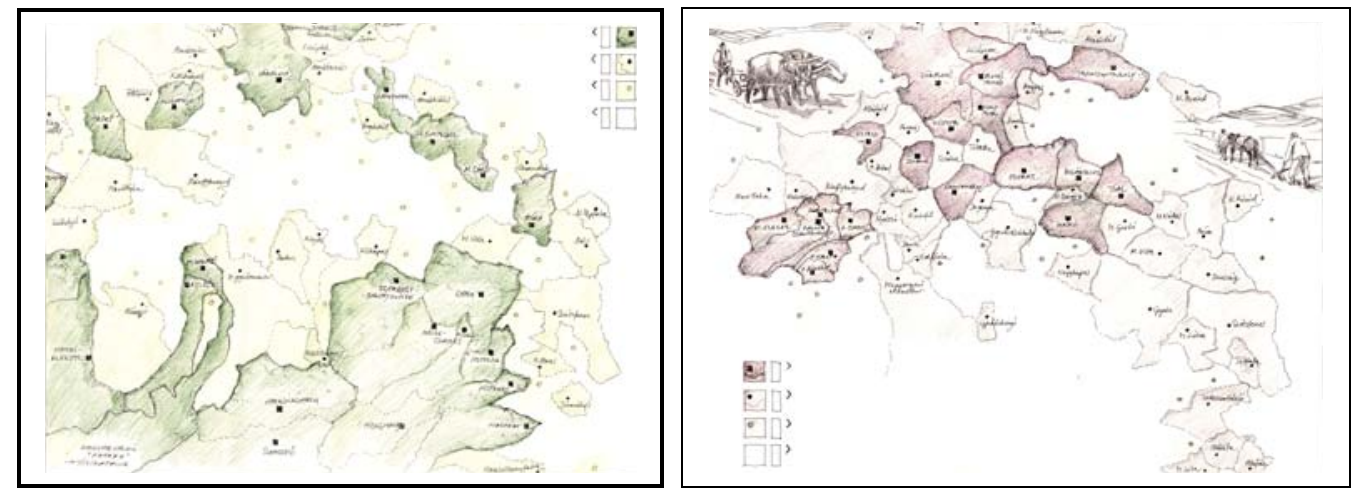

30. ábra: A tájkarakter-értékelés 4. lépése: Az erdők és a bivalytartás összesített tájértékelési pontszámaiból kapott kategóriák térképen történő ábrázolása színkódokkal (sötét=legjelentősebb, világos=nem jelentős). Látható, hogy legjelentősebb erdőtájértékelés „,nem-jellemzi” Kalotaszeget, míg a legjelentősebb bivalytarás igen.

5. A tájértékelés utolsó lépéseként egy olyan összesítés létrehozása volt a cél, amellyel megállapítható, hogy melyik falvak bírnak „KALOTASZEGIES” jegyekkel. Az erdők és legelők esetében látszódik, hogy a nagyobb jelentőségü értékek a „nem-kalotaszegiesek”, a többi tájkarakterjegy magas értékei viszont inkább Kalotaszeget jellemzik, mintsem az azt körbevevő vidéket. Ezért a 6 tájkarakter-jegy összeadásánál az erdő és a legelő tájértékelését meg kellett fordítani, azaz inverz értékét vettem figyelembe (pl.: a 21 pontos erdő átfordult max. 24-21=3 pontra). Azért, hogy mind a hat tájkarakter-jegy tájértékelése azonos súllyal szerepeljen a végső értékelő összegben, az egyes tájkarakter-jegyre kapott értékeket elosztottam az adott jegyhez tartozó faktor-számmal. Az így kapott 
értékeket összeadva a kapott érték már jellemző lesz az adott falu „kalotaszegiességére”. A falvakat ismét rendeztem e „kalotaszegiesség-érték” alapján, és az ismert módon ismét négy kategóriába soroltam öket, sötét sárgától fehérig szín-árnyalattal is jelölve azokat [37-38. ábra] Ezeket visszarendeztem eredeti zónáikba, ami kirajzolta az egy-zónába tartozó települések adatainak egységességét, jellemző átlagértékeit, belső kohéziójának mértékét. Az elemzés végeredménye így éppen a tájkarakter-zónák karakterességének mértékére fog rávilágítani objektív módon.

Az alábbi ábra a tájkarakter-jegyek fejezet-bontását és elemzési módszereit mutatja be [31. ábra]. Az egyes zónák területi megoszlását a [32. ábra] mutatja be, valamint ehhez a bevezetőhöz tartoznak még a melléklet végén szereplő átfogó területhasználati, jövedelmi megoszlást mutató adatsorok táblázatai [41. §. melléklet].

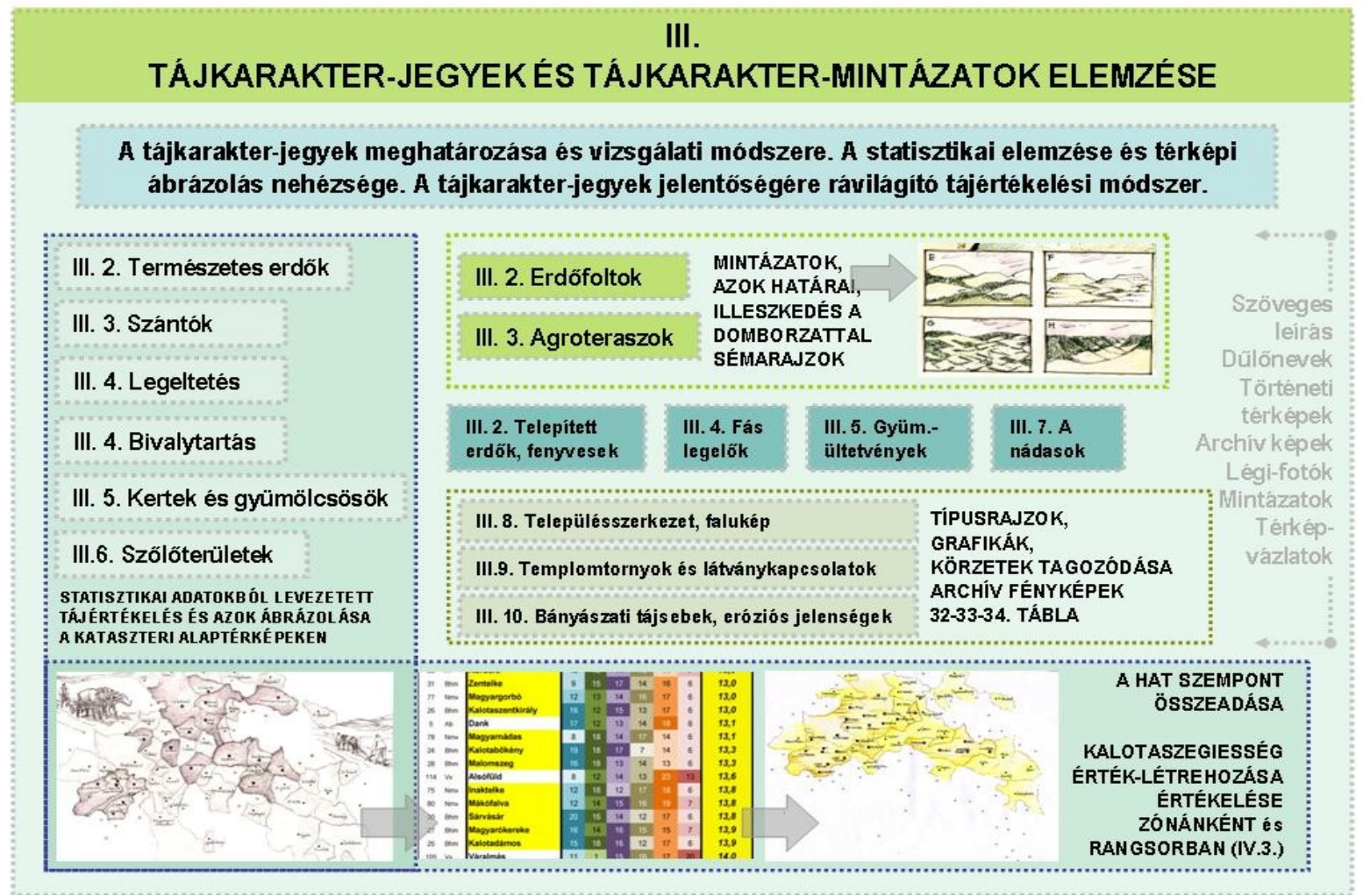

31. ábra: A kalotaszegi tájkarakter-jegyek és mintázatok elemzési rendszere

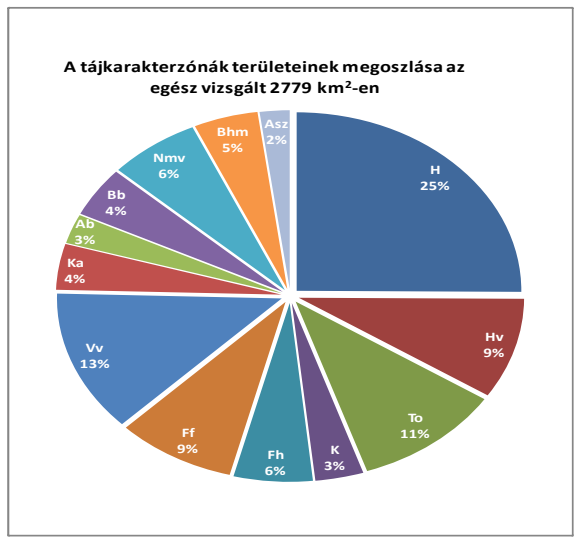

32. ábra: A tájkarakter-zónák területi eloszlása a teljes 2780 km²-es vizsgált területből 


\section{III.2. Természetes erdők tájértékelése,}

\section{és a telepített erdők tájmintázatai és típusai}

A tájkarakter megállapításában kiemelt szerepe van növényborítottságnak, a „hagyományos” és „mesterséges”, a lombhullató és tülevelü erdőtársulásoknak, gyümölcsösöknek és ültetvényeknek, valamint az egykori erdőket jelző fás legelőknek, facsoportoknak és fás szegélyeknek. ${ }^{134}$ A kalotaszegi nyitott, dombvidéki tájképben a felszínmozgalmasság mellett az erdöfoltok mintázatának látványa nagyon meghatározó karakter-tényezőként lép fel [15-17. tábla]. Az elemzéshez statisztikai adatokat, történeti térképeket, dűlőneveket és helyszíni bejárások során készült fényképeket használtam. A tájesztétikai szempontjaim ezért inkább e vegetációtípusok formai-alaktani jellemezőire, mintázati ritmusára, diverzitására és szegélyeire koncentrálnak, mintsem azok természetes társulástani jellemzőire, mert ez utóbbit népi növényismeretével együtt 1985 körül Szabó Attila ${ }^{135}$ már részletesen összefoglalta.

\section{III.2.1. Az erdőborítottság statisztikai különbségei megyei viszonylatban}

Kolozs Vármegyében az átlagos erdőborítottság kb. 30\%-os volt, jelentős belső területi eltéréseket mutatva. Látható, hogy a Mezőség valóban kopár dombságához képest a kalotaszegi tájegységek erdősültebbek, részben a hegyvidéki zárt erdőségeinek látványa, részben a falvak közötti meredekebb oldalak változó erdőfoltjai miatt. A településsoros elemzésből kiolvasható, hogy az erdők aránya 0-86\% között változik falvanként, ami igen nagy tájmintázati változatosságot okoz.

\begin{tabular}{|c|c|}
\hline Tekei-, Mezöörményesi-, Mocsi- (=mezöségi) járásokban & $2-5 \%$ \\
\hline Kolozsvári járásban (Kolozsvártól K-re fekvő falvak) & $13 \%$ \\
\hline Nádas-menti járásban (Jegenye - Egeres - Berend - Bács) & $27 \%$ \\
\hline Almási járásban (Alszeg - Váralmás) & $37 \%$ \\
\hline Bánffyhunyadi járásban (Bánffyhunyadi medence, Felszeg, Sebes-völgye) & $46 \%$ \\
\hline Gyalui járásban (Szamos-völgyek, Béles, Gyalui havasok szórt telepei) & $62 \%$ \\
\hline
\end{tabular}

33. ábra: Az erdőborítottság aránya Kolozs Vármegye járásaiban

Átlagosan alacsonyan erdősültnek és monotonnak mondható a Bánffyhunyadi-medence és a Felszegi falvak területe, ahol 5-10\% között változnak az erdők (sokszor még itt is külön tagban a havas oldalában). ${ }^{136}$ Négy település esetében a századfordulón már egyáltalán nem találunk erdőket: (Damos,

\footnotetext{
${ }^{134}$ Swanwick, p. 31.

${ }^{135}$ Péntek J. - Szabó A. (1985): Ember és növényvilág, Kalotaszeg növényzete és népi növényismerete. A könyv helyszíni terepbejárások alapján készült vegetációtérképezési céllal, történeti helynévböl és vegetációdinamikából kiolvasható tájtörténeti változásokat is említ, de alapvetően az 1980-85-ös állapotokat tükrözi. Jelenleg a MTA Vácrátóti Botanikai Int. doktorandusza, Molnár Krisztina végzi az etnobotanikai újrafelvételezését Alszeg falvaiban.

${ }^{136}$ Jákótelke, Kalotabikal, Malomszeg, Zentelke, Nyárszó, Kalotaújfalu, Sárvásár, Magyargyerőmonostor.
} 
Erdőfalva, Nagykalota és Bökény ${ }^{137}$ ). Alszeg és Nádas-mente falvaiban egymás közt változékony eloszlásúnak mondható az erdőarány, azaz egy-két falunak igen alacsony (Daróc, Bogártelke, Magyarnádas 5\%), másoknak pedig relatív magas (Méra, Kisbács, Nagypetri 40\%). Ebböl következik, hogy Alszegen és a Nádas-mentén a terület erdö-mintázati képe nem annyira homogén mint Felszegen, hanem faluról-falura igen változékonynak, heterogénnek mondható!

Magasnak mondhatjuk az erdőborítottságot $45 \%$ felett. Ezen csoport nagy részét a nagy határú, hegyvidéket borító Gyalui-Vlegyászai Havasok szórt telepei teszik ki, ${ }^{138}$ amelyeknél természetes az erdők magas aránya és ez által válik a tájkarakter-váltás egyik legfontosabb indikátorává. Ugyanakkor a magas erdőborítás másik csoportjába olyan kis települések tartoznak, amelyek alapvető geomorfológia tulajdonságait és helyzetét tekintve „kalotaszegiesnek” lehetnének mondhatók, mégis magas erdőarányuk fontos tájkarakter-váltó határterületté teszi őket. ${ }^{139}$ Ezek a falvak körvonalazzák a tájjelleg-váltást ott, ahol más (pl. geomorfológiai) tényező nem olyan erősek.

Kalotaszeg erdőkarakter szempontjából változatos képét egyrészt a környező tágabb területek viszonyában kell vizsgálni (hol- milyen tájszerkezeti váltásként, milyen határoló-szegélyként jelenik meg az erdő); másrészt a belső kistájak erdő-mintázati különbségeit kell kiemelni, harmadrészt pedig tájtörténeti változásait kell figyelembe venni.

\section{III.2.2. A Kalotaszeget határoló ,erdőszegély” éles és töredékes jellege}

Amennyiben a „,belső kalotaszegi” falvakat (Felszeg, Alszeg, Nádas-mente, Kapusi-völgy) egységes területként kezeljük, úgy azt övező külső erdőszegély -térképekre és terepbejárásaimra alapozott-, formai elemzésében két-típusú átmenetet figyeltem meg. Az egyik típus, ahol a záródó erdőállományok látványa határozott, egy-tömegben megjelenve, markáns tájkarakter-váltást okoz (A); a másik esetben változatosan, fokozatosan, töredékesen, erdőfoltosan jelenik meg az átmenet, kevésbé határozott tájszerkezeti szegélyt eredményezve (B).

(A) A hirtelen fellépő, sötét, zárt erdőállomány (Kalotaszegen 'Renget'-nek nevezett erdő) okozta éles karakterváltás hét szakaszon jelentkezik; többnyire ott, ahol magas és alacsony borítottságú területek közvetlenül találkozik, vagy ahol az erdő nagy-összefüggő állományban jelenik meg:

1. A Kőhegy/Tomoldok-előhegység K-i lábán, ${ }^{140}$ és Hodos felett igen élesen záródik az erdő, ${ }^{141}$

2. A Keleczel feletti erdőtagban hirtelen, nagy tömegben jelenik meg a fenyvesek képe,

\footnotetext{
${ }^{137}$ Ezt a 1820-as Cziráky-féle összeírás is alátámasztja: Damos: Határunkon erdőnk ugyan nincs, de mégis épületre való fát kapunk a mtgs. familiáktól az havasaikból. Erdőfalva: a falunak nincsenek egyéb káraink az erdő nem-létén kívül. Nagykalota: Erdeje a helységnek magának nincsen, épületre való erdőnk nincsen.” in: Takács, 2006.

${ }^{138}$ (Josikafalva, Szamosfö, Hideg-Szamos, Havasrekettye, Havasnagyfalu, Havasrogoz, Bánffydongó, Viság, stb.),

${ }^{139}$ Sólyomtelke, Középfüld, Nyerce, Váralmás, Csucsa, Lapupatak, Hodosfalva, Forgácskút, Zutor, Szomordok, Kiskalota.

${ }^{140}$ Itt két kisebb átmeneti védett cserés zóna található, erősen beerdősült (!) barázdarendszerrel, amely a dűlőnevek és tájmorfológia fekvése alapján meglátásom szerint az egykori Himtelke település feltételezett helye.

${ }^{141}$ Remetén, a Hodosi bekötőnél lévő nagy erdőtagot $(500 \mathrm{kh})$, amely Hodost takarta el az út felől, 1920 körül irtották ki, hogy azon új, téglány, geometrikus mintázatú szántóföldeket hozzanak létre.
} 
3. A Bedecs és Magyargyerőmonostor közötti a Valea Mare-völgy mentén élesen, egyvonalban a völgy K-i oldalán záródik a havasalji erdő, majd folyamatosan zártan húzódik egészen Pányik, Gyerővásárhely, Kiskapus, Nagykapuson át és Gyalu déli oldaláig,

4. Magyarlóna - Szászlóna - Kolozstótfalu K-i határán,

5. Alsófüldtől, majd Váralmástól Középlakig az út Ny-i oldalán, és az oldalvölgyek tetején éles záródó határvonal egészen megváltoztatja az alaktanilag is egyre szélesedő völgyek képét,

6. Forgácskút, Egeres, Bogártelke - Türe vonalában egészen Magyarsárdig húzódik a Nádas völgyének É-i peremén az erdőszegély, amelyet e völgy lezárásaként észlelhető,

7. Méra és Bács környékén (szucsági-szoros) is hasonló záródó erdő-látvány jelentkezik Kolozsvár felé, amely geomorfológiai szükületével és tájhasználat-változásával együtt erős határt jelez.

(B) A fenti éles határszakaszok között találunk töredékes, tagolt, áttört-ligetes erdőfoltokat, amelyek nem képeznek éles tájkarakter-határvonalat:

8. Sebesvár és Marótlaka környékén távoli átlátásokat nyitnak a kibukkanó kopár tetők, mert Kalotaszegtől eltérően nem dombtetőkön, hanem domboldalakon jelennek meg a zárt erdők.

9. Méregjó felé olyan gyors ütemben emelkedik a terep, hogy mire nyílt gyep az erdőségekkel találkozik, addigra optikailag kikerül a látószögböl,

10. Magyargyerőmonostor, Kalotaújfalu felett a négyzetes havasi zártlegelők és fásszegélyek adják a fraktálos erdőfoltokat, ez a geometrikus-áttört mintázat határozottan eltérő jelleget ad e vidéknek.

11. Hunyadtól É-ra, az egykori erdőből kialakított szőlőterületek, zártkertek, majd visszaerdősült gyümölcsösök mozaikos, cserjés-ligetes szerkezete változatos, áttört, laza képet ad.

$\mathrm{Az}$ említett területeken kívül, alig van -a Kalotaszegitől lényegesen eltérő- szerkezetváltás az erdőtagoltság tekintetében a berendi-, a koródi völgyben és T.Szentlászló felé. Így kijelenthető, hogy ezekben a völgyekben nem az erdőhasználat módjában rajzolódik ki tájkarakter-váltás.

\section{III.2.3. Az erdő mintázatának tájtörténeti jellemzői és eloszlása a zónákban}

Felszegen a hegyvidéken lévő erdők kivételével az erdőborítottság igen alacsony (5-10\%). Ezt a térséget már a XVIII. sz.-i megyetérképek is erdőtelennek jelzik, de a XVII. sz.-végi határleírások is alig említenek erdőt Felszeg D-i és Ny-i falvaiban ${ }^{142}$ 1602-ben Vitéz Mihály, majd Basta csapatainak támadása ellen a vidék népe ,az erdő kebelébe, a havasok közé futott”, ${ }^{143}$ ami szintén jelzi az erdők hiányát. Bár bizonyított adatok nincsenek, mégis feltételezhető, hogy Felszeg vagy a kora-középkorban vagy még azelőtt veszíthette el erdőségeit. Ezen az egykoron mogyorós-gyertyános-bükkös erdőkkel

\footnotetext{
142 Ezek: Bökény, Incsel, Méregjó, Szentkirály, Zentelke, Valkó, Malomszeg. E magyar és román települések a földesuraiknak Havasaira jártak épület- és tüzifáért, és makkoltatni is, így azok intenzívebb függőségi kapcsolatban álltak a 'Havasaljával'. Az erdőkiélés nemesi, földbirtokosi jog volt a XIX.sz-ig, a jobbágyság erdőhasználata korlátozva volt. A nemesi birtoktestek kialakulása után stabilizálódott a havasi erdők és felszegi szántók/legelők szimbiózisban álló egymásrautaltsága, és így nem volt szükség új erdők telepítésére.

${ }^{143}$ Szilágyi Sándor: Erdélyország története, 1866, in: Balogh - Fülemile, 2004., p.195.
} 
borított vidéken ${ }^{144}$ viszonylag kevés az „Irtovány/Irtás” kifejezés (Nádas-mentéhez képest), ami arra is utalhat, hogy a vidék már zömében leirtott lehetett, vagy azokat már fáslegelőkké alakították, mire a dűlőnevek magyarul állandósultak. Tudjuk, hogy Felszeg a középkorban kiemelt szereppel bírt; megmaradt müemlékeinek létrejötte sürün lakott intenzív földmüvelést és magas szintü szervezettséget igényelt. A terület magas, méltóságteljes középkori templomtornyainak a tájjal való erős kapcsolata (ellátni és messziről láttatva lenni), véleményem szerint, csakis szabad, erdőtlen, nyitott határhasználat esetén lehetett logikus. Nem zárható ki az itt élő szláv törzsek sokkal korábbi erdőirtásai sem, amely a Körös-hágó területét tehette átláthatóbbá, védhetőbbé; a római kori erdőírtás azonban kizárható a vidék magas, hüvös volta miatt. A századfordulóra a zömében Bánffy- és Esterházy családok havasi erdeinek kitermelése felgyorsult. ${ }^{145}$ Ezt megelőzően még tutajjal úsztatták a Körösön a fát, de a növekvő termelés hívja életre a vasutat 1909-re, amikor kiépül a hunyad-keleceli keskeny nyomtávú vonal felgyorsítva a Kalota-Havas, Jósika-telep, Gyurkucza erdeinek kitermelését. Felszeg K-i vízválasztó területe erdősültebbnek volt mondaható. ${ }^{146}$ Körösfö nagyobb erdeje éppen ezért önállóságot és jó fafeldolgozó kézművességet biztosított számára. Itt dinamikus tájváltozások történetek a XIX.-XX.sz.ban: sok erdőtagot, tölgyest ekkor vágtak ki vagy alakították fáslegelővé.

Alszegen, a Meszesről lefutó széles völgyek felső folyásán, a domblábakon még tagoltabb az erdőszerkezet (Felsőfüld-Nyíres), majd a völgyek alsóbb folyásán lényegesen zártabb, tömörebb, nagyobb erdőfoltokat figyelhetünk meg, különösen a kétoldali dombtetö-gerinceken végighúzódva. Alszeg erdőborítottsága két eltérő vidékre osztható: az egyik a K-i, hosszanti völgyek falvai, ahol a borítottság nemcsak statisztikailag magas (40\%), hanem optikailag is igen erős ( $V_{v}$-Váralmási völgyek ${ }^{147}$ ); a másik a Ny-i 'szőlős falvak' térsége (Asz -Alszegi szőlős), ahol az arány lényesen alacsonyabb (18\%). Így ezek között -Váralmás-Farnas-Kispetri-, határában válik szét e két tájkarakterzóna. Tájtörténetileg sem a katonai felvételek körvonalainak vizsgálata, sem a statisztika nem mutat lényeges csökkenést és erdőalakzat-módusulást, azaz e vidék kevesebb tájképi változáson esett át.

A Nádas-mente erdőségeit vizsgálva láthatjuk, hogy az 1897-es kb. 20-25\%-os arány, 1914-re lényegesen lecsökkent, 15-20\%-ra. ${ }^{148} \mathrm{~A}$ csökkenés oka, hogy az erdők itt inkább a helyi falvak, a közbirtokosság tulajdonában voltak, így a vasút kínálta gazdasági beruházásoknak jobban áldozatul estek. A már említett Egeres-Bogártelke-Türe dombtetőn záródó erdőszegély egyértelmű határt ad a

\footnotetext{
${ }^{144}$ Péntek J - Szabó A., 1985. p.36.

${ }^{145}$ Az kalotaszegi és valkói havasokból az épületfa 3/4-ed része a Körsön megy ki, a többit a hunyadi és csucsai állomásokról a vasút viszi. E kereskedés a havasi lakók kezében van, akik maguk vágják, faragják, fürészelik és szállítják ki a különböző épületfákat, amelyet darabszámra fizetnek meg. A fatermelés eme neme az erdőpusztítással egyenlö. A vállalkozóknak nem áll érdekükben a fát kímélni; annyi szálat döntenek le amennyit tetszik, s csak azt dolgozzák fel, amelyet arra alkalmasnak találnak, a többit korhadni hagyják.” In: Ker. és Iparkamara, 1878. p.89.

${ }^{146}$ Deréte-Jákótelke-Csinkó és Körösfö környéke, a Mészmárt oldala; valamint a Körös vízgyüjtő katlana, amely egybefügg a Riszeg-tetői, a Ravasz-hegyi és Ordományos erdővel és a Sztána-Kalotanádas-Jegenye hegytetői erdővel.

147 A nagy erdőborítottság oka a Váralmási-, majd a Csáky-uradalom, és a Ref. Egyház kezében összpontosuló nagytagú erdőbirtok (3000 kh!), amely a településnek ma is sötét, körbezártan erdős, 'nem-kalotaszegiessé' képet ad.

${ }^{148}$ Különösen Vista (35>28\%), Daróc $(29>5 \%)$, Bogártelke $(17>6 \%)$ esetén. Az utóbbi kettő csökkenő erdejét közel $1000 \mathrm{kH}$ Sólyomtelki erdővásárlással pótolta a századfordulón.
} 
Nádasi-mentének; K-n, a Mérai, Bácsi erdők jeleznek erős tájkarakter-váltást. Magyarsárd-Szentpál felé ugyancsak megnő a zárt erdők aránya, amelyek a kolozsvári kisnemesi családok tulajdonában voltak [15.§.melléklet]. A Kapus-Nádasi vízválasztón szintén szorosan a felszínmorfológiát követi a hosszan elnyúló Kapulat erdővonulata („Nemesek erdeje”149). A megvetődött durvamész rétegek kiszögellési pontjaitól ÉK-i, lejtős irányba a ferde dombtetőket borítják az erdőtagok, így azok a Kapus völgyéböl csak egy sötét peremszegélyként észlelhetők, míg a Nádas-mente felöl nagyobb a rálátás. Ezen az erdővidéken csak 1960 körül épült ki erdészeti céllal aszfaltozott út Nagykapus Magyargorbó között.

A tordaszentlászlói területen a három havasalji völgyfalu: Isztolna, Kisfenes, Hasadát igen magas erdőaránnyal (75-80\%) kilóg a területen egyébként alacsonyabb arányból (30\%). Általánosan elmondható, hogy D-felé (Léta, Alsófüle, Felsőfüle) egyre csökken az erdők szerepe és egyre nyíltabbá válik a tájkép, de itt a települések nagymértékü közigazgatási-területi átsorolása megnehezíti az erdők statisztikai kiértékelését.

\section{III.2.4. A mesterséges fenyőtelepítések megjelenési formái [17. tábla] [16.§.melléklet].}

A kalotaszegi táj képéhez a századforduló óta hozzátartoznak a kisebb foltokban megjelenő, de visszatérően ismétlődő, zömében örökzöld mesterséges fásítások. Ebből néhányat még a Milleniumkori „ezeréves” fásítás nyomaként tartanak számon a helyiek, ${ }^{150}$ amikor bányászati és eróziós sebeket, omlásokat fogtak meg vele, de többségét 1960-70 körül telepítettek az erózióvédelem és az egykori kőfejtők görgetegeinek megállítása céljából, ${ }^{151}$ de ma már nem jellemzőek. A fenyves-tájfásítás több helyen, visszatérő és ismétlődő formában jelenik meg, ezért a tájat jellemző mintázati elemként kezelhető. A térség geológiájával szoros összefüggésben, a fásítás majdnem mindig mészrétegek déli, kiszögellő, meredek oldalán jelenik meg, annak felső peremén vagy teljes magasságán. Ezek, a zömében nyitott kopárokkal körbevett sötét erdőfoltok jól kiemelik a geológiai alakzatokat. Legerőteljesebben az E60-fơút mentén, Jegenye-Kalotanádas és Nagykapus-Gyalu körül tünnek fel; kisebb foltokban a Nádas-mentén is; Felszegen Magyarvalkó, Damos, Jákótelke faluképére vannak hatással; feltünik Tordaszentlászló környékén is nagyobb arányban, ellenben Alszegen nem jellemző.

\section{III.2.5. Az erdők tájkarakterben betöltött jelentősége, morfológiai sémarajzok}

A történeti térképek és a mai állapot alapján kijelenthetjük, hogy Kalotaszeg területét közel 500 éve biztosan nem borítják már kiterjedt erdőségek, de területe mégsem mutat egységes képet. Az erdők itt közepes és alacsonyabb arányban, de igen változatos mintázati jellemzőkkel fordulnak elő a különböző területeken. A kopár, nyitott-ligetes erdőtagok körül a „,záródó erdőszegély” jelentős

\footnotetext{
${ }^{149}$ Ennek egyik birtokosa a magyargorbói Lészai család (200 kh), és a Vistai Úrbéresek (900kh) voltak.

${ }^{150}$ Ketesd, Magyarvalkó, Gyerővásárhely, Nagykapus, Tordaszentlászló in: Péntek J.-Szabó A., 1985. p.59.

${ }^{151}$ Jákótelki adatközlők számoltak be róla, hogy szervezett tsz.-közmunka keretében alakították ki a kisebb ültetőgödröket a meredek domboldalon, amibe a földdel elkevert fenyőcsemetéket ültették igen fáradságos munkával.
} 
karakterváltást ad a táj sziluettjeiben: azaz, ahol egy tömbben, zárt erdőségek jelennek meg, ott kijelenthetjük, hogy egy másik tájkarakterü zóna kezdődik. A nyitott, fél-nyitott dombvidéki látványokban az erdőfoltok speciálisan illeszkednek a domborzati-viszonyokhoz, ami egyedi téri- és alaktani mintázatokat hoznak létre:

- A Hunyadi-medencében, Felszegen és a Tomoldok-előhegység lábain a legalacsonyabb az erdőarány. E monoton, erdőtlen vidék tájképben erőteljesen elkülönül Alszeg K-i felétől és a Nádas-mentétől. Tájtörténeti kapcsolatrendszerét tekintve mindig erős függőségi viszonyban volt a havasi területekkel; e szimbiózis alól csak Körösfö-K.Nádas környéke képez kivételt, ahol lényegesen erdősültebb a vízválasztói hágó, így erősítve a helyi fafeldolgozói hagyományokat.

- Alszegen, a Váralmási völgyek erdősült hosszanti dombtetői erősen elkülönülnek e vidék K-i 'szőlősfalvainak' jellegétől, ahol csak kisebb erdőfoltok vannak; az erdők történeti alakzatai itt az elmúlt 300 év során stabilnak mondhatóak. Felsőfüld és Nyíres környékén nyitottabb a kép: kisebb, mozaikosabb rendszerben jelennek meg az erdőfoltok, ami e két falunak is „havasalji” jelleget ad.

- A Kapus- és Nádas-mentén szorosan a geomorfológiai viszonyokkal függ össze erdők alaktana; szinte minden település rendelkezett saját, önellátó erdőtaggal elérhető közelségben, így azok fafelhasználás szempontjából önellátóbbak voltak; éppen ezért a XX. sz.-ban jelentős erdőkitermelésnek estek áldozatul.

Az elemzés alapján az alábbi terep-, és erdőmorfológiai típusokat lehet levezetni: [15. tábla].

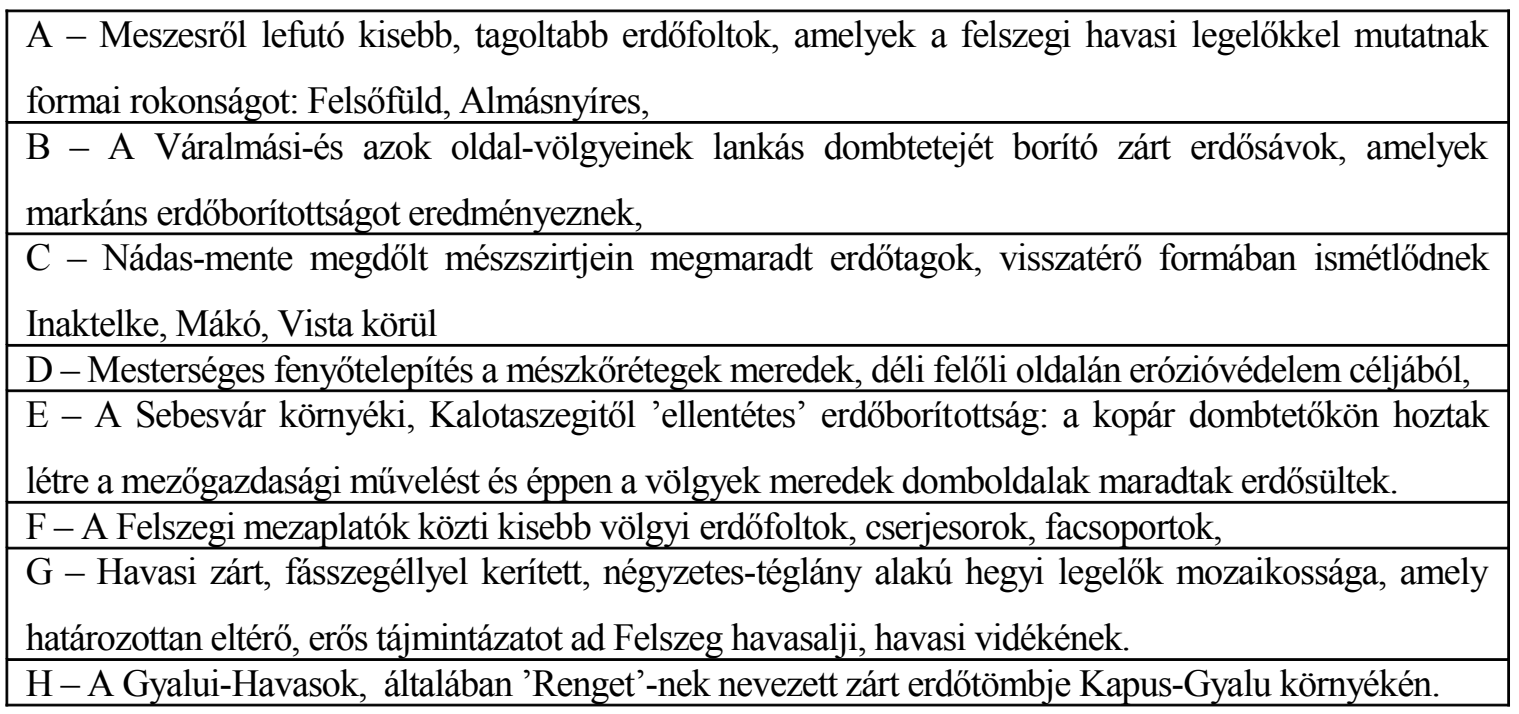

34. ábra: Az erdőmorfológia típusok áttekintője 


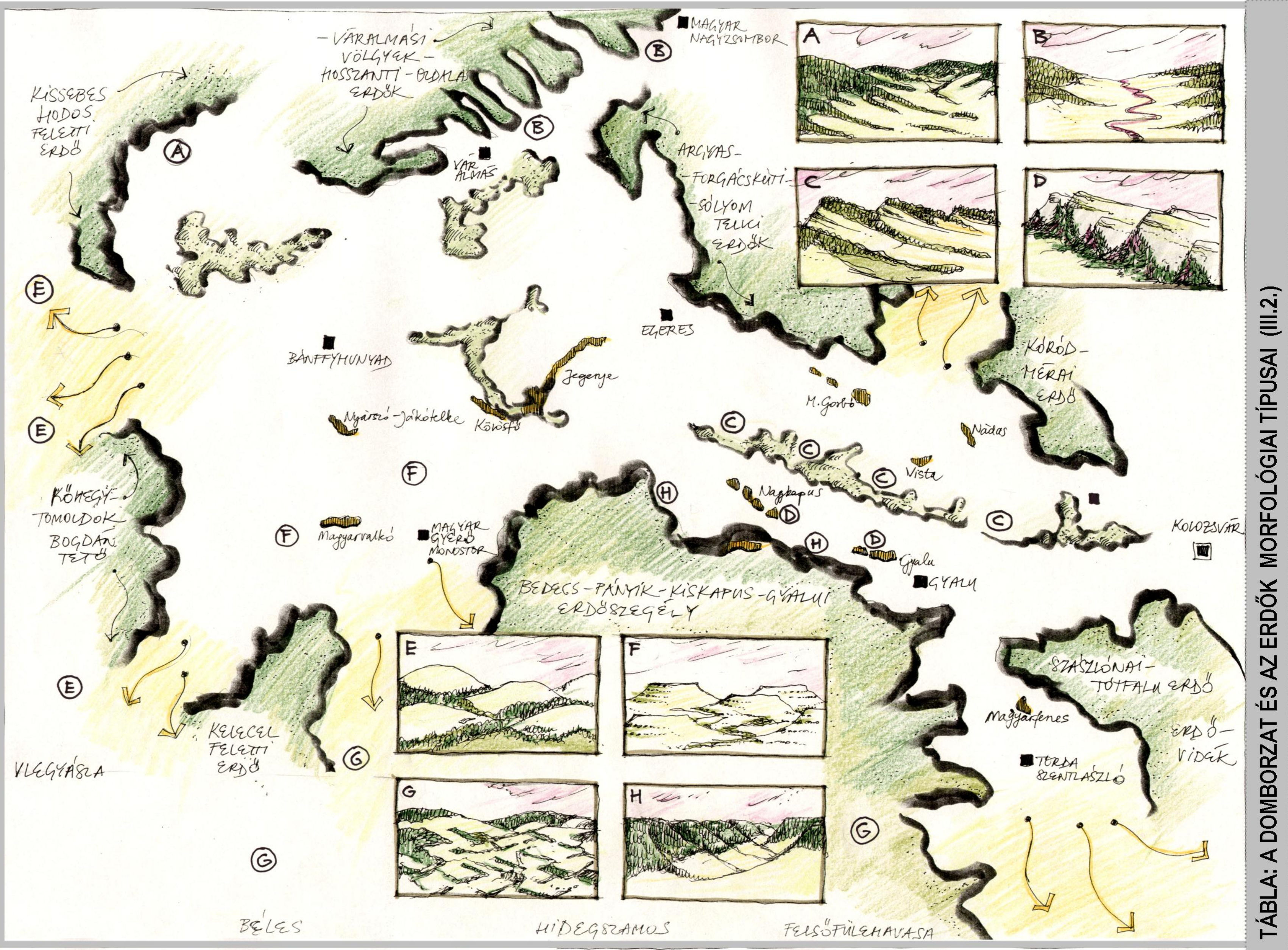

A domborzat és az erdök morfológiai típusainak leírását lásd a szövegben (III.2. fejezet) 

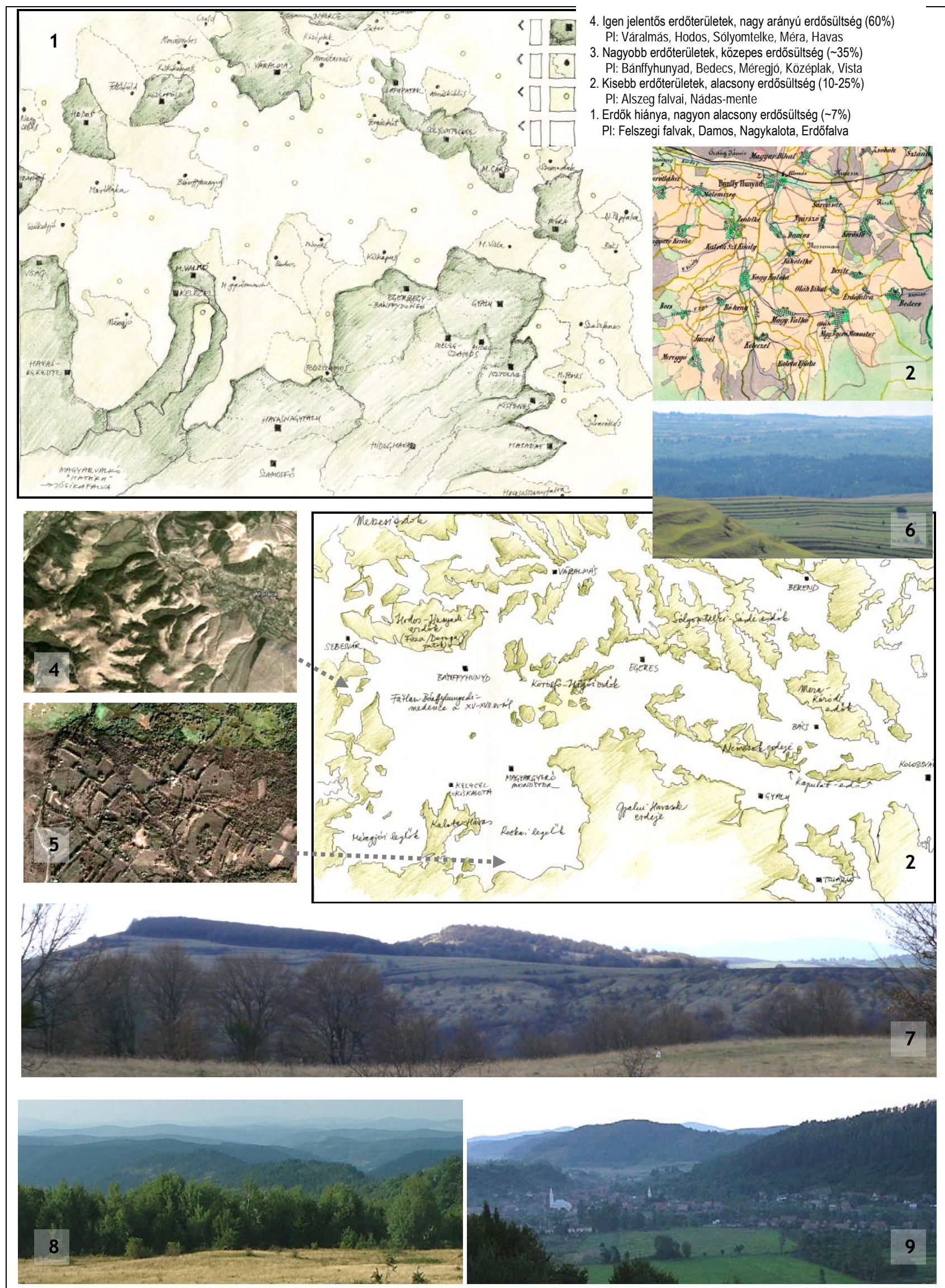

16. TÁBLA: ERDŐSZERKEZET 1. - TERMÉSZETES ERDŐK TÁJMINTÁZATAI, ALAKTANI JEGYEI

1. Erdőterületek tájértékelése 2-3. Az erdö(foltok)k kiterjedése saját és mzg.-i térképeken, melyen jó kivehető az erdőtlen Felszegen a kopár szántók kontrasztja a Gyalui Havasokkal. 4-5. Az erdők mintázatának megváltozása két átmenettel: Marótlaka környékén a dombtetői kopárok oldalában vannak erdők; a magasabb havasi területen négyzetes, zártlegelös mozaikos mintázatot adnak. 6 . Záródó erdők látványa Bedecs felett. 7. Jellegzetes erdőilleszkedés a Nádas-menti dombok lapos oldalán. 8-9. Két vidék, ahol záródik az erdőszegély, és jelentősen emelkedik az erdő-tájértékelése ezáltal változtatva meg a táj képét (Forgácskút-Sólyomtelkétöl É-ra és Váralmás környékén) 

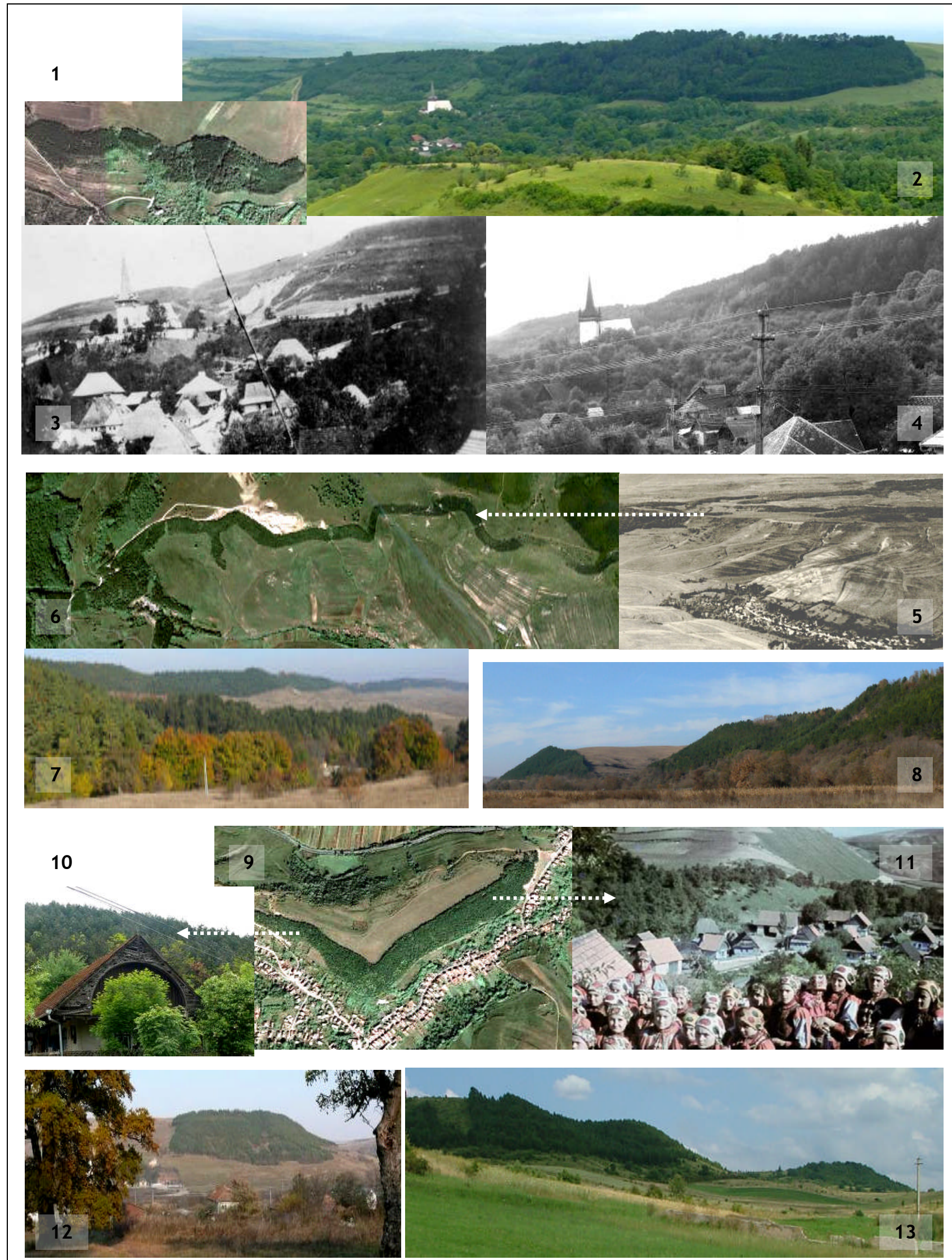

17. TÁBLA: ERDŐSZERKEZET 2. - TELEPITETT ERDÖK TÁJMINTÁZATAI, ALAKTANI JEGYEI

1-4. A telepített fenyvesek légifotója és látképe Magyarvalkón, a templom feletti Tunya oldalában; a tájváltozást jól mutatja Bátki Zsigmond 1900as felvétele és annak 2009-es újrafényképezése. 5-7. Jegenyén a visszacsatolás-kori felvétel (Erdődi - Cs. Szabó, 1941. p.12) még mutatja a kopár mészkőperemet, amelyet a fürdő környékével együtt a '70-es években, igényes vegyes állománnyal telepítettek be. 8. A meredek déli kitettségű mészkőpadok erdőfoltjai Nagykapus-Gyalu között ismétlődő, ritmikus megjelenésűek. 9-11. Vistán a faluközpont dombját már 1940 előtt fásítják a bányászati sebek miatt, ma napig átalakitva a faluképet (NM D298, Erdődi M., 1940). 12. A magyargorbói Nagy-Románia alakú fenyőtelepítés. 13. A Damos-Jákótelki közötti szirt D-re néző oldalának sötét fenyvese. 


\section{III.3. Szántók tájértékelése}

\section{és az agroteraszok tájmintázatai és típusai}

A szántóföldi müvelés során kialakult agroteraszok (= szántási teraszok, szántási lépcsők, barázdák vagy sáncok, nagyritkán padok) organikus átmenetet képeznek a domborzati adottságok és népi földhasználat között, miközben olyan egyéniesítő erővel bír a látványban, amely az egyik legerősebb tájkarakter-jellemzőjét adja e vidéknek. Ez a fejezet terjedelmi okokból nem térhet ki részletesen a határhasználatra és a hagyományos életmód teljes körü bemutatására, ${ }^{152}$ hanem a látványkapcsolatokra, a táji változásokra, tájmintázati elemekre fókuszál. A fejezet vizsgálja a teraszok kiterjedését, térformáit, térbeli sürüségét, valamint azok mikrodomborzati jellemzőit, kialakulását és átalakulását a tájhasználat-változás során. A barázdákat terasztípusokba sorolja és kiemeli tájesztétikai jelentőségüket. Továbbá a szántóföldi müvelés statisztikai adatait, téri eloszlását vizsgálja [19-23. tábla].

\section{III.3.1. A felszín teraszolásának eredete, története a szakirodalomban [17.§. melléklet]}

Mesterségesen kialakított mezőgazdasági tereplépcsők a világ minden túlnépesedett, dombos vidékén vannak, eredetük a történelem homályába vész. A szakirodalmat áttekintve tapasztalhatjuk, hogy ebben a fontos kérdésben nálunk is teljes a bizonytalanság mind a kialakulás korát, mind a technikáját, a formák osztályozását és a használati módjait tekintve. ${ }^{153}$ Az angol tájrégészeti szakirodalom mélyrehatóan foglalkozik az agroteraszok (lynchet, strip-lynchet) történetével, mivel azok a tájtörténet és a tájkép „értékét és örökségét” képezik. Rackam egész korai, bronzkori és kelta eredetet tételez fel a régészeti leletek alapján. A nyitott tájmüvelés ${ }^{154}$ elnevezései között kiemeli, hogy a 'hlinc' ( lynchet) kifejezés föként meszes alapkőzeten fordul elő, ${ }^{155}$ amely Kalotaszegre is jellemző. Ö és Kizos Krétai tájtörténeti kutatásaiban kiemelik a 'fonatos-agroteraszok'-típusát, ${ }^{156}$ és rávilágít, hogy bár fontos szerepe van a felszíni talajerózió csökkentésében és vízmegkötésben, de kialakításukkal a veszélyes földcsuszamlásos területeket mégis elkerülték; azaz a földmüves felismerte, hogy mely határrészeket nem érdemes barázdálni. Ez Kalotaszegen is helytálló, mivel éppen a vízmosásosabb Alszegen ritkábbak a teraszok. Muir középkori eredetünek tartja az angol szántási teraszokat, és szoros összefüggésbe hozza a középkori túlnépesedéssel és földhiánnyal.

\footnotetext{
${ }^{152}$ Népi földmüvelés Kalotaszeg címmel írta meg doktori disszertációját (ifj.) Kós Károly néprajzkutató 1944-ben, ebben Sztána és Jákótelke határhasználata kerül bemutatásra, de a tanulmány részletesen bemutatja a földművelés teljes eszköztárát (talajjavítás, fogatolás, szántás, vetés, szénamunka, aratás, hordás, cséplés, tárolás). Kós, ifj., 1999

${ }^{153}$ Péntek J. - Szabó A., 1985, p. 104.

${ }^{154}$ Open field-system: köfalakkal és sövényekkel nem elválasztott földek

${ }^{155}$ Rackam, 1986. p.174.

${ }^{156}$ A teraszok végeinél cikk-cakkos formában átvezető rámpák találhatók. Itt nincsenek átjárók, de a barázdák végei ilyen karakterrel fonódnak át egy másikba, vagy az eredeti terepfelszínbe. in: Kizos et. al., 2010. pp. 577-593.
} 
Mezőgazdasági teraszok szinte egész Erdély területén találhatóak, hiszen az Erdélyi-medence dombvidékének lejtöi csak így válhattak müvelhetővé, valamint a hűvösebb éghajlat a déli teraszokkal kissé „melegebbé” vált. A gyümölcs- és szőlőtermesztés számára kialakított teraszok (Élesd környéke, Szilágyság) párhuzamos, szabályos, mesterséges formavilágot tükröznek, míg a szántási teraszok finoman illeszkednek a terepviszonyokhoz. A teraszok jellegét nagymértékben befolyásolja a domborzat formavilága és a kialakítás természetessége, létrehozásának kora és célja. A barázdák nem egyedülállóan kalotaszegi jelenségek, de a térség egyes tájkarakter-zónáit el-elhagyva azonban mégis megszünnek, és csak távolabb (Mezőség, Torda környékén) jelennek meg újra, azonban eltérő formai jegyekkel (pl. Torockó környékén igen hosszú, párhuzamos, szinte szabályos sávokban), azért kiterjedésük, formájuk meghatározó a tájkarakter-zónák kialakításában.

\section{III.3.2. Az agroteraszok, szántási lépcsők, barázdák eredete Kalotaszegen ${ }^{157}$}

Helyszíni gyüjtéseim során felfigyeltem rá, hogy a lakosság annyira 'együtt él' ezekkel a térformákkal, hogy nem igazán illeti őket külön elnevezéssel. A „szántási lépcsőt” vagy ,,agroteraszt” nem használják leírásukra, és csak többszöri rákérdezésem után erőltették rá a „,barázda” vagy „sánc” fogalmakat. Azaz számukra a teraszolt táj teljes egészében „,természetes, eredeti” képződmény, a táj szerves része, maga a táj eredeti állapota, így a korábbi urbáriumokban ezért sem kapott külön kitüntetett figyelmet vagy elnevezést. ${ }^{158}$ „A völgyi falutól rendszerint távolabb eső erdőtől meghódított, oldalas helyek minden esetben csak a legelök maradtak volna, ha nem rendelkezett volna a kalotaszegi ember is az Erdély dombos-hegyes vidékein mindenhol ismert és használt fa váltóekével. A partos fődet a fa kerülőekével (=a földet mindig csak jobbra kifordító eke) nem szántották, mert a lejtősen maradt helyről a ,jó fődet” az olvadások, esők hamar lemosták volna. A fa váltóekével (=ódal v. fordító ) lehetségessé vált a hegyoldal lépcsős kiképzése, mi által a juhturma kosarazásával feljavított, dúsított humuszréteg a felső földekről nem folyhatott le az alsókba." ${ }^{159}$

A kalotaszegi teraszolás kialakulására, megjelenésére vonatkozó adatok bizonytalanok. Az első katonai felmérés még nem tartalmaz a földhasználat pontos müvelési formájára vonatkozó jelöléseket. A 1820-as Cziráky-féle összeírásban azonban többször 'barázda' megnevezéssel illetik a határt. ${ }^{160} \mathrm{~A}$ második katonai felmérés (1865) csak elszórtan ${ }^{161}$ jelez olyan, egymással párhuzamos rendszereket terasz-vonalakat, amelyek átvágják a szintvonalakat. Tudjuk továbbá, hogy 1800 körül súlyos éhínség volt e térségben, így vagy az ezt megelőző magasabb népsürüség, vagy az 1800-es évek közepének

\footnotetext{
${ }^{157}$ A témakör további kifejtése: Eplényi - Frohmann, 2011. pp. 62-66. és Eplényi, 2012a, in-press.

${ }^{158}$ Szabó T. Attila 400 esztendőnyi helynévgyüjtésében az agroterasz vagy terasz szó egyáltalán nem szerepel, csak a barázda vagy sánc szavak, azok is zömében Felszeg K-i feléből és Nádas-mentéröl, de messze nem olyan gyakoriságban, ahogy azok a tájban jelennek meg. „Barázda ( ): Mákó, Daróc, ajja: Jegenye, ák - ák között: Gyerővásárhely, Mákó; áknál: M.Gy.Monostor, tető: Jegenye”, újföld ja: Jákóktelke. „Sánc”: Gy.Vásárhely, Bogártelke, sánc közt: Sztána. A sánc kifejezés a malom, patak, kerítés-sáncot is jelenthetett.

${ }^{159}$ Kós, ifj. 1999. p. 43.

${ }^{160}$ Pl.: „künn a borázdákon vagyon elegendő vad gyümölcs”: Inaktelke, Daróc, Bogártelke, Tóttelke, Türe.

${ }^{161}$ Ezeken a megjelölt területeken mai napig is erős, széles teraszrendszerek látszódnak, pl. mákói Omlás-hegyoldal.
} 
újra intenzívebbé való földhasználata tette szükségessé az egyre magasabb domboldalak kiteraszolását. A XIX. sz. második felében keletkezett kataszteri térképek telekhatárai már pontosan egybeesnek az agroteraszok alakjával, így feltételezhetjük, hogy a barázdált terasz pereme telekhatárként szolgált. Ott, ahol nem volt mesterséges terepszegély, „ásott kövekkel” jelölték a földek szélét. ${ }^{162}$ Száraz és élösövényt (=rest) földek elválasztására nem használták, csak a gyümölcsöst kerítették vele. Az eredeti telekhatár kezdetben „,vonalat” formált, amely a szántással egy hosszú szalagsávvá, mezsgyévé változott (egyre meredekebbé váló fal), így érthető a viták kialakulása azt a kérdést illetően: vajon kihez tartozik a meredek szakasz, az alsó vagy a felső telektulajdonoshoz? E barázdaoldalakat a szomszédos telektulajdonosok különböző megosztásban kaszálták is. Hol a barázda alatti területet, hol a felettit, hol a hosszirány szerint felében megosztva. A koronavonalak megmaradását a kalotaszegi ember fukarsága is segítette, aki ekenyomával is nagyon pontosan számon tartotta a telekhatár vonalát. Tovább stabilizálhatta a rézsüt a földből ki-kidobott kövek tartóereje. ${ }^{163}$

A barázda egykori kialakulási ütemét nyomozva adatközlöim elmondták, hogy 5-6 év szántás után most is hamar kialakul kisebb barázda olyan parcellák mellett, amelyeket nem szántanak. Kós kiemeli, hogy mindig a völgy felé fordított földdel a lépcső felső koronájára rászántottak, a belső körömvonalától pedig elszántották, ezért a teraszváltozás üteme gyors kellett legyen. Ennek ellentmond Úri Márton (Inaktelke) adatközlő, aki szerint: bár az egy teraszon összes szántott sor kifelé fordult, az utolsó, legbelső sort mégis visszafelé fordították, hogy „ne nőjjön a barázda ódala.” A barázdák kialakítását segíthette a „falueke”, amely a település községi tulajdona volt, és határkerülésre, régi szüzföldek, parlagok feltörésére, köves-gyökeres földek művelésére vagy a nyilas földek kimérése, és a tavaszi vizek árkolására használták; egyik legszebb példánya Körösföi. ${ }^{164}$ Végül a földéhínség idején történt erdőirtások alakja jellemzően utalhat a barázdák kialakulására. A Kapulat erdő több pontján megfigyelhető, hogy a hegytetői erdőfoltok kitermelése szintvonalakat követő „barázda formájú” pászmákban történt a völgyek felől. Az erdő tarvágása során a gyökereket is ki kellett ásni, ezért elképzelhető, hogy a meglazult talajt már akkor nagyjából teraszos jelleggel egyengették el (pl. egy faluekével) vízszintesebb szántóföldeket hozva létre. ${ }^{165}$ A barázdák ennél pontosabb és alaposabb korának megállapításához talajmetszetekre és humusztartalom-vizsgálatokra lenne szükség, erre azonban e munka céljai nem térnek ki.

\footnotetext{
${ }^{162} \mathrm{Az}$ ásott kövek 3/4-ig földbe ásott nagy kövek voltak, hogy azt a szomszédok ne mozgathassák. A Kalotaszegen igen ritka(!), hegy-völgy irányú parcellák elválasztására használták, pl. a Riszeg-hegy és Méra oldalában találtam hasonlókat.

163 Több forrás említi ezt a jelenséget. Gyüjtésemkor azonban az idősek felhívták a figyelmet arra, hogy a határ teljes kihasználásának idejében a teraszok részüjét még kaszálták, így oda, a kaszát kicsorbító köveket bizonyosan nem „hánytak”. Ilyen, mai napig kaszált barázdarendszer már szinte csak a románok által lakott falvakban fordul elö: pl. Romángyerőmonostori Várhegy oldalában a 7m magas, közel 1 lábas rézsüket még 2012 nyarán is kétszer kaszálták (!).

${ }^{164}$ A körösföi falueke laposvasán 1800, a hosszúvasán 1780-es évszám szerepel, de ezek minden bizonnyal egy XVII. sZ.-i eke utólagosan pótolt darabjai. in: Kós, ifj. 1980a. p. 187-194.

${ }^{165}$ Erre angol tájrégészeti szakirodalomban talált analógiák alapján következtetek: Rippon tájtörténeti kutatásaiban is hoz hasonló, domboldali helyzetben lévő, szintvonalhoz igazodó, 20-30m széles telekformákat, amelyek a felfelé haladó szintvonalakat követő tarvágás következményeiként ír le. in: Rippon, 2004. p. 31.
} 
A néprajzkutatók (sajnos) csak ritkán kapták lencsevégre a „puszta tájakat”, csak az események hátterében tünik fel egy-egy tájrészlet; mégis néhány 1900-as évek elején készült kép mutatja, hogy a határ teljes területe már teraszrendszerben volt müvelve. Feltünő, hogy ekkor sem a barázdákon, sem közöttük cserje, bokor vagy magasabb fás vegetáció nem volt. A szántóföldek monoton egymásutánja domináns mezőgazdasági képet mutatott, amely müvelt, mesterségesen, fenntartott, ápolt és szabályozott jelleget adott a tájnak.

A magasabban, falutól távolabb fekvő, oldalas területeket már a század első évtizedeiben felhagyhatták, ezután már csak kaszálták, és a század második felében már csak legeltették. Szabó Attila '80-as években készült fényképeit a mai állapottal összevetve látható, hogy a románok által ma is művelt területeken (pl. Bedecs, Monostor határában), alig változott a táj képe, nem cserjésedik a terület, a kaszálókká és legelőkké vált teraszrendszereket pedig tisztítják. A cserjésedés ott a legintenzívebb, ahol sem kaszálás, sem legeltetés nem folyik. Mivel a barázdákon az állandósult franciaperjések, pannon szálkaperjés-gyepek és pusztai csenkeszesek zárt gyepszintjén jól „stabilizált” védőnövényzet jött létre, ${ }^{166}$ ezért e terepformák éleinek kopása lehetséges, de „eltűnése” nem várható a jövőben sem. A gyomosító fajok megjelenésének oka a barázda kitettségének mikroklimatikus változatossága: a belső hajlatban több faj telepedett meg, egyre változatosabb élettereket alakítva ki, növelve annak biodiverzitását. Mára a cserjésedés egyre erősebb mértéket ölt az egész határ területén, többnyire kökényesek, csipkék, mezei juhar, vadgyümölcsök társulásaiba tartozó fajokkal. A kaszálható füvek kárára való túlfejlődésük az elhanyagoltság jele - állapítja meg már '85-ben Szabó. A jelen állapot azonban sokkal természetesebbnek, lágyabbnak, kevésbé mesterkéltnek tünik, mint a korábbi „gondozott” stádium. Néhány éve a falu határán több száz juhot legeltető román/olasz bérlők az EU-s agrártámogatások elnyeréseért, újra tisztítani kezdték a kaszálókat, legelőket és így a meghódított szukcessziós területeket az erdőszegélyig szorítják vissza.

\section{III.3.3. A kalotaszegi szántási teraszok terepkövetése és szegélyhatásai}

A teraszrendszer mélyebb és részletesebb alaktani vizsgálatához a 1:5000-es szintvonalas és területhasználati térkép szükséges. ${ }^{167}$ Ebből megállapítható, hogy a teraszolás alak-, és formakövető, illeszkedik a szintvonalakhoz, illetve leköveti a lejtöszöget, így 10\%-alatt, és 30-40\% felett nem jellemző. Égtáji kitettséggel való összefüggést nem találtam. Megfigyelhető, hogy ritkák a magányos teraszok, azok inkább egymás alatti lépcsős-teraszrendszerben jelentkeznek az egész domboldalnak egyedi mintázatot adva. Szerves egységet mutatva az eredeti terepformákkal így nagyfokú természetesség-érzetét adja, szemben az Erdélyben máshol is látható mesterséges szőlö-, és gyümölcsfa-telepítési kiteraszolásokkal, amelyek egyformán, határozottan, erőszakosan és az eredeti terepalakulatokat átvágva jelennek meg.

\footnotetext{
${ }^{166}$ Péntek - Szabó A. p.106

${ }^{167}$ E léptékében nem vizsgálható a teljes kalotaszegi terület, mert azt közel 500 szelvényből állna össze.
} 
A táj komplexitásának egyik mutatója a különböző területhasználati egységek mentén létrejövő szegélyhatások intenzitása. A Csemez-féle ${ }^{168}$ módszer alapján vizsgáltam a mintaterületen a teraszlépcsők szegélyhatásait úgy, hogy „,egy teraszszirtet (noha az duplán, köröm és koronavonalból áll) - egy szegély-vonalnak” tekintettem: > egy átlagos mintaterületen 5,5km barázdahossz $/ \mathrm{km}^{2}$ arányszámot kaptam, ami a „,változatos” kategóriába esik; > egy intenzív barázdarendszeren $12 \mathrm{~km}$ barázdahossz $/ \mathrm{km}^{2}$ arányszám esett, amely pedig az ,igen változatos” kategóriába esik. Így számszerüsítve is megjelenik a teraszok vonalas alakzatainak látképben való erős hatása, nagymértékü komplexitás adva neki.

\section{III.3.4. A kalotaszegi szántási teraszok morfológiai csoportosítsa}

Az alábbiakban a morfológiailag jól elkülöníthető agroterasz-típusok leírásával foglalkozom. A fent említett terasztípusok mind organikusan követik a geomorfológiát. Az igen tagolt, változatos táj konkáv-konvex formavilágát, a vízgyüjtöi völgy-, és dombháti szerkezetben is leköveti, letapogatja: a szintvonalakat átvágva hullámzik és elkeskenyedik, majd ismét kiszélesedik. Erre jó példa Felszeg és Gyerővásárhely környékén a jellegzetes konkáv, koporsó-formájú mezaplatókról lefutó szintezettség, ahol a lejtésszög 40\%-ról fokozatosan 15\%-ig csökken, végigjárva az I-II-III-as típust. Itt a bozótosodás fentről indul, megfogva az esetleges eróziós veszélyeket (pl. a Hágó-tető; Bedecs mellett a D. Rotund és a Tirs oldala). Közel száz helyszínt vizsgálva meg az alábbi négy karakterjegyeiben eltérő típust határoltam el, melyeket sematizált rajzokkal, metszetekkel és fényképekkel is bemutatok:

I. típus: LANKÁS, LAPOS TERASZOK: Ez az enyhén dombos, max. 15\%-os lejtésszögü oldalakat jellemzi. Széles, egységes lejtésü területeken találhatóak, ahol nincsenek vízmosások vagy hirtelen terepváltozások. Jellemzően gépi müvelésre is alkalmas területek voltak, így a kollektivizálás alatt, egészen a közelmúltig használatban voltak. Ezért a becserjésedés itt lassan vagy alig indult meg. Alaktani szempontból 15-50m szélességü terasz és igen keskeny, max. 2-3m-es padka jellemzi. Igen finom plasztikájával szinte beleolvad a nyitott domboldalakba.

II. típus: EGYENLETESEN MÜVELHETÖ DOMBOLDALI TERASZOK: Ezek 15-23\%-os lejtésű területeken fordulnak elő, általában nagyobb (20-25 soros) teraszrendszerek formájában és a teraszok hossza akár elérheti a 700m-t. Szélességük kb. 10-15m között változik, így a kollektív gazdaság alatt még akár gépi múveléssel is szántani lehetett egyes részeit. A teraszok közötti rézsük 45m szélesek és közel 25\%-osak. Ebben a típusban szoros a korreláció a barázdák határa és a birtokviszonyok között.

III. típus: MEREDEK, DOMBTETÖI TERASZOK: A meredek domboldalak felső részét jellemzik a nagyon keskeny teraszú (2-3m), de igen magas padkájú (8-12m) meredek (50\%) szántási lépcsők. A rosszul megközelíthető dombtetői helyzetük miatt -emberfeletti energiákat kívánva-, csakis

${ }^{168}$ A vizsgálatot a 1:5000-es szelvények alapján, Inaktelke és Gyerővásárhely között, és az inaktelki Szabóné dülőben végeztem el. A módszer leírása: Csemez A., 1996. p.238. 
állati erővel lehetett őket művelni, melyre azonban a XIX.sz.-ben még nagy szükség volt. A szocializmusra már biztosan felhagytak a szántással és kaszálással, és legeltetni kezdték. A tájkép szempontjából azért jelentősek, mert magaslati helyzetben vannak, távolról láthatóak, éles, erős fényárnyék-hatásokat keltenek , így szinte kortárs, land-art jellegü plasztikát adnak a tájnak.

IV. típus: GYÜRT, SÜPPEDÉKES TERASZOK: A gyürt, földcsuszamlásos területeken, eróziós szakadások mellett alakult ki ez terasztípus, ahol a telekhatárok és a szántási lépcsők bevésődtek a terepfelszínbe, ugyanakkor a földmozgások miatt dinamikusan változóak maradtak. A teraszok szélessége változó, rendezetlen, spontán hatású. Itt nem a terepplasztika élessége, hanem a becserjésülés formakövető ligetes foltjai adnak ritmizálást a domboldalnak.

\section{III.3.5. Az agroteraszok kalotaszegi eloszlása, szegélyhelyzetei, morfológiai sémarajzok}

A légifotók alapján átrajzoltam a vizsgált területen a teraszolt barázdarendszereket, és megfigyeltem, hogy azok intenzitásukban, sürüségükben is eltérő mintázatokat mutatnak a különböző zónákban. Mivel az agroteraszokat fontos tájkaraktert definiáló elemnek tekintjük, ezért elterjedésének szegélyhelyzete és alaktani különbségei is kulcsfontosságúak a tájkarakter-zónák megállapításánál. A Hunyadi-medence területén hiányoznak a teraszok, mert az alacsony lankák nem indokolják azt. A '42es, animált légifotón jól látszik, hogy a tájkarakter-zóna határán jelennek meg a meredekebb oldalak, magával hozva a szintvonalakat követő teraszokat szemben a medence négyzetes telekformáival. Felszeg DK-i, havasalji határán egyértelmüen eltünnek a teraszok (Valkó, Magyargyerőmonostor felett), mert itt a meredekebb domboldalak, az erdő záródása és a hegyi bekerített legelők uralják a tájhasználatot, ugyanakkor a Tomoldok-előhegység román falvaiban igen jellemzőek (Incsel, Bocs, Méregjó), de egy fontos morfológiai tulajdonságban mégis különböznek a többi terasztól. Míg Felszegen és Nádas-mentén a dombok oldalában helyezkednek el (és a dombtetőket zömében erdők borítják), addig itt fordítva, a meredekebb domboldalakat borítják az erdők, és a barázdált szántók, kaszálók éppen a laposabb, müvelhető hegytetőkre kerülnek, kopárságuk távolról is jól láthatóvá válik. A barázdák legnagyobb kiterjedésben Felszeg magasabb (600-800m) konkáv formáin jelennek meg, a Tomoldok-hegylábaitól a Körösfői-vízválasztóig, ahol végig dominálnak a tájképben. Nagy sürüségben és karakteresen visszatérő mintázattal jellemzőek még Kapus körül és a Nádas-mente völgyeiben; továbbá Tordaszentlászló irányában, ahol sürüségét és térmorfológiáját tekintve a Kalotaszegivel igen rokon jegyeket mutat (ez összecseng egyes a néprajzi lehatárolásokkal, amelyek a Fenes-Hesdát völgyét még Kalotaszeg átmeneti területéhez kapcsolják). Alszegen is sokkal ritkábbak a teraszok, melynek oka a magasabb erdővel való borítottság és a lazább altalaj okozta mély kimosódások, amelyek meggátolták hosszan elnyúló barázdarendszerek létrejöttét. Felsőfüld-Nyíres környékén a Meszes lábainál felbukkannak a teraszok, míg a Váralmási- oldalvölgyek alluviális területein alig találunk barázdákat. Hasonlóan Forgácskút-Sólyomtelkétől É-ra és a Magyarsárd- 
Berend útvonalon É-felé sem, noha tagolt a dombvidék; ugyanakkor Papfalva-Kóród völgyében egészen Máriatelekig előfordulnak, de nem képeznek kiterjedt teraszrendszereket. Innen a Szamosmenti hátság irányában szintén nem jellemzőek, mert az egyre lankásabb táj nem kívánta meg kialakításukat, így itt a szintvonalakra merőleges telekosztás mintázata jelenik meg.

Az agroteraszok területi megoszlását, a legfontosabb típusok domborzati viszonyokkal való morfológia összefüggését mutatja az alábbi összefoglaló táblázat és a sémarajzok [35. ábra] [18. tábla].

A - A Vlegyásza alacsony tetöit, és a Tomoldok-Bogdán előhegység kopár dombtetőit borító alig cserjésedett teraszrendszer, amelyekre magaslati fekvésük miatt jól rálátni.

$\mathrm{B}-\mathrm{Az}$ intenzíven, sưrün és változatosan teraszolt Felszegi felföld, ahol a tagolt kis völgyek között hullámzó, egymásba fonódó nagy kiterjedésű teraszrendszerek..

$\mathrm{C}-\mathrm{Az}$ intenzíven, sürün és változatosan teraszolt Felszegi felföld, amelyek dominál a konkáv formákra fokozatosan felkúszó, egyre meredekebb, magasabb teraszperemek éles rajzolta.

D - A tordaszentlászlói vidék hullámzó dombjainak teraszai, amelyek ma is múvelés alatt állnak, de alacsonyabb teraszperemekkel bírnak, mint a felszegiek..

$\mathrm{E}-\mathrm{Az}$ alszegi tagolt, süppedékes, omlásos vidék teraszai, amelyek a szőlők és erdőfoltok mellett kevésbé dominálnak, de mégis elö-előfordul.

F - A Nádas-menti tipikus teraszolás a ferde hosszenti oldalvölgyeken, melyek széles, látványos borítást képeznek a felszínen.

G - A Kapus-mente ferde, megdőlt szirtjeinek déli kitettségü teraszrendszere, amelyet a kis „áj”-ak tagolnak.

35. ábra: Az agroteraszok téri eloszlása és morfológia típusai

\section{III.3.6. A szántóföldek statisztikai tájértékelése, téri eloszlása zónánként}

A szántóföldek tájértékelése ${ }^{169}$ során azok kiterjedését, nagyságát és a határben betöltött szerepét vizsgáltam, amely különböző értékeket hozott a falvak tekintetében. A 14. tábla és a 23. tábla 1.ábrája a vizsgált terület mezőgazdasági művelési ágait mutatja, ahol jól kivehető a szántók nagy területi százaléka a Hunyadi-medencében, ahol a faluhatár több mint 50\%-át teszi ki és a jövedelem 60\%-át adja. Ilyen magas jelentőség még Egeres - Mákó - Türe vidékén tünik fel, ahol a nagyobb domblaposok vannak, valamint az Almás völgy mélyebb, szétterülő falvaiban. A tájértékelés két legmagasabb fokozatát összevonva azonban már szépen kirajzolódik a néprajzi Kalotaszeg határvonala, amelyből egyértelmüen kimarad a havasi, havaslaji térség, a Ny-i hegylábi falvak és a Sárd - Lapupatak közötti erdősebb vidék.

\footnotetext{
${ }^{169}$ Szántóterületek tájértékelése 5 szempont súlyozásával: szántók területe (kh., 1897), szántók területi aránya a falu összterületéből $(\%, 1914)$, földrészek átlagos nagysága (minél kisebb, annál kalotaszegiesebb), szántó jövedelme a falu összjövedelméböl (\%), 1 kh. szántó átlagos jövedelmezősége (fillér)
} 


\section{III.3.7. Az agroteraszok tájkarakter-elemzésben betöltött szerepének összefoglalása}

Összességében megállapíthatjuk, hogy az eredetileg szántóföldi müvelést lehetővé tévő teraszok min. 200 évesek, de valószínübb, hogy 1800-nál korábbi túlnépesedéssel vannak összefüggésben, amikor a dombtetői erdők szintvonalak mentén történő, fokozatos tarvágásával tették alkalmassá az oldalakat a müvelésre. A XX. sz. során a mezőgazdasági munka fokozatos csökkenésével a távoli, dombtetői helyekről indult meg a felhagyás az alacsonyabban fekvő falu felé, és ma, az urbanizálódó, jobb módú magyar lakta területeken gyorsabb a cserjésedés üteme, mint a szegényebb, még főként gazdálkodó román falvakban. Többnyire a 10-40\% közötti lejtökön jelentkeznek, változó szélességű padokkal és mezsgyékkel, melyek egyben rögzítették és mai napig tükrözik a tulajdonviszonyokat; a teraszok gyep-vegetációja záródott, szegélyei élesek, így a terepforma stabilan bevésődött a tájba, tehát eltünése nem valószínü a jövőben. A teraszok természetesség-érzését a terepkövető, részben vízszintes, mégis hullámzó-látványa és a spontán vegetáció megjelenése adja. A teraszok okozta nagyon változatos szegélyhatások, a müvelési mód (szántók-kaszálók egymás mellettiségének) színhatásai és a fény-árnyék játékok nagy mozgalmasságot és egyediséget biztosítanak a tájképnek. A teraszok mikro-morfológiája négy fö típusba sorolható (lankás, egyenletesen müvelhető, meredek és süppedékes), de ezek mellett a domborzati viszonyokkal való összefüggése is különböző sémarajzokkal ábrázolható. A teraszok minden területen előfordulnak, de zónánként eltérően keverednek a geomorfológia adottságok függvényében, így hozva létre mintázati - intenzitásbeli különbségeket. A kalotaszegi teraszrendszer a tájkarakter legfontosabb eleme, és kiterjedésének szegélyvonalai kapcsolatban állnak a szántóföldi müveléssel és Kalotaszeg határvonalaival, így alkalmas tájkarakter-mintázati elem a tájkarakter-zónák elkülönítésére. A teraszrendszer védelemre szorul, nemcsak mint hagyományos-történeti tájhasználati forma, hanem mint esztétikai értéket hordozó táji látványelem [18.§. melléklet]. 


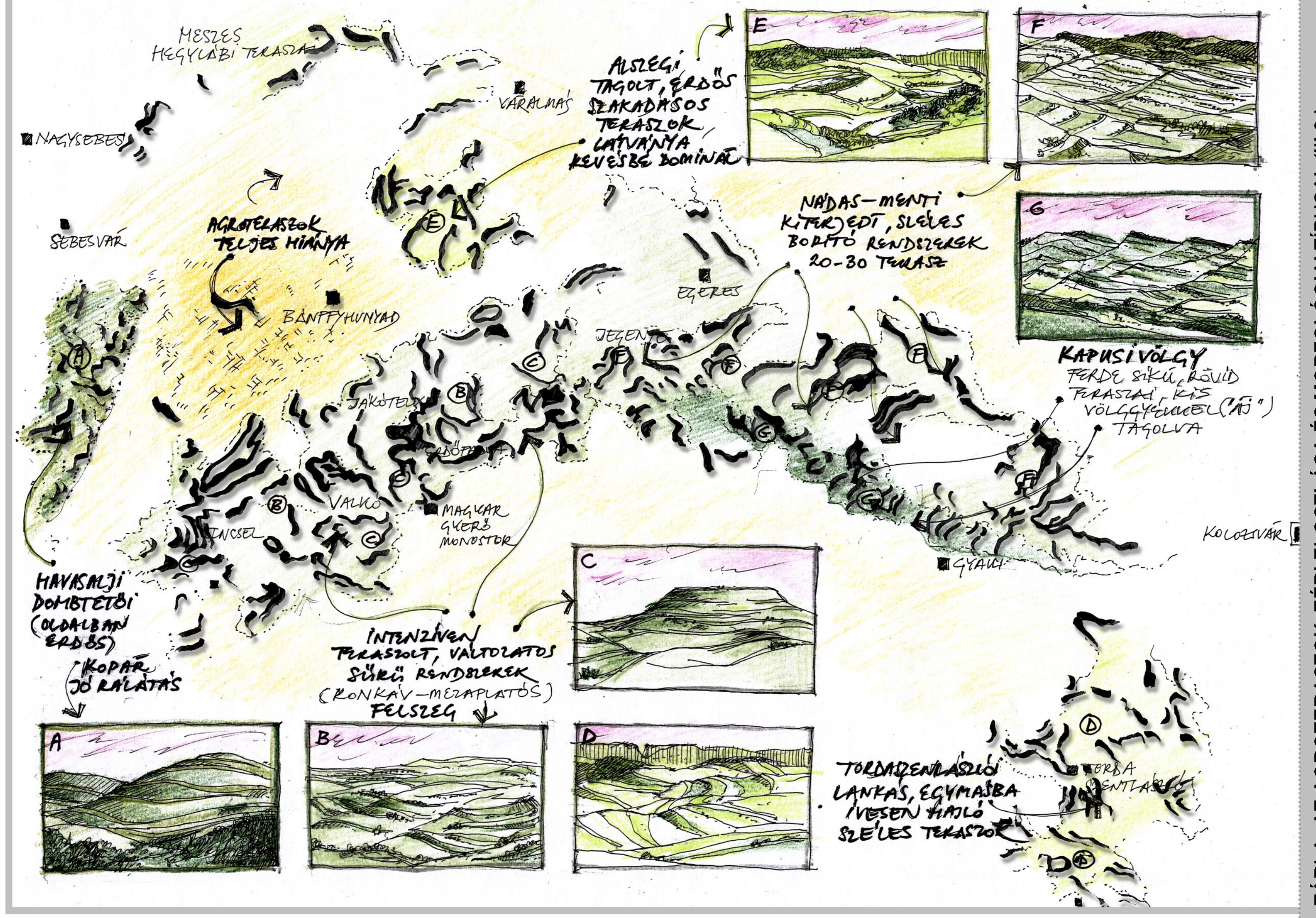

Az agroteraszok téri eloszlását és morfológiai típusainak leírását lásd a szövegben (IIl.3. fejezet) 

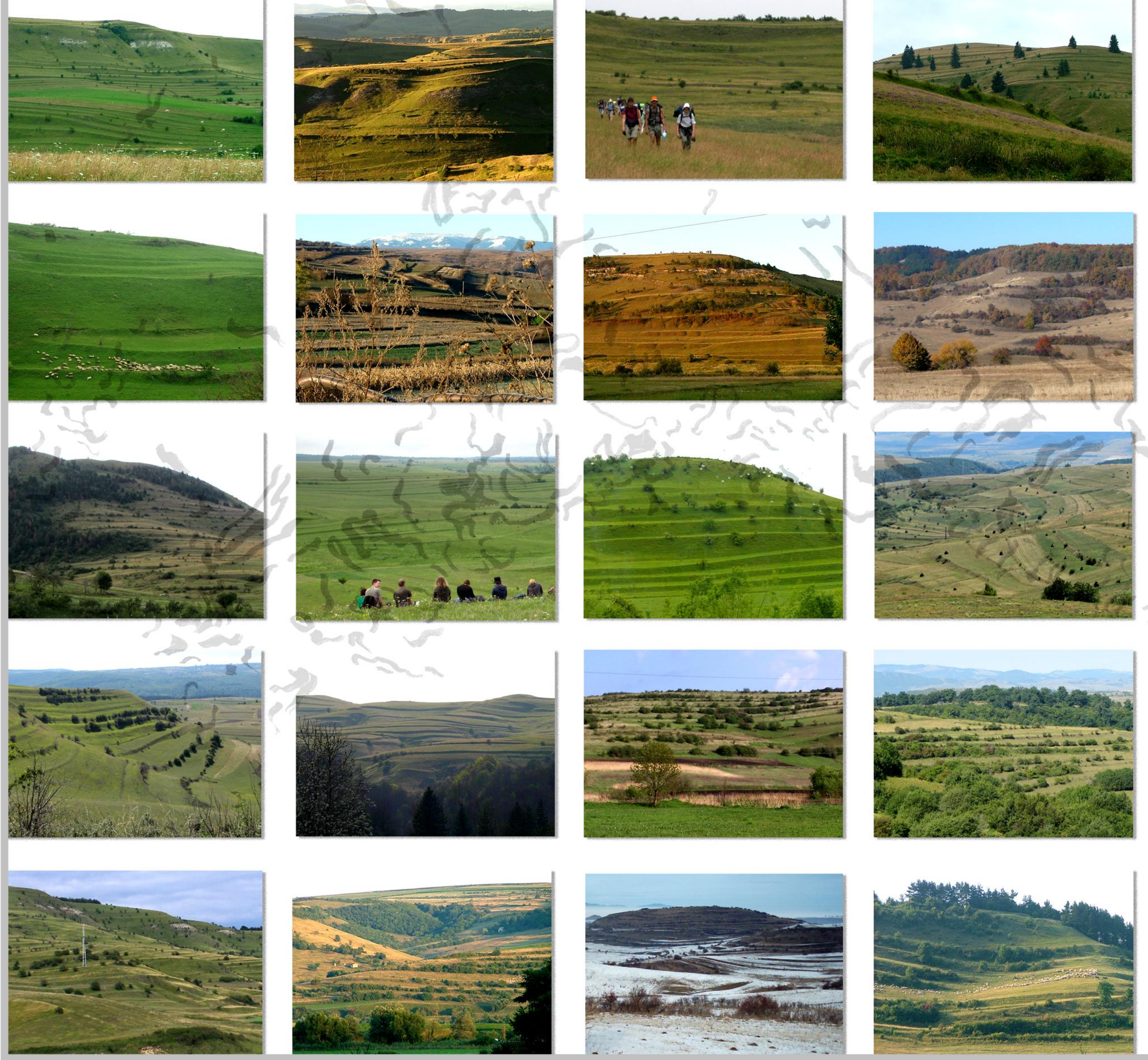

A tábla bemutatja az agroteraszok térbeli-, alaktani-, időjárási változatosságát, illeszkedésüket a terepformákra.
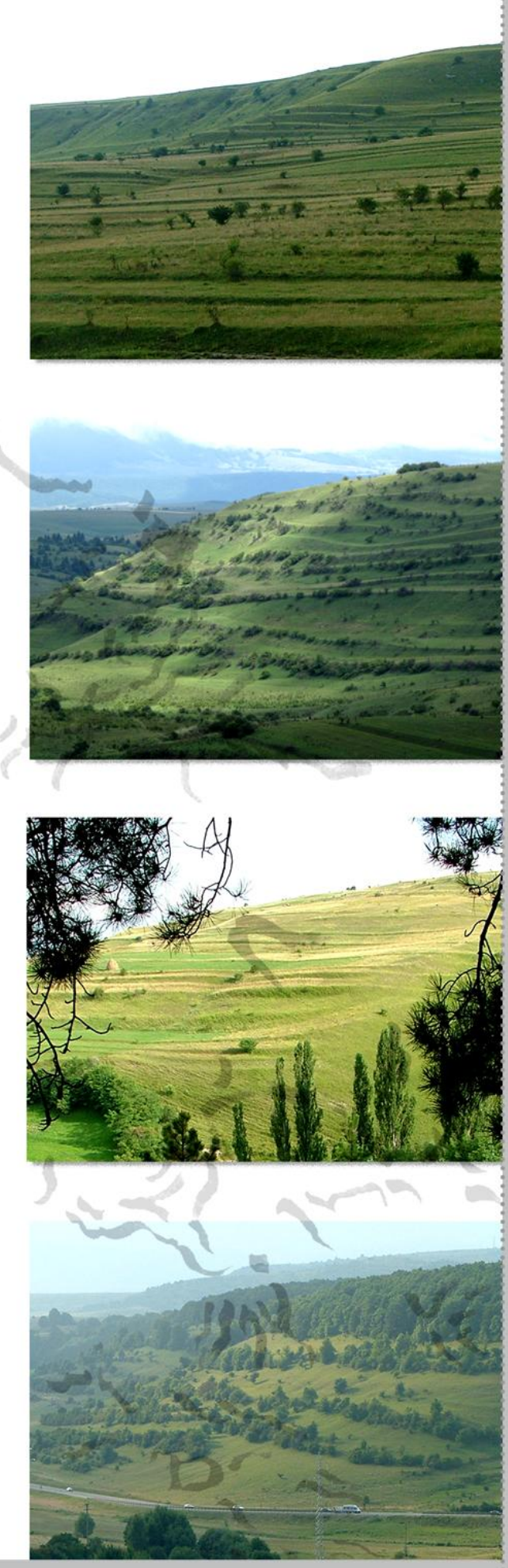

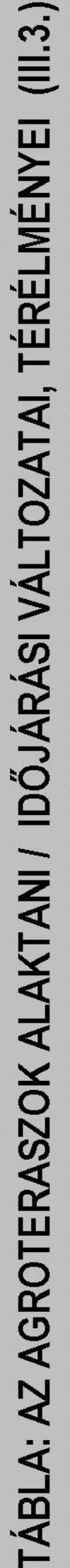
$\stackrel{\circ}{\square}$ 

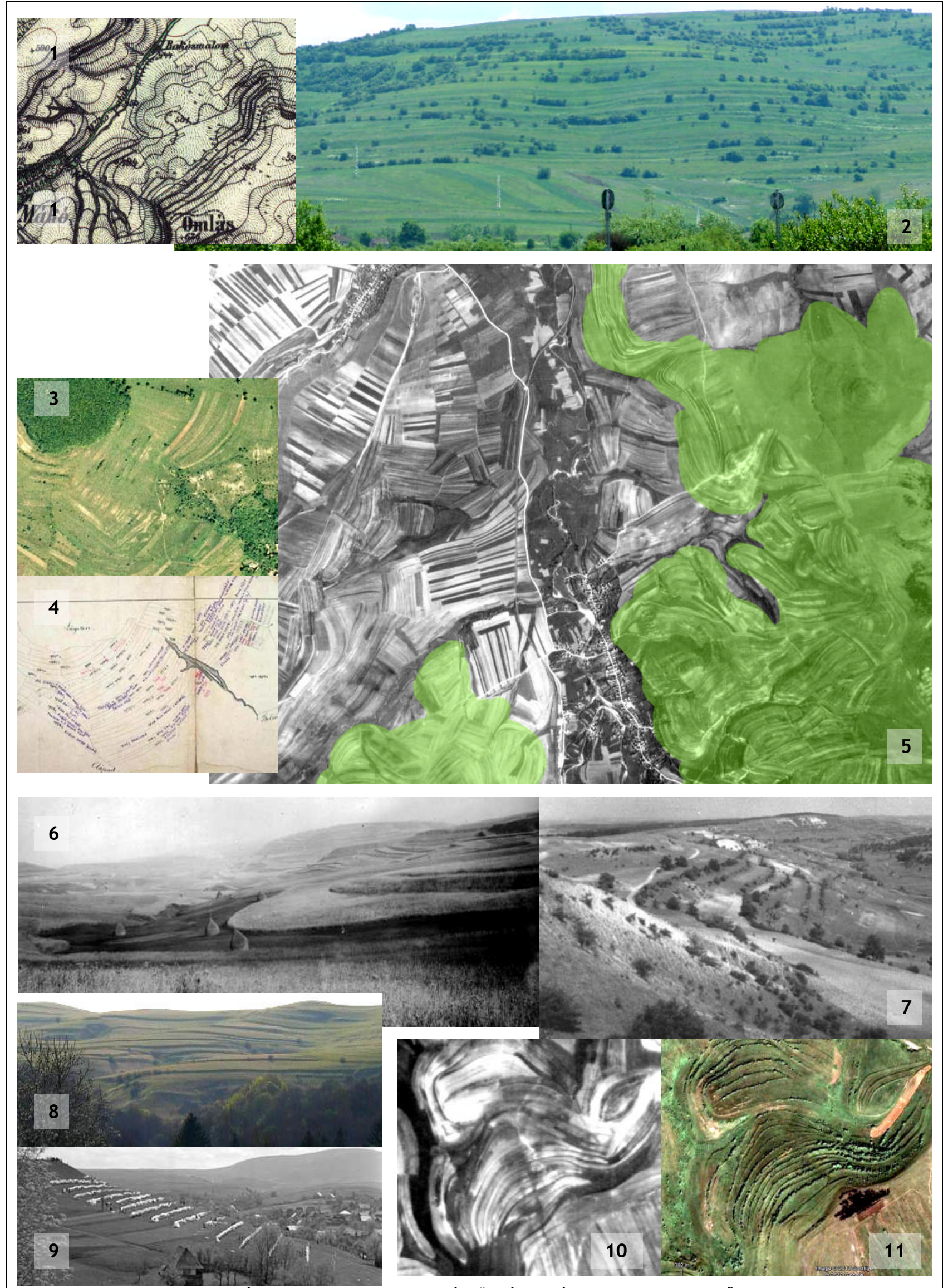

20. TÁBLA: AGROTERASZOK 1. - TÁJTÖRTÉNETE ÉS ALAKTANI JELLEMZŐI

1-2. A mákói 'Omlás' teraszrendszerének megjelenése a Il. kat. felmérésen és a mai tájképben. 3-4. A szalagszerü földbirtok/telekviszonyok szoros korrelációja a teraszokkal. 5. A '42-es légifotón látványos a Hunyadi-medence négyzetes lankás telkeinek ellentéte a dombos, íves teraszok jellegével. 6. M.Valkó intenzíven művelt tája 1900 (saját képesap) 7. A cserjésedés folyamatának megindulása a '40-as években Sztána környékén (saját képeslap) 8. Sebesvár-környéki román falvak 'fordított'=dombtetői teraszai. 9. Méregjói teraszok, amelyen a ványolt anyagokat szárítják (KJNT_08179) 10-11. Egy Kalotabikali tájrészlet cserjésedésének összehasonlítása (1942-2012) 

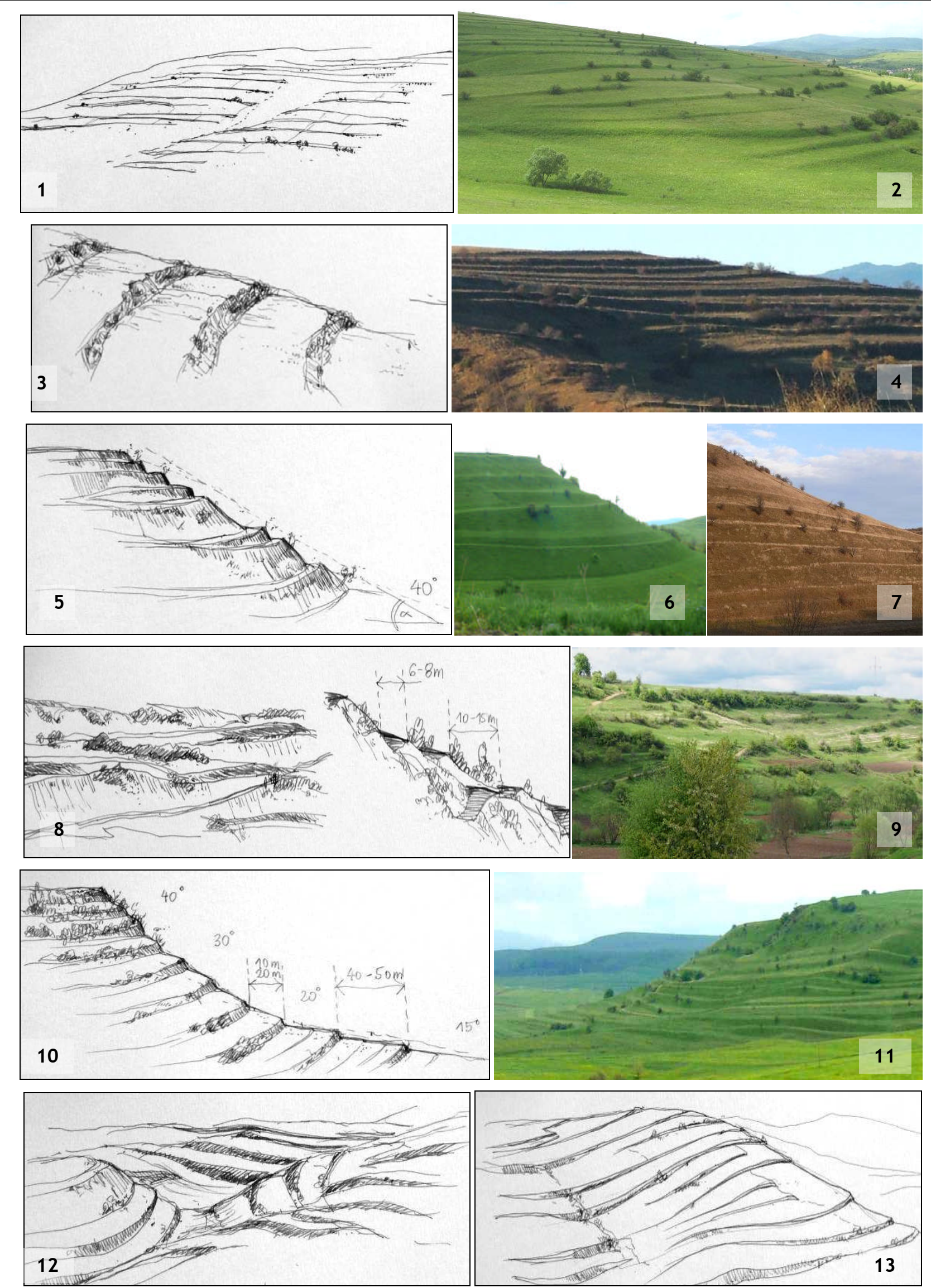

21. TÁBLA: AGROTERASZOK 2. - CSOPORTOSITÁSA FELSZÍNALAKTANI SZEMPONTBÓL

1-2. I.: lankás, lapos teraszok típusa (M.Valkó), 3-4. II. Egyenletesen müvelhetö, domboldali teraszrendszer, amely több, széles, jól müvelhető teraszból áll, 5-7. III. Meredek, magas rézsüvel rendelkezö dombtetöi teraszok (M.Valkó), 8-9. IV. Gyürt, süppedékes teraszolás (Inaktelke). 10-

11. A konkáv felszegi mezaplatók oldalán látható teraszrendszer kombináció (Hágó-tetö) 12-13. A teraszok eredeti terepforma-lekövetése völgykatlanban és dombhátakon, amely nagy-fokú természetesség-érzetet ad a látványnak. 

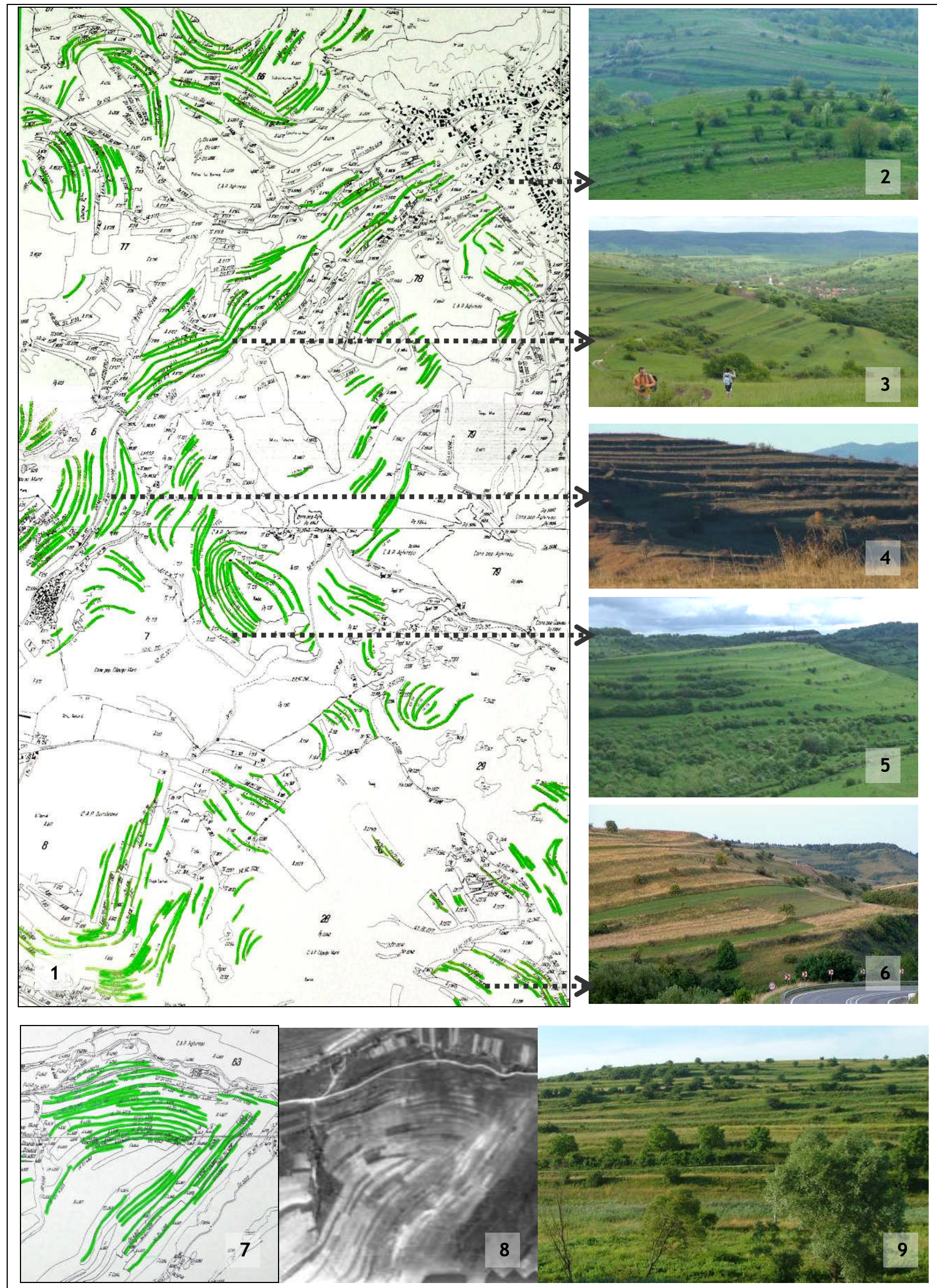

22. TÁBLA: AGROTERASZOK 3. - TÁJMINTÁZATI ÉS FELSZÍNALAKTANI JELLEMZÖI

1. Agroteraszok kis-léptékü elemzése az 1:5000 területhasználati térképen Inaktelke és Gyerővásárhely között. 2-6. A inaktelki helyszínelések során készült fényképek a tájmintázatok alaktani változatosságát mutatják, illetve azok reakcióit az évköri, idöjárási viszonyokra (fényárnyék, szinek). 7-8. Az inaktelki „Szabóné dülö”, amelyen a Csemez-féle szegélyhatás-vizsgálat elvégzése „igen változatos” eredményt hozott, a spontán fásodás hatása itt is jól látszik a '42-es légifotó és egy 2002-es fotó összevetésével. 9. A dülö látványa 2007-ben. 


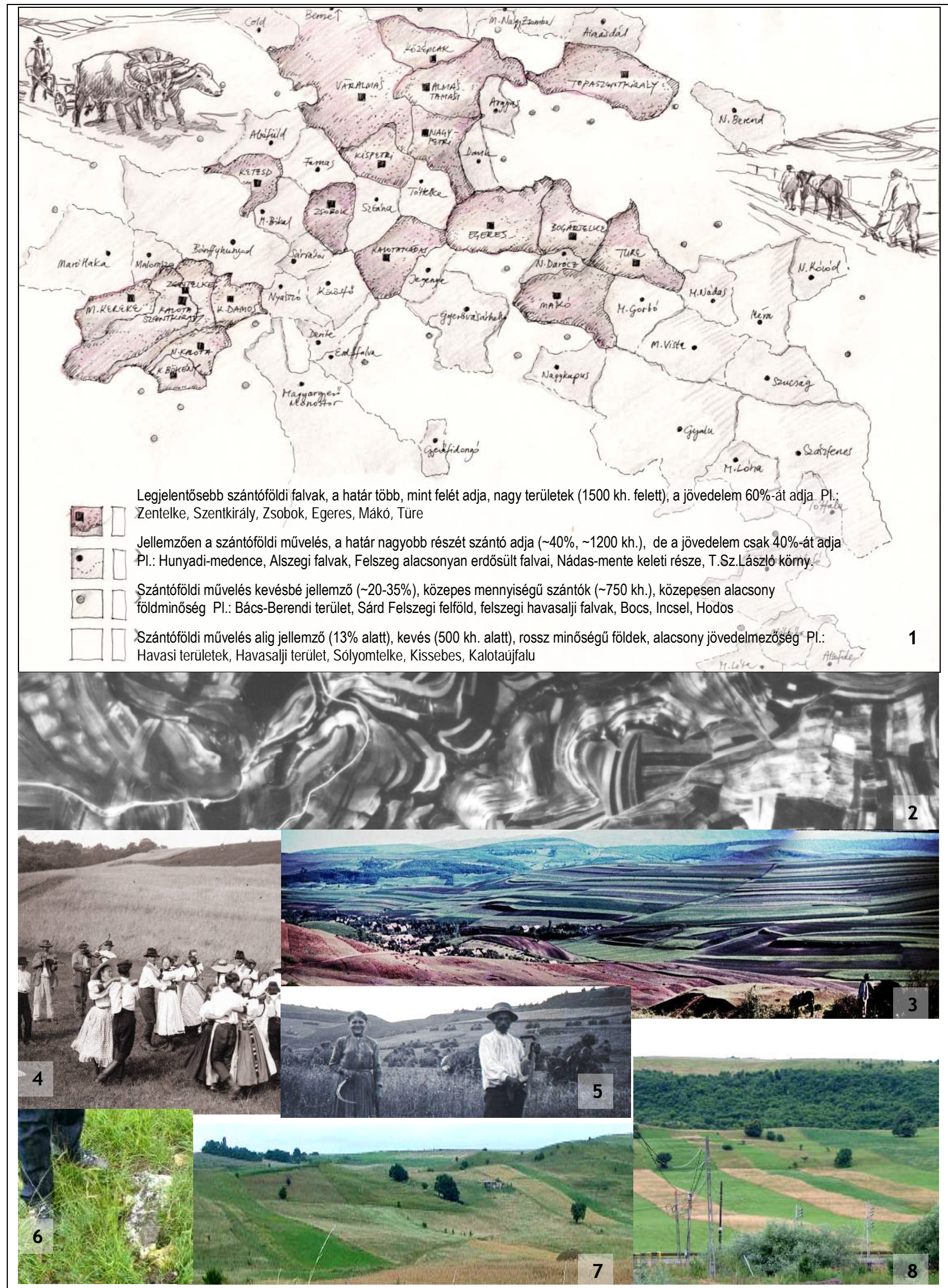

23. TÁBLA: SZÁNTÓK TÁJÉRTÉKELÉSE,TÁJMINTÁZATAI ÉS ALAKTANI JEGYEI

1. A szántók tájértékelése és téri eloszlásának ábrázolása 2. Szántók jellegzetes mintázata Felszegen (1942, légifotó) 3. Parcellák rendszere Méra határában, ahol a lankás dombon már nem kell annyira teraszolni (ez Kalotaszeg szélét is jelzi egyben) 4. Hagyományos aratókaláka zenészekkel Sztánán (Galloway, 1924) 5. A század első feléből származó kép a sarlós aratásról a háttérben kalongyákról (NM F 198915$) 6$. Ásott kő szolgál jelölésre ott ahol nincsenek teraszok 7-8. Berend-környéki és méra-andrásházi szintvonalra merőleges telekosztás, amely Kalotaszeget sehol sem jellemzi, így a mintázat megjelenése tájkarakter-váltást fog hozni. 


\section{III.4. Legeltetés, bivalytartás tájértékelése és a fás legelők tájmintázatai}

Az alábbi fejezet három tájkaraktert meghatározó mintázatként értelmezhető jegyet vizsgál részletesen, amelyek kapcsolatban vannak Kalotaszeg belső struktúrájával: ezek a bivalytartás táji vonatkozásai és jelentőségének statisztikai és térbeli vizsgálta (1); második eleme a kosarazó juhászat és a legelők statisztikai és térbeli vizsgálta (2); harmadik pedig a fás legelők tájképi szerepe, tájtörténeti változása és kiterjedése az egyes tájkarakter- zónákat illetően.

\section{III.4.1. Bivalytartás tájtörténeti vonatkozása, tájértékelése és térbeli eloszlása [24. tábla]}

Kós tanulmányában ${ }^{170}$ részletesen feldolgozza a kalotaszegi parasztgazdaság bivalytartási szokásait. A földesúri birtokokon, majd a várásokon találkozhatott először a helyi lakosság vele, de kezdetben sokan lenézték az olcsó állatot, így a szegényebb családok bátorsága kellett széleskörü elterjedéséhez. Kós az 1910-40 közötti időszakot tartja a „,meghonosodás korszakának,” amikor megnégyszereződött az állomány, ugyanakkor már a 1897-es adatsorok alapján is pontos képet kapunk mind a 116 településröl, amelyben már akkor is jelentősnek tünt a bivalytartás.

A bivaly, bár nehézkesen tartható (csökönyös, nehezen fejhetö, veszélyes), mégis szívós, ellenálló, tágtürésü és értékes-, zsíros tejü (12\%) állat. A bivalyokat nemcsak tejükért, hanem erős igavonó képességükért is tartották a köves talajokon, ezért a 'legelő és rét' müvelési ág helyett inkább a szántóterületekkel mutat erősebb korrelációt. Nem mindenhol választották szét a marhákat és bivalyokat, de általánosságban elmondható, hogy a bivalyok számára a rosszabb: oldalas, köves, bozótos-gazos, törpe-füves vagy vizes, burjános helyeket hagyták meg; mert ő még a juh után hagyott ugaron is talált ennivalót. ${ }^{171}$ A század folyamán a Nádas-mente több falujában a bányákból való fuvarozásra és áruszállításra is tartották (Egeres, Türe, Vista, Bács). A TSZ-időben átmenetileg szabályozott létszám, a '70-években ismét növekedésnek indult, ${ }^{172}$ de ma jelentősége változó. ${ }^{173}$

A bivalytartás két hagyományos, gazdálkodáshoz köthető egyedi tájértéket, visszatérő pontszerü elemet is létrehozott a kalotaszegi tájban, ezek a „bivalyfejő-kosarak” és a „bivaly-feredők.” Néhány faluban (Méra, Nádas, Nagykapus) a legelő igen messze volt, ezért kosarakat (kocsirlókat) készítettek szárazságból, rőzséből. Ezek bab-alakú, középen nyitott kisebb karámok, amelyek a bivalyok számára nyáresti szállásként és a fejést segítő nyugalmat adó, védelmező falként szolgáltak. ${ }^{174}$ Ezek a kb. 3-5m-es kosarak mai napig megtalálhatóak és állandósultak a legelőn. A parasztság a jó

\footnotetext{
${ }^{170}$ A bivaly erdélyi elterjedését a balkáni, török területek felöl a XV.sz.-ra; kalotaszegi megjelenését a 1860-70-es évekre teszi. A Kós által közölt, 1911-es állatszámlálási és helyszíni adatközlők alapján számított adatok nagyvonalakban sem illeszkednek az 1897-es statisztikával, amely már a múlt század végén sokkal jelentősebb létszámot közöl. In: Kós, ifj. 1980b, p. 215.

${ }^{171}$ Kós., ifj., 1980b. p. 219.

${ }^{172}$ Kós, ifj. 1980b. p. 215.

${ }^{173}$ Mérában mai napig nagy hagyománya van, Inaktelkén más csak néhányat tartanak. In: Füleki, 2012. p.22.

${ }^{174}$ A bivalyok fejése nagy körültekintést kívánt, mert az állat csak az megszokott helyén, ismerős személynek, ismerős tárgyak jelenlétében adta le tejét, így a mezőn is törekedni kellett.
} 
legelőn „,bivaly-feredőket” alakított ki horpákból, gátakkal, patak-dugással, amelyeknek pocsolyájában az állat a déli meleget, a légycsípéseket és a felforrósodást átvészelhette, mert eredetileg meleg égövi, mocsári állat. A bivalyok jelenkori eltünésével párhuzamosan ezek lassan feltöltődnek, helyük egyre nehezebben azonosítható, ${ }^{175}$ mégis a tájgazdálkodás fontos táji emlékei.

A bivalytartás statisztikai és térbeli eloszlása ${ }^{176}$ az alábbi tájkarater-zónákban egyöntetüen magas és minden településen egyformán jelentős: a Nádas-menti-völgy és Kapus-falvai, ahol átlagosan $\sim 40 \%$, de falvanként akár a 45-69\%-ot is eléri bivalyok aránya az össz-állatállományból; Alszeg szőlős faluiban (Asz) szintén eléri a 40\%-os arányt; de a környékén a forgácskút-tóttelki zónában (31\%), ill. Bánffyhunyad környékén is magas (27\%) a bivalyok jelentősége; amelyhez még a váralmási falvak $(\mathrm{Vv})$ is csatlakoznak (20\%). Sem a havasi $(\mathrm{H}, \mathrm{Hv})$, sem a havasalji vidékeken (Fh), sem a tordaszentlászlói körzetben (To) nem jellemző a bivalytartás a kedvezőtlen környezeti paraméterek miatt. ${ }^{177}$ Sebesváron, Székelyjón valamint Tordaszentlászló és Magyarfenes mélyebb fekvésü, vízközeli magyarlakta falvaiban ennél kissé jelentősebb az arány. Bár nem lehet egyértelmü etnikai összefüggést találni a bivalytartás szokásában a magyar-román falvak között, a táblázat tájértékelési össz-jelentőség szerinti rangsorának első 15 helyéből 10 jelentős, magyarlakta, erős gazdaságú hagyományőrző település; míg a rangsor végén jellegzetesen hegyi, kisebb gazdaságú és lakosszámú, szegényebb román település található. A 116 falvas adatsor statisztikai feldolgozása és annak térbeli ábrázolása valóban igazolta a bivalytartás jelentőségét a kalotaszegi zónákba, amely majdnem pontosan a legtöbb néprajzi és történeti besorolás által is Kalotaszegként számon tartott területet rajzolta meg. A bivalyok tartása így valóban közös jegyként, tájkarakter meghatározó tényező és hagyományos tájgazdálkodási reliktum-elemei is tájtörténeti jelentőséggel bírnak

\section{III.4.2. A kosarazó juhászat táji vonatkozásai, tájértékelése és térbeli eloszlása [25. tábla]}

A legelők a szántóföldi müvelésre nem alkalmas köves, rossz minőségü, oldalas, 'rogyinás' helyekre szorítkoztak vissza, ahol még a kaszálás is nehézkes lett volna. A legelő és a kaszáló idővel egymást felválthatta, ha a körülmények úgy kívánták. Ezek a talajra simuló felületek szorosan követik a felszínmorfológiát, sem barázdák, sem szénaboglyák nem jelennek meg rajtuk, eróziós sérüléseiket és bokrosodásukat kivéve alapvetően monoton felületek. A kosarazó juhászat szerepe kettős: egyrészt a hasznosítja a gyengébb földminőségü legelőket, másrészt a trágyázással segíti a termőtalaj táperejének visszaadását. A határ 1/3-a minden évben ugarba (,nyomásba”) kerül, amely nemcsak pihen, hanem istállótrágyát is kap, majd a juhok ,ganézzák”. Kós kiemeli, hogy a kalotaszegi parasztgazdaságban a

\footnotetext{
${ }^{175}$ Az inaktelki Lügeten a 'bihajferedő' bozótos gödre már alig felismerhető, ellenben kiskapusi északos egykori úrbéresi legelő patakdugásai mai napig jól kivehetőek a légifelvételeken.

176 Bivalytartás tájértékelése 5 szempont alapján: bivalyfogatok száma, 100 före jutó bivalyfogatok száma, a bivalyok darabszáma 1897-ben, a bivalyok 5-os megoszlása az összes (nagy)állatállományból, és végül a bivaly szántásban való nagy szerepe miatt a 100 kh. szántóra (! - nem legelöre) jutó bivalyok száma.

177 „Ott fenn száraz a fü, nincsenek vizes legelők, s nem terem kukorica, nincs kóré a bihajnak; a hegyekben fehér- és pirostarka (svájci) marha van most is.” in: Kós. Ifj., 1980b. p. 217.
} 
juhtartás jelentősége elsősorban nem a tej, a gyapjú vagy a húshaszonban, hanem mindenekelőtt a juhkosár nyomáson való költöztetése általi trágyázásban állott. ${ }^{178} \mathrm{~S}$ jelentősége a rendszeres istállótrágyázás idején is azért maradt meg, mert az úttalan hegyi földekre nem lehetett kihordani az trágyát, és a szegények nem volt elegendő marhatrágyájuk. A juhkosár mikro-táji mintázata úgy keletkezik a mai napig is, hogy a kosár áthelyezésekor egyik oldala helyben maradt és a másik három oldala vándorolt, így négyzetesen ismétlődő formák alakultak ki az adott a területen. ${ }^{179}$ Ezek bár csak időszakos jelenségek, minden falu határában 'juhturmánként' megfigyelhető, és mivel manapság egyre jelentősebbé válik tartásuk, így fontos tájhasználati jellegzetesség.

A legeltetés statisztikai és térbeli eloszlását sokkal nehézkesebb a területhasználati adatsorok alapján körvonalazni, mert az állatok és csordák fogyasztása és igényei és táji terhelésük is különböző. Mivel a rét müvelési ág pontos megoszlását nem ismerjük (lehet vizes rét vagy kaszáló) megoszlását nem ismerjük, és falvanként eltérő jellegü a kaszált és legeltetett eledel mennyisége, ezért a statisztikai adatsorok tájértékelése ${ }^{180}$ kevésbé hozott egyöntetü és koherens képet. Általánosan megfigyelhető hogy magas értékeket kaptak a Havasi területek (H, Hv), a Kapus- és Kolozsvári völgy (K, Ka) és a Felszegi felföld és Havasalja is (Ff, Fh), ami mutatja ezek szántóföldi müvelésre alkalmatlan voltát és az állattartás erős hagyományát (Magyarlóna, Szászfenes). A tordaszentlászlói terület (To) négy magasértéket kapott települése is ehhez a havasi életmódhoz áll inkább közelebb. Jelentős, de nem minden falura általános érvényü a legeltető-állattartás a Nádas-mentén (Nmv), a Bács-Berendi térségben $(\mathrm{Bb})$ és Váralmási-völgyekben ( $\mathrm{Vv})$, azaz itt a legelőarány nem tud teljes dominanciával részt venni a tájkarakter kialakításában. Végül egyöntetüen nem jelentős a Hunyadi-medencében $(B h m)$ és az Almási-zónákban (Ab, Asz), ahol egyrészt a szántóföldi müvelés és a kert- és szőlőgazdálkodás dominál helyette. A legeltető állattartás így nem a belső vidékekre, hanem a szegély- és peremfalvakra jellemző, és egyik vizsgált tájkarakter-zónában sem mutat erős, koherens megjelenést, de alapvetően inverz módon illeszkedik a néprajzi lehatároláshoz, így a végső összesítésben az adatsor ellentettjét vettem számításba, azaz ,, akkor kalotaszegiesebb - ha kevésbé jellemző rá a legeltetés”.

\section{III.4.3. A fás legelők tájtörténete és annak változás-dinamikái [26. tábla]}

A fás legelők tájmintázata hagyományos és ősi tájművelési mód, amely összefüggést mutat az erdő kiélés és erdei legeltetés korai formáival, ${ }^{181}$ amikor az erdőből kihasított belső tisztásokon legeltettek. A csökkenő erdők - növekvő szántó és legelők mellett szükség volt a nyári meleg ellen való védelemre, amelyet az idős fák lombkoronái adtak. A fás legelőkön értékes ecetnek való

\footnotetext{
${ }^{178}$ Kós, ifj., 1999. p. 67., Kós részletesen foglalkozik a témával: A kalotaszegi kosarazó juhászat c. tanulmányában, Kós., ifj. 1947.

${ }^{179}$ A juhkosár falát 2m-es vesszőfonatú mobil lészák/lászák alkották; így a 8x16/10x18m-es kosarat nap-nap után könnyen át lehetett helyezni, mert különben kiégette volna a trágya a füvet.

${ }^{180}$ A legeltetés tájértékelése 7 adatból került levezetésre: a legelő (terület és \%, 1987) és a rét méretéből (1897), a szántó jelentőségének fordított arányából, valamint a legelő állatok összetételéből (összes állat, juhok száma).

${ }^{181}$ Varga Anna cikke
} 
vadgyümölcsfák álltak, melyek megőrzése mindenkinek fontos volt. A fáslegelőt, mint bármely más legelőt tartották számon, így a régi dűlőnév-adatsorokban és művelési térképeken ${ }^{182}$ nem lehet nyomon követni létét, és az összeírások sem említik külön tájhasználati típusként. Majdnem mindegyik fás legelő az egykori természetes erdő kiirtása során keletkezett, és nem fatelepítéssel jött létre, ez azonban nem zárja ki azt, hogy egy megritkított erdős-legelő idővel ne tudna vissza-erdősülni. E folyamat időben és térben is változatos, mozgalmas képet ad, amelyet történeti térképekkel, légifotókkal részletesen vizsgáltam az egyes területeken. ${ }^{183}$ Ebböl kiderült, hogy ez egy min. 250 éves történeti tájhasználati forma volt, amely mára csökkenőben van. Környezetpszichológiai és tájkép-értékelési kutatások több elmélettel is alátámasztják a ligetes-facsoportos térszerveződés magas közkedveltségét [19.§. melléklet]. A változatos kiterjedésben és sürüségben feltünő facsoportok, az azokon változó fény-árnyék jelenségek a kalotaszegi tájképnek is magas esztétikai minőséget adnak, azért megőrzésük a táji értékvédelem fontos részét kell képezze.

\section{III.4.4. A fás legelők téri megoszlása, mintázata a tájkarakter-zónákban [20.§. melléklet].}

Alig volt, és ma sincs fás legelő a Hunyadi-medencében és Felszeg havasalji területein, ahol az erdőkiélés sokkal korábban elkezdődött; és itt a delelő forróság sem játszott olyan nagy szerepet. Így e szempontból jelentősen eltér a többi zónától; Felszeg K-i felén, Nyárszó-Körösfő környékén ma is találunk fás legelőket, mert az erdőirtások csak az elmúlt száz évben történtek. Alszegen a Meszes lefutó völgyeiben alig találunk kisebb fás-legelő tagokat, mert itt a magas erdőarány és alacsony legelőszázalék miatt kisebb volt azok jelentősége (Alsófüld), de a zsobok-sztánai magaslat egykori „öreg” erdőségéből a vasútépítés óta megritkított erdőtagok között több szép, koros fákból álló fáslegelő is található. A Nádas-mentén találhatók ma a legnagyobb és legkiterjedtebb fás legelők, mert az erdőtagok és a ligetesebb legelőfoltok között könnyebben tudtak visszafásodni, ill. változatos időbeli és térbeli dinamikával átalakulni. Tájképi szempontból a legjelentősebb a magyargorbói, 200ha-s Lészai-féle domboldalt borító terület, amelynek látványa megdöbbentő. Összegzésként megállapítható, hogy a fás-legelők bár kis alapterületek a határban, különleges „,pettyezett” mintázatai messziről feltünőek a tájképben és látványuk egyedi megjelenésü.

\footnotetext{
${ }^{182}$ Ha egy erdőtagot legelővé alakítottak, akkor azt már világos színkódokkal jelölték, még akkor is, ha azon fák, facsoportok álltak. Ha hihetünk az első katonai felmérés jelölésének (ami csak a részletesebb grafikájú lapokon különböztet meg sürü/zárt erdőt, nyitottabb erdőt és elszórt hagyásfás mintázatot), akkor állíthatjuk, hogy ez a tájhasználati forma minimum 250 éves.

183 Típusai: (1) egykori zárt erőket kiritkítanak, egyre jobban fellazítanak és abból fás legelő alakul ki: Gorbói Lészai legelő a 1880-ban még zárt erdő majd 1940-re legelő; a Zsoboki állomás környéke a II. katonai felmérésen még teljesen zárt erdő, majd 1944-ben már „fellazul” és differenciáltan egyes részei zártabb erdőséggé, mások még nyitottabb legelővé alakulnak; (2) az „eredetileg” hagyásfás terület kitermelésre került vagy bányászati céllal lett hasznosítva: a Nagykapusi fáslegelő eltünik, a Sólyomtelki helyén kaolinbánya nyílik; (3) egy „eredetileg” hagyásfás terület befásodik, visszaerdősül: pl. egy Mákó feletti ligetes erdőtag 1880-ban még liget, 1940-ben már erdőtag; ill. különböző korú hagyásfákból álló egymással érintkező ligetek, erdőtagok áthelyeződnek, térfelet váltanak: amíg az egyik megnő, a korosabb eltünik, pl.: Alsófüld; (4) a hagyásfás legelö állapota változatlan, körvonalai a 70-80 évvel ezelőtti formákat mutatják: Hodos falu alatti fáslegelö.
} 

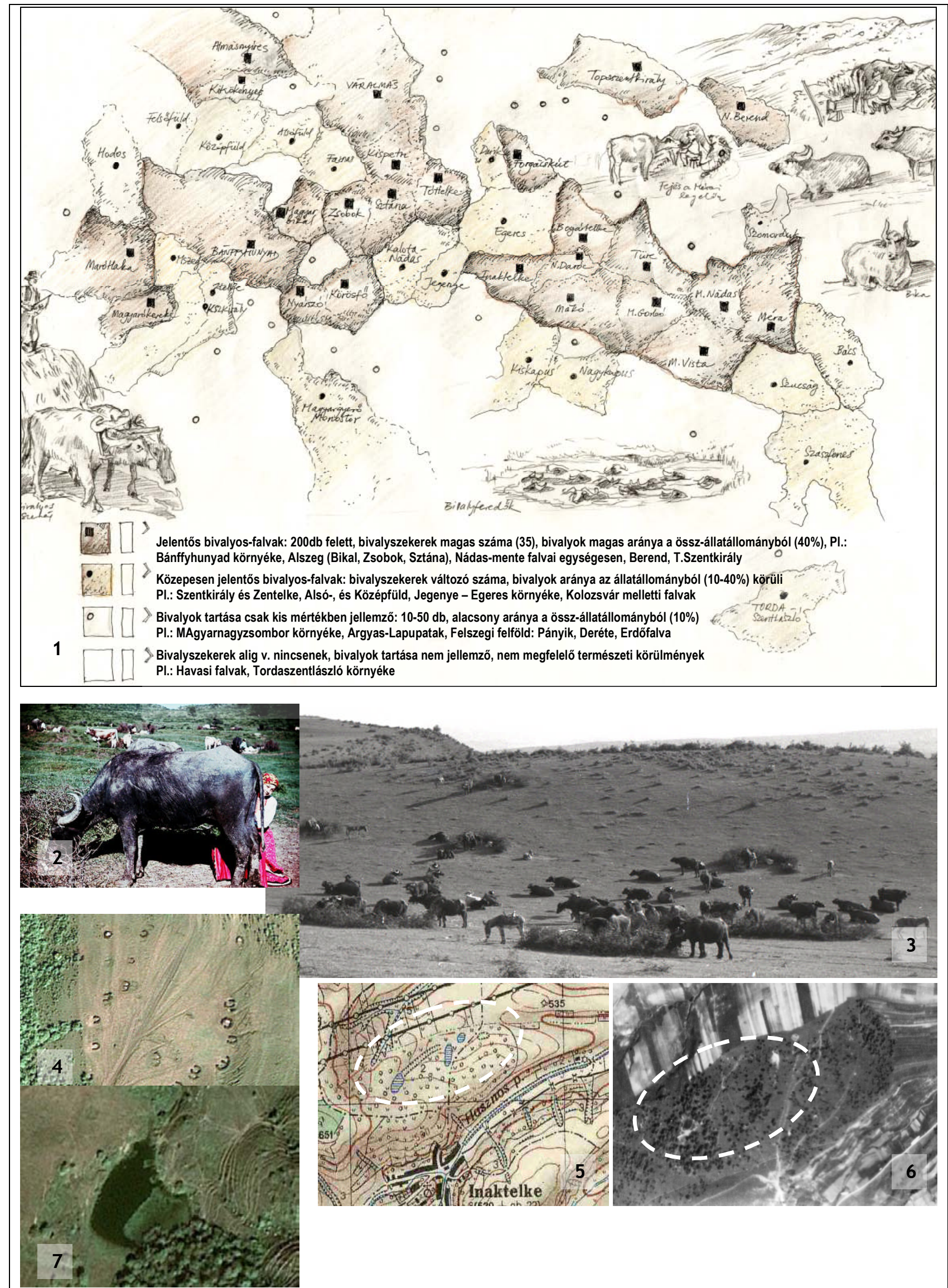

24. TÁBLA: LEGELTETÉS 1. - A BIVALYTARTÁS TÁJMINTÁZATAI, ALAKTANI JEGYEI

1. A bivalytartás tájértékelésének téri megjelenítése 2. Bivaly-, és tehénfejés Mérán a század közepén (Erdődi M., 1941, D393) 3. Rőzséből készített felkör-alakú fejőhelyeken várják a fejök az érkező bivalyokat, közelben vannak megkötve a teherhordó szamarak (Hofer T., 1962, NM F 166960) 4. Bivalykosarak a légifotón. 5-6. Az Inaktelkétöl É-ra fekvő domboldalon található fás legelő: a Lüget, ahol jól látszanak a természetes horpákban kialakított, mára feltöltődött bivaly-feredő tavak. 7. Egy „dugással”-készült „feredő” Kiskapustól délre. 

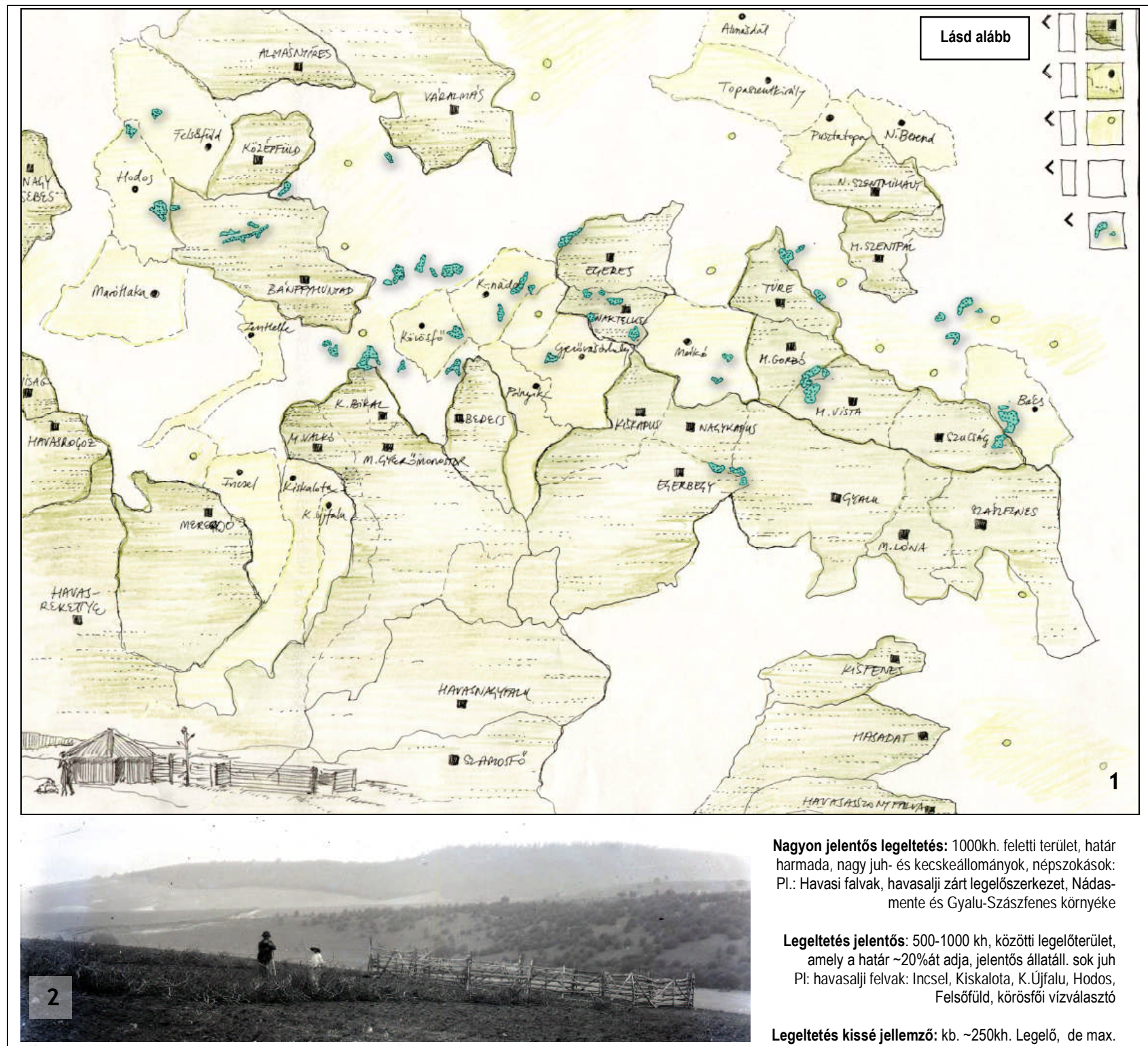

Nagyon jelentős legeltetés: $1000 \mathrm{kh}$. feletti terület, határ harmada, nagy juh- és kecskeállományok, népszokások: Pl.: Havasi falvak, havasalji zárt legelőszerkezet, Nádasmente és Gyalu-Szászfenes környéke

Legeltetés jelentős: 500-1000 kh, közötti legelöterület amely a határ $\sim 20 \%$ át adja, jelentős állatáll. sok juh PI: havasalji felvak: Incsel, Kiskalota, K.Újfalu, Hodos, Felsőfüld, körösfői vízválasztó

Legeltetés kissé jellemző: kb. 250kh. Legelő, de max. 15\%-0s arányban a határból, “ 500 legelő állat PI.: Bács-Berendi térség, Váralmási terület völgyi falvai: Magyarnagyzsombor, Középlak, Alsófüld,

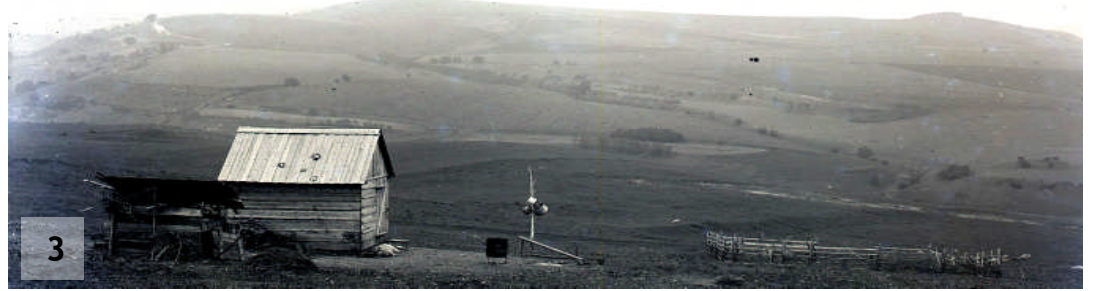

Legeltetés nem jellemző, kevés legelö és rét (150 kh. alatt), juhok alacsony száma, szántók nagy jelentösége Pl.: Alszegi barnakőszénvidék, Alszegi szőlős falvak, Bánffyhunyadi-medence

\section{HAGYÁSFÁS LEGELŐK}
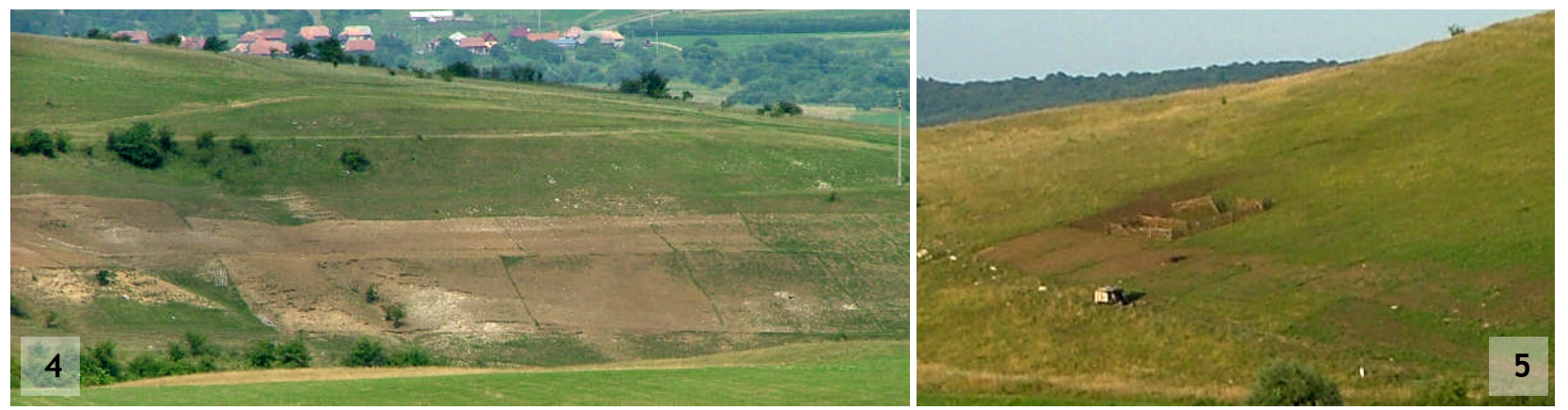

25. TÁBLA: LEGELTETÉS 2. - A LEGELŐK TÁJÉRTÉKELÉSE, A JUH-KOSARAK TÁJMINTÁZATA

1. A legeltetés tájértékelésének téri megjelenítése (7 adatból: a legelő (terület és \%, 1987) és a rét méretek (1897), a szántó jelentőségének fordított aránya, valamint a legelő állatok összetétele (összes állat, juhok száma)); a türkiz foltok a fáslegelöket jelölik. 2-3. Román „isztina” esztenáról készült sorozat a Szucság feletti domboldalban, ahol jól megfigyelhető a határ tisztasága, a spontán fásodás-cserjésedés hiánya, az eróziós sebek, a fáslegelők és a Szucság mögötti zárt erdőtömeg (Győrffy István, 1908, NM F 9495, NM F 9500). 4-5. A juhkosarak 1-2 napos áthelyezéséből adódó négyzetes mikro-mintázat (Magyarókereke, Bogártelke). 

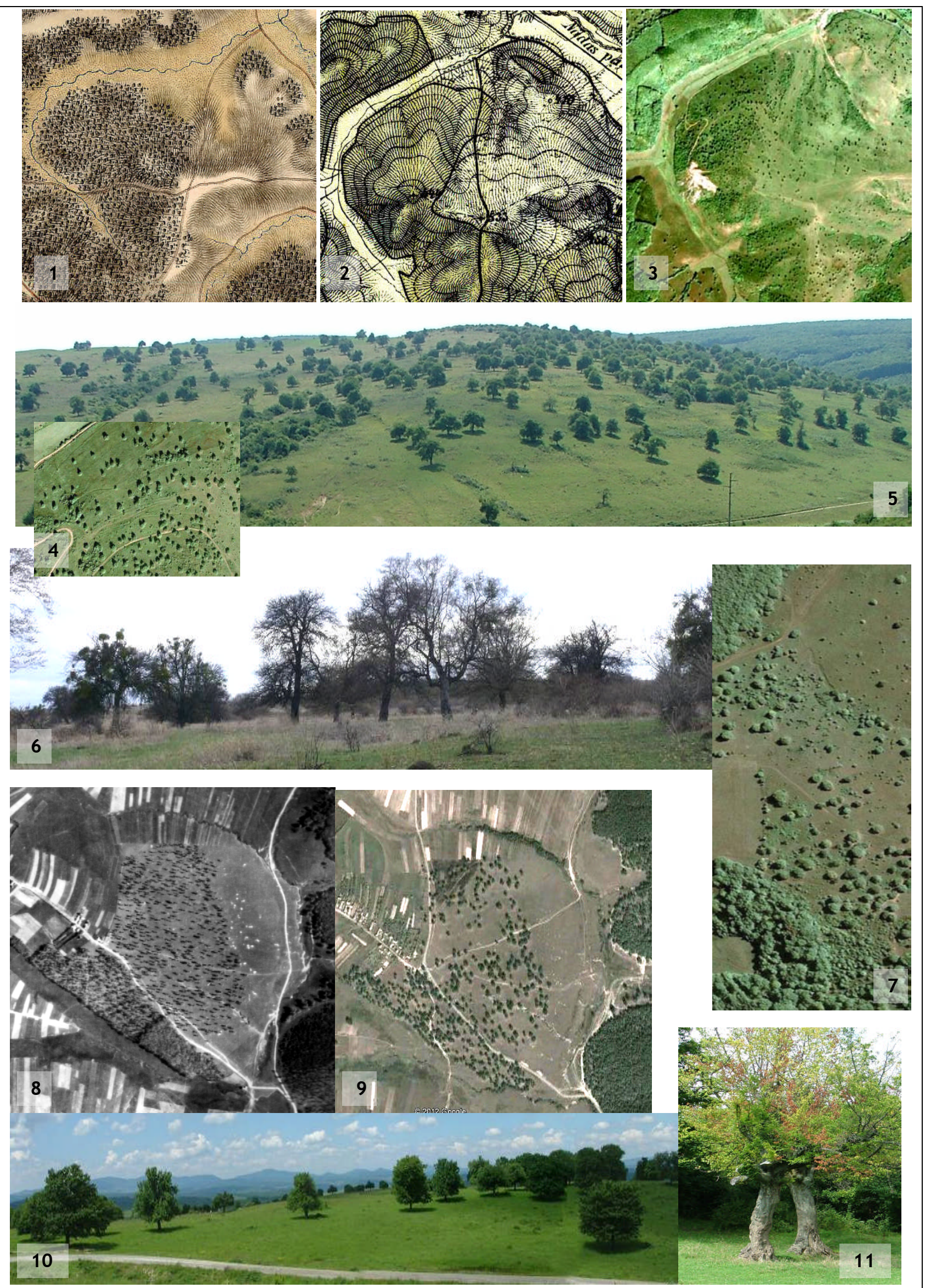

26. TÁBLA: LEGELTETÉS 3. - A FÁS-LEGELŐK TÁJMINTÁZATA, TÁJKÉPI SZEREPE

1-3. A magyargorbói Lészai-legelő tájváltozása (I - II.kat. felmérés, mai légifotó) 4-5. Ugyanennek a legelőnek a mintázata közelről és a domboldalt borító látványa. 6-7. Az inaktelki Csere, amelyet a '60-as években zárt erdőből alakítottak ki. 8-9. A Hodosi-fás legelő 60 éve (kissé megritkult), de változatlan képe. 10. Fás legelő a Zsoboki állomásnál. 11. Öreg fák az Egeres Nagykapusi fás-legelőben. 


\section{III.5. Kertek és gyümölcsösök tájértékelése és az ültetvények tájmintázatai}

A gyümölcsösök fontos szerepet töltenek be minden falu életében, és a falvaktól távolabb eső tájrészletek képi megjelenésében is; több száz év klimatikus és gazdálkodási változásai ellenére is időtállónak bizonyultak, és ma is a táj „legfenntartottabb” részei. A falun belüli gyümölcsösök mintázata szoros összefüggést mutat a településszerkezettel, amely a falut körülvevő gyümölcsöskerteken keresztül illeszkedik harmonikusan az öket övező tájba. ${ }^{184} \mathrm{Az}$ egyes gyümölcsfajok termesztésének módja, ill. haszonvételi formája nagymértékben meghatározza az egyedek habitusát, állományaik formáját, ennek révén a tájban való megjelenésüket. A hagyományos gyümölcsösök és az intenzív ültetvények jellegükben, mintázataikban és gyakoriságukban is élesen elválnak egymástól. A fejezet e két típus tájhasználtban betöltött szerepét vizsgálja statisztikai-, és azok térbeli eloszlása alapján a különböző zónákban.

\section{III.5.1. Hagyományos gyümölcsösök megjelenései a falu-, és tájszerkezetben [27. tábla]}

A kertek és gyümölcsösök a középkori településrendszer megszilárdulása óta a települések fontos részét képezik, és a domborzat adta lehetőségekre rátelepült faluszerkezettel nagyon szoros szimbiózisban vannak. A kert a statisztikák alapján a vizsgált határ kis (1-3\%-t) adja, ennek ellenére szerepe a falu gazdálkodásában és a faluképben ennél sokkal jelentősebb és változatosabb:

Települést-ölelő gyümölcsösök: Kalotaszeg szinte valamennyi -zártabb, nem szórt jellegü-, településén megfigyelhető, hogy a telkeken a csür- és zöldséges kert mögött a magánkertek kerítései megszünnek, és egy nagy települést övező kert-gyürüvé válnak, amely 80-120 méteres szélességével szinte beágyazza a falut a tájba. A gyürü-szerü szerkezet ${ }^{185}$ könnyen megközelíthetővé teszi a fákat a lakosok számára, de zártságával védelmet nyújt az esős- hideg szelek, poros viharok, vadon élő állatok rongálása ellen. Ezt kívülről sánccal, „szárazsággal” kijelölt, vagy élő kőrisből, mezei juharból metszett kerítéssel veszik körbe.

Templomkertek és temetökertek: Gyakran találunk gyümölcsöskertet a templom és temető dombján, szimbolikusan „,paradicsomi édenkertté változtatva a földi, mégis túlvilági temetőkertet.”186 Legtöbb esetben ez az egyház tulajdona; közös munkával a gyülekezet viseli gondját és a megtermelt haszon (pálinka) a tiszteletes családjáé. A valkói templom és cinterem ennek a szimbiózisnak különleges tájtörténeti példája. ${ }^{187}$

Gyümölcsös az utcaképben: A kalotaszegi utcaképet zömében zárt, fésűs beépítés jellemzi, és csak hátrébb következik a gyümölcsös. Azonban a változatos terepviszonyok eredményeképpen a falu

\footnotetext{
${ }^{184}$ E témakört bővebben feldolgozza: Eplényi - Szani, 2006. pp. 51-56.

${ }^{185}$ Ilyen épen maradt ,gyümölcsös-gyürü” veszi körbe Sztánát, Derétét, Magyarókerekét, Kökényest, Jákótelkét.

${ }^{186}$ Inaktelke, Vista, Magyarvalkó. A temető/paradicsom-kert témája bővebben: Eplényi - Kardeván-Lapis, 2008, p.2-14.

${ }^{187}$ Miháltz Elek pomológus-tiszteletes a századfordulón „új fajtáknak” számító gyümölcsfákkal kísérletezve telepítette be az addig kopár kertet; konfirmándusait kitanította az oltás-metszés alapismereteire. in: Nagy J, 1995.pp. 51-60.
} 
szerkezetében is vannak szükebb, patakparti, domboldalnak feszülő telkek, amelyek csatlakoznak az utcafronthoz megtörve a házakkal ritmizált faluképet. A több-utcás, széttelepült faluszerkezetben és a szórt havasalji falvakban még ennél is jobban dominál a házak közötti gyümölcsös-tagok látványa.

Uradalmak, magánkertek: Összefüggő, nagyobb gyümölcsöskert volt több birtokon, nagygazdaságban. ${ }^{188}$ Egy nagyobb magánkert az egykori sztána-nádasi iskola hatalmas gyümölcsöse a vasútállomás mellett a völgy védettségében. Pomológiai és tájtörténeti szempontból legértékesebb azonban a magyarókereki lelkészi kert, ahol egykor a Telegdy család udvarháza állt, melynek épülete már nem áll, de gyümölcsöse mai napig megvan, koros, közel 80 éves (körte, dió, alma-) egyedekkel.

Malomkertek: Ezek voltak a hagyományos határhasználat legidősebb, leghagyományosabb gyümölcsösei. A falutól ált. 5-7 km-re fekvő malomkert, mint önálló egység működött, így saját kerttel rendelkezett. A molnár -mint önellátó, független gazdálkodó-, hagyományosan jól értett a gyümölcsfák metszéséhez, oltásához is. ${ }^{189}$ A malmok felhagyása, pusztulása után azok kertjét továbbra is fenntartották, így ezek vagy egy-egy elöregedett gyümölcsfa jelzi még az egykori helyüket.

\section{III.5.2. Ültetvények, új gyümölcsfa-telepítések a faluhatárban [28. tábla]}

A századfordulón az uradalmi kerteken, malomkerteken kívül a határban csak som-bokrok és vadgyümölcsfák voltak, amelyböl ecetet készítettek. Az 1897-es és 1914-es adatsor között még 10\%os csökkenés volt megfigyelhető, de az első ültetvények már 1920 után megjelentek, majd a kommunizmus éveiben intenzíven (+1200ha, +25\%) megnőtt az arányuk, ${ }^{190}$ föként azokon a vidékeken, ahol korábban is jelentős volt a gyümölcstermesztés. A kollektivizálások idején a falvak határában újonnan telepített, egybefüggő ültetvényeket hoztak létre szabályos geometria rendben (kötésben és sorokban); nem egyszer kihasználva az eredeti szántási teraszolást. A legjelentősebb állami telepítések (Ketesd-Hunyad, Alsófüld-Almásnyíres és Andrásháza-Szucság-Bács) térségében voltak (zömében alma, dió, cseresznye és meggy), de továbbiak teljes leírását a melléklet tartlamazza [20.§. melléklet]. A domborulatokra helyezett „raszteres-térháló”, monokultúrás mértani mintázatával jelentősen megváltoztatta a tájképet és ,új, jellegzetesen XX.sz.-i” karaktert kölcsönzött tájkarakterzónák egyes térségeinek. Ezeket az ültetvényeket 1990-után az egykori földtulajdonosaiknak feldarabolva visszaosztották, ez fenntartásukat megnehezítette, így most leromlott, becserjésedett, elöregedett állapotban vannak, ezért sokan megkezdték azok kivágását. Az ezredforduló óta intenzívebbé váló szuburbanizálódási folyamat során ezek a közművesítés nélküli telkek is „valahogy” emeletes házakkal épületek be. A Felszeg, és a Nádas-mente faluhatáraiban történt telepítések inkább kisebb tagokban (2-8ha), körbekerítetten vagy a természetes völgyvonalak közé ágyazva, teraszolás

\footnotetext{
${ }^{188}$ Pl.: a Csákyak váralmási birtokán, a Szentiványiak farnasi birtokán, Kiskapuson a Bíró család 'Palotájában', a sztánai Gothárd Zsigmond kertjében, a zentelki Bánffy-kastély telkén, vagy a kisnemesi Szucságon.

${ }^{189}$ Inaktelkén két idős molnár család a legjobb fajtaismerő és oltó a faluban: Kalló Ferenc és Molnár Pisti, akik 2006-os helyszínelésünket és adatgyüjtésünket is segítették. In: Eplényi - Szani, 2006. pp.51.56.

${ }^{190}$ Az adatot a légifotók alapján az ültetvények területének kiszámításával kaptam.
} 
nélkül jelentek meg, ezért ezek a tájba jobban belesimulnak, beleágyazódnak (pl. Magyarvalkó, Inaktelke). Annak ellenére, hogy a pálinka manapság a táj egyetlen és legfontosabb „terméke”, a fák gondozásával, metszésével alig törödnek, alját sokan nem is kaszálják; így a gyümölcsöst fenntartása helyett csak „ki-használják.” A hagyományos gyümölcsös megőrzése, genetikai és tájképi védelme sok helyen indokolt.

\section{III.5.3. A statisztikai tájértékelése és téri eloszlása a zónákban}

Kolozs megyében a kert müvelési ág ${ }^{191}$ átlagosan 2\%-ot foglal el az összterületből, amely a bánffyhunyadi és gyalui járásban csak 1\%, de a nádas-menti, kolozsvári és almási járásban inkább 3\%os átlagot mutat. A 1897-es statisztika részletesen tartalmazza a 12 gyümölcsfaj, arányát ${ }^{192}$ egyedszámát települési bontásban; egy 1944-es ${ }^{193}$ csak általános jellegü. Ezekből kitünik a szilva dominanciája (75\%), és az alma fontos szerepe, ugyanakkor a meleg-kedvelő fajok elhanyagolható volta. Azóta az alma és dió aránya az ültetvények miatt emelkedett. A XIX.sz.-végi kertek összterülete 4000 hektárt tett ki (288 000 fát), amelyből a 10 legnagyobb kerttel rendelkező településé 1030ha-t. Ezek: Hunyad, Váralmás, Magyargyerőmonostor, Szucság, Középfüld, Gyalu, Marótlaka, Hídalmás, Egeres, Hasadat és Kisfenes. Az utóbbi kettő jó példa arra, hogy a hegylábi széttelepült falvak bár alapterületben magas kert-használatot adnak (174/150kh), fa-állományuk mégis csekély (1000 db.). Az adatsorokból képzett mutatók tájértékelése alapján ${ }^{194}$ a kertek szerepe és téri eloszlása a következő:

Magas értéket kapott zónák: A különböző tájkarakterü zónákba tartozó települések területének megoszlását vizsgálva a kert \%-os aránya -belső hangsúly eltolódásokkal ugyan de-, egységesen nagy jelentőségü az Almási Szőlősfalvakban (3,9\%) és a Bács-Berendi völgyben $(3,2 \%)$, hasonló a Hunyadi-medencében (3,2\%), a Nádas-mentén (2,8\%) a Váralmási-völgyekben (3,2\%) és az Almási barnakőszénvidéken (2,9\%). Itt nemcsak a gyümölcsfák száma magasabb, hanem a melegkedvelő fajták választéka is szélesebb. ${ }^{195}$ Legnagyobb és legsürübb gyümölcsfaállománnyal a századfordulón Szucság (19ezer db), Hunyad (14e), Gyalu (10e), Magyargyerőmonostor (11e) és Alsófüld (6e) rendelkezett; de igen jelentős Inaktelke, Jegenye, Magyarbikal, Czold, Nádaspapfalva, Tóttelke,

\footnotetext{
${ }^{191}$ Mindkét mezőgazdaság statisztika csak a „kert” művelési ágat használja, és nem különböztet meg külön „gyümölcsöst”. Mivel a faluban és közvetlenül annak környéken elhelyezkedő gyümölcsösök a kertek részét képezték, így valószínü az illeszkedés. Mivel akkor még nem voltak külterületi ültetvények, az adatsor a falukörnyéki állapotokat tükrözi.

${ }^{192}$ A gyümölcsfák fajtamegoszlása: 74\% a szilva, 13\% az alma, 5\% a körte, 2\% a dió, az eperfa és a meggy, és a maradék 2\%-ot az őszi, kajszi, mandula, cseresznye és gesztenye tette ki a századfordulón; in: Mzg. Stat. pp. 646-659.

${ }^{193}$ Solty 80000 gyümölcsfát említ elhanyagolt, kezeletlen állapotban; szerinte míg Felszegen és Alszegen inkább az alma dominál, addig Nádas-mentén a szilva. Adatai: $42 \%$ a szilva, $39 \%$ az alma és $5 \%$ a körte. Mivel adatainak forrásait nem jelzi, így meglepő és megkérdőjelezhető a szilva ekkora csökkenése. In: Solty, 1944. p. 134.

194 A statisztikai adatok az alábbi értékeket tartalmazzák:'kert' nagysága 1897/1914, a 'kert'-en megtermelt jövedelem (kor.), összes fa db.-száma, a gyümölcsfák fajtáinak megoszlása darabszámban. Származtatott adatok: 'kert' területi \% a település összes müvelt területéből 1897/1914, a 'kert'-en megtermelt jövedelem az egész határ jövedelmének \%-ban, a 'kert' müvelési ágra ill. az egész határra jutó gyümölcsfa db.-száma kh-ként,

${ }^{195}$ A melegebb zónákban az őszi, kajszi, mandula, cseresznye, eperfa összes darabszáma 9800 (5\%), míg a hủvösebb vidékeken csak 850 (1\%).
} 
Nádaskóród, Sztána, Zsobok, Kispetri gyümölcsöse is. A gyümölcstermesztésre potenciálisan alkalmas zónák egyes falvaiban ez a tájértékelés érték mégis alacsony:(Bogártelke, Nádasdaróc, Magyarnádas, Vista vagy Türe,) ennek oka a legelők és az erdők magasabb aránya.

Alacsony értéket kapott tájrészletek: A magasabban fekvő, széttelepült falvakban (Havas és Havasi völgyek zónája) kert-múvelési ágat alig vagy egyáltalán nem is jelez az adatsor. Szintén alig jelentős a hüvös Kapusi-völgyben $(0,9 \%)$, és a Felszegi havasalján $(1,1 \%)$ a hideg, fagyérzékeny időjárás és a rövidebb tenyészidőszak miatt. Ugyanakkor a Hideg-Szamos-falvaiban jelzett 500$1000 \mathrm{db}$ alma és szilvafaállománnyal szemben a csak néhány holdas kerten statisztikailag megtévesztően, extrém magas sürüség jön létre (150-200db/ kert müv. ág/ kh.). Hasonlóan „kilógnak” zónájukból a havasalji helyzetü, hüvös, árnyákos falvak is ${ }^{196}$.

Közepes „,kerti”-értéket kapott tájrészletek: A fenti két szélső értékek között foglal helyet a felszegi felföld (1,5-2\%), a tordaszentlászlói átmeneti vidék (1,5-2\%) és a gyalu-kolozsvári alluviális síkság (1,8\%). Itt a zóna szórásértéke is mutatja, hogy nagyobb belső különbségek vannak: azaz vannak védett helyzetben fekvő, jó-adottságú gyümölcsös-kertes falvak (Marótlaka, Kalotanádas, Magyargyerőmonostor, Nagykalota, Nagykapus és Magyarfenes) és közvetlenül mellettük arra sokkal kevésbé alkalmasak (Malomszeg, Bökény, Körösfö, Hodos, Kiskapus, Gesztrágy). A váralmási terület -mélyebb, és meleg fekvése ellenére-, is mutat hasonlóan erős belső szórásokat, ami alátámasztja, hogy a havasalji, magashegység alatt elhelyezkedő dombsági területeken a szélvédett helyek mikroklimatikus viszonyok, kitettség nagyon érzékenyen befolyásolják a helyi kertek, gyümölcsösök eloszlását, jelentőségét.

A kertek jelentősége alapján kijelenthető, hogy Kalotaszeg területét „inkább jellemzi” mint „,nem-jellemzi a kert, falvai nagy többségében jó gyümölcsös adottságúnak mondhatóak még a Felszegi, magasabb területeken is. A legalkalmasabb vidékek tájkarakterét a XX. sz. második felének ültetvényei lényegesen átalakították: a Hunyag-Ketesd-Füld és Szucság-Andrásháza vidéken óriási kiterjedésben, ,igen erőszakos”, tájidegen, de a Nádas-mente és Felszeg kisebb völgyeiben a tájba harmonikusabban illeszkedik az új telepítés. Az eloszlás zónánként változékony $(0,1-3,9 \%)$, de egyes településeken még a 6\%-ot is eléri: az alacsonyabban fekvő, melegebb vidékeken egyöntetüen magasabb arány, nagyobb a darabszám és több a melegkedvelő fajta; míg a magashegységi, hegyalji tájakon sokkal alacsonyabb az arány és főként szilva, alma és körte jelenik meg. A váralmási, felszegi és tordaszentlászlói, magashegység alatt elhelyezkedő dombsági területek zónáira a mikroklimatikus viszonyok (szeles, fagyzugos, kitettség) nagyon érzékenyen befolyásolják a helyi kertek eloszlását, így egy-egy tájkarakter-zónán belül is nagy szórást, eltérést mutatnak. ${ }^{197}$

\footnotetext{
196 Pányik, Kelecel, Kalotaújfalu, Bocs, Egerbegy-Bánffydongó; Alszegen Felsőfüld és Sólyomtelke, Szomordok és a tordaszentlászlói körzetben Járarákos, Hesdát, Kisfenes, Sztolna.

${ }^{197}$ Pl.: Pányik és Deréte egymástól csupán 10km-re fekszik, mégis 6 és 16-pontos értékkülönbséget mutat a tájértékelése.
} 


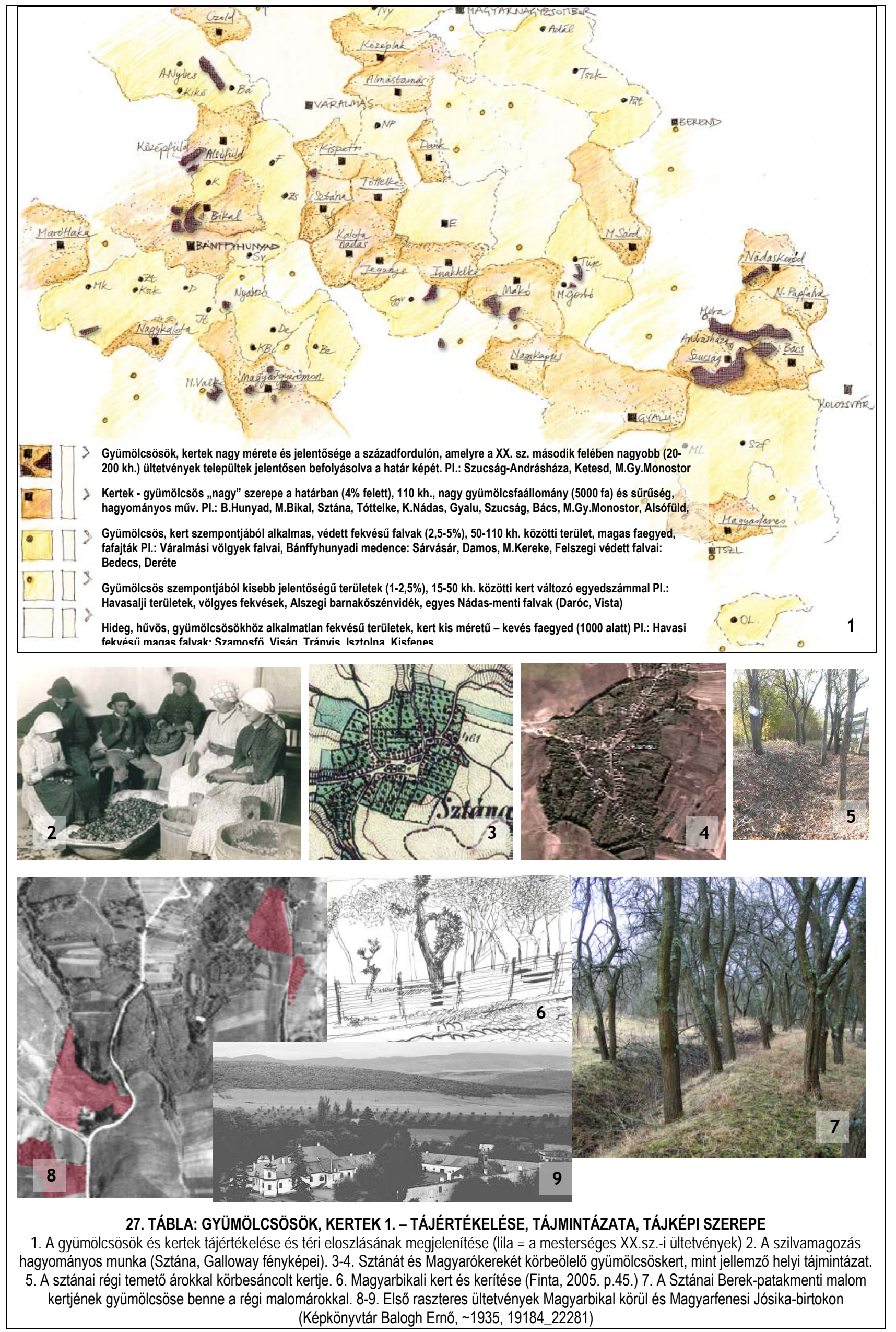



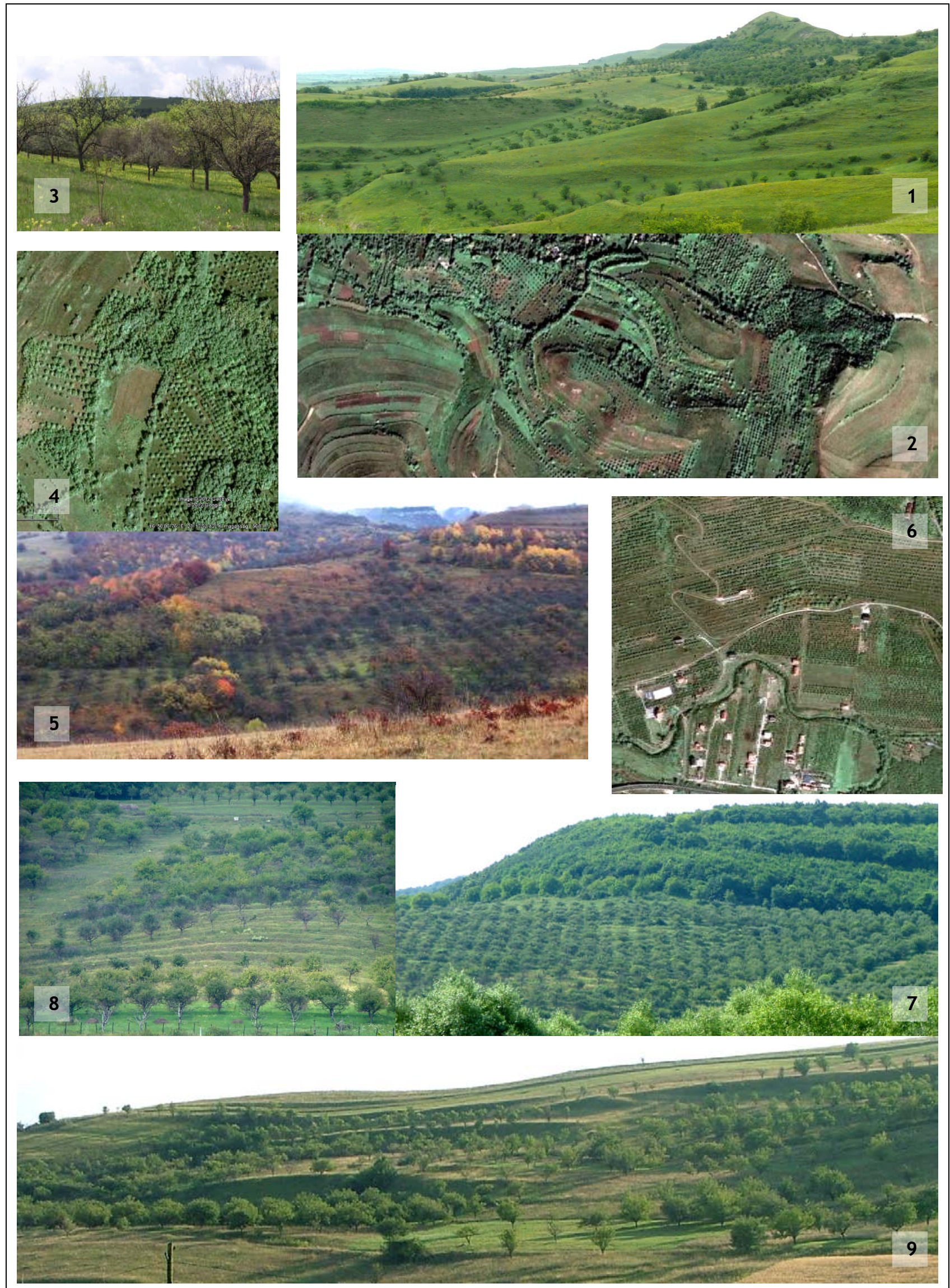

28. TÁBLA: GYÜMÖLCSÖSÖK, KERTEK 2. - TÁJÉRTÉKELÉSE, TÁJMINTÁZATA, TÁJKÉPI SZEREPE

1-2. A Magyarvalkó Nagy-. és Kismalató alatti domboldalak védett részeibe telepített kisebb gyümölcsösök, amelyek belesimulnak a tájszerkezetbe. 3-5. Az inaktelki Hasznosi kert szintén kisebb tagokban, erdőcskékkel elválasztva került betelepitésre a '70-években, tavaszi és őszi lombszíneiben is kiugrik a tájból. 6-8. Az andrásháza-szucsági hatalmas ültetvények, amelyek részben agroteraszokra, részben új teraszírozásokra kerültek és ma gyorsuló ütemben beépülnek, elhanyagoltságuk miatt kivágásra kerülnek. 9. A Türei gyümölcsös egykori agroteraszokra települt mintázata. 


\section{III.6. A szőlőterületek tájtörténete, tájmintázata és tájértékelése}

\section{III.6.1. A szőlőterületek tájtörténete, tájkarakter-mintázata [29-30. tábla]}

Kalotaszeg nem tartozik Erdély kiemelt borvidékei közé, még Csávossy szőlészeti-borászati összefoglalója ${ }^{198}$ sem említi a kolozs-megyei viszonylatokban átlagosnak tekinthető Almás-mentének falvait. A szőlőterületek átlaga a megyében mindössze $0,24 \%$; ehhez viszonyítva az alszegi 2-3\%-os arány már jelentősnek mondható. A szőlő-területek legkorábbi említése egybeesik határjárásokról szóló, és úrbéri okiratok keltezésével. ${ }^{199}$ A szőlők művelése valószínüleg középkori eredetü AlmásBánffyhunyad környékén, de Kolozsvár-Bács-Gyalu vidékén a római eredet sem zárható ki. ${ }^{200}$ A XVIIXVIII.sz.-ban még szinte minden magyarlakta településen találunk szőlőskerteket, amelyeket részben a 1800-as évek elején, az éhínség idején hagytak fel, részben pedig a románosodó lakosság hanyagolta el: „,mert bár munka lett volna a szőlőben, román falvakból mégsem jártak ide napszámosnak.”201 [21.§. melléklet] A központ Hunyad-környéke volt, ahol a hidegtöl védett meredek domboldalak jó körülményeket biztosítottak; és az országúti, városi kocsmároltatás keresletet teremtett a borra [23.§. melléklet].. A XIX. sz. végén Jankó felfigyelt már a szőlővel kapcsolatos dülőnevek sokaságára, noha szőlőt már nem látott rajtuk. Ö ezt összefüggésbe hozza egy általános lehüléssel, amelyet más határnevekkel és az azóta, azon megváltozott müvelési formákkal is alátámaszt. ${ }^{202}$ Szabó T. helynevei alapján [22.§. melléklet] igazat kell adnunk Jankónak, hogy „, a magyarlakta Kalotaszeg minden egyes falujába van egy határrész, melyet szölőröl neveztek el.” Ezt változatos szőlős dülőnevek támasztják alá, de az „új-szőlő” és „,pusztaszőlő”-nevek arra is utalnak, hogy ezek térben és időben is változtak. Mára a bor kereskedelmi haszna jelentéktelen, inkább a falvak közötti árucsere tárgya. Az elmúlt 20 évben még a lakodalmakban is kiszorította a sör, ilyenformán is csökkent jelentősége; a lakosság elöregedett és az Alszegre hétvégenként hazajárók már csak jelképesen müvelik és szüretelik a szőlőt. A XX. sz.-ra a szőlő az udvarokra, fatornácokra behúzódva a településkép karakteres részévé vált. A déli, védett és az épület éjjeli hőleadását kihasználó házoldalakon csak október-novemberben érik be az öreg szőlőtőke. Ezen falvak népi építészeti hagyományaiba is beépült a szőlőtőkék mintái, rajzai (kapufélfák, házdíszek).

A szőlősöket rendszerint déli fekvésü, meredek domboldalakon a legelők vagy erdők körül hasították ki, a partos földet vessző vagy kő támfallal kötötték meg. ${ }^{203}$ A falun kívüli szőlökben sokszor gyümölcsfákat találunk, jellemzően a gyümölcsös van a kert alsó részén. A telekhatárokat itt

\footnotetext{
${ }^{198}$ Csávossy, 2002, p. 80 .

${ }^{199}$ Legkorábbi említések: BH 1660, Ketesd 1712, Farnas 1756 (már pusztaszőlőt is említ) Kispetri - 1754, Bikal: 1399, Középlak - 1752, Sztána - 1608, Váralmás - 1627, Mákó - 1781, Szucság - 1754, Magyarókereke - 1715.

${ }^{200}$ Wanner, 2010, p.281.

${ }^{201}$ Cziráky alapján, 1820: Hodos $\sim$ Kissebes $\sim$ Nagysebes $\sim$ Sebesvárallya: Határunkban szőlők nincsenek, hanem van ide közelebb Hunyadon, Ketesden, Bikalon és Farnason, de napszámosságra egyik helyre sem járunk.

${ }^{202} \mathrm{Pl}$. egykori köles határrészen a zordabb éghajlatot is elviselő kender termett akkor. in: Jankó, 1892. pp. 32-34.

${ }^{203}$ Kós, ifj., 1994, p. 65.
} 
élősövénnyel választották el, egy-egy nagyobb tagot fásszegéllyel kerítették körbe. ${ }^{204} \mathrm{~A}$ tagolatlan legelök, szántók között feltünő sövények erősen ritmizált mintázatként jelennek meg Alszeg nagyobb részén. ${ }^{205} \mathrm{~A}$ szőlőtermesztő tájhasználat így, a szintvonalas barázdákra merőleges, völgy-felől felfutó, legyezőszerüen egyre keskenyedő, bekerített telkek mintáit hozta létre. A mára eltünt szőlők emlékét a Szucság déli domboldalán megfigyelhető telekosztás még mutatja, de a felszegi kipusztult szőlőkre utaló határvonalak mára még talaj-mintázatok formájában sem nyomozhatók ki. Fontos felismerés, hogy a szőlő önmagában ugyan csekély területi százaléka ellenére $(0,5-3,7 \%)$, domboldali rálátása miatt a határ tájkarakterében sokkal (!) markánsabban jelentkezik.

\section{III.6.2. A statisztikai tájértékelés és téri eloszlása a tájkarakter-zónákban}

Az 1860-75 között 350 kh. szőlőterület volt, ${ }^{206}$ zömében Bánffyhunyad és Alszeg környékén. Ez Alszegen 1000, Bács-Szászfenes környékén 320, és Nádas-mentén 30 szőlöbirtokost jelentett; legnagyobb termelő falvak: Váralmás, Magyarbikal, Kispetri, Ketesd és Farnas és Bánffyhunyad. Az 1897-es országos adatsor alapján a kalotaszegi területen összesen 245kh. művelt és kb. ugyanennyi, $228 \mathrm{kh}$. kiirtott (=pusztaszőlős) ${ }^{207}$ terület volt, ami jelentős csökkenést mutat. Ugyanakkor Bánffyhunyadon duplájára nőtt a szőlő, így a mezővárost leszámítva a csökkenés még drasztikusabb. 1944-ben ${ }^{208}$ már csak 200kh. oltványszőlőt említenek zömében Bánffyhunyad területén.

Az Alszegi szőlőterületek (Asz) tájkarakter-zónája kapta kivétel nélkül, minden településével ${ }^{209}$ a legmagasabb értékeket, amelyhez Bánffyhunyadot is hozzá kéne számítani, mert szőlőmüveléssel foglalkozó területei a Körös-Almás vízválasztó É-i oldalára, Alszeg felé esnek, így a Hunyadi-medence képében nem volt jelentős szerepe szőlőinek, amely indokolja saját tájkarakter-zónából $(\mathrm{Bhm})$ való kilógását. Az Alszegi barnakőszénvidék ( $\mathrm{Ab}$ ) és a Váralmási völgyek (Vv) zóna szintén kiemelt értékeket kap, de már csak a 2., 3., besorolási zónába, mert itt kisebb és inkább pusztuló volt a szőlő aránya. Ezek közül Almástamási, Tóttelke, Középlak és Váralmás jelentősége emelkedik ki, egyes ÉKi falvai ${ }^{210}$ azonban már az 1820-as összeírás során kijelentették, hogy „,szölöhelyeink nincsenek”. Ezért e település-csoport a történeti tájhasználat vizsgálta a két különböző tájkarakter-zóna határa mutat rá. A havasi, tordai, kapusi vidéken a legalacsonyabbak az értékek, és a Nádas-mentén, Felszegen és Gyalu környékén találunk elvétve egy-egy közepesen jelentős települést (Szászfenes, Kisbács, Szucság) [25.§. melléklet].

\footnotetext{
${ }^{204}$ A sztánai Fogas/Fogás L-alakú bekerített szőlőskertje 150 éve őrzi pontos formáját a legelőben.

${ }^{205}$ Ketesd és Bikal környékén nagy arányban; Bábony-Kispetri felett; és a sztánai Bükkös-hegy déli kiosztásában is.

${ }^{206} \mathrm{Ez}$ az adatsor csak a legfontosabb szőlőtermesztő falvakat tartalmazza. in: Keleti, 1875., p. 351.

${ }^{207}$ Bizonytalan a táblázatban feltüntetett 220kh. ,pusztaszőlő” helyzete, mert nem tudható, hogy az csak ebben a rövid időszakban, vagy már ezelőtt kipusztult-e. Az 1914-es adatok szerint újra magasabb, 433kh-t borított szőlö, így gyanítható, hogy ekkor csak újra ,szőlőként” tüntették fel az azelőtt már kipusztuló-félben jelölt pusztaszőlös-területeket.

${ }^{208}$ Solty, 1944., p. 134.

${ }^{209}$ Magyarbikal, Kispetri, Ketesd, Farnas, Sztána, Zsobok.

${ }^{210}$ Argyas, Dank, Forgácskút, Lapupatak, Vásártelke, Oláhköblös, Zsombor.
} 


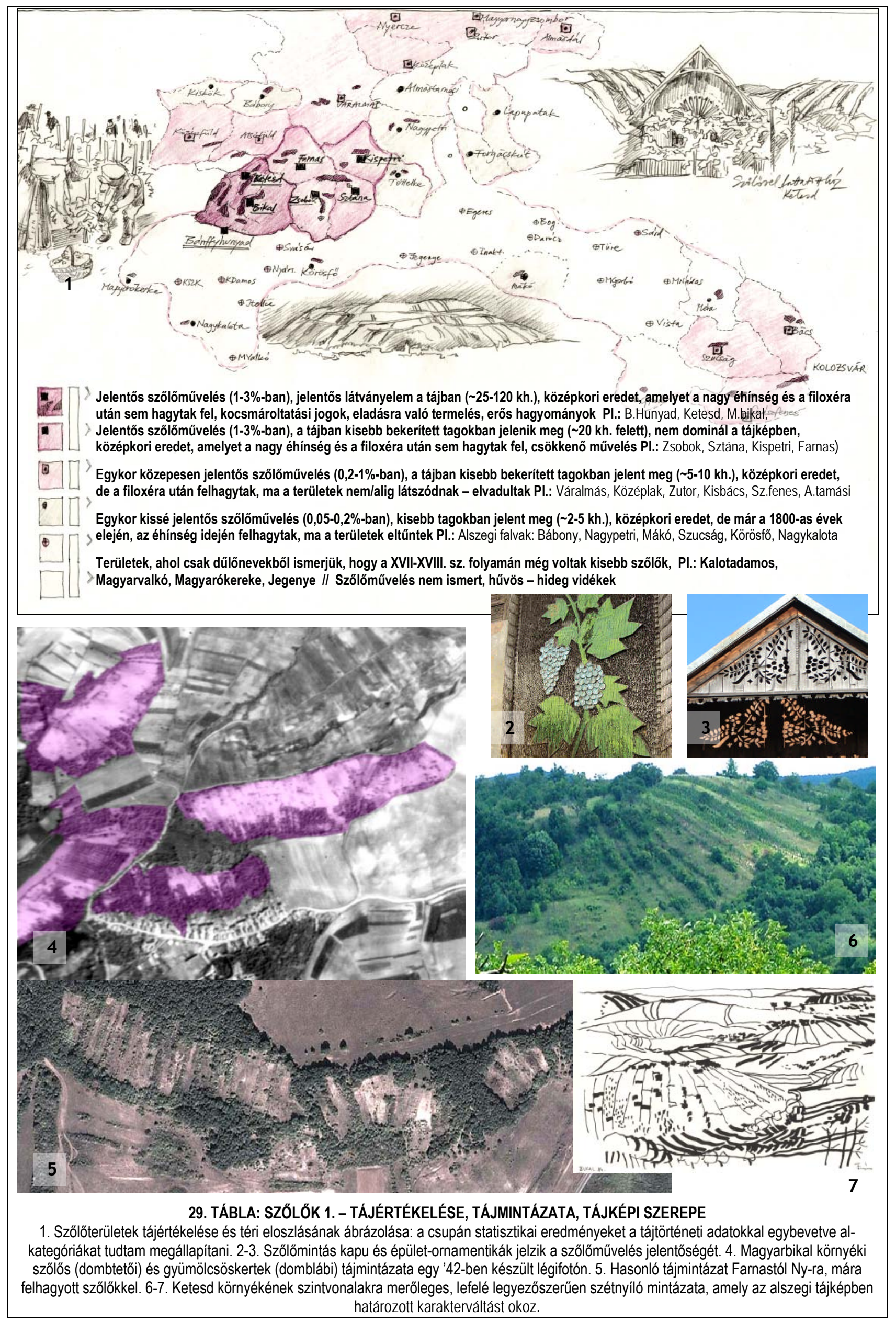



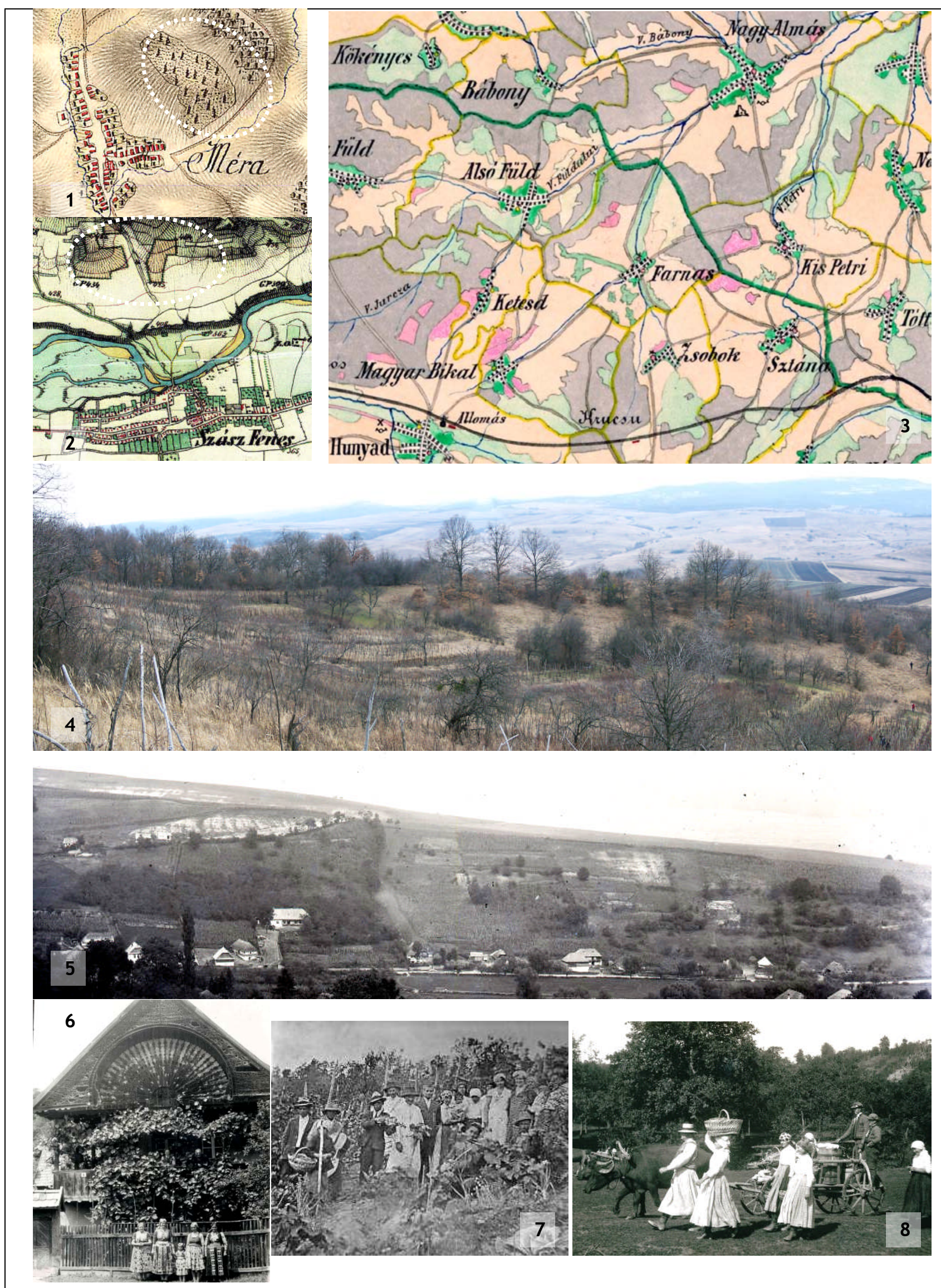

30. TÁBLA: SZŐLŐK 2. -TÁJMINTÁZATA, TÁJKÉPI-, TÁJTÖRTÉNETI SZEREPE

1-2. Nagyobb szölőterület a mérai és szászfenesi oldalban, amelyet az 1820-as éhínség, majd filoxéra után már nem telepítettek újra, így mára teljesen eltűnt (I. - II. kat. felmérés) 3. Alszeg szölö-, és gyümölcsös területei (rózsaszín). 4. A sztánai Bükkös déli oldalában található szőlőskertek, amelyet máig művelnek a Zsobokiak és Sztánaiak 5. Szucság falu délre tekintő doboldalán már csak az egykori szőlőkre utaló hegy-völgy irányú telekosztás látszik (Györffy István, 1908, NM F9316) 6. Szőlövel befuttatott tornácos ház a falukép jellegzetes eleme (saját gyüjtés) 7-8. Bábonyi szüreti kaláka zenészekkel a '50-es években (saját gyüjtés) és szüret Sztánán 1925 körül (Galloway, f.n.) 


\section{III.7. A nádasok tájtörténeti szerepe és mai előfordulása a tájkarakterben}

A geomorfológiailag a horizontális síkok, lapályos platók sok táj életében kitüntetett szereppel bírnak, de itt Kalotaszeg környékén a magas fekvésü, mozgalmas és tagolt dombvidéken mind a vízfelületek, mind nádasok szerepe elhanyagolható. Bár Nádas-mente nevét a „nádas”-ról veszi, a 1897-es statisztikák még itt is nagyon alacsony „nádas”-müvelési ágat jeleznek [31. tábla].

\begin{tabular}{|l|l|}
\hline Mocsi-, Kolozsvári-, Mezöörményesi járásban (701; 194, 157 kh) & 0,$65 ; 0,2 ; 0,25 \%$ \\
\hline Nádas-menti járásban ( 83 kh) & $0,15 \%$ \\
\hline Tekei (30 kh), Bánffyhunyadi (11 kh), Almási (4 kh), Gyalui járásban (0 kh) járásban & 0,$04 ; 0-0-0 \%$ \\
\hline
\end{tabular}

36. ábra:A nádas aránya Kolozs Vármegye járásaiban

A Mezőség tájökológiai vizsgálata ${ }^{211}$ rávilágított a középkori tórendszer és vízszintszabályozás középkori tájgazdálkodásban betöltött szerepére, bár az állóvizek hiányában ezt a vidéket nem igazán jellemezhette a vízgazdálkodás. Az első katonai felmérés grafikájának alaposabb vizsgálata azonban sok átjárhatatlan vizes lápot, rétet és több kisebb halastavat is jelöl, amely utal a XVII-XVIII. sz.-i intenzívebb vízgazdálkodására. A dűlőnevek is alátámasztják az egykori a halastavak, kenderáztatók, duzzasztott gátak (=dugások) szerepét. ${ }^{212}$ A XIX. sz. második felének ipari, szabályozási beavatkozásai a vizes élőhelyeket csökkentették, majd a XX.sz.-ban végleg eltűntek a vízgazdálkodáshoz köthető pontszerü táji emlékek, helyük ma már csak tájrégészeti terepbejárásokkal rekonstruálhatók.

Nagy kiterjedésü, szinte átjárhatatlan nádas borította a tág, alluviális Egeres-Bogártelkimedencét ${ }^{213}$, elkülönítve ezt a kis területet a Nádas-mente alapvető tájkarakterétöl (ami sokkal szükebb völggyel bír); majd a XX.sz.-i ipari használat lassan feltöltötte és gyár-üzemeivel beépítve erös iparijelleget adott e táj karakterének. A mákói természetes szükület felett -ahol a középkorban duzzasztógát állhatott,- nagyobb, átjárhatatlan vizes, lapályos terület volt eredetileg, melyet a postaút elkerült É-felé (Egeres, Bogártelke, Türe felé) [26.§. melléklet]. Hasonló, vízzel borított helyzet alakult ki Vista és Magyarnádas között is, ahol a Nádas felveszi az É-ról beömlő Nádaska-patakot (Berendi ). Ezt a lapályos területet mind a római út, mind a postaút szintén É-felé kerülte el. Összességében kijelenthető, hogy a nádasok legnagyobb jelentőséggel itt fordultak elö, még ha a vasútépítés ebből sokat fel is töltött. Felszegen néhány holdas nádasok tünnek fel különösebb látványhatás nélkül; és Alszegen sem jelentősek, noha itt is több széles völgyfenék van. ${ }^{214}$

\footnotetext{
${ }^{211}$ Makkai, 2003.

${ }^{212}$ Pl.: Bogártelke (1695): „Piscatura. A falu alatt van egy nagy rettenetes Réthség, a ki nem restelné magát mulatni rajta. Mongák, hogy rák, hal igaz elégh és különbnél különbek vannak. Csík is elég büvön benne"; Hunyad: Két tó között (1673); K.Szentkirály: Csonkos tó (1715); Deréte: Halastó (1744); de gyakori a „Rétben való Tóhej, Halastó gátjánál, Büdös tó, Halász tó, Kígyóstó, Kenderhej, Kákástó, Száraztó, Füzes tóhely, Gát végében, Tsikos tó, Két gát között, stb." kifejezés, melyből majdnem minden faluban előfordul néhány. in. Szabó T. A., 1942.

${ }^{213}$ Bogártelkén 35 (2\%), Darócon 41 (5\%), Egeresen 5 (1\%) kh. mutat a statisztika.

${ }^{214}$ Bocs 5, Felsőfüld 1, Hodosfalva 2, Kissebes 3, Hídalmás 1, Vásártelke 1 kh. mutat a statisztika.
} 


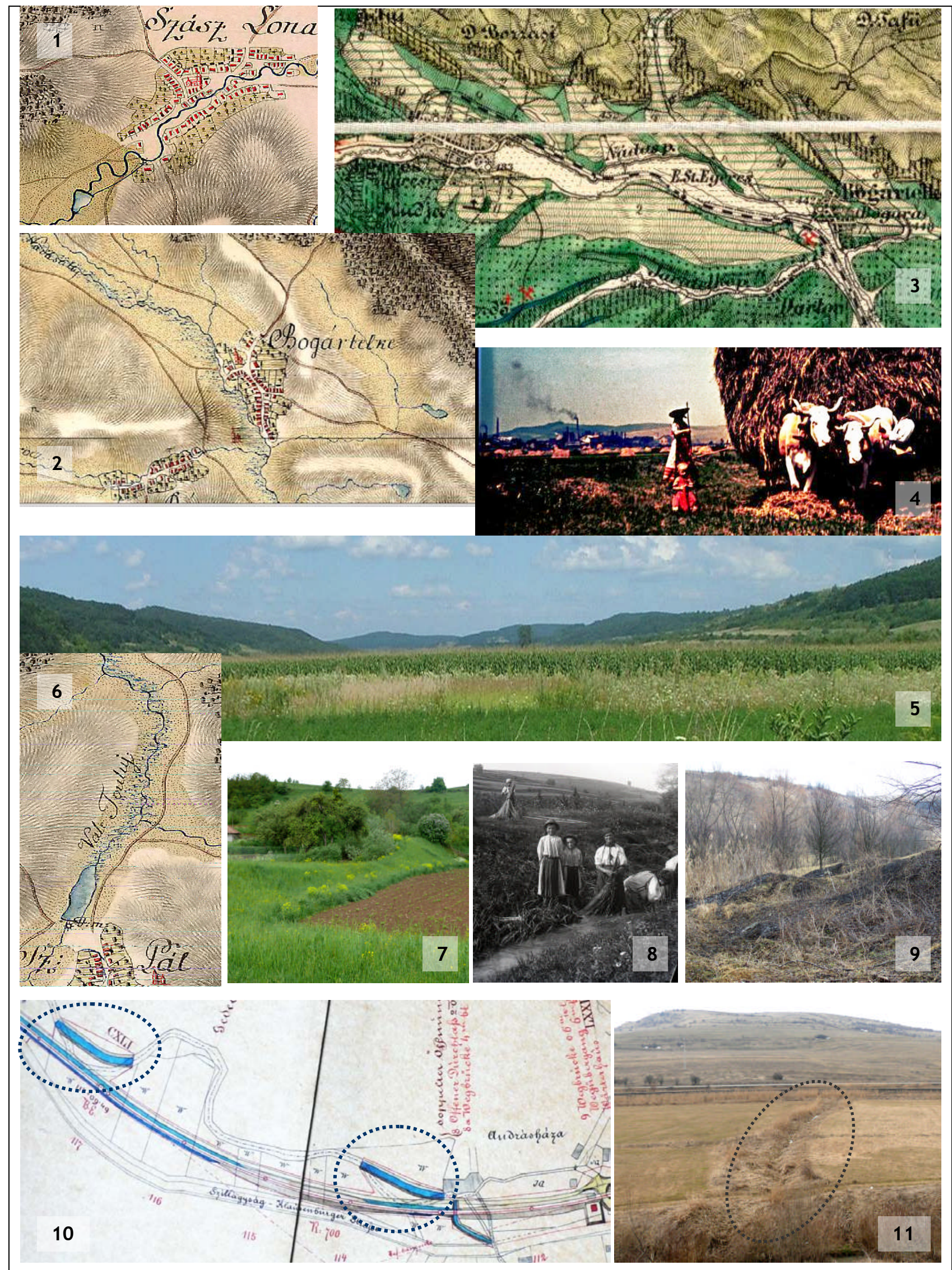

31. TÁBLA: NÁDASOK TÁJI MINTÁZATA, TÁJKÉPI-, TÁJTÖRTÉNETI SZEREPE

1. Duzzasztott gát jelölése Szászlóna felett, a Fenes-patakon (I. kat. felmérés) 2-3. Az Egeresi-medence átalakulása: az I. kat. felmérés látszik a Bogártelke környéki nádas és a két kisebb tó, amelyből a kaolin-gyár ülepitőjét alakították ki. 4. A kiépült és müködő iparvidék (Erdődi M. 1941., NM D 4669) 5. Az Almás-patak elvizenyősödött völgye Középlaknál. 6. A Nádaska-patakon lévő komplex vízszabályozás malmokkal és halastóval Magyarszentpál községnél. 7. Valószínüleg középkori halastó átszakadt gátja az inaktelki „Gát” falurészben. 8. A kender áztatása folyóvízben Mákón a századfordulón (NM F70476) 9. Kenderáztatók kővel kisáncolt medencéi Sztánán, amely ma alig felismerhető. 10-11. A Nádas-szabályozásai a vasútépítés idején átvágásokkal bevezető csatornákkal (MÁV tervtár I.II.3. Nagyvárad - Kolozsvár vonal). 


\section{III.8. A településszerkezet és a falukép tájkaraktert befolyásoló szerepe}

A tájkarakter megállapításban az épített környezetnek, a faluszerkezetnek és az utcaképnek is fontos szerepe van, mivel a javarészt szük völgyekben, völgyek találkozásánál, vízgyüjtők eldugottabb mellékágai mentén kialakult kalotaszegi falvak az egész völgy látványára hatással vannak és azok településszerkezete is ehhez igazodik. ${ }^{215}$ Bátky korán felfigyel rá, hogy az utcás településrendszer mellett részint csoportos településfejlödés is van, ahol a telkek -általában nemzetségi alapon-, tömbök köré vannak csoportosulva. ${ }^{216}$ Furu a völgyi falvakban egyutcás, elágazó utcás és sokutcás falvakat különböztet meg; míg másokon a domboldalra felkapaszkodó havasi szórt települések szeres szerkezetének hatását figyeli meg, amelyeket nem tekint Kalotaszegiesnek, noha azok épületállománya rokonságot mutat a tájegység völgyi falvaival [32. tábla].

\section{III.8.1. A település-típusok bemutatása, jellemzése és azok mintázati jellemzői}

- Zárt utcaképü, egy- két- vagy több utcás falu: A típus ismérve, hogy a házak többnyire az utca felé orientálódnak, a lakóépülettel erős, zárt utcaképet, utcafrontot adva. A kisvízfolyások melletti völgyek adják az utcákat, innen a domboldalra felfutó fésüs telkeken a ház annak nagyobb arányát foglalja el. Ebben a „zárt téri rendszerben” az utcák szerkezete a terepmorfológiához alkalmazkodva válik egy- vagy kétutcássá. A legtöbb magyarlakta és több román falu ebbe a típusba tartozik. Ezen típus kialakulásához erősen hozzájárult a századforduló népi építészetében történt ízlésváltás és az új ornamentikák megjelenése, így képzeletbeli határvonala majdnem jól definiálja a Kalotaszeg kiterjedését. ${ }^{217}$ A háború előtti, hagyományos utcakép (8-10 házzal) már csak Méregjón és Romángyerőmonostoron maradt meg. E faluképeknek hagyományos, jellegzetes elemei (kerítések, sasfás utcakapuk, szakállszárítók, leveles szekérkapuk, gémeskutak) [27.§. melléklet]. mára eltüntek, mert a népi építészeti emlékeket nem védi helyi szabályozás, másrészt az egykor magas művészi érzékéről híres kalotaszegiek mintha elveszítették volna jó ízlésüket és szépérzéküket, így egyre gyorsuló pusztulás, rongálás jellemzi e részleteket. Így a ,jólét” miatt több magyar településen már csak egy-egy hagyományos épület ékelődik a kockaházak közé. A legzártabb, legmeredekebb falú hűvösebb, szoros-völgyekben inkább román falvak találhatóak. ${ }^{218}$

- Havasi szórt településkép, köztestelkekkel, utcakép nélkül: Ennek jellemzői, hogy a kis alapterületü házak a nagyobb telkeken, csoportosan vagy egymástól távol helyezkednek el, de zárt

\footnotetext{
${ }^{215}$ Furu, 2007. p. 18.

${ }^{216}$ Bátky, 1907, p. 50.

${ }^{217}$ Inaktelke 1880 -as, pontos kataszteri térképén a lakóépületek sokkal szabálytalanabbul állnak és nem alkotnak erőteljes utcafrontot. Következtetésem, hogy amikor a szalmafedeles egyszerü épületeket felváltották az oromfalas, elől jelképekkel díszített, reprezentatívabb mintázatú házak, akkor alakult ki a zárt-rendezett utcakép ( 1920 körül), azaz az épületek a társadalmi változásokat tükrözve, „magamutogatva kifelé” fordultak.

${ }^{218}$ Tóttelke, K.Nádas, Kalotabikal, Bocs, Incsel, Egerbegy, Isztolna, Kisfenes, Argyas, Forgácskút, Szomordok falvait az eldugott kalotaszegi falvakhoz képest is rosszabbul közelíthetőek meg, igen izoláltak.
} 
utcaképet nem alakítanak ki. A telkeket fás szegélyek, vízszintes deszkakerítések választják el, amely kertet, legelörészt, de akár még kisebb közbeékelt szántót is tartalmazhat. A sok utca-szerü 'köz' szövevényes rendszert képez; a csomópontoknál alakul ki egy-egy kisebb telepközpont (bolt, kocsma). Magyarok e környéken sehol sem élnek ilyen településformában. Pl.: Roska, Magura, Bánffydongó.

- Átmeneti, széttelepült telekosztású, völgyi helyzetű falu, amely a fent említett két alaptípus (zárt utcaképü/ nyílt, szórt) között két köztes településszerkezet jött még létre e vidéken. Az egyik a szükebb vagy tágabb völgyekben elhelyezkedő, hosszanti, de mégis nagyobb belső kertjeivel széttelepülö telekosztás, ahol a kertekhez sövénnyel bekerített legelők is csatlakoznak, és a zárt utcakép helyett lazább, sikátoros, facsoportokkal tarkított a falukép jön létre, ahol a házak egymástól igen távol, de végül is egy utcára szerveződnek. Pl.: Közép és Felsőfüld, Hasadát, Kisfenes.

- Átmeneti, széttelepült telekosztású, elágazó helyzetű falu: A másik a magaslati vagy tágasabb alluviális helyzetben fekvő falvak, ahol nem alakul ki „fóutca” hanem szövevényes, elágazó az útvonalhálózat és ahhoz igazodva a telkek és kertek változatos formájúak; ezeken a házak általában az utca vagy a központ felé néznek, de a közöttük lévő nagy távolság és kerti tagok miatt szintén nem alakul ki zárt falukép. Pl.: Farnas, Pányik, Marótlaka.

Végül Egerbegy, Bedecs (két határvidéket jelölő falu) településszerkezete tökéletesen alátámasztja a tájkarakter-zónák közötti szerkezetváltást: mivel mindkét falu „,egyik felén” zárt, „másik felén" szórt falukép figyelhető meg.

\section{III.8.2. A népi ornamentika jellege és kisugárzása a környékre}

Bátky és Malonyai korai lakóépület-felvételeit tanulmányozva kiderül, hogy a ma ,jellegzetes, híres és tipikus pávás ornamentikájú” lakóépületek a tájegység alig 100 éves divatirányzatának hozadékai. A néprajzi érdeklődéssel, a világkiállítással megnyíltak a díszítőművészeti lehetőségek, és nem kizárt, hogy a svájci-típusú villaépítészet, fürdőépítészet faszerkezeti motívumait vették át az ügyes kezü ácsok, asztalosok. Inaktelke régi lakóépületeinek oromzatát idörendi sorba rendezve kirajzolódik a díszítőmotívumok 1910-30 közötti dinamikus fejlődése. Kalotaszeg szegélyvidékének román falvaiban helyszínelve döbbentem meg azon, hogy a kalotaszegihez mennyire hasonló házmintázatok láthatóak ott is. ${ }^{219}$ Amikor a magyarok a kommunizmus éveiben lakóépületeiket átépítették (a gazdasági épületek megmaradtak), akkor a románok szegényebb életkörülményeik miatt a hagyományos formákat, elemeket és épületrészeket megőrizték. Így e falvakban sok, ma érintetlenhagyományos megjelenésű udvart találni (pl. Argyason, Tóttelkén 15-20 ház). E „müvies-kalotaszegi” formakincs kisugárzása azonban a Havasok felé is jelentős volt, ahol ácsmesterség révén meg is honosodott, és mai napig sok hasonló „cifraház” található.

${ }^{219}$ Tóttelki adatközlök mesélték, hogy a háború után magyar mestereket hívtak meg a környékröl (pl. oda Inaktelkéről Rác Ferencet, aki több évet töltött időszakosan a faluban), hogy számukra is hasonló kivitelü épületeket, kapukat készítsen. 


\section{III.9. A templomtornyok és látványkapcsolataik tájkarakterre ható szerepe}

A Kalotaszegről kialakult táj képéhez szorosan hozzátartozik az égbeszökö, karcsú, négyfiatornyos, zsindellyel fedett templomtornyok látványa. E kanonizálódott látványhoz Kós, Thoroczkay, Debreceni XX. sz. eleji grafikái és metszetei nagyban hozzájárultak, amelyek néhány templom „ikonját” nemcsak építészettörténeti jelentőséggel ruházták fel, hanem egyenesen „magyarságszimbólummá” tették, tájképi jelentőségét megannyi írás dicséri [28.§. melléklet], [33. tábla].

A Hunyadi-medence és a felszegi táj vaskos, markáns megjelenésü középkori templomtornyai a lazább dombvidéken és az alacsony erdőborítottság mellett, a kopár tájban messziről feltünő, erőteljes fókuszpontokként jelennek meg, ${ }^{220}$ és mint a legismertebbek a vidéken, kulturális szimbólumokká váltak az elmúlt 100 évben. Damos, Méregjó, Bedecs, Magyarbikal és Ketesd (egykori) hasonló tornyai zártabb völgyi helyzetük miattkevésbé dominálnak a tájképben, noha a saját faluképüknek fontos, látványos és domináns fókuszaik. A Nádas-mentén a középkori, egyterü kisebb kőtemplomokhoz (Daróc, Vista, Sárd) torony helyett harangláb tartozott, amelynek látványa a tájban nem volt nagy-hatókörzetü, erős látvány-determináló.

Szinte Gábor és Balázs Ilona századelejei kutatásai és dokumentációi hívták fel a figyelmet a vidék román fatemplomainak építészettörténeti és esztétikai értékeire, majd Miklósi-Sikes Csaba levéltári kutatásai további emlékeket tártak fel, sokszor már csak elbontásuk szöveges közlésével. A fatemplom, és fatorony vagy harangláb önmagában, külön is megjelent. Szinte tanulmánya ${ }^{221}$ rávilágít a magyar és román faépítészet szoros kapcsolatrendszerére és egymásra hatására. A zsindellyel fedett, fatornyos vagy haranglábas román fatemplomok az 1700-as évekre már minden faluban megépülnek: ezek a középkori templomoknál sokkal kisebbek, alacsonyabbak és sötétbarna színúek. A magaslaton álló épületek beleolvadtak a zárt völgy fásabb környezetébe, így nem tudtak saját falujuk látótávolságán túl megjelenni a tájban. Kivétel a csodálatosan karcsú, égbeszökő felsőfüldi templom, amelynek látványa dominál a völgy felső folyásán. E „,mobil” faszerkezetes épületek közül a XX.sz.ban többet is áthelyeztek (pl.: Magyarvalkóit> Egeresre, Tamásfalvit> Ferencbányára). Végül az 1920as években kezdődött új román templomépítési hullám neo-bizánci stílusú, centrális tömbjei, nagy látvány-hatósugarú, de erőszakos, tájidegen elemekké váltak a völgyek képében. ${ }^{222}$

A templomok mellett a kastélyok, kúriák, udvarházak is fontos térszervező fókuszpontok voltak. Vizuális hatásaik sokkal kevésbé jelentkeztek a tájkarakterben, mint a templomtornyoké, de társadalmi-, és gazdasági orientáló erejük jelentőssé tette őket a zónáikban. A kutatás nem tud ezek kertművészeti-, és tájtörténeti jelentőségével részletes foglalkozni, de a melléklet a teljesség igénye nélkül, mutat be a feltárt képi forrásokból néhányat [29.§. melléklet].

\footnotetext{
${ }^{220}$ Bánffyhunyad, Kalotaszentkirály, Körösfő, Magyarvalkó, Magyargyerőmonostor.

${ }^{221}$ Szinte, 1913, p. 17. (lásd a 28.§. mellékletben).

${ }^{222}$ Bánffyhunyad, Romángyerőmonostor, Középfüld, Váralmás, Egeres-gyártelep, Magyargorbó, Szucság és Gyalu.
} 


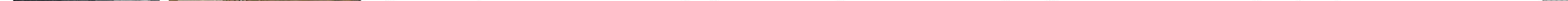

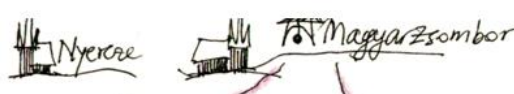

F̂ $^{*}=$

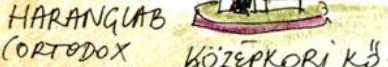

Y.REFORM) TEMPLOM FA ZSINDGWYL

柴定

Bgadralke

CORTODOX.V.
REFORMATUS

régi román templom. 10. Kalotanádasi torony alig kibukkanó süvege 11. Kalotabikal 12. Egerbegy 14 . Máriatelek 15 . Sárdi régi és új templom 


\section{III.10. A bányászati tájsebek, eróziós jelenségek}

\section{tájkaraktert befolyásoló szerepe}

A földtani szerkezet változatosságából már kitünt, hogy bányászható kőzetekben Kalotaszeg egységesen gazdagnak mondható, de a vulkáni és üledékes kőzetek bányái eltérő karaktert és mintázatot adnak egy-egy tájkarakter-zónának. A felszíni beavatkozások (kőfejtők, ipari épületek, eróziók) a vidék tájtörténetének organikus és fontos részét képezik és a faluképben is markánsan tükröződnek. Annak ellenére, hogy ezek a mikrodomborzati formák sokszor csak „,pontszerüen” ábrázolhatók a vizsgálati térképeken, kitettségük miatt a tájészlelésben mégis kiemelt jelentőségüek. ${ }^{223}$

\section{III.10.1. Bányák és bányászati tájsebek, kőfejtők téri tagozódása [34. tábla]}

A | B körzet A vulkáni kőzetek fejtése 1870 indult meg nagyobb ütemben, amelyet elsősorban útépítésre használtak (útkavicsolás, járdakövezés, vasút). A fejtés központja az eruptív Vlegyásza É-i nyúlványain a Kissebesi Gránitkőbánya Rt. ${ }^{224}$ volt. A Sebes-Körös völgyében 1940 körül jelölt kilenc különálló bánya mára összenött. Szerencsés tény, hogy a Marótlaki-csúp Ny-i oldalának tájsebe nem jelentkezik a Hunyadi-medence képében. A sötétszürke, ciklop-alakú épületkő viszont megjelenik e környék faluképéiben [30.§. melléklet]. A gyerővásárhelyi Köves-hegy DK-i oldalában volt a község kőbányája, amelyből piroxén-andezitet és egy másikból kvarctrachitot már „emberemlékezet óta fejtettek,"225 ide tartozik még a Pányiktől D-re fekvő dácitbánya is. További két andezitbánya volt Gyalunál. ${ }^{226}$ Összességében elmondható, hogy ezek a bányák a fơuthoz közel feküdtek; a stabil kőzeten megtelepedő vegetáció és szürkés színük miatt kevésbé feltünőek a tájlátványban; a kissebesi központon kívül mára jelentőségüket vesztették.

Sokkal erőteljesebben jelentkeznek a tájképben a világos eocén alsó- és felső durvamészrétegekhez kapcsolódó kőfejtők [31.§. melléklet]. A zónák tájkarakteréhez a vörösesbarna rendzina talajjal borított lejtőkön felbukkanó -mészkő fehér- és az agyagfejtők vörös-, foltjai is hozzájárulnak. A mára némiképp behegedt domboldali kőfejtők messziről „csak” felszíni eróziónak tünnek, de közelebbről vizsgálva jól kivehető egy-egy jobb minőségü mészkőréteg tudatos kifejtésének ténye. ${ }^{227} \mathrm{~A}$ Nádas-menti temetők 1800 -as évekből datált faragott sírkövei is bizonyítják a korai kitermelésüket. Néhány nagyobb kivételével ma már ezek kőfejtők nincsenek használatban. Egyes fejtők ma is jól

${ }^{223}$ Edvi-Illés Aladár körösfői akvarelljei korán a kalotaszegi „tájesszencia” részévé tették eróziót; majd Kós és Solty is felfigyelt e talajsebekre, mint kiemelt tájelemekre: „E terület túlnyomó része egyhangú, kietlen, sőt szomorú föld. Kopasz, köves dombok, esömosott árkokkal szaggatott hegyoldalak, fátlan... kínosan müvelt oldalas szántók egyhangú, lehangoló egymásutánja... sovány, köves, alig arasznyi termöföld, száraz, meszes kietlenség a túlnyomó része. Solty, 1944., p.124.

${ }^{224}$ A társaság képekkel gazdag illusztrált ismertetője fontos tájtörténeti forrás: a kissebesi erős, mállásnak, kopásnak nagyon ellenálló kvarzporfír követ zömében kockakönek használták; kísérö bányavágányokkal ellátva teraszosan müvelték. A rétegesebb marótlaki dácitbánya (5km-re) csak zúzottkőnek volt alkalmas. in: Glasner, 1905. pp.1-19.

${ }^{225}$ Csonka-hegy és a Köves É-i oldalán ma is látszik helye (Hofer és Schafarzik alapján, 1904. p. 146.)

${ }^{226}$ Gyalutól nyugatra és keletre, in: Schafarzik, 1904. p.145.

${ }^{227}$ Pl.: Egeresi Kerekdombon a vasút felett, M.Gorbótól Ny-ra vagy a M.Nádasi vasútállomás feletti oldalon. 
láthatóak (körösföi, erdőfalvi és hágó-tetői kőfejtő), míg másokat csak tájrégészeti terepkutatással lehet megtalálni (ilyenek pl. a türei kőfejtők teljesen benőtt gödrei az út jobbján). A három magashegység felé az erdőborítottság miatt, Szilágyság és Mezőség irányba a puhább oligocén kőzetek miatt tünnek el jelezve a tájkarakter-zóna határát; Jára irányába szintén eltünnek és a „kalotaszegihez-hasonlósürüségben” majd csak Torda környékén jelentkeznek újra. A különböző térképek, terepszemlék és dűlőnév-összeírások segítségével közel 50 mészkőfejtőt és tucat mészkemencét azonosítottam, amelyek Kalotaszeg geológiai határával -különösen az eocén rétegekkel-, szinte tökéletesen egybeesnek. Egyértelmű a geológiai tényező nagy hatása a hagyományos gazdálkodásra és a tájkarakterre. A mészkőkőfejtők térbeli és időbeli tagolódásáról ${ }^{228}$ elmondható, hogy azok a Hunyadimedence kivételével egyenletesen jelentkeznek Kalotaszegen, de négy körzetben mégis sürüsödnek kiemelt gazdasági-, ipari szerepet kapva és ezért tájképi következményekkel is:

C: Jelentős körzet Zsobok-Sztána-Tóttelke-Nagykapus környéke. A mészkő szép tarka, habos, eres-foltos változatát -melyet a Gáldomb DNy-i oldalából fejtettek-, ,zsoboki márvány” (alabástrom) néven hozták forgalomba a századfordulón. ${ }^{229}$ [32.§. melléklet].

D: A legnagyobb felszíni tájsebekkel rendelkező körzet Egeres-Jegenye környéke, ahol a 1877es térkép még csak három kőfejtőt jelölt. A Kalotanádas-felé eső (mára fásított) hegygerincen szintén bányák müködtek ekkor, tájsebei ma is látszódnak. A Gyerővásárhely felé bővülő bányákban mai napig intenzív felszíni kitermelés folyik, amely nemcsak az értékes gipszvegetációt veszélyezteti, de egyre komolyabb tájképi hatásai már dominálnak a vízválasztó tájképében. Egeres környéke a XX.sz.ra az É-ra fekvő, oligocén rétegekből fejtett barnakőszén-bányászatáról is híressé vált, melynek meddőhányói ma is látszódnak. Majd a bogártelki kaolingyár kezdte meg a homok-kitermelést. Míg a Sólyomtelke felé eső hatalmas meddőhányói és bányatavai nem érvényesülnek a Nádas-völgyi tájképben, addig a feltöltődött és kiszikkadt ülepítő maradandó táji beavatkozást hozott a Kis-és Nagyhegy mögötti természetes vizes horpában (töltések, vezetékek, épületek, szalagok). [33.§. melléklet].

E: A Nádas-menti kőbányászatnak Vista volt a központja. Kőfejtésre utaló dűlőnevek már 1700-as évektől szerepelnek a vidéken, de a jó minőségre épített, kolozsvári igényeket is kielégítő, szervezett kőfejtés-kőfaragás a vasút-építés idején lendült fel. A környéken számos kisebb kőfejtőt és mészkemencét jeleznek a térképek, amelyekből többet magam is helyszíneltem. ${ }^{230}$ A magas müvészi

\footnotetext{
${ }^{228}$ A kőfejtők időbeli változásának, hangsúly-áthelyeződéséről évről-évre részletes adatokat közöl „A Kol. Kereskedelmi és Iparkamara Jelentése kerülete gazdasági, kereskedelmi, ipari és forgalmi viszonyairól nevezett évben” c. sorozat (1878-1913) ${ }^{229}$ A kő szépségét Mike Lajos zsoboki ref. lelkész ismerte fel, majd a vasút kiépülése után társult Szepessy Lajossal és esztergált dísztárgyaikkal komoly sikereket értek el hazai és nemzetközi kiállításokon. Szepessy a II.vh.-ig élt Zsobokon, ahol gazdag dendrológia parkot alakított ki a jellegzetesen századfordulós „svájci villája” feletti domboldalon, amelynek egyes egyedei mai napig megvannak. In. Kereskedelmi és iparkamara, 1878. p. 132-133. és Sas, 2007. pp.156-162. és pp. 425-430.

${ }^{230}$ Nagykapus felett a Köves és Medve-hegyen, Inaktelke: Kősziklán, Darócon, M.Gorbói keresztnél és a türei malomnál, a Türébe vezető út mellett befüvesedve kőfejtők sora látszik, Vistában 6, M.Nádason, Mérában 2.
} 
érzékkel rendelkező Kalotaszeg több falujában építőkő és sírkőkészítésre szakosodott népi kőfaragó ipar alakult ki, ${ }^{231}$ és ez a hagyományos épületekre és a faluképre is nagy hatással volt [35. tábla].

F: Fontos körzet volt még Szucság - Bácsi-torok - Hója tető, ahol a jó minőségü épületkövet nagy darabokban fejtő bánya „emberemlékezet óta létezik”, 232 és a bánya felett 'kőbányászok szerszámait javitó ' római kovácsműhelyt tárták fel, ${ }^{233}$ így itt tájtörténetileg igazolható egy, a nagyvárosi igényeket kielégítő, közel 2000 éves agglomerációs ipari táj léte.

Felszegen inkább magányos fejtőket találunk, amelyek környékén nem épült ki nagyobb ,ipari körzet”. Ezeket ${ }^{234}$ az elmúlt 50 évben felhagyták, azok becserjésednek, alig megtalálható tájsebei csak kis hatókörzetben érvényesülnek. Egyre kevesebb a kőfaragói munka és a kőfaragáshoz értő mesterember; továbbá az olcsó beton, a mükő kiszorították a hagyományos alapanyagot.

\section{III.10.2. Talajok, eróziós jelenségek táji mintázata, téri eloszlása [36. tábla]}

Kalotaszeget zömében mezobázikus, telített barna erdőtalajok, földes kopár talajok, valamint kőzethatású rendzina, és márgán képződött rendzina talajok borítják; savanyú talajok a gyalui tönk környékére jellemzők, míg a podzolosodott agyagbemosódásos vörösesbarna erdőtalajok a Mezőség irányában jelennek meg. ${ }^{235}$ Általában elmondható, hogy Kalotaszegen igen rossz minőségü termőtalaj volt egykor és van ma is; és ez éppen ott változik meg, azaz válik jobb minőségüvé (pl. Középlak, Berend felé), ahol más geológiai, domborzati és müvelési váltások is megjelennek ${ }^{236}$ [34.§. melléklet].

Alszegen és Nádas-mentén a XIX. sz. legnagyobb táji léptékű terepalakítása a vasútépítés volt. Ez a Zsobok-Sztána-Egeres-szakaszon komoly beavatkozásokat kívánt: a töltés és bevágás müszaki kivitelezése, a híd-alagút-rézsűk kiépítése több évvel lassította a munkát, amelynek talajszerkezeti kérdéseivel részletesen foglalkoztak [35-37.§. melléklet]. Mára a töltés a vegetáció miatt belesimult a tájba, de az akkor megjósolt állandó földcsuszamlások mai napig gondot jelentenek és munkát adnak a CFR-mérnökeinek. E tájváltozás új megállókat, „új távlati tájképeket” nyitott meg. Kós Károlyt is megragadta festői szépsége, majd Varjúvárát is ide építette, amelyet a Sztánai Nyaralótelep követett.

A talajerózió terén emlékezetes év volt 1897, amikor a szokatlanul nagy téli és tavaszi esőzésektől

\footnotetext{
${ }^{231}$ Sírkőfaragásáról híres Vista geológia és néprajzi hagyományait dolgozza fel Hála. In: Hála, 1995. p.159.

${ }^{232}$ Schafarzik, 1904. p. 144.

${ }^{233}$ Tulogdy, 1943. p. 141.

${ }^{234}$ Kő lelőhelyek: Hunyad - Dinnye-domb, M.Kereke-Hármas-Szikla, Magyarvalkó- Tunya, Vársza dülő; Jákótelke -Kőlik, a Mészmárt D-i oldala, Erdőfalvi bánya, a Hágó-tetői bekötő út menti bánya, Kőrösfő - a Nádasi útnál. Mészkő-szerü, kristályos konglomerátumot fejtő malomkőbánya volt M.Gy.Monostori a Rákos-pataknál és a Vártető oldalában; DongóBedecs közötti hegylaposon, amit a Kapusi malmokban használnak. In: Koch 1889, p. 34.

${ }^{235}$ Talajosztályokkal bemutatott térképvázlatot közöl Szabó A 1985, p. 30-32.

236 A Cziráky-féle 1820-as parasztvallomások határleíró passzusa korai hiteles forrás a talajminőségre vonatkozóan. Ez alapján ,a kalotaszegi települések határának harmada, fele mondható csak jónak, más részük igen oldalas, kövecses, rosszul művelhető; a Felszegi falvak még a trágyát is rosszul tartják; Alszegen sárgás, porondos a föld; a meredek völgyfö-falvakban szakadozott, vízmosásos a táj; ugyanakkor Kórod-Berend és Középlak-Zutor irányában sokkal jobbnak, feketébbnek, lapályosabbnak mondható, amelyet trágyázni sem igazán kellett.” In Takács, 2006.
} 
komoly földcsuszamlások keletkeztek ${ }^{237}$ [38.§. melléklet]. A falvak agyag-porondos házaihoz használt agyagot a falu határából szedték (pl. Inaktelkén a Lüget oldalából), ezeknek növekvő szakadási mai napig látszódnak. A termőföld minőség-romlásának veszélyét már a XX.sz közepén felismerték. A visszacsatoláskor az EMGE-Talajvédelmi Szakosztálya komoly munkálatokat terveztek a további talajpusztulások megakadályozására [39.§. melléklet].

Kalotaszeg talajszerkezeti állapotáról elmondhatjuk, hogy a történeti felszíni tájsebek állandósultak. Az eróziós sebek mintázatai nehezen ábrázolhatóak a térképeken, mert azok kis alapterületủek, de nagy gyakorisággal fordulnak elő. Sok népmüvészeti felvétel már-már szorosan kapcsolódik a környező tájsebek domináns látványához (pl. Körösfö) [40.§. melléklet].. Az egykori kőfejtők zöme mára nincs használatban, cserjésedik, de még azonosítható. A felszíni talajsebek csak kis része növekszik, mert a húsz éve egyre csökkenő a mezőgazdasági müvelés (különösen a szántás), és az állatállomány drasztikus csökkenése miatt a felszíni talajszakadások többsége lelassult és inkább begyepesedve záródik. A legnagyobb lemosódások Alszegen, és a Nádas-menti ferde üledékrétegek Dfelé néző meredekebb oldalain láthatóak. A falvak határában állandósult tehénhajtókon és a túllegeltetett oldalakban erős a megnyílt felszín lemosódása . A régi mészkőbányák mellett láthatóak a legnagyobb tájsebesek, amelyeket még a fenyőfásítás is nehezen stabilizált.

\section{III.10.3. Az iparosodás és a szuburbanizáció hatása a tájkarakterre}

A XIX-XX.sz.- bányászatra alapozott iparosítása és az elmúlt 20 év szuburbanizációs iparosodása alapján három területet lehet kijelölni, ahol az ipar felülírva a mezőgazdasági tájat, végérvényesen megváltoztatta a táj karakterét: (1.) A Kissebes-Marótlaki völgyszakasznak dominánsan maghatározó látványelemévé vált a mára összeért, hatalmas kiterjedésű felszíni kőfejtő, amely betonrostáival, futószalagjaival alapvetően megváltoztatta annak tájkarakterét. (2.) Az Egeresimedencéről kijelenthetjük, hogy közel 130 éve kezdett átalakulni bányászati ipari tájjá, amely az egyre növekvő (mész-, gipsz-) bányagödrök mellett eleinte csak kisebb, tájba simuló müszaki létesítmények és korában is igényes épületekkel bővült, de nem uralta a környéket. A barnakőszén- és kaolinbányászattal, majd az 1950 utáni betelepítéssel, igénytelen új lakóépületekkel és hatalmas gyárüzemekkel visszafordíthatatlanul megváltoztatta a sziluetteket, az átlátásokat és a völgy ártéri arculatát. A bővülő jegenyei bányákban mai napig intenzív kitermelés folyik, amely nemcsak az értékes gipszvegetációt veszélyezteti, de komoly tájképi hatásai is vannak. (3.) A Kapusi-völgyben a szocializmus alatt vasgyár épült ki, majd Gyalu környékén erőmüvek és manapság az autópálya hozadékaként sok a logisztikai központ, benzinkút, igénytelen ipari épület, amely a szászfenesi szuburbanizációs folyamatokkal együtt szintén teljes karakterváltozást okozott.

${ }^{237}$ Szádeczky személyesen megvizsgálta a bökényi süllyedést, a dankit, türeit, ketesdit, farnasit, az Egeres-Sztána vasútvonal mentén bekövetkezett csuszamlásokat és a m.gorbói nagy csúszást, amely miatt a vasutat is Nádas túlpartjára helyezték át. 


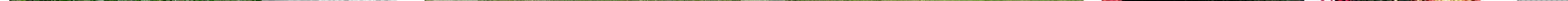



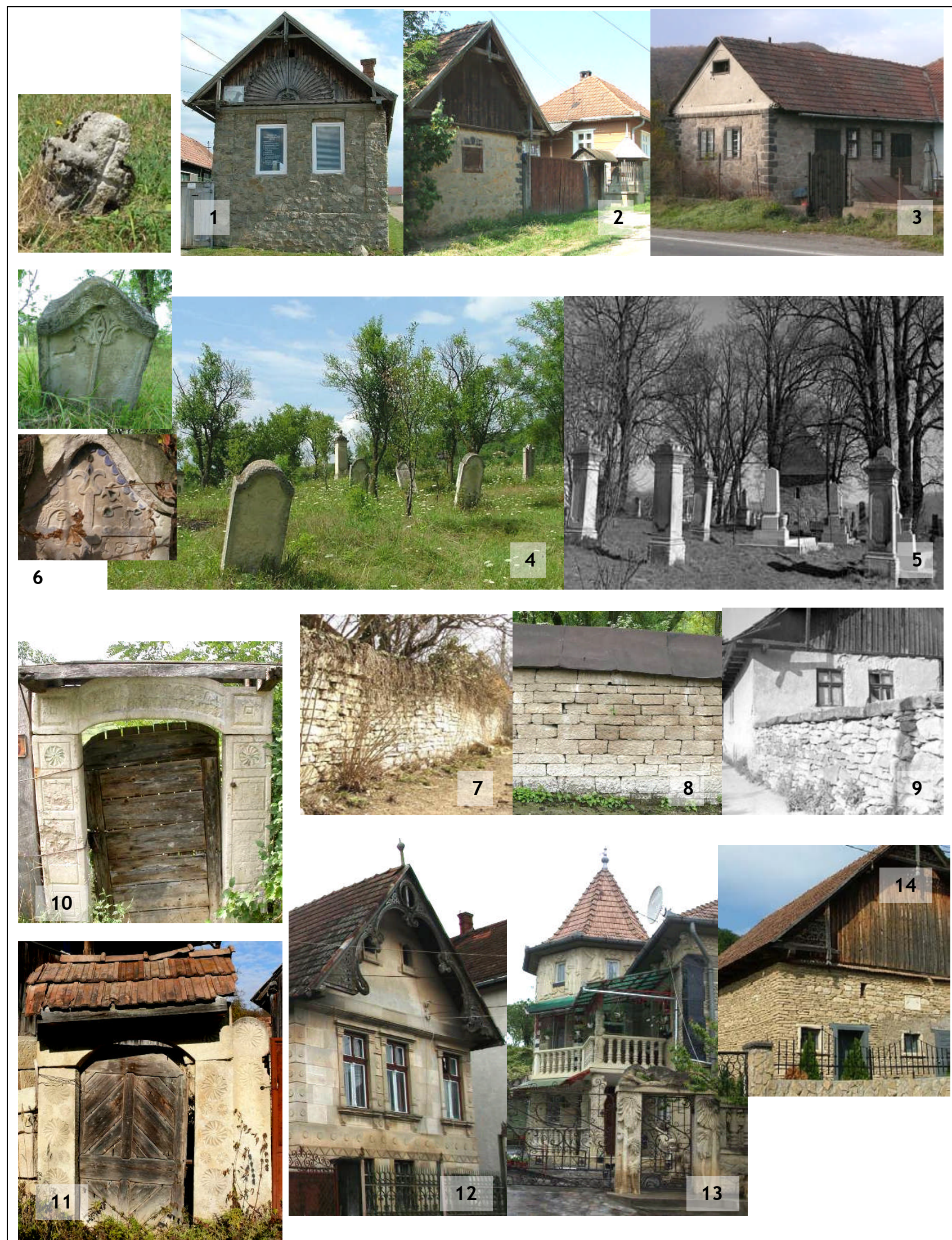

35. TÁBLA: A KÖBÁNYÁSZAT HATÁSA A FALUKÉPRE, ANNAK KARAKTERÉRE

1-3. A XX.sz. elején épült sötétszürke/fekete dácitciklop-kőből készült épületek jellemzőek Hunyad környékén (fötér, Malomszeg, Remete) 4. Türei temető XVIII-XIX.sz.-i sírkövei 5. Nádasdaróci temető a háttérben a XII. sz.-i kőtemplommal és az elötérben a '30-as évek oszlopos jellegü síremlékeivel. 6. Erdőfalvi román sírkereszt és az inaktelki sírkövek magas művészi érzékről tanúskodó részletei. 7-9. Szárazon rakott kőkerítések (Sztána, Zsobok, Vista: KJNT_07807) 10-11. Igen ritka, kőből faragott kapusasfák Kispetriben és Kalotanádason. 12-13. Vistai faragott kőház faornamentikával a '30-as évekböl, és naiv figurákkal díszített Cifra-ház Vistán a '70-es évekböl. 14. Csür Magyarszentpálon, ahol jellegzetes a vakolatlan, lapos kövekböl álló falazás. 


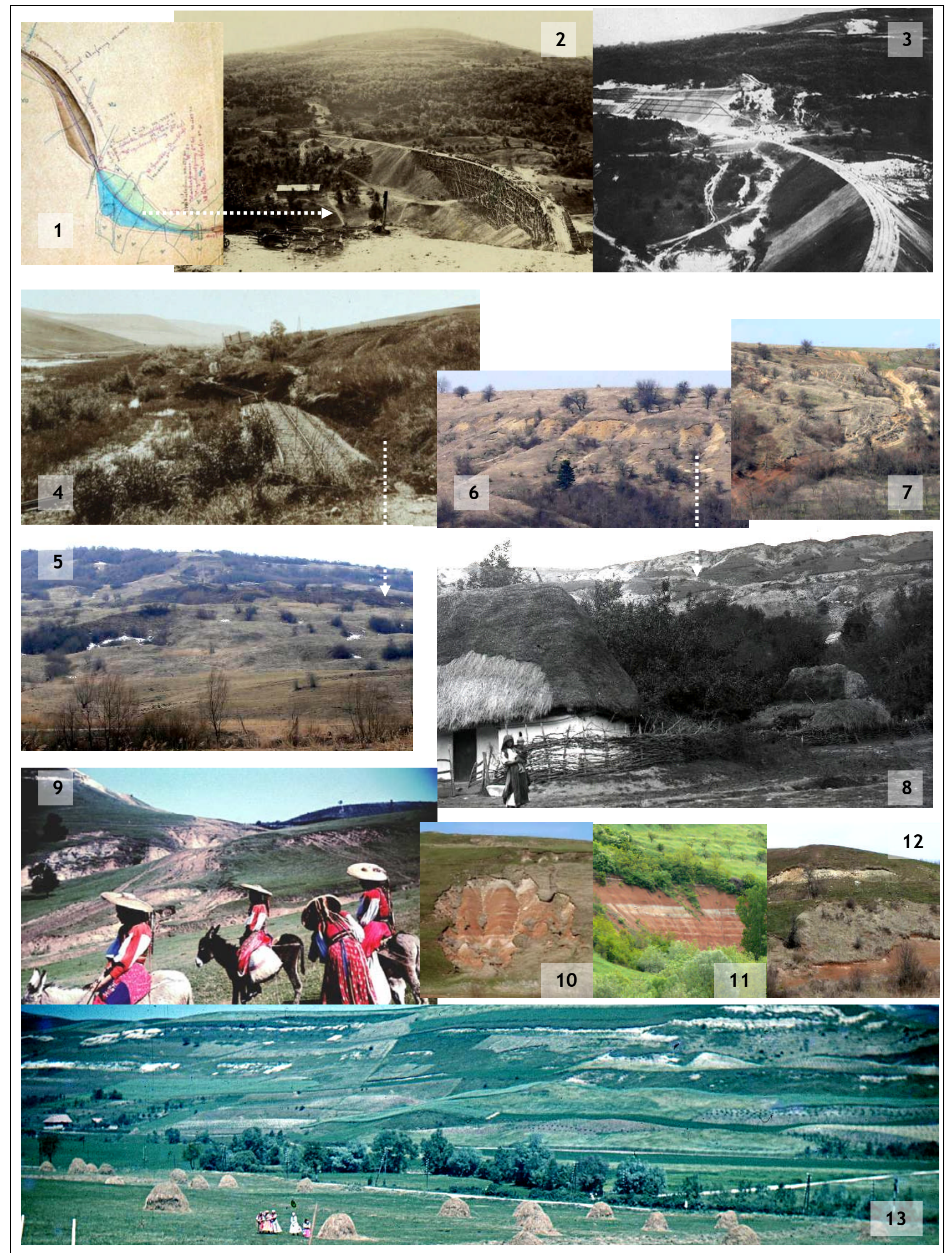

36. TÁBLA: A TALAJSEBEK HATÁSA A TÁJKÉPRE, ANNAK KARAKTERÉRE

1-3. A Sztánai vasúti beavatkozás földmunkáinak dimenziója és az ahhoz tartozó rézsümegkötések (Veress Ferenc: Kolozsvár és környéke c. album Képkönyvtár és http://vmek.oszk.hu/02100/02109/html/552.html), 4-5. A magyargorbói földcsúszás, amely használhatatlanná tette a

vasúti pályatestet, ezért azt később a Nádas-patak bal oldalára helyezték át (Közlekedési Múzeum, Fotótára A-713-II/3.) 6-8. Az Inaktelki Lügetszél szakadásos oldala a XIX. sz. végén (NM F3452) és mai felvételeken. 9. A vistai oldal eróziós sebei, földfolyások kitaposások (Erdődi M., 1942 NM D465). 10-12. A vörös agyagos föld tájsebei a Nádas-völgyében (M.Gorbó, Andrásháza, M.Nádas) 13. Kisméra és a Méra felé vezető bekötő út melletti oldal, ahol fehéren villannak ki az eróziós tájsebek (Erdődi M. NM, D789 - részlet) 


\section{A TÁJKARAKTER-ELEMZÉSEK EREDMÉNYEI ÖSSZEVETÉSEK, KÖVETKEZTETÉSEK}

A dolgozat utolsó fejezete a kutatás eredményeit rendszerezi és elökészíti a külön füzetben található téziseket. Elsőként a két tájkarakter-elemzés módszertan eredményeit, és területi konklúziót mutatom be. Majd a tájkarakter-jegyek, és mintázatok szintetizálását célzó összevető táblázatból vonok le következtetéseket Kalotaszeg egységességének és tagoltságának táji és néprajzi relációjában.

\section{1. A felszínmorfológiai- és térélmény-alapú tájkarakter-elemzés}

\section{eredményei és összefüggései a térségi tagozódással, zónákkal}

A II. fejezet tértípusainak konklúziójaként megállapítható, hogy a vizsgált terület, nem egy egyöntetü felszínmorfológiai tájegység, hanem a teljes földtörténeti sort felsorakoztató, változatos idöpontban keletkezett, és alapkőzetei miatt a későbbi korokban is különbözőképpen reagáló domborzati forma, amelynek eltérő alaptulajdonságai nagyon változatos alakzatokat, térformákat hoztak létre. Ez igazolja az alapos és részletes felszínmorfológia-vizsgálat szükségességét e sokszínű dombvidéken, továbbá azt, hogy az eltérő alakzatok érdemi tájkarakter-jegyeit adják majd a tájkarakter-elemzésnek. Ezek a különbségek annyira jelentősek, hogy megkérdőjelezve Kalotaszeg és környékének egységességét, inkább annak tagoltságát támasztják alá, úgymint:

A magasabb hegyvonulatok (Gyalui-Havasok, Vlegyásza, Tomoldok előhegység) távlati képei markáns tájképi lehatárolást adnak a belső dombvidéknek D-röl és Ny-ról, ugyanakkor É-on, K-en és DK-en nincsen ilyen domináns sziluett-formáló erök. Emiatt itt nem olyan határozott az átmenet a Borsa-völgye- Mezőség-, Torda- és Erdővidék felé. Ezt a jelenséget a társadalom-néprajzi kutatások is hasonlóan látják, mivel ez utóbbi két terület irányában nincsenek olyan éles etnikai és népmüvészeti választóvonalak sem. A Vlegyésza sziluett-formáló, domináns tájképi ereje csak Felszeg, és Alszeg néhány magasabb pontján dominál, de Nádas-mentére nincs hatással lényeges különbséget okozva a Ny-i és a K-i zónák között. Ezt a tagolást megerösíti, hogy az egyébként nem magaslati látványként megélt 'Körösfö-Pányiki vízválasztó plató' mégis nélkülözhetetlen szerepü e tájkarakter-zónák szétválasztásában. Ez a vízválasztó-szerep összefügg a kora-középkori megyerendszer kialakulásával is: mivel itt volt a gyepüzóna (Kiskapus ${ }^{238}$ ), majd a Bihar (Ny) - és Kolozs (K) megye közti határvonal és e két egyházmegye határvidéke is.

A Gyalui hegység passzívabb látványelem, platós szerkezetével nem uralkodik annyira a tájképben, mint a Vlegyásza. A Magyargyerőmonostor-Bedecs-Kapusi-völgyet (Lonka-patak) a Köves heggyel együtt félhold alakban magához kapcsolja a stabil vízhozamú hegyi patakjaival és azok

${ }^{238}$ Balázs É., 1939. térkép. 
malomrendszerével együtt. Bár ma már ezek nincsenek használatban, e vidék jól körvonalazza az egykori híres Kabos-Gyerőffy-Radó birtoktestet, melynek központja Monostor és Kiskapus volt.

A hegyvidékek között elhelyezkedő, belső eocén dombvidék jól faragható, értékes, fehér mészkőrétege egységesíti és összekapcsolja: Felszeget, Alszeget és Nádas-mentét. Ennek előfordulása és kiterjedése 90\%-ban a néprajzi szempontból lehatárolt Kalotaszeget fedi le. Azonban az első látásra egyöntetü „belső eocén dombvidék” geológiai rétegzettségét és mikrodomborzatát alaposabban leírva, jól megkülönböztethetőek azok a felszínmorfológiai jellegzetességek, amelyek az egyes tájrészletek belső individualitásához vezetnek (vízszintes mezapatós ill. ferde síkú tértípus).

A puha, ellenállóbb oligocén- neogén sorbéli üledékek nem rendelkeznek sem jó épületkővel, sem karakteres formációkkal. Így Alszeg É-i területei (Füld-Váralmás), ill. Sárdtól É-ra fekvő bácsberendi térség az előbbitől lényegesen eltérő, lankásan-elterülő, tompa táji alakzatokat mutat. Visszatérő domborzati alakzatok hiányában látványuk jellegtelen és semleges.

A Nádas-mente geomorfológiai szerkezete és vízrajzi struktúrája teljesen egységes: egy fővölgy köré szervezett, egyforma oldalvölgyek sorából áll. Ez az erős „belső kohézió” a zóna néprajzi tulajdonságainak hasonlóságaiban is megnyilvánul. Ezzel szemben Felszeg és Alszeg, amit önmagában koherens néprajzi és társadalomszerkezeti egységként tekintenek, a táj térélményei szempontjaiból több zónába sorolhatóak (lásd bővebben a IV.8. fejezetben).

Tordaszentlászló vidéke, amit alapvetően ugyanazok a kőzetek építenek fel, mégsem rendelkezik visszatérő vizuális jegyekkel, és több olyan geológia-formációt, domborzati-elemet is tartalmaz már, amelyek egyike sem jellemzi Kalotaszeg vidékét (pl.: arany-előfordulás, függőleges sziklafalak, mészkőhasadék-szerü alakzatok).

A vízfolyások vizsgálata egyrészt rávilágított arra, hogy Kalotaszegen nincsenek domináns ártéri folyóvölgyek, ugyanakkor a több kisebb vízfolyás vízgyüjtő-területe és annak határa fontos térhatároló képződmény, mert azok adták a tájegységek elnevezéseit, az arra épülő járási- beosztásokat is. Ezek a vízgyüjtők a tájkarakter-zónák lehatárolásának is alapját adták.

A kisebb és változó vízhozamú hegyvidéki patakok nagy esése tette lehetővé malomközpontok kialakulását, amelyek már a XVIII. sz.-ban jelentős gazdasági szereppel bírtak (Kiskalota-, Bedecs-, Zsobok környéke). A malmok fenntartása rendszeres irányított szabályozást követelt, ami a tájrészletek erősebb kapcsolatához vezetett. Így egy vonalas természeti elem (patak) és az ahhoz kapcsolódó pontszerü táji beavatkozások (malmok) térségi kapcsolathálót hoztak létre erősítve az adott vidék (zóna) entitását. 


\section{IV.2. A tájkarakter-jegyek jelentőségére rávilágító tájértékelési módszer hiányosságai}

Kutatásomban a századforduló településsoros statisztikai adatsorait használtam fel az egyes táji-zónák tájkarakter-jegyeinek objektivizálásához. Az ezek jelentőségére rávilágító tájértékelés módszerének kidolgozása és alkalmazása alapján több lényeges megállapítás tehető:

Az adatsorhoz tartozó térképes források, faluhatárok ismerete nélkül az adatsor félrevezető. Az adatok arra a településre szolgáltatnak reprezentatív értékekkel, ahol a település adminisztratív határai szorosan illeszkednek az organikus, helyi tájhasználathoz. Ezért minden esetben részletesen össze kell hasonlítani az adatsort annak téri kiterjedésével, és a település határait tájilag pontosítani kell az adatsorok értékelése elött.

A nagybirtokosi rendszer ismerete nélkül az egyes települések arculata megtévesztő lehet, mert a pl. egy-egy tömbben elhelyezkedő egyházi-, alapítványi-, nemesi erdőtag nemcsak az adatsort módosítja, de a tájképben is határozott váltást okozhat (pl.: Méra, Bács, Váralmás nagy egyházi erdőtagjai eltérő kezelést, tájtörténeti beavatkozásokat mutatnak, ami ezáltal a tájkaraktert is módosítja).

A kis alapterületű települések sok esetben alulmaradnak a végleges pontszámokat tekintve, mivel területi mutatóik, jövedelmük, állatlétszámuk is igen alacsony (pl.: Bogártelke, Nádasdaróc, Jákótelke általában alacsony értékek mutat). Ellenben a nagy települések jellemzően dominálnak, elvonva a figyelmet az adott zónában átlagos értékről.

Végeredményben kijelenthető, hogy az adatsorok önmagukban hasznosak és látványos eloszlásokat mutathatnak, de azok csak alapos háttérvizsgálatokkal, valós helyszíneléssel fordíthatók le a tájkarakter-elemzéshez szükséges vizuális- vagy mintázati összetevőkké.

\section{IV.3. A tájkarakter-jegyek jelentőségére rávilágító tájértékelési módszer összefoglalása}

\section{és a tájkarakter-zónákra vetített konklúziói a „,kalotaszegiesség” tükrében}

A tájértékelés ${ }^{239}$ utolsó lépéseként egy olyan összesítés létrehozása volt a cél, amellyel megállapítható, hogy melyik falvak bírnak a „LEGKALOTASZEGIES” jegyekkel. Az erdők és legelők esetében látszódott, hogy a nagy-jelentőségü értékek lettek a „nem-kalotaszegies területek”, a többi tájkarakter-jegy esetében azonban a magas értékek inkább Kalotaszeget jellemezték, mintsem az azt körbevevő vidéket. Ezért a 6 tájkarakter-jegy összeadásánál az erdő és a legelő tájértékelését át kellett fordítani, azaz inverz értékét vettem figyelembe (pl.: a 21 pontos erdő átfordult max.24- 21=3 pontra). Azért, hogy mind a hat tájkarakter-jegy tájértékelése azonos súllyal szerepeljen a végső értékelő összegben, az egyes tájkarakter-jegyre kapott értékeket elosztottam az adott jegyhez tartozó faktor-számmal. Az így kapott értékeket összeadva a kapott érték már jellemző lesz az adott falu

\footnotetext{
${ }^{239}$ A módszer korábbi lépéseinek leírását részletesen a III.1.4. fejezet mutatja be. Az egyes tájkarakter-jegyek statisztikai levezetését lásd hátul táblázatos formában, és a táblákon bemutatott színezett térképeken; a zónákra való összesítéseit pedig a 41.§. mellékletben.
} 
„kalotaszegiességére”. A falvakat ismét rendeztem e „kalotaszegiesség-érték” alapján, és az ismert módon ismét négy kategóriába soroltam őket, sötét sárgától fehérig szín-árnyalattal is jelölve azokat [37-38. ábra]. Ezeket visszarendeztem eredeti zónáikba, ami kirajzolta az egy zónába tartozó települések adatainak egységességét, jellemző átlagértékeit, belső kohéziójának mértékét. Az elemzés végeredménye így a tájkarakter-zónák karakterességének mértékére fog rávilágítani objektív módon.

Az tájértékelés elött azt feltételeztem, hogy a tájkarakter-jegyek több adatból összeálló tájértékei egy-egy tájkarakter-zónában egységes, de legalábbis nagyon hasonló képet fognak mutatni. Az eredmény nem hozott egyöntetüen koherens képet a fent említett hibák miatt (és a táj természetes diverzitása miatt sem), azonban bizonyos zónák tekintetében mégis „szemléletes karakterességet mutatott":

- A két havasi zóna: Havas, Havasi völgyek (H, Hv) falvainak értékei egymáshoz nagyon hasonlítanak, és szinte minden tulajdonságukat, értékelésüket tekintve jelenősen eltérnek, alulmaradnak a többi 11 zónától, ami azt mutatja, hogy a magassági, domborzati és klimatikus viszonyok $\sim 800 \mathrm{~m}$ felett teljesen más mezőgazdasági berendezkedést eredményeznek, amely azután teljesen megváltoztatja az ottani táj karakterét is. Ez a táji adottság településszerkezeti váltást is hoz magával, valamint erős etnikai, vallási, népmüvészeti eltérésekhez is vezet. Csak a három alacsonyabban fekvő, föút-menti völgyi falu (Kissebes, Nagysebes és Sebesvár) tekinthető kivételnek [37. ábra - A].

- Statisztikailag szintén egyöntetủen kisebb értékekkel bír (azaz alig hozza a kalotaszegies tipikusság-jegyeit) a Tordaszentlászlói-vidék, valamint a Felszegi havasalja (Fh) és a Bács-Berendizóna $(\mathrm{Bb})$. Itt -néhány falu kivételével- a zóna-átlag alacsony értéket mutat.

- Egyöntetüen a legmagasabb, egymáshoz képest a legerősebb belső kohézióval, azaz tipikusan kalotaszegi jellemzőkkel három zóna bír: az Alszegi szőlővidék (Asz), a Bánffyhunyadi-medence (Bhm) és a Nádas-menti völgy (Nmv). Ez annak köszönhető, hogy a zónák falvainak lehatárolása területileg nagyon organikus (csak Bánffyhunyad lóg ki több hatalmas erőtagja miatt több szempontból is); valamint, hogy falvaik valóban hasonló táji adottságokkal rendelkeznek. Ezért ezekben tájegységekben a statisztikai adatok már önmagukban is alátámasztják a tájkarakter-zóna településeinek együvé tartozását. [37. ábra - B].

- A tájértékelés segítségével két zóna nem volt egyértelmüen jellemezhető. Az egyik a Felszegi felföld (Ff) zónája, amely egy magas-fekvésü tagolt dombvidék (így két szomszédos falu is akár igen eltérő lehet az erdő \%-os megoszlását tekintve vagy a szélvédettség miatt a gyümölcsösök jelentőségében is nagy különbség mutatkozhat); valamint a térségben sok a havasalji erdőtagokkal felnagyított területü falu, ami az adatsort torzította (Valkó, Pányik, Kalotaújfalu). A másik a szintén alacsony koherenciát mutató Váralmási völgyek (Vv) zónája, amely a legnagyobb területủ zóna. Mivel ez a vidék geológiáját, tájélményeit tekintve nagyon eltér Kalotaszegtöl, kezdetben feltételeztem, hogy a statisztikák ezt alá is fogják támasztani. A tájértékelés azonban megmutatta, hogy a favak nagy része 
rendelkezik kalotaszegies jellemzőkkel, bár ez részben a századfordulós szőlők, gyümölcsösök nagy szerepének is köszönhető. Erdőborítottsága és legelőinek szerepe azonban jelentős (azaz itt, mint nem jellemző tulajdonság, alacsony értéket kapott). Összességében ebben a zónában sok az átstrukturálásra utaló belső egyenetlenség, ami tükrözi a kezdeti felvetést, hogy Szilágyság- Mezőség felé nincsenek olyan erős tájkarakter-váltások. A zóna területileg mégsem választható szét könnyen, így a szomszédos falvakkal (az alszegi szőlővidékkel, és a szintén diverz Alszegi barnakőszénvidékkel) való átrendezéssel lehetne javítani a zónák statisztikai egyenletességét. További két kis zóna (Kapusi-völgy, Kolozsvári alluvium) 4-3 településével szintén nem tudott erős belső egységet felmutatni, ami ismét a módszer korlátaira világít rá [37. ábra - C].

A tájkarakter-jegyek jelentőségére rávilágító összértékek (min.4 - max.18) lehetőséget adtak arra, hogy a falvakat a „kalotaszegiesség” szempontjából emelkedő sorrendbe rendezzem. [38. ábra]. A sor alsó negyedében lévő falvak között (alsó 25\%) csak 4 olyan település található, amelyeket elözetes ismereteim alapján kalotaszegiesnek soroltam volna be, de végül alacsony pontszámot értek el (Egerbegy, Magyarvalkó, Pányik és Kalotaújfalu - ezek mindegyike rossz területlehatárolással rendelkezik). A mezöny második negyedébe is csak néhány, szintén inkább felszeg-havaslaji település került be azok eltérő klimatikus-, erdőborítottsági adataik miatt (Bedecs, Kiskapus, Magyargyerőmonostor, Gyerővásárhely). A középmezőny felső részén már sürübbek a kalotaszegies falvak, ebből föként a Váralmási-völgyek és az Alszegi barnakőszénvidék falvai lógnak ki, amelyek magas szőlő/kert-értékeikkel felhívják a figyelmet arra, hogy létjogosultságuk lenne statisztikailagértékelésében Kalotaszeghez tartozni. A legmagasabb értékü falvak (felső 25\%) közé szintén csak 4, olyan 'kilógó' település esett, amelyeket kezdetben nem tartottam Kalotaszegiesnek (Tóttelke, Váralmás, Alsófüld és Dank) [38. ábra].

A tájkarakter-jegyek jelentőségét alátámasztó tájértékelésről elmondhatjuk, hogy azok zömében koherens, hasonló értékü régiókat hoztak létre, ami a tájészlelésen alapuló tájkarakter-zónák helyes felállítását támasztotta alá. A nagyobb belső különbségekkel rendelkező zónák táji tagoltságra, vagy valamilyen háttérben meghúzódó területi, besorolási problémára hívták fel a figyelmet. Az is kiderült az értékelés során, hogy csak azok a zónák tudnak igazán egységes, hasonló eredményt felmutatni, amelyeket területi lehatárolása organikus módon illeszti az eredeti táji határokhoz azaz fekvésüket tekintve is hasonlóak. A „legsárgább = legkalotaszegiesebb” településeket végül térképesen is megjelenítettem a korábbiakhoz hasonló módon [37. tábla - alsó térképe]. Ezen jól látható, hogy a sárga falvak nagyjából körvonalazzák a néprajzi Kalotaszeget, annak leglényesebb vidékeit. A kertgyümölcsös és szőlö-értékek miatt az egész lehatárolás északra, a védett, melegebb Almási-völgy-felé tolódik el, de lefedi a Hunyadi-medencét, a Nádas-mentét is, ugyanakkor a felszegi, hűvösebb falvak maradnak ki belöle. 


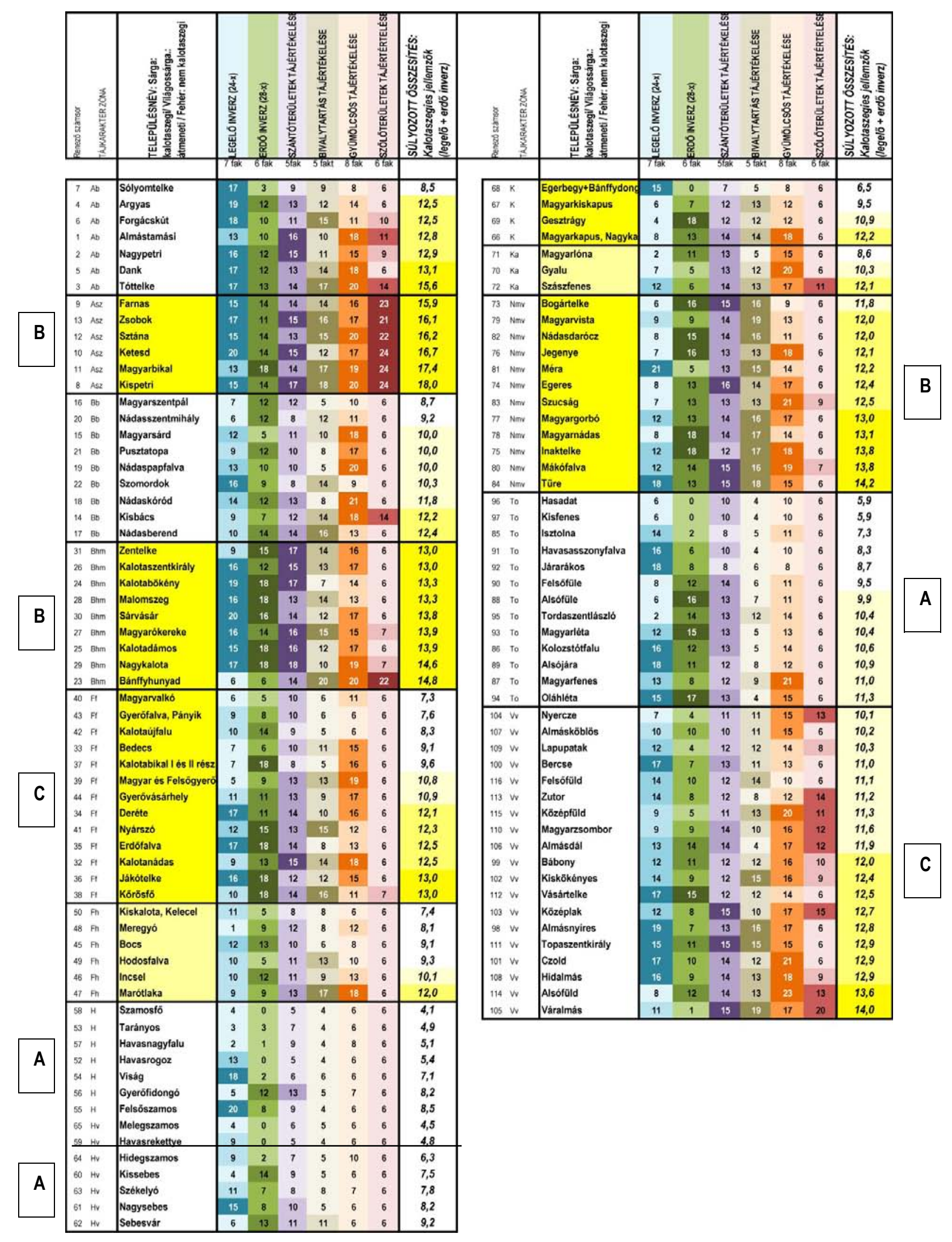

37. ábra: A statisztikailag levezetett 6 tájkarakter-jegy összesítése ,kalotaszegies” tájértékük alapján:

A: A Havas, Havasi-völgyek zónája egyöntetüen „,nem kalotaszegies” jellemzőkkel bír, valamint a Tordaszentlászlói zóna, amely koherensen alacsony értékek mutat (erre utal nagyon halvány árnyalatuk).

B: Három zóna (Asz, Bhm, Nmv) egyöntetü magas értékekkel bír (erre utalnak erős színeik, sötét-sárga fokozatuk), amelyek alátámasztják tájkarakter-egységességüket és jó lehatárolásukat.

C: A Felszegi felföld és Váralmási völgyek vidéke diverz eredményei erős tájkarakter- széttagoltságot ill. a módszer korlátait jelzik (kataszteri területének össze-nem-illését a tájhatárokkal) 


\begin{tabular}{|c|c|c|c|c|c|c|c|c|c|c|c|c|c|c|c|c|c|c|c|}
\hline 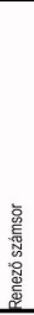 & 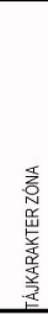 & 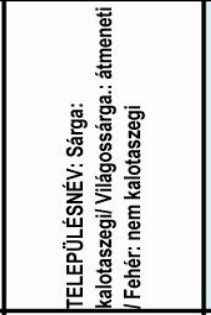 & 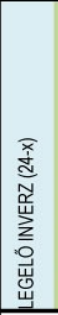 & 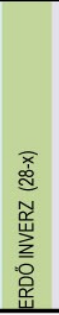 & 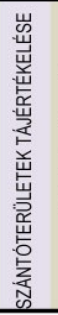 & 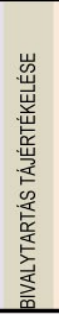 & 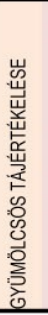 & 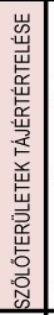 & 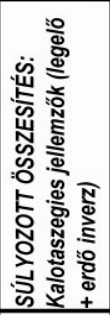 & 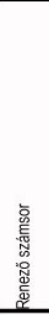 & 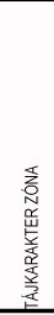 & 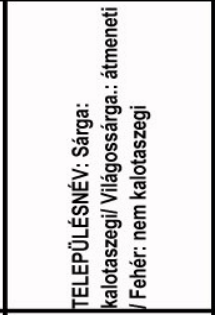 & 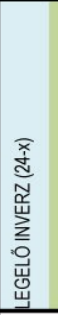 & 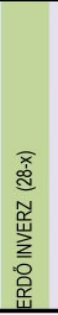 & 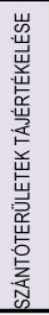 & 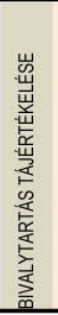 & 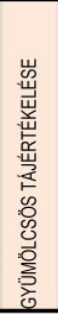 & 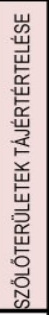 & 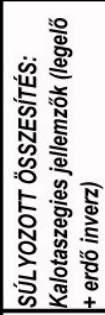 \\
\hline & & & 7 fak & 6 fak & 5 fak & 5 fakt & 8 fak & 6 fak & & & & & $7 \mathrm{fak}$ & 6 fak & 5 fak & 5 fakt & 8 fak & 6 fak & \\
\hline 58 & H & Szamosfö & 4 & 0 & 5 & 4 & 6 & 6 & 4,1 & 115 & $v_{v}$ & Középfüld & 9 & 5 & 11 & 13 & 20 & 11 & 11,3 \\
\hline 65 & $\mathrm{Hv}$ & Melegszamos & 4 & 0 & 6 & 5 & 6 & 6 & 4,5 & 110 & vv & Magyarzsombor & 9 & 9 & 14 & 10 & 16 & 12 & 11,6 \\
\hline 59 & $\mathrm{Hv}$ & Havasrekettye & 9 & 0 & 5 & 4 & 6 & 6 & 4,8 & 18 & $\mathrm{Bb}$ & Nádaskóród & 14 & 12 & 13 & 8 & 21 & 6 & 11,8 \\
\hline 53 & $\mathrm{H}$ & Tarányos & 3 & 3 & 7 & 4 & 6 & 6 & 4,9 & 73 & Nmv & Bogártelke & 6 & 16 & 15 & 16 & 9 & 6 & 11,8 \\
\hline 57 & $\mathrm{H}$ & Havasnagyfalu & 2 & 1 & 9 & 4 & 8 & 6 & 5,1 & 106 & vv & Almásdál & 13 & 14 & 14 & 4 & 17 & 12 & 11,9 \\
\hline 52 & $\mathrm{H}$ & Havasrogoz & 13 & 0 & 5 & 4 & 6 & 6 & 5,4 & 79 & Nmv & Magyarvista & 9 & 9 & 14 & 19 & 13 & 6 & 12,0 \\
\hline 96 & To & Hasadat & 6 & 0 & 10 & 4 & 10 & 6 & 5,9 & 99 & $\mathrm{vv}$ & Bábony & 12 & 11 & 12 & 12 & 16 & 10 & 12,0 \\
\hline 97 & To & Kisfenes & 6 & 0 & 10 & 4 & 10 & 6 & 5,9 & 82 & Nmv & Nádasdarócz & 8 & 15 & 14 & 16 & 11 & 6 & 12,0 \\
\hline 64 & $\mathrm{Hv}$ & Hidegszamos & 9 & 2 & 7 & 5 & 10 & 6 & 6,3 & 47 & Fh & Marótlaka & 9 & 9 & 13 & 17 & 18 & 6 & 12,0 \\
\hline 68 & k & Egerbegy+Bánffydong & 15 & 0 & 7 & 5 & 8 & 6 & 6,5 & 34 & $\mathrm{Ff}$ & Deréte & 17 & 11 & 14 & 10 & 16 & 6 & 12,1 \\
\hline 54 & $\mathrm{H}$ & Viság & 18 & 2 & 6 & 6 & 6 & 6 & 7,1 & 72 & $\mathrm{Ka}$ & Szászfenes & 12 & 6 & 14 & 13 & 17 & 11 & 12,1 \\
\hline 40 & $\mathrm{Ff}$ & Magyarvalkó & 6 & 5 & 10 & 6 & 11 & 6 & 7,3 & 76 & Nmv & Jegenye & 7 & 16 & 13 & 13 & 18 & 6 & 12,1 \\
\hline 85 & To & Isztolna & 14 & 2 & 8 & 5 & 11 & 6 & 7,3 & 66 & K & Magyarkapus, Nagykan & 8 & 13 & 14 & 14 & 18 & 6 & 12,2 \\
\hline 50 & $\mathrm{Fh}$ & Kiskalota, Kelecel & 11 & 5 & 8 & 8 & 6 & 6 & 7,4 & 81 & Nmv & Méra & 21 & 5 & 13 & 15 & 14 & 6 & 12,2 \\
\hline 60 & $\mathrm{Hv}$ & Kissebes & 4 & 14 & 9 & 5 & 6 & 6 & 7,5 & 14 & $\mathrm{Bb}$ & Kisbács & 9 & 7 & 12 & 14 & 18 & 14 & 12,2 \\
\hline 43 & $\mathrm{Ff}$ & Gyerōfalva, Pányik & 9 & 8 & 10 & 6 & 6 & 6 & 7,6 & 41 & $\mathrm{Ff}$ & Nyárszó & 12 & 15 & 13 & 15 & 12 & 6 & 12,3 \\
\hline 63 & $\mathrm{Hv}$ & Székelyó & 11 & 7 & 8 & 8 & 7 & 6 & 7,8 & 17 & $\mathrm{Bb}$ & Nádasberend & 10 & 14 & 14 & 16 & 13 & 6 & 12,4 \\
\hline 48 & Fh & Meregyó & 1 & 9 & 12 & 8 & 12 & 6 & 8,1 & 102 & vv & Kiskökényes & 14 & 9 & 12 & 15 & 16 & 9 & 12,4 \\
\hline 56 & $\mathrm{H}$ & Gyeröfidongó & 5 & 12 & 13 & 5 & 7 & 6 & 8,2 & 74 & Nmv & Egeres & 8 & 13 & 16 & 14 & 17 & 6 & 12,4 \\
\hline 61 & $\mathrm{Hv}$ & Nagysebes & 15 & 8 & 10 & 5 & 6 & 6 & 8,2 & 35 & $\mathrm{Ff}$ & Erdőfalva & 17 & 18 & 14 & 8 & 13 & 6 & 12,5 \\
\hline 42 & $\mathrm{Ff}$ & Kalotaújfalu & 10 & 14 & 9 & 5 & 6 & 6 & 8,3 & 4 & $A b$ & Argyas & 19 & 12 & 13 & 12 & 14 & 6 & 12,5 \\
\hline 91 & To & Havasasszonyfalva & 16 & 6 & 10 & 4 & 10 & 6 & 8,3 & 112 & vv & Vásártelke & 17 & 15 & 12 & 12 & 14 & 6 & 12,5 \\
\hline 7 & $A b$ & Sólyomtelke & 17 & 3 & 9 & 9 & 8 & 6 & 8,5 & 6 & $A b$ & Forgácskút & 18 & 10 & 11 & 15 & 11 & 10 & 12,5 \\
\hline 55 & $\mathrm{H}$ & Felsőszamos & 20 & 8 & 9 & 4 & 6 & 6 & 8,5 & 83 & Nmv & Szucság & 7 & 13 & 13 & 13 & 21 & 9 & 12,5 \\
\hline 71 & Ka & Magyarlóna & 2 & 11 & 13 & 5 & 15 & 6 & 8,6 & 32 & $\mathrm{Ff}$ & Kalotanádas & 9 & 13 & 15 & 14 & 18 & 6 & 12,5 \\
\hline 16 & $\mathrm{Bb}$ & Magyarszentpál & 7 & 12 & 12 & 5 & 10 & 6 & 8,7 & 103 & $v_{v}$ & Középlak & 12 & 8 & 15 & 10 & 17 & 15 & 12,7 \\
\hline 92 & To & Járarákos & 18 & 8 & 8 & 6 & 8 & 6 & 8,7 & 98 & $\mathrm{vv}$ & Almásnyires & 19 & 7 & 13 & 16 & 17 & 6 & 12,8 \\
\hline 33 & $\mathrm{Ff}$ & Bedecs & 7 & 6 & 10 & 11 & 15 & 6 & 9,1 & 1 & $A b$ & Almástamási & 13 & 10 & 16 & 10 & 18 & 11 & 12,8 \\
\hline 45 & $\mathrm{Fh}$ & Bocs & 12 & 13 & 10 & 6 & 8 & 6 & 9,1 & 111 & vv & Topaszentkirály & 15 & 11 & 15 & 15 & 15 & 6 & 12,9 \\
\hline 62 & $\mathrm{Hv}$ & Sebesvár & 6 & 13 & 11 & 11 & 6 & 6 & 9,2 & 2 & $A b$ & Nagypetri & 16 & 12 & 15 & 11 & 15 & 9 & 12,9 \\
\hline 20 & $\mathrm{Bb}$ & Nádasszentmihály & 6 & 12 & 8 & 12 & 11 & 6 & 9,2 & 101 & $\mathrm{vv}$ & Czold & 17 & 10 & 14 & 12 & 21 & 6 & 12,9 \\
\hline 49 & $\mathrm{Fh}$ & Hodosfalva & 10 & 5 & 11 & 13 & 10 & 6 & 9,3 & 108 & vv & Hidalmás & 16 & 9 & 14 & 13 & 18 & 9 & 12,9 \\
\hline 90 & To & Felsőfüle & 8 & 12 & 14 & 6 & 11 & 6 & 9,5 & 36 & $\mathrm{Ff}$ & Jákótelke & 16 & 18 & 12 & 12 & 15 & 6 & 13,0 \\
\hline 67 & k & Magyarkiskapus & 6 & 7 & 12 & 13 & 12 & 6 & 9,5 & 38 & $\mathrm{Ff}$ & Körösfö & 10 & 18 & 14 & 16 & 11 & 7 & 13,0 \\
\hline 37 & $\mathrm{Ff}$ & Kalotabikal I és II rész & 7 & 18 & 8 & 5 & 16 & 6 & 9,6 & 31 & $\mathrm{Bhm}$ & Zentelke & 9 & 15 & 17 & 14 & 16 & 6 & 13,0 \\
\hline 88 & To & Alsófüle & 6 & 16 & 13 & 7 & 11 & 6 & 9,9 & 77 & Nmv & Magyargorbó & 12 & 13 & 14 & 16 & 17 & 6 & 13,0 \\
\hline 15 & $\mathrm{Bb}$ & Magyarsárd & 12 & 5 & 11 & 10 & 18 & 6 & 10,0 & 26 & $\mathrm{Bhm}$ & Kalotaszentkirály & 16 & 12 & 15 & 13 & 17 & 6 & 13,0 \\
\hline 21 & $\mathrm{Bb}$ & Pusztatopa & 9 & 12 & 10 & 8 & 17 & 6 & 10,0 & 5 & $A b$ & Dank & 17 & 12 & 13 & 14 & 18 & 6 & 13,1 \\
\hline 19 & $\mathrm{Bb}$ & Nádaspapfalva & 13 & 10 & 10 & 5 & 20 & 6 & 10,0 & 78 & Nmv & Magyarnádas & 8 & 18 & 14 & 17 & 14 & 6 & 13,1 \\
\hline 46 & $\mathrm{Fh}$ & Incsel & 10 & 12 & 11 & 9 & 13 & 6 & 10,1 & 24 & $\mathrm{Bhm}$ & Kalotabökény & 19 & 18 & 17 & 7 & 14 & 6 & 13,3 \\
\hline 104 & vv & Nyercze & 7 & 4 & 11 & 11 & 15 & 13 & 10,1 & 28 & $\mathrm{Bhm}$ & Malomszeg & 16 & 18 & 13 & 14 & 13 & 6 & 13,3 \\
\hline 107 & $\mathrm{vv}_{\mathrm{v}}$ & Almásköblös & 10 & 10 & 10 & 11 & 15 & 6 & 10,2 & 114 & vv & Alsófüld & 8 & 12 & 14 & 13 & 23 & 13 & 13,6 \\
\hline 109 & vv & Lapupatak & 12 & 4 & 12 & 12 & 14 & 8 & 10,3 & 75 & Nmv & Inaktelke & 12 & 18 & 12 & 17 & 18 & 6 & 13,8 \\
\hline 22 & $\mathrm{Bb}$ & Szomordok & 16 & 9 & 8 & 14 & 9 & 6 & 10,3 & 80 & Nmv & Mákófalva & 12 & 14 & 15 & 16 & 19 & 7 & 13,8 \\
\hline 70 & Ka & Gyalu & 7 & 5 & 13 & 12 & 20 & 6 & 10,3 & 30 & $\mathrm{Bhm}$ & Sárvásár & 20 & 16 & 14 & 12 & 17 & 6 & 13,8 \\
\hline 95 & To & Tordaszentlászló & 2 & 14 & 13 & 12 & 14 & 6 & 10,4 & 27 & $\mathrm{Bhm}$ & Magyarókereke & 16 & 14 & 16 & 15 & 15 & 7 & 13,9 \\
\hline 93 & To & Magyarléta & 12 & 15 & 13 & 5 & 13 & 6 & 10,4 & 25 & $\mathrm{Bhm}$ & Kalotadámos & 15 & 18 & 16 & 12 & 17 & 6 & 13,9 \\
\hline 86 & To & Kolozstótfalu & 16 & 12 & 13 & 5 & 14 & 6 & 10,6 & 105 & $v_{v}$ & Váralmás & 11 & 1 & 15 & 19 & 17 & 20 & 14,0 \\
\hline 39 & $\mathrm{Ff}$ & Magyar és Felsögyerö & 5 & 9 & 13 & 13 & 19 & 6 & 10,8 & 84 & Nmv & Türe & 18 & 13 & 15 & 18 & 15 & 6 & 14,2 \\
\hline 69 & k & Gesztrágy & 4 & 18 & 12 & 12 & 12 & 6 & 10,9 & 29 & $\mathrm{Bhm}$ & Nagykalota & 17 & 18 & 18 & 10 & 19 & 7 & 14,6 \\
\hline 89 & To & Alsójára & 18 & 11 & 12 & 8 & 12 & 6 & 10,9 & 23 & $\mathrm{Bhm}$ & Bánffyhunyad & 6 & 6 & 14 & 20 & 20 & 22 & 14,8 \\
\hline 44 & $\mathrm{Ff}$ & Gyerõvásárhely & 11 & 11 & 13 & 9 & 17 & 6 & 10,9 & 3 & $A b$ & Tóttelke & 17 & 13 & 14 & 17 & 20 & 14 & 15,6 \\
\hline 87 & To & Magyarfenes & 13 & 8 & 12 & 9 & 21 & 6 & 11,0 & 9 & Asz & Farnas & 15 & 14 & 14 & 14 & 16 & 23 & 15,9 \\
\hline 100 & $v_{v}$ & Bercse & 17 & 7 & 13 & 11 & 13 & 6 & 11,0 & 13 & Asz & Zsobok & 17 & 11 & 15 & 16 & 17 & 21 & 16,1 \\
\hline 116 & $v_{v}$ & Felsőfüld & 14 & 10 & 12 & 14 & 10 & 6 & 11,1 & 12 & Asz & Sztána & 15 & 14 & 13 & 15 & 20 & 22 & 16,2 \\
\hline 113 & vv & Zutor & 14 & 8 & 12 & 8 & 12 & 14 & 11,2 & 10 & Asz & Ketesd & 20 & 14 & 15 & 12 & 17 & 24 & 16,7 \\
\hline 94 & To & Oláhléta & 15 & 17 & 13 & 4 & 15 & 6 & 11,3 & 11 & Asz & Magyarbikal & 13 & 18 & 14 & 17 & 19 & 24 & 17,4 \\
\hline & & & & & & & & & & 8 & Asz & Kispetri & 15 & 14 & 17 & 18 & 20 & 24 & 18,0 \\
\hline
\end{tabular}

38. ábra: A települések tájértékelési rangsora „kalotaszegiesség- összpontszáma” szerint

A falu nevének sárgításai saját előzetes ismereteim alapján történt (zónánként), a pontszám sárgítása pedig az tájértékelés eredményeképpen. Jól látható a két skála szoros korrelációja.

Az első 25\%-ban kilógó falvak: Egerbegy, Magyarvalkó, Pányik és Kalotaújfalu; a felső 25\%-ben kilógó falvak: Tóttelke, Váralmás, Alsófüld, Dank. 


\section{IV.4. A tájkarakter-elemzés két megközelítésnek összehasonlítása: előnyei, hátrányai}

A II. és III. fejezet, azaz a tájkarakter-elemzés két irányának megismerése és végigkövetése után módszertani tapasztalataimnak összevetését az alábbi mátrix tartalmazza:

\begin{tabular}{|c|c|c|}
\hline & $\begin{array}{l}\text { II. GEOMORFOLÓGIAI- ÉS TÉRÉLMÉNY- } \\
\text { ALAPÚ TÁJKARAKTER-ELEMZÉS }\end{array}$ & $\begin{array}{l}\text { III. TÁJKARAKTER-JEGYEK ÉS } \\
\text { TÁJKARAKTER-MINTÁZATOK } \\
\text { (statisztikai) ELEMZÉSE }\end{array}$ \\
\hline 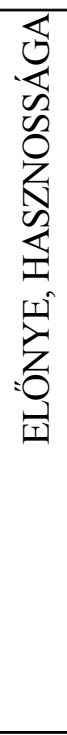 & $\begin{array}{l}\text { Egységben szemléli az egész vidéket, annak } \\
\text { valós térbeli hatásaira fekteti hangsúlyt; } \\
\text { A téregységek mozgalmassága-, a kisebb } \\
\text { felszínformák sokkal jobban, finomabban } \\
\text { leírhatók, mint térképek alapján; } \\
\text { - A látvány-kapcsolatok, sziluettek, táji } \\
\text { fókuszpontok és egyéb látképet-befolyásoló } \\
\text { tényezők pontosabban azonosíthatók; } \\
\text { - Beépíti a perceptuális tapasztalatokat, } \\
\text { érzékszervi hatásokat (pl. időjárás); } \\
\text { Asszociációs - fenomenológiai } \\
\text { gyakorlatokkal lehetőség nyílik a tájrészlet } \\
\text { szimbolikus tartalmának megragadására; } \\
\text { Elösegíti a változatos tájhasználatú hegyalji- } \\
\text { dombvidéki tájak tértagozódásának } \\
\text { megállapítását; }\end{array}$ & $\begin{array}{l}\text { - Az adatsor bizonyos táji sejtéseket } \\
\text { objektíven alá tud támasztani; } \\
\text { - Megfelelö, releváns adatsorok } \\
\text { kombinálásával olyan értékek vezethetők le, } \\
\text { amelyek sokkal jobban alátámasztják egy- } \\
\text { egy múvelési ág tájban betöltött szerepét; } \\
\text { - Ha több szempont hasonló végső-értékei } \\
\text { egy zónán belül nagyon erös kohéziót } \\
\text { mutatnak, akkor azok tájképi megfelelője is } \\
\text { általában hasonlóan jelentős; } \\
\text { - A létezö és térképezhető mintázatok/minták } \\
\text { és azok téri eloszlása nagy segítséget nyújt a } \\
\text { zónák lehatárolásához; }\end{array}$ \\
\hline 峝 & $\begin{array}{l}\text { - Sok terepszemlét és jó helyismeretet, nagy } \\
\text { időráfordítást igényel; } \\
\text { - Az elemzés rögzítésére a fényképezőgép } \\
\text { csak korlátozottan alkalmas, a szöveges } \\
\text { leírás és grafikai ábrázolás a célravezető, } \\
\text { amely jó háttér-kézségeket feltételez; } \\
\text { - Mindent a térélménynek rendel alá és } \\
\text { figyelmen kívül hagyja tájtörténeti } \\
\text { háttérismerteket, azok helytörténeti } \\
\text { jelentőségét; } \\
\text { A tájleírás nem számszerüsíthető ill. nehezen } \\
\text { objektivizálható; }\end{array}$ & $\begin{array}{l}\text { - Az adatsorok automatikus átvétele sok hibát } \\
\text { tartalmazhat, amelyeket csak helyismerettel } \\
\text { lehet kiszürni, korrigálni; } \\
\text { - Az értékelés térképes szemléltetése ellenére } \\
\text { sem tudja kijelölni az összetartozó zónákat, } \\
\text { hanem csak arra tud rávilágítani, hogy egy- } \\
\text { egy tulajdonság mennyire lesz meghatározó } \\
\text { abban a tájkarakterben; } \\
\text { - Sok tájrészletben kevés az erős mintázattal } \\
\text { bíró foltszerü elem, ami megnehezíti az } \\
\text { eltérő karakterü területek szétválasztását. }\end{array}$ \\
\hline
\end{tabular}

39. ábra: A tájkarakter-elemzés két megközelítésének összehasonlítása

\section{IV.5. A tájkaraktert meghatározó tájkarakter-jegyek prioritási sorrendje Kalotaszegen}

A kutatás elején helyszíni bejárások során körvonalaztam a tájkaraktert meghatározó hipotéziseimet, amelyeket azután térélmény-alapú-, szöveges-, térképes-, statisztikai- és rajzivizsgálatoknak vetettem alá. Az egyes tájkarakter-zónák lehatárolásában, azok egyediségének meghatározásában végeredményképpen az alábbi prioritási sorrendet tudtam felállítani:

\section{FELSZÍNMORFOLÓGIA, DOMBORZAT:}

Hegyvidéki, hegylábi és dombvidéki helyzeténél fogva Kalotaszeg környékén a legfontosabb tájkarakter-jegy a felszínmorfológiai változatosság. A sokszínű alaktani formák itt sokkal jelentősebben befolyásolják a térélményeket, mint egy síkvidéki/hegyvidéki környezetben. Ennek egyik oka a harmadkori mészkő-üledékek változatos alaktana és kapcsolata az öspalákkal ás vulkanikus formációkkal; másik oka a négy vízgyüjtő eltérő dinamikájú völgyrendszere, ami további belső 
reliefkülönbségeket és nagyobb felszínmozgalmasságot eredményez. A mozgalmas terepfelszín miatt a vízválasztó peremek fontos sziluett-szegélyként jelentkeznek a zónák között, és a térbeli tagoltság nagyon megkívánja és indokolja az alaposabb térélmény-alapú vizsgálatot.

\section{ERDÖBORÍTOTTSÁG:}

E vidék fontos tulajdonsága az erdőborítottság alacsony és közepes aránya és az erdők domborzati viszonyokkal való különböző illeszkedésének egyedi alaktani jellemzői. Mivel nem kiugróan alacsony vagy magas az erdő-borítottság foka, így a záródó-erdőszegély és a nagy erdőtömbök belső arány-különbségeinek felismerése a tájkarakter-zónák elhatárolásához vezet (pl. a Bánffyhunyadi medencében igen alacsony: 1-3\%; a Váralmási völgyekben ezzel szemben kiemelkedően magas, 30-40\%.), illetve a zónák határa is sok esetben a záródó erdőszegély vonalán halad, ahol karakteresen elsötétül a mezőgazdasági táj képe. Az erdő tájképben való szerepét tovább egyéniesíti a domborzati tagoltsággal való változatos morfológiai viszonyok sora [15. tábla].

\section{AZ AGROTERASZOK MINTÁZATA:}

A tájkaraktert harmadsorban a vizuális, erősen ismétlődő, visszatérő mintázati jelleggel rendelkező tájhasználati módok határozzák meg. Kalotaszeg környékén az agroteraszok adnak ilyen fontos karakterességet. A szintvonalakat hullámzóan, mégis változatosan [18. tábla] követő barázdák formáival több zónában is látványosan megjelennek. A mintázat eloszlása jól térképezhető, így kiterjedésének határát, sűrüségét, alaktani típusait az egyes zónák lehatárolásánál szignifikánsak. (A teraszolás mellett, az elkerített román hegyi legelők mozaikossága, a szőlőmüvelés függőleges, legyezőszerủen szétnyíló telekosztásai; a fás legelök ligetes-pettyezett mintázata és a gyümölcsösök raszteres térháló-rendszere is egyedi grafikai jellemzőkkel bíró tájkarakter-mintázati jegyek, de ezek csak néhány zóna területén jelentkeznek.)

\section{VIZUÁLISAN DOMINÁLÓ LÁTVÁNYELEMEK:}

A negyedik, zónalehatárolást segítő tájkarakter-jegy a nagy látványhatósugárral rendelkező elemek, objektumok és fókuszok. Éppen e táji nyitottságnak és mozgalmasságnak köszönhetően a magashegységek sziluettjei és a karakteres középkori, magas templomtornyok erős hatást gyakorolnak az őket körülvevő tájra, ugyanakkor a sokkal nagyobb számban megmaradt, alacsony XVIII. sz.-i román fatemplomok csak lokálisan hatnak a településeik szükebb faluhatáraira. A tájkarakterben jelentőssé vált a XX. sz.-i iparosítások beavatkozásai, amely bányászati tájsebeivel, tározóival, vertikális gyárépületeivel és manapság szabályozatlan agglomerációs széttelepülésével több helyen felülírta a mezőgazdasági tájhasználatot. Ennek erőssége olyan jelentős, hogy egyes zónákban már-már altípusokat hozhatna létre (pl.: a Nádas-menti völgyön belül az Egeresi-medence „XX.sz.-i bányászati ipari tájjá változott”). 


\section{KEVÉSBÉ LÉNYEGES TÁJKARAKTER-JEGYEK:}

A tájkarakter-elemzés során megállapítottam, hogy a statisztikai adatok alapján levezetett szántó-, legelő- tájértékelése és a valós látványban való karakteressége nem mutat minden esetben erős korrelációt. Bár ezek jelezhetnek hangsúlyeltolódásokat, nem határozzák meg a zóna alapvető tájkarakterét, és a vizuális hangsúlyok között is csak csekély szerepet töltenek be, így statisztikai tájértékelésüknek nem szabad túlzott jelentőséget tulajdonítani

\section{IV.6. A tájkarakter-jegyek és tájkarakter-mintázatok konklúziói és az} agroteraszok kiemelt jelentősége Kalotaszegen

A tájértékelés és annak térképes ábrázolása során kiderült, hogy bizonyos művelési ágak: a kert-gyümölcsösök és az erdők statisztikai vizsgálata viszonylag jól tükrözik a falvak valós tájképében betöltött jelentőségét, mert azok erős vizuális mintázati-jegyekkel is bírnak. A gyümölcsösök kisebb, mozaikos vagy gyürüszerüen körbeölelő foltjai és az erdők sötétzöld zárt tömegei látványos, jól térképezhető mintázatokat alkotnak.

További mintázati ritmusokat adnak a tájnak a fás legelők laza, de egységes „tájat pöttyöző” ligetei; a XX. sz. tájváltozások eredményeképpen létrejött mesterséges, peremeket-követő fenyőfoltok, a szőlőművelés hegy-völgy irányú tőkéinek legyezős tagolásai, és a kiterjedt geometrikus-raszteres ültetvények foltjai. Ezek kis alapterületi kiterjedésük és a művelési ágak arányában betöltött igen kis százalékuk ellenére, adott tájkarakterben sokkal nagyobb vizuális jelentőséggel bírhatnak, mint az előzetesen feltételezhető lett volna. Ezt egyedi alakzati megjelenése, különleges színük vagy a domboldalakon megjelenő nagyobb látványkitettségük okozza.

A rét és legelő művelési ág „,mintázat”- hiányában nehezebben megjeleníthető, és a tájban betöltött szerepe is nehezebben határozható meg egymással való felcserélhetőségük miatt. Amennyiben a legelökön, réteken nincsenek látványos alaktani mintázatok, addig azok nem tudnak a tájkarakterben domináns szerepet betölteni. Ebből a szempontból a Gyalui/Vlegyászai havasain megjelenő zártlegelőtelepülés struktúra markáns, tájkarakter-határoló erővel bír. Ez a vidék eltérő karaktert mutat, mert itt a cserjesávok, fás-szegélyek egymáshoz érő, sürü, mozaikos négyzetes-téglány kiosztásai borítják a tájat. Ezek a mintázatok téri, alaktani változatosságuk folytán már képesek lesznek erősebb karakterjegyeket adni ezeknek a müvelési ágaknak.

A kalotaszegi táj legjelentősebb mintázatát azonban az agroteraszok hullámzó teraszrendszerei, csoportos-vonalas mintái adják, melyek a domboldalakat borító lepel-foltokként jelentkeznek a tájban. Ezek vizuális dominanciája már az első helyszínelések alkalmával feltűnt, de szisztematikus vizsgálata további részleteket tárt fel azok táji szerepéről: morfológia szempontból négy típusba soroltam őket, tájtörténetileg és alaktanilag elemeztem, fényképes példákkal és sematikus grafikákkal szemléltettem azokat. A barázdák mintázatának legsürübb kiterjedése a Felszegi felföldön és a Nádas-mentén igen 
szorosan korrelál a tájkarakter-zónahatárokkal. A havasalji területeken ez a művelési mód a románok által is alkalmazott, de egy határozott különbséggel: míg Kalotaszegen az erdős dombtetők alatti oldalakban jelenik meg a teraszolás, addig ott fordítva, a meredek erdős domboldalak feletti, lapos magaslati hegytetőkön. Ma a város-közeli falvakéban gyorsabb ütemben folyik a teraszok cserjésedése, ami vizuálisan még inkább kiemeli azok vonalrajzolatait nagyobb természetességet adva a tájnak. A tájesztétikai vizsgálatból levonható volt, hogy ez az emberi kéz által 'döbbenetes' idő és energiaráfordítással létrehozott, dinamikus terepplasztikai beavatkozás egyedi, 'máshol-meg-nemismételhető' helyspecifikus táji elem, amely esztétikai értékét egyfelől a változatos és ritmikusan ismétlődő fényviszonyainak, másfelől pedig a természetes, 'nem-szándékosan-szépséget-létrehoznivágyó ' müalkotás-hatású erejének köszönheti. Ezért nemcsak hagyományos tájtörténeti-művelése és alapvető tájkaraktert-meghatározó volta miatt, hanem esztétikai szépsége miatt is védelemre javasolt tájkarakter-jegy.
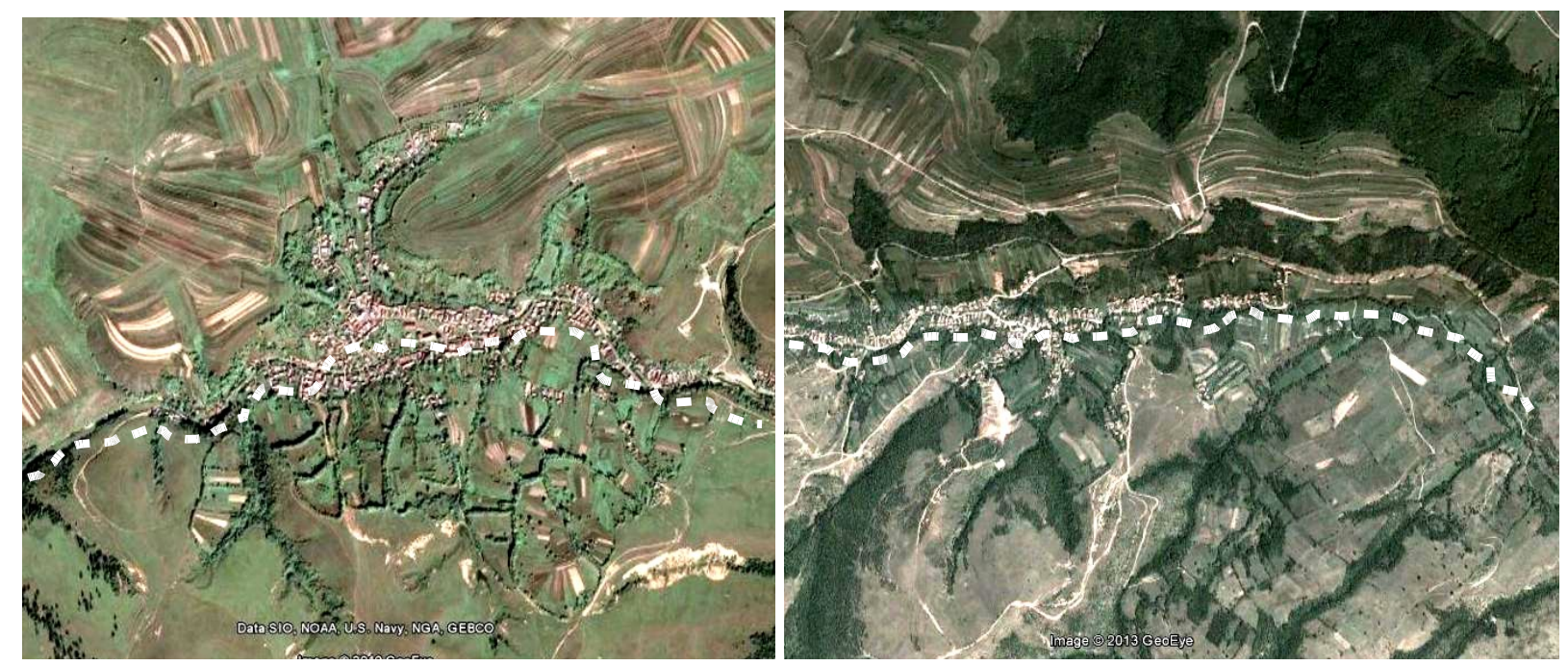

40. ábra: Bedecs és Egerbegy faluszerkezete és a környező táj Jól látszik az eltérés az agroteraszos- szalagos telekosztás (fent) és a zártlegelős, fásszegélyekkel elválasztott telkek (lent) tájkarakter-mintázatai között

IV.7. Kalotaszeg egységességének ill. tagoltságának megállapítása jellemző tér-élményei, tájkarakter-jegyei, tájkarakter-mintázatainak összevetésével

A vizsgált terület egyedi táji jellemzőinek meghatározásában két megközelítést írtam le [3-4. tábla]. Az egyik Kalotaszeget 'egységes tájkarakterünek' tekintette volna, a másik Kalotaszeg és tágabb környezetének egyes 'zónáit, és azok egyedi tájkarakterét' határozta meg. A vizsgálat és az értékelés során azonban a táj 'egységességére ill. tagoltságára' vonatkozóan is meghatározásra kerültek tájkarakter-jegyek, tájkarakter-mintázatok. Az eredményeket táblázatos formában szintetizáltam: 


\section{EGYSÉGESSÉGET BIZONYÍTÓ TÉRÉLMÉNYEK, TÁJKARAKTER-JEGYEK, - MINTÁZATOK, JELENSÉGEK}

Közös jegy a dombvidéki fekvés, a tagolt, mozgalmas, nagy reliefkülönbségeket mutató, változatos völgystruktúrákkal rendelkező domborzat, amelynek nem része a széles, tág alluviális medence és folyóvölgyi tértípus. Ez a domborzati alaktan állandóan változó látványokat, látványmintázatokat ad. [13. tábla ]

A harmadidőszaki üledékrétegek közül az eocén rétegek általános geológia övezete, és annak markáns fehéres, kibukkanó kőzete összekapcsolja Felszeget, Alszeget lés Nádas-mentét. [3. tábla ]

Az oligocén Váralmási-völgyekben és a Mezöség felé esö neogén rétegekben nincs geológiai változatosság és a köfejtés-köfaragás jelentöségét veszti (a környezö vidéktöl való erös eltérését mutatja)

Az eocén alsó és felső durvamészkőre települt kőbányák, kőfejtők (és azok tájsebei) is közös jegyek: hasonló tájtörténeti jelentőséggel rendelkező ipari tevékenységet mutatnak a tájegységek között. [34. tábla ]

Közös jegy az közepes erdö-borítottság és az erős szegélyhatás, ahol a laza erdőtagok „összezáródnak” és éles határvonalat képeznek - ez az erdőhatár szinte körbezárja Kalotaszeget. [15. tábla ]

Közös jegy az agroteraszok tájkarakter-mintázatának kiterjedése, amely bár más erdélyi tájegységet is jellemez, de itt Kalotaszeg-körül eltünik, és csak távolabb bukkan fel újra. [18. tábla ]

A bivalytartás XIX-XX. sz.-i aránya, magas tájértékelése minden tájegységet jellemző, közös jegyként kezelhetö. [24. tábla ]

A gyümölcsösök-kertek kiterjedése, viszonylag magas tájértékelési eredményei fontos általános, összekapcsoló tájkarakter-jegyként definiálható. [27. tábla ]
TAGOLTSÁGOT BIZONYÍTÓ TÉRÉLMÉNYEK, TÁJKARAKTERJEGYEK, - MINTÁZATOK, JELENSÉGEK

A mozgalmas terepfelszín alól csak a bánffyhunyadi-medence-zóna kivétel, amely bár lankás, sík karakterü, mégis a látványkapcsolatokban ott is megjelenik a hegy/dombvidék képe.

A Vlegyásza magashegységének sziluett-látványa csak a nyitott Bánffyhunyadi medencéböl, a Felszegi felföldről - vízválasztóról és Alszeg egyes falvaiból érvényesül, de a Nádas/ Kapus-patakmentére már alig van hatással (a szöktetők et kilátóit kivéve, ahonnan azonban csak felcsillan kéklő csúcsa) > erős K-Ny-i tagolást okoz.

Jelentös különbséget mutat az eocén rétegek alaktani változatossága: felszegi vízszintes mezaplatós és a kapus/nádas-menti ferde, dőlt síkú szögtetők, amelyek Felszeget és Nádas-mentét alapvetö tértípusaiban elkülönítik egymástól.

Az erdők belső arány-különbségei lényeges eltérést mutatnak egyes zónák, tájegységek között (Felszegen, Bhm., Ff.: nagyon alacsony, Nádasmentén: közepes, Alszegen: magas).

Az agroteraszok az egyes zónákban eltéró területi megoszlásban, eltérő mintázati sürüségben jelennek meg (pl. Alszegen és a Bhm-ben sokkal kevésbé jelennek meg).

Mesterséges, erózióvédő fenyőtelepítések Alszeget nem jellemzik.

A gyümölcstermesztésre alkalmas területek, azok tájértékelései a völgyi védett, melegebb adottságok miatt eltolódást mutatnak Alszeg/Szilágyság felé. A raszteres gyümölcsösök nagy kiterjedése csak Nádas-mente és Alszeg egyes részén dominál a tájkarakterben.

A szőlők előfordulása teljes Kalotaszeget jellemezte (az egykori dűlőnevek alapján), de a XIX. sz. végi statisztikák elkészülésére már sok faluból eltünt. [29. tábla ]

A Czikáry-féle határösszeírások közös jegye Kalotaszeget illetően az igen rossz ('szakadásos, agyagos, köves') talajminőség, amely a váralmási völgyek mélyebb falvaiban és Bács-Berend környékén javul. Így az eróziós sérülések, csúszások, megnyílások is kis pontszerüségük ellenére közös tájkaraktermintázatként tekinthetőek. [34. melléklet ]

Kalotaszeg nagy részén extenzívebbé váló mezőgazdasági tájhasználat dominál, amelybe kisebb
A szőlők nagyobb kiterjedéssel, táitörténeti jelentőséggel, erős tájkarakter-mintázatot képezve ma már csak Alszeg szölös falvaiban érvényesül.

Az erős tájkarater-mintázattal rendelkező fás legelők inkább a vízválasztó környékén és Nádasmentén jellemzők nagy arányban, de hiányoznak Felszegen.

Az erőteljes iparosodás, szuburbanizációs széttelepülés Nádas-mentét (Egeres és Szucság) és 


\begin{tabular}{|l|l|}
$\begin{array}{l}\text { tájidegen beavatkozások jöttek létre (föleg az utak } \\
\text { mentén), de a határ spontánul cserjésedő arculata } \\
\text { természetességét erősíti. }\end{array}$ & Kapus - Szászfenes vidékét jellemzi. \\
\hline $\begin{array}{l}\text { Közös jegyként tekinthető a „zárt-szerkezetü falukép”, } \\
\text { amelyben a gazdag népi ornamentikával ellátott } \\
\text { lakóépületek képeznek erős utcafrontot. [32. tábla ] }\end{array}$ & $\begin{array}{l}\text { A középkori, magas fiatornyos, zsindellyel fedett } \\
\text { templomtornyok erös vizuális hatása csak } \\
\text { Felszegen (Ff-Fh) és Hunyadi-medencében } \\
\text { jelentős. }\end{array}$ \\
\hline $\begin{array}{l}\text { A Hunyadi-piacolás, vásárolás központi szerepe a } \\
\text { XVIII. sz. óta Kalotaszeg k közös „találkozóhelye”. [2. } \\
\text { tábla: C] }\end{array}$ & $\begin{array}{l}\text { A külső vásározó célpontok a tagoltságot } \\
\text { támasztják alá. }\end{array}$ \\
\hline
\end{tabular}

41. ábra: Kalotaszeg tájkarakter-egységét és tagoltságát összehasonlitó táblázat

Kijelenthető, hogy a III. fejezetben vizsgált kilenc tájkarakter-jegy mindegyike érintette a Kalotaszegi tájat. Mindegyik fontos összetevő-alkotóeleme e tájkarakternek, de a kistájakat tekintve különböző arányban és jelentőséggel jelennek meg, ezáltal az egységesség mellett erős diverzitást is mutatnak. Ez a tény párhuzamba állítható Kalotaszeg néprajzi és társadalmi tagozódásával, amely már a XIX. sz. folyamán végzett néprajzi kutatások alapján is igen eltérő tájegységekre bomlott. A tájkarakter-elemzés ezt a téri tagozódást támasztotta alá, ugyanakkor közös jegyeket is igazolt.

\section{IV.8. A tájkarakter-zónák tagozódásának összevetése}

\section{a társadalmi, néprajzi tájegységekkel, népmüvészeti jellemzőivel ${ }^{240}$}

A disszertáció alapvető célkitüzése annak megállapítása volt, hogy az egyedi és jelentőségteljes „Kalotaszegi-népművészettel” párhuzamosan létezik-e „Kalotaszegi táj”, azaz igazolható-e tájkarakteregység szempontjából egy létező néprajzi egység. Mivel tudjuk, hogy a néprajzi szempontból Kalotaszeg több tájegységre (Alszeg, Felszeg, Nádas-mente, Átmeneti vidék) bomlik, így további felvetés volt, hogy a ma Kalotaszegként összevont térség tájegységei közötti népművészeti különbségek megfeleltethetőek-e tájképi szempontból, ill. azok eltérései hogyan tükröződnek-e az egyes tájkarakter-zónákban? A fenti egységességet/tagoltságot mutató összevetés már a legtöbb táji szempontot összevetette, itt most annak néprajzi-társadalmi vetületeire mutatok rá.

Kalotaszeget a korai írásos források és XVI-XVIII. sz-i. térképek Felszeg vidékével, a „Kalata”-vizének területével azonosítják. Az első tájleírások is ezt a hegyaljai vidéket mutatták be román településeivel együtt. A nagy kiterjedésű Felszeget tájkarakter-elemzési szempontból több zónára kellett osztani: havas - havasi völgyek - hegyalja - felföld - medence. Mivel ezek alapvető természeti adottságukba és tájhasználatukban nagyon különböznek (pl.: erdők - szántók végletes aránya), így ezek között szoros egymásra-utalsági viszony jött létre - így válva komplex tájjá, amit már korán különálló „,névvel” illettek (Kalataszeg). Erre több lábon álló tájhasználatra alapozott a középkori templom/kolostor-építészet és a vízi energiára épülő malomrendszer és birtokigazgatás is. Ez a nagy

\footnotetext{
${ }^{240}$ A fejezetben bemutatott néprajzi, társadalmi, identitási kérdések háttereként az ezt a témát teljes mélységében feldolgozó könyv alapján teszem meg: Balogh - Fülemile, 2004. pp.: 29-92. A viseletek- és jelek-, szimbólumok téri eloszlásait jól mutatja be Faragó - Nagy - Vámszer, 1977. és Vasas, 1994.
} 
kiterjedésű FELSZEGI-földrajzi egység (=szeg, szegelet) később etnikai megoszlása következtében magyar és román településekre esett szét. A házassági/társadalmi kapcsolatai és népművészeti hagyományai ezt az etnikai megosztottságot tükrözik, ami ugyanakkor nem pontosan fedi a tájkarakterzóna határokat. A magyar vidék a Hunyadi-medence és a Felszegi felföld egyes faluiból áll össze, de kimarad belőle pl. Erdőfalva, Bedecs, Derite, Nagykalota; míg a román hegyaljai falvak ezt a magyar lakta területet félkör-szerüen övezik.

Alszeg, szemben Felszeggel, már a római időben is lakott volt, jól kiépített, Szilágyság felé orientálódott infrastruktúrával, amelyet vásározási kapcsolatai végig megőriztek. Bánffyhunyad mezővárosi szerepéhez a „melegebb” irányból kapcsolódott, így teremtve meg a havasi termékek és a gyümölcsös táji egységét, „Fel+Alszeg szimbiózisát”. Ebből egyenesen következik e két tájegység közötti erős tájkarakterbeli különbség, amit több ízben is alátámaszt e kutatás. Az Alszegei szőlösfalvak, barnakőszénvidék és a Váralmási-völgyeket vizsgálva a zónák nem mindig mutattak belső koherenciát, és a tájkarakter-határok is nehezen voltak kijelölhetőek (a kalotaszegiesség rangsor felső „kilógó falvai is itt találhatóak”: Dank, Tóttelke, Váralmás).

Alszeg és Felszeg a helyi népmüvészet „ősi” formáinak őrzőiként tartják magukat számon mind a mai napig. Népviseletük keveset változott az elmúlt század során, a divatirányzatoknak jobban ellenállt, aminek egyik oka a hegylábi eldugottsága is volt. Mindkettőt rövid vállfős ingek, alsó pántlika nélküli, alig gyöngyözött, darázsolt-derekú, egyszínű szoknyák jellemzik; itt inkább csak kerek kontyokat tettek és az egyszerübb, keskeny pártát is vízszintesen vagy kissé ferdén tették fel nem az konfirmáció évében. Mindkettő számára kiemelten fontos Hunyad városa, piaca - szolgáltatásai. Házassági kapcsolataiban egymással összeköttetésben álltak a határvidéken (Ketesd, Bikal, Zsobok). Mindkét vidéket belső-lábas, kissé lent-hangsúlyos forgású tánckultúra jellemezi és mulatságokhoz zenészeiket általában Hunyadról fogadták, ami a mezővárossal való szoros kapcsolatra utal.

A Nádas-mente kelet-orientált, inkább Kolozsvár-felé nyitott vidék, melynek régi helyneveiben és megnevezésében sehol nem fordult elő a Kalota/Kalata kifejezés. Önmagában erős völgystruktúrája jól lehatárolja, és a Nádas-mente ütőere felé orientálja, amit a malomrendszer, a vasút és közút is megerősített. A jelen kutatás tájkarakter-elemzése is alátámasztotta e vidék egységét, és erős közös karakterjegyeit, illetve azt, hogy e zóna sok szempontból eltér Felszegtől és Alszegtől is. Kolozsvári agglomerációs helyzete illetve nyersanyagainak kiaknázása már itt is megindult a római korban, de a falvak közötti középkori birtoklás azt a vidéket jobban megosztotta, így az - egyébként nagyobb alapterületü és lakos-számú - falvak erős település-önazonossággal, és büszkeséggel rendelkeznek. Magukat inkább „Cifra-Kaloatszeginek nevezték”, amely utal a városiasodás és a vasút által könnyebben befolyásolt, egyre dekoratívabbá és díszesebbé váló viseletükre. Jellemző e vidékre a hosszú-ujjú, hosszan hímzett vállfős ing, és a szoknyák derék-darázsolása helyett, inkább annak alsó részén található gazdag pántlikás díszítés, ami nagyon jelentős viseletbeli eltérés; a rózsás-alapmintájú 
kötényeket itt gazdag gyöngykirakással díszítik hímzés helyett; a konfirmáció évétől a nagy, széles pártát szinte függőlegesen hordák, majd hegyes kontyot viseltek. Csak ezen a vidéken ismert a férfiaknak a gyöngyös-bokréta viselése. Tánclépéseket illetően hatalmas eltérés van, hiszen itt külsőlábas forgás a jellemző és a legényes szerepe is sokkal jelentősebb; zenészeiket nem Hunyadról, hanem a környező falvakból fogadták. Házassági kapcsolatokat inkább falun belül, ill. csak egymás között kötöttek. Jegenye és Egeres társadalmi kapcsolataiban kilóg, ellenben tájilag nagyon hasonló jegyekkel bír. Szintén kérdéses Bács helyzete, amit tájkarakter-szempontból nem sorolható ide.

A századforduló népmüvészeti felfedezése és a vasútvonal nemzetközi kapcsolatrendszere az egész vidéket erőltetetten „egységes Kalotaszegként” kezdte bevezetni a „tudományos néprajzi” vidékek közé, így a korábbi tagoltságát feloldotta és a nemzetközi világkiállításokon, bemutatókon, művésztelepeken egyre inkább összemosta belső differenciáit. A fenti tömör néprajzi összegzés célja éppen az volt, hogy ezekre a különbségre rávilágítson, és alátámassza, hogy a Kalotaszeg népmüvészeti tagoltsága éppen annyira hasonló egymáshoz és egyben különböző is, ahogy az tájkarakterében is tükröződik. Az alább képsorok (balról) Felszeg- Alszeg- és Nádas-mente viseleteit mutatják archív és mai képsorokon.
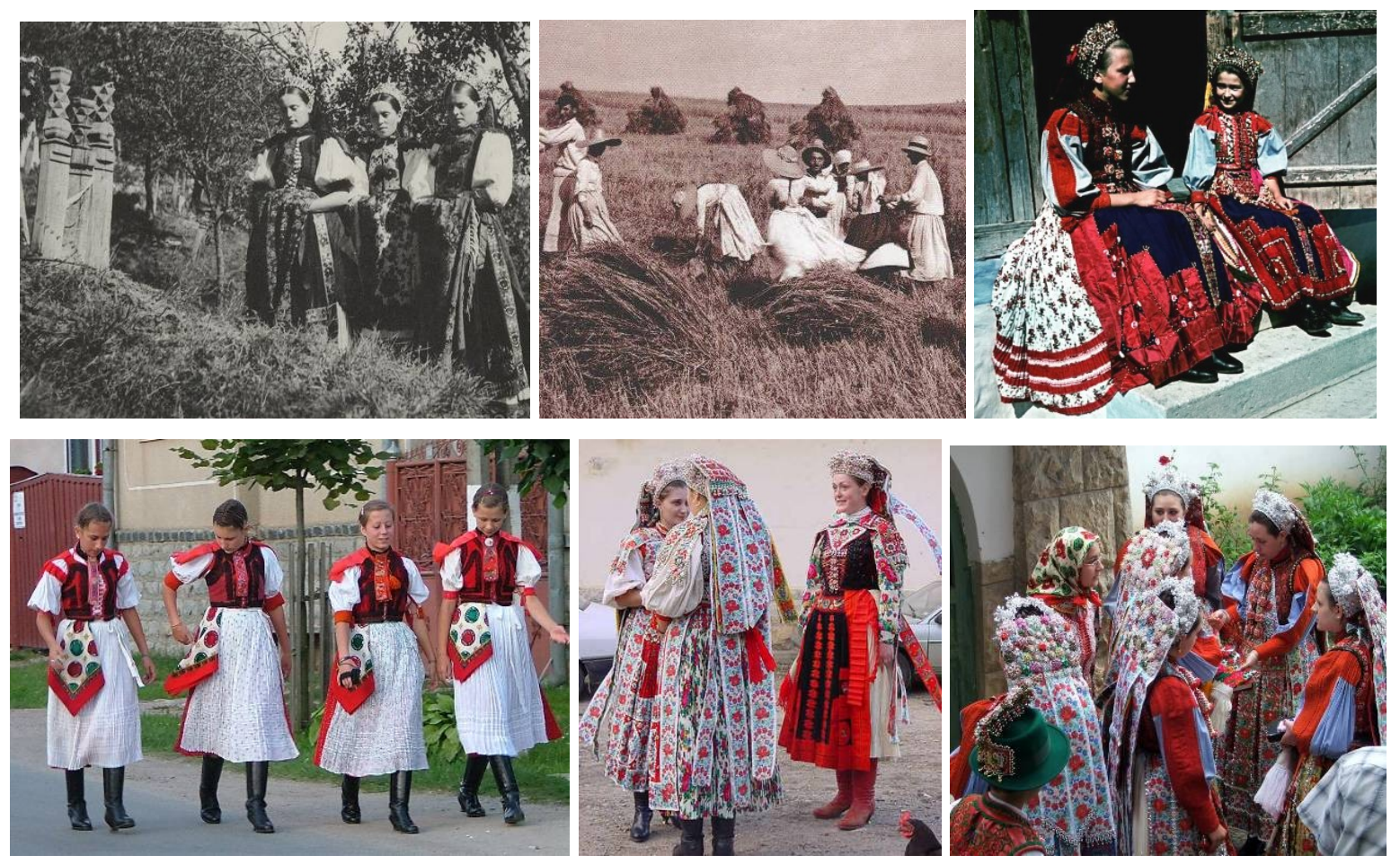

„A legidösebb testvér, a korban rangidős, hagyományörzö, bölcs és mértéktartó Felszeg... A középső testvér Alszeg, se nem bölcs-elmélkedö, sem szépitkezö, hanem e világban élö, józaneszü, dolgos leány... A legfiatalabb leánytestvér, a Nádas-mente: legszebb és legcsinosabb, mondanák a népmeséink. Bár sajnos bájosságán túl elö-elö bukkan öntetszelgö hiúsága is, mégis jobban ismerve szépségét meg tudjuk ezt bocsátani." (Eplényi, 2005. p.) 


\section{IV.9. Az általam definiált Kalotaszeg, mint „Táj” és annak egyes tájkarakter-zónái}

A tájkarakter-elemzés végeredményeképpen részben módosítanom kellett eredeti feltevéseimet és a helyszínelés során tett táji besorolásaimat most a munka végén áttekintve néhány pontosítás szükséges [37. tábla - felső térképe].

Felszeg táját alapvetően három tájkarakter-zónájából vontam össze (Bánffyhunyadi-medence, Felszegi havasalji és Felszegi felföld) bevonva Hodos, Marótlaka vidékét egészen fel Méregjóig, ameddig a záródó erdőszegély és az agroteraszos müvelés tart. D-en a keleceli erdők jelzik a határt a havasi tájszerkezet felé. Ehhez a tájegységhez szervesen tartoznak az -ugyan etnikai szempontból mára kilógó-, K-i román falvak is Bedecs körül. Mindezek által Felszeg önmagában nagy kiterjedésű táji komplexumot képez, amit a Vlegyésza fog egybe és amely egykor „Kalataszeg” táját jelentette.

A vízválasztó plató K-i oldalán lévő Kapusi-völgy havasalji tájkarakterével Felszeghez áll a legközelebb. A plató kiterjedt volta miatt széles átmenetet képez (Riszeg-hegy, Hágó-tető, Pányik, Kalotanádas, Jegenye, Gyerővásárhely), amelyet néprajzilag és társadalmilag sem könnyü egyik egységhez sem sorolni. Annyi azonban egyértelmü, hogy a Kapus-völgy még Gyalui előtt összeszükül, és ott biztosan ,véget ér” a Kalotaszegi táj.

A Nádas-mente mind-megannyi irodalomban hasonlóan van lehatárolva, amit tájkaraktere is alátámaszt, hiszen egy éles peremmel bezárt, befelé-orientált völgy-rendszer. Határát Alszeg felé a Sztána-Nádasi magaslati vasúti megálló adja, D-i és É-i határát a vízválasztó peremen haladó erdősáv, de a zóna egységes karaktere csak a szucsági, „Fileki”-malomig tart, amely után erős völgyhatással veszi el addig jellemző jegyeit. Ehhez a zónához É-ról a Berendi-patak csak nagyon halványan teszi hasonlatossá, inkább csak Magyarsárdig, ameddig még a szögtetős formációk jellemzik.

Végül Alszeg tájkarakterének pontosítása bizonytalan kissé. Egyértelmű a hat szőlős település összetartozása, de a statisztikai tájértékelés alapján további hozzájuk „hasonló tájhasználatú és kalotaszegiességü” falvak bevonása indokolt: így Tóttelke, Nagypetri, Dank és Almástamási nyitott, erdőtlenebb területét lehet még ide bevonni, hogy térélmény-egysége ne szakadjon meg. A tájkarakterelemzési prioritása alapján egyértelmü azonban, hogy Alsófüld környékének tág alluviális völgye és Váralmás környékének lankás dombú zárt erdőségei már semmiképpen nem tartozik ehhez a tájszerkezethez. 


\section{V. ÖSSZEFOGLALÁS}

Doktori disszertációmban a magyar kulturális örökség emblematikus néprajzi vidékét, Kalotaszeget vizsgáltam. Kutatási kérdésem az volt, hogy a népmüvészeti hagyományait és társadalmi kapcsolatrendszerét tekintve jól feltárt tájegység jellemzőit a táj karakterességnek, egyediségének kérdésével vessem össze. Fodor Ferenc megfogalmazásában ,, a tájak akkor születnek meg, amikor az ember felismeri más területektől elkülönülö egyéniesitö jegyeit ... és a tájrészlet önálló karakterjegyeit felismerve a lakossága által külön nevet kap.” Ezzel a szemlélettel és kutatási céllal kívántam meghatározni mindazokat a táji jellemzőket, amelyek Kalotaszeggel összefüggésbe hozhatók látványkapcsolataik, téri helyzetük, mintázati jellegük vagy tájhasználatuk révén. A nemzetközi tájkarakter-elemzési szakirodalom két (történeti- és fejlesztési célú) megközelítéséből átemeltem a tájtörténeti, tájesztétikai és táji vizualitásra hangsúlyt fektető elemeket.

A vizsgálatba először a konvencióként (néprajzi, földrajzi) „kalotaszegi”-nek elfogadott falvakat vontam be. Mivel azonban a belső vidék táji-határaira, táji átmeneteire is kíváncsi voltam, további falvak bevonására volt szükség, amellyel 116 településre bővült a vizsgált falvak száma (ez $2780 \mathrm{~km}^{2}$-területet tesz ki). Ezekböl 101 településen végeztem helyszínelést, dokumentálást, és sok településen mélyebb tájleírásokat, rajzokat és elemzéseket is készítettem. A tájegység hagyományos tagoltságából adódóan a kutatás nemcsak a közös, egységességet alátámasztó táji jegyeket kereste, hanem annak tagoltságát is igazoló, a tájegységek különbségeire rávilágító jellemzőket is (Felszeg, Alszeg, Nádas-mente, Átmeneti vidék).

A kutatásban két, különböző megközelítésű tájkarakter-elemzést végeztem el, részben egymásra épülve, de közben össze is hasonlítva azok módszertani kérdéseit. A II. fejezetben a közel 10 év helyszínelései során megtapasztalt térélményeket, látványkapcsolatokat kiegészítettem a geológiai, felszínmorfológiai háttérismeretekkel (az adottságok pontosításával); és az igen mozgalmas terepfelszín „hegyeit és völgyeit” alaktanilag elemezve alakítottam ki olyan domborzati tér-típusokat (A-N), amelyek Kalotaszeget és a kibővített környékét jellemezik. Ez után került sor a tájkaraktertípusok és tájkarakter-területek hierarchikus rendszerezésére, amelyből kikristályosodott a „tájkarakterzóna" általam bevezetett fogalma. Ezek olyan konkrét területi egységek, amelyeket hasonló térélmény és felszínmorfológia jellemez, és összefüggést mutatnak a néprajzi háttérismeretekkel is.

$\mathrm{Az}$ így létrejött 13 tájkarakter-zónát saját szempontokból összeállított, jelen-orientált, helyszínen-megélt, tájesztétikai jellegü leírásokkal láttam el (térrészek változatossága, felszínalaktani jellemzők, természetesség mértéke, gondozottság-ápoltság témaköre, koherencia, komplexitás, képiesség- és szimbólumtartalom). A zónákról három-dimenziós modellrajzokat készítettem, hogy a téri tagolását, jellemző felszínmorfológiáját, látványkapcsolatait vissza tudjam adni, mindezzel rekonstruálva a zóna egyediségét és vizuális megjelenését. 
A kutatás III. fejezetének alapját további Kalotaszeget jellemző tájkarakter-jegyek és tájkarakter-mintázatok elemzése adta kilenc fejezet köré rendezve. Ennek egyik alapját a XIX-XX. sz. fordulójáról származó mezőgazdasági statisztikák adták, a statisztikákban szereplő tájhasználati módokra (6 db) önálló tájértékelési módszert dolgoztam ki (erdő, szántó, legelö, bivalytartás, gyümölcs-kert, szőlő) amelynek eredményeként egy objektív, számszerü tájértékelési értéket kaptam. Több éves forráskutatásom eredményeként ezeket kiegészítettem tájtörténeti adatokkal, térképekkel, légi fotókkal, tervekkel és archív képekkel. Ezeket összerendezve egy múlt-orientált, tájtörténeti-jellegü tájkarakter-elemzés rajzolódott ki, amely kiemelt figyelmet fordított a tájkarakter-jegyek téri eloszlására, arányaira, mintázati grafikájára, még akkor is, ha azok csak csekély kiterjedésúek voltak (gyümölcs-ültetvények raszterei, szőlőskertek sávjai, pettyezett fáslegelők, szalag-szerű mesterséges fenyőtelepítések, nádasok). Az erdők és agroteraszok mintázati-vizsgálata esetében kis sémarajzokat készítettem, amelyek azok tipikus megjelenési formájukat és a domborzattal való összefüggéseit tükrözték. Éppen e rajzi megfogalmazások világítottak rá e két tájkarakter-jegy kiemelt szerepére, mivel azok megjelenése az egyes zónákban egymástól eltérő látványú és sürüségü. Végezetül három erőteljesen antropogén szempont eloszlását, tájképben való megjelenését vizsgáltam: a településszerkezetét, a templomtornyok látványkapcsolatait és e vidéken jelentős bányászati tevékenységek-, tájsebek-, talajsebek- tájkaraktert befolyásoló tájtörténeti és jelenlegi szerepét.

A IV. fejezet összevetette a két megközelítés módszertani-kérdéseit és a zónákat érintő területi eredményeit. Elsőként a felszínmorfológiai-, és térélmény-alapú tájkarakterezés eredményeit mutattam be, amelyben kitekintettem a zónák regionális relációra is. Másodszor a tájkarakter-jegyek jelentőségére rávilágító tájértékelési módszer eredményeit összegeztem tábláztatok segítségével. A „kalotaszegeiesség” végső tájértékelési pontszámát a zónák statisztikai jellemzőiből, átlagértékeiből határoztam meg, és e végső pontszám alapján rendeztem sorba a falvakat, amelyek látványos korrelációt mutattak az előzetesen (kiindulásként) „kalotaszegiesség-szempontjából” besorolt tulajdonságukkal. Összehasonlítottam a II.-III. fejezet módszertani megközelítésének előnyeit és hátrányait és felállítottam a kalotaszegi tájkaraktert meghatározó jegyek prioritási sorrendjét. Végül Kalotaszeg egységességének és tagoltságának jellemző tájkarakter-jegyeit és tájkarakter-mintázatait táblázatban vetettem össze, hozzákapcsolva néprajzi, népmüvészeti, társadalmi tulajdonságaikat is. Mindezek áttekintését segíti a dolgozat végébe füzött összefoglaló: a „Kalotaszeg tájkarakter-elemzési táblázata". Ez tartalmazza a települések néprajzi, helytörténeti besorolását; az összes vizsgált tájkarakter-elemzési szempont eredményeit, a zónák sémarajzait valamint a teljes kutatás eredménye alapján készített saját besorolásomat is. 


\section{KöSZÖNETNYILVÁNíTÁS}
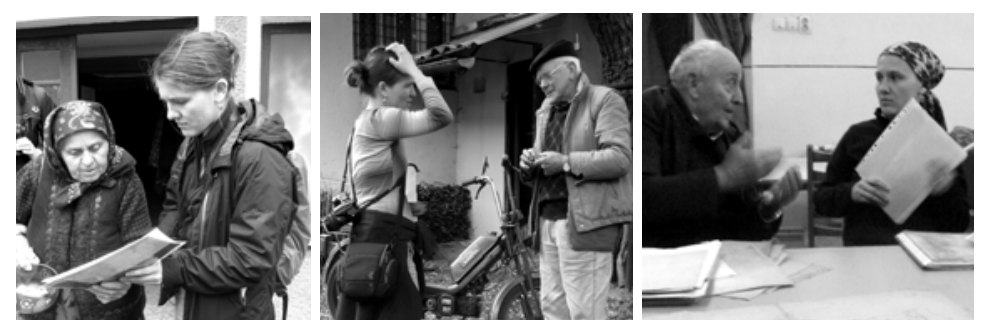

Mindenek elött köszönettel tartozom édesanyámnak, aki nemcsak a népművészet szeretetét adta át nekem, de legtöbbet segített munkám tájértékelési részében az adatfeldolgozás-kiértékelés, a végső összeállitás terén is. Hálás vagyok továbbá kollégáimnak, Fekete Albertnek és Kabai Róbertnek 10 éve történt lelkes invitálásukért a Sztánai Mühely munkájába, amelynek hatására egyre inkább megszerettem és megismertem Kalotaszeg vidékét.

Köszönöm témavezetőm, Fatsar Kristóf közremúködését a terepszemlék, tanulmányutak során és ezekhez nyújtott tanszéki anyagi hozzájárulását, tanácsait; és Báthoryné Nagy Ildikó Réka szakmai segítségét, kitartó korrigálást, amellyel strukturált, precíz mederben tartotta sokszor kreatívan csapongó ötleteimet.

Köszönöm továbbá a korábbi és jelenlegi opponensek Kollányi László, Füleky György, Illyés Zsuzsa, és Karancsi Zoltán kritikáit, meglátásit, amivel hozzájárultak a munka tökéletesítéséhez.

Köszönöm a kalotaszegi polgármesterek, tiszteletesek, adatközlők, házigazdák segítségét, akik, hol a határban segítették az adatgyüjtést, hol ebédre invitálva meséltek a táj történetéröl, térképeket, fényképeket szedve elő kedvemért. ... Végül, de nem utolsó sorban, köszönöm férjem és születendő gyermekem végtelen türelmét. 


\section{IRODALOM}

Ajtai - Fogarasi - Váradi, é.n.

Antalné Szép - Bán, 2007

Árvay, 1943

Appleton, 1980

Aston, 1985

Balázs É, 1939

Balázs Gy, 1903

Balogh I, 1935

Balogh - Fülemile, 2001

Balogh - Fülemile, 2004

Barabás, 1910

Baross, 1893

Bátky, 1907

Benigni, 1837
Ajtay Ferenc - Fogarasi László - Váradi István (szerk.): Kalotaszeg és környéke. Az Erdélyi Kárpát Egyesület Kolozsvári Osztályának kiadványa Kolozsvár, é.n.

Antalné Szép Ildikó - Bán Mária: Szucság hét évszázada. Kolozsvár, 2007.

Árvay József: A térszíni formák nevei Kalotaszegen.

(Dolgozatok a Magyar Királyi Ferenc József Tudományegyetem Magyar Nyelvtudományi Intézetéből, 9.sz.) Kolozsvár, 1943.

Appleton, Jay (szerk.): The Aesthetics of Landscape. Oxford, 1980.

Aston, Michael: Interpreting the Landscape - Landscape Archeology in Local Studies. Batsford - London, 1985.

Balász Éva: Kolozs megye kialakulása, (Település és Népiségtörténeti Értekezések, 3.sz.) Budapest, 1939.

Balázs Gyula: A Kolozsvári Kereskedelmi és Iparkamara területén üzött házi iparok törzskönyve. Kolozsvár, 1903.

Balogh Ilona: Magyar fatornyok - A magyar faépitészet emlékei Erdélyben (Néprajzi füzetek, 1. sz.) Budapest. 1935.

Balogh Balázs - Fülemile Ágnes: Adatok Kalotaszentkirály és Zentelke téeszesítés előtti paraszti gazdálkodásához. In: Hála József - Szarvas Zsuzsa - Szilágyi Miklós (szerk.): Számadó. Tanulmányok Paládi-Kovács Attila tiszteletére. Budapest, 2001. pp. 145-156.

Balogh Balázs - Fülemile Ágnes: Társadalom, tájszerkezet, identitás Kalotaszegen. Budapest, 2004.

Barabás Endre: Kolozs vármegye közgazdasági leírása. (Megyei monográfiák - Mo. közgazdasági és közművelődési állapota) Budapest, 1910.

Baross Károly, bellusi : Magyarország földbirtokosai: az összes 100 holdnál többel bíró magyar birtokosok névsora, a tulajdonukban levö földterületek mivelési ágak szerinti feltüntetésével. Budapest, 1893.

Bátky Zsigmond: Néhány adat Bánffyhunyad és környékének népies építkezéséhez. In: Néprajzi Értesitő. 1907. VIII. sz. pp. 50-70.

Benigni J. H.: Handbuch der Statistik und Geograpie des Großfürstenthums Siebenbürgen. III. Heft - Geographie. Hermannstadt, 1837. 
Bielz, 1857

Bielz, 1903

Berde, 1914

Bíró J, 1943

Bourassa, 1991

Buday, 1912

Cholnoky, 1918

Csánki, 1912

Csánki, 1913

Csányi 1912

Csávossy, 2002

Csemez, 1996.

Csima - Módosné, 2010

Cosgrove - Daniels, 1988

Dékány, 1918

Drexler, 2010

Dublinszki-Boda, 2010.
Bielz, Eduard Albert: Handbuch der Landeskunde

Siebenbürgens eine physikalisch - statistisch - topographische Beschreibung dieses Landes, Hermannstadt, 1857.

Bielz, Eduard Albert: Siebenbürgen - Ein Handbuch für Reisende. Hermannstadt, 1903.

Berde Béla: A Kolozs megyei Szucság község története. Budapest, 1914.

Bíró József: Az erdélyi kastélyok. Budapest, 1943.

Bourassa, Steven: The Aesthetics of Landscape, Belhaven, London, 1991.

Buday Árpád: Vannak-e Limes maradványos a Meszesen? (Dolgozatok az Erdélyi Nemzeti Múzeum Érem- és Régiségtárából - 3. kötet) Kolozsvár, 1912.

Cholnoky Jenő: Magyar Földrajzi Társaság Alföld Bizottságának jelentése az 1917. évről. In: Földrajzi Közlemények, XLVI., VI. füzet, pp. 257-266.

Csánki Dezső: Kolozs vármegye birtokállapotai a XV. században, in: Erdélyi Múzeum, 1912. XXIX. sz., pp. 297-332.

Csánki Dezső: Magyarország történeti földrajza a Hunyadiak korában-V. kötet. Budapest, 1913.

Csányi Károly: Képek Erdélyből, in: Magyar Épitőmüvészet.1912. (X. évf.) 9-10.sz. pp.1-44.

Csávossy György: Jó bornak szép hazája Erdély. Budapest, 2002.

Csemez Attila: Tájtervezés - tájrendezés, Budapest, 1996.

Csima Péter - Módosné B. Ildikó: Települési tájkarakter elemzés az Ipoly vidékén, in: Ormos Imre Tudományos Ülésszak - LOV 2009, Tájépitészeti tanulmányok. (szerk. Sallay Ágnes) Budapest, 2010.

Cosgrove, Denis - Daniels, Stephen: The Iconography of Landscape. Essays in the Symbolic Representation, Design and Use of Past Environments. Cambridge, 1988.

Dékány István: A földrajz tudományos módszere és ismerettana (A tájtényező a fejlödésben), in: Földrajzi Közlemények, XLVI. Kötet, 1. Füzet, pp. 1-22.

Drexler Dóra: Táj és tájértelmezés. Budapest, 2010.

Dublinszky-Boda Brigitta: A szentendrei-sziget mezőgazdasági tájkaraktere, in: Ormos Imre Tudományos Ülésszak - LOV 2009, Tájépitészeti tanulmányok. (szerk. Sallay Ágnes), Budapest, 2010. 
Galloway album, 2010

Gazdacímtár, 1897

Gazdacímtár, 1911

Gyarmathy, 1897.

Eplényi, 2005

Eplényi - Szani, 2006

Eplényi - Kardeván-Lapis, 2008

Eplényi, 2008

Eplényi, 2011a

Eplényi 2011b

Eplényi - Kardeván-Lapis, 2011

Eplényi - Frohmann, 2011
Tötszegi Tekla: Zene, tánc, hagyomány: Denis Galloway romániai fotói, 1926-1932. Budapest, 2010.

A Magyar Korona Országainak Mezögazdasági Statisztikája II.kötet - Gazdacímtár (szerk.: Magyar Kir. Központi Statisztikai Hivatal)

Magyarországi Gazdacímtár - Magyarország, Horváth- és Szlavonországok 100 kat. holdon felüli birtokosainak és bérlőinak címjegyzéke, az egyes megyék részletes monográfiájával, (szerk.: Rubinek Gyula)

Gyarmathy Zsigáné: Kalotaszeg (1897) idézi: Sas Péter (szerk.): Kalotaszeg - Magyar írók írásai Kalotaszegröl, a kalotaszegi emberröl. Budapest, 2007. p. 8.

Eplényi Anna: Kalotaszeg táj-lélek-rajza. In: Fekete Albert (szerk.): Az Erdélyi táj kérdései. Kolozsvár, 2005., pp. 20-28.

Eplényi Anna - Szani Zsolt: "Kalotaszegi gyümölcsösök” - Híd a település és a táj között, In: Füleky György (szerk.): A táj változása a Kárpát-medencében: Település a tájban-V. Tájtörténeti Konferencia kiadványkötete, Gödöllő. 2006, pp.5156.

Eplényi Anna - Kardeván Lapis Gergely: Tájköltészet: Kalotaszegi Elégia - Irodalmi kert Magyarvalkón, In: $4 D$ Tájépitészeti és Kertmüvészeti Folyóirat. 2008. (12.sz.) pp.2-14.

Eplényi Anna: Tájkapuk Kalotaszegen, In: 4D - Tájépitészeti és Kertmüvészeti Folyóirat. 2008. (12.sz.). pp. 34-43.

Eplényi Anna: The history of regional landscape linkages and gates in the region of Kalotaszeg, Transylvania. In: Workshop on Landscape History - Proceedings. (ed.: Balázs Pál és Konkoly-Gyúró Éva) Sopron, 2011. pp. 59-74.

Eplényi Anna: Historic landscape pattern and land-use in Kalotaszeg. In: Workshop on Landscape History - Proceedings. (ed.: Balázs Pál és Konkoly-Gyúró Éva) Sopron, 2011. pp. 4558.

Eplényi Anna - Kardeván-Lapis: Gergely: The BEAUTY of LYNCHETS - Traditional agricultural terraces in vernacular landscapes and contemporary landforms as representation of high aesthetical value, In: ECLAS Conference: Ethics/Aesthetics Absztakt kötet. Sheffield, 2011. pp.165-166.

Eplényi Anna - Frohmann, Erwin: Lynchets Ackerterrassenlandschaften in Rumänien - Die landschaftsprägenden Ackerterrassen in Kalotaszeg. In: Zoll+ Österreichische Schriftenreihe für Landschaft und Freiraum 2011. (21. évf.) pp. 62-66. 
Eplényi - Frohmann, 2007.

Eplényi, 2012a

Eplényi, 2012b

Eplényi - Oláh, 2011

Ercsei, 2001

Erdődi - Cs. Szabó, 1941

Fall, 1916

Fairclough - Rippon, 2002

Faragó - Nagy - Vámszer, 1977

Ferenczi, 1992

Fichtel, 1780

Finta, 2005

Fodor, 1938

Fromann, 2009

Furu, 2007
Anna Eplényi, Erwin Frohmann: Methods for landscape architects to analysis open-space, in: Book of Abstracts (ed: N.,Müller, D. Knight, P. Werner), "Urban Biodiversity and Design" - 3rd Conference of the Competence Network Urban Ecology, 2007. május 22-25., Erfurt, 2008. p.67.

Eplényi Anna: A kalotaszegi agroteraszoknak -mint a tájmintázat legjellemzőbb karakterelemének-, mikrodomborzati, tájesztétikai és tájtörténeti vizsgálata. In: Füleky György (szerk.): A táj változása a Kárpát-medencében: Történelmi emlékek a tájban, IX. Tájtörténeti Konferencia kiadványkötete, 2012, in-press

Eplényi Anna: Egyedi tájértékek és reliktum tájelemek változásainak retrogresszív tájanalízise - Kalotaszeg példáján. In: Füleky György (szerk.): A táj változása a Kárpátmedencében: Történelmi emlékek a tájban, IX. Tájtörténeti Konferencia kiadványkötete, 2012, in-press

Eplényi Anna - Oláh Brigitta: Tájrajzolatok-Kétnyelvü illusztrált segédlet a tájépitészeti rajzoktatáshoz, BCE, Tájépítészeti Kar - Egyetemi jegyzet. Budapest, 2011.

Ercsei Judit (szerk.): Kalotaszeg bibliográfiája. Kolozsvár, 2001.

Erdődi Mihály: A Felszabadult Erdély - fényképalbum, (Bevezető tanulmányt írta Cs. Szabó László) Budapest, 1941.

Fall Endre: Gyalu vára. Temesvár, 1916

Fairclogh Graham - Rippon, Stephen (szerk.): Europe's Cultural Landscape: archaeologists and the management of change. Eurpae Archaeologiae Consilium, Exeter, 2002.

Faragó József - Nagy Jenő - Vámszer Géza: Kalotaszegi Magyar Népviselet (1949-1950), Bukarest, 1977.

Ferenczi István: A daciai északi limes-szakasz nyugati felének főbb kutatási eredményeiről. In: Erdélyi Múzeum, 1992. LIV. Kötet, 1-4.sz. pp. 52-66.

Fichtel Johann Ehrenreich: Beytrag zur Mineralgeschichte von Siebenbürgen. Nürnberg, 1780.

Finta József: Az én Kalotaszegem, Budapest. 2005.

Fodor Ferenc: Tájéletrajzi tanulmányok a Jászságban. In: Földrajzi Közlemények. 1938. LXVI. Évf. 6-7.sz. pp.141-158.

Frohmann, Erwin: Theoretische Hintergründe und Methoden zur ästhetischen Beschreibung von Landschaft Skriptum im Rahmen der LV „Ästhetik und Raumbewusstsein“, Universität für Bodenkultur, 2009 - Egyetemi segédlet, kézirat

Furu Árpád: Kalotaszeg népi épitészete. Kolozsvár, 2007. 
Füleki, 2012

Glasner, 1905

Grimm, 1863

Gyarmathy, 1896

Györffy, 1987

Hála, 1995

Hála, 2006

Hauer - Stache, 1863

Hefty, 1911

Hegyesy, 1888

Herepei - Szabó T. A., 1939

Hoffer, 1909

Horváth - Kubinszky, 2002

Hoskins, 1955

Jakó, 1945

Jankó, 1892
Füleki László: Bivalyok közt Mérában, In: Folkmagazin, XIX. évf. 6.sz. p. 22.- képmelléklettel

Glasner Antal: A Kissebesi Gránitköbányák Rt. Telepeinek és müködésének ismertetése. Budapest, 1905.

Grimm, Josef: Das Urbarialwesen in Siebenbürgen. Wien, 1863.

Gyarmathy Zsigáné: Tarka képek a kalotaszegi varrottas világából, reprint: Budapest, 2000.

Györffy György: Az Árpád-kori Magyarország történeti földrajza: Bihar megye, Kolozs megye. Budapest, 1987.

Hála József: Kőbányászat és kőfaragás a Kalotaszegi Magyarvistán. In: Életmód és tradíció 7. Ásványok, közetek, hagyományok. (Történeti és néprajzi dolgozatok), Budapest, 1995. pp. 158-188.

Hála József: Kalataszeg vázolata - Régi irások és képek Kalotaszegröl. Marosvásárhely, 2006.

Hauer, Franz Ritter von - Stache, Guido: Geologie Siebenbürgens, nach den Aufnahmen der k.k. geologiachen Reichsansalt und Literarischen Hülfsmitteln. Wien, 1863.

Hefty Gyula Andor: A térszíni formák nevei a magyar népnyelvben. Különlenyomat a Magyar Nyelvőrből. Budapest, 1911.

Hegyesy Vilmos: Csöndességben. Falusi levél és Utazás külföldön. Második falusi levél. In: Sas Péter (szerk.): Kalotaszeg - Magyar irók irásai Kalotaszegröl, a kalotaszegi emberröl. Budapest, 2007. pp.156-162. és pp. 425-430.

Herepei János - Szabó T. Attila: Levéltári adatok faépítészetünk történetéhez: Fatemplomok és haranglábak, in: Erdélyi Tudományos Füzetek, 107. sz. Kolozsvár, 1939. pp.10-19.

Hoffer András: A Kiskapus és Gyerővásárhely közötti terület Geológia viszonyai különös tekintettel az eruptikus közetekre. Doctori Értekezés. Kolozsvár, 1909.

Horváth Ferenc - Kubinszky Mihály: A Magyar Keleti Vasút Nagyvárad- Kolozsvár- Brassó fővonala és a hozzácsatlakozó szárnyvonalak. In: Müszaki Szemle. 2002. 17.sz., pp.7-14.

Hoskins W. G.: The Making of English Landscape. Leicester, 1955.

Jakó Zsigmond: Az elpusztult települések kutatása. In: Erdélyi Tudományos Füzetek 194.sz., Kolozsvár, 1945.

Jankó János: Kalotaszeg magyar népe. Budapest, 1892. 
Jegenyefürdő, sz.n., 1892,

Jékely, 2004

Laszlovszky, 2008

Kabai B, 1973

Kabai R, 2010.

Kaplan, 1989

Karancsi, 2002

Kataszteri, 1914a

Kataszteri, 1914b

Kelemen, 1943

Kelemen, 1944

Kelemen, 1977

Keleti, 1875

Kizos et. al., 2010

Kol. Kereskedelmi és iparkamara jelentése, 1878
Sz.n.: Fürdőügy: Jegenyefürdő. In: Erdély - Turista és fürdőügyi és néprajzi folyóirat, I. füzet, I. kötet., pp. 48-51.

Jékely Zoltán: Kalotaszegi Elégia. Szerkesztette és előszavát írta Győri János. Budapest, 2004.

Laszlovszky József: Az Európai Táj Egyezmény és a hazai tájrégészet. In: Müemlékvédelem, 2008. 52.évf. 2.sz. pp.101104.

Kabai Béla: Kalotaszegi mủemlékek kis adattára. In: Korunk, 1973. 11.sz. pp.87-100.

Kabai Róbert: Skócia tájkarakter felmérése és az eredmények gyakorlati hasznosítása. In: Tájökológiai Lapok, 2010. 8.évf., 1.sz. pp.97-109.

Kaplan, Rachel and Steven: The Experience of Nature - A Psychological Perspective, Cambridge - New York Melbourne

Karancsi Zoltán: Természetes és antropogén eredetü környezetváltozás a Medves-térség területén, doktori értekezés, SZTE, Természeti földrajzi Tanszék, 2002.

Kolozs Vármegye adóközségeinek területe és kataszteri tisztajövedelme mivelési áganként és osztályonként, az 1909. évi $V$. T.-czikk alapján végrehajtott kataszteri kiigazitása után. Budapest, 1914.

Torda-Aranyos Vármegye adóközségeinek területe és kataszteri tisztajövedelme mívelési áganként és osztályonként, Az 1909. évi $V$. T.-czikk alapján végrehajtott kataszteri kiigazitása után. Budapest, 1914.

Kelemen Lajos: Kolozsvár közvetlen környékének történelmi és müemlékei. Kolozsvár, 1943.

Kelemen Lajos: Kalotaszeg történelmi és müemlékei. In: Kolozsvári Szemle, III. évf., 2.sz., pp.97-112.

Kelemen Lajos: Kalotaszeg történelme és müemlékei. In: Kelemen Lajos: Müvészettörténeti tanulmányok, Bukarest, 1977. pp. 206-213.

Keleti Károly (szerk.): Nemzetközi Statistika: Szölészet, I. Magyarország szölészeti statistikája 1860-1873, Magyar Kir. Statisztikai Hivatal, Budapest, 1875

Kizos, T. - Koulouri, M. - Vakoufaris, H. - Psarrou, M.: Preserving Characteristics of the Agricultural Landscape through Agri-environmental Policies: The Case od Cultivation Terraces in Greece. In: Landscape Research. 2010. Vol. 35. No. 6. pp.577-593.

A kolozsvári Kereskedelmi és Iparkamara Jelentése kerülete gazdasági, kereskedelmi, ipari és forgalmi viszonyiról 1878-ban. 
Koch, 1874

Koch,1884

Koch, 1894

Koch -

Hofmann, 1889

Koch, 1900

Kogutovicz, 1918

Konkoly-Gyúró et. al., 2010

Kós, ifj., 1947

Kós, ifj., 1980a

Kós, ifj., 1980b

Kós, ifj., 1999

Kós, 1915

Kós, 1938

Kós, 1943

König, 2001

Kőváry, 1892
Kolozsvár, 1878.

Koch Antal: Adatok Kolozsvár vidéke földtani

képződményeinek pontosabb ismeretéhez, in: Földtani Közlöny, 1874. IV. évf., 10-11.sz., pp.251 -283. 1 térképmelléklettel

Dr. Koch Antal: Magyarázatok a Magyar Korona Országainak Részletes Földtani Térképéhez: Kolozsvár Vidéke, 18. zóna/XXIX. rovat jelü lap (1:75,000), Magyar Kir. Földtani Intézet. Budapest, 1884.

Koch Antal: Az erdélyrészi medencze harmadkori képződményei, I. Paleogén csoport. In: A Magyar Királyi Földtani Intézet Évkönyve, Budapest, 1894. X. kötet, pp. 162356.

Koch Antal - Hofmann Károly: Magyarázatok a Magyar Korona Országainak Részletes Földtani Térképéhez: BánffyHunyad Vidéke, 18. zóna/XXVIII. rovat jelü lap $(1: 75,000)$, Magyar Kir. Földtani Intézet, Budapest, 1889.

Koch Antal: Az erdélyrészi medencze harmadkori képzödményei, II. Neogén csoport. Budapest, 1900

Kogutovicz Károly: Magyarország 1:200000 méretű néprajzi térképe, in: Földrajzi Közlemények, XLVI. kötet- VII-X. füzet, 1918. - térképmelléklet

Konkoly-Gyúró Éva,Tirászi Ágnes, Wrbka Thomas, Prinz Martuin, Renetzeder Christa: Határon átívelö tájak karaktereA Fertös-Hanság medence és Sopron térsége, Konkoly - Gyúró Éva (szerk.), Nyugat-Magyarországi Egyetem Környezet és Földtudományi Intézet, Sopron, 2010.

Kós Károly: A kalotaszegi kosarazó juhászat. In: Erdélyi Néprajzi Tanulmányok - 9. Kolozsvár, 1947. pp.3-28.

Földmüvelés és határbarázdáló faekék Erdélyben. In: Munka, eszköz, néphagyomány. Bukarest, 1980. pp. 131-196.

A bivaly kalotaszegi parasztgazdaságban. In: Munka, eszköz, néphagyomány. Bukarest, 1980. pp. 197-277.

Kós Károly: Népi földmüvelés Kalotaszegen - Balassa Iván bevezető tanulmányával (1944-es doktori disszertációjának kiadása), Győrffy István Néprajzi Társulat. Debrecen, 1999.

Kós Károly: Testamentum és agrikultura. Sztána, 1915.

Kós Károly: Kalotaszeg. Budapest, 1938.

Kós Károly: Erdei Lak. In: Kovács László (szerk.): Séta bölcsőhelyem körül. Kolozsvár, 1943.

König Frigyes: Várak és eröditmények a Kárpát-medencében Budapest, 2001.

Kőváry László: Erdély régiségei és történelmi emlékei. 
Kútvölgyi, 2005

Kürthy - Koch, 1876

Kürthy, 1878

Lebrecht, 1804

Magyar, 2004

Makkai, 2003

Malonyai, 1907

Marienburg, 1813

Marschrouten, 1864

Miháltz, 1926a

Miháltz, 1926b

Miklósi-Sikes, 1999

Meinig, 1979

Muir, 1999

Muir, 2004

Mzg. Stat., 1897

Mzg. Stat., 1900
Kolozsvár, 1892.

Kútvölgyi Mihály: Virágos Kalotaszeg. Budapest, 2005.

Kürthy Sándor: A Hideg-Szamos vidékének geológia viszonyai (jegyzetekkel kísérte Koch Antal). In: Földtani Közlöny. 1876. IV. évf. 6-7.sz. pp.165-175.

Kürthy Sándor: Földtani észleletek M.-Nádas, Sárd, Gorbó, SztKirály és M.-N.-Zsombor vidékein. In: Erdélyi Múzeum. 1878. V. évf., 3.sz. pp. 33-44.

Lebrecht, Micheal: Versuch einer Erbdeschreibung des Grossfürstenthums Siebenbürgen. Hermannstadt, 1804.

Magyar Zoltán: Kalotaszegi népmondák. Budapest, 2004.

Makkai Gergely: Az Erdélyi-Mezösége tájökológiája, Tanulmányok. Marosvásárhely, 2003.

Malonyai Dezső: A magyarság néprajza - I. kötet. Budapest, 1907.

Marienburg, Lucas Joseph: Geographie des Großfürstenthums Siebenbürgen I- II. Band. Hermannstadt, 1813.

Sz.n.: Militar Marsch-Routen-Buch für Siebenbürgen. Wien, 1864.

Miháltz István: Adatok Kalotaszeg morfológiájához. Földrajzi Közlemények. 1926. LVI. Évf. pp.144-153.

Miháltz István: Magyarvalkó környékének földtani viszonyai. In: Györffy István és Ortvay Rudolf (szerk.): A M. Kir. Ferenc József Tudományegyetem Tudományos Közleményei,

Természettudományi Értekezések, Szeged, 1926. II. kötet, 2 füz. Pp.95-114.

Miklósi-Sikes Csaba: A kalotaszegi falvak népi építészetéröl és levéltári adatok Kalotaszeg faépítészetének történetéhez. In: Balassa M. Iván - Cseri Miklós (szerk.): Népi Épitészet Erdélyben. Szentendre, 1999. pp.57-118.

Meinig, D.W.: Reading the landscape: an appreciation of W.G. Hoskins and J.B. Jackson. In: D.W. Meinig (szerk.): The Interpretation of Ordinary Landscapes. New York,1979. pp.195-244.

Muir, Richard: Approaches to Landscape. London, 1999.

Muir, Richard: Landscape Encyclopedia - A Reference Guide to the Historic Landscape. Bollington, 2004.

A Magyar Korona Országainak Mezögazdasági Statisztikája Első rész (szerk.: Országos Magyar Statisztikai Hivatal)

A Magyar Korona Országainak Mezőgazdasági Statisztikája Ötödik kötet - Végeredmények (szerk.: Magyar Kir. Központi 
Nagy O, 1959

Nagy J, 1995

Nagy J, 1984

Nagy János, 1870

Ode et. al., 2008

OMGE, 1886

Pávai, 2006

Pávay, 1871

Petrán, 1908

Péntek J - Szabó A, 1980

Péntek J - Szabó A, 1985

Rackam, 1986

Rackam - Moody, 1996

Rázsó, 1944

Riccabona, 1991

Rippon, 2004
Statisztikai Hivatal)

Nagy Olga: Hagyomány és haladás két kalotaszegi faluban. In: Korunk, 1959. 18. évf., 10.sz. pp.1450-1463.

Nagy Jenő: Gyümölcsös a Vlegyásza Alján. In: Kriza János Néprajzi Társaság évkönyve 3. Kolozsvár, 1995. pp 51-60.

Nagy Jenő: Néprajzi és nyelvjárási tanulmányok. Bukarest, 1984.

Nagy János: A Sztánai töltés és bevágás. In: Magyar Mérnökegylet Közlönye, 1870, XXIII. Évf., pp.499-506.

Ode, Åsa - Tveit, Mari - Fry, Gary: Capturing Landscape Visual Character Using Indicators: Touching Base with Landscape Aesthetic Theory. In: Landscape Research, 2008. 33.évf., 1.sz., pp.89-117.

Sz.n.: A parasztbirtok állapota Somogy-, Kolozs-, SzolnokDoboka- és Torontál Megyékben. Országos Magyar Gazdasági Egyesület: Jelentése az illető gazdasági egyleteknek a szövetségbe lépett gazdasági egyesületek végrehajtó bizottságához. Budapest, 1886.

Pávai István: Erdély a magyar néprajz-, népzene- és a néptánckutatás tájszemléletében. In: Zenetudományi Dolgozatok 2004-2005. Budapest, pp.193-216.

Pávay Elek: A Kolozsvár és Bánfy-Hunyad (!) közti vasútvonal ingadozó talajának geológiai szerkezete. In: Földtani Közlöny. 1871. VII.sz., pp.130-145.

Petrán József: A Gyalui Vár. Kolozsvár, 1908.

Péntek János - Szabó T. Attila: A régi növényvilág és változásai a kalotaszegi földrajzi nevek tükrében, In: Nyelvészeti tanulmányok. Bukarest, 1980. pp.131-172.

Szabó Attila - Péntek János: Ember és növényvilág -

Kalotaszeg növényzete és népi növényismerete. Bukarest, 1985.

Rackam, Oliver: The history of the Countryside - The classic history of Britain' landscape, flora and fauna. London, 1986.

Rackam, Oliver - Moody, Jennifer: The making of the Cretan landscape. Manchester, 1996.

Rázsó Imre: Talajpusztulás és talajvédelem Erdélyben. Budapest, 1944.

Riccabona, S.: Ästhetische Eigenwerte und Bewertungsmethodik. In: Landschaftswasserbau 11, Wien, 1991.

Rippon, Stephen: Historic Landscape Analysis - Deciphering the counrtyside. York, 2004. 
Schafarzik, 1904

Schema, 1761

Schmidl, 1835

Sebess, 1921

Sebestyén, 2007

Sebestyén, 2001

Sebestyén, 1996

Söllner, 1856

Solty, 1944

Steward Smith, 1933

Szabó T. A. 1934

Szabó T. A, 1939

Szabó T. A, 1940

Szabó T. A, 1942

Szádeczky, 1897a

Szádeczky, 1897b

Szádeczky, 1900
Schafarzik Ferenc: A Magyar Korona Országainak területén létezö kőbányák részletes ismertetése. Budapest, 1904.

Sz.n.: Neu und richtiges Dorf-Strassen Schmea Durch Ganz Hungarn, Croaten, Sclavonien, Banat und Siebenbürgen. Pest, 1761.

Schmidl, Adolf: Reisehandbuch durch das Königriech Ungarn mit den Nebenländern und Dalmatien, nach Serbien, Bukarest und Constantinopel. Wien, 1835.

Sebess Dénes: Új Románia földbirtokpolitikája Erdélyben. Budapest, 1921.

Sebestyén Kálmán: Körösföi Riszeg alatt - Egy kalotaszegi település évszázadai. Budapest, 2007.

Sebestyén Kálmán: Kalotaszegi régi malmok. In: Honismeret. XXIX. évf. (2001) 1. sz. pp. 91-98.

Sebestyén Kálmán: Magyarbikal története. Magyarbikal, 1996.

Söllner, J.: Statistik des Großfürstenthums Siebenbürgen. Hermannstadt, 1856.

Solty Ernő: Kalotaszeg mezőgazdasága. In: Kolozsvári Szemle, 1944. III.évf. 2. sz., pp.124-136.

Steward Smith, Lovina: Hungary Land and People, as seen by personal experiences from 1907-1932. Budapest, 1933.

Szabó T. Attila: A helynévgyüjtés jelentősége és módszere. In: Magyar Nyelv, 1934. XXX.évf. 5-6 sz. pp.160-180.

Szabó T. Attila: Bábony története és Települése. In: Erdélyi Tudományos Füzetek 104.sz. Kolozsvár, 1939.

Szabó T. Attila: A kalotaszegi nagybirtokok jobbágyságának szolgáltatása és adózása 1640-1690. In: Erdélyi Tudományos füzetek 114.sz. Kolozsvár, 1940.

Szabó T. Attila: Kalotaszeg helynevei - I. Adatok. Kolozsvár, 1942.

Szádeczky Gyula: A danki földcsúszás. In: Értesitő az Erdélyi Múzeum-Egylet Orvos-Természettudományi Szakosztályából. Kolozsvár, 1897., XXII. évf. XIX. kötet, pp.234-244.

Szádeczky Gyula: Az 1897. évi erdélyi földcsúszásokról. In: Erdély - Honismertetö lap. Kolozsvár, 1897. VII. évf. 1-3.sz. pp.2-5.

Szádeczky Gyula: Az Egeres-környéki gipsz és barnaszén képződéséröl. In: Erdély - Honismertetö lap. Kolozsvár, 1900. IX. évf., 4.sz. pp.41-44. 
Swanwick, 2002

Szinte, 1913

Takács, 2006

Teleki, 1918.

Tokaji, 1913

Torma, 1880

Tulogdy, 1930

Tulogdy, 1943

Tulogdy, 1944

Várady - Borbély, 1989

Vasas, 1994

Wanner, 2010

Wöbse, 2002
Swanwick, Cary: Landscape Charcter Assesment - Guideance for England and Scotland. The Countryside Agency \& Scottish National Heritage, 2002.

Szinte Gábor: Kolozsmegyei fatemplomok. In: Néprajzi Értesitö, 1913. IX.évf. pp.1-31.

Takács Péter: Kolozs vármegyei parasztvallomások 1820-ból (a Conscriptio Czirakyiana gépelt átirata). Debrecen, 2006.

Teleki Pál: A földrajzi gondolat története, Budapest, 1918.

Tokaji László: Eladó ország - Az Erdélyrész földbirtokforgalom utóbbi 10 évi adatai. Az erdélyrészi földbirtokpolitikafeladati. Az állam és a társadalom teendői. Kolozsvár, 1913.

Torma Károly: A Limes Dacicus Felső része. Budapest, 1880.

Tulogdy János: Kolozsvár környékének geomorfológia kialakulása. Az Erdélyi Múzeum Egyesület természettudományi szakosztályának közleményei, Kolozsvár, 1930.

Tulogdy János: Kolozsvár környékének kirándulóhelyei. In: Kolozsvári Szemle II. évf, 2. sz. pp.136-146.

Tulogdy János: Kalotaszeg földrajza, in: Kolozsvári Szemle. III. 2. sz., pp.113-123.

Várady Árpád - Borbély Anikó: Kalotaszeg: Felszeg, és Alszeg és Nádasmente. Budapest, 1989.

Vasas Samu: Népi jelvilág Kalotaszegen, Budapest, 1994.

Wanner, Robert: Forts, fields and towns: Communities in Northwest Transylvania from the first century BC to the fifth century AD. Doktori disszertáció, School of Archaeology and Ancient History, University of Leicester, 2010.

Wöbse, Hans Hermann: Landschaftästhetik - Über das Wesen, die Bedeutung und den Umgang mit landschaftlicher Schönheit, Stuttgart, 2002. 
1. ábra: Kalotaszeg fekvése és a néprajzi szempontból közismert tájegységei ............................ 8

2. ábra: Az általam vizsgált falvak (kb. 120 falu) és kereszttel az általam helyszínelt falvak........ 8

3. ábra: A gyürüs lehatárolás sémája: „Kalotaszegies- Átmeneti- Nem kalotaszegi” övezetek.... 10

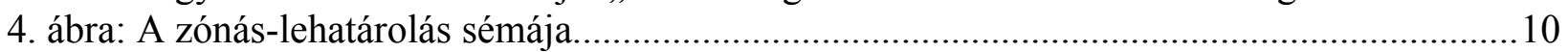

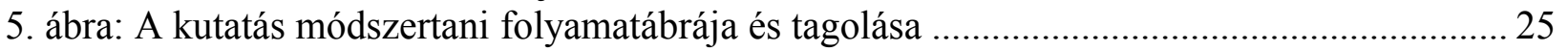

6. ábra: A II. és III. fejezet megközelítésének összehasonlítása …........................................... 35

7. ábra: A térélmény és felszínmorfológiai tájkarakter elemzés folyamatábrája..........................36

8. ábra: A felszínmorfológiai tértípusokat jellemző táblázat................................................. 51

9. ábra: A tájkarakter-típusok, tájkarakter-területek és tájkarakter-zónák hierarchikus kapcsolata .........52

10. ábra: A tájkarakter-zónák lehatárolása a geológiai alaptérkép, a tértípusok, ...................... 54

11. ábra: A tájesztétikai értékelés szempontjainak bemutatása ............................................56

12. ábra: A Bánffyhunyadi-medence tájkarakter-zóna modellrajza ÉK-felől............................57

13. ábra: A Felszegi havasalja tájkarakter-zóna modellrajza D-felől........................................58

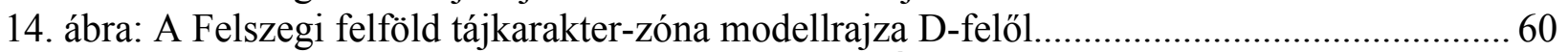

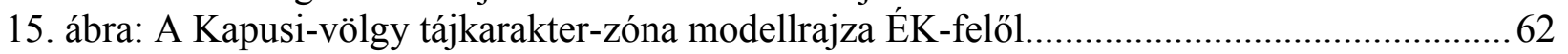

16. ábra: A Havas és havasi völgyek-tájkarakter-típusának általános modellrajza.......................63

17. ábra: A Tordaszentlászlói-vidék tájkarakter-zóna modellrajza DK-felől.............................64

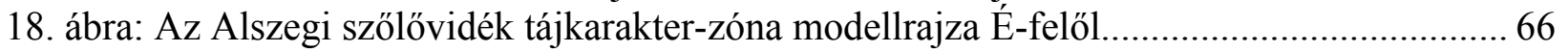

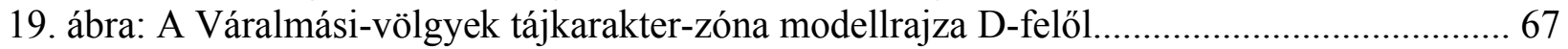

20. ábra: Az Almási barnakőszén-vidék tájkarakter-zóna modellrajza D-felől..........................68

21. ábra: A Nádas-menti-vidék tájkarakter-zóna modellrajza DK-felöl...................................69

22. ábra: A Bács-Berendi-vidék tájkarakter-zóna modellrajza DNy-felől................................. 71

23. ábra: A Kolozsvári alluvium tájkarakter-zóna modellrajza ÉK-felől.................................. 72

24. ábra: A II. és III. fejezet megközelítésének összehasonlítása...............................................74

25. ábra: A tájkarakter-jegyek megállapítása során létrejött fejezetcímek ................................75

26. ábra: A vizsgált 116 település közigazgatási, adókataszteri határa (1914) OSZK, TM 310376

27. ábra: A tájkarakter-zónák térélmény-alapú és kataszteri besorolása közötti különbségek.......77

28. ábra: A tájértékeléshez használt nyers statisztikai adatok és az azokból számolt adatok........78

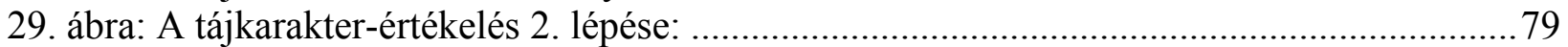

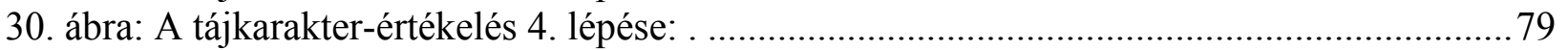

31. ábra: A kalotaszegi tájkarakter-jegyek és mintázatok elemzési rendszere........................... 80

32. ábra: A tájkarakter-zónák területi eloszlása a teljes $2780 \mathrm{~km} 2$-es vizsgált területből............. 80

33. ábra: Az erdőborítottság aránya Kolozs Vármegye járásaiban............................................. 81

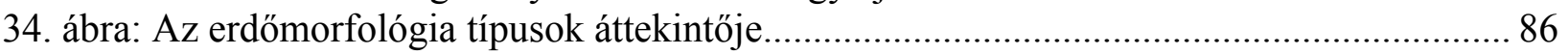

35. ábra: Az agroteraszok téri eloszlása és morfológia típusai...............................................93

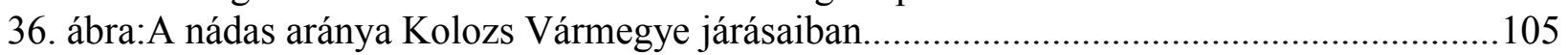

37. ábra: A statisztikailag levezetett 6 tájkarakter-jegy összesítése „kalotaszegies” alapján: ... 118

38. ábra: A települések tájértékelési rangsora „kalotaszegiesség- összpontszáma” szerint........ 119

39. ábra: A tájkarakter-elemzés két megközelítésének összehasonlítása................................. 120

40. ábra: Bedecs és Egerbegy faluszerkezete és a környező táj.......................................... 123

41. ábra: Kalotaszeg tájkarakter-egységét és tagoltságát összehasonlító táblázat....................... 125 


\section{TÁBLÁK JEGYZÉKE}

Vastagon szedve az A3-as méretủ lapok és azok illeszkedése a fejezetekhez.

1. Kalotaszeg áttekintő térképvázlata: települések és útvonalak (I.3.)

2. Kalotaszeg regionális kapcsolatainak és téri tagozódásának ábrái (I.6.)

3. Kalotaszeg geológiájának áttekintő térképvázlata (II.1.a.)

4. A Gyalui Havasok és a tordaszentlászlói terület geomorfológiája

5. A Vlegyásza geomorfológiája, tájképi szerepe

6. 6.a. A Meszes geomorfológiája 6.b. Újkori vulkánosság

7. Eocén üledékek - a felszegi alsó durvamészkő-rétegek geomorfológiája

8. Eocén üledékek - a nádas-menti felső durvamészkő-rétegek geomorfológiája

9. 9.a. Eocén - rétegek eltünése Kolozsvár környékén, neogén rétegek geomorfológiája,

9.b. Harmadkori oligocén rétegek geomorfológiája,

9.c. Újkori üledékek: diluvium, alluvium

10. Kalotaszeg vízrajzának áttekintő térképvázlata (II.1.b)

11. Vízfolyások és völgytagoltság morfológiája -1 .

12. Vízfolyások és völgytagoltság morfológiája -2 .

13. Felszínmorfológia tértípusok megállapítása és rajzai (II.2.)

14. A vizsgált terület mezőgazdasági területhasználati térképe (III.)

15. A domborzat és az erdő́k morfológiai típusai (III.2.)

16. Erdőszerkezet 1. - természetes erdők tájmintázatai, alaktani jegyei

17. Erdőszerkezet 2. - telepített erdők tájmintázatai, alaktani jegyei

18. Az agroteraszok téri eloszlása és morfológiai típusai (III.3.)

19. Az agroteraszok alaktani / időjárási változatai, térélményei (III.3.)

20. Agroteraszok 1. - tájtörténete és alaktani jellemzöi

21. Agroteraszok 2. - csoportosítása felszínalaktani szempontból

22. Agroteraszok 3. - tájmintázati és felszínalaktani jellemzői

23. Szántók tájértékelése, tájmintázatai és alaktani jegyei

24. Legeltetés 1. - a bivalytartás tájmintázatai, alaktani jegyei

25. Legeltetés 2. - a legelők tájértékelése, a juh-kosarak tájmintázata

26. Legeltetés 3. - a fás-legelők tájmintázata, tájképi szerepe

27. Gyümölcsösök, kertek 1. - tájértékelése, tájmintázata, tájképi szerepe

28. Gyümölcsösök, kertek 2. - tájértékelése, tájmintázata, tájképi szerepe

29. Szőlök 1. - tájértékelése, tájmintázata, tájképi szerepe

30. Szőlők 2. - tájmintázata, tájképi-, tájtörténeti szerepe

31. Nádasok táji mintázata, tájképi-, tájtörténeti szerepe

32. A településszerkezet és a falukép típusai (III.8.)

33. A templomtornyok látványkapcsolatai és típusai (III.9.)

34. Bányászati körzetek és azok tájkaraktert befolyásoló szerepe (III.10.)

35. A köbányászat hatása a faluképre, annak karakterére

36. A talajsebek hatása a tájképre, annak karakterére

37. Kalotaszeg tájkarakter-elemzésének összefoglalása (IV.) 


\section{MELLÉKLET-JEGYZÉKE}

A melléklet a szövegtörzzsel párhuzamos halad, és a témához (paragrafus-jellel [§]) a megnevezett melléklet logikailag, csoportosan kapcsolódik (képekkel, ábrákkal, térképekkel vagy szövegekkel).

1. §. Kalotaszeghez köthető programjaim, szemléim, helyszíneléseim, publikációm:................ 146

2. §. S. Rippon tájtörténeti megközelítésü tájkarakter-elemzésének ábrái ............................... 147

3. §. C. Swanwick tájtervezői-megközelítésü tájkarakter-elemzésének ábrái .......................... 147

4. §. A tájkarakter-elemzés tájesztétikai megközelítésének áttekintő ábrái.............................. 149

5. §. Konkoly-Gyúró Éva által alkalmazott módszer térképvázlatai ........................................ 150

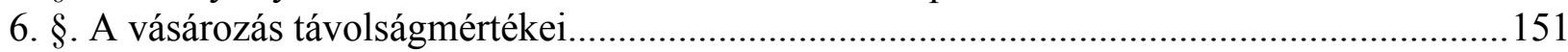

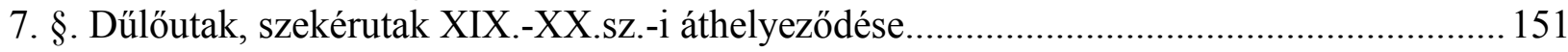

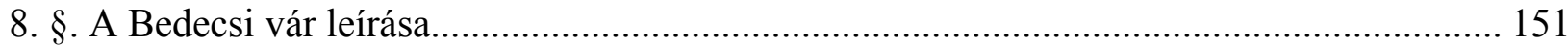

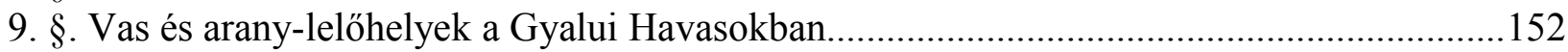

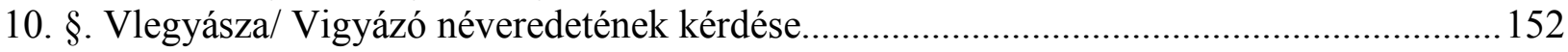

11. §. A Vlegyásza térélményéhez, időjárásához kapcsolódó leírások .................................... 153

12. §. Magyarvalkó geológiai és geomorfológia leírásai a XVIII.sz.-ból................................ 154

13. §. Felszegi malmok összeírása és jellemzése a Cziráky-féle összeírásból........................... 155

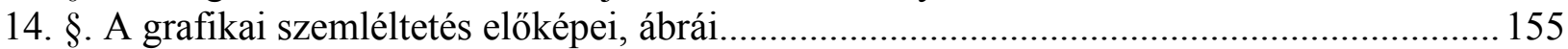

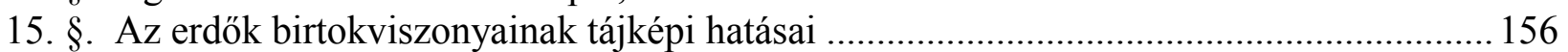

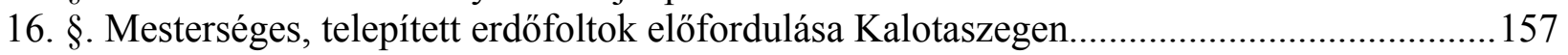

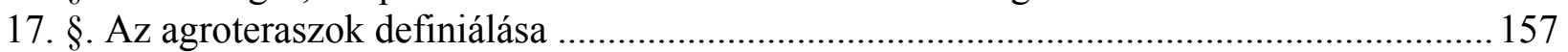

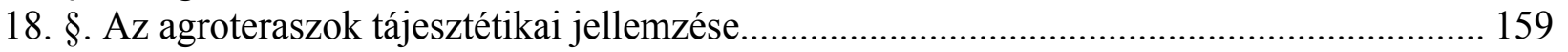

19. §. A „Kilátás-Medenék”- modell környzetpszichológia megközelítése................................. 160

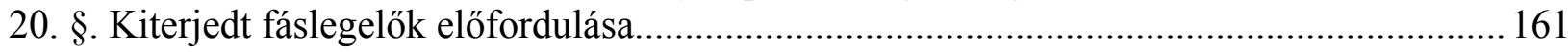

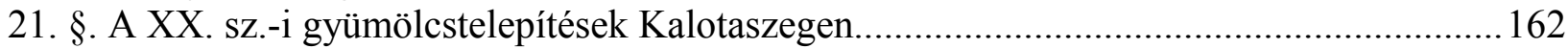

22. §. Szőlőművelésre utaló dűlőnevek Szabó T. Attila összeírásából.......................................163

23. §. Bánffyhunyad szőlőműveléssel összefüggő dűlőneveinek időrendi vizsgálata................ 163

24. §. Szőlőterületek területi és történeti megoszlása a területen............................................ 165

25. §. A szőlöterületek tájtörténeti jellegü tájértékelése......................................................... 167

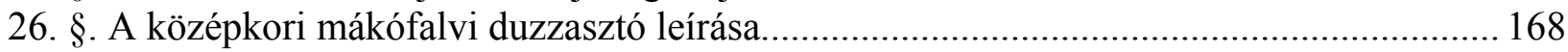

27. §. A kalotaszegi falukép elemeinek részletes bemutatása................................................ 168

28. §. A kalotaszegi tornyok jelentőségét alátámasztó idézetek:.............................................169

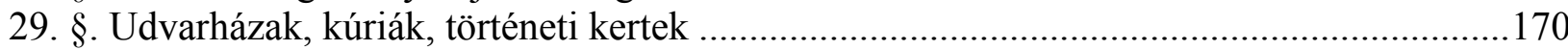

30. §. A Kissebes - Marótlaki bányák tájtörténeti és tájképi fényképdokumentációja................ 175

31. §. A mészkőfejtés és annak tájképi következményei.....................................................176

32. §. A zsoboki márványgyár tulajdonosának Szepessy Lajosnak és kertjének bemutatása..... 177

33. §. Az Egeres környéki bányászati - ipari beavatkozások és létesítmények leírása................177

34. §. A talajminőségre vonatkozó jellemzések a Cziráky-féle leírás alapján......................... 178

35. §. A vasútépítés talajtani és tájtörténeti vizsgálata......................................................... 179

36. §. A sztánai töltés és bevágás tervi és fényképes dokumentációja.................................... 181

37. §. Pávay talajszelvényénekbemutatása a Sztána-Zsoboki vasútvonalon.............................. 182

38. §. Talajcsúszások a XIX.sz. végén Szádeczky beszámolói alapján....................................182

39. §. Solty beszámolója az EMGE visszacsatolás kori munkálatairól.................................... 184

40. §. Eróziós jelenségek a néprajzi felvételeken........................................................... 185

41. §. A mezőgazdasági statisztikák területi és jövedelmi áttekintő diagramjai a tájkarakterzónánként. 


\section{MELLÉKLET}

\section{1. §. Kalotaszeghez köthető programjaim, szemléim, helyszíneléseim, publikációm:}

2001: I. Hagyományőrző Sztánai Farsang, résztvevő

2002: II. Hagyományőrző Sztánai Farsang, résztvevő - Nyári Építőkaláka, Sztána

2003: III. Hagyományőrző Sztánai Farsang, résztvevő - Nyári Építőkaláka, Sztána

2004: IV. Hagyományőrző Sztánai Farsang, szervező

- Magyarvalkó: Hagyományőrző Szilveszteri Mulatság szervezése, Kertész Táncegylet, Pázmány Péter Katolikus Egyetem Néptánccsoportja

2005: V. Hagyományőrző Sztánai Farsang - szervező

- Helytörténeti, földrajzi kirándulás: Inaktelke - Szucság - Szászlóna - Tordai Hasadék

- I. Inaktelki Hagyományőrző Szilveszteri Mulatság szervezése, Kertész Táncegylet - publikáció: Eplényi Anna: Kalotaszeg táj-lélek-rajza, In: Fekete Albert (szerk.): Az Erdélyi táj kérdései, 2004., Kolozsvár

2006: VI. Hagyományőrző Sztánai Farsang - szervező

- Sárvásár: Bánffyhunyadi Regionális Térségfejlesztési Mühely - Megbeszélés, résztvevő

- Zsobok: Regionalitás, közösségépítés, szórványgondozás. Nemzetközi összefogás a szórványkérdésben c. konferencia; előadás tartása, MTA

- I. Nyárszó Játszótérépítő Kaláka, szervezö (MTA Néprajzi Kutatóintézet: Balogh Balász, Fülemile

Ágnes, BCE Kert-, és Településépítészeti Tanszék, Lépték-terv, Kertész Táncegylet)

- II. Inaktelki Hagyományőrző Szilveszteri Mulatság szervezése, Kertész Táncegylet

- publikáció: Eplényi Anna, Fekete Albert, Kabai Róbert: Örökségvédelmen alapuló vidékfejlesztés a

Sztánai Völgyben, Konferencia-kötet: Regionalitás, közösségépités, szórványgondozás. Nemzetközi

összefogás a szórványkérdésben, 2006, június 9-21. Zsobok, MTA - Etnikai-Nemzeti Kisebbségkutató Intézet, 65-74.o.

- publikáció: Eplényi Anna, Szani Zsolt: "Kalotaszegi gyümölcsösök" - Híd a település és a táj között, Konferenciakötet: A táj változása a Kárpát-medencében: Település a tájban, 2006. június 10-13., Tokaj, pp. 51-56.

2007: VII. Hagyományőrző Sztánai Farsang - szervező

- II. Nyárszó Játszótérépítő Kaláka, szervező (MTA Néprajzi Kutatóintézet: Balogh Balász, Fülemile

Ágnes, BCE Kert-, és Településépítészeti Tanszék)

- III. Inaktelki Hagyományőrző Szilveszteri Mulatság szervezése, Kertész Táncegylet

2008: VIII. Hagyományőrző Sztánai Farsang - szervező

- publikáció: Eplényi Anna, Kardeván Lapis Gergely: Tájköltészet: Kalotaszegi Elégia-Irodalmi kert Magyarvalkón, 4D - Tájépitészeti és Kertmüvészeti Folyóirat (12), 2008/3: 2-14.o,

- publikáció: Eplényi Anna: Tájkapuk Kalotaszegen, 4D - Tájépitészeti és Kertmüvészeti Folyóirat (12), 2008/3: 34-43.o.

2009: IX. Hagyományőrző Sztánai Farsang - szervező

- Magyarvalkó: CEEPUS- egy hetes „Tájesztétikai és Tájköltészeti Mühely”, Prof. Erwin Frohmann, Kardeván Lapis Gergely, Dr. Szani Zsolt, 20 osztrák és magyar tájépítész-hallgató részvételével - Landscape History of Kalotszeg, Előadás tartása a Sheffieldi Egyetem tájrégészeti képzésén belül

- Landscape Poetry, Előadás tartása a Sheffieldi Egyetem tájépítészeti képzésén belül

2010: X. Hagyományőrző Sztánai Farsang - szervező 
- Inaktelke és Nádas-mente: Tájtörténeti Szemle, tájrégészeti-, dűlőnév-kutatási munkarésszel, BCE tájépítész-hallgatók részvételével

- publikáció: Eplényi Anna: A kalotaszegi agroteraszoknak-mint a tájmintázat legjellemzőbb

karakterelemének-, mikrodomborzati és tájtörténeti vizsgálata, VIII. Tájtörténeti Konferencia,

Tájhasználat és tájátalakulás a 18-20. században, 2010. július 8-10, Kalocsa

- publikáció: Anna Eplényi: The history of regional landscape linkages and gates in the region of

Kalotaszeg, Transylvania, Conference and workshop on Landscape History, TransEcoNet - Univeristy

of West Hungary, Faculty of Forestry, Sopron, 2010. április 22.,

- publikáció: Anna Eplényi: Historic landscape pattern and land-use in Kalotaszeg, Conference and workshop on Landscape History, TransEcoNet - Univeristy of West Hungary, Faculty of Forestry, Sopron, 2010. április 22.,

2011: Három hetes tájkarakterezési terepszemle Kalotaszegen és tágabb környezetében - elöadás: ECLAS Konferencia, Sheffield, előadás: Anna Eplényi, Gergely Kardeván Lapis: The BEAUTY of LYNCHETS | Traditional agricultural terraces in vernacular landscapes and contemporary landforms as representation of high aesthetical value, in: ECLAS Conference: Ethics/Aesthetics Abstracts, 2011.pp. 165-166.

- publikáció: Eplényi Anna, - Frohmann, Erwin: Lynchets - Ackerterrassenlandschaften in Rumänien - Die landschaftsprägenden Ackerterrassen in Kalotaszeg, Zoll+ Österreichische Schriftenreihe für Landschaft und Freiraum (Nr.18) 2011. 21. évf., pp. 62-66.

- Nyári, egy-hónapos teremszemle Kalotaszeg szegélyterületeinek bejárásával

2012: XII. Hagyományőrző Sztánai Farsang - szervező

- Két hetes tájkarakterezési terepszemle Kalotaszegen és tágabb környezetében

- Nyertes „határon túli emlékhelyek” pályázat előkészítése - Magyarvalkó: Miháltz - Jékelyi emlékkert - 2011: publikáció: Eplényi Anna: Retrogressziv tájtörténeti vizsgálati módszertan Kalotaszeg egyedi tájértékeinek és táji eseményeinek példáján - in-press 2012, Konferencia-kötet: IX. Tájtörténeti Konferencia - Történelmi emlékek a tájban, 2012. június 26-28., Keszthely,

\section{2. §. S. Rippon tájtörténeti megközelítésü tájkarakter-elemzésének ábrái}

A tájmintázatot alkotó „szövet” felépítése az elemi részecskékből (ház > telek > falu); A angol tájban visszatérő zártlegelők, cserjesávval lekerített parcelláinak erős mintázata Történeti tájmintázatot bemutató ábrái forrás: Rippon, 2004.
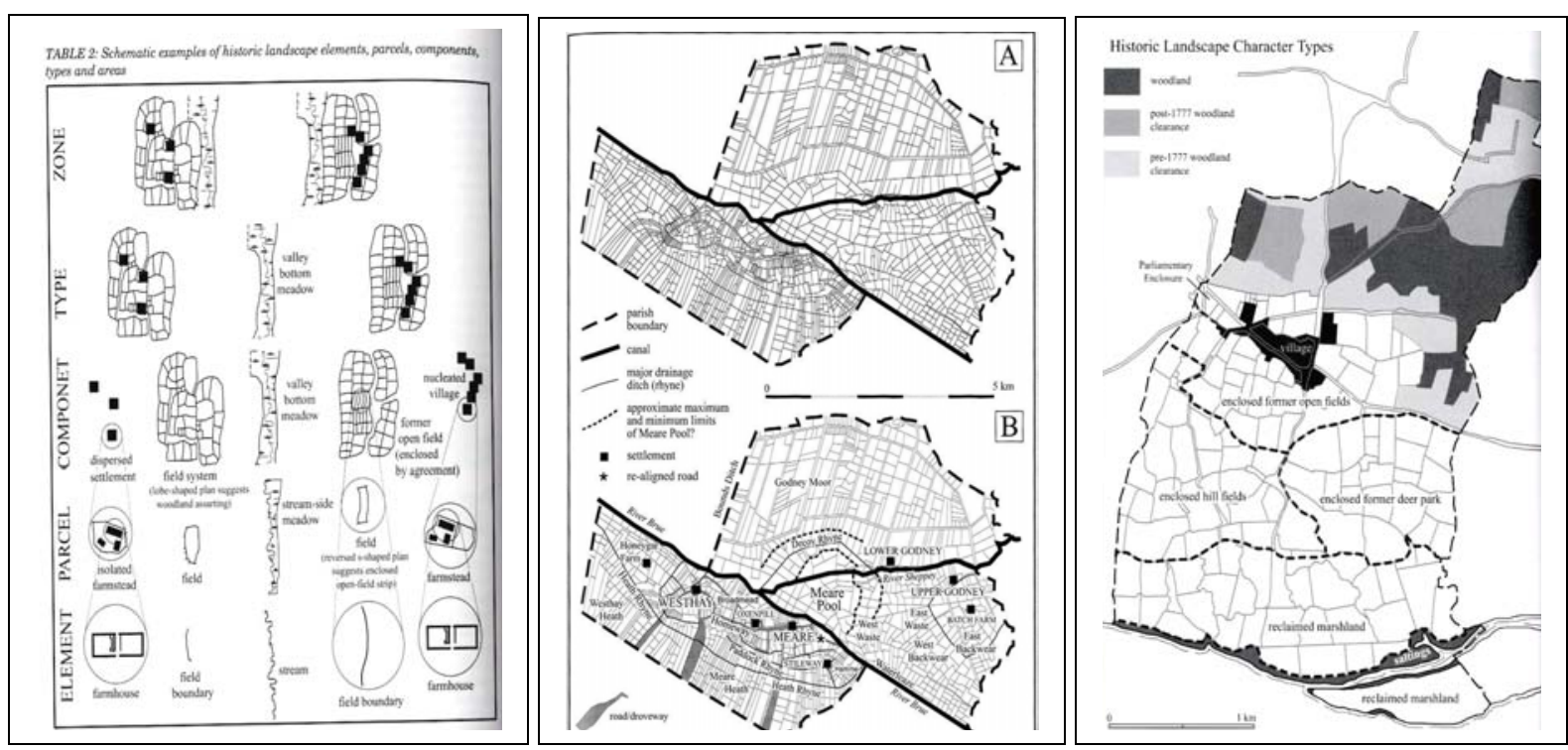


\section{3. §. C. Swanwick tájtervezői-megközelítésű tájkarakter-elemzésének ábrái}

A tájkarakter-típusok és tájkarakter-területek elkülönítése a regionális léptéktől a helyiig (2.3)

A tájkarakter-elemzést megalapozó témakörök lehatárolása típusokban és térben (4.3)

A tájkarakter-típusok és tájkarakter-területek felosztása (2.2)

A National Forest területére levezett tájkarakter-típusok és tájkarakter-területek (6.2)

A tájlátványok felvételi adatlapjának szempontjai (5.2)

A tájkarakter-elemzés esztétikai tényezői (5.2) forrás: SWanwick, 2002.
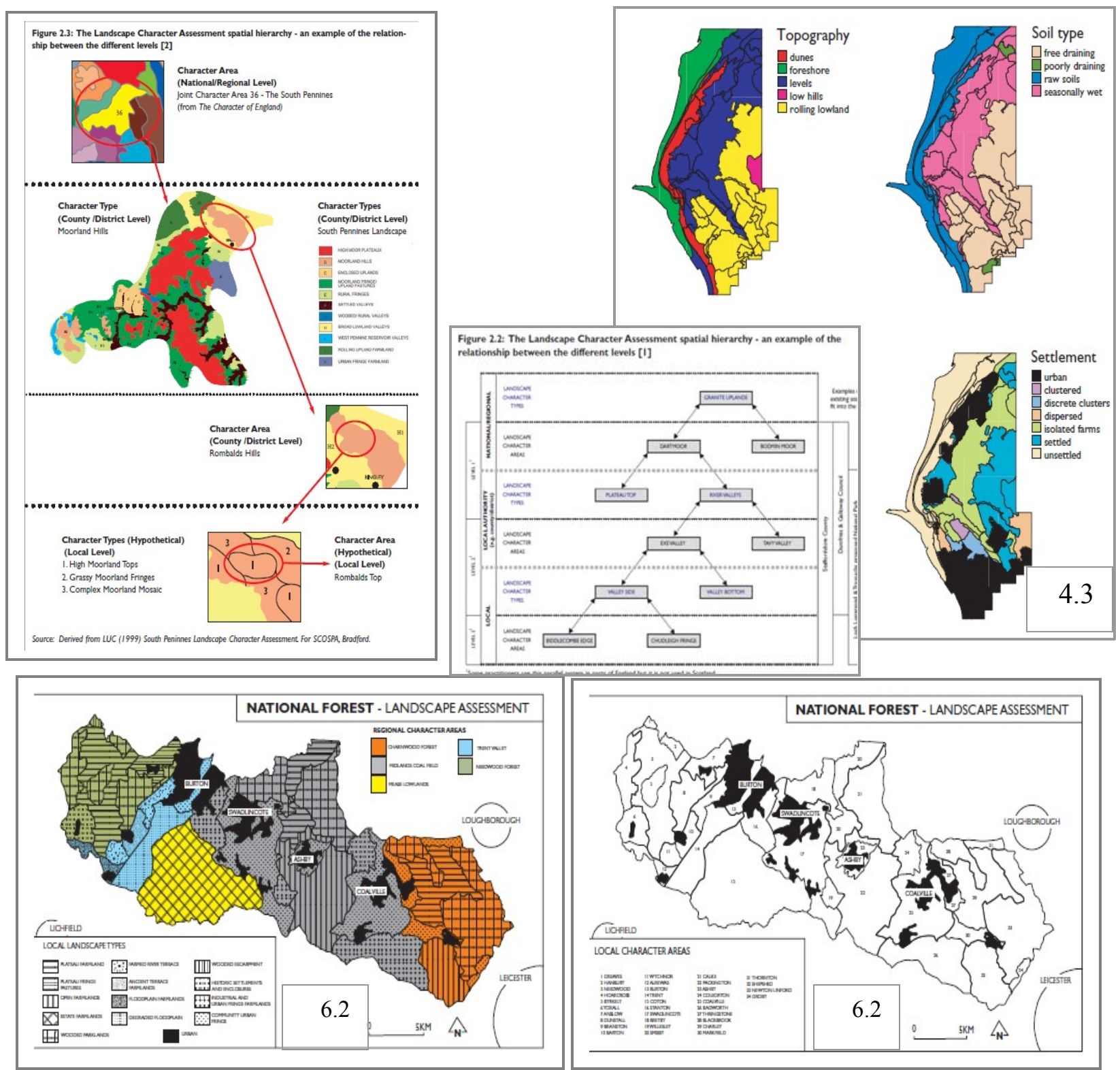

\begin{tabular}{|c|c|c|c|c|c|}
\hline Visual Assessment Criteria: & & & & & \\
\hline PATTERN (2 Dimensionaly: & dominant & strong & broken & weak & 5.2 \\
\hline SCALE: & intimate & small & medium & lange & \\
\hline TEXTCRE: & smooth & (textured & fough & very rough & \\
\hline COLOLR: & monochrome & muted & colourful & garish & \\
\hline COMPLEXTTY: & uniform & simple & diverses & complex & \\
\hline REMOTENESS: & wild & remote & vacant & active & \\
\hline UNITY: & untfied & interrupted & fragmented & chaotic & \\
\hline FORM (3 Dimensional): & straight & angular & curved & sinuous & \\
\hline ENCLOSURE: & expansive & open & enclosed & constrained & \\
\hline VISUAL DYNAMIC: & sweeping & spreading & dispersed & channelled & \\
\hline \multicolumn{6}{|l|}{ Perception: } \\
\hline SECURITY: & intimate & comfortable & safe & unsettling & threatening \\
\hline STIMULUS: & monotonous & bland & interesting & challenging & inspiring \\
\hline TRANQUILLITY: & inaccessible & remote & vacant & peraceful & busy \\
\hline PLEASURE: & unpleasant & pleasant & attractive & beautiful & \\
\hline
\end{tabular}


Box 5.2: Some of the aesthetic factors in Landscape Character Assessments

Balance and Proportion

The relative quantities of different elements within the view affect balance and proportion. Criteria such as a $1 / 3$ to $2 / 3$ relationship (rule of thirds) can be used to assess how well balanced the landscape is in aesthetic terms. Temporal effects should be considered. Proportions may change with the seasonal addition or loss of elements.

\section{Scale}

Here the overall scale of the landscape must be assessed once the factors that define it have been established. These include the degree of enclosure by landform or woodland and the main positions from which the landscape is viewed - scale increases with elevation and distance. Scale is closely related to balance, proportion and enclosure.

\section{Enclosure}

Where elements are arranged so that they enclose space, this has an effect on the overall composition so that the space and mass become as one. It also has a great effect on scale due to the interaction of the height of the enclosing elements and the distance between them.

\section{Texture}

This varies according to scale, but can be defined in relative terms as coarse, intermediate or fine. Texture is determined by crops, tree cover, size of trees, species, size of fields, etc. It is an important contributor to design unity and diversity, susceptible to change by addition or loss of elements.

\section{Colour}

This refers to the dominant colours of fields. woodlands, the built environment and other landscape elements. It includes any notable seasonal effects due to farming activity and seasonal change.

\section{Diversity}

This needs to be assessed in two ways. First, within the boundaries of the landscape type the minor variations of the landscape should be assessed to determine overall how uniform or diverse the landscape is. Second, the diversity of a typical composition should be evaluated. Additionally, trends for change should be borne in mind, that is whether the degree of diversity is increasing or decreasing.

\section{Unity}

The repetition of similar elements, balance and proportion, scale and enclosure, all contribute to unity. The degree to which contrasting elements disrupt a composition depends also on the context. For example a single quarry in the midst of an otherwise unified landscape pattern may cause a high degree of discontinuity.

\section{Form}

This term describes the shapes of fields, woods, of linear features, of landform. e.g. rectangular, curvilinear, rounded, flat, etc. It is a very important factor in defining ancient or planned landscapes. We pick out forms and shapes very quickly, often on slight evidence.

Source: Based on Forest Authority England (1992) Forest Authority Guidelines on landscape assessment for Indicative Forestry Strategies. Unpublished draft, as in CCP 423, Countryside Commission.

\section{4. §. A tájkarakter-elemzés tájesztétikai megközelítésének áttekintő ábrái}

A Kaplan házaspár által kidolgozott kognitív tájpreferencia elmélet mátrixa (Kaplan, 1989, p.53.) A táj vizuális karakterjegyeinek elemzéséhez kapcsolódó táj-, környezetpszichológiai tézisek és a táj vizuális karakterjegyeinek rendezése kilenc témakör szerint (in: Ode et. al., 2008. p.92.)

\begin{tabular}{|lcc|}
\hline Table 2-1 & $\begin{array}{l}\text { ORganization OF THE KAPLAN AND KAPLAN } \\
\text { MODEL OF ENVIRONMENTAL PrEFERENCE }\end{array}$ \\
\hline $\begin{array}{l}\text { Characteristics } \\
\text { of Information }\end{array}$ & Understanding & Exploration \\
$\begin{array}{l}\text { Immediate } \\
\text { Inferred or Predicted }\end{array}$ & $\begin{array}{l}\text { Coherence } \\
\text { Legibility }\end{array}$ & $\begin{array}{l}\text { Complexity } \\
\text { Mystery }\end{array}$ \\
\hline
\end{tabular}

Table 2. Concepts describing landscape character-relationships to theories of landscape preference and experience

\begin{tabular}{lll}
\hline Concept & Theory & References \\
\hline Complexity & Biophilia & Kellert \& Wilson (1993) \\
Coherence & Information Processing Theory & Kaplan \& Kaplan (1982, 1989) \\
Disturbance & Biophilia & Kellert \& Wilson (1993) \\
Stewardship & Aesthetic of care & Nassauer (1995) \\
Imageability & Spirit of place/genius & Lynch (1960); Litton (1972); \\
& loci/vividness & Bell (1999) \\
& Topophilia & Tuan (1974) \\
Visual scale & Prospect-refuge theory & Appleton (1975) \\
& Information Processing Theory & Kaplan \& Kaplan (1982, 1989) \\
Naturalneps & Restorative landscapes & Kaplan \& Kaplan (1989); \\
& & Ulrich (1979, 1984) \\
& Biophilia hypothesis & Kellert \& Wilson (1993) \\
Historicity & Topophilia & Tuan (1974) \\
& Landscape heritage/ & Lowenthal (1979, 1985); \\
historic landscapes & Fairclough et al. (1999) \\
& Restorative landscapes & Kaplan \& Kaplan (1989); \\
& & Ulrich (1979. 1984)
\end{tabular}




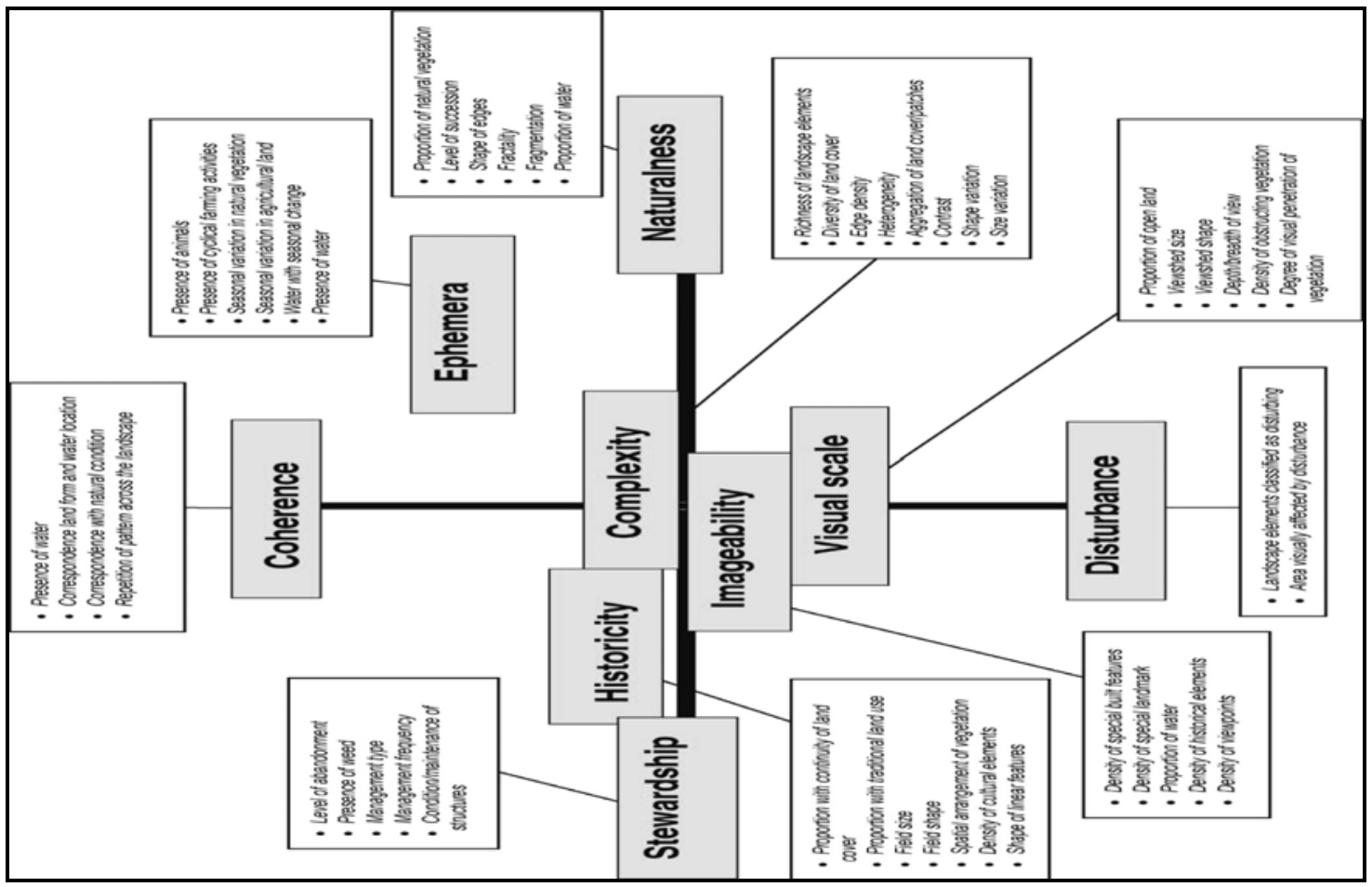

\section{5. §. Konkoly-Gyúró Éva által alkalmazott módszer térképvázlatai}

A három kiindulási adat: 1. Relieftípusok // 2. Emberi hatás // 3. Felszínborítottsági dominancia 4. Az ezekből összefektetéssel létrehozott 63 tájkarakter-típus (=tájmozaik)

5. A helyszíni és szakértöi megítélés alapján leegyszerüsített 13 tájkarakter-típus

Forrás: (Konkoly-Gyúró et al., 2010)
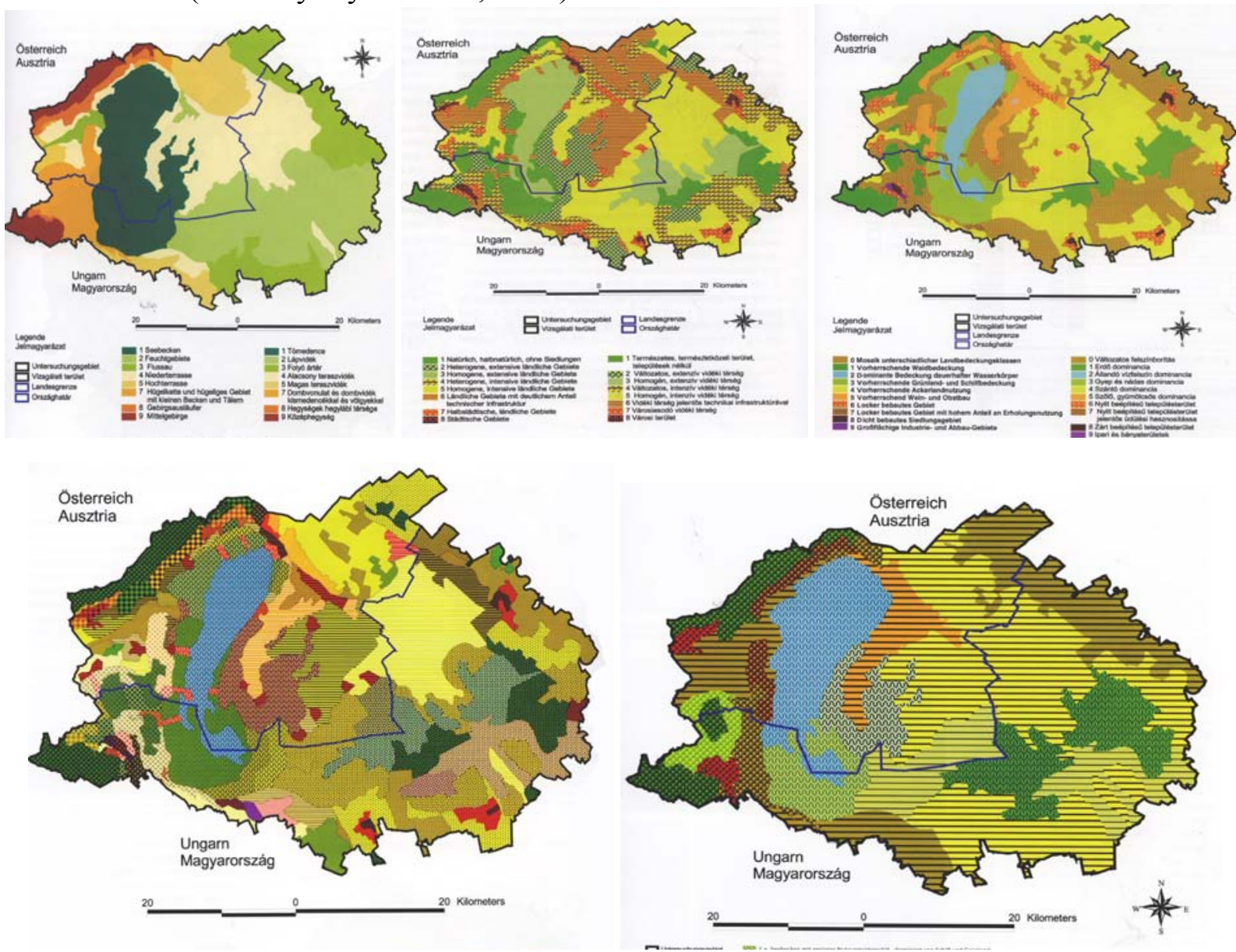


\section{6. §. A vásározás távolságmértékei}

A távolságmérésre ekkor vagy a 'Stáció-t használták, amely a fogatos közlekedés esetén az állatok pihentetése, fogatcsere közötti időt jelentette, általában 3-4 órát. Pl. Körösfőről Kolozsvár két stáció, vagy a magyar szárazföldi 'mérföldet', ami megközelítően $8-9 \mathrm{~km}$ volt, pl. Bocsról Nagyvárad 8 mérföld távolságra volt, és végül a 'napi járóföldet' ami az oda-vissza utat és az ott töltött időt jelentette, pl: Marótlaka-Abrud három-napi járóföld. (in: Takács, 2006.)

\section{7. §. Dülőutak, szekérutak XIX.-XX.sz.-i áthelyeződése}

Magyargyerőmonsotorra „nyílegyenesen” Jézus domja-Nyárszó-Jákótelke-K.Bikal útvonal vezetett, és még Jankó János saját felmérése is ezt mutatja; Sebesvártól-Malomszegen át rövid út vezetett Zentelkére, Hunyad elkerülésével, amelyet sok térkép fóútként jelöl; ill. Nagykapus-Nádik-ér völgyeGyerővásárhely -'Papp erdeje'-Egeres útvonal vezetett Szilágság felé. Ezek a motorizáció elterjedésével szerepüket vesztették. Az akkor még Hunyadról Bikalon és Farnason át vezető országút a XX.sz. első felében kezd áthelyeződni Ketesd-Alsófüld felé, és eközben a Hangos-tető melletti fogadó (Farnas déli határában) is jelentóségét veszti.

\section{8. §. A Bedecsi vár leírása}

„A községtől keletre, 2,5 km-re, egy fenyves erdővel borított ÉK-DNy irányú hegynyúlványon, melyet délkeletről a Vár-völgye, északról a Kapus-patak határol, találjuk a bedecsi vár csekély maradványait. A kisterületü, középkori hegyi várról okleveles említés nem maradt fenn. Jellege és maradványai alapján fennállása a 13-14. századra tehető. A hegygerinctől kettős árokkal leválasztott kis vár területe 40x15 méter. Felszíne a kincskeresők turkálása miatt erősen bolygatott, ezért a vár alaprajza nehezen kivehető. Az északi oldalon, ahol kissé lankásabb a hegyoldal a Kapus-patak felé, a plató peremén várfal maradványát találjuk. A várfalnak egy 2 méter hosszú, szögben megtörő darabja 1-1,5 méter magasan ma is jól látható. A plató D-i részén a hegyoldal meredek és szakadékos, itt falazat nyoma nem figyelhető meg. A községben lakók elmondták, hogy az 1940-es években még több falszakasz is látszott a vár területén, ezeket azonban a kincskeresők szétdúlták." - Szöveg és a képek forrása: http://jupiter.elte.hu/index.html, 2012.03.21.

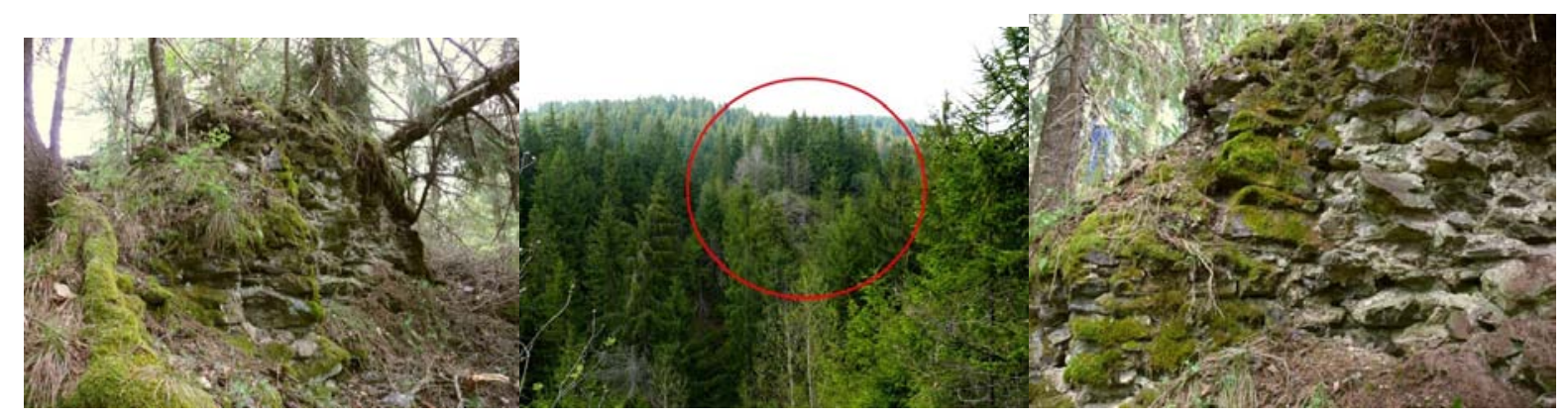




\section{9. §. Vas és arany-lelöhelyek a Gyalui Havasokban}

A Gyalui havasok szemmel látható további táji jellegzetessége a Kiskapus és Egerbegy határában megfigyelhető vörhenyes színü finomleveles agyagcsillámpala, amely néhol annyira bőven tartalmaz pirit-kristályokat, hogy az egész pala agyagos vörös- és barnavasérc telepekké változik. „Egy ilyen telepet a kiskapusi Bányabércen túl fekvő mély oldalvölgyben régebben bányászni is kezdtek, amit a most is látható tárnák bizonyítanak."- írja Koch Antal 1889-ben. ${ }^{1}$ Az 1864-es Pesty-féle összeírásban még az szerepel, hogy a „Bányabérc onnan veszi nevét, hogy e hegyben hajdan vasbányászati kísérletek folytak, nyomai mai is láthatók." ${ }^{2} \mathrm{~A}$ XX. sz. második felében épült ki a Nagykapusi Vasgyár, amely erős ipari jelleget adott a völgynek, de tárnái a Nagykapus feletti (elzárt) domboldal erdőjéből nyílnak így nem láthatóak. A Gyalui Havasok délebbi völgyeiben (Hideg-Szamos) fontos ásványkincs az 1838-óta megtalált arany, ${ }^{3}$ amelyet azonban nagyon kis mennyiségben, 2 munkással bányásztak a Schreiber-Végh család Sándor-József-Jakab-bányájában 1880-1900 körül. ${ }^{4}$ Az arany bányászata délre, Jára-Aranyosvölgye, Abrudbánya felé kezd csak jelentősebbé válni, annak a területnek a nyersanyagai erősen eltérnek a Kalotaszegitöl.

\section{0. §. Vlegyásza/ Vigyázó néveredetének kérdése}

A hegységet Téglás Ercsei-féle Kalotaszeg első leírásában és annak Merei-féle cáfolatában is Vlegyászának (Vlediásza) nevezik. A visszacsatolás utáni újbóli magyarosítás hevében Tulodgy ${ }^{5}$ így érvel: „Kalotaszeg nyugati határát alkotja a $1838 m$ magasra emelkedő Kalota hegység. Így nevezte már Lázár diák hazánk legrégebbi általa rajzolt térképén (Kalata Alpes). Így nevezték az 1600-as, és 1700-as évek térképén. Tehát az a helyes neve a gyönyörü hegységnek, és nem a késöbbi Vlegyásza vagy a Vigyázó elnevezés." Egy 1813-as erdélyi tájleírás (Marienburg, 1813) megkülönbözteti a Gebirge Vledasza-t és annak előhegységét, a Kalota hegyet: „Die Höchsten Gebirge diese Comitats find die Grenzgebirge gegen das K. Ungarn zu ...Die Gebirge Vladiása. Noch weiter ist das Gebirge Balamirása und tiefe in den Comitat herein das Gebirge Kalota oder Mogura máre. Kleinere flüsse sind:)(...) den am Gebirge Kalota entspringenden Kalota, den am Fuße des Gebirges Vlediáßa entspingenden Szekellö...”. Koch ${ }^{6}$ geológiai tájleírásában így fogalmaz: , a legtágabb értelemben vett Vlegyásza hegytömeges a Sebes-folyó völgye által leszelt keleti rész a Bogdán vagy a Kalotaszegi hegység nevei alatt is ismeretes”. Ebböl feltételezhetjük, hogy a XIX. sz. közepén mindkét elnevezés használatban volt, és más terület megnevezésre szolgált: a Vlegyásza, ahogy az több kéziratos térképen is szerepel a magashegységre volt értendő, a Kalotahegy(ség) pedig ennek előhegységére (ma Bogdán-Tomoldok). Terepszemléim során megállapítottam, hogy ma már senki sem használja a Kalota-hegység fogalmat, a felszegi magyar lakosság is egyértelműen, kizárólag csak is a Vlegyásza megnevezést használja.

\footnotetext{
${ }^{1}$ Koch - Hofmann, 1889, p. 11. Szabó T. A., 1942., p. 172.

${ }^{3}$ Kürthy - Koch, 1876., pp. 165-175.

${ }^{4}$ Kol. Kereskedelmi és Iparkamara éves Jelentései alapján

${ }^{5}$ Tulogdy, 1944, p. 114.

${ }^{6}$ Koch - Hofmann, 1889. p.5.
}

${ }^{2}$ 1941-es dülőnév-összeírásban azonban már a Bánya-patakánál lévő ,„Juk (!) barlangszerü nyilás neve, amelyről azt tartják, hogy egy régi aranybánya bejárata, ... a falubeliek emlékeznek, hogy itt mérnökök kutattak, de nem kaptak aranyat”. In: 


\section{1. §. A Vlegyásza térélményéhez, időjárásához kapcsolódó leírások}

Merei-Gracza: „Az agg Vlediásza, e’ felhőkben meredező sivatag, talán többet érdemel egy pár szónál melyekben csak magossága és természeti fekvése érintetik. Ez a hegy az, mely mintegy örök időkre írt jóslókönyv, elemi vihart, vagy derült napot ígér Kalotaszeg szorgalmas gazdáinak, melyet ha nap lemenetekor köd borít, tavasszal és ősszel sanyarú időre, télben tartós havazás után kiderülve kemény hidegre számolunk, és nyárban, egy tojásnyi felhő bérczei felett pillantok alatt óriásodva, villámtüz, zúgó zápor, vagy éppen felhőomlás dúl egész vidékünken; közmonda: ködöl a' Vlediásza, vége a 'jóidőnek, mert sokszor hoz borút e' hegy vidám derüre, és tartja kötve a' földmíves gazdát. ... Azon részét a Vlediászénak, hol a’ fenyők már tenyészni megszünnek, temérdek islandicum (transsilvanicum) és apró, sủrün öszve-nőtt borsfenyő borítja, mely legfennebb fél ölre növekedve, földszint terül-el, szász meg száz ágazatokra kanyarodva le a' fenyvesig. A’ Vlediásza bár magos, hideg és egy örökös széltanya, de nem hazája még is egy örökös télnek, nyárelő hóban lanyhán esősvén, megtarkul 's már közepén annak, a' kikelet nyomai látszódnak; azonban a' rövid nyarat komor tél váltja fel nemsokára, 's bészappanyozott bérczei gúnymosollyal tekintenek a' b.hunyadi szőlőhegyre, hol Bacchus körmibe fúva, és sokszor fog koczogva, alig szürheti el savanyú borát."’

Jankó: Eső lesz, ha a Vlegyásza közel jön, felmagasodik és a zöldje tisztán látszik; ... Ellenben szép időt várhatni, ha reggel a Vlegyásza le van rokkanva vagy nagyon meg van alapulva s aszály (fekete füst) látszik rajta; ha a felhő Magyarvalkó felé húzódik. ${ }^{8}$

Gyarmathy Zsigáné: Délnyugaton az egymás fölé emelkedő kékzománcú hegység háta mögött magasan, fenségesen trónol a mi havaink hegykirály az öreg Vlegyásza. Volt egykor ő is fiatal, és akkor tüzes belsejének szikráit ontotta; most kiégett vulkánja fölött hó ragyog, oldalának barázdáit bársonyos öblökké simogatta az évszázadok keze, a mélyebb gerincekben nyaranta is ragyog a hó, és innen mármint Bánffyhunyadról - tekintve olyan az, mintha a távolság kékjében nagy fehér madár úszna. A Vlegyásza tájának vadregényes szépsége megkapó; a hegységeket sötét fenyves borítja; óriás sziklák alján kristályvizek zubognak, a szakadékok vágásain át sötétkék hegycsúcsok tűnnek fel; szóval fenséges szép ez a havas. ${ }^{9}$

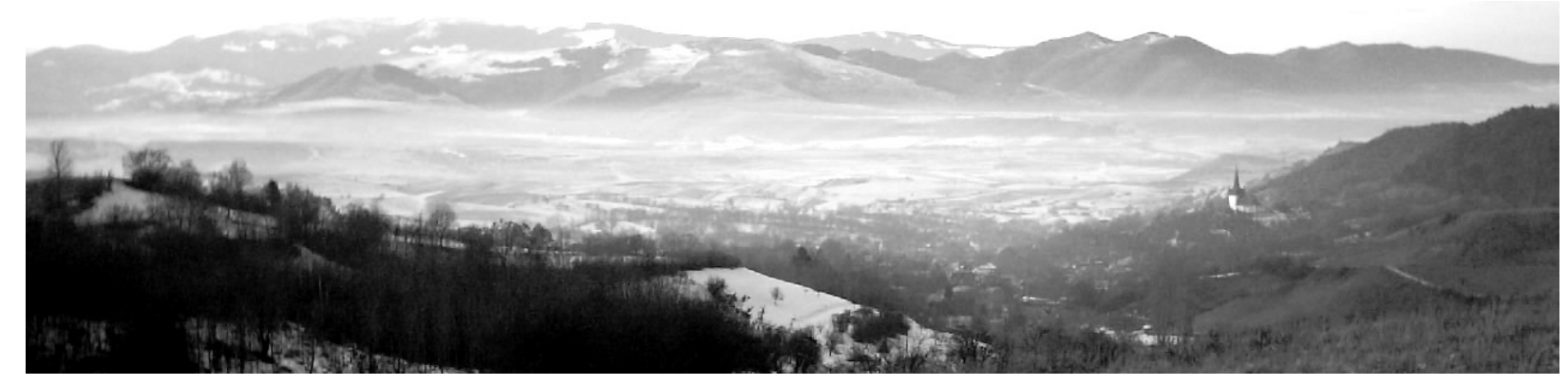

\footnotetext{
${ }^{7}$ Merei Gracza György, 842 - idézi Hála, 2006. pp.26.27.

${ }^{8}$ Jankó, 1892. p. 189.

${ }^{9}$ Gyarmathy, 1897.
} 


\section{2. §. Magyarvalkó geológiai és geomorfológia leírásai a XVIII.sz.-ból}

Fichtel 1780-ban személyesen látogat el Magyarvalkó környékére, amelynek tájmorfológiáját részletesen (és némi csodálattal átitatott lelkesedéssel) mutatja be. A Valkó környéki mezaplatós formációk festőiségét később is dicsérik. A XIX. sz. közepén Hauer szintén felhívja a figyelmet a valkói hegyek kontúrformáinak különlegességére. Megállapítható, hogy a Felszegi táj legkorábbi felfedezői német geológusok voltak, akik megfigyeléseiket már a XVIII. sz. végén publikálták Magyarvalkó és Magyargyerőmonostor környékéről. A tájleírások alátámasztják a környék egyedi geomorfológia arculatát; kövületeinek gazdag bemutatása pedig jelzi Valkó korán kitüntetett szerepét:

„Walko: Wenn von Banffy-Hunyad dahin gefahren wird, trifft man zwei, ostern der Strasse gelegene, und nicht weit voneinander entfernte, für sich frei stehende hohe und zugespitzte Berge an, die in einer konischen Gestalt so regulär gebaut, auch so artig und abwechselnd bewachsen sind, daß man sie, wenn ihre Höhe und Größe nicht widerspräche, für Berge, so die Kunst zusammen getragen und angepflantzet hätte, halten würde. Zwei Stunden weiter auf der fast ebenen Strasse fortgefahren, kommt man an der Fuß von wieder zwei nebeneinander frei und abgesetzt stehenden Bergen, zwischen welchen in einem tiefen Loche, ich nicht sagen, Thale das Dorf Walko lieget. Es finden sich in dieser Gegend noch mehrere Dörfer, die eben diese Lage haben, und gegen den Horizont, in gewaltsam ausgewaschenen Vertiefungen stachen, auch mit so steilen Rupturen umgeben sind, daß kaum an einem Orte eine Ausfahrt angebracht werden konnte. Wer immer diese Gegend mit einigen Aufmerksamkeit betrachtet, wird sich von einer ehemaligen wüthenden Fluth überzeugen, und von der, als allgemein angekommenen Hypothese, das die Berge von Merre erbaut worden. ${ }^{\text {"10 }}$

„Walko, eine ehrwürdige Gegend...“ 11

„Magyar Valkó: die Umgegend dieses Dorfes ist durch ihre sonderbare Bildung und die Menge der Versteinerungen, welche man dasselbest antrifft, für den Geologen besonders merkwürdig. “ ${ }^{12}$

„In der Umgebung von Valkó zeigt das eocene Gebirge besonders scharfe und schroffe Contourformen. Besonders fällt ein hoher spitzer Kegel zwischen Gyerő Monostor und diesem Orte in die Augen, der auf grosse Entfernung und von verschiedenen Seiten aus gesehen, denselben die umgebenden Berge beherrschenden und von ihnen abstechenden Charakter behält.... In ähnlicher Weise schafkantig and steil abgebrochen nach mehren Richtungen sind auch die meisten kleineren und weniger auffallenden Berge seiner Umgebung... die verschiede Höhe der Lage verbunden mit der Verschiedenheit des geologischen Materials bedingt andere Formenverhältnisse der Landschaft.“ 13

\footnotetext{
${ }^{10}$ Fichtel, 1780, p. 52-55.

${ }^{11}$ Lebrecht, 1789. p. 246

${ }^{12}$ Benigni, 1837. p. 27.

${ }^{13}$ Hauer - Stache, 1863. pp. 450-451.
} 


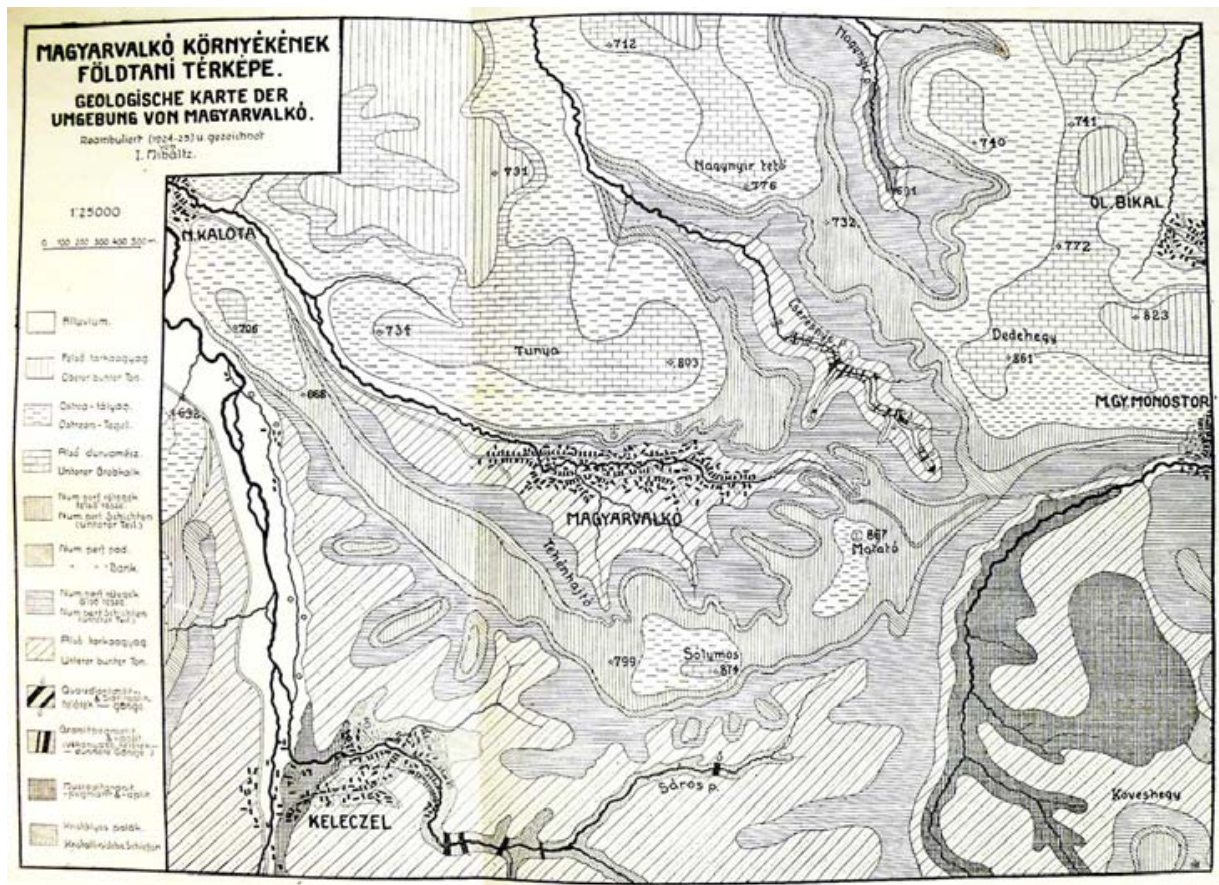

Magyarvalkó környékének XX.sz.-i földtani térképe (Miháltz, 1926b.)

\section{3. §. Felszegi malmok összeírása és jellemzése a Cziráky-féle összeírásból}

Kelecel: Itt, benn a helységünkben, vagyon b. Bánffi (!) György Rusz Györgyi nevủ emberinek egy 1 kövű malma. A Határunkon Petre Szimnak, és más Girze Mitrujnak egy kövük. A mi számunkra elegendők. Nagykalota: A Fejér (?) vizén vadnak fürészeink, melyek ugyan az uraságé, de a destkét és lécet onnan szerezzük. A Méregjói szomszéd határon vagynak ványolómalmok. A szomszéd Székjó vizén szoktak tőlünk tutajjal járni Nagyváradra. Lisztelő malmaik vagynak nékünk maguknak. Egy néhány parasztoknak itt benn, a faluban Kálma Vonnak kétkövü, csakugyan a faluba Bara Mitrének 1 kövü, ugyanott Nyikora Mihálynak 2 kövü, Koza Vonnak 1 kövü, Roska Györgyinek egykövü. Incsel: Helységünkben malom nincsen, de van a földesuraságnak várcai prédiumában. 4 lisztelő malom vagyon. Kettő tkts Datzó János úré, két-két köv, 1 tkts Keresztes Elek úré, 1 kövü, Egy Zámbó Elek és Ferenc uraké, 1 kövü, melyek helységünknek elegendők. Ványolómalmaink a szomszédban elegendőek vagynak. Úgy fürészmalmok is. Magyarvalkó: Malmunk van a határon 3, idevaló gazdáké. Méregjó: Vagynak határinkban jó ványoló malmok, ahol öltözékre való gyapjú szöttyeinket megványolhatjuk. Malmok benn a faluban elegendőek vannak, 6. Sebesvárallya: Alkalmas nagyságú folyóvizünk van, a Székellyó vize, mely itt folyván le falunk mellett, szoktunk tutajokkal Váradig kimenni. Kenderáztató vizünk a faluban van elég, és minden időbe örölhetünk, úgy papíros és ványoló malmunk is vagynak. Székelyó: Lisztelő malmaink vagynak itt is a faluban, és annál fogva minden időben őrölhetünk eleget Vagynak fürészmalmok is, melyeken szoktuk vágni a deszkákat és léceket. ${ }^{14}$

\section{4. §. A grafikai szemléltetés előképei, ábrái}

Tájkarakter-elemzésnél alkalmazott, magas-nézőpontú látványrajz (Swanwick, 2002., 5.2.)

2,5 D-s tájtérképek és terepmodell rajzok metodikája (Eplényi - Oláh, 2011. pp.168-173)

\footnotetext{
14 Takács, 2006.
} 

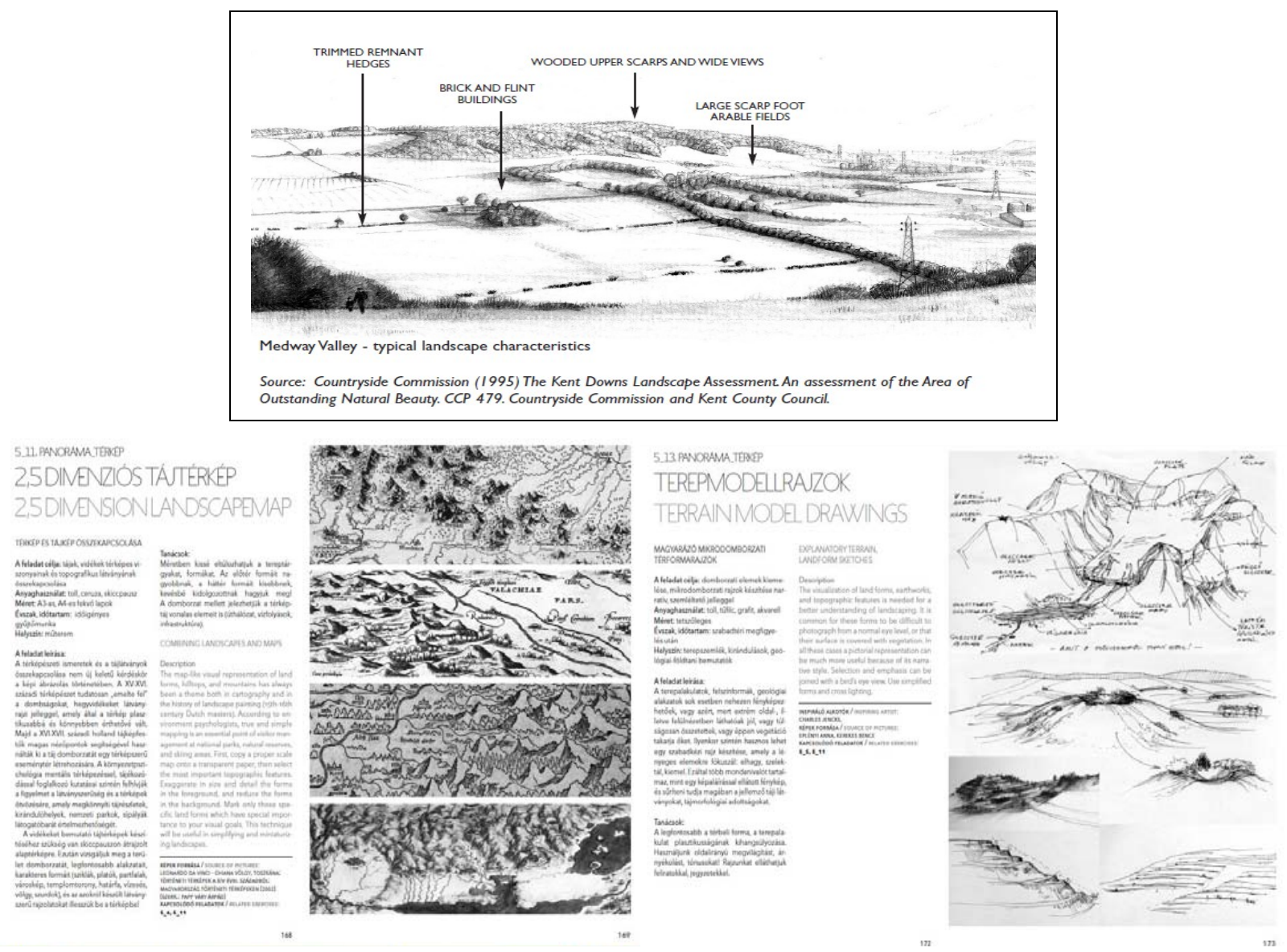

\section{5. §. Az erdők birtokviszonyainak tájképi hatásai}

Az erdők kiterjedésének vizsgálatakor fontos figyelembe venni azok tulajdonviszonyait, mert pl. Mérán a Kolozsvári Szt. Erzsébet Aggház (1800kh); a bácsi (1450kh) és kolozsmonostori (3500 kh) határban a Kolozsvári Róm. Kat. Tanulmányi Alap birtokolt nagyobb tagban erdőt, amelynek egységes kezelése nem engedte meg szétaprózódását, így zárt erdejének sötét képe mai nap is erős hatással van a tájkarakterre. Hasonló a helyzet Sárd - Szentpál környékén is, ahol kisnemesi egy-tömbben történő birtoklása is jelentősen megnöveli az erdők arányát, és záródó látványát. P1.: „Magyarsárd: Halmágyi Sándor - 217, Kertész István - 50, Krizbai D. Béla - 128, Lázásr Ferenc - 65, Teleki L. Gyula gróf 523, Kertész János dr. - 50, Kertész János dr és Samu - 156; összesen 894 kH, ami a egész település erdejének 60\%-a, Szentpál: Teleki L. Gyula gróf - 463 kH. ami a egész település erdejének 80\%-a, Nádaszentmihály: Szereday Aladárné - 751, ami a egész település erdejének 90\%-a.."15

\footnotetext{
${ }^{15}$ Gazdacímtár, 1911.
} 


\section{6. §. Mesterséges, telepített erdőfoltok előfordulása Kalotaszegen}

Magyarvalkón a Bátki felvételeken ( 1900) még jól látszódnak a komoly eróziós sérülések, amelyeket a század első felében kezdtek fásítani, majd a '70-es években felgyorsult és a domboldal Ny-i részén is tovább húzódott. Damos és Jákótelke között szintén a déli meredek oldalon történt fásítás.

Az E60-út mentén Körösfőnél, Nagykapusnál, Gyalunál, végig az út É-i oldalán, a mészkőszirtek meredek D-i oldalain ismétlődő foltokban jelenik meg. Egerbegy határában (a Kalotaszegi falvakhoz hasonlatosan) szintén a D-felé néző, vasoxidos eróziós talaj megfogására ültettek hosszan elnyúló fenyősávot. A Vista központjában fekvő domb fásítása még a II. vh. előtti korszakra tehető, amelyet később bővítettek és mára a falukép markáns eleme.

A Nádas-menti falvakban több helyen látni a tölgyesek, bükkösök közé telepített fenyő̈ultetvényt a '70-es évekből, amely soronként beszámozva a lakosok rendelkezésére állt épületfaként, így azok raszteres, mértani kiültetést követnek. Magyargorbón a délre tekintő domboldalon adatközlők elmondása szerint a fásítás „Nagy-Románia” alakzatban történt, mert a vasútról erre a dombra jól rá lehetett látni; Gorbó és Magyarnádas környékén egykori kisebb kőfejtők tájsebeit és igen meredek omlásait is gyéren fásították, de azok a mai napig sem erősödtek meg. Jegenye: a völgy Ny-i peremén történt feketefenyő hosszan elnyúló (100m széles, $5 \mathrm{~km}$ hosszú) vonala jelentősen megváltoztatta a völgy képét; szintén erőteljes fásítás volt a Fürdő környékén is, ahol feketefenyő, erdei fenyő, vörösfenyő és luc elegyesével fásítottak.

Magyarfenesen a falu felé magasodó meredek Szőlő-hegy fásított D-i oldala mára a falukép domináns elemévé vált.

\section{7. §. Az agroteraszok definiálása}

Szabó A. osztályozása a kalotaszegi teraszjelenségről: Szántási lépcsőnek vagy hagyományos agroterasznak nevezünk minden olyan népi eszközzel hegy- és domboldalakon mzg.-i múvelés céljára kialakított lépcsőszerü felszíni formát, amely a lejtőre merőlegesen, a szintvonalakkal párhuzamosan halad. Gyalult lépcsőnek (technikai terasznak) a számítások, mérések, tervek alapján talajgyalulással kialakított felszíni formát nevezzük, itt többnyire gyümölcstelepítésre vagy meddőhányók újbóli termővé tételére hozták létre. Terasznak (geomorfológia fogalom) a vízfolyások által kialakított teraszlépcsőket tekintettük. Mindhárom terepalakulat sorsa a rézsűn és a koronán megtelepedett növényzettől is függ. ${ }^{16}$

O. Rackam definálása: „On slopes the action of the plough tends to move earth downhill and to pile it against the lower field boundary to form a terrace called a lynchet. The steeper Celtic fields tends to be narrow and to follow the contours to form the flights of terraces marked as „Strip Lynchets” on maps. (...) Celtic field and strip lynchets can be dated from the pottery int he banks and their relation to barrows. Most of them are earlier then the Celtic (that is Iron Age) period. Some appear to be Neolithic origins; they were in use throughout the Bronze Age."17

\footnotetext{
${ }^{16}$ Péntek J- Szabó A., 1985. p.105.

${ }^{17}$ Rackam, 1986. p. 159.
} 
R. Muir definálása: „Given the immense effort needed to carve out the terraces and the meagre returns that could be expected from cultivating many of the flights, it seems likely that many systems of strip lychets exist as memorials to communities afflicted by overpopulation and landhunger, where suitable level and low-lying ground was in short supply. Since the strip lynchets are seen to cut older Celtic field systems in several different location they can safely be regarded as the different as the creation of medieval peasant farming." 18

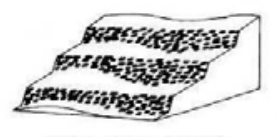

stepped terraces (parallel)

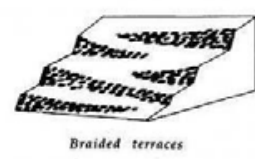

12.1 Types of terraces

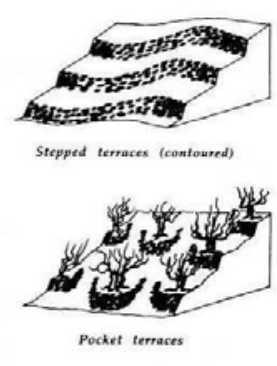

Pocket terraces

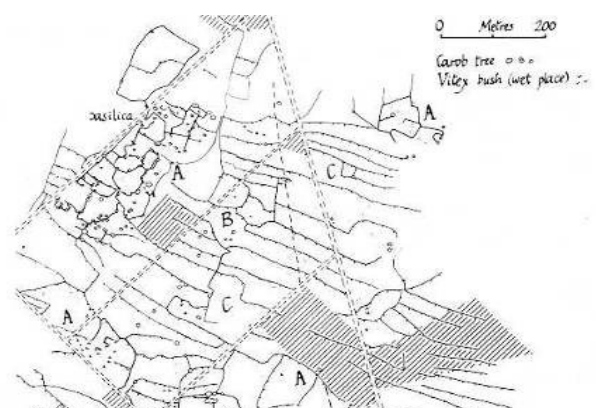

Terasztípusok, és a kőfalakkal megfogott teraszok O. Rackam krétai tájtörténeti kutatásaiban
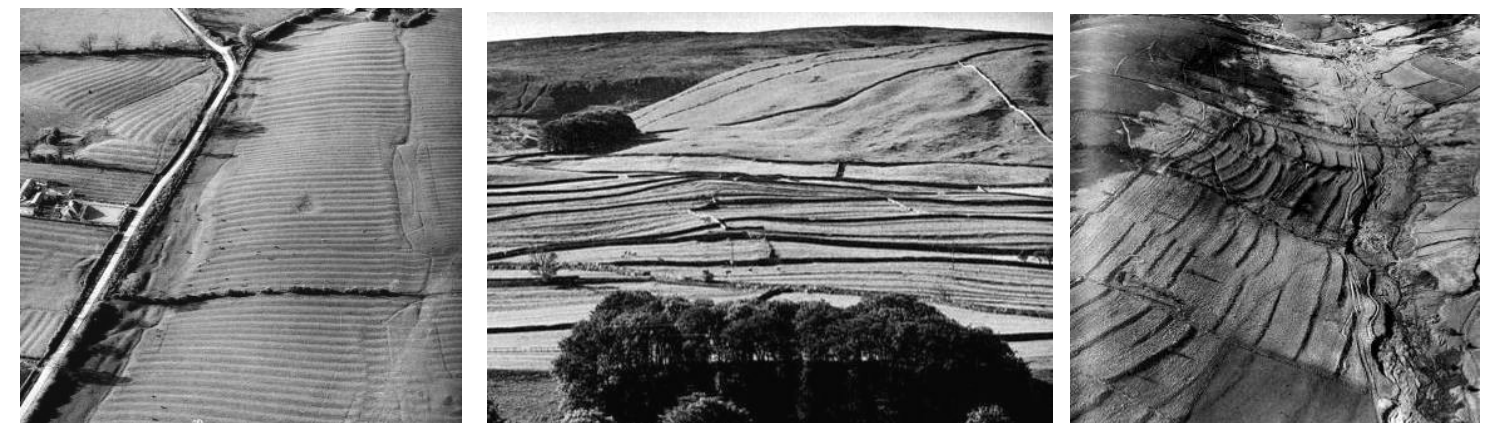

R. Muir megnevezései az angol tájtörténeti szakirodalomban: (1) ridgre-and-furrow = szántási barázdák sík területen, (2-3) ,strip lynchet” későbbi falakkal megjelölve és középkori teraszolás
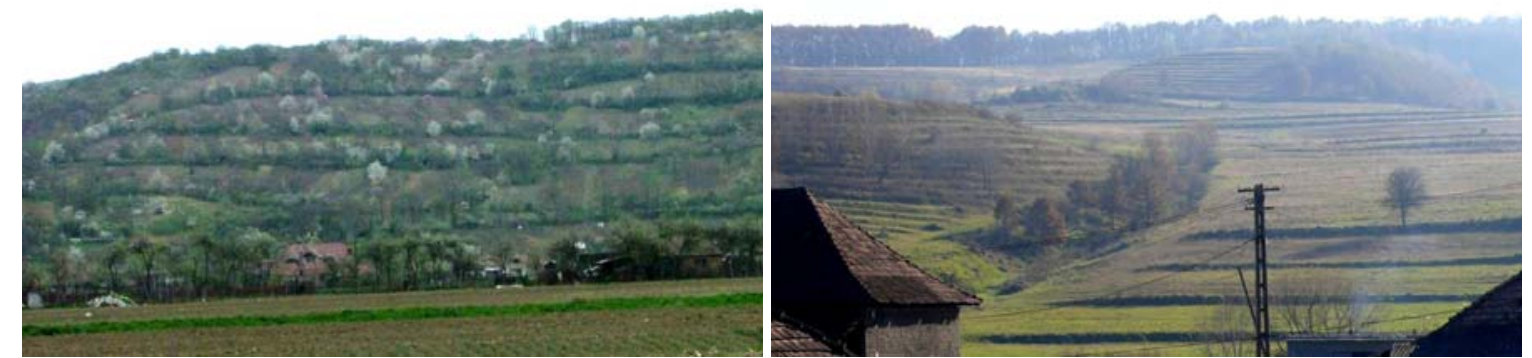

Teraszolási rendszer hatását keltő tájhasználat szilágysági szőlőtermesztő domboldalban; szántóföldi művelésre kialakított teraszrendszer a Meszes keleti oldalán (Csömörlö): látható a barázdák merev, egységes, mesterségesen létrehozott jellege, valószínüleg a szocializmus korában traktorokkal és barázdáló gépekkel készült
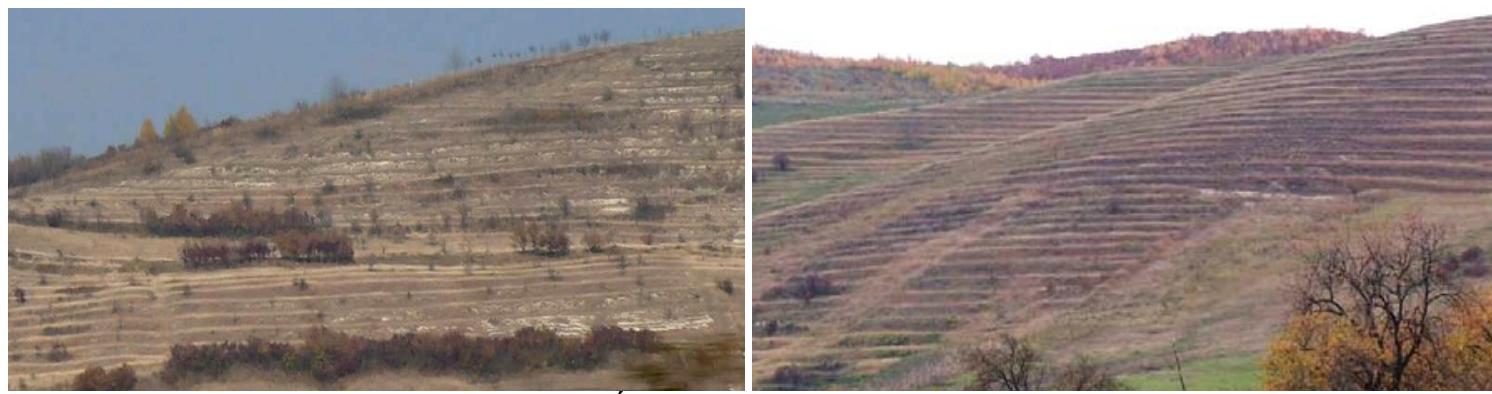

Hosszanti gyümölcsös és szőlős teraszrendszer Élesd környékén, az E60 föúttól északi irányba - déli kitettséggel: a teraszolás egyenletes, vízszintes, mereven ismétlődő, ezáltal mesterségessége erőteljesebb, nem alkalmazkodik a terep mozgalmasságához.

${ }^{18}$ Muir, 2004. p. 246. 


\section{8. §. Az agroteraszok tájesztétikai jellemzése}

A Riccabona-féle tájesztétikai elemzése a Magyarvalkó környéki agroteraszokra vonatkoztatva a 2009-es mühely munkájából:

Egyediség: a teraszolás beavatkozása helyhez kötött, lokális, egyedi, ezáltal megismételhetetlen; jellege inkább szobrászati/plasztikus, mintsem képies; egyedi, mint reliktum tájelem; nagy méretei szakrális dimenziót adnak a mintázatnak; a forma beleolvad a felszínbe ezáltal eggyé válik vele; a különböző alakú domboldalak teraszai különbözőek, nem egy „máshol-már-alkalmazott” mesterséges teraszolás átvétele.

Téri kiterjedés: dombos nyitott tér; folyamatosan egymásba folyó-átváltozó-hullámzó formák, változékony és flexibilis tájalakulatok közötti változatos horizont-élmények, amelyben a kisebb és nagyobb részterek folyamatosan váltakoznak, de szintézisben maradnak egymással - azaz tapintható a kapcsolatrendszerük; a kontúrvonalak belátást engednek a mélyebb geológia tájszerkezetekbe és ki is emelik azt; a teraszolás a tér minden irányában kiterjed.

Diverzitás: a teraszok nem egyformák, csak hasonlóak, így azok méretben, szélességben, hosszban is különböznek; az élesebb és tompább élek folyamatosan váltakoznak; a szélek hol hirtelen, hol lassan tünnek el; a lépcsők a fény-árnyék hatások miatt a napszakokkal és évszakokkal is váltakoznak; ahogy az árnyék a kerekded dombokon áthalad más hatást ad neki; diverz a benapozottság és hóolvadás mértéke, és ezáltal az azon létrejövő mikroklíma és vegetáció is, ami magasabb biodivezitásához és a különböző zöld színárnyalatok kialakulásához vezet.

Természetesség-érzet: a terepi formakövetés miatt spontán vonalúak a teraszok, ami erősíti a beavatkozás természetes jellegét; a megtelepedő cserjék-bozótok spontaneitása az intenzív tájhasználathoz képest most egy természet-közelibb érzetet hozott létre, ahol a szukcesszió a tájban organikusabban jelenik meg; mivel a teraszolás nem ugyanúgy fordul elö minden domboldalon, így nem uralkodik a tájképben; a beavatkozás mértéke is illeszkedik egy elvárható kézi terepalakításhoz; a formák spontaneitása és könnyedsége szintén természetességét erősíti.

Harmónia-tartalom: végtelenül hullámzó terepformák, azok lágy megformálása, a domborzathoz igazodó jellege kiegyensúlyozottságot tükröz; a „völgyes-dombos”, „hullámzó és síkszerüen kiegyenlített" formavilág közötti egyensúly párbeszédesen jön létre; a beavatkozás mértéke humán - az eredeti terepviszonyokat tiszteletben tartó.

Szimbolikus-tartalmak, asszociációk: „elgondolkodtató, nyugodt, szabadság, álmodozásra késztet, melankolikus, gondtalan élet, hajtogatott papirlegyezö, hullámzó tenger, víz, békés, érezhetö a megmunkálás időbeli dimenziója, a múlt munkás kezei, a cserjecsoportok - mint bokornyájak haladnak a teraszokon.” Erős szobrászati asszociációk - a táj mint homogén anyagból készült festetlen szobor, és mint (nem képies) három-dimenziós forma tapintásra, azaz bejárásra, körbejárásra késztet, ahogy ezt az ott gazdálkodó földműves tette. A hatalmas geoplasztikus formák kiterjedését megpillantva döbbenetet érzünk (astonishment vagy sublime minőség), ekkor a téri kiterjedéshez kapcsolódó „óriási” erőt feltételező beavatkozás időbeli mélysége is megjelenik, egy erőteljes történetiség-érzéssel, azaz 
átérezhetővé válik a formák időbeli mélysége, amelyet Bahtyin irodalmi művekben „kronotoposz” élménynek hív: tér - idő együttállásnak.

A formák kopársága, a föld - ég látványa is egy ősi, teremtő archetípust hív elő; Természet és ember együttes alkotása de úgy, hogy az ember (szellem) munkája nem a természettel szemben hatott, hanem mintegy annak lényegét -földtörténeti gyermekkorát- hozta felszínre és engedi láttatni a „szintvonalakkal”. A Teremtő munkája és a teremtmények legszorosabb szükségletei együttesen hozták létre öntudatlanul, és így müalkotás lett belőle: saját magára (a Teremtő keze nyomára) reflektál. Ez a táj a létfenntartás érdekében végzett emberi munka terméke, amelyben a szépség „véletlen ráadás”, azaz a természetes szépség éppen akkor jön létre, amikor azt nem célként tekintjük, hanem egy organikus tevékenység melléktermékeként a természetességében ,szép”. A barázdák ebben az értelmezésben éppen azáltal adnak magas esztétikai értéket a vidéknek, hogy azok a kétkezi, túlélésért folytatott táji beavatkozás időben egymásra rakodó termékei. Simmel szerint „ahol valóban tájat látunk, s már nem az egyes természeti tárgyak összességét, ott keletkezése közben érjük tetten a müalkotást.”

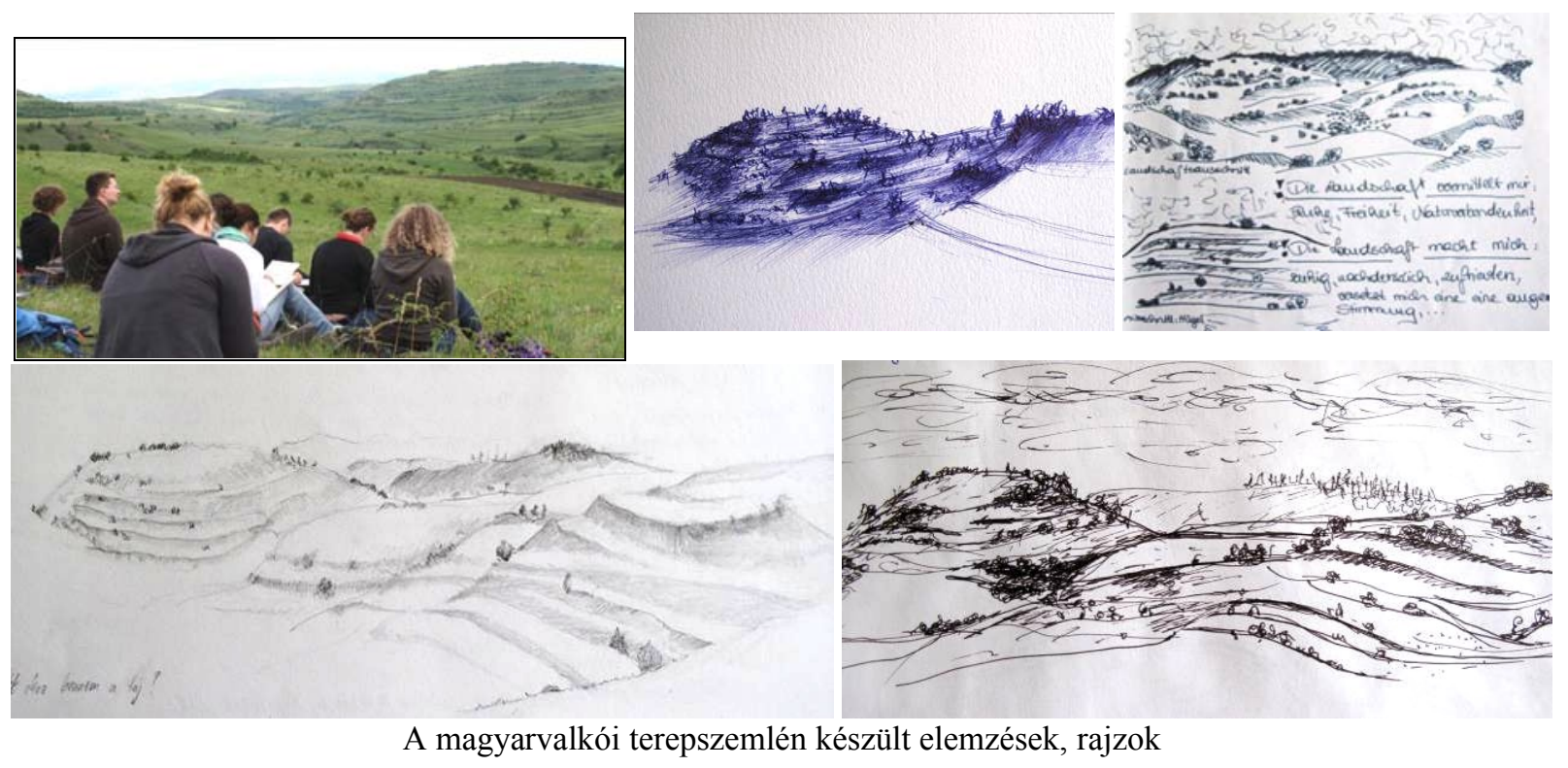

\section{9. §. A „Kilátás-Medenék”- modell környzetpszichológia megközelítése}

Jay Appleton The aesthetics of landscape (1975) címü könyvében a tájkép-preferenciát a „Prospect - Refuge (kilátás - menedék) modellel” magyarázta, amely szerint a szavanna típusú tájak térrendszere lehetőséget adott az elbújásra, visszahúzódásra - ugyanakkor a vadászles helyzet kilátást is biztosított; az evolúciós fejlődésünkbe ez igen mélyen beleivódott, éppen ezért a gyerek tájpreferenciái között is első helyen áll; ugyanakkor hangsúlyozza, hogy a barokk tájképfestészeti hagyományok, köztük Claude Lorrain képeinek ehhez hasonló térszervezése, kulturális szintén mélyen beleivódott az európai képi konvenciókba, és ma is nagy erővel határozza meg a látványpreferenciákat. S. és R. Kaplan, és R. Ryan, (1983) With people in mind címü könyvében összegzi, hogy több száz képértékelő kísérleteik eredményeképpen magas preferenciával illetik az angol „parkland” típusú tájképeket, mert azok „olvashatóak, érthetőek, koherensek, és hívogatóak”. R.S. Ulrich ugyancsak az angol tájképi kertek Appletoni-alapokon nyugvó széleskörü elterjedésével és kanonizálódásával magyarázza a mai ligetes térszervezés közkedveltségét és kiemelten magas képértékelési eredményeit. 


\section{0. §. Kiterjedt fáslegelők előfordulása}

1880 körül nagy fás legelő volt Jegenye és a 'Papp erdeje’ között; Tóbérczén; Inkatelke és Mákó között; a kaolinbányászat intenzívvé válásáig Bogártelke és Sólyomtelke között egy 100ha-s ligetes fás legelőből ma csak egy falat maradt; Inaktelkén ma a Lüget és a Csere a két legnagyobb fáslegelö; Egeres és Nagypetri között a vízválasztón laza szerkezetủ fás liget található egykori zárt erdő helyén; Szucság és Kisbács között található még egy nagyobb tag, valamit a méra-nádaskóródi egybefüggő erdőből történő darabos kitermelés/visszatelepítés folyománya miatt az erdőtag körül több fás legelö is megjelenik.

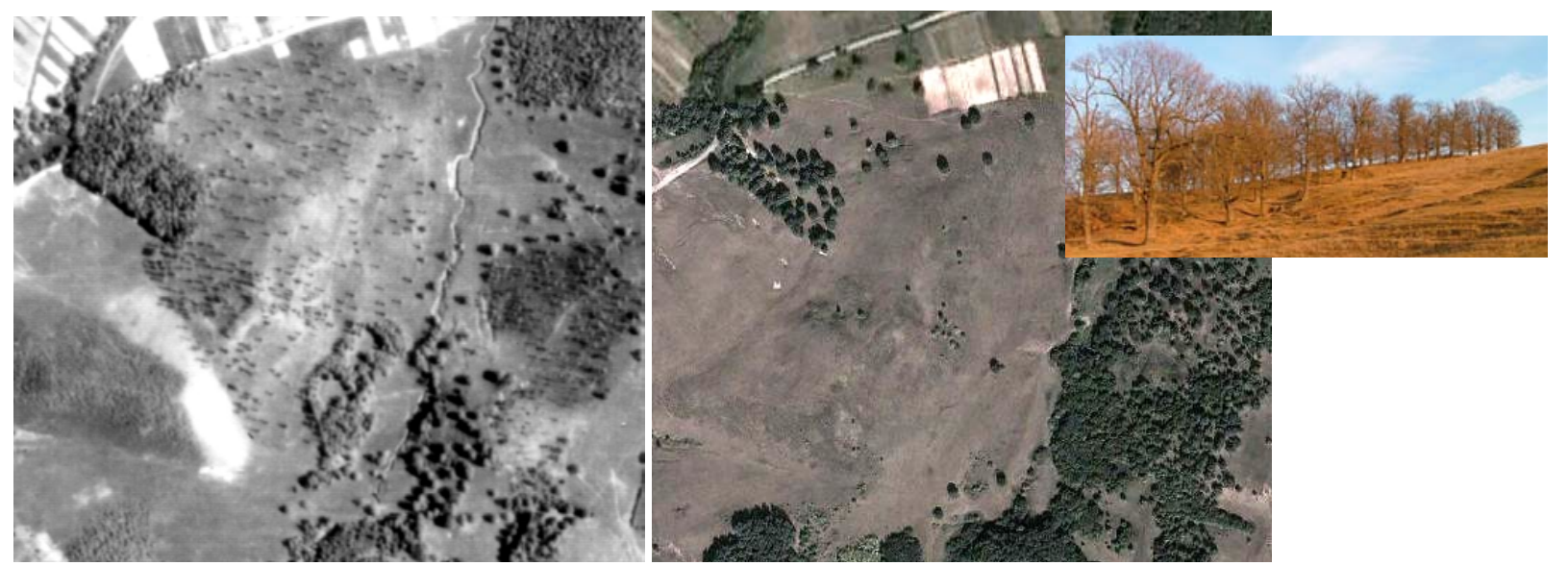

Alsófüld melletti legelő változatos korú és állományú hagyásfákkal
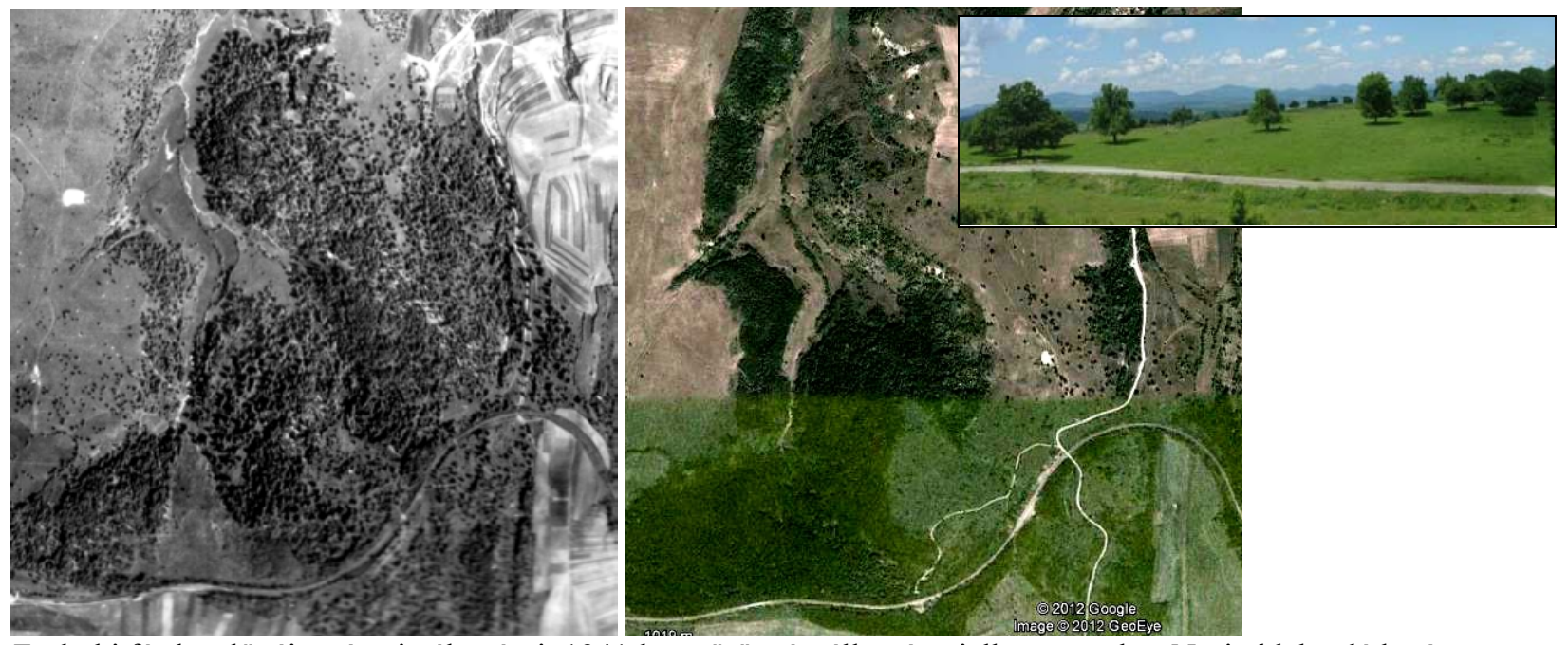

Zsoboki fás legelő tájtörténeti változásai: 1941-ben sürü, zárt állomány jellemezte, de a Ny-i oldalon látható patakpart nyitottabb volt > ez már megfordult, a patakpart záródott, és a középsỏ rész nyílt meg
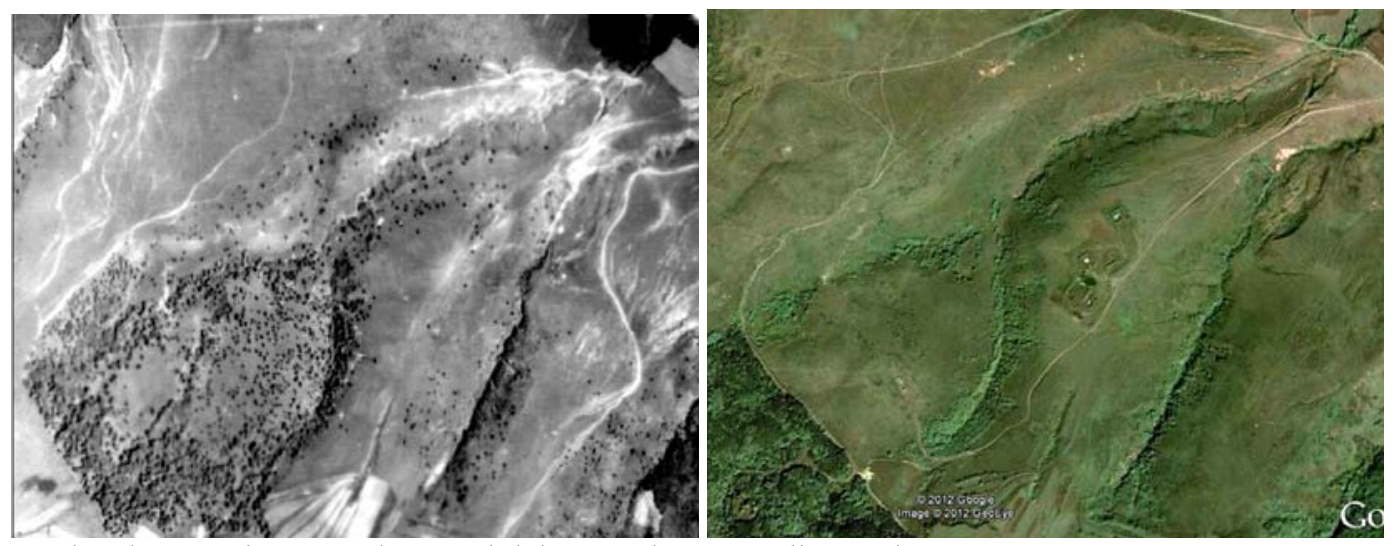

Fás legelő 1944-ben Nagykapustól délre, amely mára teljesen eltünt. 


\section{1. §. A XX. sz.-i gyümölcstelepítések Kalotaszegen}

A XX. sz. második felének gyümölcsös-telepítései a telepítés téri kiterjedése és táji dominanciája sorrendjében:

Andrásháza-Bács térsége ( 300ha): uralja a Nádas-mentének völgyét a Méra melletti Kerekdombtól egészen Bács faluig, ezáltal domináns gyümölcstermesztési tájkaraktert adva a térségnek; főként alma és diófák mesterséges teraszokon, geometrikus rendszerben.

Szucság ( 250ha): az É-i kitettségü gyümölcsösök (alma, dió, meggy, cseresznye) uralják a falut körbevevő domboldalak látványát, amelyre a falu felett feldolgozó üzem is épült.

Ketesd-Bánffyhunyad-Magyarbikal ( 120ha): a '80-as évek végén és a rendszerváltáskor került kialakításra a gyümölcsös a településektől távolabb, É-i, szélvédett domboldalakon, sok helyütt a korábbi ültetvények - szőlőterületek, kisebb erdőtagok közé, így látványa csak néhány látványpontból dominál.

Alsófüld és Középfüld közötti ( 100ha) Dl. Muncelului D-i és É-i kitettségü domboldalain, a XVIII. sz.-i egykori szőlőskertek mellé telepített, már elöregedett, kiritkult, rosszul fenntartott gyümölcsös.

Almásnyíres és Bábony közötti ( 100ha) déli kitettségü domboldalon, alig kiterasszírozott felszínen már elöregedett, elhanyagolt gyümölcsös.

Magyar- és Romángyerőmonostoron $(20+9+6+2+2+2=\sim 41 \mathrm{ha})$, magas fekvésük ellenére mindig is magas volt a kertek aránya a széttelepült településszerkezet miatt; a kommunizmus ültetvényei azonban új területeket vontak be a fásításba általában azokat széles mezővédő erdősávval körbezárva.

Magyarvalkón ( 25ha), a Nagy- és Kis Malató Ny-ra néző védett domboldalában kisebb tagokban almaültetvények találhatóak, inkább a völgyfeneki helyzetben lévő területeken, így a felszín nincs kiterasszírozva, hanem a fás szegélyek, völgyvonalak közé organikus ékelődik be, ezáltal nem idegen a tájkaraktertöl.

Kispetritől ( 25ha) NY-ra a Bükkös hegy ÉK-i oldalában, a szőlőkertek között.

Mákófalva ( 25ha) a feletti völgykatlan É-i kitettségű oldalában időszakos vízfolyások erdősávjaival elválasztott telkeken.

Inaktelke - Gyerővásárhely ( 20ha), Hasznosi-kert a Hasznos-patak Nádék tető oldalában.

Türe és Magyargorbó $(20+8+5$ ha) a Gorfóbői völgy végi nagyobb tag mellett, a két falu közötti Nádas-katlan oldalaiban vannak kisebb bekerített gyümölcsösök.

Magyarókereke és Kalotaszentkirály felett( 6ha) felett a Hármas-kőszikla alatt van egy kisebb hosszanti gyümölcsös az előhegység keleti védett völgyében.

Kiskapustól ( $\sim 5$ ha) ÉNY-ra, Szamára településrész felett foghíjas gyümölcsös található.

Nyárszó ( 5ha) falutól délre helyezkedik el egy kisebb tag a Falkafenyő - Jézus dombja K-i oldalán. 


\section{2. §. Szőlőmüvelésre utaló dülőnevek Szabó T. Attila összeírásából}

Szőllő: Bánffyhunyad, Magyarbikal, Jegenye, Kisbács, Mákó, Türe, Vista, Farnas, Váralmás Szőlő alatt: Damos, Ketesd, Nyárszó, Méra, Vista, Farnas, Kispetri, Középlak, Zsobok Szőlő allja, allya: Damos, Magyarbikal, Nyárszó, Türe, Nagypetri, Váralmás Szőlőárka: Türe, Farnas Szőlő bérc: Sztána Szőlő felett: Damos, Nyárszó, Magyarnádas Szőlő fö/fü: Sárvásár, Bogártelke, Inaktelke, Kisbács, Mákó, Méra, Türe, Vista Szőlőgödre: Tamásfalva, Középlak Szőlő gyepű mellett: Sárvásár Szőlő háta megett: Kispetri Szőlőhegy: Damos, Magyarókereke, Magyarnádas, Magyarsárd, Méra, Szucság, Türe, Kispetri, Nagypetri Szőlőhely: Damos Szőlőkert, szőlőskert: Nyárszó, Türe, Középlak, Inaktelke Szőlőkút: Kőrösfő Szőlők lába: Ketesd Szőlő máj, mál: Magyarvalkó, Nyárszó, Mákó, Magyarnádas, Zsobok (Szőllőmájoldal) Szőlő megetti erdő: Bábony Szőlőoldal: Damos, Kalotaszentkirály, Körősfö, Magyarbikal, Magyarókereke, Nyárszó, Sárvásár, Zentelke, Gyerővásárhely, Egeres, Jegenye, Türe, Farnas, Sztána Szőlőpataka: Gyerővásárhely, Nádasdarócz, Jegenye, Türe Szőlősárok: Inaktelke Szőlőtető: Nyárszó, Sárvásár, Gyerővásárhely, Bogártelke, Egeres, Kisbács, Mákó, Szucság, Türe Szőlőútja: Vista, Farnas, Zsobok Szőlővölgy torka: Kiskapus, Sztána (továbbá sok utótagos összetételbe előfordul)

Újszőlő, újszőllőalja, újszőlőhegy, újszőlősoldal: Ketesd 1778, Magyarbikal 1891, Farnas 1891, Zsobok 1864. Pusztaszőlő, pusztaszőlő-oldal: Kiskapus 1864, Mákó 1781, Türe, Bábony, Farnas, Nagypetri, Méra 1671!, Kisbács (puszahely), Szucság (régi szőlőnél) 1781, Középlak, Jákótelke 1763, Damos 1735, Andrásháza 1766, Nagykapus 1891.

\section{3. §. Bánffyhunyad szőlőmüveléssel összefüggő dülőnneveinek időrendi vizsgálata}

\section{A vizsgálat összefoglalását lásd a soron következő táblázatban.}

Szabó T. Attila történeti helynévösszeírása ${ }^{19}$ alapján egy választott mintaterületen megtettem a szőlőmüveléssel kapcsolatos helynevek rendszerszerü vizsgálatát. A választás egyrészt azért esett Bánffyhunyadra, mert itt jelentősebb szőlőterületek vannak, másrészt mezővárosi szerepe miatt 1660-tól egyenletesen vannak határnév-adatsorok (50 időpontból). Mivel a szőlőterület kitüntetett határhasználati mód és egyben jövedelemforrás is, azért ezeket külön feltüntették, kigyüjtötték, még akkor is, ha maga a dülőnév nem is tartalmazta a szőlő szót. Az adatsorokat időrendi sorrendben tüntettem fel 1660-1941 között. Sajnálatosan az elmúlt 150 évből csak 1864, 1866 és 1941-es adatok vannak, így a közelmúlt változásait nem jól tükrözik. Az évszámokhoz rendelve mindig egymás alatt tüntettem fel a hasonló/rokon nevű helyszíneket, így szemléletes azok ismétlődése, eltűnés, megjelenése. A táblázat és az 1941-es térképvázlat elemzése során az alábbi megállapítások tehetők.

- A szőlős-dűlőnevek nagy változatosságot mutatnak: közel 60 alapnév és azok al-változatai jelennek meg.

- A dűlőnevek általában (90\%) nem tartalmazzák a szőlő szót, hanem őrzik a szőlőművelés elötti használat nevét, a szőlős-nevezetủek jellemzően újabbak.

${ }^{19}$ Szabó T. A., 1942., pp. 5-32. 
- A 60 névből csupán 15 az, amely visszatérő, gyakran ismétlődő, ugyanakkor 75\% csak egyszerkétszer fordul elö; ez utalhat arra, hogy kisebb, új helyszíneket is próbáltak müvelés alá vonni vagy arra, hogy a falu környéki kertekben kisebb magán-szőlős-kertek is lehettek.

- Az évszázadok során újratelepítés is lehetett, mert ugyanabban a tagban szölö - majd pusztaszőlö- majd megint szölő terület is előfordul; ennek értelmezést nehezítheti, hogy a felhagyás után a szőlőtőkéket nem mindig ásták ki, így azokat utólagosan is „szőlőként kezelik”, noha már nem művelik.

- A XVII.sz.-ban meglevő szőlőshelyek: Középoldal=Ketesd felé való oldal/ Nagyoldal/ Vaskapu/ Csere/ Miriszló/ Szénégető/ Hosszú Bükk> amely közül több, egykori erdőből való területnyerésre utal. Ezek a területek a későbbi századokban is állandósult szőlőterületként használják, szinte mai napig megőrizve ez $>350$ éves kontinuitást feltételez, így valószínủ, hogy ezeken a területeken már ezt (1660) megelőzően is szőlők lehettek.

- A XVIII. sz.-ban új helyszínek jelennek meg: Csengő Csergő/ Boros Botos/ Hernót/ Kópa/ Majláth, ezek nem szerepelnek minden összeírásban, és Csergő kivételével a XIX. sz.-ban már ritkábban említik, azaz ezek eshettek teljes területekkel a filoxéra áldozatául.

- A XIX. sz.-ban „Vaskapu, Cser-oldal, Szénégető” terület felhagyásra kerül, új helyszínek is megjelennek, de már nem állandósodnak.

- A nevek és térképek egybevetésével megállapítható, hogy szőlők nagyobb tagban, domboldalban helyezkedtek el, a hegy-völgy irányba elősövénnyel felosztva (Közép-oldal: Kis , Alsó , Felső $\sim, \sim$ Felsőlábban, $\sim$ tetején) vagy (Hosszú-Bükk: alsó $\sim$ felső $\sim$ két $\sim$ között). 


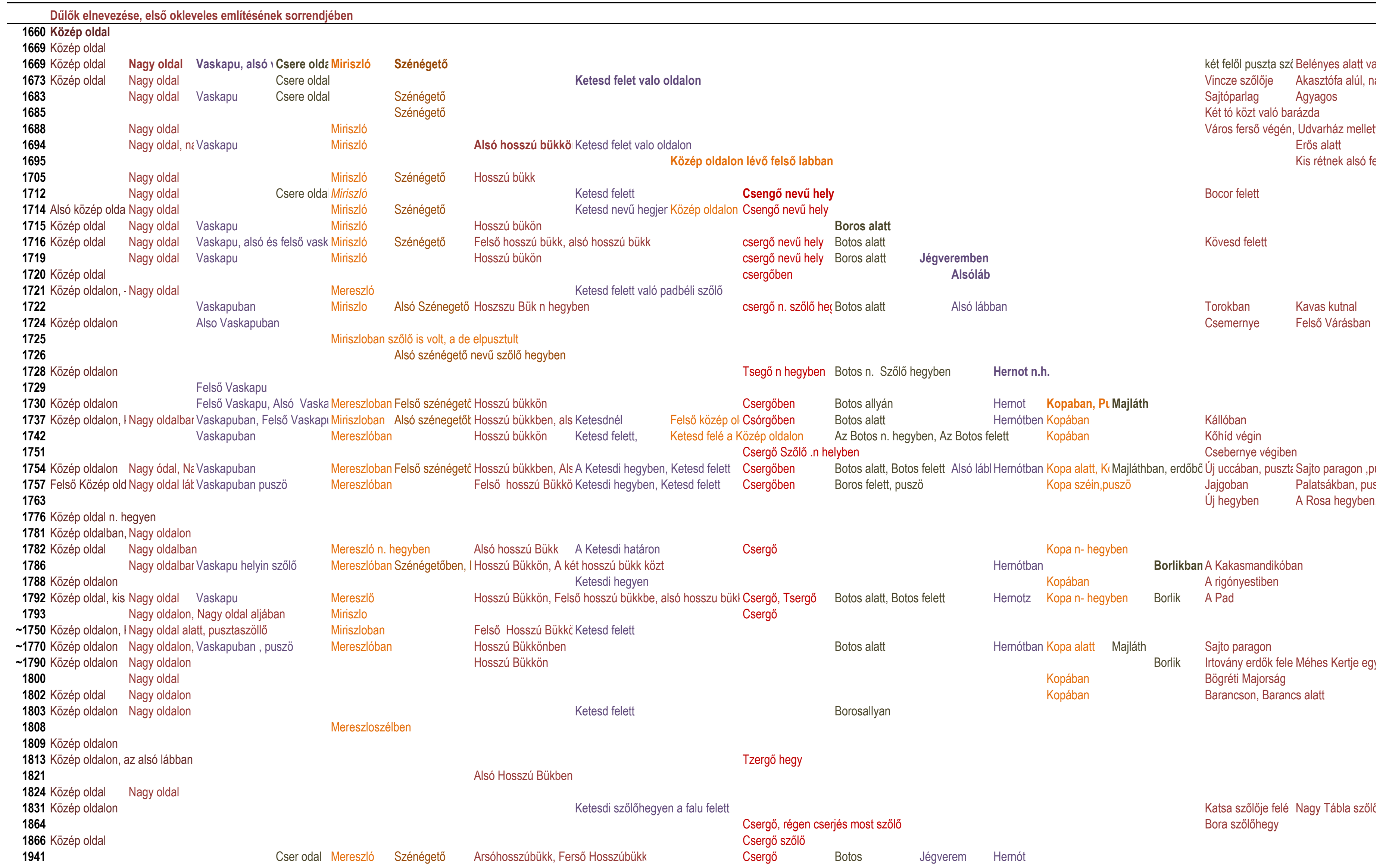


- A 60 névből csupán 15 az, amely visszatérő, gyakran ismétlődő, ugyanakkor 75\% csak egyszerkétszer fordul elö; ez utalhat arra, hogy kisebb, új helyszíneket is próbáltak müvelés alá vonni vagy arra, hogy a falu környéki kertekben kisebb magán-szőlős-kertek is lehettek.

- Az évszázadok során újratelepítés is lehetett, mert ugyanabban a tagban szölö - majd pusztaszőlö- majd megint szölő terület is előfordul; ennek értelmezést nehezítheti, hogy a felhagyás után a szőlőtőkéket nem mindig ásták ki, így azokat utólagosan is „szőlőként kezelik”, noha már nem művelik.

- A XVII.sz.-ban meglevő szőlőshelyek: Középoldal=Ketesd felé való oldal/ Nagyoldal/ Vaskapu/ Csere/ Miriszló/ Szénégető/ Hosszú Bükk> amely közül több, egykori erdőből való területnyerésre utal. Ezek a területek a későbbi századokban is állandósult szőlőterületként használják, szinte mai napig megőrizve ez $>350$ éves kontinuitást feltételez, így valószínủ, hogy ezeken a területeken már ezt (1660) megelőzően is szőlők lehettek.

- A XVIII. sz.-ban új helyszínek jelennek meg: Csengő Csergő/ Boros Botos/ Hernót/ Kópa/ Majláth, ezek nem szerepelnek minden összeírásban, és Csergő kivételével a XIX. sz.-ban már ritkábban említik, azaz ezek eshettek teljes területekkel a filoxéra áldozatául.

- A XIX. sz.-ban „Vaskapu, Cser-oldal, Szénégető” terület felhagyásra kerül, új helyszínek is megjelennek, de már nem állandósodnak.

- A nevek és térképek egybevetésével megállapítható, hogy szőlők nagyobb tagban, domboldalban helyezkedtek el, a hegy-völgy irányba elősövénnyel felosztva (Közép-oldal: Kis , Alsó , Felső $\sim, \sim$ Felsőlábban, $\sim$ tetején) vagy (Hosszú-Bükk: alsó $\sim$ felső $\sim$ két $\sim$ között). 


\section{4. §. Szőlooterületek területi és történeti megoszlása a területen}

A dolgozat részletesen foglalkozott a szőlőterületek eloszlásával, tájtörténeti adataival, amely terjedelme miatt csak a melléklet tudott megjelenni. Az 1820-as Cziráky-féle összeírás ${ }^{20}$ azoknál a településnél emelte ki a szőlő meglétét, ahol annak haszna, jövedelme volt - illetve ott emelte ki hiányát, ahol az a klimatikus körülmények között vagy a szomszédos szőlősök miatt feltételezhető lett volna. A szőlőmüvelés egyik központja Bánffyhunyad másik pedig Kolozsvár volt.

A bánffyhunyad-váralmási terület klimatikus adottságai és a Vlegyásza hideg szelétől való védettsége folytán alkalmas a szőlötermesztésre. A meredek, nehezen szántható, de napsütötte domboldalak megfelelőek a szőlőnek. Bár a részletesebb határjárások a XVII-XVIII. századiak, néhány dokumentum alapján feltételezhetjük, hogy ezen a területen középkori eredetűek a szőlők (Magyarbikal, 1399). ${ }^{21}$ A Váralmási uradalom és az Almás-Monostora ehhez adhatott szervezeti hátteret. A vincellérek szaktudása, a több-felé megoszló szőlőhegyek biztonsága még a nehezebb éveket is segítettek átvészelni. Magyarbikal és Ketesd hasonlóan kiemelt helyzetben voltak a többi alszegi falu között: must-adót fizettek az évi termelés szerint a XIX. sz. közepéig; falvaikban 'korcsma' müködött egész évben, melyböl kiegészítő jövedelemre tettek szert, mivel az italmérés joga Szent Mihálytól újesztendőig a falvaké volt. ${ }^{22}$ Hasonló továbbá a két falu abban is, hogy az 1800-as évek elején fellépő éhínség alatt is müvelték szőlöiket, így a falu határát még 1914-ben is 3,7\% (60 hold) és 2,7\%-át (28 hold) borította szőlő, ami erdélyi viszonylatban igen magasnak számít! A művelés népi építészeti vonatkozására már Bátky felfigyelt, aki Ketesd környékén kisebb szőlőkalibákat fényképezett 1900 körül. Kós is hasonló félig földbe ásott, ágasfás-szelemenes szalmás tetejű kaliba rajzát mutatja be Sztánáról. ${ }^{23}$ Kiemelt jogai voltak Bánffyhunyadnak is ${ }^{24}$ ahol területileg növekvő tendenciát mutat a statisztika és az egyre bővülő a „szőlős” határnevek száma is. A 1820-as összeírásban hangsúlyosan kiemelik a románság szőlőműveléstől való távolmaradását: mert bár munka lett volna a szőlőben, román falvakból mégsem jártak ide napszámosnak. ${ }^{25}$ Alsó és Középfüldön fekvő szőlők kipusztulását is „hasznára élte meg” a két falu régtől elrománosodott lakossága ${ }^{26}$ Fontos kiemelni, hogy a mezőváros szőlőműveléssel foglalkozó területei a Körös-Almás vízválasztó É-i oldalára, Alszeg felé estek, így a Hunyadi-medence képében nem volt jelentős szerepe szőlőnek, ez is indokolja a tájkarakter-zónából való kilógását.

Alszeg más falvaiban: Kispetri (2,3\%), Farnas (2,2\%), Zsobok (1,3\%), Sztána (1,2\%), Váralmás $(0,5 \%)$ is hagyományos volt a szőlőmüvelés, de a falu összterületéhez viszonyítva kisebb

\footnotetext{
${ }^{20}$ Végi idézi Takács, 2010

${ }^{21}$ Kolozsmonostori Konvent összeírása alapján, in: Sebestyén, 1996, p. 58.

${ }^{22}$ Cziráky: Ketesd: Szokás szerint tartoznak a Mlgos gróf Bánffi György, László és Pál uraknak: (...) szőlő termeléshez képest proportionált adóval, must. - minden esztendőben változván a termés szerint. (...) Közönséges jövedelme helységünknek a folyó korcsma, mely egész esztendőt által a falué, és a közönség hasznára árultatik az ital benne. Magyarbikal: Gyümölcsöseink mind a telkeinken, mind a szölőinkben bőven vagynak. Jövedelme helységünknek és lakosainknak a szokott korcsmárolásbéli szabadságunk.

${ }^{23}$ Kós, ifj., 1994, p. 65.

${ }^{24}$ Cziráky: Bánffyhunyad: „Szőlőhegyeink vagynak, és az azokból való termesztésüket - különösen a helység két országos vására alkalmatosságával- itt helyben szoktunk eladni. Megveszik borainkat még a szomszéd még a szomszéd helybélien is. Ezen szőlők müvelésére helységbeli szegényeink készpénzzel fizettetnek."

${ }^{25}$ Cziráky: Hodos $\sim$ Kissebes Nagysebes Sebesvárallya: Határunkban szőlők nincsenek, hanem van ide közelebb Hunyadon, Ketesden, Bikalon és Farnason, de napszámosságra egyik helyre sem járunk.

${ }^{26}$ Cziráky: Alsóföld Középfüld: Szőlőink voltak, de (azok a mi hasznunkra (!)) elpusztulván, s ma már csak szántónak használjuk a földjét. Ma már senki sem mível szőlöt. Idegenek pedig nem bírtak itt soha szőlöt
} 
hányadot tett ki. Itt kissé bajosabb volt mủvelésük, nagy hasznot nem hoztak, de a lakosság még a 1800as évek elején lévő éhínség és nélkülözés idején is kitartott hagyományos táji örökségük fáradságos müvelése mellett. ${ }^{27}$ Többlettermelésre nem futotta, de saját szükségleteiket ellátta, rokonsági kapcsolatai révén borát a környéken elajándékozta és a falu hagyományos eseményein (szüreti bál, szüreti-kaláka, lakodalom) a mainál sokkal fontosabb szerepe volt. Ezek a szőlők területileg alig fogytak, de fenntartását tekintve csökkent állapotban még mai napig megtalálhatók a Zsobok, falu feletti domboldalban, a falutól délre fekvő völgyben, Farnastól nyugatra a Székesalj patak mentén és a Kispetri-Farnas-Sztána közötti Bükkös-hegy oldalában, a Fogasban. Itt a szőlőterületek látványa megjelenik, de nem dominál a tájképben, mivel a szőlő sokszor kisebb erdőtaggal, gyümölcsössel nőtt össze. Bár a lakosság csökkenésével elhanyagoltabbá válnak a szőlők, a hétvégén hazajáró kolozsvári közép-korosztály a szüreti munkákba még besegít, így biztosítva a kontinuus fenntartást.

Az Almás-völgyének más falvaiban elvétve találunk szölőre utaló nyomokat (1-5 kh.). Ezeket már 150-200 éve felhagyhatták; az időjárás hülése, majd a filoxéra miatt kipusztultak és később a zömében addigra már románosdó lakosság nem telepítette újra: ide tartozik Tamásfalva, Tóttelke, ${ }^{28}$ Kiskökényes, Hidalmás, Nyerce, Bábony, ${ }^{29}$ Középlak, Zutor. Noha a klimatikus adottságok erre még alkalmasak lennének itt is, egyértelműen kimutatható a lakosság etnikai összetételének megváltozásával járó szőlő-felhagyás. Alszeg É-i falvai, amelyek távolabb helyezkednek el a ketesd-hunyadi központtól már az 1820-as összeírás során kijelentették, hogy „szölöhelyeink nincsenek”, ezek: Argyas, Dank, Forgácskút, Lapupatak, Vásártelke, Oláhköblös, Zsombor. Az utóbb említett két település-csoport vonala fontos „vízválasztó” a történeti tájhasználat és tájkarakter vizsgálata során is, mivel az első még öriz olyan fontos tájszerkezeti elemet, amely egy korábbi korszakban -ha kis mértékben is- Alszegi jelleget adott a környéknek, míg a második korábban sem mutatott azzal táji hasonlóságot.

A mára szőlőkkel csak házfalakon, tornácokon rendelkező Felszegen szintén a történeti helynévanyag vizsgálata mutat érdekes „tájkarakter-vízválasztó” vonalat. Felszeg magasabb és hűvösebbhegyalji falvaiban egyáltalán nem szerepel az összeírásokban szőlőművelésre utaló dűlőnév: Magyar- és Oláhgyerőmonostor, Bocs, Incsel, Bökény, Nagykalota, Méregjó, Kiskalota, Erdőfalva, Bedecs. Azonban Kalotaszentkirály, Magyarókereke, Zentelke, Damos, Jákótelke, Nyárszó, Sárvásár, Körösfő, sőt még Gyerővásárhely és Magyarvalkó (!) is rendelkezett szőlőterületekkel a dűlőnevek tanulsága szerint (lásd a fenti dűlőnév-listát). Már a 1700-as években „pusztásodott/pusztaszőlő” névvel említik, és az első kat. felmérés sem jelöli, ezért feltételezhető, hogy olyan késő-középkori szőlők, amelyek a XVII-XVIII.sz.

\footnotetext{
${ }^{27}$ Cziráky: Farnas: Szölőhegyeink vannak, de azokat mi magunk míveljük. Kispetri Nagypetri: Ezen határnak olyas szőlöshelyei nincsenek, melyek munkájukból mi valamit kaphatnánk. Hanem kevés szőlöjek az uraságoknak vagyon, és vagyon minekünk is colonicalis házaink után. A mi számunkra, mikor terem, jó bor, de csakugyan a szőlőművelésbe nem sok haszony vagyon. Mindazonáltal minthogy igen kevésből áll, mívelhettyük. ... Borból vagy mustból adunk tizedet. Nagyalmás: Ezen helységnek egy kis szölőhegye is volt, de amelyet ők a közebbről elmúlt nagy szükség idején az múveletlenségben tartanak. Csakugyan ha felfogattatnék, és jó mívibe vétetvén, az uraság szőlőihez hasonló jóságú bort teremne. Ezen szőlőhegy egész ajjában szép gyümölcsös vagyon. Zsobok Sztána: Itten olyas szőlőhegyek nincsenek, hogy a bornak jósága tekintetéböl annak mívelésére a munkások fogadásából jövedelmet kaphatnánk. Hanem nekünk vagyon egyegy kevés colonicialis szőlőnk, amelyben nem éppen a jobb bor terem, de mégis megérdemli, hogy ne hagyjuk elpusztulni, noha haszon nagy nincs benne.

${ }^{28}$ Cziráky Tamásfalva Tóttelke: Nagy szőlőhegyek nincsenek, a határon colonicalis szőlőhelyek igen kevés, az uraságnak vagyon kevés.

${ }^{29}$ Bábonyi adatközlőm (Eszes Márton, 80) a századforduló után újratelepített falusi szőlőről mutatott fényképeket.
} 
fordulóján pusztulhattak ki. A magyar-román etnikai különbség itt is, mint Alszegen, szorosan korrelál a szőlőmüveléssel.

A szőlőművelés másik központja Kolozsvár környéke volt; a Szászfenes-Hoja tető közötti déli fekvésü védett oldalakon már az első katonai felmérés is több darabban szőlőt jelöl. A római időkben több villa, gazdasági egység volt a Kis-Szamos környékén, így a szőlő római eredete sem kizárt. ${ }^{30}$ A XVIII-XIX.sz.-ban ezeket kolozsváriak birtokolták és az ő városi és helybeli napszámosaikkal müvelték (70kh-300 gazda $)^{31}$. A jelenség a városi mezögazdasági vonzáskörzet XIX.sz.-i intenzitását támasztja alá, azaz a szőlők nem a helyi hagyományos mủvelését, hanem külső gazdasági szándékot tükröznek. Ezek a kisebb tagok a XX.sz. első feléig megvoltak, helyük ma csak körvonalazható a légifelvételeken.

A Nádas-mentének sok „szőlős”-helyneve ellenére már a XIX. sz. elején alig volt szőlöje. Összhangban az első kat. felméréssel és az 1820-as összeírással Bács és Méra környékén ${ }^{32}$ voltak nagyobb tagban szőlők (5-10kh.), valamint kisebbek Mákó és Szucság határában (1-2 kh.), ahol minden bizonnyal vegyes használatú gyümölcsös-szőlős kertek lehettek (mára mind a négy terület teljesen eltűnt, sem tőkéik, sem teraszaik nem látszódnak). 1820-ban dủlőnevek tanúsítják a szőlőhelyeket Jegenyén, Inaktelkén, Egeresen, Bogártelkén, Mákón, Türében, Vistában, Andrásházán, le végig a Nádas-mente völgyeiben. A vasúti kapcsolattal Alszeg felöl könnyen megoldható volt a borszállítás, ezért nem volt indokolt a szőlők újratelepítése. Mára a határból kivétel nélkül eltűntek a szőlők, azonban a XX. sz.-i fényképek alapján megállapíthatjuk, hogy behúzódva az udvarokra, fatornácokra a szőlő a településkép elkerülhetetlen részévé vált. Ezeken a déli védett, és az épület éjjeli hőleadását kihasználó házoldalakon októberben érik be az öreg szőlőtőke, amelyből több tíz-liter mustot, bort készítenek a családnak vagy csemegeszőlőként fogyasztják.

\section{5. §. A szőlőterületek tájtörténeti jellegü tájértékelése}

4.a.: Legjelentősebb a Hunyadi szőlőkk területe: magas területi és \%-os aránnyal (3-4\%); jelentős tájkarakter-mintázat jön létre a szintvonalara merőleges tagolásokkal; a XV. sz.-tól folyamatos fenntartás jellemzi, ahol kiemelt szerepe volt, mint mzg.-i tevékenység: eladásra termel, kocsmároltatási jogai vannak. (BHunyad, Bikal, Ketesd);

4.b.:Ehhez hasonló az Alszegi szőlősvidék: közepes területi, \%-os aránnyal (1-2\%); közepesen jelentős tájkarakter-meghatározó erővel, mivel csak egyes falurészeken jelenik meg; kocsmároltatási jogai nem voltak; az 1800-as évek elején lévő éhínség és nélkülözés idején is kitartottak müvelése mellett,

\footnotetext{
${ }^{30}$ Wanner, 2010., p.281.

31 Cziráky Gyalu: Szőlőhelyek legközelebb a kolozsvári határon vadnak, melyeket idegen napszámosok által míveltetvén a Kolozsváriak, ottan napszámosság által lehet pénzt keresni. Kolozsmonostor: A határunk béli szőlőnyilakból csak egynehányan bírunk. Többnyire a kolozsvári lakosok bírják, melyeket idevaló és kolozsvári pénzzel fizetett napszámosokkal míveltetnek. Szászfenes Magyarlóna: Itten a helységben az allodialis helyen épült egynéhány szőlőjeken kívül olyan szőlőhegyek nincsenek, hanem a szomszéd, monostori határon lévő Hója nevezetü szőlőhelyet a kolozsvári szőlősgazdák idegen pénzen fogadott napszámosok által műveltetvén bővséges alkalmatosságot adatnak a pénzkeresésre. Tótfalu Isztolna: szőlőművelésből Kolozsvár környékén lehet napszámosság által kevés pénzt keresni.

${ }^{32}$ Cziráky Kisbács: Vagyon egy darab hasznavehetlen szőlőhegy is, melynek mívelése a szük esztendőktől fogva félbehagyatván, mást ma a benne lévő gyümölcsös fákon termő hasznonnál egyebet nem hajt. Méra: Szőlő termő helyünk van, hanem az éhség bejövetelével az elalélt nép gyengesége miatt napszámossal nem mívelhettük, ennélfogva mostan puszta.
} 
eladás helyett inkább árucsere jellemzi, a szőlők területileg alig fogytak, de fenntartása mai napig is „hagyomány” a lakosság körében (Szt, Zso, Fa, KP, VA).

3-2.: Közepesen jelentős szőlőterületek: a XIX. sz. végéig kisebb területeken (1-5kh), de jól fenntartott szőlők; a románosodó lakosság vagy/és a filoxéra miatt felhagyják, a tájkarakterre csekély hatással voltak, de mára kivétel nélkül eltüntek; tájtörténetileg fontos lehetett szerepük, ezek a táblázatos eredmények alapján, közép-magas és közép-alacsony értékü területek (Alszeg, Bács, Méra, Szucság, Szászfenes).

1.a.: Egykor csekély jelentőségü szőlőterületek: ahol már térképes alátámasztás sincs, és csak dủlőnevek tanúsítják a szőlő meglétét, amelyen saját használatra termeltek; főleg magyar lakosságú falvakban jellemző, ahol az időjárás hűvösödése és a 1820 körüli éhínség idején végleg felhagyták és mára nyoma veszett (Felszegi és Nádas-menti falvak: Körösfö, Magyarókereke, Türe, Mákó, Inaktelke).

1.b.: Végül szőlőtlen területek azok, ahol semmilyen adat, dủlőnév sem utal szőlő jelenlétére.

\section{6. §. A középkori mákófalvi duzzasztó leírása}

„1760: Hallota e a tanú, hogy a Mákó nevü faluból, amelyból patak le jő és szakad a Nádaspatakjában, régi üdőben nem ot folyt le, hol mostan foly, hanem aláb és valamélly halastót csinálván az Erdélyi Fejedelmek közül a Nádas patakára (mellynek Gáttya most is látzik)...? A halastónak is hallottam hírét, hogy lét volna, láttzikis a Gáttya, azon mákai patak árkának Situátiojából is meg lehet üsmerni, hogy soha oda follyamát emberi industria nélkül nem vehette volna, aztot pedig Levélből hallottam olvasni, hogy ezen mákói Réth Mákó Terinek hivattatnék." ${ }^{33}$

\section{7. §. A kalotaszegi falukép elemeinek részletes bemutatása}

- kerítés: a XIX. sz.-ban jellemzőbbek a vesszőből, mogyoróból font kerítések, amelyek a század közepére eltüntek; a kőbányászattal foglalkozó vidéken gyakoriak a szárazon rakott, hasított mészkőtömbből készült kőfalak; ma leggyakoribb a függőleges deszkás-léckerítés, amely inkább hézagos - áttört jellegű, nem olyan átláthatatlan, mint Erdély más részein. ${ }^{34} \mathrm{~A}$ kommunizmus éveiben több hegesztett fémkerítés készült, amelynek díszítését a helyi írásos kézimunka mintakincseiből merítették és a magyar falvakban a faragott kapukkal együtt sokszor zöldre v. barnára festették.

- az utcakapuk két nagy típusba sorolhatók: a kapuk 90\%-a egyszerü utcakapu, amelynek kezdetben szalmás, majd zsindelyes vagy cseréppel fedett tetejét két faragott kapufélfa tartotta. Ha e mellett leveles (széles) szekérkapu is állt, akkor azok szintén faragott sasfákhoz voltak erősítve. Felszegen és Alszegen a kapuhoz müvésziesen illesztett szakállszárítót (ülést) alakítottak ki, Nádasmentén csak egyszerü padot illesztettek hozzá. A másik „kötött” kapu-típusából egykoron és mai is kevesebb állt (10\%). Ezek a székely-kapuk arányait idézik, de a három magas oszlopot nem galambdúcos, hanem egyszerübb cserepes, zsindelyezett fedél fogja közre, hogy a középső kapurész alatt

${ }^{33}$ Szabó T. A., 1941. p. 232.

${ }^{34}$ Furu, 2007. p. 58. 
a szénásszekér is elférjen. Középső levelei áttört lécrácsos mintát követnek, mégis épületekhez illeszkedve zárt térfalat hoz létre a faluképben (pl. Méra, Nyárszó). Mindkét típus a környék román falvaiban is előfordul. A kapuk arányát, részleteit, ornamentális díszítései településenként max. 2-3 változatot követnek, amely a faluban dolgozó ács-asztalos generációk kézjegyével azonosítható.

- az utcaképből kiemelkedve a gémeskutak egykor nagy szerepet játszottak, ahogy a sáncok, árkok, hidak is, amelyeket kőből kirakva ízlésesen alakítottak ki, de az elmúlt 20 évben túlzott méreteket öltöttek a beton-átereszek, vaskorlátos betonhidak formájában. A közösségi falumegújítás néhány szép példája ellenére (Sztána, Nyárszó) a hulladékgyűjtők, bekerített játszóterek, giccses szoborkompozíciók, beton kerítéselemek, színes hőszigetelések és tetők intenzíven rongálják településközpontok esztétikáját.

\section{8. §. A kalotaszegi tornyok jelentőségét alátámasztó idézetek:}

Ha Kalotaszeg épületeit, klasszikusan nagyszerű fatornyait és jellegzetes falusi házait környezetüktől megfosztva, az erdőtlen hegyek messze nyúló vonulataiból, a lombos falvakból kitépve akárha Erdély valamelyik más vidékére is helyeznénk, gyökértelenül, idegenszerüen vesznének el, míg jelenlegi helyükön, a földön, amelyből kinőttek és amelyhez létük kötve van, természet és ember lelkének müvészi kifejezői. Különösen áll ez a fatornyos, többnyire kerített templomokra, amelyek magaslatokon, a falutól távol eső hegyoldalakon, magányosan elhelyezve dacos büszkeséggel emelkednek a falvak fölé, védelmezve és őrt állván felettük. Négy fiatornyos, árkádos fa toronysisakjaik égre rajzolódó körvonalai valósággal egy-egy helység messze látszó szimbólumaivá magasodnak. in: Balogh I., 1935. pp. 48-49.

A fatorony önmagában is megállhat, és építészetileg véve éppen úgy, mint esztétikailag, egy befejezett egészet képez; de a fatemplom a torony nélkül, akárcsak egy lakóház benyomását keltené. Mihelyt a torony rajta van megváltozik a hangulat-keltés, és a templom kiemelkedik a profán épületek sorából. A középfüldi fatemplom belső szerkezete elég tanulságot nyújt, hogy miképpen egyesült a két elem -a templom és torony- egymással. Mert míg a bikali és a farnosi tornyokat szemléltük, még nem is gondoltunk arra, hogy a fatemplom a mai alakjában a két test eggyé olvasztásából telt ki. in: Szinte, 1913, p. 17. 


\section{9. §. Udvarházak, kúriák, történeti kertek}

Az alábbiakban vizuálisan mutatom be a Kalotaszeg-környéki udvarházakat, kúriákat, kúriakerteket, amelyeknek társadalmi- és gazdasági-szerepük, tájtörténeti és kertművészeti jelentőségük volt:
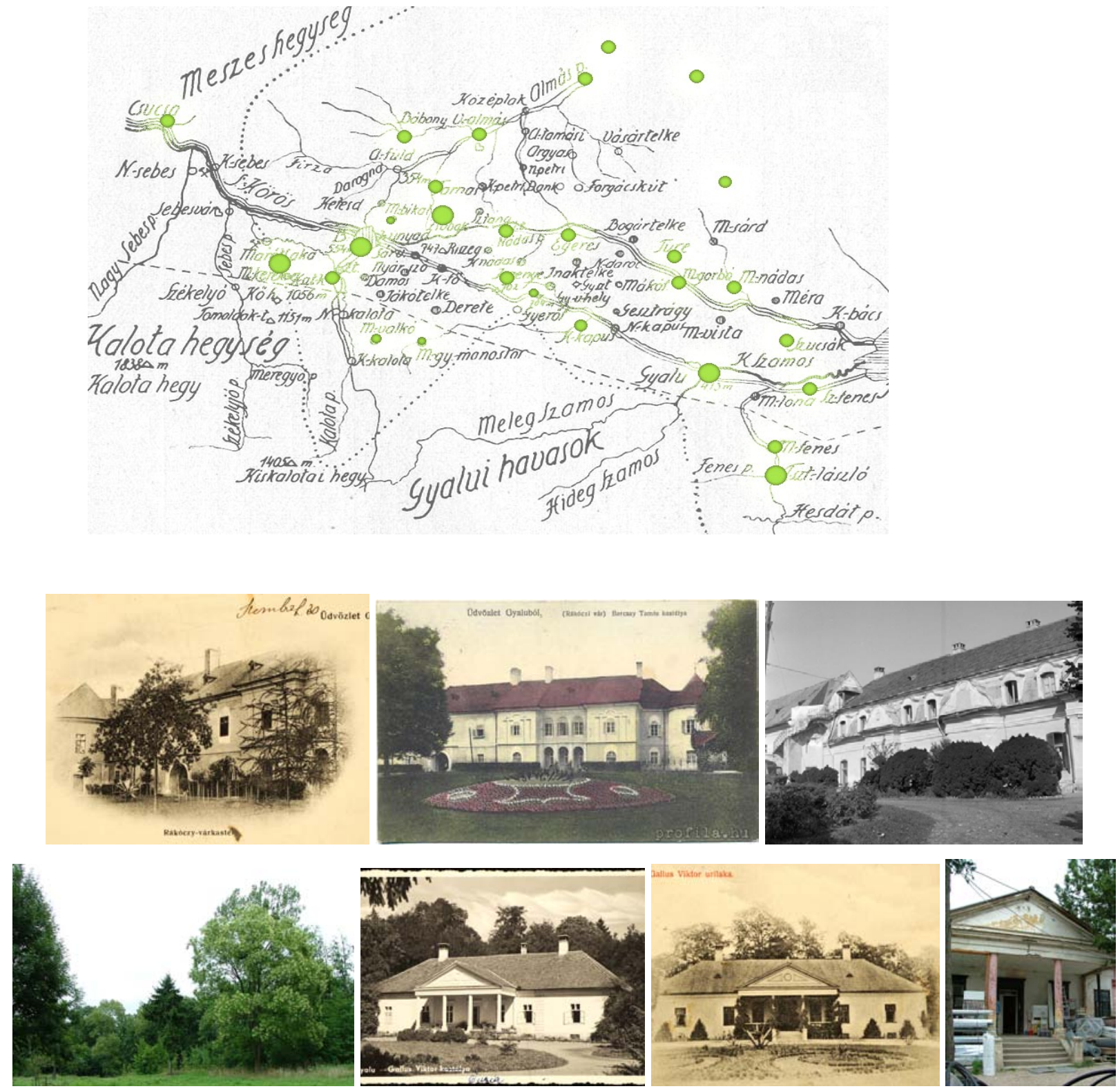

Gyalu: Rákóczi Vár, majd Barcsai-kastély (Barcsai Domonkos) és Gallus Viktor
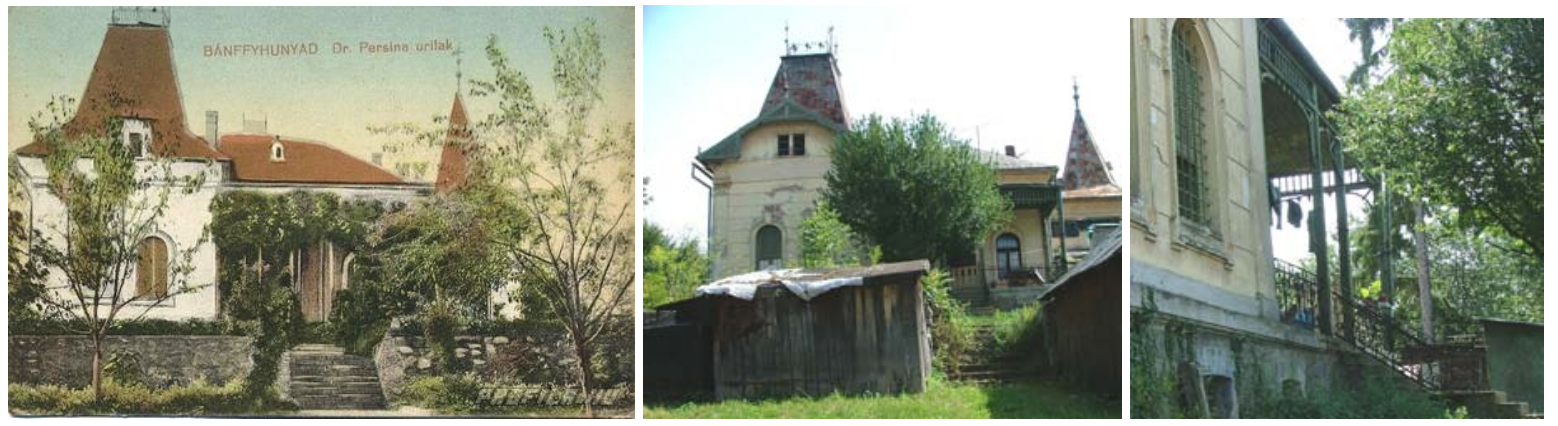

Bánffyhunyad: Dr. Persina Viktor (ügyvéd) villája 

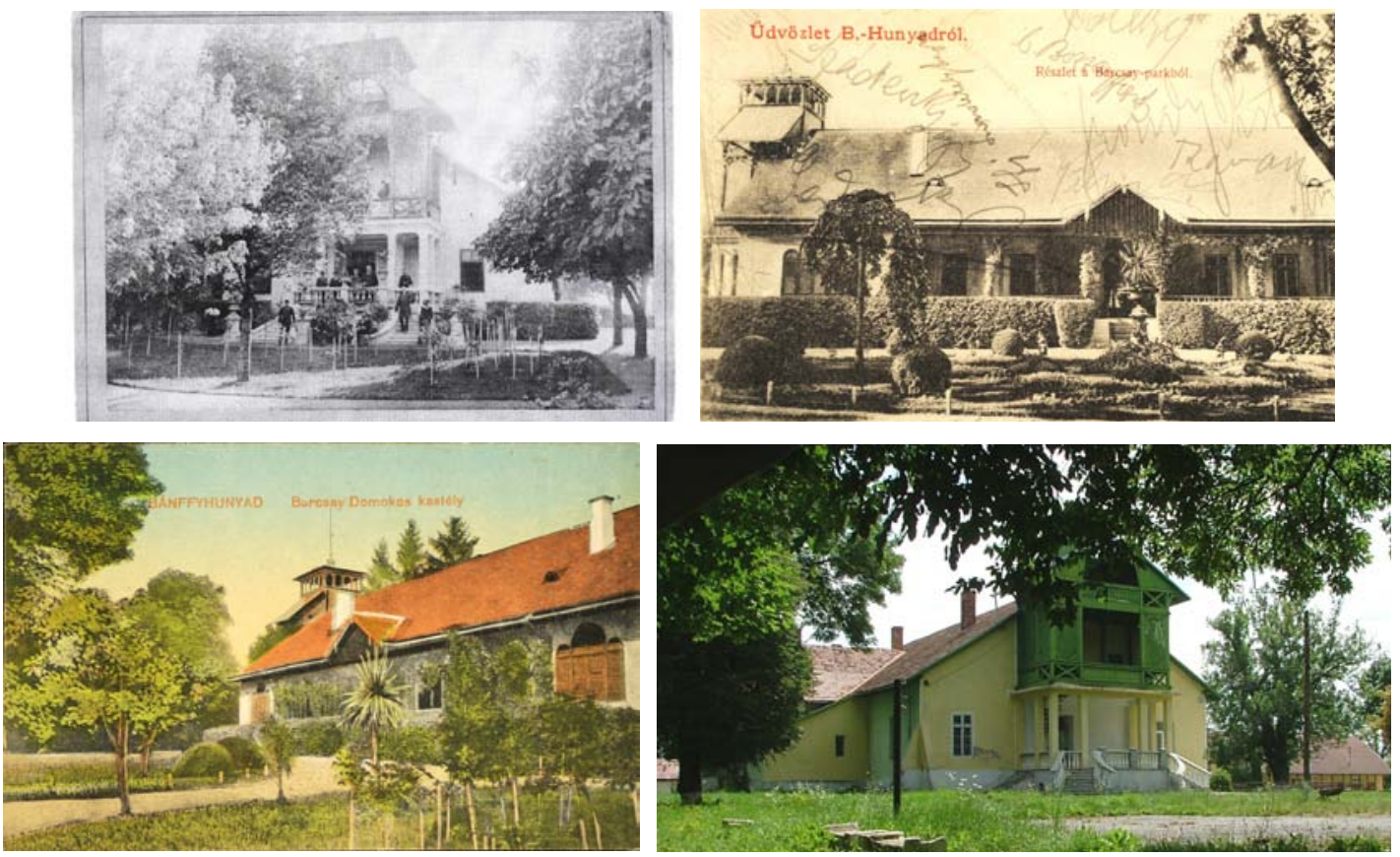

Bánffyhunyad: Barcsay Domonkos Kastélya, ma nevelőotthon.
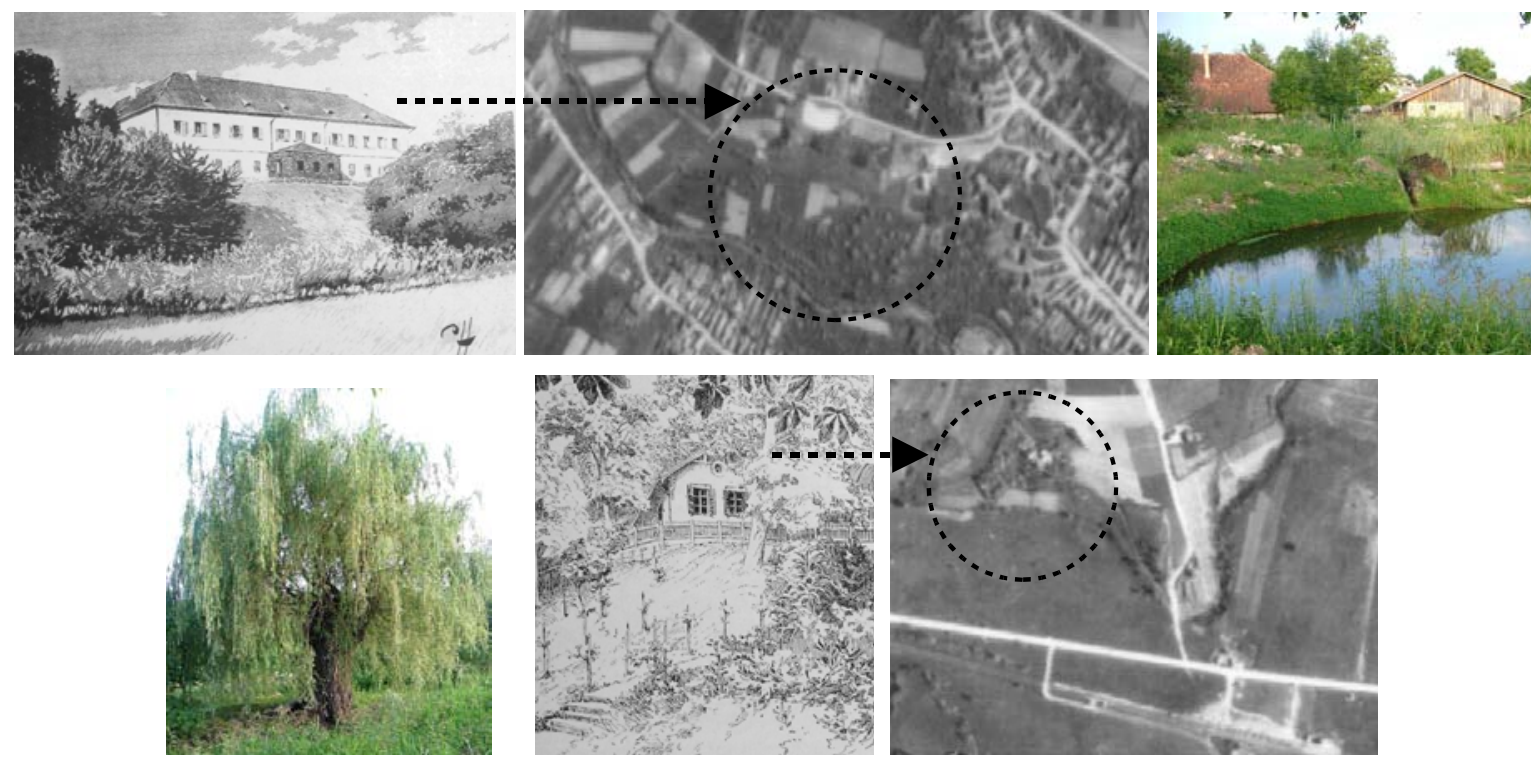

Zentelke (Kalotaszentkirály): Bánffy - Josika kastély (elbontva a II. vh. után), Remetei Bánffy vadászház (Malomszegi vasúti kirérőnél, Hodos felé, elbontva kertje látszik)
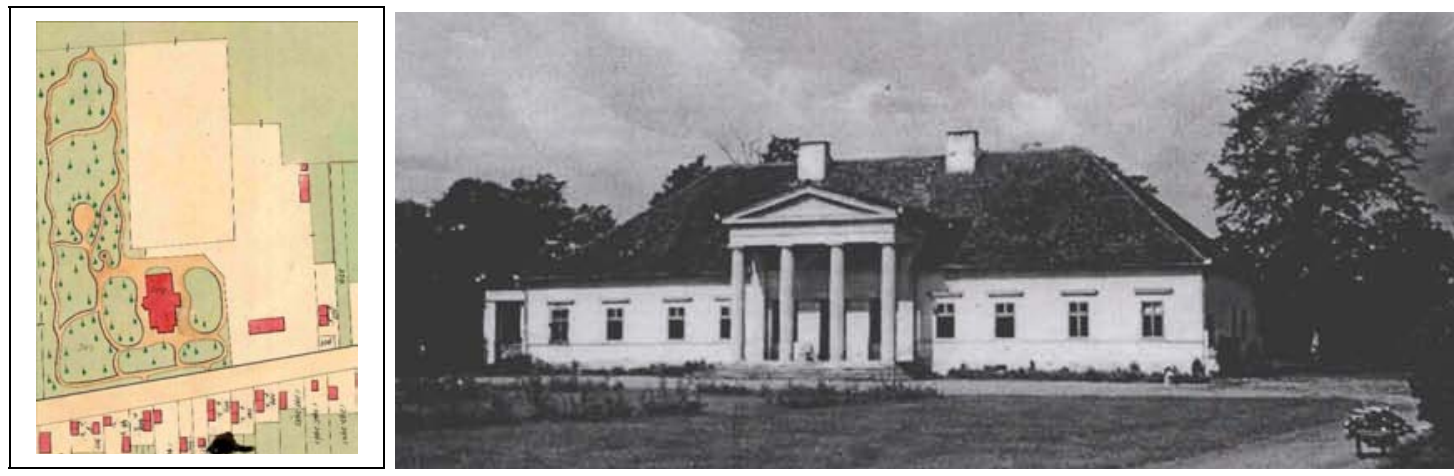

Szászfenesi Mikes kastély 

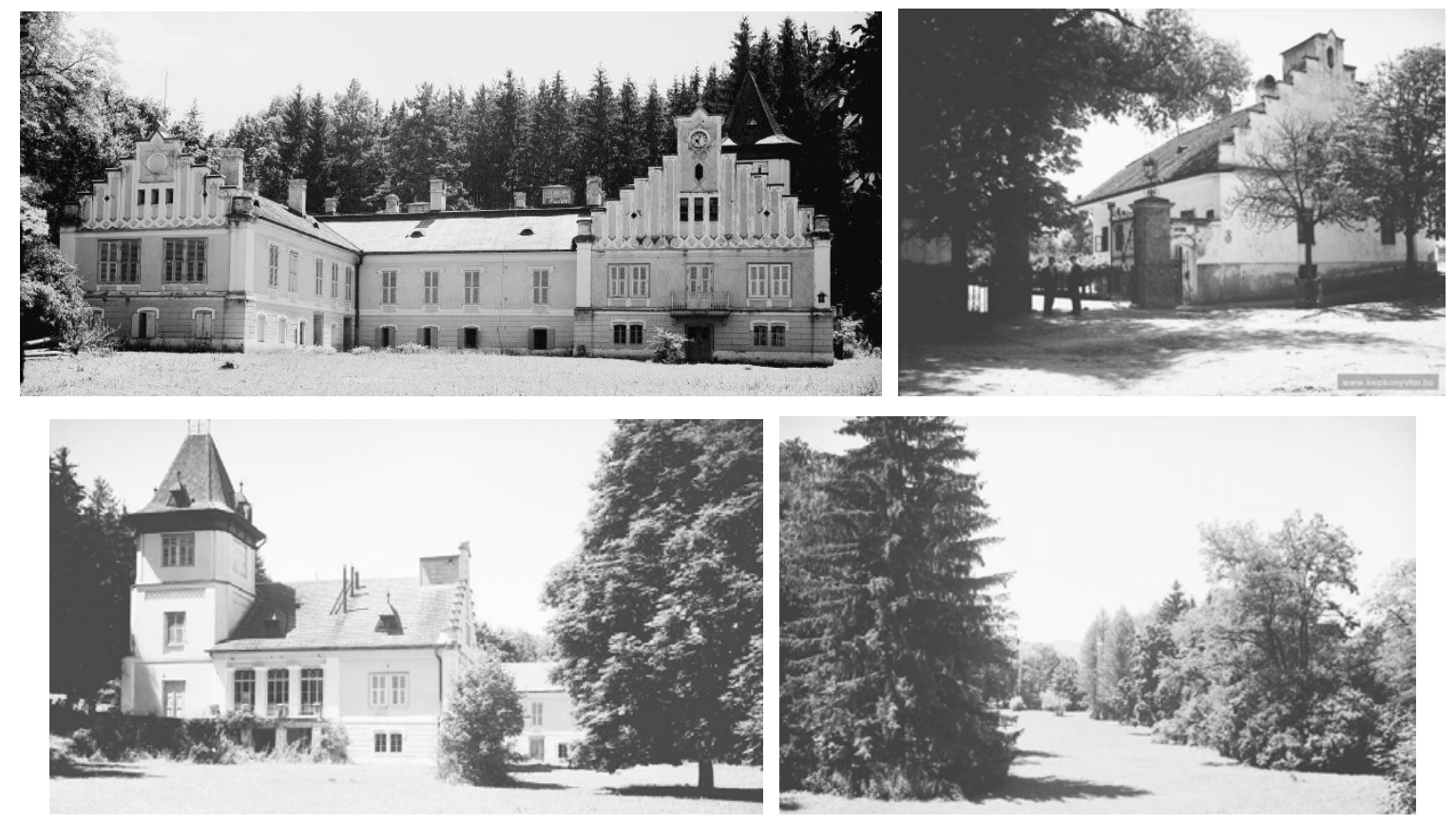

Tordaszentlászlói Szécsényi-kastély: ma is teljes terjedelmű kertjével - dendrológiailag jelentős növényállománnyal
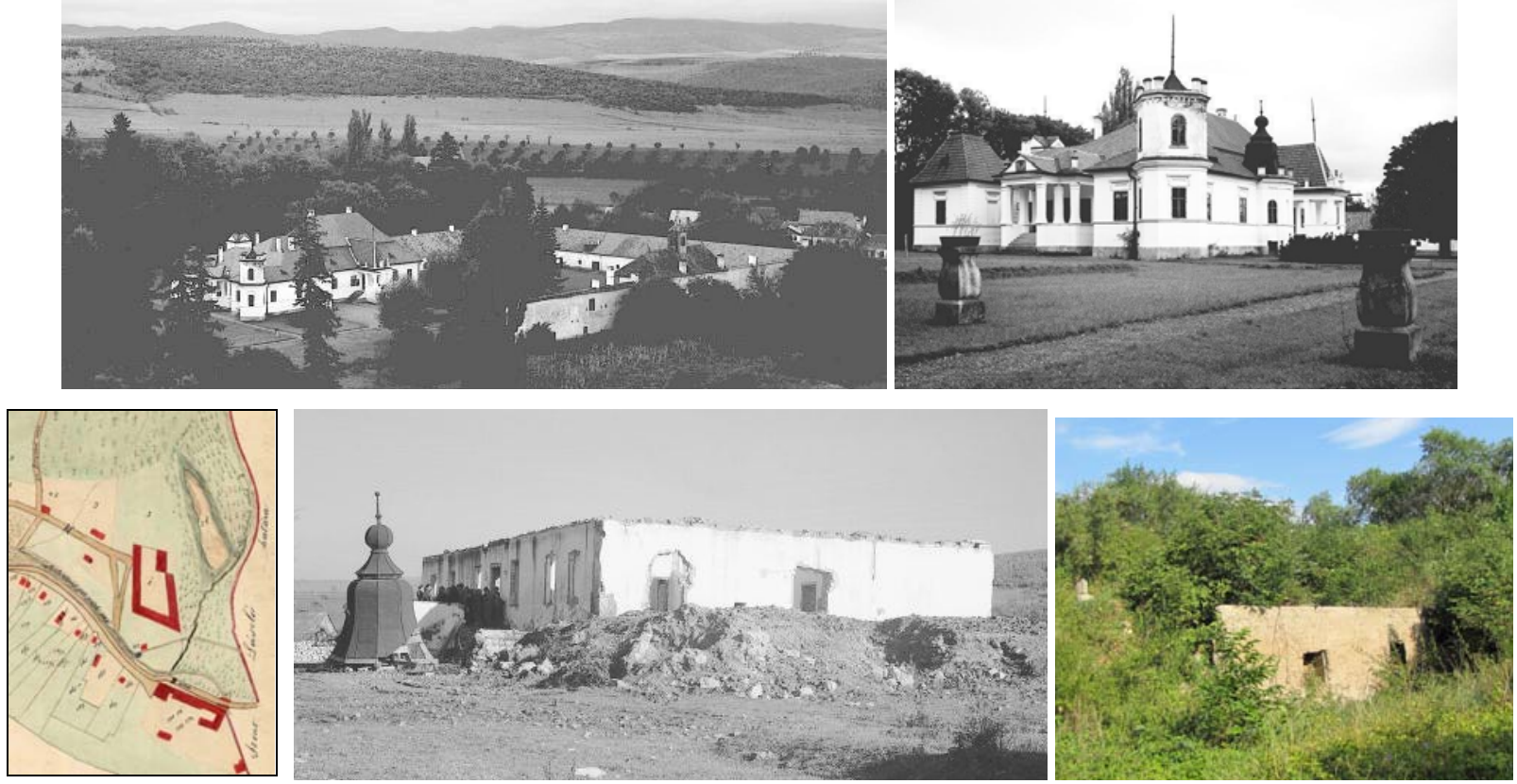

Magyarfenesi Mikes-kastély
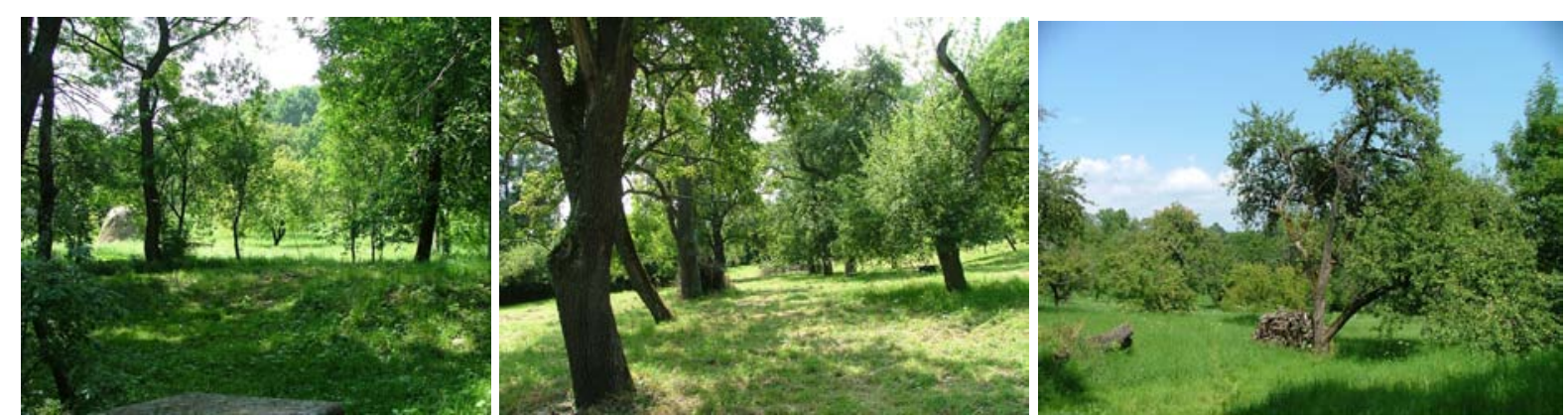

Magyarókereke: Az elpusztult Telegdy kúria gyümölcsöse 

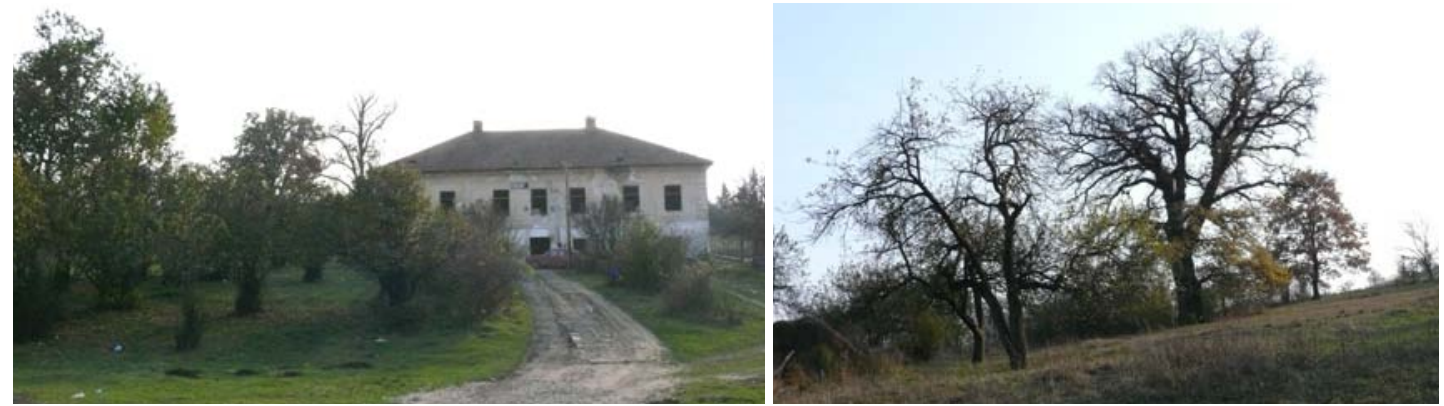

Magyargorbó: Id és ifj. Lészay Ferenc kúriája és kertjének öreg tölgy és hársfái
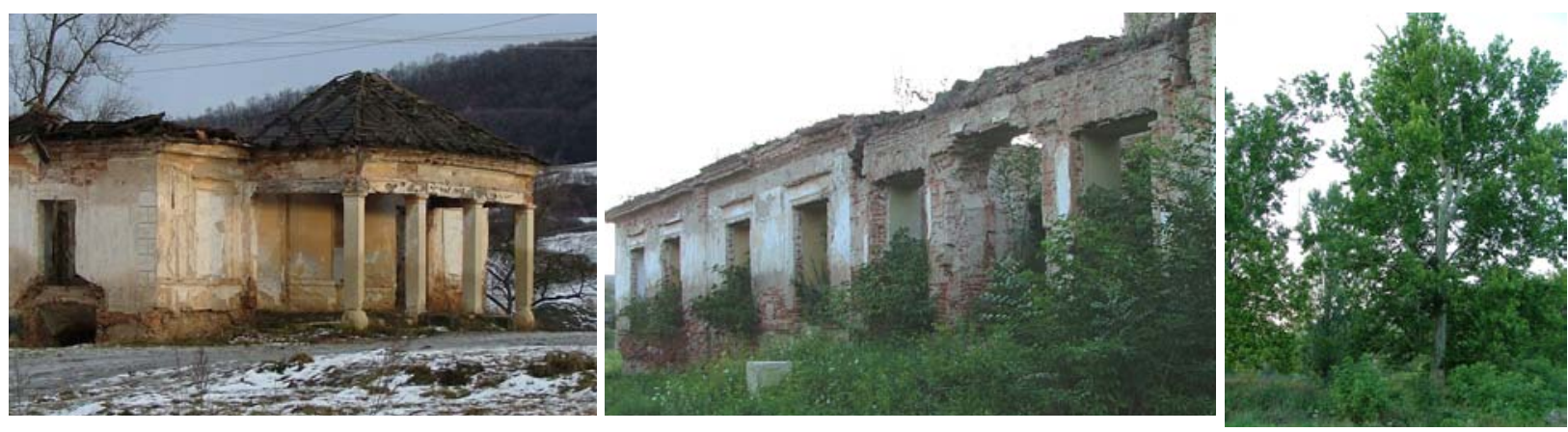

Váralmási Csáki-kastély TSz-átalakítása és annak „maradványai”
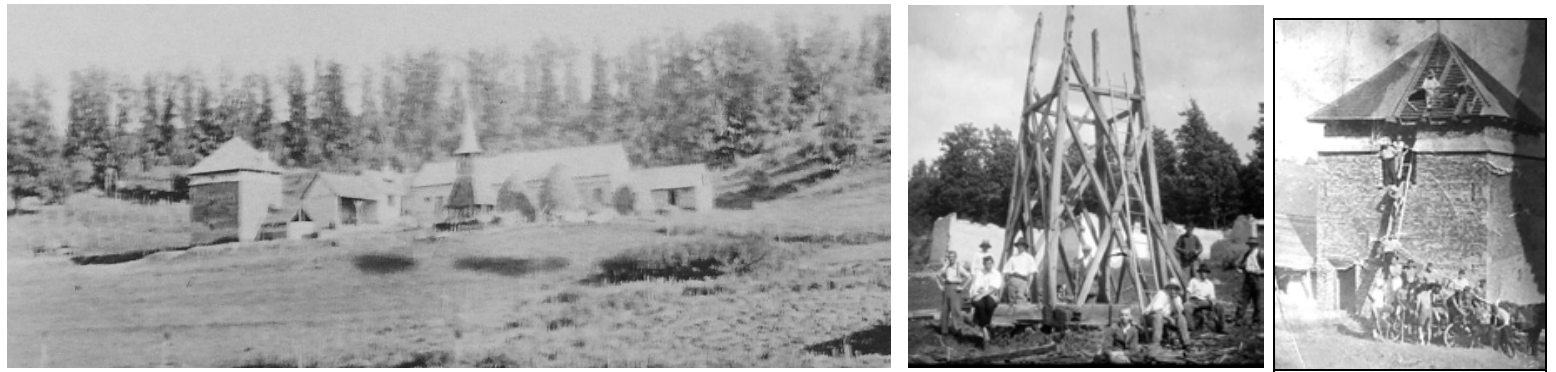

Bábony: A Kós által tervezett Mezőgazdasági Tanintézet „mintatanyája” (mára elpusztult)
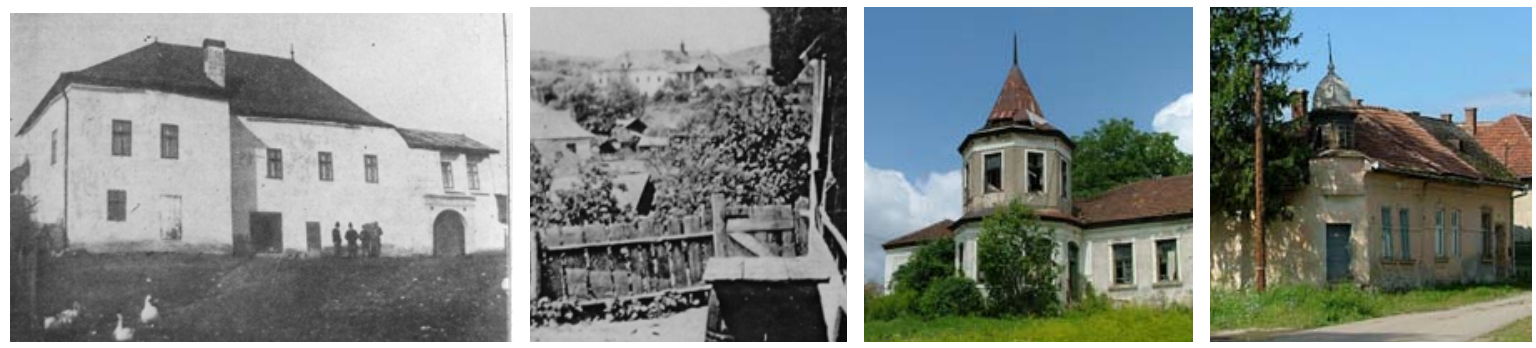

Egeres - Bocskai kastély (Kelemen, Néprajzi Múzeum: F30488) és egy román pópa kúriája a '30-as évekből
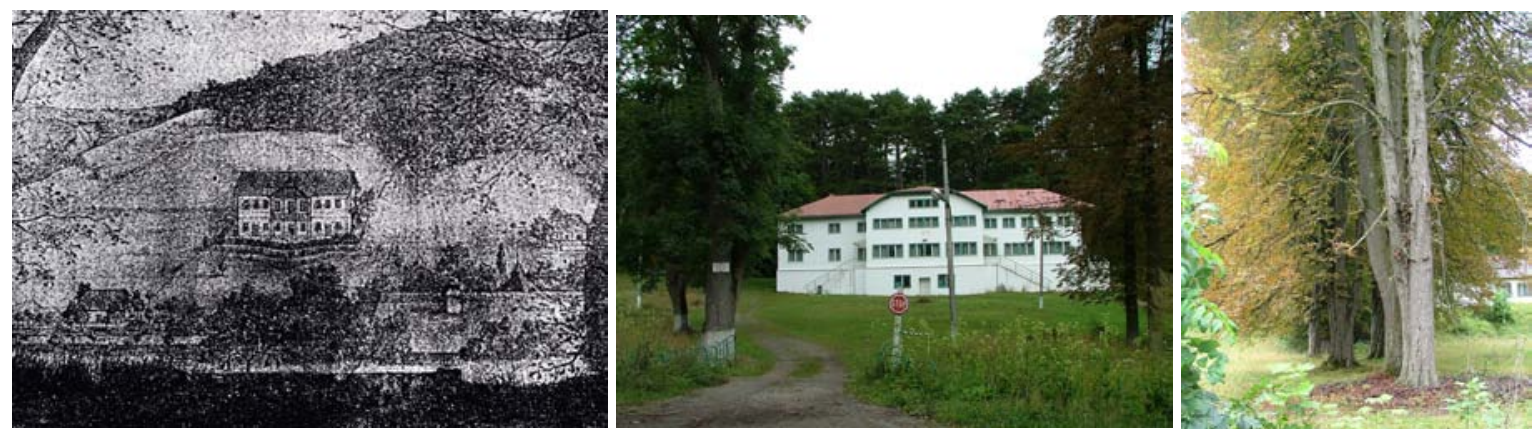

Jegenye: Hermann Antal nyaralója (Erdély folyóirat) és az abból átalakított fásított gyermeküdülő 


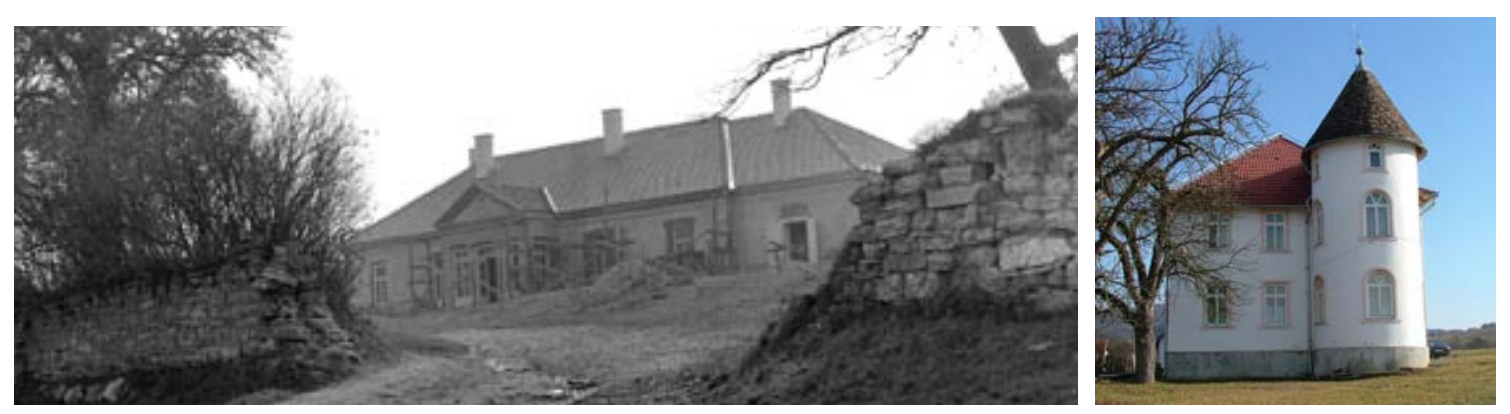

Farnas: Szentiványi kúria (ma Idősek otthona) KJNT_06305_88
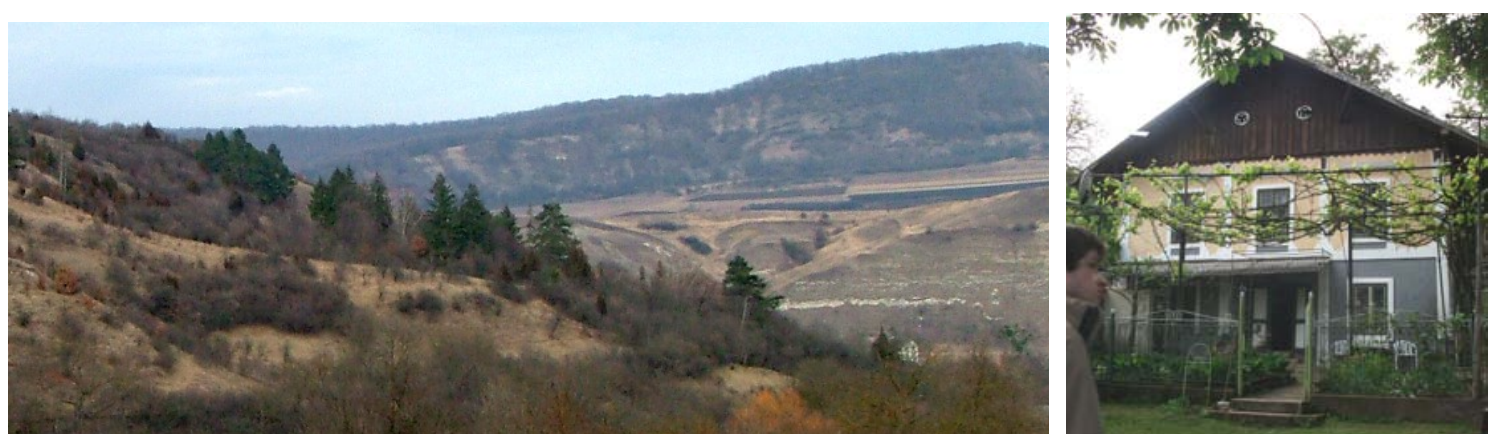

Zsobok: Szepessy-Lajos debrológiai kertje a domboldalon

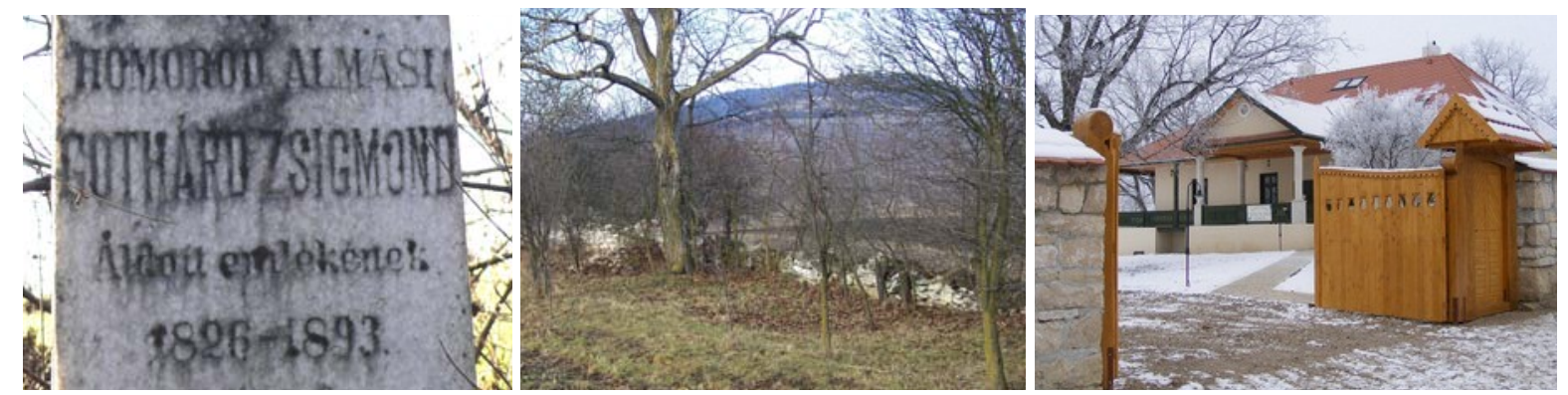

Sztána: Homoródalmási Gothárd Zsigmond sírköve, kúriája (majd román parókia ma Kéki-rigó panzió)
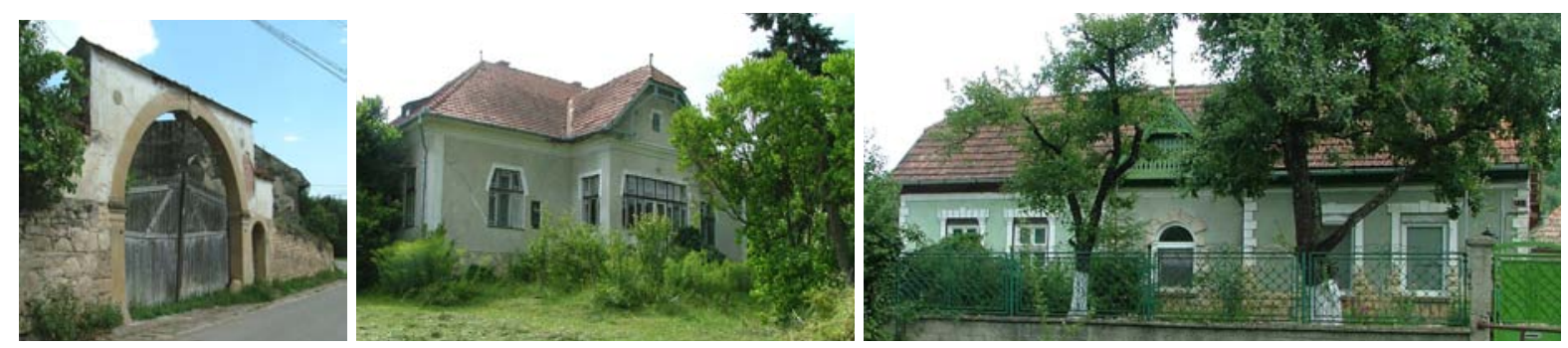

Szucsági kisnemesi kúriák
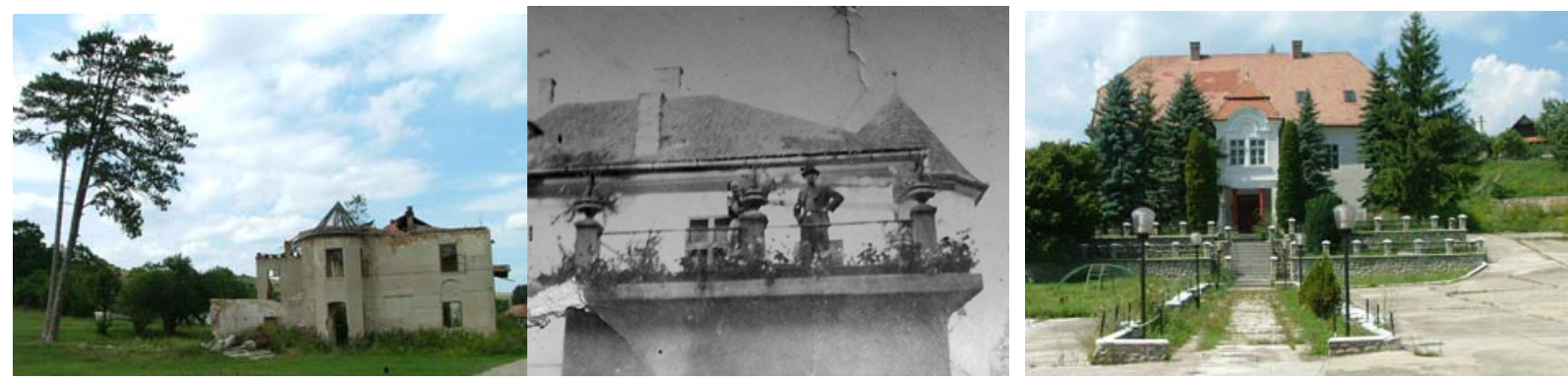

Magyarszentpál - Teleki L. Gyula kúriája, majd iskola; Magyarnádasi kastély 


\section{0. §. A Kissebes - Marótlaki bányák tájtörténeti és tájképi fényképdokumentációja}

1: A Kissebes - Sebesvár környéki vulkáni kőzeteket fejtő felszíni művelésủ bányák (5270ny1941, képeslap a századfordulóról) 2: Képeslap Kissebesről, 3-5.. Képdokumentáció a Kissebesi Gránitkőbányák Rt. Kiadványából (Glasner, 1905) 6-7.: A Kissebes Sebesvár felőli faluvégén álló, sötétszürke dácitciklop-kőből készült egykori vezetőségi épületek, amelyek a századfordulós képen is látszódnak, 8-9: Marótlaki Csúp Ny-i irányba lefejtett oldala (Balog Ernő, Képkönyvtár 19387_22484; EA) 10-11.: A Kissebestől É-ra fekvő fejtés ma (EA)
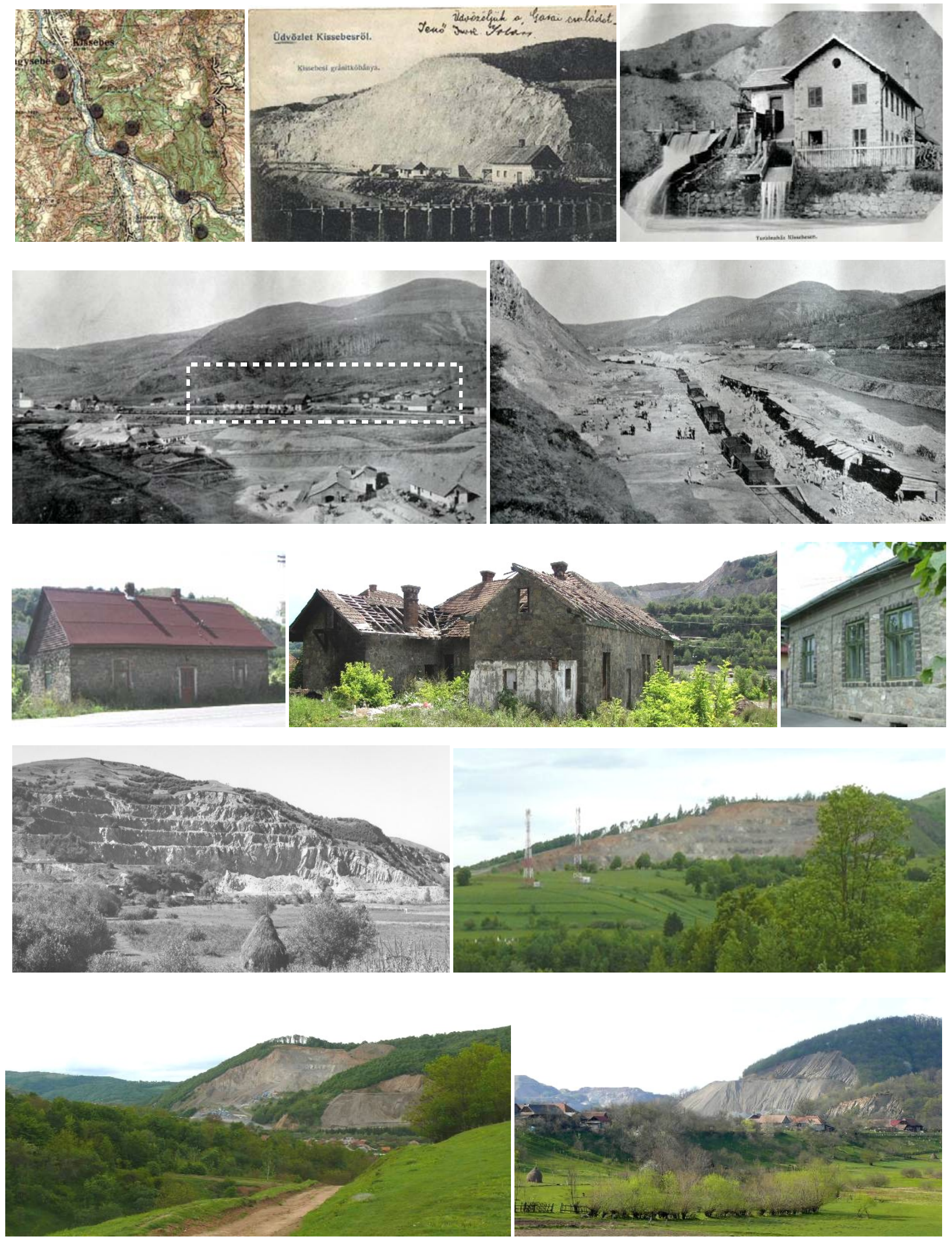


\section{1. §. A mészkőfejtés és annak tájképi következményei}

A kalotaszegi, jó minőségủ eocén-mészkőrétegek kifejtése maradandó tájsebeket okozott. A távolról eróziónak tünő szakadások közelről jól mutatják egy-egy ellenálló mészkőréteg kifejtésének tényét (képpárok): 1.: Egeres - Kerekdomb; 2-3.: Magyarnádas - Vista környéke, 4.: Inaktelke -

Kü'szikla, 5.: Jegenye Nádas-felé eső bércének peremén lévő bánya 6.: Begyepesedett türei kőfejtők látványos bányagödrei a türei út jobb oldalán, lent: A mészkőbányák, kőfejtők szoros kapcsolata az eocén időszakból származó üledékekkel. 7. A kőfejtők korrelációja az eocén rétegekkel (Koch térképén, zöld színnel jelzett)
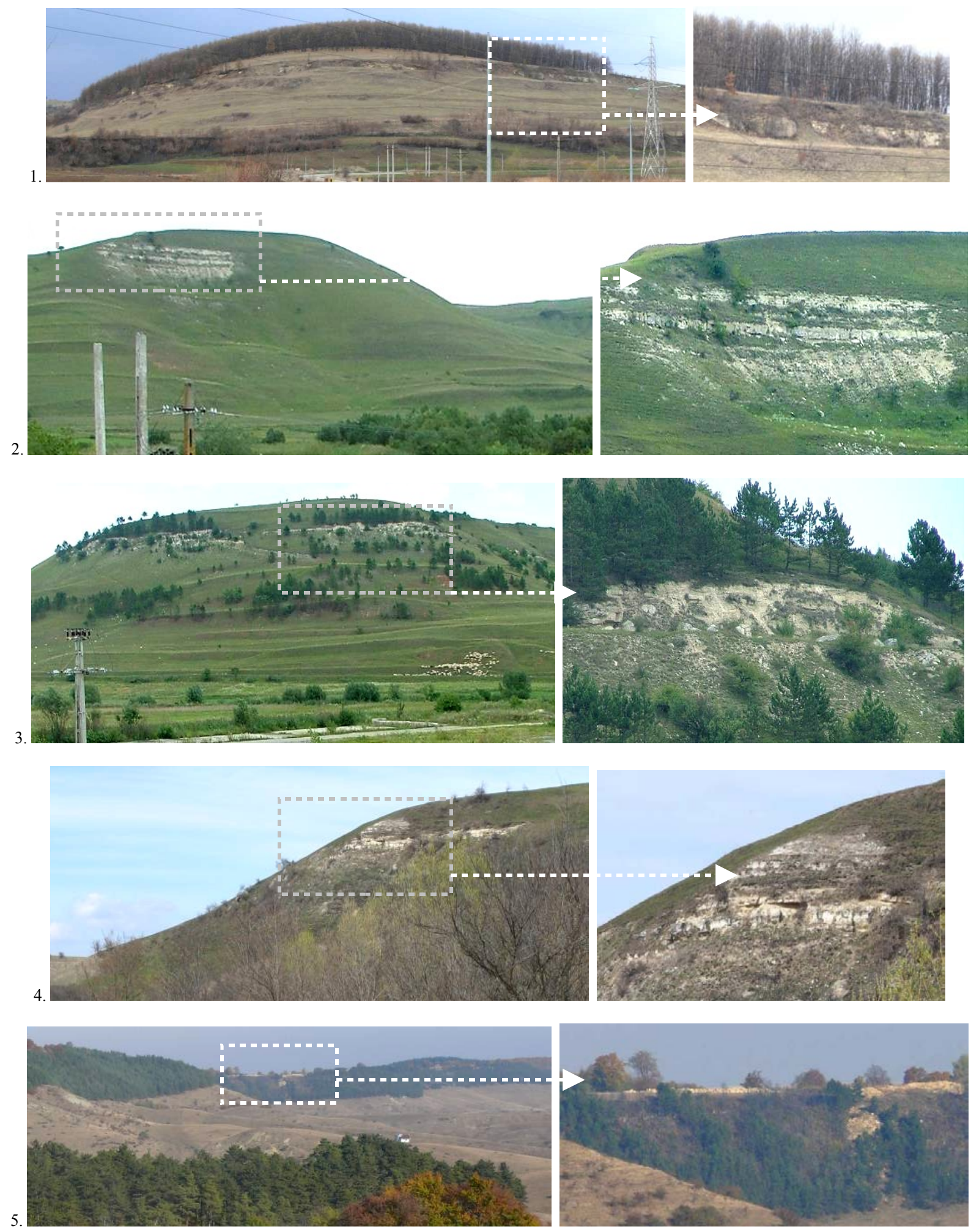

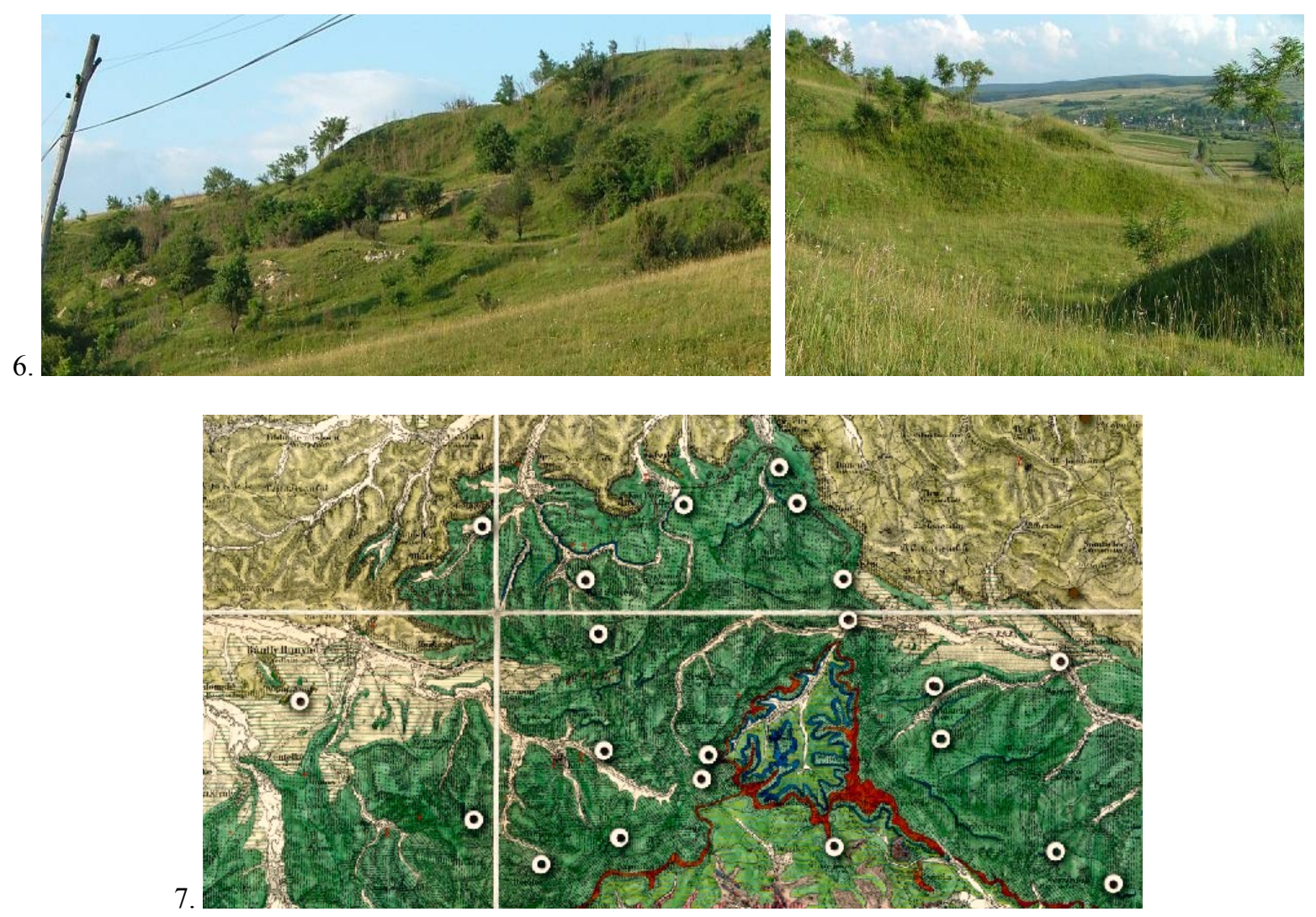

\section{2. §. A zsoboki márványgyár tulajdonosának Szepessy Lajosnak és kertjének bemutatása}

Szepessy Lajosról keveset tudni (felesége Gajzágó Katalin, két gyermeke Lajos és Aladár). Ö maga igazgatósági szerepkört (MUTUAL, Gresham Bizt.) töltött be Kolozsváron, és alapítótagja volt az 1887-ban megalakult „UNIO” Kolozsvári Szabadkőműves Páholynak. (Dr. Berényi Zsuzsanna történész személyes közlése). Jó kapcsolatot ápolhatott Hegyesy Vilmossal, aki részletes leírásokat adott kertjéről. A park dendrológia értékeit tekintve a legjelentősebb lehetett Kalotaszegen.

„Körülöttem a park tujái, spireái, fenyőcsoportjai, fagyalbokrai, platánjai és szomorúfüzei között a nagyobb és apróbb szárnyasok ezrei meg ezrei rendezik a legszebb, legandalítóbb koncertet, ... Zsobok harmadik érdekessége az a pompás park, melyet a Szepessy ízlése varázsolt egyik hegyoldalra, közönséges apró kertek és szőlők helyébe. A tuják minden akklimatizáló faja, veigelák, spireák, thamarix, libocédrus, egy-egy ritka gyümölcsfaj, pompás virág-parthiek, különbözö fenyőnemek stb. - nagyrész ezek alkotják a fölötte gazdag múkertet... taka változatosság és mindenütt mintaszerủ csín s kiváló ízlés a berendezésben. Ez a pompás kert igazi dísze messzi vidéknek." ${ }^{35}$

\section{3. §. Az Egeres környéki bányászati - ipari beavatkozások és létesítmények leírása}

Az Egeres - Jegenyei mészkőbánya és gipszgyár 1888 őszén kezdte meg müködését, tulajdonosa Kramer Tivadar volt. A cég igényes századfordulós központi épülete Egeres-gyártelepen, gesztenye és hársfákkal övezve, helyi védelmet érdemelne. A jegenyei völgy torkolatánál előforduló telepekről nagyban fejtett nyers gipszet földolgozták és az égetett és lisztté őrölt gipszet Bp.-re és Bécsbe is szállították. ${ }^{36}$

\footnotetext{
${ }^{35}$ Hegyesi Vilmos 1888-as levelei. in: Sas (szerk.) 2007. pp. 156-162 és pp. 425-427.

${ }^{36}$ Koch., p. 31.
} 
Az akkor 12 fővel múködő, jól felszerelt üzem alacsony árai miatt rövid idő alatt nagy sikereket ért el, mütrágya terményeiket uradalmak vették alkalmazásba. ${ }^{37}$ Az 1950-es évektől a gipszbánya inaktelki Szénafü felé terjeszkedett és a Nagyerdőn nyitotta meg hatalmas fejtőit, ahova drótköteles csillék vezettek a Gyártelepről. Jegenyéről és a környékről is egyre többen kezdtek dolgozni a bővülő bányában, amely ipari központtá vált. A Bogártelke feletti kaolingyár szintén ekkor kezdte a homokkitermelést, később ülepítőként a Bogártelkétől Türe felé eső, Kis- és Nagy-hegy mögötti természetes horpát választotta, amelyet már az első katonai felmérés vizes mocsárként jelöl. A mára feltöltődött és kiszáradt ülepítő maradandó táji beavatkozásokat hozott: töltéseket, ülepítőket, vezetékeket. A kaolingyár épületei a Nádas-völgyében, a falutól Egeres felé találhatóak; Sólyomtelke felé eső hatalmas meddőhányói és bányatavai azonban nem érvényesülnek a Nádas-völgyi tájképben.

Egeres környéke a XIX-XX.sz. fordulójára nemcsak gipsz-bányáiról lett ismert, hanem barnakőszén-bányászatáról is, amely újabb iparosítást eredményezett: kiépült a Ferencbánya nevü jellegzetes századfordulós ikerházas lakótelep Forgácskút és Dank között (Ticu-Colonie). Ekkor épült ki Egeresről „út” ezen települések felé, amely a román településeket némiképp Kalotaszeg „felé fordította”. A körtvélyesi és Borzás-tetőn lévő Pojana Grube tárnákhoz Egeresről keskeny nyomtávú, lóvontatású ipari vágány épült 1910 körül, amelynek töltés-alapját helyszíni bejárásaim során még megleltem.

Ehhez az ipari tájképhez kapcsolódik még a villanytelep hatalmas épülete a '20-as évekből, és a magas feszültségü vezetékek, lecserélt drótkötélpályák, csővezetékek, ülepítők, tárnabejáratok, hatalmas meddőhányók Argyastól, Ferencbányán át a Sólyomtelki határig, és végül a Bogártelke feletti -rekreációs célokat is szolgáló, noha veszélyes-, bányatavak is.

\section{4. §. A talajminőségre vonatkozó jellemzések a Cziráky-féle ${ }^{38}$ leírás alapján}

FELSZEG: Bánffyhunyad: két rész jónak, három rész középszerü, egy rész oldalas és kövessége miatt terméketlen és bajosabban művelhető. Bocs: határunk trágya nélkül nem jó. Méregjó: Határunk fele jó, fele terméketlen, bajosan művelhető, az egész határa egyharmada köves. Nyárszó: az egész határunk kétharmad részben jobbacska, egyharmad része gyengébb. Zentelke: határunk egy része jó, más trágya nélkül nem jó, a bocsi forduló távolságáért nehezen trágyázható, és oldalassága miatt nem tartja.

ALSZEG: Argyas: határunk oldalas és öszveomladozott. Forgácskút: némely oldalas helyen kősziklás és helye-helyen öszveomladozott. Kispetri: a föld színe fekete, kövecses, veres, sárga. Nagypetri: a határ egyharmada jó, egyik része középszerű, más gyengébb, mivel hegyesebb, ezen része sárgásabb színü, kövecses, nagyobb része feketébb. Zsobok: határunk fele jobb és trágyázhatóbb, és több része hegyesebb, a föld színe elegyes, sárga, kövecses. Középlak: a két forduló meglehetős termékenyűek, nevezetesen és teres, szép helyek... Zsombor: határunk jóságra nézve mind egyformák, teres helyek mind jók, a föld fekete, némely hely agyagos, sárga és apró köves

NÁDAS-MENTE: Bogártelke: a határ egy része éppen jó, mivel jól is műveljük és trágyázzuk, egy része alábbvaló, egyharmad része pedig még alábbvalóbb. Daróc: a határban sok hasznavehetetlen hely is vagyon. Inaktelke: a határ harmad részit mondhatni alávalónak, amelynek nagy része

\footnotetext{
${ }^{37}$ A Kol. Kereskedelmi és Iparkamara Jelentése kerülete gazdasági, kereskedelmi, ipari és forgalmi viszonyairól 1890, p.115.

${ }^{38}$ Takács, 2002.
} 
hasznavehetetlen is, a határ fekvése nagyobbára oldalas, vízmosásos, elszakadozott úgy, hogy mívelhetetlen, károssá vált sok helyekben, afelett hogy kevés törés hely vagyon, szinte az egész határ köves, agyagos, veres színü, minélfogva míveljük a határt négy ökörrel és hattal. Jegenye: az egész határ oldalas, amellett forrásos és vízmosásos is, inkábbat agyagos és köves, egyharmada hasznavehetetlen. Gyerővásárhely: az egész határ köves és agyagos, mind a két forduló kemény, bajos művelhető, trágya nélkül nem terem

ÁTMENETI FALVAK: Kajántó: a határ egyharmada agyagos, két része fekete, termékeny föld, trágya nélkül is terem középszerűleg. Kórod: határ harmada fejér, agyagos, más harmada hegyes, oldalos, harmad része lapos és teres, fekete jó föld lévén. Sárd: Határunk teres, egy része barázdás, lapályos és hegyes, földünk egy része agyagos, más porondos és más fekete is, trágyát eddig még nem hordattunk földeinkre. Szentmihálytelke: egynegyede része hegyes, oldalas, háromnegyede teres, lapályos, fekete földből áll, trágya nélkül termett. ${ }^{39}$

\section{5. §. A vasútépítés talajtani és tájtörténeti vizsgálata}

A talajtani kutatások a vasútépítés korával is összefüggnek, ugyanis a Zsobok-Egeres közötti szakasz állandó talajmozgásai voltak a vasútvonal átadásának legnagyobb ellenségei. A kor kiemelkedő geológusa, Pávay Elek rámutat, hogy a vasútpályát ,szakavatott geológus minden bizonnyal a Szamosvölgyben vezette volna át, mert ott nem lett volna kitéve a róthomokkő öv (Kochnál felső tarka agyag) veszélyes siklóinak." ${ }^{40}$ A Hunyadtól folyamatosan emelkedő vonalat a Riszeg-tető lábánál kellett átvezetni: erre több nyomvonalterv is kínálkozott Sárvásártól Körösfő vagy Sztána felé. Végül a „Sztánai nagy töltés és bevágás" földmunkái bizonyultak költséghatékonyabbnak a körösföivel szemben, ahol a terep olyan hirtelen emelkedik a Hágó felé, hogy átvágása a sztánai nyomvonal földmozgatását is felülmúlta volna. A Keleti Vasútvonal legmagasabb pontját Zsoboknál éri el (563m), ahol közel 10\% emelkedésben halad a sztánai kitérőig ${ }^{41}$. A zsoboki vízválasztóra eső $(12 \mathrm{~km})$ földmunka $230.000 \mathrm{~m}^{3}$, míg maga a Sztánai töltés-bevágás $(1 \mathrm{~km}) 270.000 \mathrm{~m}^{3}$ földmozgósítást jelentett. 1869 őszén 600 munkás dolgozott a faragatlan bükkfagerendákból készült, 260m hosszú és 32m magas töltésalapnak készülő állványon, ${ }^{42}$ és az eredetileg bevágásnak tervezett, később beboltozásra kerülö alagúton. ${ }^{43}$ Veress sorozata hüen támasztja alá a tájváltozás jellegét és komoly mértékét a tartó-szerkezetek és talajmozgatás terén. A talaj folytonos mozgása miatt azonban az építkezés nagy nehézségekbe ütközött: a bevágások lejt-ékei, valamint a töltések biztosítására nagy és hosszú támfalak létesítése, átereszek meghosszabbítása, nagy terjedelmü árokfalak és völgyzárak építése vált szükségessé. ${ }^{44}$ Pávay $1871-$ ben $^{45}$ felhívta a kivitelezés figyelmét a Zsobok feletti tarkaagyag rétegekben található kékes, légköri nedvességtől és csapadéktól

\footnotetext{
39 Takács, 2010.

${ }^{40}$ Pávay, 1871. p. 143. (lásd alább)

${ }^{41}$ A Sztánai állomás párhuzamos vonalai a vonatot felhúzó dupla mozdonyok cseréje miatt készültek.

${ }^{42}$ A megdöbbentő földmozgósítású építkezést Veress Ferenc kolozsvári fényképész képeiből jól ismerjük.

${ }^{43}$ Az építkezésről részletesen, tervlapokkal beszámol: Nagy János, 1870, pp. 499-506.

${ }^{44}$ A M. Kir. Államvasutak Keleti vonalak ismertetése., 1883., p.29

${ }^{45}$ Pávay, 1871., p. 138-143. Pávay cikkében közérthetően és 3 keresztmetszet ábrával szemléltetve mutatja be e zsoboki talajrétegek problémáit és az azokra adható kultúrmérnöki megoldásokat - részletesen lásd a képmellékletben. (lásd a következő mellékletet)
} 
sikamlóssá váló „Szivaj”-rétegekre, amelyek síklapként csúsznak el egymáson veszélyes „siklókat” képezve. Cikkében kiemeli, hogy a vidék lakossága jól ismerte e helyi viszonyokat, mert nem egyszer látta már, hogy egy földtér a rajta gyökerező nagy fatörzsekkel együtt útnak indul lefelé, és ők figyelmeztették az építőket, hogy „oda bizony hiába hordják a földet, mert az ismét le fog csúszni”. Hanyagsággal vádolja a vállalkozókat, hogy a közönséges vízlecsapolási munkák mellett a siklók kiszárítására és teherkönnyítésére irányuló lépéseket sem tették meg. Ö komplex „tájépítészeti” megoldást javasolt a siklók kiszárítására: teraszírozással, a lejtőfokok gyűjtő-tárnázásával, kőtuskókból készült gyámfalakkal és bizonyos speciális helyzetben lévő hegytetői erdők kivágásával. A fent leírt mérnökéről 'Fleischhacker Einschnitt'-nak nevezett-, bevágás kiemelése alkalmával azonban olyan nagy földcsuszamlások támadtak, hogy a fenékig már kiemelt bevágásnak alagútszerü beboltozása és a lecsuszamlott anyagoknak a boltozat feletti elterítése mutatkozott szükségesnek, ezért épült meg végül a sztánai alagút. A munkálatok a megnyitás után még 1872-77. között is intenzíven folytak és nem egyszer félbeszakították a közlekedést. Az egeres-nádasi vonalszakaszon az előforduló számos malomgát és mélyen bevágott hosszú mellékvölgyek árvizeinek kedvezőtlen hatása folytán, a patak medre folyton annyira emelkedett, hogy nagyobb esőzések (1880-as Nádasi árvizek), hóolvadások alkalmával az amúgy is szük völgyet elárasztván, az iszapolt Nádas vizét a pályatest felé szorította, a védműveket szétrombolta, így 1881-ben a pályaszín emelése $4 \mathrm{~km}$ hosszban eszközöltetett. ${ }^{46}$

${ }^{46}$ A M. Kir. Államvasutak Keleti vonalak ismertetése., 1883., p.30 


\section{6. §. A sztánai töltés és bevágás tervi és fényképes dokumentációja}

1,3.: A Bánffyhunyad ás Sztána közötti vasúti hosszmetszet, amelyen jól látszik a Sztánai „Nagy töltés és bevágás" talajmozgósításának mértéke. (MÁV tervtár, I.II.3. Nagyvárad - Kolozsvár vonal), 2, 4.: Tervmelléklet Nagy János: A Sztánai töltés és bevágás c. cikkéből (Nagy János, 1870, XXXVI. Tábla) 5-8.: Képriport Veress Ferenc: Kolozsvár és környéke c. albumból, 1870 előtt (Képkönyvtár Képarchívum: 6368070270,64449 71039, 65000 71590 és http://vmek.oszk.hu/02100/02109/html/552.html)

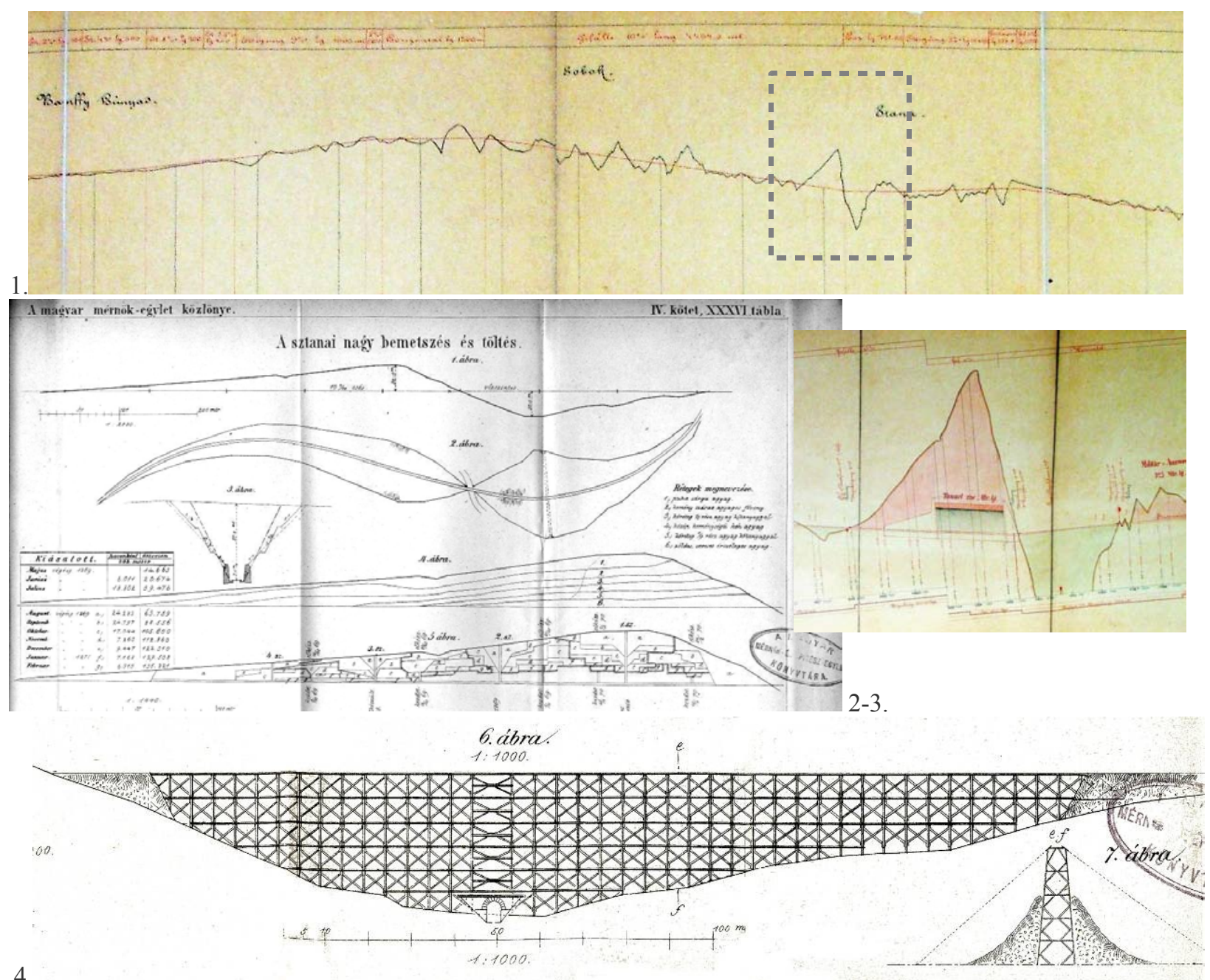

4.
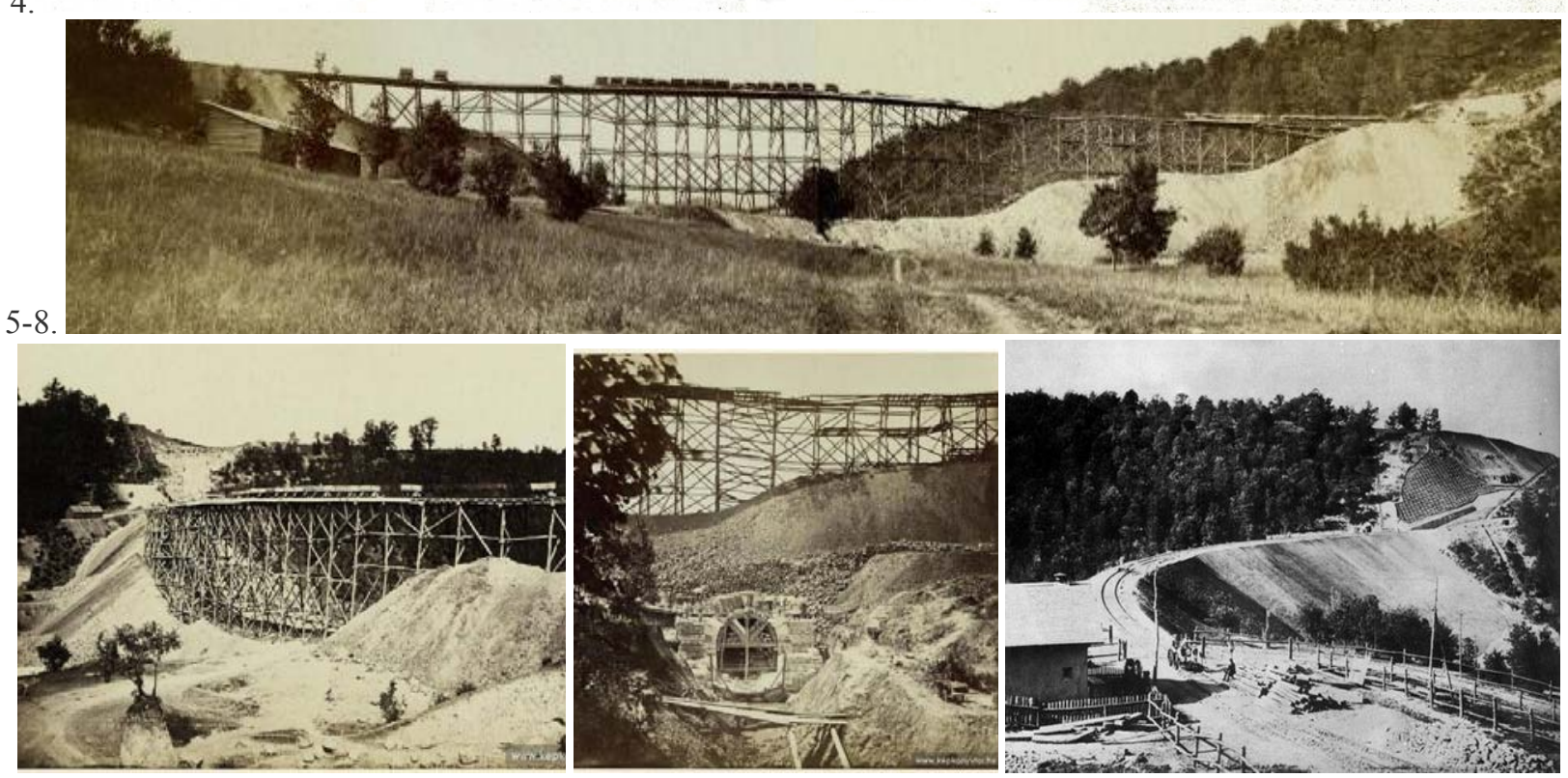


\section{7. §. Pávay talajszelvényénekbemutatása a Sztána-Zsoboki vasútvonalon}

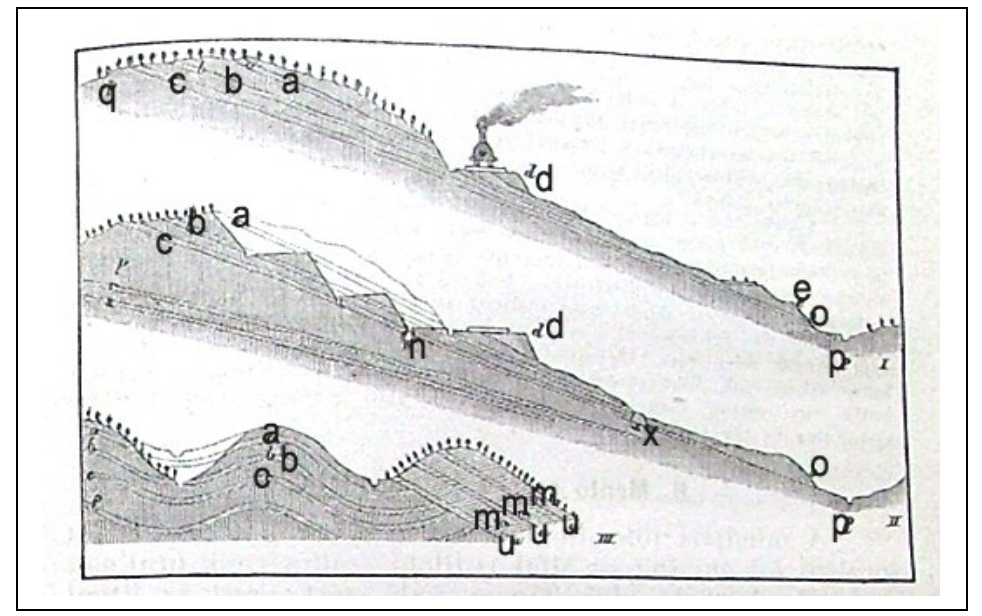

Sztána környékének földtani viszonyai: ${ }^{47}$

I. ábra: a. b. c. Rőthomokkőben rejlő vékony szivaj rétegek, melyek könnyen siklót alkotnak, d. Siklóra épült vasúti töltés, e. A siklón lecsúszott vasúti töltés, o. Egy régi természetes sikló maradványa, kidomborodott mellső részével, p. hosszvölgyi patak medre, q. Róthomokkő, amely az ingatag talajú domborzatnak mindenütt fö és alapkőzetét képezi, s egyszersmind a siklók közti közegeket alkotja.

II. ábra: n. gyütárna, mely a legalsó síklapot metszi át, és felfogja a felette lévő földtér telekmentesítésére szolgáló lejtfokok sarkainál alkalmazott lecsapoló árkok, csatornák és alagcsövek vizeit is, x. kőtuskókból épült gyámfal és burkolat a vasúti töltés alatti földtér lesiklásának meggátlására, ha a kiszárítás magára elégséges nem lenne

III. ábra: u betűkkel jelzett rétegei a felső nummulit képleteknek gipsz és mész-rétegei, amik a sztánai alagút felett láthatóak, s melyek márgás kőzetű rétegek által vannak egymástól elválasztva (m.) A középső domborzat erdejének kiírtása is nagyban hozzájárulna a siklós talaj kiszárításához, annak dacára, hogy a két szomszédvölgy erdeje lábon marad, mert a balfelöli völgy, mint a pontozott rétegvonalakból látható kirágványos völgy révén az a. és b. szivaj rétegeknek a balfelöli hegy hasonló minőségü és tulajdonságú rétegeivel összekötése meg lett szakítva, tehát az erdős talaj felső szivaj-rétegeinek nedve nem szivároghat a megerdőtlenített domborzathoz tartozókéba át. A jobb felőli erdős hegyről sem nyerhetnek a szivaj-rétegek víztápot, mivel az ottani fekvények más irányba dőlnek. Így itt jól kiszárítható a három sikló.

\section{8. §. Talajesúszások a XIX.sz. végén Szádeczky beszámolói alapján}

A táj- és talajváltozásokban emlékezetes év volt 1897. Szádeczky Gyula beszámol az év földcsúszásairól, amelyek közül személyesen megvizsgálta a dankit, magyargorbóit, türeit, ketesdit, farnasit, az Egeres-Sztána vasútvonal mentén bekövetkezett csúszásokat, továbbá a bökényi süllyedést. Valamennyi csúszásnak oka az 1896. téli és 1897. tavaszi szokatlanul nagy esőzésekben, másrészt pedig ezen vidék sajátságos geológiai alkotásában keresendők. ${ }^{48} \mathrm{~A}$ vidék tanulmányozásánál megállapítja, hogy a föld, sőt sziklacsúszás a letűnt geológiai időkben már többször ismétlődött, és valószínűleg nem is ezek

${ }^{47}$ Ábra és jegyzet: Pávay, 1871, p. 139.

${ }^{48}$ Szádeczky, 1897b., p. 2 
voltak a legnagyobbak. 1897 húsvétján a danki földesuszamlás komoly károkat okozott a falu lakóépületiben, fatemplomában, kertjeiben: maga alá fordítva a virágzó fákat, felismerhetetlenné tette a határt, átmetszve az Egeresre vezető utat: „Az út felett gyepes legelőt hasit a csúszás merev határvonala, amely 10 m-t meghaladó homokos szakadási fallal kezdödik a tetö közelében. Innét indult ki az egész csúszás. A határt képezö szakadás mentén néhány méterrel majd felemelkedett, majd lesüllyedt a csúszott földrész, melyet óriás harántbarázdák lepnek el, helyenként sürün, 1-2 m-es távolságban egymás mellett, másutt, föleg a nedves, gyepes helyeken ritkábban. Ezen 40-50, de némelykor 200-300 lépés hosszú barázdák, repedések mentén is hol emelkedett, hol süllyedt vagy szétnyílott a föld, söt helyenként oldalmozgásokat is végzett." 49

Június 23-án újabb csúszás volt Dankon, azután június 26-án történt a magyargorbói nagy szakadás és csúszás, amely a vasutat $2 \mathrm{~km}$ hosszban tönkretette, és méreteit tekintve a Dankinak kétszerese volt „Ezeknél a csúszás oka sokkal inkább abban rejlik, hogy a vízeresztö homokos felületeken át óriás viztömeg hatolt a talajba és ott a vizrekesztő agyagos rétegeken azok gyenge hajlásánál fogva lefolyván, az agyag felületét egészen ellágyitotta, sikamlóssá, iszaphoz hasonlóvá tette. Ennek következtében a vizzel túlterhelt felsö rétegek elvesztették egyensúlyi helyzetüket, megindultak a síkos lejtön és Magyar-Gorbón mozgásba hoztak egy millió $m^{2}$-nél nagyobb felületü földtömeget. Ha a csúszott réteg közepes vastagságát csak 10m.-nek is vesszük, a mi éppen nem túlzott számitás tekintve, hogy 20-30 m-es falakat is találunk a csúszott területen, valóban óriási (t. i. tízmillió köbméternél nagyobb)." ${ }^{50}$

Az elvitt vonalat a szakadás után a Nádas-túlsó oldalára helyezték és két új vashíddal emelték át és vissza a Nádason. A gorbói domboldalon ma is megkülönböztethető a lágy, hepehupás, szakadozott talajfelszín mikromorfológiája, de mára az stabilnak mondható. A danki csúszás erővonalai azonban még ma is folyamatosan mozgatják a Nagypetri feletti oldalt, és az út komoly betontámasztékok ellenére is folyamatosan repedezik és szakad. Szádeczky gondolatai így ma is érvényben vannak: „Nagyon valószinü tehát, hogy ha a természeti erők hatásának útjába gátat nem vetünk azzal, hogy a vizeknek szabad lefolyását biztositjuk és a megsérült helyeket, különösen a lecsúszott terület alját, az egésznek támasztékát az elmosástól keritésekkel meg nem védelmezik, akkor a csúszás a jövőben is ismétlődni fog. ${ }^{, 51}$

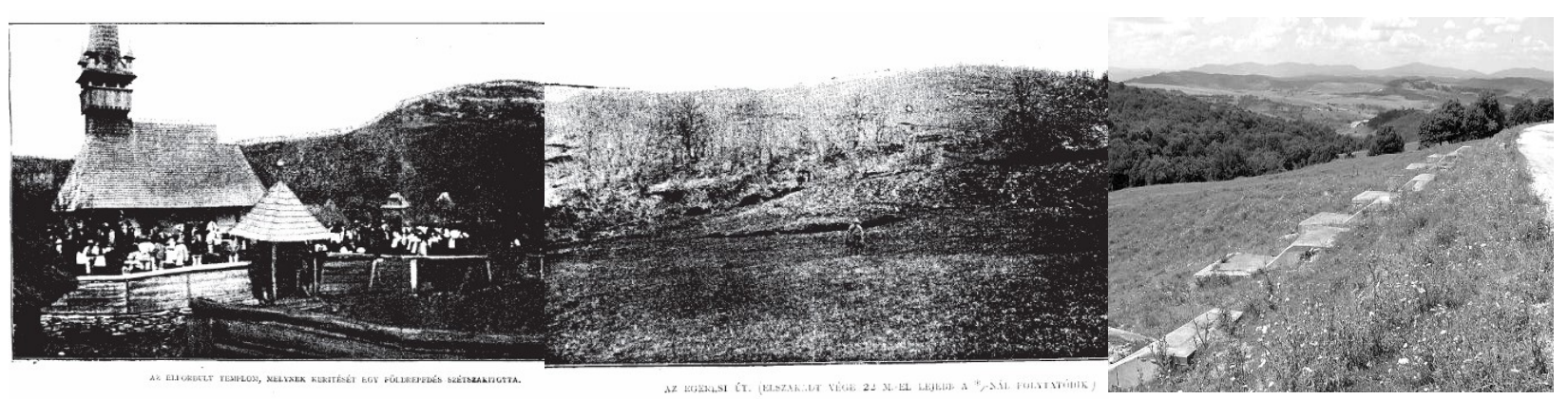

\footnotetext{
${ }^{49}$ Szádeczky, 1897b., p. 4. bővebben továbbá Szádeczky 1897a.

${ }^{50}$ Szádeczky, 1897b., p.3.

${ }^{51}$ Szádeczky, 1897b., p.5.
} 


\section{9. §. Solty beszámolója az EMGE visszacsatolás kori munkálatairól}

Solty így foglalja össze 1940 körül: „az esztelen erdőirtás következményeként Kalotaszeg tekintélyes területe részben elkopárosodott, másrészt pedig elvizenyősödött. A hegyoldalakban lévő erdők azelött gátat tudtak vetni a lerohanó víz pusztító hatásának, de az erdőirtás után a víz a hegyoldalakról a humuszt lehordva igen sok helyen úgyszólván teljesen hasznavehetetlenné tette az azelőtt termékeny területeket is. A lehordott talaj pedig eliszaposította a patak és folyómedreket (a Nádas is szakaszosan függő mederben folyik ${ }^{52}$ ), ami által azok árterületei megnövekedtek és elvizenyősítették a régi jó kaszálókat.” A visszacsatolás után elsőrendű feladatként a talajpusztulás megakadályozást és a lepusztult, terméketlen, vagy csak kis jövedelmet hajtó területek megjavítását, újra termelésbe való bevonását tüzték ki célul. Összefoglalójában (hivatkozások nélkül sajnos) beszámol a Kolozsvári M. Kir. Kultúrmérnöki Hivatal és az Erdélyi Magyar Gazdasági Egyesület 'Talajvédelmi szakosztályának'53 munkálatairól: Körös-patak bánffyhunyadi- és a Nádas-patak méra-magyarnádasi szakaszának ,jó karba” helyezéséről, és lelkes további adatgyüjtési, támfalazási, vízmosásmegkötő gátak terveit említi, de kiemeli, hogy Kalotaszegen nincs egyetlenegy olyan község sem, ahol e munkálatokat ne kellene a legsürgősebben elvégezni. A kultúrmérnöki munkákkal párhuzamosan kell folynia az erdőgerincek, meredek hegyoldalak és vízmosások befásításával és sáncolási munkákkal. ${ }^{54}$ Az újraszerveződött E.M.G.E ekkor intenzíven megkezdte ugyan a sáncolási bemutatókat, és Gazdaköreit buzdította a sáncolási munkálatok megkezdésére, de ezek inkább a Mezőség sokkal rosszabb állapotú területei felé irányultak. ${ }^{55}$ Bár sem a terveket, sem a megvalósult eredményeket nem ismerjük pontosan, mégis feltételezhetjük, hogy addig soha nem látott mértékủ táji lépékủ beruházást jelentett ez a kalotaszegi föld megmentéséért.

52 Rázsó, 1944. p. 6, Rázsó Imre tanulmánya mellett Imre József (Talajmozgások és típusaik az Erdélyi medencében) és Kund Ede munkái érintik az erdélyi talajmozgások típusait és a talajvédelem kérdését, de kevés releváns adattal Kalotaszegre vonatkozólag.

${ }^{53}$ Az EMGE anyagi évek óta „,inventar” (=rendezés) alatt vannak a Kolozs megyei levéltárban és azok többszöri felkérésre sem kutathatóak.

${ }^{54}$ Solty, 1944. p. 126

${ }^{55}$ Az Erdélyi Gazda lapszámai beszámolnak a talajvédelmi feladatokról és sáncolási munkákról, de a sem fényképek nincsenek azonosítva, sem helyszíneket nem említ. Valószínü azonban, hogy csak kisebb uradalmi mintaterületeken használták a sáncoló-gépeket, és talán a „hagyományosan” kiteraszolt Kalotaszegei tájon nem volt elsődlegesen fontos e feladat. Az EMGE archívum rendezése után e témakör pontosításra kerülhet majd. 


\section{0. §. Eróziós jelenségek a néprajzi felvételeken}

1-2.: Edvi Illés Aladár „ikonná vált” akvarelljei az erodált mészkősziklán álló Körösfői templomról, 3-5.: Erodált körösfơii mészszirtek (Néprajzi Múzeum, Erdődi Mihály, 1941, D386, D371, D372), 6-7.: Szénagyüjtés a Mérai határban (Néprajzi Múzeum, Erdődi Mihály, 1941, D277, F105609)
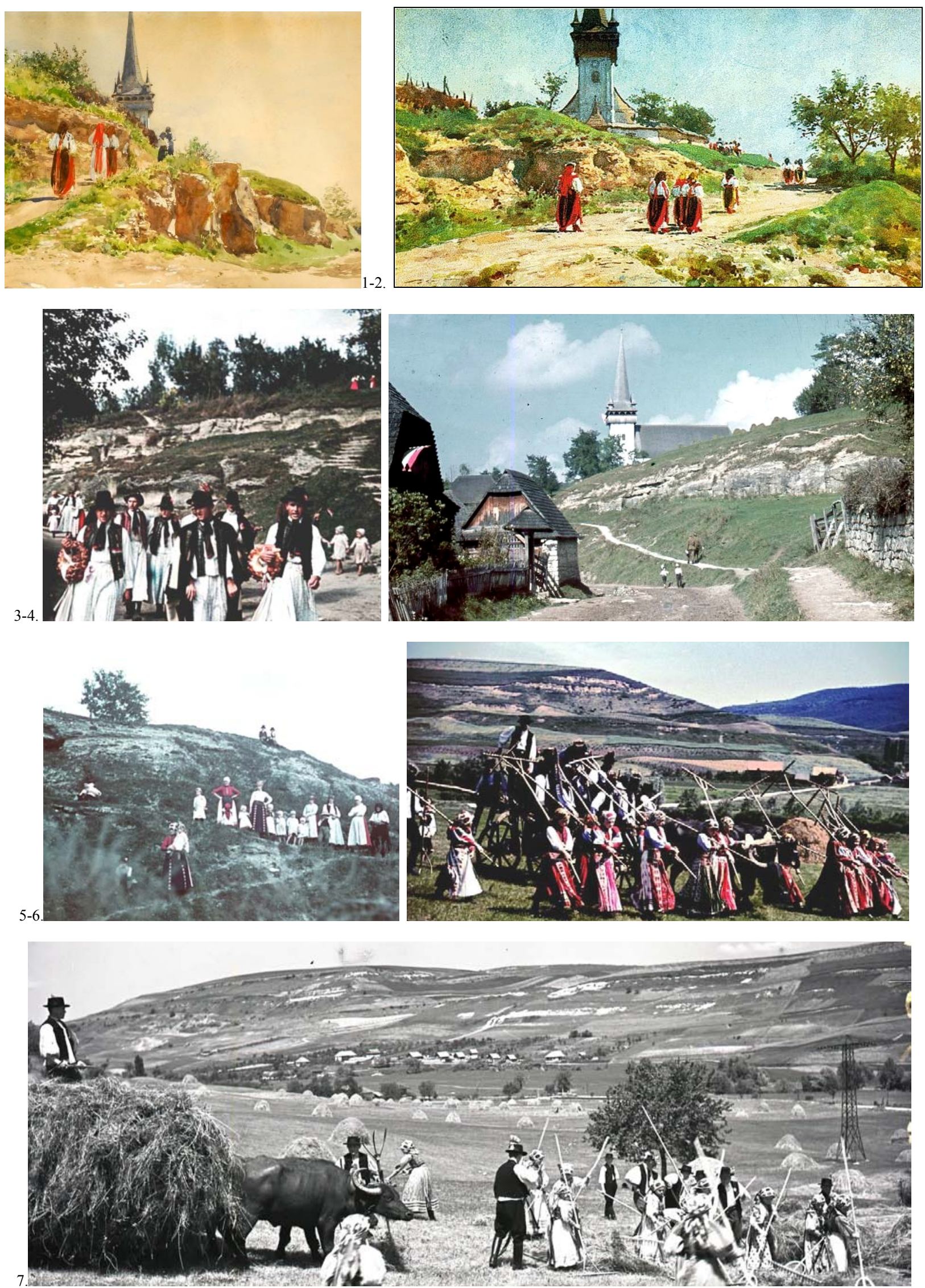
41. §. A mezőgazdasági statisztikák területi és jövedelmi áttekintő diagramjai a tájkarakter-zónánként

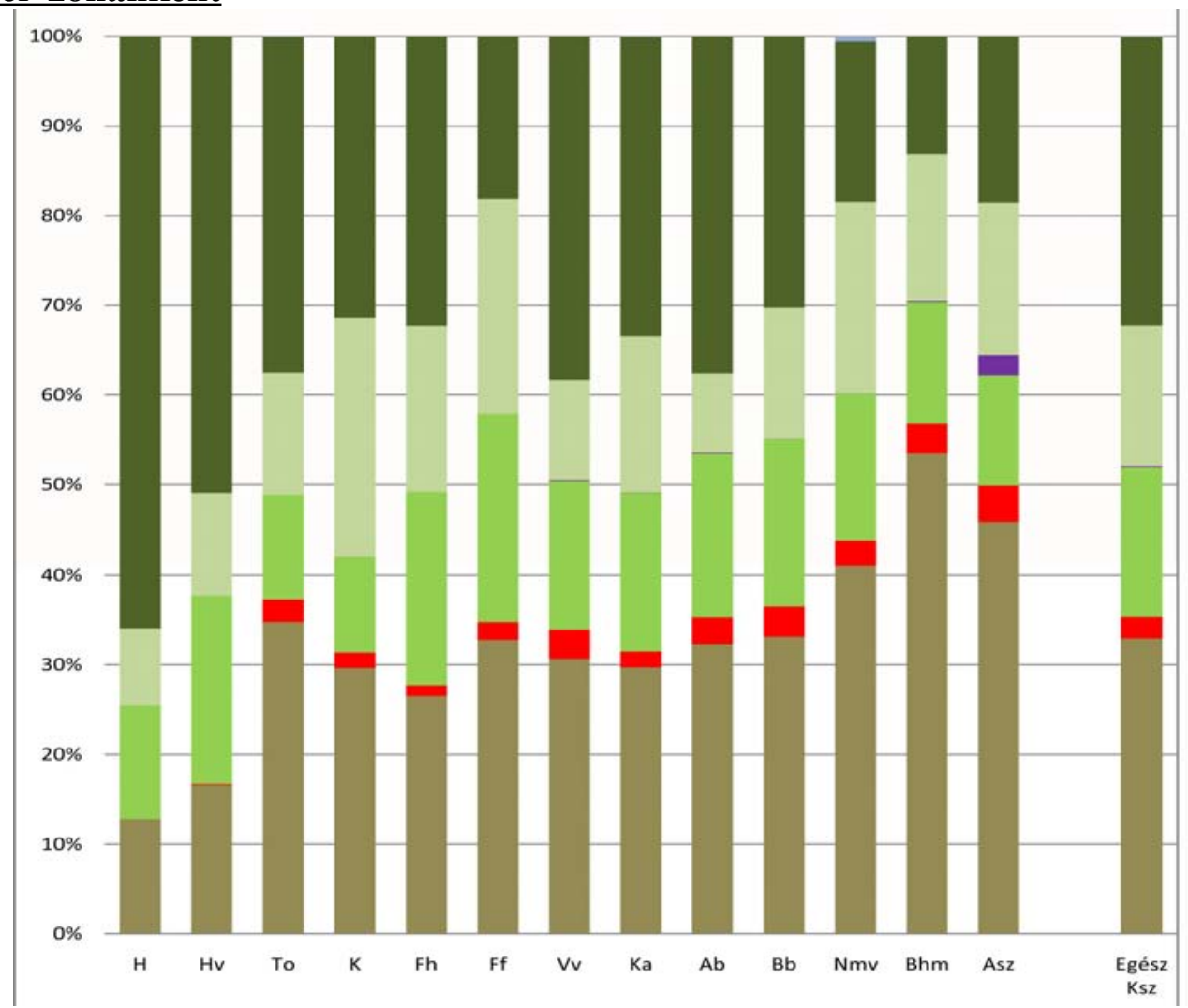

A tájkarakter-zónák százalékos területhasználati megoszlása, minden falut egy adatként (egyformának) tekintve

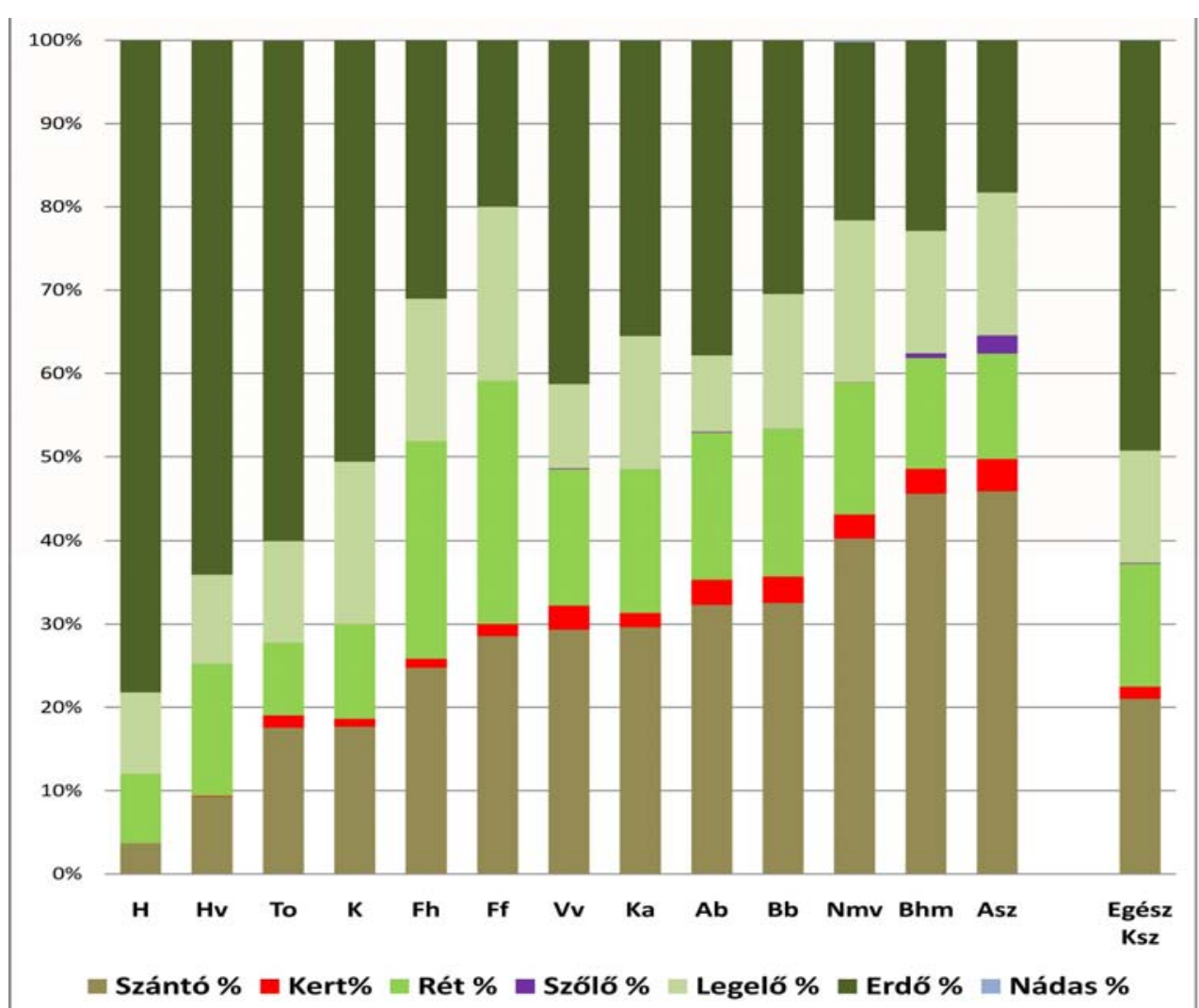

A tájkarakter-zónák százalékos területhasználati megoszlása, minden falut területi kiterjedésével súlyozva 


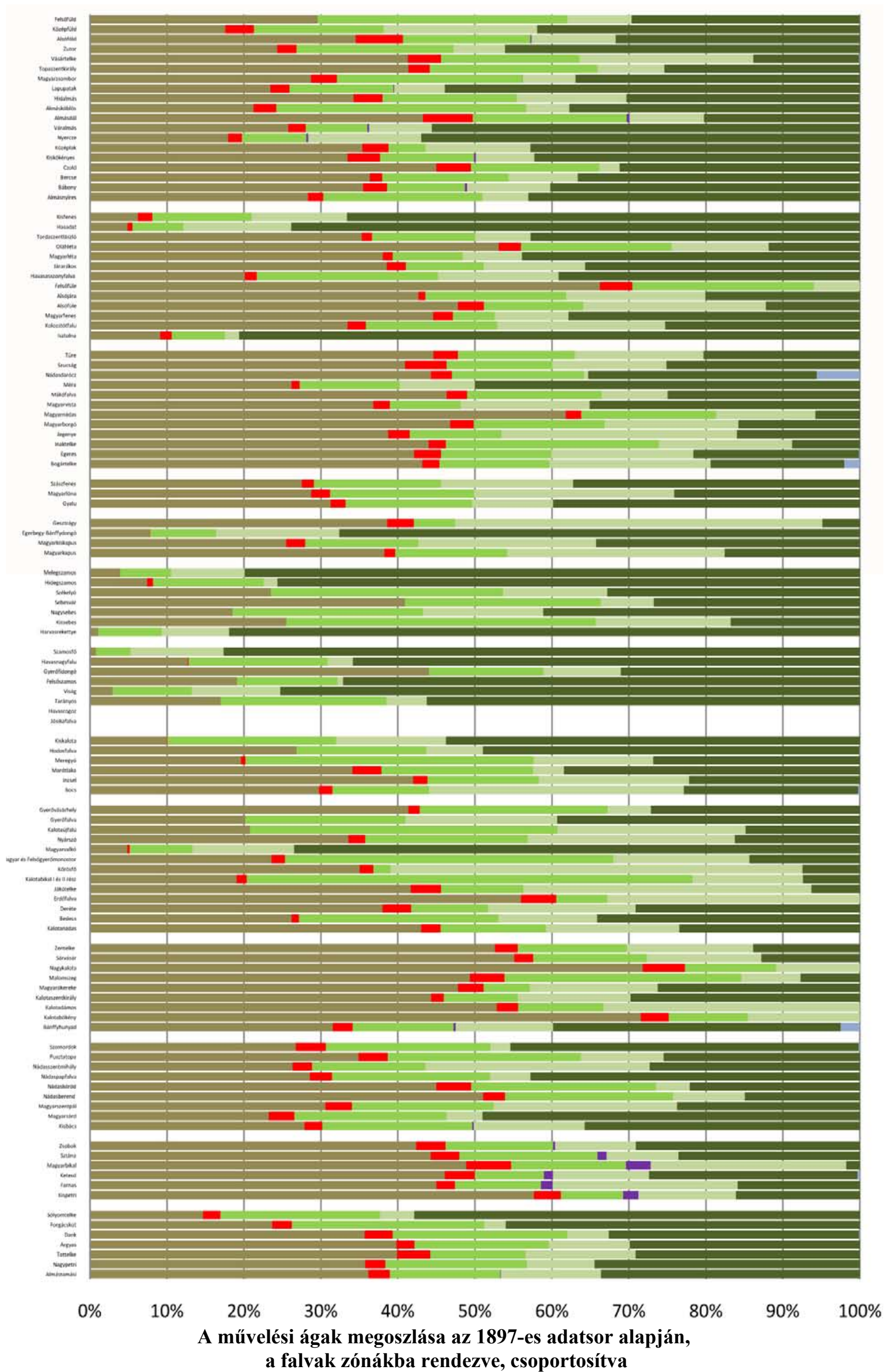




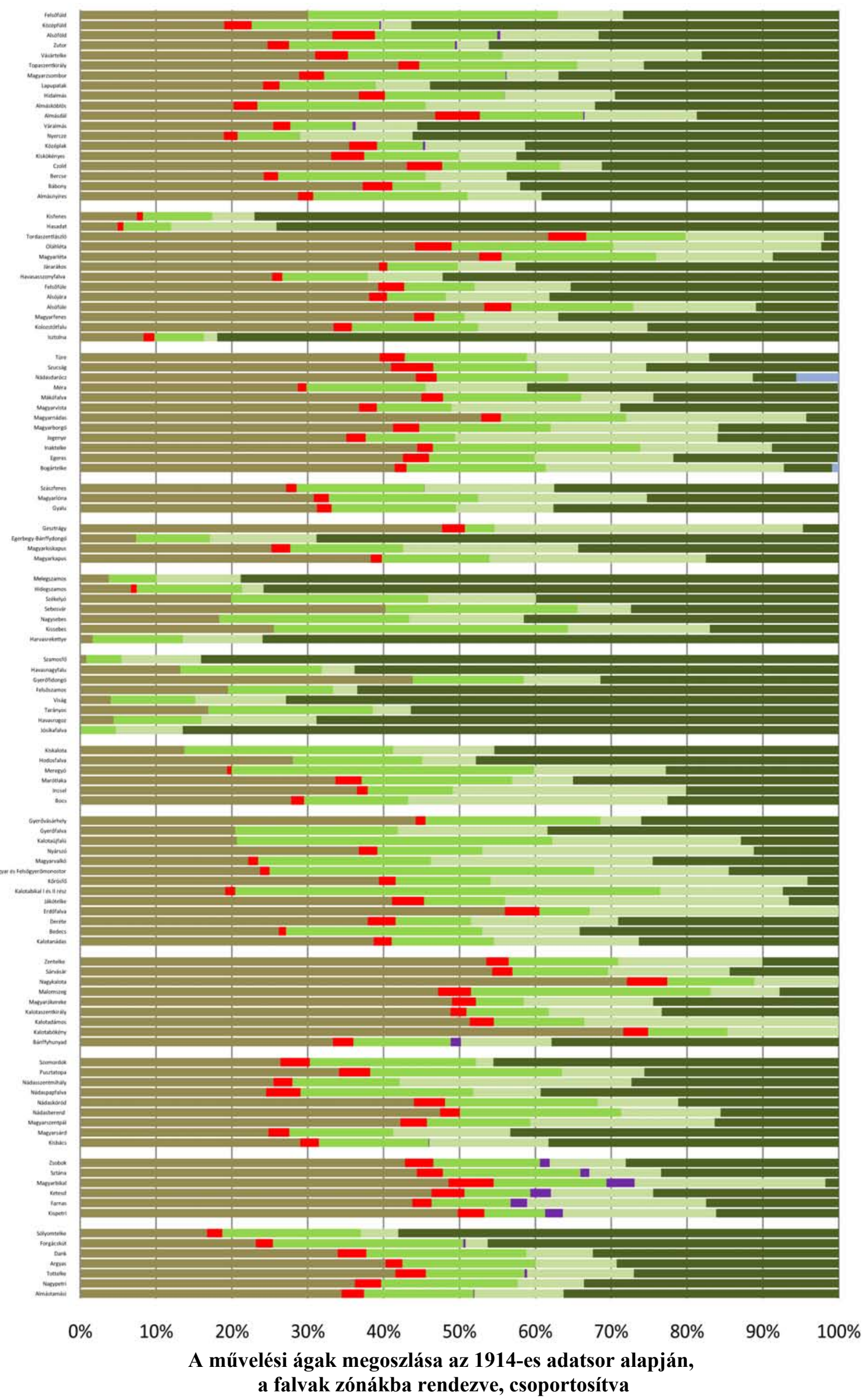




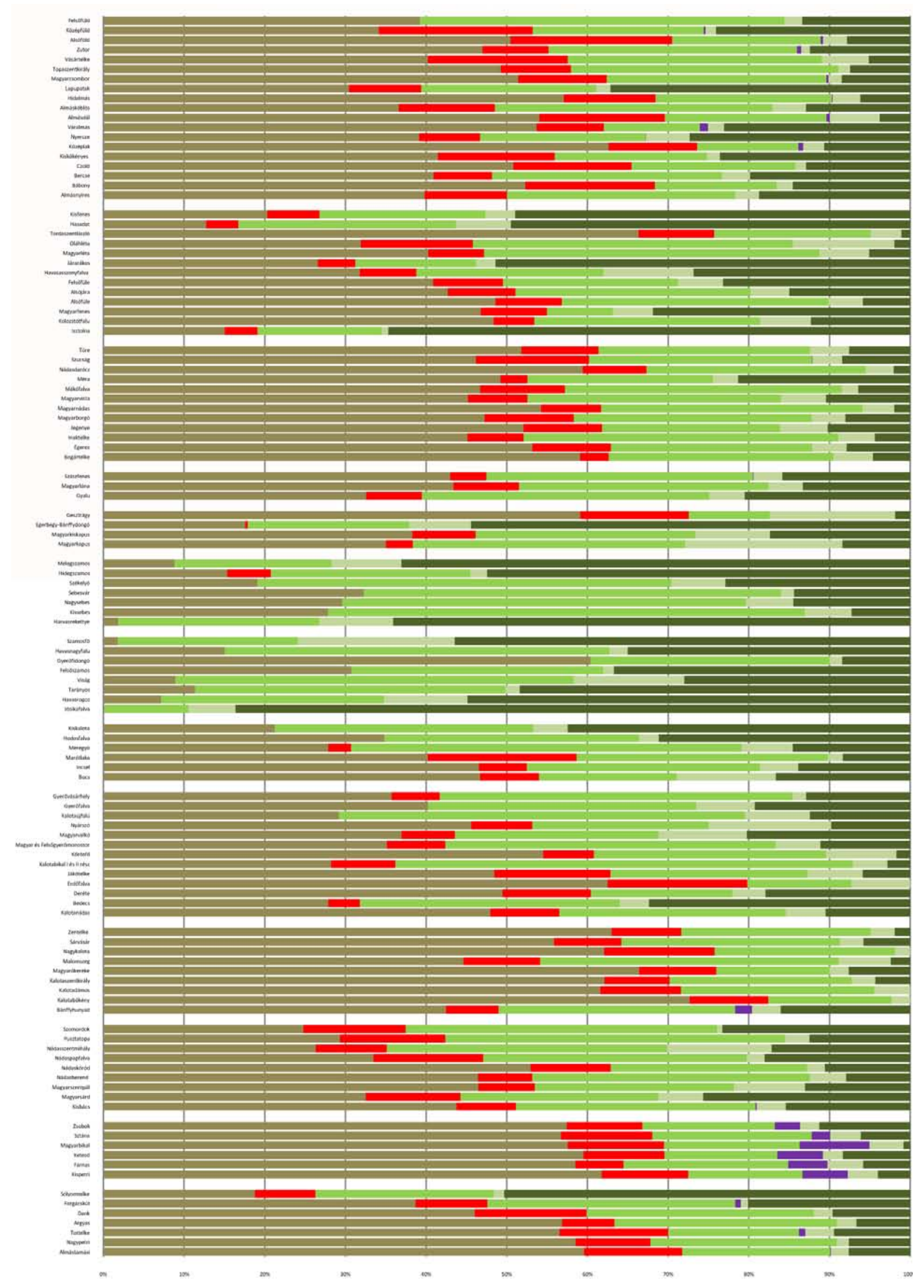

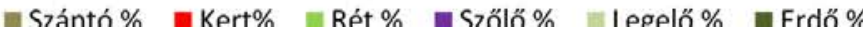

A múvelési ágakból származó jövedelem, százalékos megoszlása az 1914-es adatsor alapján, a falvak zónákba rendezve, csoportosítva 


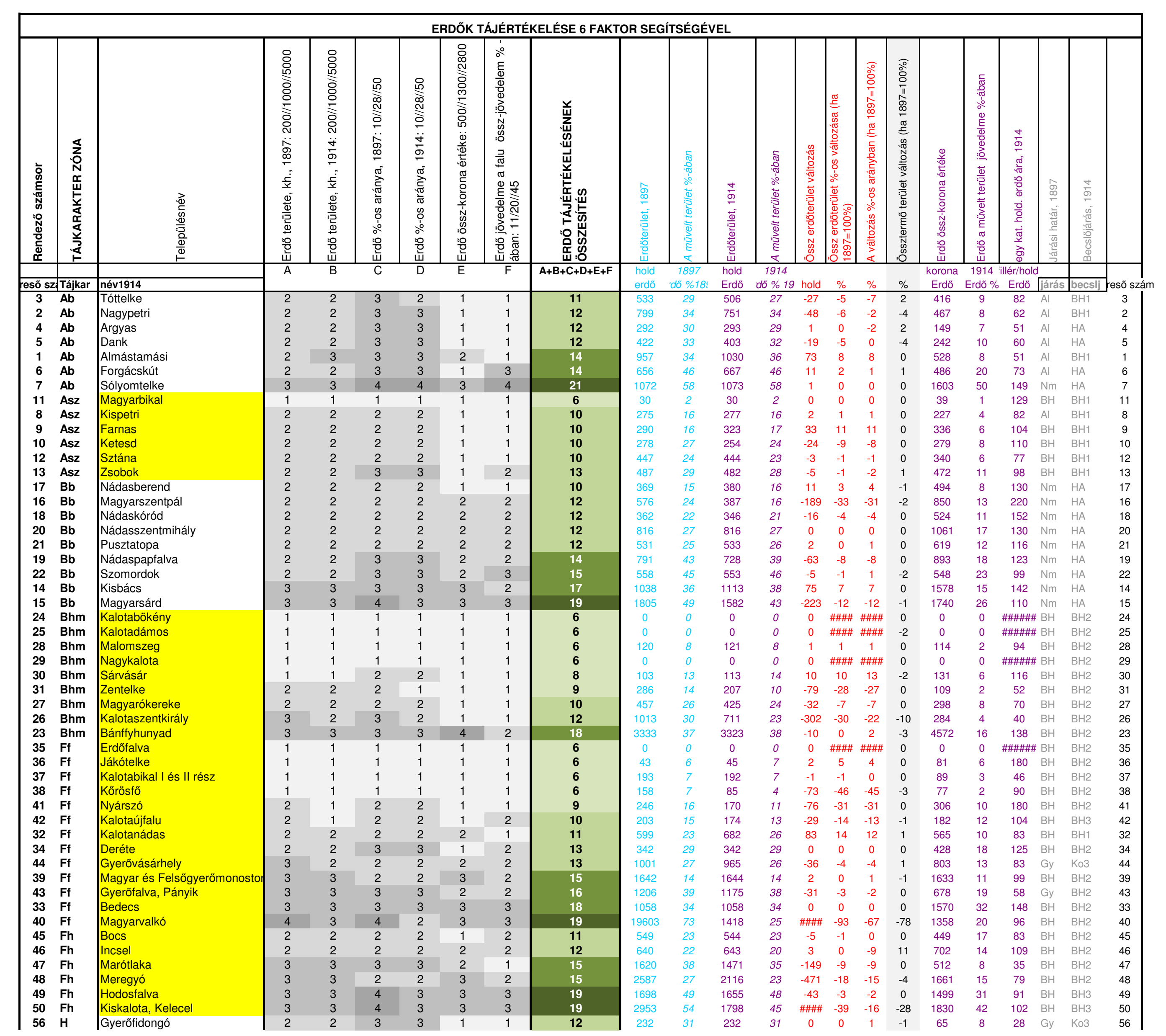




\begin{tabular}{|c|c|c|c|c|c|c|c|c|c|c|c|c|c|c|c|c|c|c|c|c|c|c|c|}
\hline 55 & H & |Felsőszamos & 2 & 2 & 4 & 4 & 1 & 3 & 16 & 674 & 67 & 638 & 63 & -36 & -5 & -5 & 0 & 319 & 37 & 50 & Gy & Ко3 & 55 \\
\hline 53 & $\mathrm{H}$ & Tarányos & 3 & 3 & 4 & 4 & 3 & 4 & 21 & 2590 & 56 & 2597 & 56 & 7 & 0 & 0 & 0 & 2176 & 48 & 84 & $\mathrm{BH}$ & $\mathrm{BH}_{3}$ & 53 \\
\hline 54 & $\mathrm{H}$ & |Viság & 4 & 4 & 4 & 4 & 3 & 3 & 22 & 10935 & 75 & 10127 & 73 & -808 & -7 & -3 & -4 & 1372 & 28 & 14 & $\mathrm{BH}$ & $\mathrm{BH}_{3}$ & 54 \\
\hline 57 & $\mathrm{H}$ & Havasnagyfalu & 4 & 4 & 4 & 4 & 4 & 3 & 23 & 8575 & 66 & 8187 & 64 & -388 & -5 & -3 & -1 & 4101 & 35 & 50 & Gy & Ко3 & 57 \\
\hline 51 & H & |Jósikafalva & 4 & 4 & 4 & 4 & 4 & 4 & 24 & & \#\#\#\# & 24729 & 86 & & \#\#\# & \#\#\# & \#\#\#\# & 12995 & 84 & 53 & $\mathrm{BH}$ & BH2 & 51 \\
\hline 52 & H & Havasrogoz & 4 & 4 & 4 & 4 & 4 & 4 & 24 & 8208 & 71 & 7502 & 69 & -706 & -9 & -3 & -6 & 2886 & 55 & 38 & $\mathrm{BH}$ & Вн3 & 52 \\
\hline 58 & H & Szamosfö & 4 & 4 & 4 & 4 & 4 & 4 & 24 & 38418 & 83 & 39060 & 84 & 642 & 2 & 2 & 0 & 9946 & 56 & 25 & Gy & Коз & 58 \\
\hline 60 & Hv & Kissebes & 2 & 2 & 2 & 2 & 1 & 1 & 10 & 296 & 17 & 299 & 17 & 3 & 1 & 1 & 0 & 175 & 7 & 58 & $\mathrm{BH}$ & Вн3 & 60 \\
\hline 62 & $\mathrm{Hv}$ & Sebesvár & 2 & 2 & 2 & 2 & 1 & 2 & 11 & 556 & 27 & 555 & 27 & -1 & 0 & 2 & -2 & 440 & 14 & 79 & $\mathrm{BH}$ & $\mathrm{BH} 3$ & 62 \\
\hline 61 & Hv & Nagysebes & 3 & 3 & 3 & 3 & 2 & 2 & 16 & 2248 & 41 & 2234 & 42 & -14 & -1 & 1 & -2 & 910 & 14 & 41 & $\mathrm{BH}$ & $\mathrm{BH} 3$ & 61 \\
\hline 63 & $\mathrm{Hv}$ & |Székelyó & 3 & 3 & 3 & 3 & 2 & 3 & 17 & 1234 & 33 & 1528 & 40 & 294 & 24 & 22 & 2 & 867 & 23 & 57 & $\mathrm{BH}$ & $\mathrm{BH} 3$ & 63 \\
\hline 64 & $\mathrm{Hv}$ & Hidegszamos & 3 & 3 & 4 & 4 & 4 & 4 & 22 & 4331 & 76 & 4331 & 76 & 0 & 0 & 0 & 0 & 3071 & 52 & 71 & Gy & Ко3 & 64 \\
\hline 59 & Hv & Harvasrekettye & 4 & 4 & 4 & 4 & 4 & 4 & 24 & 19584 & 82 & 12334 & 76 & \#\#\# & -37 & -7 & -32 & 5732 & 64 & 46 & $\mathrm{BH}$ & $\mathrm{BH} 3$ & 59 \\
\hline 65 & $\mathrm{Hv}$ & Melegszamos & 4 & 4 & 4 & 4 & 4 & 4 & 24 & 6069 & 80 & 5955 & 79 & -114 & -2 & -1 & -1 & 3848 & 63 & 65 & Gy & Ко3 & 65 \\
\hline 69 & k & Gesztrágy & 1 & 1 & 1 & 1 & 1 & 1 & 6 & 31 & 5 & 30 & 5 & -1 & -3 & -3 & 0 & 21 & 2 & 70 & Gy & Ко3 & 69 \\
\hline 66 & $\mathrm{~K}$ & Magyarkapus, Nagykapus & 2 & 2 & 2 & 2 & 2 & 1 & 11 & 399 & 18 & 398 & 18 & -1 & 0 & 0 & 0 & 805 & 8 & 202 & Gy & Ko1 & 66 \\
\hline 67 & $\mathrm{~K}$ & Magyarkiskapus & 3 & 3 & 3 & 3 & 3 & 2 & 17 & 1329 & 34 & 1327 & 34 & -2 & 0 & 0 & 0 & 1362 & 17 & 103 & Gy & Ko1 & 67 \\
\hline 68 & K & Egerbegy+Bánffydongó & 4 & 4 & 4 & 4 & 4 & 4 & 24 & 6220 & 68 & 6315 & 69 & 95 & 2 & 2 & 0 & 4434 & 54 & 70 & Gy & Ко3 & 68 \\
\hline 71 & Ka & Magyarlóna & 2 & 2 & 2 & 2 & 3 & 2 & 13 & 803 & 24 & 805 & 25 & 2 & 0 & 5 & -4 & 1651 & 13 & 205 & Gy & Ko1 & 71 \\
\hline 72 & Ka & Szászfenes & 3 & 3 & 3 & 3 & 4 & 2 & 18 & 2637 & 37 & 2651 & 37 & 14 & 1 & 1 & 0 & 4148 & 16 & 156 & Gy & Ko1 & 72 \\
\hline 70 & $\mathrm{Ka}$ & Gyalu & 3 & 3 & 3 & 3 & 4 & 3 & 19 & 3450 & 40 & 3253 & 38 & -197 & -6 & -6 & 0 & 5608 & 21 & 172 & Gy & Ko1 & 70 \\
\hline 75 & Nmv & lnaktelke & 1 & 1 & 1 & 1 & 1 & 1 & 6 & 167 & 9 & 167 & 9 & 0 & 0 & 0 & 0 & 170 & 4 & 102 & $\mathrm{Nm}$ & HA & 75 \\
\hline 78 & $\mathrm{Nmv}$ & Magyarnádas & 1 & 1 & 1 & 1 & 1 & 1 & 6 & 99 & 6 & 73 & 4 & -26 & -26 & -26 & -1 & 95 & 2 & 130 & $\mathrm{Nm}$ & HA & 78 \\
\hline 73 & Nmv & |Bogártelke & 2 & 1 & 2 & 1 & 1 & 1 & 8 & 304 & 17 & 110 & 6 & -194 & -64 & -63 & -1 & 254 & 5 & 231 & $\mathrm{Nm}$ & HA & 73 \\
\hline 76 & Nmv & Jegenye & 1 & 1 & 2 & 2 & 1 & 1 & 8 & 188 & 16 & 187 & 16 & -1 & -1 & 0 & 0 & 227 & 10 & 121 & $\mathrm{Nm}$ & HA & 76 \\
\hline 82 & Nmv & |Nádasdarócz & 2 & 1 & 3 & 1 & 1 & 1 & $\stackrel{9}{10}$ & 218 & 30 & 42 & ${ }_{24}^{6}$ & -176 & -81 & -81 & 0 & 38 & 2 & 90 & $\mathrm{Nm}$ & HA & 82 \\
\hline 80 & Nmv & |Mákófalva & 2 & 2 & 2 & 2 & 1 & 1 & 10 & 822 & $\begin{array}{l}25 \\
21\end{array}$ & 800 & 24 & -22 & -3 & -2 & -1 & 477 & 6 & 60 & $\mathrm{Nm}$ & ${ }^{H A}$ & 80 \\
\hline $\begin{array}{l}74 \\
77\end{array}$ & Nmv & Magyargorbó & 2 & 2 & 2 & $\begin{array}{l}2 \\
2\end{array}$ & $\begin{array}{l}2 \\
2\end{array}$ & $\begin{array}{l}1 \\
1\end{array}$ & $\begin{array}{l}11 \\
11\end{array}$ & $\begin{array}{l}820 \\
390\end{array}$ & $\begin{array}{l}21 \\
16\end{array}$ & $\begin{array}{l}825 \\
390\end{array}$ & $\begin{array}{l}22 \\
16\end{array}$ & $\begin{array}{l}5 \\
0\end{array}$ & $\begin{array}{l}1 \\
0\end{array}$ & $\begin{array}{l}1 \\
1\end{array}$ & $\begin{array}{c}0 \\
-1\end{array}$ & $\begin{array}{l}898 \\
507\end{array}$ & $\begin{array}{l}8 \\
8\end{array}$ & $\begin{array}{l}\begin{array}{l}109 \\
130\end{array}\end{array}$ & $\begin{array}{l}\mathrm{Nm} \\
\mathrm{Nm}\end{array}$ & $\begin{array}{l}\text { HA } \\
\text { HA }\end{array}$ & $\begin{array}{l}74 \\
77\end{array}$ \\
\hline 83 & Nmv & |Szucság & 2 & 2 & 2 & 2 & 2 & 1 & 11 & 842 & 25 & 852 & 25 & 10 & 1 & 1 & 0 & 673 & 8 & 79 & $\mathrm{Nm}$ & HA & 83 \\
\hline 84 & Nmv & Türe & 2 & 2 & 2 & 2 & 2 & 1 & 11 & 570 & 20 & 477 & 17 & -93 & -16 & -16 & 0 & 544 & 8 & 114 & $\mathrm{Nm}$ & HA & 84 \\
\hline 79 & Nmv & Magyarvista & 3 & 3 & 3 & 3 & 2 & 1 & 15 & 1276 & 35 & 1036 & 29 & -240 & -19 & -18 & -1 & 837 & 10 & 81 & $\mathrm{Nm}$ & HA & 79 \\
\hline 81 & Nmv & Méra & 3 & 3 & 4 & 3 & 3 & 3 & 19 & 1860 & 50 & 1504 & 41 & -356 & -19 & -18 & -1 & 2087 & 21 & 139 & $\mathrm{Nm}$ & HA & 81 \\
\hline 94 & To & Oláhléta & 1 & 1 & 2 & 1 & 1 & 1 & 7 & 175 & 12 & 30 & 2 & -145 & -83 & -81 & -11 & 47 & 2 & 157 & To & To 1 & 94 \\
\hline 88 & To & |Alsófüle & 2 & 1 & 2 & 1 & 1 & 1 & 8 & 208 & 12 & 180 & 11 & -28 & -13 & -11 & -2 & 269 & 6 & 149 & To & To 1 & 88 \\
\hline 93 & To & |Magyarléta & 2 & 1 & 3 & 1 & 1 & 1 & 9 & 652 & 44 & 129 & 9 & -523 & -80 & -80 & 0 & 175 & 5 & 136 & To & To 1 & 93 \\
\hline 95 & To & |Tordaszentlászló & 3 & 1 & 3 & 1 & 1 & 1 & 10 & 1657 & 43 & 20 & 2 & \#\#\# & -99 & -95 & -74 & 32 & 1 & 160 & To & To 1 & 95 \\
\hline 86 & To & |Kolozstóttalu & 2 & 2 & 2 & 2 & 2 & 2 & 12 & 359 & 25 & 359 & 25 & 0 & 0 & 0 & 0 & 630 & 12 & 175 & Gy & Ko1 & 86 \\
\hline 90 & To & Felsőfüle & 1 & 2 & 1 & 3 & 2 & 3 & 12 & 0 & 0 & 568 & 35 & 568 & \#\#\# & \#\#\#\# & 57 & 853 & 23 & 150 & To & To 1 & 90 \\
\hline 89 & To & Alsójára & 3 & 2 & 2 & 3 & 1 & 2 & 13 & 1023 & 20 & 775 & 38 & -248 & -24 & 90 & -60 & 462 & 15 & 60 & To & To 1 & 89 \\
\hline 87 & To & Magyarfenes & 2 & 2 & 3 & 3 & 3 & 3 & 16 & 853 & 38 & 828 & 37 & -25 & -3 & -2 & -1 & 2068 & 32 & 250 & Gy & Ko1 & 87 \\
\hline 92 & To & |Járarákos & 2 & 2 & 3 & 3 & 2 & 4 & 16 & 568 & 36 & 629 & 43 & 61 & 11 & 19 & -7 & 951 & 51 & 151 & To & To 1 & 92 \\
\hline 91 & To & Havasasszonyfalva & 3 & 3 & 3 & 4 & 2 & 3 & 18 & 1553 & 39 & 1187 & 52 & -366 & -24 & 33 & -43 & 712 & 27 & 60 & & To 1 & 91 \\
\hline 85 & To & | Isztolna & 3 & 3 & 4 & 4 & 4 & 4 & 22 & 1685 & 81 & 1686 & 82 & 1 & 0 & 2 & -2 & 3236 & 65 & 192 & & Ko1 & 85 \\
\hline 96 & To & Hasadat & 4 & 4 & 4 & 4 & 4 & 4 & 24 & 16766 & 74 & 16801 & 74 & 35 & 0 & 0 & 0 & 5828 & 49 & 35 & To & To 2 & 96 \\
\hline 97 & To & Kisfenes & 4 & 4 & 4 & 4 & 4 & 4 & 24 & 6278 & 67 & 7184 & 77 & 906 & 14 & 16 & -1 & 3428 & 49 & 48 & To & To 2 & 97 \\
\hline 112 & vv & |Vásárte & 1 & 2 & 2 & 2 & 1 & 1 & 9 & 172 & 14 & 223 & 18 & 51 & 30 & 31 & -1 & 117 & 5 & 53 & $\mathrm{Al}$ & AA & 112 \\
\hline 106 & vv & Almásdál & 2 & 2 & 2 & 2 & 1 & 1 & 10 & 406 & 20 & 367 & 19 & -39 & -10 & -8 & -2 & 219 & 4 & 60 & $\mathrm{Al}$ & AA & 106 \\
\hline 114 & $\mathrm{vv}$ & Alsófüld & 2 & 2 & 3 & 3 & 1 & 1 & 12 & 617 & 32 & 616 & 32 & -1 & 0 & 0 & 0 & 431 & 8 & 70 & BH & $\mathrm{BH} 1$ & 114 \\
\hline 111 & $\mathrm{vv}$ & Topaszentkirály & 3 & 3 & 2 & 2 & 2 & 1 & 13 & 1034 & 25 & 1030 & 26 & -4 & 0 & 1 & -2 & 797 & 7 & 77 & $\mathrm{Al}$ & A & 111 \\
\hline 99 & $\mathrm{vv}$ & Bábony & 2 & 2 & 3 & 3 & 1 & 2 & 13 & 544 & 40 & 550 & 42 & 6 & 1 & 4 & -3 & 499 & 15 & 91 & $\mathrm{Al}$ & BH1 & 99 \\
\hline 101 & $\mathrm{vv}$ & Czold & 2 & 2 & 3 & 3 & 2 & 2 & 14 & 585 & 31 & 585 & 31 & 0 & 0 & 0 & 0 & 584 & 13 & 100 & Al & BH1 & 101 \\
\hline 107 & $\mathrm{vv}$ & Almásköblös & 2 & 2 & 3 & 3 & 2 & 2 & 14 & 801 & 38 & 675 & 32 & -126 & -16 & -15 & -1 & 517 & 13 & 77 & Al & HA & 107 \\
\hline 116 & $\mathrm{vv}$ & Felsöfüld & 2 & 2 & 3 & 3 & 2 & 2 & 14 & 814 & 30 & 781 & 28 & -33 & -4 & -4 & 0 & 669 & 13 & 86 & $\mathrm{BH}$ & $\mathrm{BH} 3$ & 116 \\
\hline $\begin{array}{l}108 \\
110\end{array}$ & $\begin{array}{l}V_{v} \\
\text { vy }\end{array}$ & \begin{tabular}{|l} 
Hidalmás \\
Magyarzsombor
\end{tabular} & $\begin{array}{l}3 \\
3\end{array}$ & $\begin{array}{l}3 \\
3\end{array}$ & $\begin{array}{l}3 \\
3 \\
3\end{array}$ & $\begin{array}{l}3 \\
3\end{array}$ & $\begin{array}{l}2 \\
2\end{array}$ & 1 & $\begin{array}{l}15 \\
15\end{array}$ & $\begin{array}{l}1146 \\
1458\end{array}$ & $\begin{array}{l}30 \\
37\end{array}$ & $\begin{array}{l}1109 \\
1164\end{array}$ & $\begin{array}{l}29 \\
37\end{array}$ & $\begin{array}{l}-37 \\
6\end{array}$ & $\begin{array}{c}-3 \\
0 \\
0\end{array}$ & $\begin{array}{c}-3 \\
0 \\
0\end{array}$ & $\begin{array}{r}-1 \\
0\end{array}$ & $\begin{array}{l}566 \\
902\end{array}$ & $\begin{array}{l}6 \\
8\end{array}$ & $\begin{array}{l}51 \\
62\end{array}$ & Al & $A$ & 108 \\
\hline 102 & vv & Kiskökényes & 2 & 2 & 3 & 3 & 2 & 3 & 15 & 479 & 42 & $\begin{array}{l}4704 \\
479\end{array}$ & 43 & 0 & 0 & 1 & -1 & 630 & $\begin{array}{l}8 \\
24\end{array}$ & $\begin{array}{l}62 \\
132\end{array}$ & Al & $\begin{array}{l}\text { HA } \\
\text { BH1 }\end{array}$ & $\begin{array}{l}110 \\
102\end{array}$ \\
\hline 103 & $v v$ & Középlak & 3 & 3 & 3 & 3 & 2 & 2 & 16 & 1156 & 43 & 1134 & 41 & -22 & -2 & -3 & 1 & 838 & 11 & 74 & $\mathrm{Al}$ & BH1 & 103 \\
\hline 113 & vv & Zutor & 3 & 3 & 3 & 3 & 2 & 2 & 16 & 1134 & 46 & 1139 & 46 & 5 & 0 & 0 & 0 & 797 & 12 & 70 & $\mathrm{Al}$ & HA & 113 \\
\hline 98 & vv & Almásnyíres & 3 & 3 & 3 & 3 & 3 & 2 & 17 & 2762 & 43 & 2510 & 39 & -252 & -9 & -9 & 0 & 2248 & 19 & 90 & Al & $\mathrm{BH} 1$ & 98 \\
\hline 100 & vv & Bercse & 3 & 3 & 3 & 3 & 2 & 3 & 17 & 1137 & 37 & 1140 & 44 & 3 & 0 & 19 & -16 & 904 & 20 & 79 & $\mathrm{Al}$ & 11 & 100 \\
\hline 115 & vv & Középfüld & 3 & 3 & 3 & 4 & 3 & 3 & 19 & 2003 & 42 & 2688 & 56 & 685 & 34 & 35 & 0 & 2044 & 24 & 76 & BH & $\mathrm{BH} 1$ & 115 \\
\hline 104 & vv & |Nyercze & 3 & 3 & 4 & 4 & 3 & 3 & 20 & 1940 & 57 & 1924 & 56 & -16 & -1 & -1 & 1 & 1456 & 27 & 76 & Al & $\mathrm{BH} 1$ & 104 \\
\hline 109 & Vv & |Lapupatak & 3 & 3 & 4 & 4 & 3 & 3 & 20 & 1152 & 54 & 1157 & 54 & 5 & 0 & 0 & 0 & 1559 & 7 & 135 & Al & $\mathrm{HA}$ & 109 \\
\hline 105 & $v_{v}$ & |Váralmás & 4 & 4 & 4 & 4 & 4 & 3 & 23 & 5084 & 55 & 5084 & 56 & 0 & 0 & 0 & 0 & 5257 & 23 & 103 & $\mathrm{Al}$ & $\mathrm{BH} 1$ & 105 \\
\hline
\end{tabular}




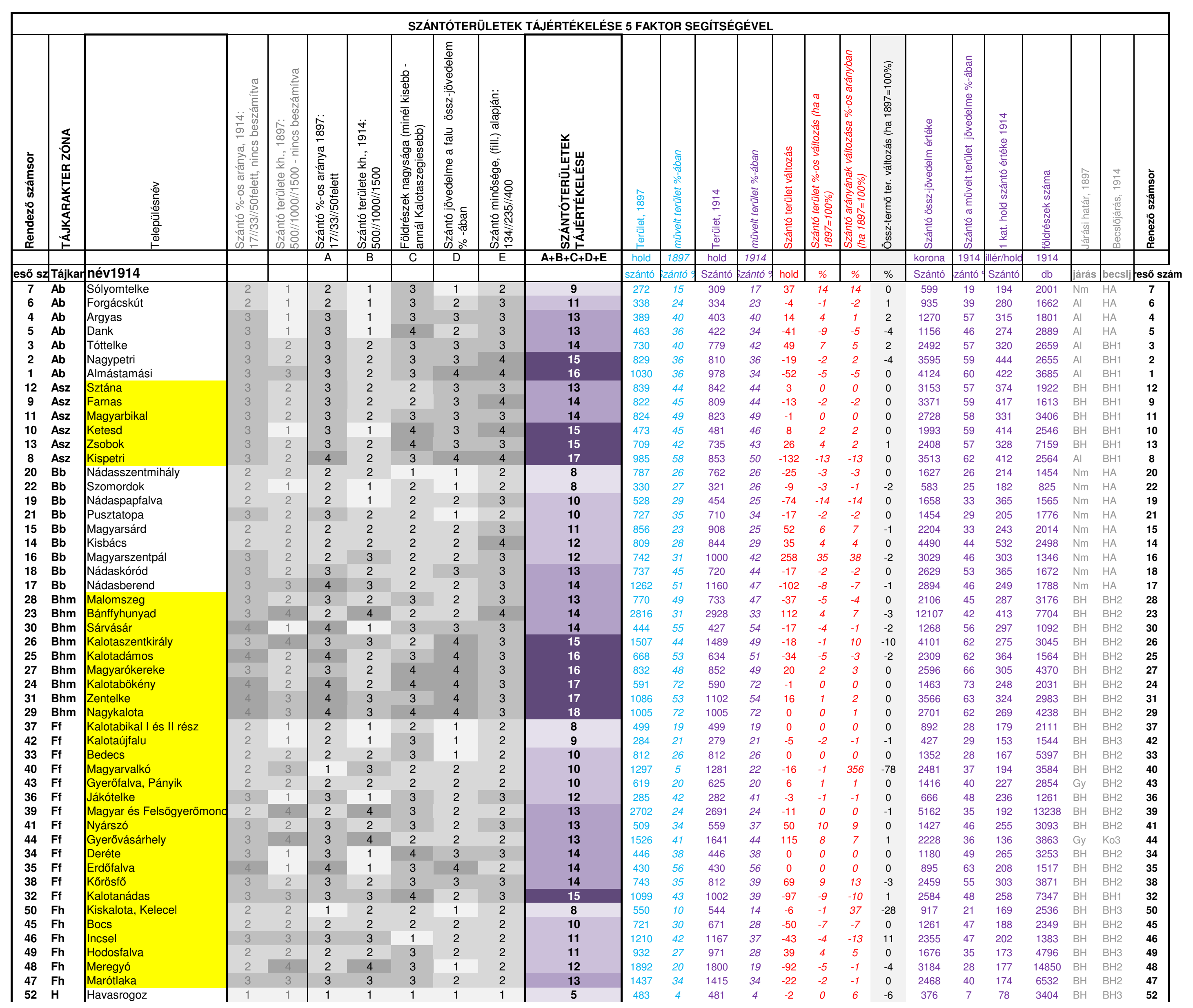




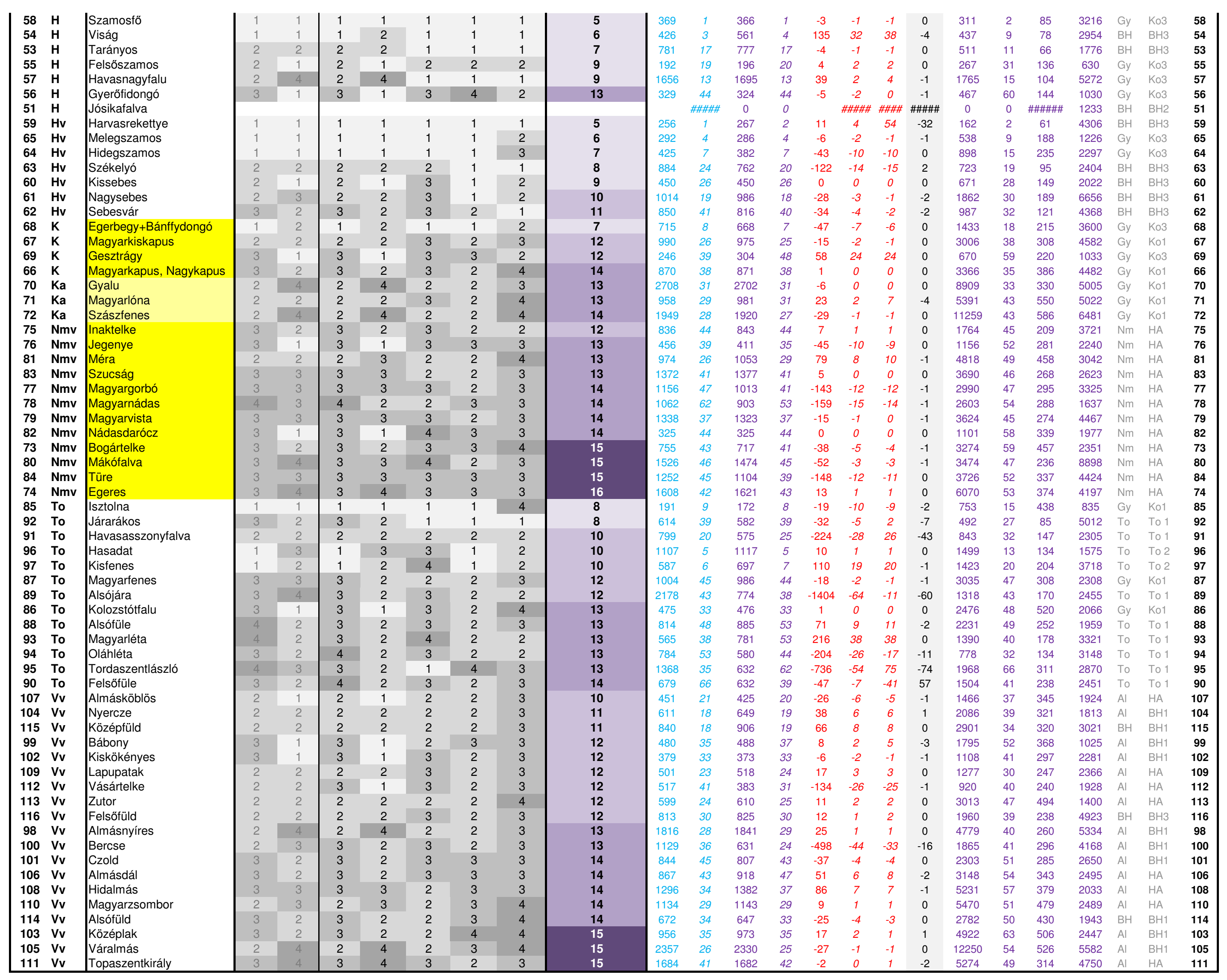




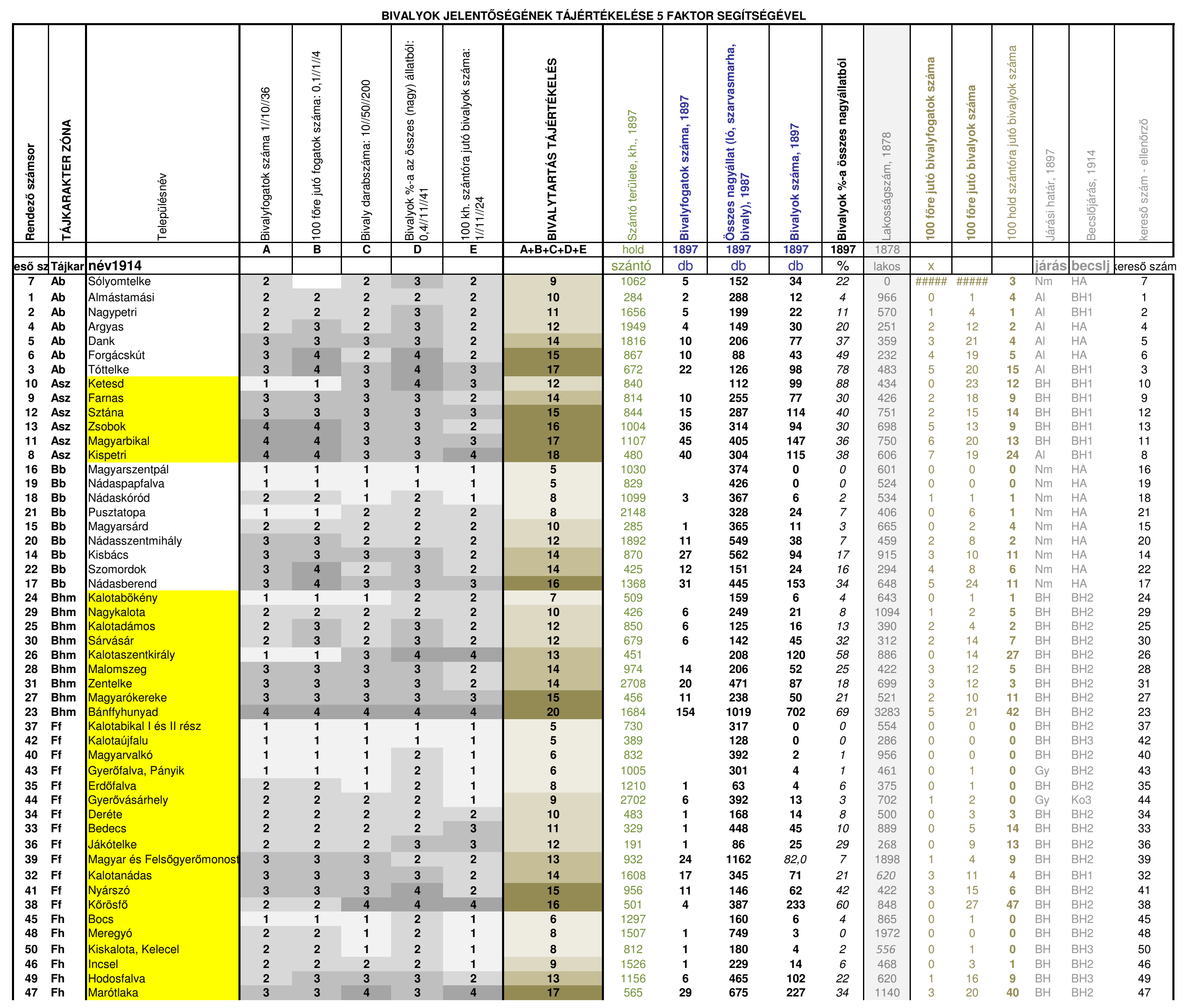




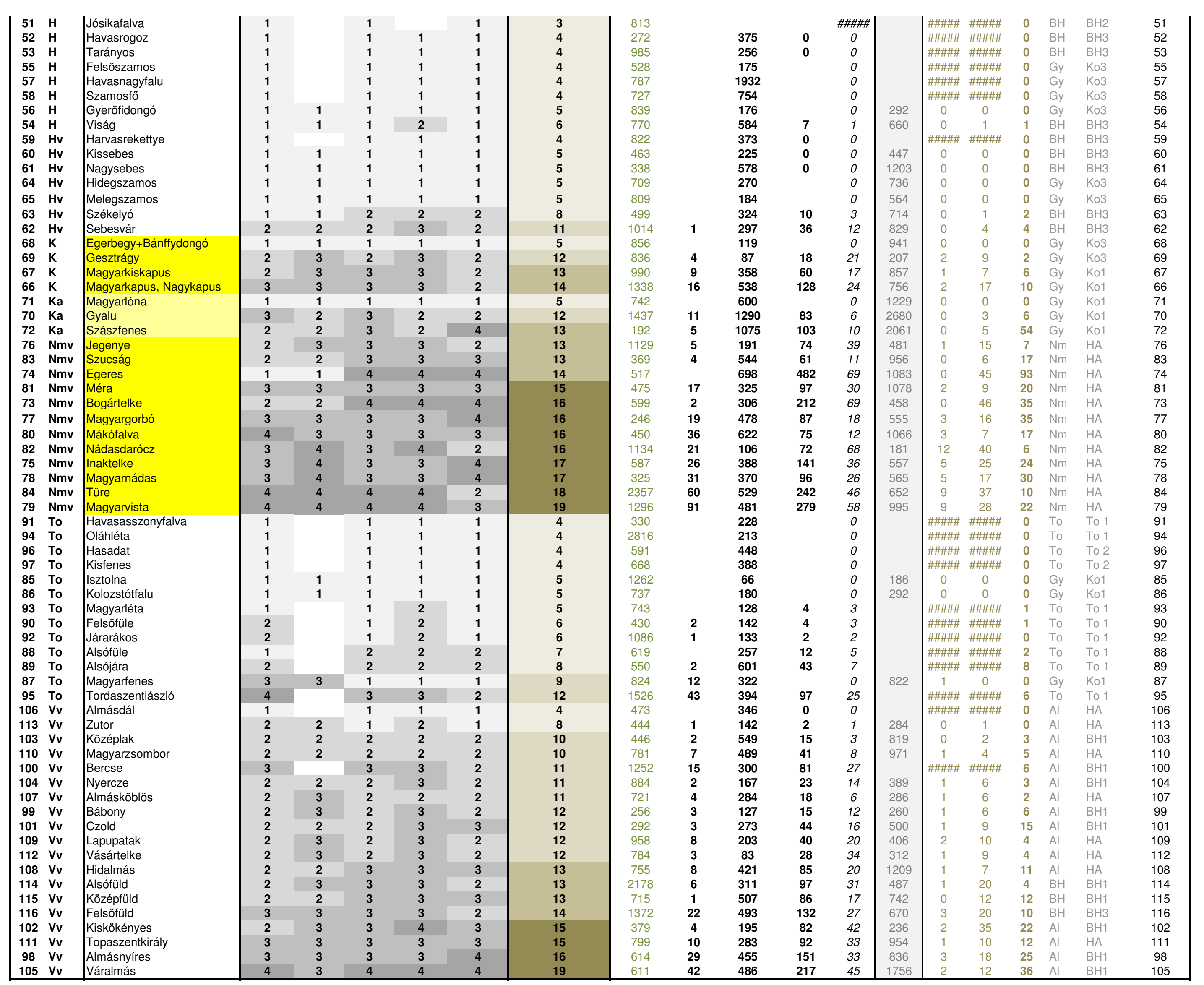


LEGELÖTERÜLETEK TÁJÉRTÉKELÉSE 7 FAKTOR SEGíTSÉGÉVEL

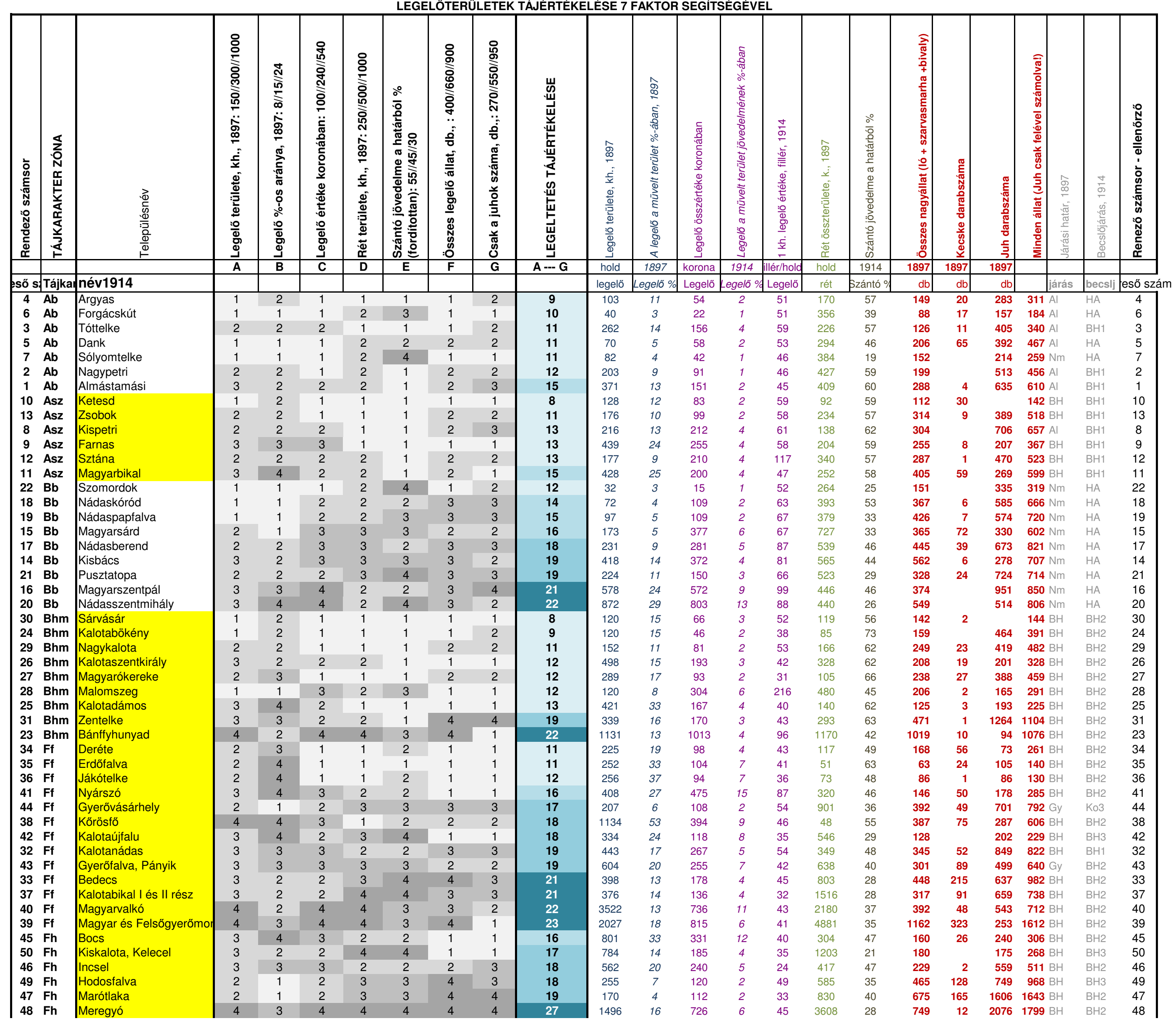




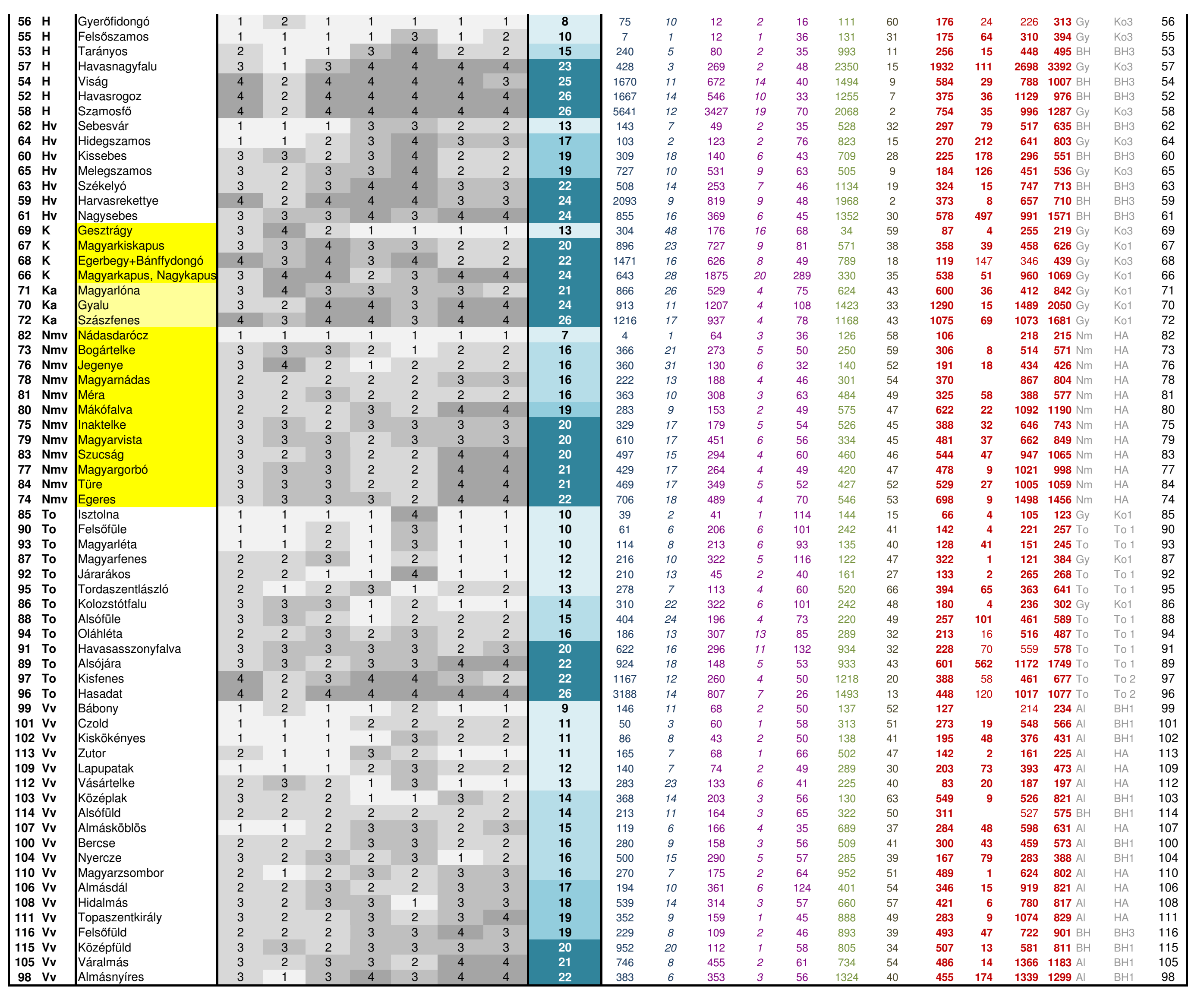




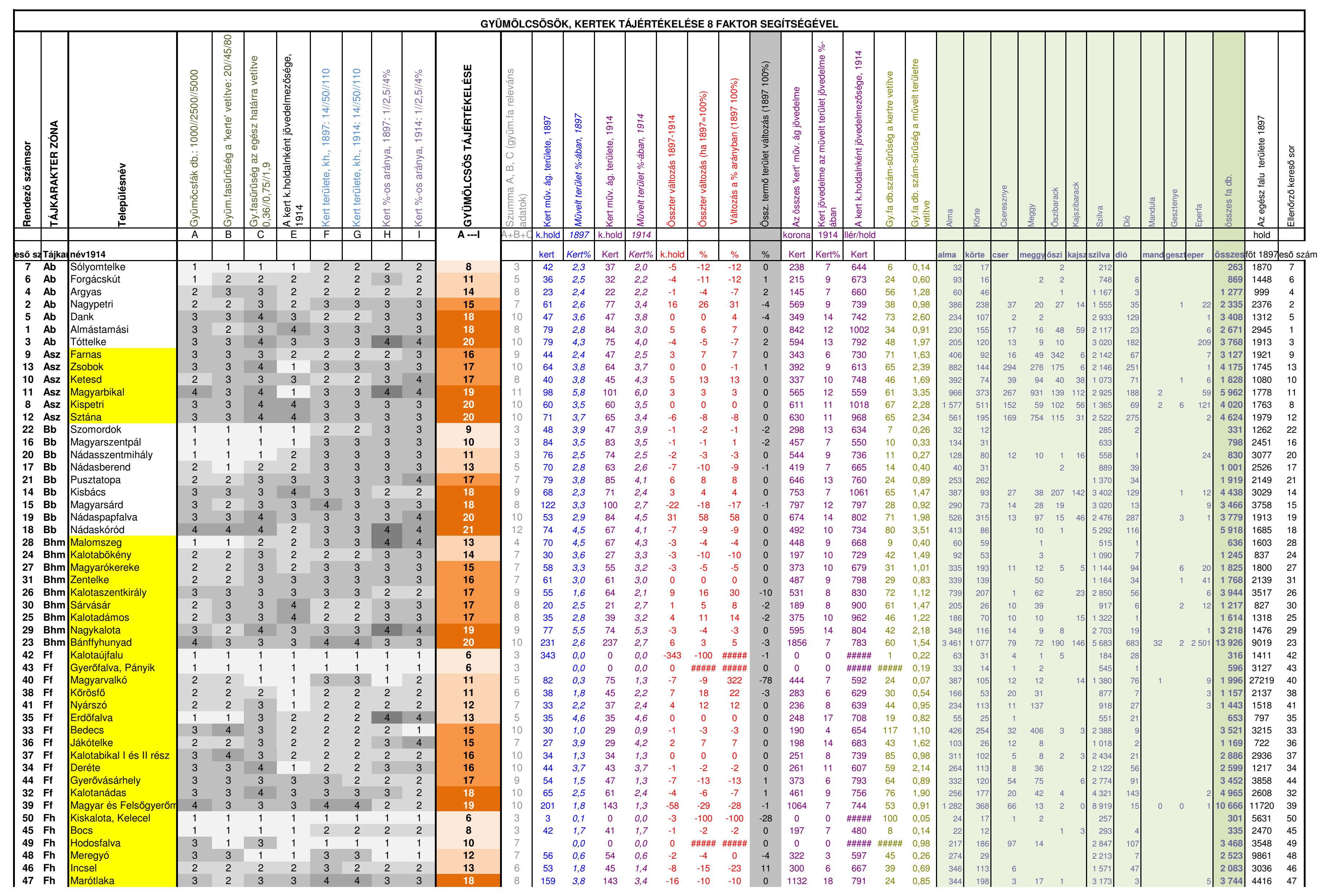




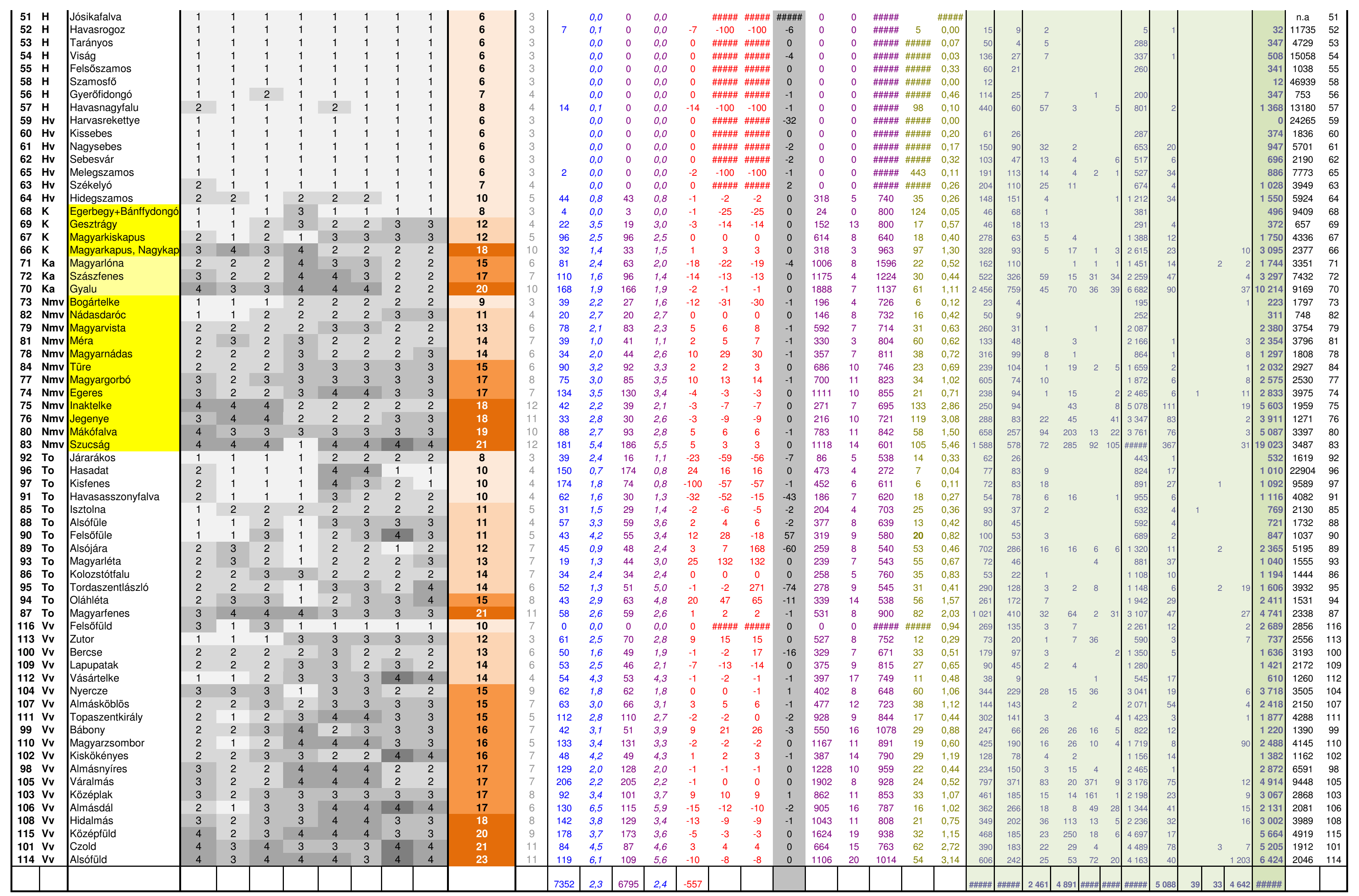




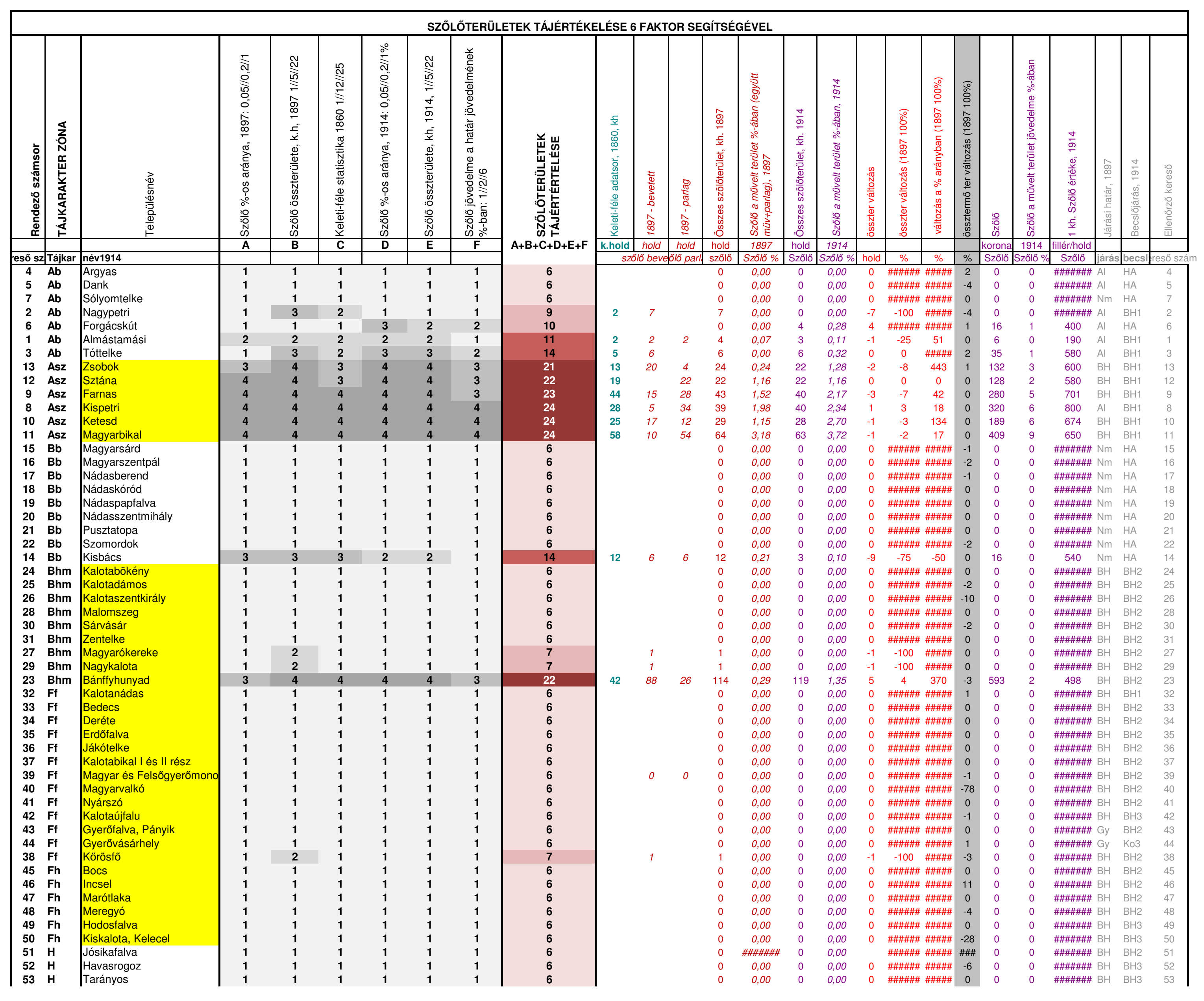




\begin{tabular}{|c|c|c|c|c|c|c|c|c|c|c|c|c|c|c|c|c|c|c|c|c|c|c|c|c|c|c|}
\hline 54 & H & |Viság & 1 & 1 & 1 & 1 & 1 & 1 & 6 & & & & 0 & 0.00 & 0 & 0.00 & 0 & \#\#\#\#\# & " \#\#\#\# & -4 & 0 & 0 & \#\#\#\#\#\# _ & $\mathrm{BH}$ & $\mathrm{BH} 3$ & 54 \\
\hline 55 & $\mathrm{H}$ & Felsốszamos & 1 & 1 & 1 & 1 & 1 & 1 & 6 & & & & 0 & 0,00 & 0 & 0,00 & 0 & \#\#\#\#\# & f \#\#\#\#\# & 0 & 0 & 0 & 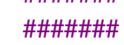 & & Ко3 & 55 \\
\hline 56 & H & Gyerơfidongó & 1 & 1 & 1 & 1 & 1 & 1 & 6 & & & & 0 & 0,00 & 0 & 0,00 & 0 & \#\#\#\#\# & f \#\#\#\#\# & -1 & 0 & 0 & \#\#\#\#\#\# & & Кo3 & 56 \\
\hline 57 & H & Havasnagyfalu & 1 & 1 & 1 & 1 & 1 & 1 & 6 & & & & 0 & 0,00 & 0 & 0,00 & 0 & \#\#\#\#\# & F \#\#\#\#\# & -1 & 0 & 0 & 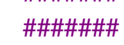 & & Ко3 & 57 \\
\hline 58 & $\mathrm{H}$ & Szamosfö & 1 & 1 & 1 & 1 & 1 & 1 & 6 & & & & 0 & 0,00 & 0 & 0,00 & 0 & \#\#\#\#\# & F \#\#\#\# & 0 & 0 & 0 & \#\#\#\#\#\# & & Ко3 & 58 \\
\hline 59 & $\mathrm{Hv}$ & Harvasrekettye & 1 & 1 & 1 & 1 & 1 & 1 & 6 & & & & 0 & 0,00 & 0 & 0,00 & 0 & \#\#\#\#\# & F \#\#\#\# & -32 & 0 & 0 & \#\#\#\#\#\# & & BH3 & 59 \\
\hline 60 & $\mathrm{Hv}$ & Kissebes & 1 & 1 & 1 & 1 & 1 & 1 & 6 & & & & 0 & 0,00 & 0 & 0,00 & 0 & 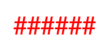 & F\#\#\#\# & 0 & 0 & 0 & \#\#\#\#\#\# & & BH3 & 60 \\
\hline 61 & Hv & Nagysebes & 1 & 1 & 1 & 1 & 1 & 1 & 6 & & & & 0 & 0,00 & 0 & 0,00 & 0 & 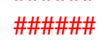 & ; \#\#\#\# & -2 & 0 & 0 & \#\#\#\#\#\# & $\mathrm{BH}$ & BH3 & 61 \\
\hline 62 & $\mathrm{Hv}$ & Sebesvár & 1 & 1 & 1 & 1 & 1 & 1 & 6 & & & & 0 & 0,00 & 0 & 0,00 & 0 & 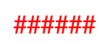 & 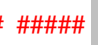 & -2 & 0 & 0 & 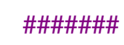 & & BH3 & 62 \\
\hline 63 & $\mathrm{Hv}$ & Székelyó & 1 & 1 & 1 & 1 & 1 & 1 & 6 & & & & 0 & 0,00 & 0 & 0,00 & 0 & 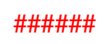 & ＃\#\#\# & 2 & 0 & 0 & \#\#\#\#\#\# & & BH3 & 63 \\
\hline 64 & $\mathrm{Hv}$ & Hidegszamos & 1 & 1 & 1 & 1 & 1 & 1 & 6 & & & & 0 & 0,00 & 0 & 0,00 & 0 & \#\#\#\# & \#\#\#\# & 0 & 0 & 0 & \#\#\#\#\# & & Коз & 64 \\
\hline 65 & $\mathrm{Hv}$ & Melegszamos & 1 & 1 & 1 & 1 & 1 & 1 & 6 & & & & 0 & 0,00 & 0 & 0,00 & 0 & 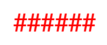 & ; \#\#\#\# & -1 & 0 & 0 & \#\#\#\#\# & & Коз & 65 \\
\hline 66 & $\mathrm{~K}$ & Magyarkapus, Nagykapus & 1 & 1 & 1 & 1 & 1 & 1 & 6 & & & & 0 & 0,00 & 0 & 0,00 & 0 & 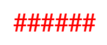 & ; \#\#\#\# & 0 & 0 & 0 & \#\#\#\#\# & & Ko1 & 66 \\
\hline 67 & $\mathrm{~K}$ & Magyarkiskapus & 1 & 1 & 1 & 1 & 1 & 1 & 6 & & & & 0 & 0,00 & 0 & 0,00 & 0 & 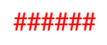 & ; \#\#\#\# & 0 & 0 & 0 & \#\#\#\#\# & & Ko1 & 67 \\
\hline 68 & $\mathrm{k}$ & Egerbegy+Bánffydongó & 1 & 1 & 1 & 1 & 1 & 1 & 6 & & 0 & 0 & 0 & 0,00 & 0 & 0,00 & 0 & 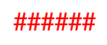 & " \#\#\#\# & 0 & 0 & 0 & \#\#\#\#\# & & Ко3 & 68 \\
\hline 69 & $\mathrm{~K}$ & Gesztrágy & 1 & 1 & 1 & 1 & 1 & 1 & 6 & & & & 0 & 0,00 & 0 & 0,00 & 0 & \#\#\#\# & 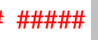 & 0 & 0 & 0 & \#\#\#\#\# & & Коз & 69 \\
\hline 70 & $\mathrm{Ka}$ & Gyalu & 1 & 1 & 1 & 1 & 1 & 1 & 6 & & & & 0 & 0,00 & 0 & 0,00 & 0 & 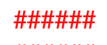 & ; \#\#\#\# & 0 & 0 & 0 & \#\#\#\#\#\# & & Ko1 & 70 \\
\hline 71 & $\mathrm{Ka}$ & Magyarlóna & 1 & 1 & 1 & 1 & 1 & 1 & 6 & & & & 0 & 0,00 & 0 & 0,00 & 0 & \#\#\#\# & 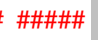 & -4 & 0 & 0 & \#\#\#\#\# & & Ko1 & 71 \\
\hline 72 & $\mathrm{Ka}$ & Szászfenes & 1 & 2 & 3 & 2 & 2 & 1 & 11 & 20 & 2 & & 2 & 0,00 & 4 & 0,06 & 2 & 100 & \#\#\#\# & 0 & 17 & 0 & 420 & Gy & Ko1 & 72 \\
\hline 73 & Nmv & Bogártelke & 1 & 1 & 1 & 1 & 1 & 1 & 6 & & & & 0 & 0,00 & 0 & 0,00 & 0 & \#\#\#\#\# & ～\#\#\#\# & -1 & 0 & 0 & \#\#\#\#\# & $\mathrm{Nm}$ & HA & 73 \\
\hline 74 & Nmv & Egeres & 1 & 1 & 1 & 1 & 1 & 1 & 6 & & & & 0 & 0,00 & 0 & 0,00 & 0 & \#\#\#\#\# & ; \#\#\#\#\# & 0 & 0 & 0 & \#\#\#\#\#\# & & HA & 74 \\
\hline 75 & $\mathrm{Nmv}$ & Inaktelke & 1 & 1 & 1 & 1 & 1 & 1 & 6 & & & & 0 & 0,00 & 0 & 0,00 & 0 & \#\#\#\#\# & 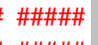 & 0 & 0 & 0 & 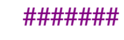 & & HA & 75 \\
\hline $\begin{array}{l}76 \\
77\end{array}$ & Nmv & Jegenye & 1 & 1 & 1 & 1 & 1 & 1 & 6 & & & & 0 & 0,00 & 0 & 0,00 & 0 & \#\#\#\#\# & F\#\#\#\# & 0 & 0 & 0 & 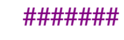 & & HA & 76 \\
\hline 77 & $\mathrm{Nmv}$ & Magyargorbó & 1 & 1 & 1 & 1 & 1 & 1 & 6 & & & & 0 & 0,00 & 0 & 0,00 & 0 & \#\#\#\# & F \#\#\#\# & -1 & 0 & 0 & 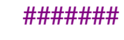 & & HA & 77 \\
\hline 78 & $\mathrm{Nmv}$ & Magyarnádas & 1 & 1 & 1 & 1 & 1 & 1 & 6 & & & & 0 & 0,00 & 0 & 0,00 & 0 & \#\#\#\# & F \#\#\#\# & -1 & 0 & 0 & \#\#\#\#\# & & HA & 78 \\
\hline $\begin{array}{l}79 \\
81\end{array}$ & Nmv & Magyarvista & 1 & 1 & 1 & 1 & 1 & 1 & 6 & & & & 0 & 0,00 & 0 & 0,00 & 0 & \#\#\#\#\# & F \#\#\#\# & -1 & 0 & 0 & \#\#\#\#\# & & HA & 79 \\
\hline $\begin{array}{l}81 \\
82\end{array}$ & $\begin{array}{l}\mathrm{Nmv} \\
\mathrm{Nmv}\end{array}$ & $\mid \begin{array}{l}\text { Méra } \\
\text { Nádasdarócz }\end{array}$ & $\begin{array}{l}1 \\
1\end{array}$ & $\begin{array}{l}1 \\
1\end{array}$ & $\begin{array}{l}1 \\
1\end{array}$ & $\begin{array}{l}1 \\
1\end{array}$ & $\begin{array}{l}1 \\
1\end{array}$ & $\begin{array}{l}1 \\
1\end{array}$ & $\begin{array}{l}6 \\
6\end{array}$ & & & & $\begin{array}{l}0 \\
0\end{array}$ & $\begin{array}{l}0,00 \\
0,00\end{array}$ & $\begin{array}{l}0 \\
0\end{array}$ & $\begin{array}{l}0,00 \\
0,00\end{array}$ & $\begin{array}{l}0 \\
0\end{array}$ & 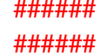 & 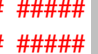 & $\begin{array}{r}-1 \\
0\end{array}$ & $\begin{array}{l}0 \\
0\end{array}$ & $\begin{array}{l}0 \\
0\end{array}$ & $\begin{array}{l}\text { \#\#\#\#\# } \\
\text { \#\#\#\#\#\# }\end{array}$ & & $\begin{array}{l}\text { HA } \\
\text { HA }\end{array}$ & $\begin{array}{l}81 \\
82\end{array}$ \\
\hline 84 & Nmv & Türe & 1 & 1 & 1 & 1 & 1 & 1 & 6 & & & & 0 & 0,00 & 0 & 0,00 & 0 & 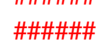 & F \#\#\#\# & 0 & 0 & 0 & \#\#\#\#\# & & HA & 84 \\
\hline 80 & $\mathrm{Nmv}$ & Mákófalva & 1 & 1 & 2 & 1 & 1 & 1 & 7 & 1 & & & 0 & 0,00 & 0 & 0,00 & 0 & 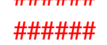 & F \#\#\#\# & -1 & 0 & 0 & \#\#\#\#\# & & HA & 80 \\
\hline 83 & Nmv & Szucság & 1 & 2 & 1 & 2 & 2 & 1 & 9 & & 1 & & 1 & 0,00 & 1 & 0,03 & 0 & 0 & \#\#\#\# & 0 & 5 & 0 & 540 & $\mathrm{Nm}$ & HA & 83 \\
\hline 85 & To & Isztolna & 1 & 1 & 1 & 1 & 1 & 1 & 6 & & & & 0 & 0,00 & 0 & 0,00 & 0 & \#\#\#\#\# & ; \#\#\#\# & -2 & 0 & 0 & \#\#\#\#\#\# & & Ko1 & 85 \\
\hline 86 & To & Kolozstótfalu & 1 & 1 & 1 & 1 & 1 & 1 & 6 & & & & 0 & 0,00 & 0 & 0,00 & 0 & \#\#\#\#\# & \% \#\#\#\# & 0 & 0 & 0 & 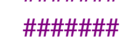 & & Ko1 & 86 \\
\hline 87 & To & Magyarfenes & 1 & 1 & 1 & 1 & 1 & 1 & 6 & & & & 0 & 0,00 & 0 & 0,00 & 0 & \#\#\#\#\# & \% \#\#\#\# & -1 & 0 & 0 & \#\#\#\#\#\# & & Ko1 & 87 \\
\hline 88 & To & Alsófüle & 1 & 1 & 1 & 1 & 1 & 1 & 6 & & & & 0 & 0,00 & 0 & 0,00 & 0 & \#\#\#\#\# & \% \#\#\#\# & -2 & 0 & 0 & \#\#\#\#\#\# & & To 1 & 88 \\
\hline 89 & To & Alsójára & 1 & 1 & 1 & 1 & 1 & 1 & 6 & & & & 0 & 0,00 & 0 & 0,00 & 0 & \#\#\#\#\# & \% \#\#\#\# & -60 & 0 & 0 & \#\#\#\#\#\# & & To 1 & 89 \\
\hline 90 & To & Felsőfüle & 1 & 1 & 1 & 1 & 1 & 1 & 6 & & & & 0 & 0,00 & 0 & 0,00 & 0 & \#\#\#\#\# & ; \#\#\#\# & 57 & 0 & 0 & \#\#\#\#\#\# & & To 1 & 90 \\
\hline 91 & To & Havasasszonyfalva & 1 & 1 & 1 & 1 & 1 & 1 & 6 & & & & 0 & 0,00 & 0 & 0,00 & 0 & \#\#\#\# & 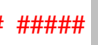 & -43 & 0 & 0 & 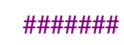 & & To 1 & 91 \\
\hline 92 & To & Járarákos & 1 & 1 & 1 & 1 & 1 & 1 & 6 & & & & 0 & 0,00 & 0 & 0,00 & 0 & 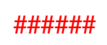 & 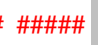 & -7 & 0 & 0 & 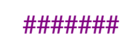 & & To 1 & 92 \\
\hline 93 & To & Magyarléta & 1 & 1 & 1 & 1 & 1 & 1 & 6 & & & & 0 & 0,00 & 0 & 0,00 & 0 & \#\#\#\# & 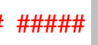 & 0 & 0 & 0 & 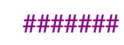 & & To 1 & 93 \\
\hline 94 & To & Oláhléta & 1 & 1 & 1 & 1 & 1 & 1 & 6 & & & & 0 & 0,00 & 0 & 0,00 & 0 & \#\#\#\# & 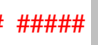 & -11 & 0 & 0 & \#\#\#\#\# & & To 1 & 94 \\
\hline 95 & To & |Tordaszentlászló & 1 & 1 & 1 & 1 & 1 & 1 & 6 & & & & 0 & 0,00 & 0 & 0,00 & 0 & \#\#\#\# & 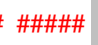 & -74 & 0 & 0 & \#\#\#\#\# & & To 1 & 95 \\
\hline 96 & To & Hasadat & 1 & 1 & 1 & 1 & 1 & 1 & 6 & & & & 0 & 0,00 & 0 & 0,00 & 0 & 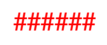 & " \#\#\#\#\# & 0 & 0 & 0 & \#\#\#\#\# & & To 2 & 96 \\
\hline 97 & To & |Kisfenes & 1 & 1 & 1 & 1 & 1 & 1 & 6 & & & & 0 & 0,00 & 0 & 0,00 & 0 & 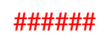 & " \#\#\#\# & -1 & 0 & 0 & 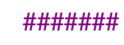 & & To 2 & 97 \\
\hline 98 & Vv & Almásnyíres & 1 & 1 & 1 & 1 & 1 & 1 & 6 & & & & 0 & 0,00 & 0 & 0,00 & 0 & 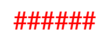 & ; \#\#\#\# & 0 & 0 & 0 & \#\#\#\#\# & & $\mathrm{BH} 1$ & 98 \\
\hline 100 & Vv & Bercse & 1 & 1 & 1 & 1 & 1 & 1 & 6 & & & & 0 & 0,00 & 0 & 0,00 & 0 & 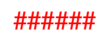 & ; \#\#\#\# & -16 & 0 & 0 & \#\#\#\#\# & & $\mathrm{BH} 1$ & 100 \\
\hline 101 & Vv & Czold & 1 & 1 & 1 & 1 & 1 & 1 & 6 & & & & 0 & 0,00 & 0 & 0,00 & 0 & \#\#\#\# & ; \#\#\#\# & 0 & 0 & 0 & \#\#\#\#\# & & $\mathrm{BH} 1$ & 101 \\
\hline 107 & Vv & Almásköblös & 1 & 1 & 1 & 1 & 1 & 1 & 6 & & & & 0 & 0,00 & 0 & 0,00 & 0 & \#\#\#\#\#" & 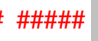 & -1 & 0 & 0 & \#\#\#\#\# & & HA & 107 \\
\hline 111 & Vv & Topaszentkirály & 1 & 1 & 1 & 1 & 1 & 1 & 6 & & & & 0 & 0,00 & 0 & 0,00 & 0 & \#\#\#\#\# & 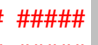 & -2 & 0 & 0 & \#\#\#\#\#\# & & HA & 111 \\
\hline 112 & Vv & Vásártelke & 1 & 1 & 1 & 1 & 1 & 1 & 6 & & & & 0 & 0,00 & 0 & 0,00 & 0 & 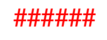 & 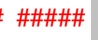 & -1 & 0 & 0 & \#\#\#\#\# & & HA & 112 \\
\hline 116 & Vv & Felsőfüld & 1 & 1 & 1 & 1 & 1 & 1 & 6 & & & & 0 & 0,00 & 0 & 0,00 & 0 & 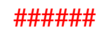 & 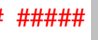 & 0 & 0 & 0 & \#\#\#\#\# & $\mathrm{AH}$ & BH3 & 116 \\
\hline 109 & Vv & Lapupatak & 2 & 2 & 1 & 1 & 1 & 1 & 8 & & & 2 & 2 & 0,09 & 0 & 0,00 & -2 & -100 & -100 & 0 & 0 & 0 & 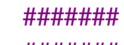 & Al & HA & 109 \\
\hline 102 & Vv & Kiskökényes & 3 & 2 & 1 & 1 & 1 & 1 & 9 & & & 3 & 3 & 0,26 & 0 & 0,00 & -3 & -100 & -100 & -1 & 0 & 0 & \#\#\#\#\#\# & $\mathrm{Al}$ & $\mathrm{BH} 1$ & 102 \\
\hline 108 & $\mathrm{Vv}$ & Hidalmás & 1 & 2 & 1 & 2 & 2 & 1 & 9 & & 1 & 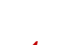 & 1 & 0,00 & 1 & 0,03 & 0 & 0 & \#\#\#\# & -1 & 8 & 0 & 800 & Al & HA & 108 \\
\hline 99 & Vv & $\mid \begin{array}{l}\text { Bábony } \\
\text { KKZzónf:̈l|d }\end{array}$ & 3 & 3 & 1 & 1 & 1 & 1 & 10 & & 1 & 4 & 5 & 0,30 & 0 & 0,00 & -5 & -100 & -100 & -3 & 0 & 0 & 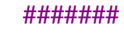 & $\mathrm{Al}$ & $\mathrm{BH} 1$ & 99 \\
\hline 115 & Vv & 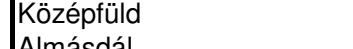 & 1 & 3 & 1 & 2 & 3 & 1 & 11 & & 8 & & 8 & 0,00 & 9 & 0,19 & 1 & 13 & \#\#\#\# & 0 & 17 & 0 & 190 & $\mathrm{BH}$ & $\mathrm{BH} 1$ & 115 \\
\hline 106 & Vv & Almásdál & 3 & 3 & 1 & 2 & 2 & 1 & 12 & & 7 & & 7 & 0,35 & 3 & 0,15 & -4 & -57 & -56 & -2 & 24 & 0 & 800 & Al & HA & 106 \\
\hline $\begin{array}{l}110 \\
104\end{array}$ & $\begin{array}{l}v_{v} \\
v v\end{array}$ & $\begin{array}{l}\text { Magyarzsombor } \\
\text { Nyercze }\end{array}$ & $\begin{array}{l}2 \\
3\end{array}$ & $\begin{array}{l}3 \\
3\end{array}$ & $\begin{array}{l}1 \\
2\end{array}$ & $\begin{array}{l}2 \\
2\end{array}$ & $\begin{array}{l}3 \\
2\end{array}$ & 1 & $\begin{array}{l}12 \\
13\end{array}$ & 5 & $\begin{array}{l}3 \\
1\end{array}$ & $\begin{array}{l}2 \\
8\end{array}$ & $\begin{array}{l}5 \\
9\end{array}$ & 0,05 & $\begin{array}{l}5 \\
1\end{array}$ & $\begin{array}{l}0,13 \\
0,03\end{array}$ & $\begin{array}{c}0 \\
-8\end{array}$ & $\begin{array}{c}0 \\
-89\end{array}$ & $\begin{array}{l}149 \\
-88\end{array}$ & $\begin{array}{l}0 \\
1\end{array}$ & $\begin{array}{c}27 \\
2\end{array}$ & $\begin{array}{l}0 \\
0\end{array}$ & $\begin{array}{l}540 \\
190\end{array}$ & $\begin{array}{l}\mathrm{Al} \\
\mathrm{Al}\end{array}$ & $\begin{array}{l}\mathrm{HA} \\
\mathrm{BH} 1\end{array}$ & 110 \\
\hline 114 & vv & Alsófüld & 2 & 3 & 1 & 3 & 3 & 1 & 13 & & 5 & 3 & 8 & $0 ., 15$ & 8 & 0,41 & $\begin{array}{l}-8 \\
0\end{array}$ & $\begin{array}{l}-89 \\
0\end{array}$ & $\begin{array}{l}-80 \\
167\end{array}$ & 0 & 2 & 0 & $\begin{array}{l}190 \\
190\end{array}$ & $\begin{array}{l}\text { Al } \\
\text { BH }\end{array}$ & $\begin{array}{l}\text { BH1 } \\
\text { BH1 }\end{array}$ & $\begin{array}{l}104 \\
114\end{array}$ \\
\hline 113 & $v_{v}$ & Zutor & 1 & 3 & 2 & 3 & 3 & 2 & 14 & 5 & 6 & & 6 & 0.00 & 6 & 0,24 & 0 & 0 & \#\#\#\# & 0 & 32 & 1 & 540 & $\mathrm{Al}$ & HA & 13 \\
\hline \multirow{3}{*}{105} & Vv & Középlak & 1 & 3 & 3 & 3 & 3 & 2 & 15 & 18 & 14 & & 14 & 0,00 & 8 & 0,29 & -6 & -43 & \#\#\#\# & 1 & 46 & 1 & 580 & $\mathrm{Al}$ & BH1 & 103 \\
\hline & $\mathrm{vv}$ & Váralmás & 3 & 4 & 4 & 3 & 4 & 2 & 20 & 52 & 17 & 18 & 35 & 0,20 & 34 & 0,37 & -1 & -3 & 89 & 0 & 235 & 1 & 690 & Al & $\mathrm{BH} 1$ & 105 \\
\hline & & összesen & & & & & & & & 351 & 245 & 228 & 473 & & 430 & & & & & & & & & & & \\
\hline
\end{tabular}




\begin{tabular}{|c|c|c|c|c|c|c|c|c|c|c|c|c|c|c|c|c|c|c|c|c|c|c|}
\hline & & & & & & & LLEPÜL & SEK ÉS & AZÓN & $\overline{\text { ÁK } 1914}$ & es ADA & TAIBÓL & YERT \%- & MEGOS & LÁSOK & & & & & & & \\
\hline 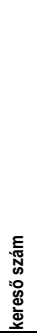 & 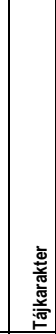 & 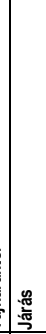 & 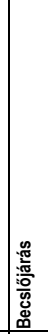 & & 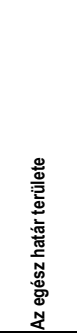 & 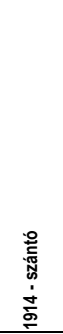 & 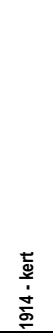 & 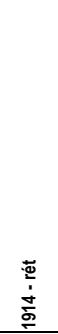 & 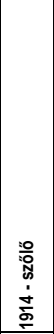 & 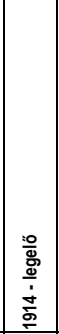 & $\begin{array}{l}\text { 읗 } \\
\dot{0} \\
\dot{+} \\
\dot{5}\end{array}$ & 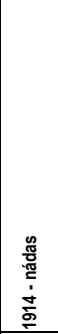 & 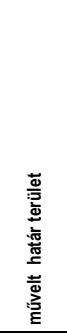 & 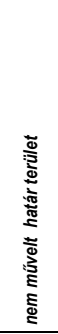 & 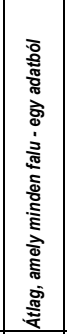 & 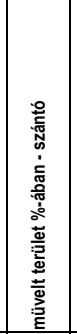 & 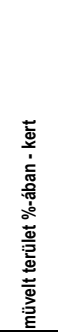 & 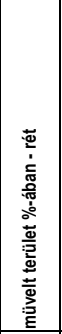 & 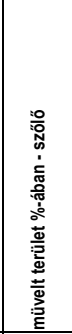 & 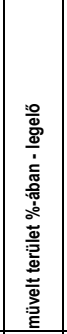 & 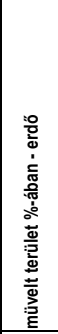 & 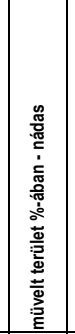 \\
\hline & & & & & $\stackrel{+}{\circ}$ & k.hold & k.hold & k.hold & k.hold & k.hold & k.hold & hold & $\stackrel{2}{\frac{\pi}{2}}$ & $\frac{2}{2}$ & & $\stackrel{5}{\frac{\pi}{2}}$ & $\stackrel{2}{\frac{\pi}{2}}$ & $\stackrel{9}{2}$ & $\stackrel{9}{2}$ & $\stackrel{9}{2}$ & $\stackrel{9}{2}$ & $\frac{9}{2}$ \\
\hline & & & & név1914 & hold & Szántó & Kert & Rét & Szölä & \begin{tabular}{|l|l|} 
Legelö \\
\end{tabular} & Erdö & Nádas & hold & hold & & Szántó \% & Kert\% & \begin{tabular}{|l|} 
Rét \% \\
\end{tabular} & Szölö \% & Legelö of & Erdö \% & Nádas \% \\
\hline 1 & $\mathrm{Ab}$ & Al & $\mathrm{BH} 1$ & Almástamási & 2938 & 978 & 84 & 410 & 3 & 334 & 1030 & 0 & 2839 & 99 & & 34,4 & 3,0 & 14,4 & 0,1 & 11,8 & 36,3 & 0,0 \\
\hline 2 & $A b$ & Al & BH1 & Nagypetri & 2353 & 810 & 77 & 402 & 0 & 196 & 751 & 0 & 2236 & 117 & & 36,2 & 3,4 & 18,0 & 0,0 & 8,8 & 33,6 & 0,0 \\
\hline 3 & $A b$ & Al & BH1 & Tottelke & 1914 & 779 & 75 & 244 & 6 & 264 & 506 & 0 & 1874 & 40 & & 41,6 & 4,0 & 13,0 & 0,3 & 14,1 & 27,0 & 0,0 \\
\hline 4 & $A b$ & Al & $\mathrm{HA}$ & Argyas & 1026 & 403 & 22 & 176 & 0 & 107 & 293 & 0 & 1001 & 25 & & 40,3 & 2,2 & 17,6 & 0,0 & 10,7 & 29,3 & 0,0 \\
\hline 5 & $A b$ & Al & HA & Dank & 1281 & 422 & 47 & 262 & 0 & 109 & 403 & 0 & 1243 & 38 & & 34,0 & 3,8 & 21,1 & 0,0 & 8,8 & 32,4 & 0,0 \\
\hline 6 & $A b$ & Al & $\mathrm{HA}$ & Forgácskút & 1464 & 334 & 32 & 362 & 4 & 42 & 667 & 0 & 1441 & 23 & & 23,2 & 2,2 & 25,1 & 0,3 & 2,9 & 46,3 & 0,0 \\
\hline 7 & $A b$ & $\mathrm{Nm}$ & HA & Sólyomtelke & 1872 & 309 & 37 & 338 & 0 & 91 & 1073 & 0 & 1848 & 24 & & 16,7 & 2,0 & 18,3 & 0,0 & 4,9 & 58,1 & 0,0 \\
\hline & & & & Zóna - Össz.terület & 12848 & 4035 & 374 & 2194 & 13 & 1143 & 4723 & 0 & 12482 & 366 & Átlag & 32,3 & 2,9 & 18,2 & 0,1 & 8,8 & 37,6 & 0,0 \\
\hline & & & & Osszter. területileg \%-os & 102,9 & 32,3 & 3,0 & 17,6 & 0,1 & 9,2 & 37,8 & 0,0 & 100,0 & 2,9 & Szórás & 9,1 & 0,8 & 4,0 & 0,1 & 3,9 & 11,0 & 0,0 \\
\hline 8 & Asz & $\mathrm{Al}$ & $\mathrm{BH} 1$ & Kispetri & 1761 & 853 & 60 & 137 & 40 & 346 & 277 & 0 & 1713 & 48 & & 49,8 & 3,5 & 8,0 & 2.3 & 20,2 & 16,2 & 0,0 \\
\hline 9 & Asz & $\mathrm{BH}$ & BH1 & Farnas & 1921 & 809 & 47 & 192 & 40 & 436 & 323 & 0 & 1847 & 74 & & 43,8 & 2,5 & 10,4 & 2,2 & 23,6 & 17,5 & 0,0 \\
\hline 10 & Asz & $\mathrm{BH}$ & BH1 & Ketesd & 1078 & 481 & 45 & 90 & 28 & 140 & 254 & 0 & 1038 & 40 & & 46,3 & 4,3 & 8,7 & 2,7 & 13,5 & 24,5 & 0,0 \\
\hline 11 & Asz & BH & BH1 & Magyarbikal & 1779 & 823 & 101 & 252 & 63 & 426 & 30 & 0 & 1695 & 84 & & 48,6 & 6,0 & 14,9 & 3,7 & 25,1 & 1,8 & 0,0 \\
\hline 12 & Asz & $\mathrm{BH}$ & BH1 & Sztána & 1982 & 842 & 65 & 344 & 22 & 180 & 444 & 0 & 1897 & 85 & & 44,4 & 3,4 & 18,1 & 1,2 & 9,5 & 23,4 & 0,0 \\
\hline 13 & Asz & $\mathrm{BH}$ & BH1 & Zsobok & 1769 & 735 & 64 & 241 & 22 & 172 & 482 & 0 & 1716 & 53 & & 42,8 & 3,7 & 14,0 & 1,3 & 10,0 & 28,1 & 0,0 \\
\hline & & & & Zóna - Össz.terület & 10290 & 4543 & 382 & 1256 & 215 & 1700 & 1810 & 0 & 9906 & 384 & Átlag & 46,0 & 3,9 & 12,4 & 2,2 & 17,0 & 18,6 & 0,0 \\
\hline & & & & Osszter. területileg \%-os & 103,9 & 45,9 & 3,9 & 12,7 & 2,2 & 17,2 & 18,3 & 0,0 & 100,0 & 3,9 & Szórás & 2,8 & 1,2 & 4,0 & 0,9 & 6,9 & 9,4 & 0,0 \\
\hline & & & & & & & & & & & & & & & & & & & & & & \\
\hline $\begin{array}{l}14 \\
15\end{array}$ & $\mathrm{Bb}$ & $\mathrm{Nm}$ & HA & \begin{tabular}{|l} 
Kisbács \\
Magyarsárd
\end{tabular} & $\begin{array}{l}3034 \\
3748\end{array}$ & 844 & 71 & 421 & 3 & 457 & 1113 & 0 & $\begin{array}{l}2909 \\
3655\end{array}$ & 125 & & 29,0 & $\begin{array}{l}2,4 \\
2,\end{array}$ & $\begin{array}{l}14,5 \\
137\end{array}$ & 0,1 & $\begin{array}{l}15,7 \\
155\end{array}$ & 38,3 & 0,0 \\
\hline $\begin{array}{l}15 \\
16\end{array}$ & $\begin{array}{l}\mathrm{Bb} \\
\mathrm{Bb}\end{array}$ & $\begin{array}{l}\mathrm{Nm} \\
\mathrm{Nm}\end{array}$ & $\begin{array}{l}\text { HA } \\
\text { HA }\end{array}$ & $\begin{array}{l}\text { Magyarsárd } \\
\text { Magyarszentpál }\end{array}$ & $\begin{array}{l}3748 \\
2443\end{array}$ & $\begin{array}{l}908 \\
1000\end{array}$ & $\begin{array}{l}100 \\
83\end{array}$ & $\begin{array}{l}499 \\
322\end{array}$ & $\begin{array}{l}0 \\
0\end{array}$ & $\begin{array}{l}566 \\
577\end{array}$ & $\begin{array}{l}1582 \\
387\end{array}$ & $\begin{array}{l}0 \\
0\end{array}$ & $\begin{array}{l}3655 \\
2369\end{array}$ & $\begin{array}{l}93 \\
74\end{array}$ & & $\begin{array}{l}24,8 \\
42,2\end{array}$ & $\begin{array}{l}2,7 \\
3,5\end{array}$ & $\begin{array}{l}13,7 \\
13,6\end{array}$ & $\begin{array}{l}0,0 \\
0,0\end{array}$ & $\begin{array}{l}15,5 \\
24,4\end{array}$ & $\begin{array}{l}43,3 \\
16,3\end{array}$ & $\begin{array}{l}0,0 \\
0,0\end{array}$ \\
\hline 17 & $\mathrm{Bb}$ & $\mathrm{Nm}$ & $\mathrm{HA}$ & Nádasberend & 2540 & 1160 & 63 & 519 & 0 & 321 & 380 & 0 & 2443 & 97 & & 47,5 & 2,6 & 21,2 & 0,0 & 13,1 & 15,6 & 0,0 \\
\hline 18 & $\mathrm{Bb}$ & $\mathrm{Nm}$ & HA & Nádaskóród & 1702 & 720 & 67 & 329 & 0 & 174 & 346 & 0 & 1636 & 66 & & 44,0 & 4,1 & 20,1 & 0,0 & 10,6 & 21,1 & 0,0 \\
\hline 19 & $\mathrm{Bb}$ & $\mathrm{Nm}$ & $\mathrm{HA}$ & Nádaspapfalva & 1933 & 454 & 84 & 422 & 0 & 164 & 728 & 0 & 1852 & 81 & & 24,5 & 4,5 & 22,8 & 0,0 & 8,9 & 39,3 & 0,0 \\
\hline 20 & $\mathrm{Bb}$ & $\mathrm{Nm}$ & HA & Nádasszentmihály & 3075 & 762 & 74 & 422 & 0 & 914 & 816 & 0 & 2988 & 87 & & 25,5 & 2,5 & 14,1 & 0,0 & 30,6 & 27,3 & 0,0 \\
\hline 21 & $\mathrm{Bb}$ & $\mathrm{Nm}$ & $\mathrm{HA}$ & Pusztatopa & 2148 & 710 & 85 & 526 & 0 & 226 & 533 & 0 & 2080 & 68 & & 34,1 & 4,1 & 25,3 & 0,0 & 10,9 & 25,6 & 0,0 \\
\hline 22 & $\mathrm{Bb}$ & $\mathrm{Nm}$ & HA & Szomordok & 1243 & 321 & 47 & 266 & 0 & 28 & 553 & 0 & 1215 & 28 & & 26,4 & 3,9 & 21,9 & 0,0 & 2,3 & 45,5 & 0,0 \\
\hline & & & & Zóna - Össz.terület & 21866 & 6879 & 674 & 3726 & 3 & 3427 & 6438 & 0 & 21147 & 719 & Átlag & 33,1 & 3,4 & 18,6 & 0,0 & 14,7 & 30,3 & 0,0 \\
\hline & & & & Osszter. területileg \%-os & 103,4 & 32,5 & 3,2 & 17,6 & 0,0 & 16,2 & 30,4 & 0,0 & 100,0 & 3,4 & Szórás & 9,2 & 0,8 & 4,6 & 0,0 & 8,4 & 11,6 & 0,0 \\
\hline & & & & & & & & & & & & & & & & & & & & & & \\
\hline 23 & $\mathrm{Bhm}$ & $\mathrm{BH}$ & $\mathrm{BH} 2$ & Bánffyhunyad & 9035 & 2928 & 237 & 1125 & 119 & 1051 & 3323 & 0 & 8783 & 252 & & 33,3 & 2,7 & 12,8 & 1,4 & 12,0 & 37,8 & 0,0 \\
\hline 24 & $\mathrm{Bhm}$ & $\mathrm{BH}$ & $\mathrm{BH} 2$ & Kalotabökény & 867 & 590 & 27 & 86 & 0 & 121 & 0 & 0 & 824 & 43 & & 71,6 & 3,3 & 10,4 & 0,0 & 14,7 & 0,0 & 0,0 \\
\hline 25 & Bhm & $\mathrm{BH}$ & $\mathrm{BH} 2$ & Kalotadámos & 1324 & 634 & 39 & 147 & 0 & 414 & 0 & 0 & 1234 & 90 & & 51,4 & 3,2 & 11,9 & 0,0 & 33,5 & 0,0 & 0,0 \\
\hline 26 & Bhm & $\mathrm{BH}$ & $\mathrm{BH} 2$ & Kalotaszentkirály & 3171 & 1489 & 64 & 331 & 0 & 455 & 711 & 0 & 3050 & 121 & & 48,8 & 2,1 & 10,9 & 0,0 & 14,9 & 23,3 & 0,0 \\
\hline 27 & $\mathrm{Bhm}$ & $\mathrm{BH}$ & $\mathrm{BH} 2$ & Magyarókereke & 1795 & 852 & 55 & 109 & 0 & 297 & 425 & 0 & 1738 & 57 & & 49,0 & 3,2 & 6,3 & 0,0 & 17,1 & 24,5 & 0,0 \\
\hline 28 & Bhm & BH & $\mathrm{BH} 2$ & Malomszeg & 1604 & 733 & 67 & 491 & 0 & 141 & 121 & 0 & 1553 & 51 & & 47,2 & 4,3 & 31,6 & 0,0 & 9,1 & 7,8 & 0,0 \\
\hline 29 & Bhm & $\mathrm{BH}$ & $\mathrm{BH} 2$ & Nagykalota & 1470 & 1005 & 74 & 160 & 0 & 155 & 0 & 0 & 1394 & 76 & & 72,1 & 5,3 & 11,5 & 0,0 & 11,1 & 0,0 & 0,0 \\
\hline 30 & $\mathrm{Bhm}$ & $\mathrm{BH}$ & $\mathrm{BH} 2$ & Sárvásár & 834 & 427 & 21 & 99 & 0 & 126 & 113 & 0 & 786 & 48 & & 54,3 & 2,7 & 12,6 & 0,0 & 16,0 & 14,4 & 0,0 \\
\hline 31 & $\mathrm{Bhm}$ & $\mathrm{BH}$ & BH2 & Zentelke & 2132 & 1102 & 61 & 297 & 0 & 392 & 207 & 0 & 2059 & 73 & & 53,5 & 3,0 & 14,4 & 0,0 & 19,0 & 10,1 & 0,0 \\
\hline & & & & Zóna-Össz.terület & 22232 & 9760 & 645 & 2845 & 119 & 3152 & 4900 & 0 & 21421 & 811 & Átlag & 53,5 & 3,3 & 13,6 & 0,2 & 16,4 & 13,1 & 0,0 \\
\hline & & & & Osszter. területileg \%-os & 103,8 & 45,6 & 3,0 & 13,3 & 0,6 & 14,7 & 22,9 & 0,0 & 100,0 & 3,8 & Szórás & 12,1 & 1,0 & 7,1 & 0,5 & 7,1 & 13,2 & 0,0 \\
\hline 32 & $\mathrm{Ff}$ & $\overline{\mathrm{BH}}$ & $\overline{\mathrm{BH} 1}$ & Kalotanádas & 2682 & 1002 & 61 & 350 & $\overline{0}$ & 495 & 682 & $\overline{0}$ & 2590 & 92 & & 387 & 24 & 13,5 & 0,0 & 191 & 26,3 & 0,0 \\
\hline 33 & $\mathrm{Ff}$ & $\mathrm{BH}$ & $\mathrm{BH} 2$ & Bedecs & 3214 & 812 & 29 & 802 & 0 & 398 & 1058 & 0 & 3099 & 115 & & 26,2 & $\begin{array}{l}2,4 \\
0,9\end{array}$ & 25,9 & 0,0 & 12,8 & 34,1 & 0,0 \\
\hline 34 & $\mathrm{Ff}$ & BH & BH2 & Deréte & 1218 & 446 & 43 & 117 & 0 & 228 & 342 & 0 & 1176 & 42 & & 37,9 & 3,7 & 9,9 & 0,0 & 19,4 & 29,1 & 0,0 \\
\hline 35 & $\mathrm{Ff}$ & BH & $\mathrm{BH} 2$ & Erdöfalva & 799 & 430 & 35 & 51 & 0 & 252 & 0 & 0 & 768 & 31 & & 56,0 & 4,6 & 6,6 & 0,0 & 32,8 & 0,0 & 0,0 \\
\hline 36 & $\mathrm{Ff}$ & $\mathrm{BH}$ & $\mathrm{BH} 2$ & Jákótelke & 724 & 282 & 29 & 73 & 0 & 257 & 45 & 0 & 686 & 38 & & 41,1 & 4,2 & 10,6 & 0,0 & 37,5 & 6,6 & 0,0 \\
\hline 37 & $\mathrm{Ff}$ & BH & $\mathrm{BH} 2$ & Kalotabikal I és || rész & 2933 & 499 & 34 & 1462 & 0 & 422 & 192 & 0 & 2609 & 324 & & 19,1 & 1,3 & 56,0 & 0,0 & 16,2 & 7,4 & 0,0 \\
\hline 38 & $\mathrm{Ff}$ & $\mathrm{BH}$ & $\mathrm{BH} 2$ & Körösfö & 2131 & 812 & 45 & 258 & 0 & 861 & 85 & 0 & 2061 & 70 & & 39,4 & 2,2 & 12,5 & 0,0 & 41,8 & 4,1 & 0,0 \\
\hline 39 & $\mathrm{Ff}$ & $\mathrm{BH}$ & $\mathrm{BH} 2$ & Magyar és Felsőgyerőmo & 11646 & 2691 & 143 & 4859 & 0 & 2013 & 1644 & 0 & 11350 & 296 & & 23,7 & 1,3 & 42,8 & 0,0 & 17,7 & 14,5 & 0,0 \\
\hline 40 & $\mathrm{Ff}$ & BH & $\mathrm{BH} 2$ & Magyarvalkó & 5962 & 1281 & 75 & 1316 & 0 & 1694 & 1418 & 0 & 5784 & 178 & & 22,1 & 1,3 & 22,8 & 0,0 & 29,3 & 24,5 & 0,0 \\
\hline 41 & $\mathrm{Ff}$ & $\mathrm{BH}$ & $\mathrm{BH} 2$ & Nyárszó & 1563 & 559 & 37 & 210 & 0 & 545 & 170 & 0 & 1521 & 42 & & 36,8 & 2,4 & 13,8 & 0,0 & 35,8 & 11,2 & 0,0 \\
\hline 42 & $\mathrm{Ff}$ & $\mathrm{BH}$ & $\mathrm{BH} 3$ & Kalotaújfalú & 1429 & 279 & 0 & 562 & 0 & 336 & 174 & 0 & 1351 & 78 & & 20,7 & 0,0 & 41,6 & 0,0 & 24,9 & 12,9 & 0,0 \\
\hline 43 & $\mathrm{Ff}$ & Gy & $\mathrm{BH} 2$ & Gyerőfalva & 3126 & 625 & 0 & 657 & 0 & 604 & 1175 & 0 & 3061 & 65 & & 20,4 & 0,0 & 21,5 & 0,0 & 19,7 & 38,4 & 0,0 \\
\hline 44 & $\mathrm{Ff}$ & Gy & Ko3 & Gyerōvásárhely & 3846 & 1641 & 47 & 855 & 0 & 201 & 965 & 0 & 3709 & 137 & & 44,2 & 1,3 & 23,1 & 0,0 & 5,4 & 26,0 & 0,0 \\
\hline & & & & Zóna - Össz.terület & 41273 & 11359 & 578 & 11572 & 0 & 8306 & 7950 & 0 & 39765 & 1508 & Átlag & 32,8 & 2,0 & 23,1 & 0,0 & 24,0 & 18,1 & 0,0 \\
\hline & & & & Osszter. területileg \%-os & 103,8 & 28,6 & 1,5 & 29,1 & 0,0 & 20,9 & 20,0 & 0,0 & 100,0 & 3,8 & Szórás & 11,5 & 1,5 & 15,0 & 0,0 & 10,7 & 12,3 & 0,0 \\
\hline$\overline{45}$ & $\mathrm{Fh}$ & $\overline{\mathrm{BH}}$ & $\mathrm{BH} 2$ & Bocs & 2472 & 671 & 41 & 330 & 0 & 825 & 544 & 0 & 2411 & 61 & & 27,8 & 1,7 & 13,7 & $\overline{0,0}$ & 34,2 & 22,6 & 0,0 \\
\hline $\begin{array}{l}45 \\
46\end{array}$ & $\mathrm{Fh}$ & $\mathrm{BH}$ & $\mathrm{BH} 2$ & $\begin{array}{l}\text { Bocs } \\
\text { Incsel }\end{array}$ & $\begin{array}{l}2472 \\
3365\end{array}$ & $\begin{array}{l}6 / 1 \\
1167\end{array}$ & $\begin{array}{l}41 \\
45\end{array}$ & $\begin{array}{l}330 \\
358\end{array}$ & 0 & $\begin{array}{l}825 \\
984\end{array}$ & $\begin{array}{l}544 \\
643\end{array}$ & 0 & $\begin{array}{l}411 \\
3197\end{array}$ & $\begin{array}{l}01 \\
168\end{array}$ & & $\begin{array}{l}2,8 \\
36,5\end{array}$ & $\begin{array}{l}1, I \\
1,4\end{array}$ & $\begin{array}{l}13, I \\
11,2\end{array}$ & $\begin{array}{l}0,0 \\
0,0\end{array}$ & $\begin{array}{l}34,2 \\
30,8\end{array}$ & $\begin{array}{l}22,6 \\
20,1\end{array}$ & 0,0 \\
\hline 47 & Fh & $\mathrm{BH}$ & $\mathrm{BH} 2$ & Marótlaka & 4435 & 1415 & 143 & 834 & 0 & 338 & 1471 & 0 & 4201 & 234 & & 33,7 & 3,4 & 19,9 & 0,0 & 8,0 & 35,0 & 0,0 \\
\hline 48 & $\mathrm{Fh}$ & $\mathrm{BH}$ & $\mathrm{BH} 2$ & Meregyó & 9515 & 1800 & 54 & 3702 & 0 & 1617 & 2116 & 0 & 9289 & 226 & & 19,4 & 0,6 & 39,9 & 0,0 & 17,4 & 22,8 & 0,0 \\
\hline 49 & $\mathrm{Fh}$ & BH & $\mathrm{BH} 3$ & Hodosfalva & 3539 & 971 & 0 & 589 & 0 & 246 & 1655 & 0 & 3461 & 78 & & 28,1 & 0,0 & 17,0 & 0,0 & 7,1 & 47,8 & 0,0 \\
\hline 50 & $\mathrm{Fh}$ & $\mathrm{BH}$ & $\mathrm{BH} 3$ & Kiskalota & 4088 & 544 & 0 & 1089 & 0 & 529 & 1798 & 0 & 3960 & 128 & & 13,7 & 0,0 & 27,5 & 0,0 & 13,4 & 45,4 & 0,0 \\
\hline & & & & Zóna - Össz.terület & 27414 & 6568 & 283 & 6902 & 0 & 4539 & 8227 & 0 & 26519 & 895 & Átlag & 26,5 & 1,2 & 21,5 & 0,0 & 18,5 & 32,3 & 0,0 \\
\hline & & & & Összter. területileg \%-os & 103,4 & 24,8 & 1,1 & 26,0 & 0,0 & 17,1 & 31,0 & 0,0 & 100,0 & 3,4 & Szórás & 8,6 & 1,3 & 10,6 & 0,0 & 11,5 & 12,3 & 0,0 \\
\hline 51 & $\mathrm{H}$ & $\mathrm{BH}$ & $\mathrm{BH} 2$ & Jósikafalva & 29070 & 0 & 0 & 1333 & 0 & 2530 & 24729 & 0 & 28592 & 478 & & 0,0 & 0,0 & 4,7 & 0,0 & 8,8 & 86,5 & 0,0 \\
\hline $\begin{array}{l}51 \\
52\end{array}$ & $\mathrm{H}$ & $\mathrm{BH}$ & $\begin{array}{l}\mathrm{BH} 2 \mathrm{Z} \\
\mathrm{BH} 3\end{array}$ & $\begin{array}{l}\text { Josikaralva } \\
\text { Havasrogoz }\end{array}$ & $\begin{array}{l}290 / 0 \\
11069\end{array}$ & 481 & 0 & $\begin{array}{l}1333 \\
1259\end{array}$ & 0 & $\begin{array}{l}2530 \\
1656\end{array}$ & $\begin{array}{l}24 / 29 \\
7502\end{array}$ & 0 & $\begin{array}{l}28592 \\
10898\end{array}$ & $\begin{array}{l}4 / 8 \\
171\end{array}$ & & $\begin{array}{l}0,0 \\
4,4\end{array}$ & $\begin{array}{l}0,0 \\
0,0\end{array}$ & $\begin{array}{l}4, I \\
11,6\end{array}$ & $\begin{array}{l}0,0 \\
0,0\end{array}$ & $\begin{array}{c}8,8 \\
15,2\end{array}$ & $\begin{array}{l}86,5 \\
68,8\end{array}$ & $\begin{array}{l}0,0 \\
0,0\end{array}$ \\
\hline 53 & $\mathrm{H}$ & $\mathrm{BH}$ & $\mathrm{BH} 3$ & Tarányos & 4737 & 777 & 0 & 1000 & 0 & 232 & 2597 & 0 & 4606 & 131 & & 16,9 & 0,0 & 21,7 & 0,0 & 5,0 & 56,4 & 0,0 \\
\hline 54 & $\mathrm{H}$ & $\mathrm{BH}$ & $\mathrm{BH} 3$ & Viság & 14404 & 561 & 0 & 1548 & 0 & 1659 & 10127 & 0 & 13895 & 509 & & 4,0 & 0,0 & 11,1 & 0,0 & 11,9 & 72,9 & 0,0 \\
\hline 55 & $\mathrm{H}$ & Gy & Ко3 & Felsőszamos & 1039 & 196 & 0 & 139 & 0 & 32 & 638 & 0 & 1005 & 34 & & 19,5 & 0,0 & 13,8 & 0,0 & 3,2 & 63,5 & 0,0 \\
\hline 56 & $\mathrm{H}$ & Gy & Ko3 & Gyerőfidongó & 752 & 324 & 0 & 108 & 0 & 75 & 232 & 0 & 739 & 13 & & 43,8 & 0,0 & 14,6 & 0,0 & 10,1 & 31,4 & 0,0 \\
\hline 57 & $\mathrm{H}$ & Gy & Ко3 & Havasnagyfalu & 13141 & 1695 & 0 & 2392 & 0 & 555 & 8187 & 0 & 12829 & 312 & & 13,2 & 0,0 & 18,6 & 0,0 & 4,3 & 63,8 & 0,0 \\
\hline 58 & $\mathrm{H}$ & Gy & Ko3 & Szamosfö & 46919 & 366 & 0 & 2166 & 0 & 4868 & 39060 & 0 & 46460 & 459 & & 0,8 & 0,0 & 4,7 & 0,0 & 10,5 & 84,1 & 0,0 \\
\hline & & & & Zóna-Össz.terület & 121131 & 4400 & 0 & 9945 & 0 & 11607 & 93072 & 0 & 119024 & 2107 & Átlag & 12,8 & 0,0 & 12,6 & 0,0 & 8,6 & 65,9 & 0,0 \\
\hline
\end{tabular}




\begin{tabular}{|c|c|c|c|c|c|c|c|c|c|c|c|c|c|c|c|c|c|c|c|c|c|c|c|}
\hline 59 & $\mathrm{Hv}$ & $\mathrm{BH}$ & $\mathrm{BH} 3$ & Harvasrekettye & 16532 & 267 & 0 & 1931 & 0 & 1705 & 12334 & 0 & 16237 & 295 & & 1,6 & 0,0 & 11,9 & 0,0 & 10,5 & 76,0 & 0,0 & 1,8 \\
\hline 60 & $\mathrm{Hv}$ & $\mathrm{BH}$ & $\mathrm{BH} 3$ & Kissebes & 1834 & 450 & 0 & 683 & 0 & 330 & 299 & 0 & 1762 & 72 & & 25,5 & 0,0 & 38,8 & 0,0 & 18,7 & 17,0 & 0,0 & 3,9 \\
\hline 61 & $\mathrm{Hv}$ & $\mathrm{BH}$ & $\mathrm{BH} 3$ & Nagysebes & 5670 & 986 & 0 & 1349 & 0 & 814 & 2234 & 0 & 5383 & 287 & & 18,3 & 0,0 & 25,1 & 0,0 & 15,1 & 41,5 & 0,0 & 5,1 \\
\hline 62 & $\mathrm{Hv}$ & $\mathrm{BH}$ & $\mathrm{BH} 3$ & Sebesvár & 2190 & 816 & 0 & 514 & 0 & 143 & 555 & 0 & 2028 & 162 & & 40,2 & 0,0 & 25,3 & 0,0 & 7,1 & 27,4 & 0,0 & 7,4 \\
\hline 63 & $\mathrm{Hv}$ & $\mathrm{BH}$ & $\mathrm{BH} 3$ & Székelyó & 4021 & 762 & 0 & 995 & 0 & 546 & 1528 & 0 & 3831 & 190 & & 19,9 & 0,0 & 26,0 & 0,0 & 14,3 & 39,9 & 0,0 & 4,7 \\
\hline 64 & $\mathrm{Hv}$ & Gy & Ko3 & Hidegszamos & 5928 & 382 & 43 & 795 & 0 & 162 & 4331 & 0 & 5713 & 215 & & 6,7 & 0,8 & 13,9 & 0,0 & 2,8 & 75,8 & 0,0 & 3,6 \\
\hline \multirow[t]{3}{*}{65} & \multirow[t]{3}{*}{$\mathrm{Hv}$} & Gy & Ko3 & Melegszamos & 7738 & 286 & 0 & 474 & 0 & 837 & 5955 & 0 & 7552 & 186 & & 3,8 & 0,0 & 6,3 & 0,0 & 11,1 & 78,9 & 0,0 & 2,4 \\
\hline & & & & Zóna - Össz.terület & 43913 & 3949 & 43 & 6741 & 0 & 4537 & 27236 & 0 & 42506 & 1407 & Átlag & 16,6 & 0,1 & 21,0 & 0,0 & 11,4 & 50,9 & 0,0 & 4,1 \\
\hline & & & & Összter. területileg \%-os & 103,3 & 9,3 & 0,1 & 15,9 & 0,0 & 10,7 & 64,1 & 0,0 & 100,0 & 3,3 & Szórás & 13,8 & 0,3 & 11,0 & 0,0 & 5,3 & 25,6 & 0,0 & 1,9 \\
\hline 66 & $\mathrm{~K}$ & Gy & Ko1 & Magyarkapus & 2378 & 871 & 33 & 322 & 0 & 649 & 398 & 0 & 2273 & 105 & & 38,3 & 1,5 & 14,2 & 0,0 & 28,6 & 17,5 & 0,0 & 4,4 \\
\hline 67 & $\mathrm{k}$ & Gy & Ko1 & Magyarkiskapus & 4324 & 975 & 96 & 575 & 0 & 894 & 1327 & 0 & 3867 & 457 & & 25,2 & 2,5 & 14,9 & 0,0 & 23,1 & 34,3 & 0,0 & 10,6 \\
\hline 68 & $\mathrm{k}$ & Gy & Ko3 & Egerbegy-Bánffydongó & 9384 & 668 & 3 & 898 & 0 & 1287 & 6315 & 0 & 9171 & 213 & & 7,3 & 0,0 & 9,8 & 0,0 & 14,0 & 68,9 & 0,0 & 2,3 \\
\hline 69 & $\mathrm{k}$ & Gy & Ko3 & Gesztrágy & 658 & 304 & 19 & 25 & 0 & 259 & 30 & 0 & 637 & 21 & & 47,7 & 3,0 & 3,9 & 0,0 & 40,7 & 4,7 & 0,0 & 3,2 \\
\hline & & & & Zóna - Össz.terület & 16744 & 2818 & 151 & 1820 & 0 & 3089 & 8070 & 0 & 15948 & 796 & Átlag & 29,6 & 1,7 & 10,7 & 0,0 & 26,6 & 31,3 & 0,0 & 5,1 \\
\hline & & & & Osszter. területileg \%-os & 105,0 & 17,7 & 0,9 & 11,4 & 0,0 & 19,4 & 50,6 & 0,0 & 100,0 & 5,0 & Szórás & 17,5 & 1,3 & 5,0 & 0,0 & 11,1 & 27,8 & 0,0 & 3,7 \\
\hline 70 & $\mathrm{Ka}$ & Gy & Ko1 & Gyalu & 9188 & 2702 & 166 & 1419 & 0 & 1113 & 3253 & 0 & 8653 & 535 & & 31,2 & 1,9 & 16,4 & 0,0 & 12,9 & 37,6 & 0,0 & 5,8 \\
\hline 71 & $\mathrm{Ka}$ & Gy & Ko1 & Magyarlóna & 3322 & 981 & 63 & 627 & 0 & 709 & 805 & 0 & 3185 & 137 & & 30,8 & 2,0 & 19,7 & 0,0 & 22,3 & 25,3 & 0,0 & 4,1 \\
\hline 72 & $\mathrm{Ka}$ & Gy & Ko1 & Szászfenes & 7433 & 1920 & 96 & 1191 & 4 & 1208 & 2651 & 2 & 7072 & 361 & & 27,1 & 1,4 & 16,8 & 0,1 & 17,1 & 37,5 & 0,0 & 4,9 \\
\hline & & & & Zóna-Össz.terület & 19943 & 5603 & 325 & 3237 & 4 & 3030 & 6709 & 2 & 18910 & 1033 & Átlag & 29,7 & 1,8 & 17,6 & 0,0 & 17,4 & 33,5 & 0,0 & 4,9 \\
\hline & & & & Osszter. területileg \%-os & 105,5 & 29,6 & 1,7 & 17,1 & 0,0 & 16,0 & 35,5 & 0,0 & 100,0 & 5,5 & Szórás & 2,2 & 0,3 & 1,8 & 0,0 & 4,7 & 7,1 & 0,0 & 0,9 \\
\hline 73 & $\mathrm{Nmv}$ & $\mathrm{Nm}$ & HA & Bogártelke & 1810 & 717 & 27 & 317 & 0 & 543 & 110 & 15 & 1729 & 81 & & 41,5 & 1,6 & 18,3 & 0,0 & 31,4 & 6,4 & 0,9 & 4,5 \\
\hline 74 & $\mathrm{Nmv}$ & $\mathrm{Nm}$ & $\mathrm{HA}$ & Egeres & 3974 & 1621 & 130 & 529 & 0 & 698 & 825 & 5 & 3808 & 166 & & 42,6 & 3,4 & 13,9 & 0,0 & 18,3 & 21,7 & 0,1 & 4,2 \\
\hline 75 & $\mathrm{Nmv}$ & $\mathrm{Nm}$ & HA & Inaktelke & 1960 & 843 & 39 & 519 & 0 & 329 & 167 & 0 & 1897 & 63 & & 44,4 & 2,1 & 27,4 & 0,0 & 17,3 & 8,8 & 0,0 & 3,2 \\
\hline 76 & $\mathrm{Nmv}$ & $\mathrm{Nm}$ & HA & Jegenye & 1271 & 411 & 30 & 138 & 0 & 406 & 187 & 0 & 1172 & 99 & & 35,1 & 2,6 & 11,8 & 0,0 & 34,6 & 16,0 & 0,0 & 7,8 \\
\hline 77 & $\mathrm{Nmv}$ & $\mathrm{Nm}$ & $\mathrm{HA}$ & Magyarborgó & 2520 & 1013 & 85 & 425 & 0 & 543 & 390 & 0 & 2456 & 64 & & 41,2 & 3,5 & 17,3 & 0,0 & 22,1 & 15,9 & 0,0 & 2,5 \\
\hline 78 & $\mathrm{Nmv}$ & $\mathrm{Nm}$ & $\mathrm{HA}$ & Magyarnádas & 1816 & 903 & 44 & 282 & 0 & 406 & 73 & 0 & 1708 & 108 & & 52,9 & 2,6 & 16,5 & 0,0 & 23,8 & 4,3 & 0,0 & 5,9 \\
\hline 79 & $\mathrm{Nmv}$ & $\mathrm{Nm}$ & HA & Magyarvista & 3712 & 1323 & 83 & 354 & 0 & 800 & 1036 & 0 & 3596 & 116 & & 36,8 & 2,3 & 9,8 & 0,0 & 22,2 & 28,8 & 0,0 & 3,1 \\
\hline 80 & $\mathrm{Nmv}$ & $\mathrm{Nm}$ & HA & Mákófalva & 3395 & 1474 & 93 & 597 & 0 & 312 & 800 & 0 & 3276 & 119 & & 45,0 & 2,8 & 18,2 & 0,0 & 9,5 & 24,4 & 0,0 & 3,5 \\
\hline 81 & $\mathrm{Nmv}$ & $\mathrm{Nm}$ & HA & Méra & 3814 & 1053 & 41 & 576 & 0 & 490 & 1504 & 3 & 3667 & 147 & & 28,7 & 1,1 & 15,7 & 0,0 & 13,4 & 41,0 & 0,1 & 3,9 \\
\hline 82 & $\mathrm{Nmv}$ & $\mathrm{Nm}$ & HA & Nádasdarócz & 748 & 325 & 20 & 127 & 0 & 179 & 42 & 41 & 734 & 14 & & 44,3 & 2,7 & 17,3 & 0,0 & 24,4 & 5,7 & 5,6 & 1,9 \\
\hline 83 & $\mathrm{Nmv}$ & $\mathrm{Nm}$ & HA & Szucság & 3499 & 1377 & 186 & 455 & 1 & 487 & 852 & 0 & 3358 & 141 & & 41,0 & 5,5 & 13,5 & 0,0 & 14,5 & 25,4 & 0,0 & 4,0 \\
\hline 84 & $\mathrm{Nmv}$ & $\mathrm{Nm}$ & HA & Türe & 2928 & 1104 & 92 & 450 & 0 & 672 & 477 & 0 & 2795 & 133 & & 39,5 & 3,3 & 16,1 & 0,0 & 24,0 & 17,1 & 0,0 & 4,5 \\
\hline & & & & Zóna - Össz.terület & 31447 & 12164 & 870 & 4769 & 1 & 5865 & 6463 & 64 & 30196 & 1251 & Átlag & 41,1 & 2,8 & 16,3 & 0,0 & 21,3 & 17,9 & 0,6 & 4,1 \\
\hline & & & & Osszter. területileg \%-os & 104,1 & 40,3 & 2,9 & 15,8 & 0,0 & 19,4 & 21,4 & 0,2 & 100,0 & 4,1 & Szórás & 5,9 & 1,1 & 4,3 & 0,0 & 7,2 & 11,0 & 1,6 & 1,6 \\
\hline 85 & To & Gy & Ko1 & Isztolna & 2098 & 172 & 29 & 135 & 0 & 36 & 1686 & 0 & 2058 & 40 & & 8,4 & 1,4 & 6,6 & 0,0 & 1,7 & 81,9 & 0,0 & 1,9 \\
\hline 86 & To & Gy & Ko1 & Kolozstótfalu & 1448 & 476 & 34 & 237 & 0 & 318 & 359 & 0 & 1424 & 24 & & 33,4 & 2,4 & 16,6 & 0,0 & 22,3 & 25,2 & 0,0 & 1,7 \\
\hline 87 & To & Gy & Ko1 & Magyarfenes & 2339 & 986 & 59 & 89 & 0 & 277 & 828 & 0 & 2239 & 100 & & 44,0 & 2,6 & 4,0 & 0,0 & 12,4 & 37,0 & 0,0 & 4,3 \\
\hline 88 & To & To & To 1 & Alsófüle & 1724 & 885 & 59 & 267 & 0 & 269 & 180 & 1 & 1661 & 63 & & 53,3 & 3,6 & 16,1 & 0,0 & 16,2 & 10,8 & 0,1 & 3,7 \\
\hline 89 & To & To & To 1 & Alsójára & 2115 & 774 & 48 & 157 & 0 & 278 & 775 & 0 & 2032 & 83 & & 38,1 & 2,4 & 7,7 & 0,0 & 13,7 & 38,1 & 0,0 & 3,9 \\
\hline 90 & To & To & To 1 & Felsôffüle & 1636 & 632 & 55 & 149 & 0 & 204 & 568 & 0 & 1608 & 28 & & 39,3 & 3,4 & 9,3 & 0,0 & 12,7 & 35,3 & 0,0 & 1,7 \\
\hline 91 & To & To & To 1 & Havasasszonyfalva & 2399 & 575 & 30 & 257 & 0 & 224 & 1187 & 0 & 2273 & 126 & & 25,3 & 1,3 & 11,3 & 0,0 & 9,9 & 52,2 & 0,0 & 5,3 \\
\hline 92 & To & To & To 1 & Járarákos & 1550 & 582 & 16 & 137 & 0 & 113 & 629 & 0 & 1477 & 73 & & 39,4 & 1,1 & 9,3 & 0,0 & 7,7 & 42,6 & 0,0 & 4,7 \\
\hline 93 & To & To & To 1 & Magyarléta & 1540 & 781 & 44 & 303 & 0 & 228 & 129 & 0 & 1485 & 55 & & 52,6 & 3,0 & 20,4 & 0,0 & 15,4 & 8,7 & 0,0 & 3,6 \\
\hline 94 & To & To & To 1 & Oláhléta & 1339 & 580 & 63 & 280 & 0 & 360 & 30 & 0 & 1313 & 26 & & 44,2 & 4,8 & 21,3 & 0,0 & 27,4 & 2,3 & 0,0 & 1,9 \\
\hline 95 & To & To & To 1 & Tordaszentlászló & 1041 & 632 & 51 & 134 & 0 & 187 & 20 & 0 & 1024 & 17 & & 61,7 & 5,0 & 13,1 & 0,0 & 18,3 & 2,0 & 0,0 & 1,6 \\
\hline 96 & To & To & To 2 & Hasadat & 22892 & 1117 & 174 & 1423 & 0 & 3153 & 16801 & 0 & 22668 & 224 & & 4,9 & 0,8 & 6,3 & 0,0 & 13,9 & 74,1 & 0,0 & 1,0 \\
\hline 97 & To & To & To 2 & Kisfenes & 9507 & 697 & 74 & 850 & 0 & 524 & 7184 & 0 & 9329 & 178 & & 7,5 & 0,8 & 9,1 & 0,0 & 5,6 & 77,0 & 0,0 & 1,9 \\
\hline & & & & Zóna -Össz.terület & 51628 & 8889 & 736 & 4418 & 0 & 6171 & 30376 & 1 & 50591 & 1037 & Átlag & 34,8 & 2,5 & 11,6 & 0,0 & 13,6 & 37,5 & 0,0 & 2,9 \\
\hline & & & & Osszter. területileg \%-os & 102,0 & 17,6 & 1,5 & 8,7 & 0,0 & 12,2 & 60,0 & 0,0 & 100,0 & 2,0 & Szórás & 18,3 & 1,4 & 5,5 & 0,0 & 6,8 & 27,9 & 0,0 & 1,4 \\
\hline 98 & $\mathrm{Vv}$ & Al & $\mathrm{BH} 1$ & Almásnyíres & 6584 & 1841 & 128 & 1302 & 0 & 627 & 2510 & 0 & 6408 & 176 & & 28,7 & 2,0 & 20,3 & 0,0 & 9,8 & 39,2 & 0,0 & 2,7 \\
\hline 99 & Vv & Al & BH1 & Bábony & 1376 & 488 & 51 & 84 & 0 & 137 & 550 & 0 & 1310 & 66 & & 37,3 & 3,9 & 6,4 & 0,0 & 10,5 & 42,0 & 0,0 & 4,8 \\
\hline 100 & Vv & Al & BH1 & Bercse & 2695 & 631 & 49 & 506 & 0 & 280 & 1140 & 0 & 2606 & 89 & & 24,2 & 1,9 & 19,4 & 0,0 & 10,7 & 43,7 & 0,0 & 3,3 \\
\hline 101 & Vv & Al & BH1 & Czold & 1909 & 807 & 87 & 292 & 0 & 103 & 585 & 0 & 1874 & 35 & & 43,1 & 4,6 & 15,6 & 0,0 & 5,5 & 31,2 & 0,0 & 1,8 \\
\hline 102 & Vv & Al & BH1 & Kiskökényes & 1160 & 373 & 49 & 141 & 0 & 85 & 479 & 0 & 1127 & 33 & & 33,1 & 4,3 & 12,5 & 0,0 & 7,5 & 42,5 & 0,0 & 2,8 \\
\hline 103 & Vv & Al & BH1 & Középlak & 2893 & 973 & 101 & 166 & 8 & 361 & 1134 & 0 & 2743 & 150 & & 35,5 & 3,7 & 6,1 & 0,3 & 13,2 & 41,3 & 0,0 & 5,2 \\
\hline 104 & Vv & Al & $\mathrm{BH} 1$ & Nyercze & 3526 & 649 & 62 & 279 & 1 & 510 & 1924 & 0 & 3425 & 101 & & 18,9 & 1,8 & 8,1 & 0,0 & 14,9 & 56,2 & 0,0 & 2,9 \\
\hline 105 & Vv & Al & BH1 & Váralmás & 9452 & 2330 & 205 & 753 & 34 & 747 & 5084 & 0 & 9153 & 299 & & 25,5 & 2,2 & 8,2 & 0,4 & 8,2 & 55,5 & 0,0 & 3,2 \\
\hline 106 & Vv & Al & HA & |Almásdál & 2088 & 918 & 115 & 268 & 3 & 290 & 367 & 0 & 1961 & 127 & & 46,8 & 5,9 & 13,7 & 0,2 & 14,8 & 18,7 & 0,0 & 6,1 \\
\hline 107 & Vv & Al & $\mathrm{HA}$ & Almásköblös & 2193 & 425 & 66 & 466 & 0 & 469 & 675 & 0 & 2101 & 92 & & 20,2 & 3,1 & 22,2 & 0,0 & 22,3 & 32,1 & 0,0 & 4,2 \\
\hline 108 & Vv & Al & $\mathrm{HA}$ & |Hidalmás & 3978 & 1382 & 129 & 593 & 1 & 548 & 1109 & 0 & 3762 & 216 & & 36,7 & 3,4 & 15,8 & 0,0 & 14,6 & 29,5 & 0,0 & 5,4 \\
\hline 109 & Vv & Al & HA & Lapupatak & 2182 & 518 & 46 & 273 & 0 & 153 & 1157 & 0 & 2147 & 35 & & 24,1 & 2,1 & 12,7 & 0,0 & 7,1 & 53,9 & 0,0 & 1,6 \\
\hline 110 & Vv & Al & $\mathrm{HA}$ & Magyarzsombor & 4147 & 1143 & 131 & 948 & 5 & 271 & 1464 & 0 & 3962 & 185 & & 28,8 & 3,3 & 23,9 & 0,1 & 6,8 & 37,0 & 0,0 & 4,5 \\
\hline 111 & Vv & Al & $\mathrm{HA}$ & Topaszentkirály & 4286 & 1682 & 110 & 834 & 0 & 352 & 1030 & 0 & 4008 & 278 & & 42,0 & 2,7 & 20,8 & 0,0 & 8,8 & 25,7 & 0,0 & 6,5 \\
\hline 112 & Vv & Al & $\mathrm{HA}$ & Vásártelke & 1259 & 383 & 53 & 251 & 0 & 325 & 223 & 0 & 1235 & 24 & & 31,0 & 4,3 & 20,3 & 0,0 & 26,3 & 18,1 & 0,0 & 1,9 \\
\hline 113 & Vv & Al & HA & Zutor & 2561 & 610 & 70 & 540 & 6 & 104 & 1139 & 0 & 2469 & 92 & & 24,7 & 2,8 & 21,9 & 0,2 & 4,2 & 46,1 & 0,0 & 3,6 \\
\hline 114 & Vv & $\mathrm{BH}$ & BH1 & Alsóföld & 2042 & 647 & 109 & 314 & 8 & 252 & 616 & 0 & 1946 & 96 & & 33,2 & 5,6 & 16,1 & 0,4 & 12,9 & 31,7 & 0,0 & 4,7 \\
\hline 115 & Vv & $\mathrm{BH}$ & BH1 & Középfüld & 4926 & 906 & 173 & 804 & 9 & 192 & 2688 & 0 & 4772 & 154 & & 19,0 & 3,6 & 16,8 & 0,2 & 4,0 & 56,3 & 0,0 & 3,1 \\
\hline 116 & Vv & $\mathrm{BH}$ & $\mathrm{BH} 3$ & Felsôfüld & 2858 & 825 & 0 & 905 & 0 & 237 & 781 & 0 & 2748 & 110 & & 30,0 & 0,0 & 32,9 & 0,0 & 8,6 & 28,4 & 0,0 & 3,8 \\
\hline & & & & Zóna - Össz.terület & 62115 & 17531 & 1734 & 9719 & 75 & 6043 & 24655 & 0 & 59757 & 2358 & Átlag & 30,7 & 3,2 & 16,5 & 0,1 & 11,1 & 38,4 & 0,0 & 3,8 \\
\hline & & & & Osszter. területileg \%-os & 103,9 & 29,3 & 2,9 & 16,3 & 0,1 & 10,1 & 41,3 & 0,0 & 100,0 & 3,9 & Szórás & 8,1 & 1,4 & 6,8 & 0,1 & 5,8 & 12,0 & 0,0 & 1,4 \\
\hline
\end{tabular}




\begin{tabular}{|c|c|c|c|c|c|c|c|c|c|c|c|c|c|}
\hline AUKARAATER ZONA BESOROLAS & Alszegi barnköszzénv. & Alcronicấlík & Biass-berendités.sen & & 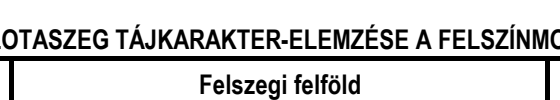 & NKKaA & 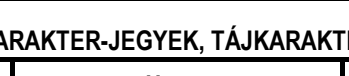 & MNTAZZATOK És TAAUI & JKAPARAER-ZONAK OSSZZ & SZZEVETESEBEEN & & & \\
\hline $\begin{array}{ll}\text { lepullesnév: } & \text { (eredeti }\end{array}$ & & & & 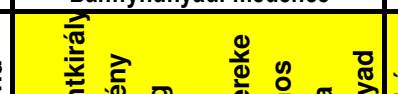 & & 戊 & Havas & Havasilvolgyex & Kapusiviogy & 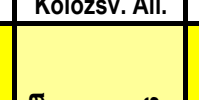 & Nadas-mentivolyy & 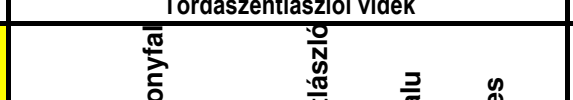 & Varamassvolyyer \\
\hline 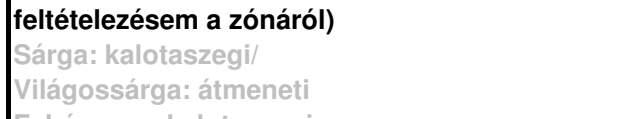 & & & & & & & & & & & & & 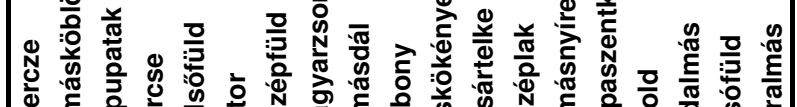 \\
\hline 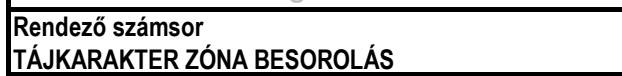 & & & & & & & & & & & & & \\
\hline 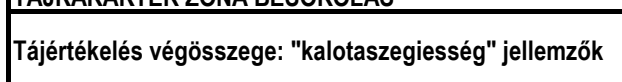 & 9121213131316 & 16161616171718 & 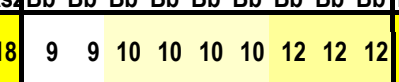 & 213131313141414141515 & 5 & $\begin{array}{lllllll}3 & 78 & 9 & 9 & 10 & 12 \\
\end{array}$ & $\begin{array}{lllllll}3 & 4 & 5 & 5 & 5 & 78\end{array}$ & $\begin{array}{|lllllll|}5 & 5 & 6 & 7 & 8 & 8 & 9\end{array}$ & 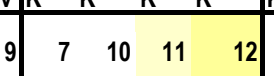 & $\begin{array}{llll}2 & 9 & 10 & 12\end{array}$ & 2121212121212121313141414 & 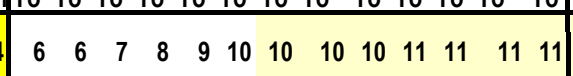 & 1010101111111112121212121313131313141 \\
\hline 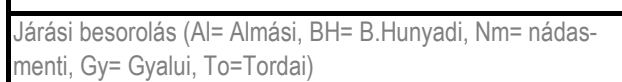 & 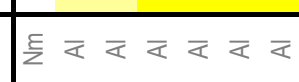 & 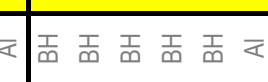 & 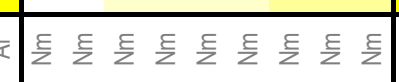 & 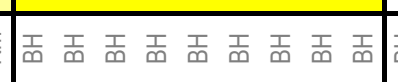 & 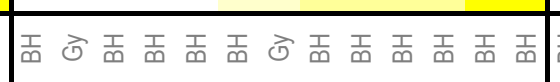 & 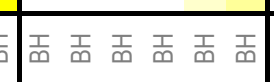 & 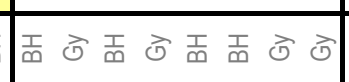 & 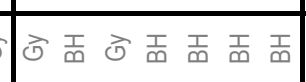 & 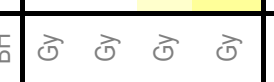 & ने के बे: & 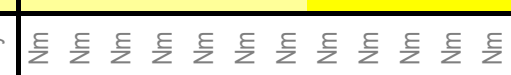 & 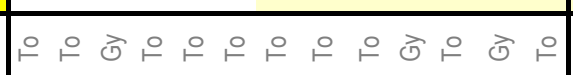 & 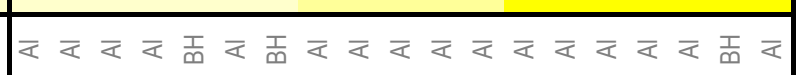 \\
\hline 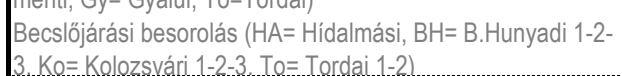 & 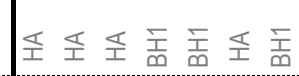 & 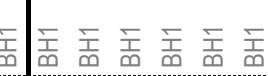 & 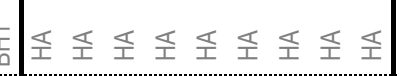 & 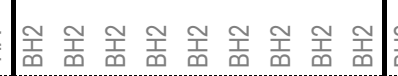 & 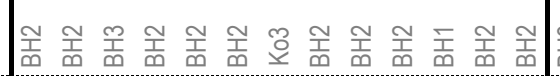 & 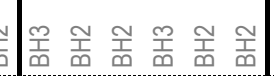 & 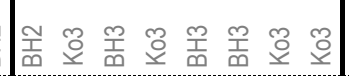 & 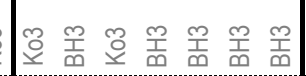 & 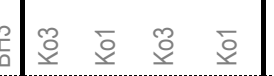 & $\mid \overline{1}=$ & 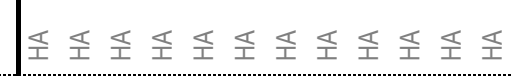 & 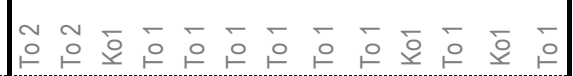 & 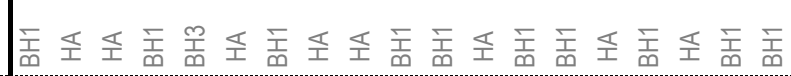 \\
\hline 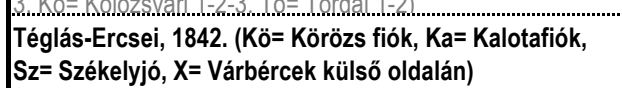 & & $x \times x \times$ & & 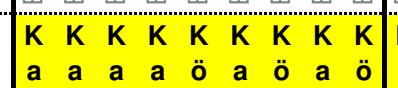 & 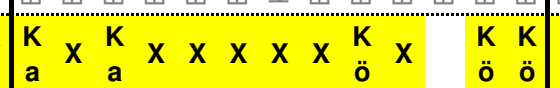 & $\mid \begin{array}{lll}k \\
k \\
a\end{array}$ & $\begin{array}{|lll|}\mathrm{x} & \mathrm{sz} & \mathrm{sz} \\
\end{array}$ & 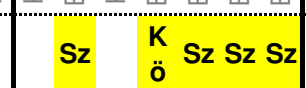 & & & & & $x \quad x$ \\
\hline 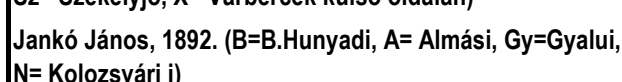 & A & В В В В В А & $\mathrm{N}$ & 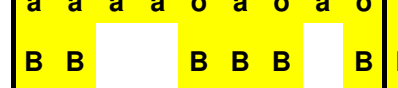 & $\begin{array}{llll}A & A & B & G \\
B & B & B\end{array}$ & & & & & & N N N N N N N & & \\
\hline 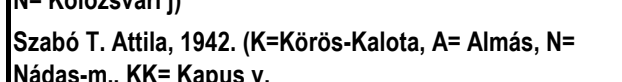 & A & A A AKK A & n & к к к & к k & & & & кк кк кк & & N N N N N N N N N N N N & & 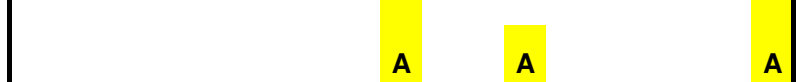 \\
\hline 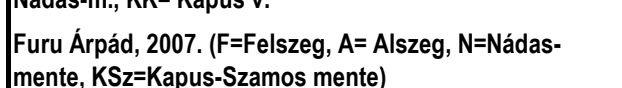 & A A & AAAAA A & $\mathrm{N}$ & FFF FFFF & FFFFF & FFF & & & $\left|\begin{array}{ll}\mathrm{KSz} K S z & \mathrm{KSz}\end{array}\right|$ & & N N N N N N N N & $\mathrm{ksz}$ & \\
\hline 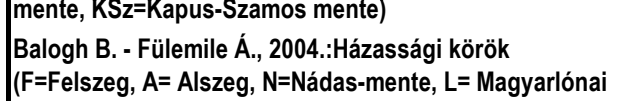 & A & AAAAAA & & & & & & & $\mathrm{N} / \mathrm{L}$ & & N N N & L L & A \\
\hline 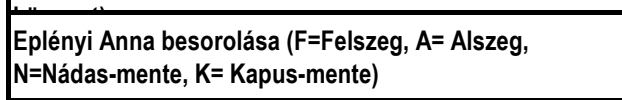 & A A A : & $A A A A A A$ & n & FFFFFFFFF & FFFFFFFFFFFF & $=\mid F F F F F$ & & & $k \quad k \quad k \quad k$ & & N N N N N N N & & \\
\hline II.FEEZET & & & & EOCÉN-FELSÓ & & & & & & & & & \\
\hline Geologiali ellemzök, alapkózet & $\begin{array}{l}\text { OLGGOCEN } \\
\text { RETEGEK }\end{array}$ & $\begin{array}{l}\text { EOCEN-ELLSO } \\
\text { DURVAMESZKÖ }\end{array}$ & OLGGOCÉN RÉTEGEK & 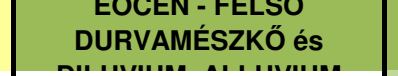 & $\begin{array}{l}\text { EOCCNN-ALSOOE ESS ELLSÖ } \\
\text { DURVAMESZKó }\end{array}$ & $\begin{array}{l}\text { ERRPTTV } \\
\text { KÖZTEK } \\
\text { KOT. }\end{array}$ & $\begin{array}{l}\text { OSPALAKA ALLO } \\
\text { TARAAGAYAG }\end{array}$ & $\begin{array}{l}\text { OOSPAALAK, ALSO } \\
\text { TARKAAYYG }\end{array}$ & $\begin{array}{l}\text { ALSO } \\
\text { TARAAAGA, }\end{array}$ & $\left|\begin{array}{c}\text { ALSO } \\
\text { TARKAGY }\end{array}\right|$ & $\begin{array}{l}\text { EOCÉNN- FELSOÓ DURVAMAÉSZ } \\
\text { (egyountetún) }\end{array}$ & veGYes & OLIGOCÉN RÉTEGEK \\
\hline Külölleges morrológia alakzatok & NINCS & MEREDEK OLAALAK & NINCS & NINCS & MEZAPLAÓS SZERKEZEET DOMINÁL & 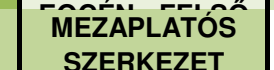 & NINCS & NINCS & 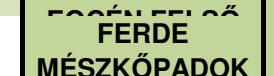 & I EEREE & FERDE MÉSZKÖPADOK & Nincs & PÁRHUZAMMOS HOSSZANTT VöLGYeK \\
\hline Vilyszzerterzeti jellemzzok & SZÜKEBB, TÁGABB & \begin{tabular}{l|l} 
B & SZÜK, TAGOLT \\
\end{tabular} & SZÉLESEN NYTTOTT, TÁ & MEDENGE HELYZET, TÁ & 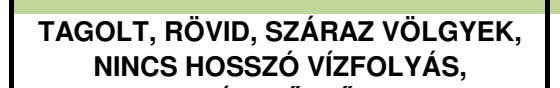 & & PLATOK & $\mid \begin{array}{c}\text { MEEYY, SZÜK, } \\
\text { MEREDEK HỨOS, }\end{array}$ & 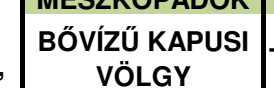 & $\mid$ Tág VöLar $\mid$ & $\begin{array}{l}\text { NADAS FóVÖLLYYE ES EGYYFORMA } \\
\text { OLDALOOLGYK }\end{array}$ & 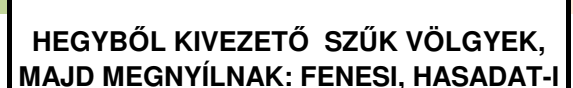 & 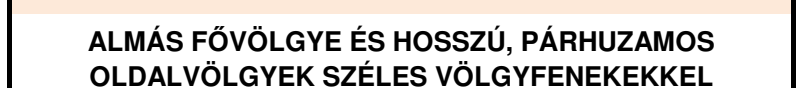 \\
\hline & cosent & cosent? & $\longleftrightarrow$ & $\rightarrow$ & $\Rightarrow \Leftrightarrow$ & & & & 事 & & & Mring & $\vec{m}=\vec{x}$ \\
\hline 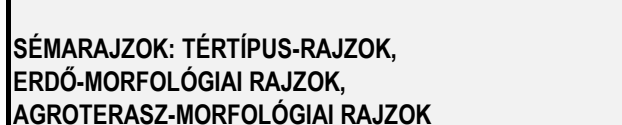 & $\longleftrightarrow$ & & & & & & & & & & & & 2 \\
\hline & & 230 & & & $\leq 2$ & & & & 3 & & Sis & ? & \\
\hline 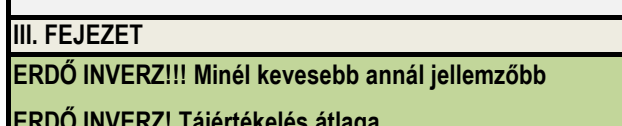 & 312101012 & 14111414 & \begin{tabular}{|l|l}
121251210 \\
10
\end{tabular} & $\frac{115121}{151}$ & $\sqrt{58146189}$ & & 000310 & 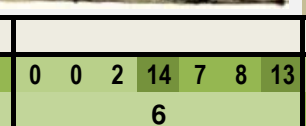 & 07.18 & $\begin{array}{lll}1 & 5 & 6 \\
7 & 6\end{array}$ & $169 \begin{array}{l}15165131313 \\
14\end{array}$ & 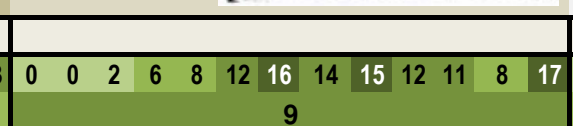 & $4104710859914119 / 158711109 / 12$ \\
\hline 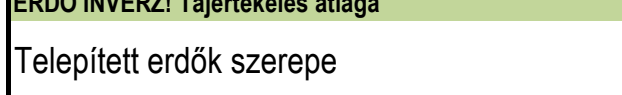 & NEM JELLEMZö & NEM JELEEMZб & $\begin{array}{l}\text { ELVÉTVE JELENIK MEG, } \\
\text { NEM JJLLLMZÖ }\end{array}$ & $\begin{array}{l}\text { ELVÉTTEE JELENIK MEG, } \\
\text { NEM JELLEMZE }\end{array}$ & JELLEMZZ, GYAKOKAR, VISZZATÉRÓ & $\begin{array}{l}\text { ELVÉTVE, } \\
\text { JELENIK MEG, }\end{array}$ & NEM JELLEMZÖ & NEM JELLEMZÖ & $\begin{array}{l}\text { JELLEZZ, } \\
\text { G YYAOOFI, }\end{array}$ & JELEMZÓ & |JELLEMZZ, , VYAKORII VISZZATÉRO & ELVÉTVE JELENIK MEG, NEM JELLEMZÖ & NEM JELLEMZÖ \\
\hline 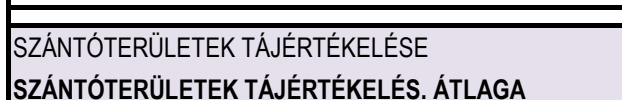 & 9131116151314 & 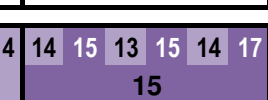 & 71281110108131214 & 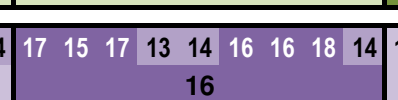 & $\mid \sqrt{10} 109108131314131415121214$ & $4 \begin{array}{llllll}8 & 12 & 10 & 11 & 11 & 13 \\
\end{array}$ & 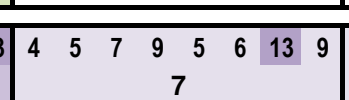 & $\begin{array}{llllllll}6 & 5 & 7 & 9 & 8 & 10 & 11\end{array}$ & 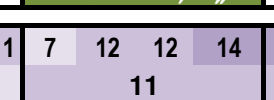 & \begin{tabular}{|lll}
13 & 13 & 14 \\
13 &
\end{tabular} & 4151414131316131414121515 & $101081081_{14}^{14} 13131313121213$ & $\mid 11101213121211141412121215131315141414$ \\
\hline 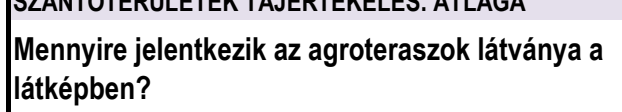 & NEM & ALIG & NEM & $\begin{array}{l}\text { ALLG, CSAK A AAVASALJI } \\
\text { TERASZOK LATSZODNAK }\end{array}$ & $\begin{array}{l}\text { MARKÁNSAN ÉS ERÖTELLESEN } \\
\text { DOMINAL }\end{array}$ & $\begin{array}{c}\text { MARKANSAN ESS } \\
\text { EROOTELLESEN }\end{array}$ & NEM & NEM & $\left|\begin{array}{c}\text { MARKÁNSAN ÉS } \\
\text { ERÓOELLLESEN }\end{array}\right|$ & KISSÉ & \begin{tabular}{|l} 
MARKÁNSAN ÉS ERÖTELJESEN \\
DOMINAL
\end{tabular} & KöZEPESEN DOMINÁL, VALTOZZATOSAN & KISSÉ JELENTKEZZIK, CSAK AZ OLDALVÖLGYEKBEN \\
\hline 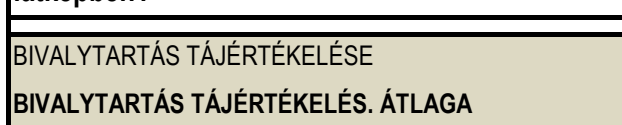 & $\begin{array}{l}91215101 \\
9\end{array}$ & $\begin{array}{l}14161512 \\
15\end{array}$ & $8 \sqrt[51210859]{10}$ & 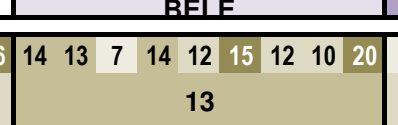 & 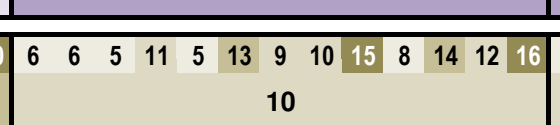 & 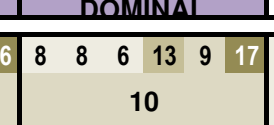 & $\longdiv { \sqrt { 3 4 4 4 6 5 } }$ & $\begin{array}{lllllll}5 & 4 & 5 & 5 & 8 & 5 & 11 \\
& 6 & & \end{array}$ & 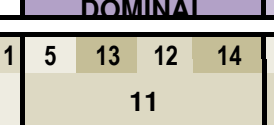 & 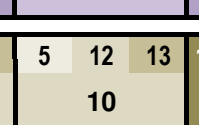 & 161916131514131617171618 & 44454667125589 & $\begin{array}{l}11111211148131041215121010161512131 \\
12\end{array}$ \\
\hline EGLLTETES & 1813 & 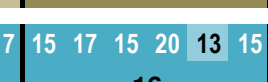 & 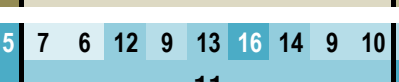 & |9 916191620 & 9107 & $0 \mid 111$ & 5201 & $0 \begin{array}{llll}4 & 9 & 9 & 4\end{array}$ & $\begin{array}{l}6 \\
6\end{array}$ & $\mid \begin{array}{ll}2 & 7 \\
7\end{array}$ & $\mid \begin{array}{llllll}6 & 9 & 8 & 721 & 8\end{array}$ & 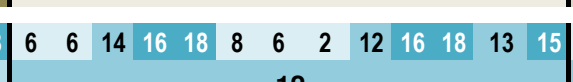 & 71012171414991312141712191517168 \\
\hline & 17 & 16 & 11 & 15 & 10 & & 8 & 8 & 8 & $\begin{array}{l}7 \\
\text { NEM }\end{array}$ & 11 & 12 & \\
\hline Fảs legelök gyakorisáaga, látuánya & RITKA & MEGJELENIK & MEGJELENIK & NEM JELLEMZÖ & RiTKA (Körơsstố Környéḱn) & | NEM JELEEMZÖ & NEM JELLEMZÖ & NEM JELLEMZÖ & RITKA & 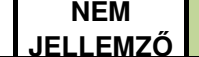 & GYAKORI, DOMINÁL & RITKA & RITKA \\
\hline 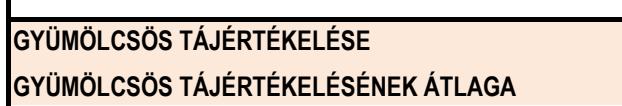 & 8141118151820 & 0161720171820 & 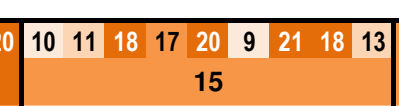 & 361714131715171920 & 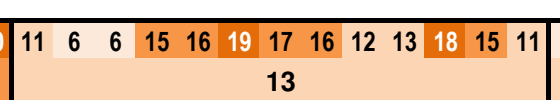 & 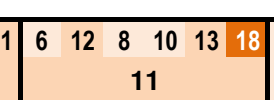 & $\mid \begin{array}{llllllll}6 & 6 & 6 & 8 & 6 & 6 & 7 & 0\end{array}$ & 566106766 & 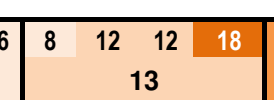 & $\left|\begin{array}{ccc}15 & 20 & 17 \\
17 & \end{array}\right|$ & 91311181417221714181915 & 1010111081111141314122115 & 15151413101220161716161417 \\
\hline XX. sz. gyümölcs-ültetevények & NEM JELLEMZZ̈ & $\begin{array}{l}\text { NAGY } \\
\text { KITERAEEESÜ, } \\
\text { LÁTVANANYSAN }\end{array}$ & $\begin{array}{l}\text { KISEBB TAGOKBAN } \\
\text { FoRDU ELOO, DE } \\
\text { TAVOLROL IS JOL }\end{array}$ & \begin{tabular}{|c|c|} 
KIIEBB TAGOKBAN \\
FOROLLLEOD DE \\
TAVOLROLIS JOL
\end{tabular} & $\begin{array}{c}\text { KISEBB TAGOKBAN FORDUL ELÓ, DE } \\
\text { TAVOLROL IS SOL LATHATO }\end{array}$ & $\left|\begin{array}{c}\text { KISEBB } \\
\text { TAGOKBAN, ALLGG } \\
\text { ESZLELLETETÓ }\end{array}\right|$ & NEM JELLEMZÖ & NEM JELLEMZÖ & $\begin{array}{l}\text { KISEBB } \\
\text { TAGOKBAN, } \\
\text { ALLG }\end{array}$ & $\mid \begin{array}{c}\text { KISEBB } \\
\text { TAGOKGAN } \\
\text {, ALIG }\end{array}$ & $\begin{array}{l}\text { NAGY KITERJEDÉSBEEN, } \\
\text { LATVANYOSAN DOMINALL }\end{array}$ & KISEBB TAGOKBAN, ALIG ÉSZLELLHETó & $\begin{array}{l}\text { KISEBB TAGOKBAN FORDOLL EEŌ, DE TÁVOLRÓL IS JOL } \\
\text { LATHATOO }\end{array}$ \\
\hline ATLAGA & $\begin{array}{llll}6 & 6 & 10119 & 9\end{array}$ & $\sqrt{4232122242424}$ & $\begin{array}{ll}66 & 666 \\
7\end{array}$ & $\begin{array}{llllll}6 & 6 & 6 & 6 & 6 & 7 \\
& \end{array}$ & 6666666666666 & 66666666 & $\begin{array}{lllllllll}6 & 6 & 6 & 6 & 6 & 6 & 6 & 6 & 6 \\
& 6 & \end{array}$ & $\begin{array}{lllllll}6 & 6 & 6 & 6 & 6 & 6\end{array}$ & 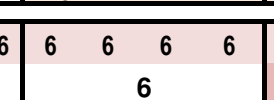 & 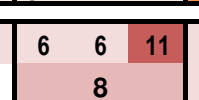 & 666666966676 & \begin{tabular}{lllllllllllll|}
6 & 6 & 6 & 6 & 6 & 6 & 6 & 6 & 6 & 6 & 6 & 6 & 6 \\
\end{tabular} & 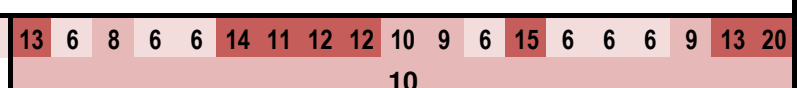 \\
\hline Szölolom mintázati ierje a tajjképben & ELVÉtVE & \begin{tabular}{|l|} 
JELENTÖS, \\
NOMNÁ
\end{tabular} & NEM & NEM & NEM & NEM & NEM & NEM & NEM & NEM & NEM & NEM & ELVÉtVE \\
\hline 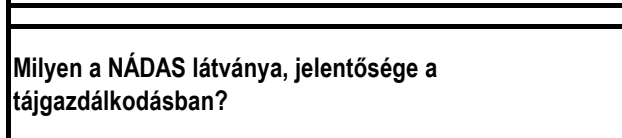 & $\begin{array}{l}\text { NEM JELLEMZÖ, } \\
\text { NINCS SZEREPE }\end{array}$ & \begin{tabular}{|l|} 
NEM JELLEMZÖ, \\
NINCS SZEREPEE
\end{tabular} & $\begin{array}{l}\text { A NÁDASKA PATAK } \\
\text { MENTEN CEEKELY } \\
\text { KITERJEDEESEEN }\end{array}$ & \begin{tabular}{|l} 
KISSE MEGJELENIK \\
HUNYAD ES SZENTKKIRALY \\
KÖRNYEKKEN
\end{tabular} & NEM JELLEMZOZ, NINCS SZZEREPE & $\left|\begin{array}{c}\text { NEM MELLEZZO, } \\
\text { NINSS SEREREE }\end{array}\right|$ & $\begin{array}{l}\text { NEM JELLEMZÓ, NINCS } \\
\text { SZEREPE }\end{array}$ & $\begin{array}{l}\text { NEM JELLEMZZ̈, } \\
\text { NINCS SZEREPE }\end{array}$ & \begin{tabular}{|l|}
$\begin{array}{c}\text { NEM JELLEMZö, } \\
\text { NINCS SZEREPEE }\end{array}$ \\
\end{tabular} & $\begin{array}{l}\text { JELENTŐS } \\
\text { A SZAMOS } \\
\text { MENTEN }\end{array}$ & $\begin{array}{l}\text { KISSE MEGJELENIK A AÁDAS } \\
\text { MENTEN, DEAZ EGERESI } \\
\text { MEDENCEREN JELENTÓS }\end{array}$ & NEM JELLEMZOZ, NINCS SZEREPE & $\begin{array}{l}\text { DOMINÁNSAN MEGJELENIK AZ ALMAS.PATAK } \\
\text { VÖLGYEBEN ESS AZ OLDAVOZLGYEKBEN }\end{array}$ \\
\hline 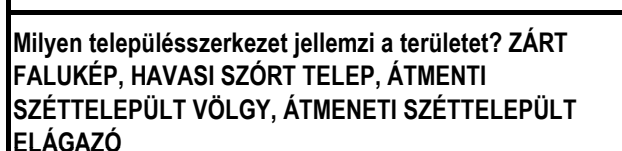 & 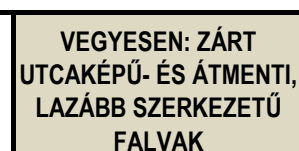 & 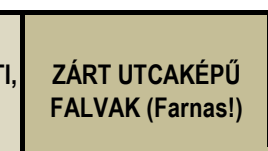 & 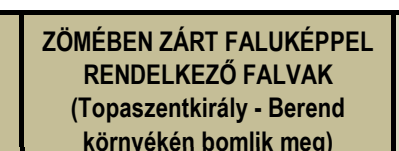 & 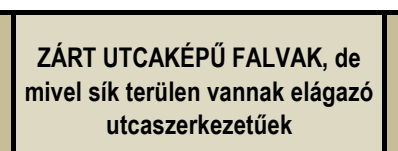 & 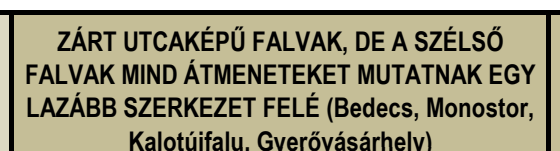 & 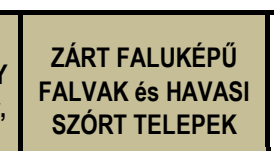 & HAVAS IZZORR TELLPFEK & HAVASI SZÓRT TELLPEKK & 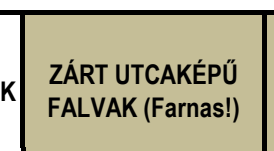 & 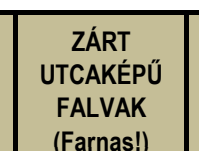 & ZART UTCAKÉPU FALVAK & 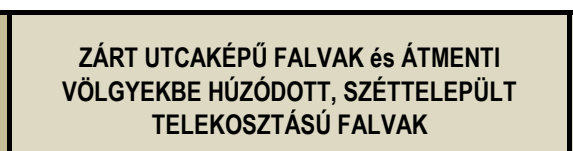 & 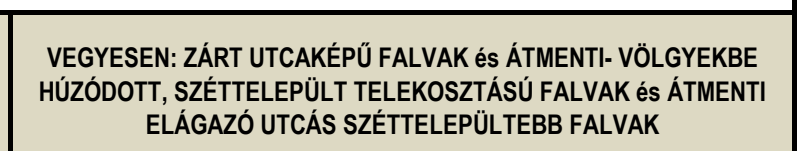 \\
\hline 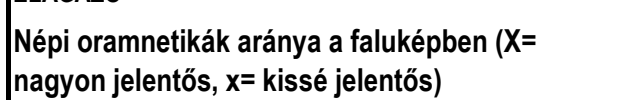 & $\mathrm{x} \times$ & $x \times \times \times \times x$ & & $\left|\begin{array}{llllllll}x & x & x & x & x & x & x & \times\end{array}\right|$, & $x \times \times \times \times \times \quad \times x \times \times \times \times 1$, & $x \times \times \times x \times$ & & & $x \times x$ & $\times$ & $x \times x \times x \times$ & $\times \times x$ & $\times \times$ \\
\hline $\begin{array}{l}\text { Mennyire dominala a hayyományos templom. } \\
\text { tornyok atajképben? }\end{array}$ & $\begin{array}{c}\text { ROMÁN } \\
\text { FATORNYK, } \\
\text { KISEBB TERUULTEN }\end{array}$ & \begin{tabular}{l|l} 
MEGLELENIK, \\
RALATAST \\
ENGED TÖBB
\end{tabular} & $\begin{array}{l}\text { ROMÁN FATORNYOK, } \\
\text { KISEBB TERÜLETEN }\end{array}$ & 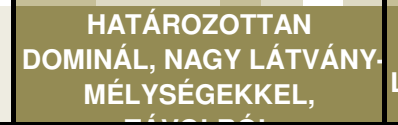 & 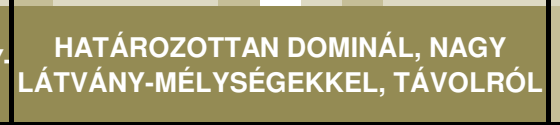 & $\begin{array}{l}\text { MEGJULENII, } \\
\text { RALATAST, } \\
\text { ENGED TOBB }\end{array}$ & $\begin{array}{l}\text { ROMÁN FATORNYOK, } \\
\text { KISEBB TERÜLETEN }\end{array}$ & $\begin{array}{c}\text { ROMAN } \\
\text { FATONAYOK, } \\
\text { KISEBB TERULLTEN }\end{array}$ & & & 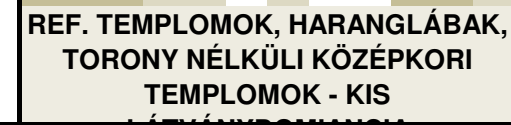 & $\begin{array}{l}\text { ROMAN FATORNYOK, KISEBB } \\
\text { TERÜLLTTEN }\end{array}$ & ROMÁN FATORNYOK, KISEBB TERÜLETEN \\
\hline 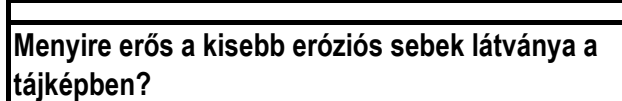 & $\begin{array}{l}\text { JELLEWZO, } \\
\text { GYAKOFI }\end{array}$ & $\begin{array}{l}\text { JELLENZO, } \\
\text { GYAORBI }\end{array}$ & $\begin{array}{l}\text { ELÓFORDDLL, DE NEM } \\
\text { ERÓTELLES }\end{array}$ & $\begin{array}{l}\text { NEM JELLEMZÓ, NINCS } \\
\text { SZEREEE }\end{array}$ & JELLEMZÖ, GYAKORI & $\begin{array}{l}\text { JELLENZO', } \\
\text { GYYKORII }\end{array}$ & $\begin{array}{l}\text { NEM JELLEMZZÖ, NINCS } \\
\text { SZEREPE }\end{array}$ & $\begin{array}{l}\text { NEM JELLEMZÖ, } \\
\text { NNNCS SEERRPEE }\end{array}$ & 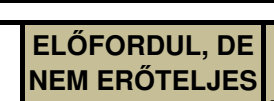 & $\begin{array}{l}\text { ELEFOROU } \\
L, D E N E M \\
\end{array}$ & JELLEMZZ̈, GYAKORI & ELÖFORDUL, DE NEM ERÓTELLJES & ELÖFORDUL, DE NEM EROÓTELJES \\
\hline 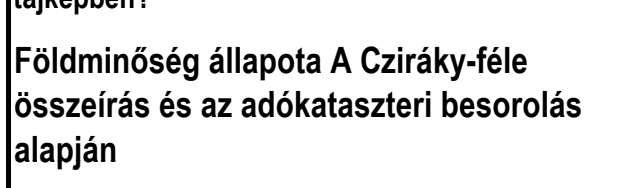 & $\begin{array}{l}\text { KOZZEESS } \\
\text { MINSOSEGUU }\end{array}$ & 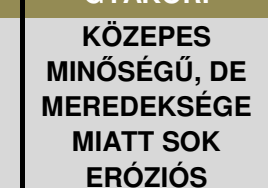 & 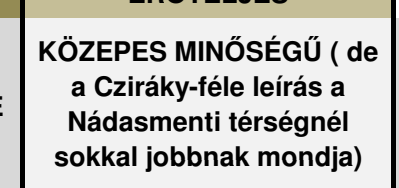 & KÖZEPES MINöSÉGGú & 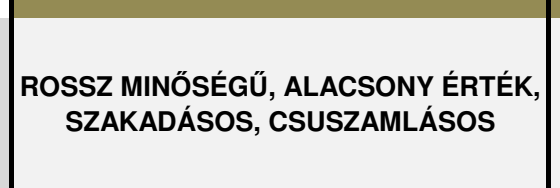 & $\begin{array}{l}\text { NAGYON ROSSZ } \\
\text { MINÓSEGUU, } \\
\text { ALACSONY } \\
\text { ERTEK, } \\
\text { SZAKAEASOS, }\end{array}$ & 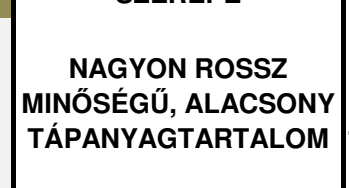 & $\begin{array}{c}\text { NAGYGON ROSSZ } \\
\text { MINÓSEGUU, } \\
\text { ALACSONY } \\
\text { TÁANYAGTARTALO } \\
\text { M }\end{array}$ & $\mid \begin{array}{c}\text { ROSSZ } \\
\text { MNOOSSGGU, } \\
\text { ALACSONY } \\
\text { ERTEK }\end{array}$ & $\mid$ & 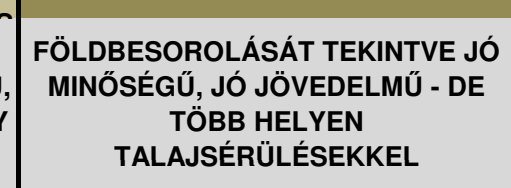 & KÖZEPES, VEGYES MINÖSÉGUU & $\begin{array}{l}\text { JÓ MINÖSÉGGU, JOL MÜVELHETŌ, KEVESEBB } \\
\text { FöLDFOLYAS, KÖVESSEGG }\end{array}$ \\
\hline \begin{tabular}{|l} 
Szźntó fillérl hold értékelése \\
Iparosodás mértéke, szuburbanizációs \\
folyamatok
\end{tabular} & 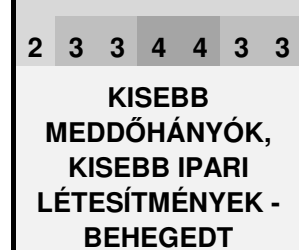 & 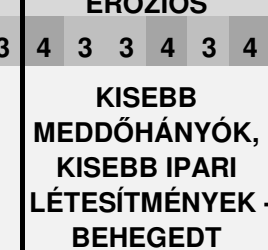 & 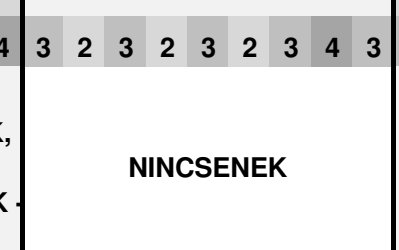 & 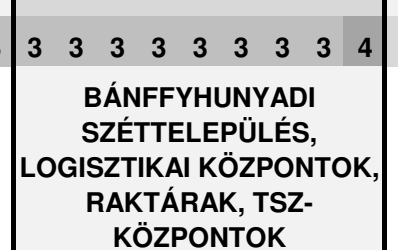 & 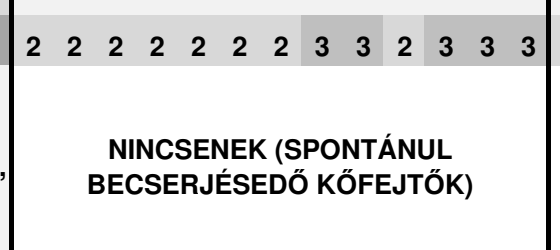 & $\left|\begin{array}{llllll}3 & \left|\begin{array}{llllll}2 & 2 & 2 & 2 & 2 & 2\end{array}\right|\end{array}\right|$ & 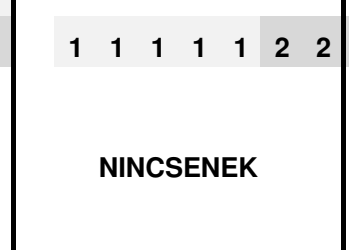 & 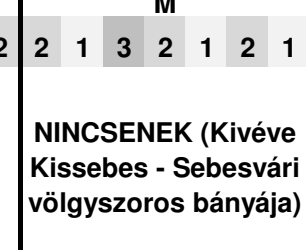 & $\mid \begin{array}{cccc}2 & 3 & 2 & 4 \\
\text { KAPUSI } \\
\text { VASGYÁR } \\
\text { EPUULEE } \\
\text { EOMINÁL } \\
\text { DOMINA } \\
\text { VÖLGYBEN }\end{array}$ & 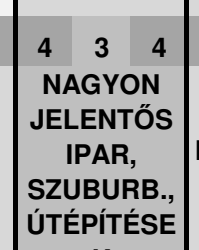 & 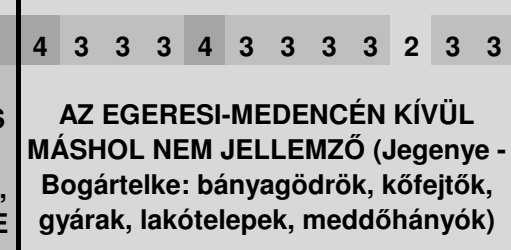 & 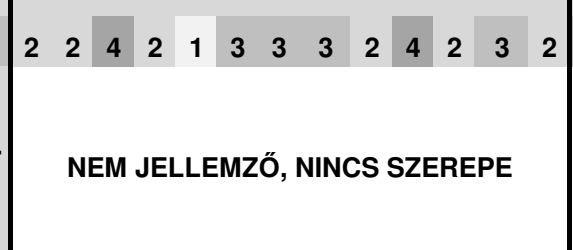 & $\begin{array}{llllllllllllllllllll}3 & 3 & 3 & 3 & 3 & 4 & 3 & 4 & 3 & 3 & 3 & 3 & 4 & 3 & 3 & 3 & 3 & 4\end{array}$ \\
\hline & & & & & & & & & & & & & \\
\hline
\end{tabular}

